\title{
Potentiodynamic Polarization Studies on Candidate Container Alloys for the Tuff Repository
}

Manuscript Completed: January 1992

Date Published: January 1992

Prepared by

N. G. Thompson, J. A. Beavers, C. L. Durr

Cortest Columbus Technologies, Inc.

2704 Sawbury Boulevard

Columbus, $\mathrm{OH} 43235$

\author{
Prepared for \\ Division of Regulatory Applications \\ Office of Nuclear Regulatory Research \\ U.S. Nuclear Regulatory Commission \\ Washington, DC 20555 \\ NRC FIN D1692
}

\section{DISCLAIMER}

This report was prepared as an account of work sponsored by an agency of the United States Government. Neither the United States Government nor any agency thereof, nor any of their employees, makes any warranty, express or implied, or assumes any legal liability or responsibility for the accuracy, completeness, or usefulness of any information, apparatus, product, or process disclosed, or represents that its use would not infringe privately owned rights. Reference herein to any specific commercial product, process, or service by trade name, trademark, manufacturer, or otherwise does not necessarily constitute or imply its endorsement, recommendation, or favoring by the United States Government or any agency thereof. The views and opinions of authors expressed herein do not necessarily state or reflect those of the United States Government or any agency thereof. 


\section{RELATED DOCUMENTS}

The following is a listing of Topical Reports summarizing the research performed in the various tasks of the program issued to Cortest Columbus Technologies, Inc. (CC Technologies):

"Environmental Effects On Corrosion In The Tuff Repository." NUREG/CR-5435 published February, 1990.

"Immersion Studies On Candidate Container Alloys For The Tuff Repository." NUREG/CR-5598 published May, 1991.

"Pitting, Galvanic, And Long-Term Corrosion Studies On Candidate Container Alloys For The Tuff Repository." NUREG/CR-5709 published January, 1992. 


\section{DISCLAIMER}

Portions of this document may be illegible in electronic image products. Images are produced from the best available original document. 


\section{ABSTRACT}

Cortest Columbus Technologies, Inc. (CC Technologies) is investigating the long-term performance of container materials used for high-level radioactive waste packages. This information is being developed for the Nuclear Regulatory Commission to aid in their assessment of the Department of Energy's application to construct a geologic repository for disposal of highlevel radioactive waste. This report summarizes the results of cyclic-potentiodynamic-polarization (CPP) studies performed on candidate container materials for the Tuff Repository. The CPP technique was used to provide an understanding of how specific variables such as environmental composition, temperature, alloy composition, and welding affect both the general- and localizedcorrosion behavior of two copper-base and two $\mathrm{Fe}-\mathrm{Cr}-\mathrm{Ni}$ alloys in simulated repository environments.

A statistically-designed test solution matrix was formulated, based on an extensive search of the literature, to evaluate the possible range of environmental species that may occur in the repository over the life of the canister. Forty-two CPP curves were performed with each alloy and the results indicated that several different types of corrosion were possible. The copper-base alloys exhibited unusual CPP behavior in that hysteresis was not always associated with pitting.

The effects of temperature on the corrosion behavior were evaluated in two types of tests; isothermal tests at temperatures from $50^{\circ} \mathrm{C}$ to $90^{\circ} \mathrm{C}$ and heat-transfer tests where the solution was maintained at $50^{\circ} \mathrm{C}$ and the specimen was internally heated to $90^{\circ} \mathrm{C}$. In the isothermal test, CPP curves were obtained with each alloy in simulated environments at $50^{\circ} \mathrm{C}, 75^{\circ} \mathrm{C}$, and $90^{\circ} \mathrm{C}$. The results of these CPP experiments indicated that no systematic trends were evident for the environments tested.

In the heat-transfer test, CPP tests were performed with a specimen internally heated to $90^{\circ} \mathrm{C}$ while maintaining the test solution at $50^{\circ} \mathrm{C}$. The results of these experiments indicated that in simulated $\mathrm{J}-13$ well water, heat transfer appeared to have an effect on the corrosion behavior of each of the four alloys. Heat transfer did not appear to have a major effect in more aggressive simulated environments.

Lastly, the effects of welding on the corrosion behavior of the alloys in simulated environments were examined. Rod material was welded into a V-shaped grove in plate material. The weld was machined and evaluated by the CPP technique. These studies showed that welding had relatively little effect on the CPP behavior of the $\mathrm{Fe}-\mathrm{Cr}-\mathrm{Ni}$ alloys in the environments that were selected. Welding was found to be detrimental to the performance of the copper-base alloys in both simulated groundwater and in a solution shown to promote pitting of the wrought copperbase alloys. 



\section{TABLE OF CONTENTS}

Page

Executive Summary $\ldots \ldots \ldots \ldots \ldots \ldots \ldots \ldots \ldots \ldots \ldots \ldots \ldots \ldots \ldots \ldots$

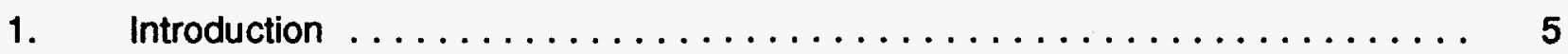

2. Background - The Tuff Repository Environment $\ldots \ldots \ldots \ldots \ldots \ldots \ldots$

$2.1 \quad$ Nominal Environment $\ldots \ldots \ldots \ldots \ldots \ldots \ldots \ldots \ldots \ldots \ldots \ldots$

2.2 Thermal Effects $\ldots \ldots \ldots \ldots \ldots \ldots \ldots \ldots \ldots \ldots \ldots \ldots \ldots \ldots, 10$

2.3 Radiation Effects $\ldots \ldots \ldots \ldots \ldots \ldots \ldots \ldots \ldots \ldots \ldots \ldots \ldots, 15$

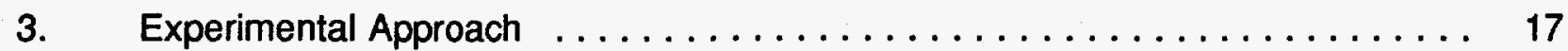

3.1 Test Technique $\ldots \ldots \ldots \ldots \ldots \ldots \ldots \ldots \ldots \ldots \ldots \ldots \ldots, 17$

3.2 Candidate Alloys Evaluated $\ldots \ldots \ldots \ldots \ldots \ldots \ldots \ldots \ldots \ldots, 20$

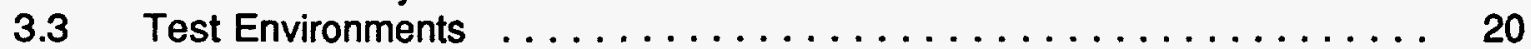

3.4 Environmental Test Matrix - Statistical Approach ............ 22

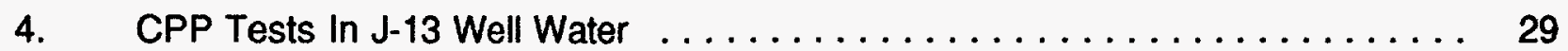

5. CPP Tests In Chloride Solutions $\ldots \ldots \ldots \ldots \ldots \ldots \ldots \ldots \ldots \ldots \ldots \ldots \ldots$

6. Statistical Matrix-CPP Tests For Copper-Base Alloys $\ldots \ldots \ldots \ldots \ldots \ldots \ldots \quad 47$

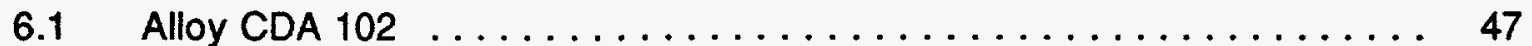

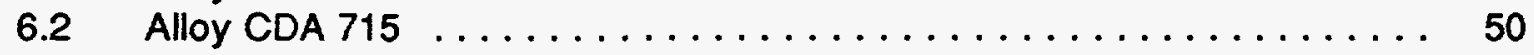

7. Statistical Matrix-CPP Tests For Fe-Cr-Ni Alloys $\ldots \ldots \ldots \ldots \ldots \ldots \ldots \ldots$

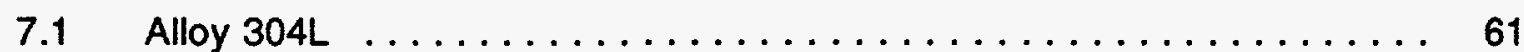

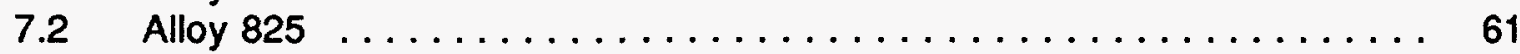

8. Effects Of Temperature On CPP Behavior .................. 67

$8.1 \quad$ Copper-Base Alloys $\ldots \ldots \ldots \ldots \ldots \ldots \ldots \ldots \ldots \ldots \ldots \ldots, 67$

8.2 Fe-Cr-Ni Alloys $\ldots \ldots \ldots \ldots \ldots \ldots \ldots \ldots \ldots \ldots \ldots \ldots \ldots, 71$

9. Effects Of Heat Transfer On CPP Behavior $\ldots \ldots \ldots \ldots \ldots \ldots \ldots \ldots \ldots$

$9.1 \quad$ Copper-Base Alloys $\ldots \ldots \ldots \ldots \ldots \ldots \ldots \ldots \ldots \ldots \ldots \ldots, 77$

$9.2 \quad$ Fe-Cr-Ni Alloys $\ldots \ldots \ldots \ldots \ldots \ldots \ldots \ldots \ldots \ldots \ldots \ldots \ldots \ldots$ 


\section{TABLE OF CONTENTS (Continued)}

Page

10. Effects Of Welding On CPP Behavior $\ldots \ldots \ldots \ldots \ldots \ldots \ldots \ldots \ldots$

10.1 Copper-Base Alloys $\ldots \ldots \ldots \ldots \ldots \ldots \ldots \ldots \ldots \ldots \ldots \ldots$

10.2 Fe-Cr-Ni Alloys $\ldots \ldots \ldots \ldots \ldots \ldots \ldots \ldots \ldots \ldots \ldots \ldots \ldots, 88$

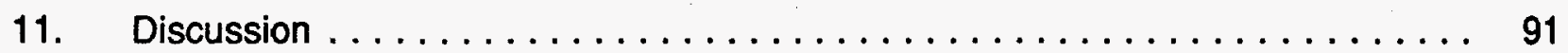

11.1 CPP Tests In J-13 Well Water ......................... 91

11.2 Statistical Matrix of CPP Tests $\ldots \ldots \ldots \ldots \ldots \ldots \ldots \ldots \ldots .92$

11.2.1 Copper-Base Alloys $\ldots \ldots \ldots \ldots \ldots \ldots \ldots \ldots \ldots \ldots$

11.2.2 Fe-Cr-Ni Alloys ......................... 104

11.3 Thermal Effects On CPP Behavior $\ldots \ldots \ldots \ldots \ldots \ldots \ldots \ldots \ldots \ldots$

11.3.1 Isothermal Tests . ..................... 111

11.3.2 Temperature Gradient Tests ................. 112

11.4 Effects Of Welding On CPP Behavior ................. 113

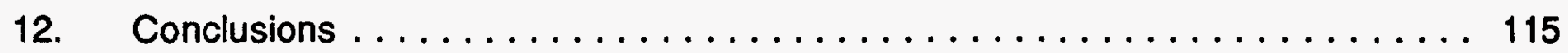

13. Recommendations For Further Research $\ldots \ldots \ldots \ldots \ldots \ldots \ldots \ldots \ldots$

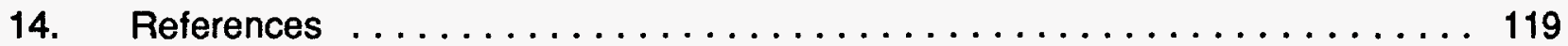

Appendix A: Potentiodynamic Curves For Alloy CDA $102 \ldots \ldots \ldots \ldots \ldots \ldots \ldots$

Appendix B: Potentiodynamic Curves For Alloy CDA $175 \ldots \ldots \ldots \ldots \ldots \ldots$.

Appendix C: Potentiodynamic Curves For Alloy 304L . . . . . . . . . . . . . 165

Appendix D: Potentiodynamic Curves For Alloy $1825 \ldots \ldots \ldots \ldots \ldots \ldots \ldots$. . . . 187

Appendix E: Temperature-Effect Studies . . . . . . . . . . . . . . . . 209

Appendix F: Temperature-Effect Studies With Heat-Transfer Specimens . . . . . . . . 222

Appendix G: Welding-Effect Studies . . . . . . . . . . . . . . . 232

Appendix H: Welding Specifications For Container Materials ........... 245

Appendix I: Candidate Alloy Compositions $\ldots \ldots \ldots \ldots \ldots \ldots \ldots \ldots \ldots$ 


\section{LIST OF FIGURES}

Page

Figure 2.1 Representative Stratigraphic Section in Nevada Tuff (Drillhole

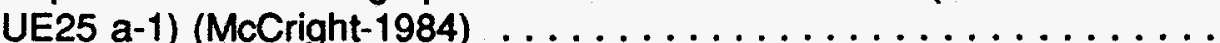

Figure 2.2 Comparative Canister Surface Temperature-Time Profiles For Different Waste Packages In A Tuff Repository (Vertical Emplacement, $50 \mathrm{~kW} /$ acre Areal Loading) (McCright-1984) ........

Figure 2.3 Silicon And Sodium Concentrations In J-13 Well Water Reacted With Crushed G-1 Material At $150^{\circ} \mathrm{C}$ As A Function of Time In Days (Knauss-1985a) . . . . . . . . . . . . . . . . . .

Figure 2.4 Aluminum, Potassium, Calcium, Magnesium, And pH Analyses From J-13 Well Water Reacted With Crushed G-1 Material At $150^{\circ} \mathrm{C}$ As A Function of Time In Days (Knauss-1985a) ...........

Figure 3.1 Schematic Of Typical Cyclic Potentiodynamic Polarization Curve .................................

Figure 3.2 Electrochemical Cell Used For Ambient Pressure Potentiodynamic Polarization Experiments

Figure 4.1 CPP Curve For Alloy CDA 102 In Actual J-13 Well Water At $80^{\circ} \mathrm{C}$ Run At A Scan Rate Of $3.6 \mathrm{~V} / \mathrm{hr}$ Following A One To Two

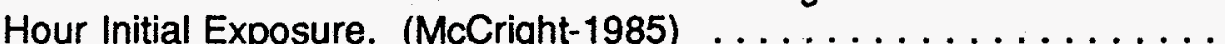

Figure 4.2 CPP Curve For Alloy CDA 102 In Simulated J-13 Well Water At $80^{\circ} \mathrm{C}$ Run At A Scan Rate Of 3.6 V/hr Following A One Hour

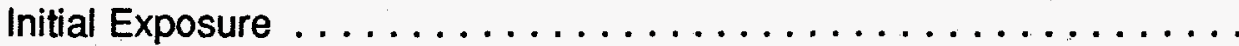

Figure 4.3 CPP Curve For Alloy CDA 102 In Actual J-13 Well Water At $80^{\circ} \mathrm{C}$ Run At A Scan Rate Of 3.6 V/hr Following A One Hour

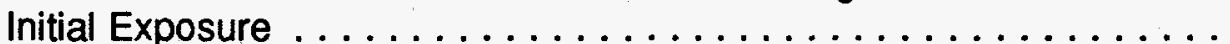

Figure 4.4 CPP Curve For Alloy CDA 102 in Simulated J-13 Well Water At $80^{\circ} \mathrm{C}$ Run At A Scan Rate Of $3.6 \mathrm{~V} / \mathrm{hr}$ Following A Fifteen Hour

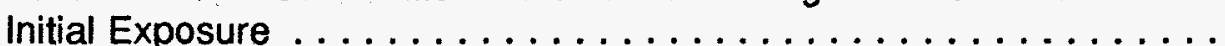

Figure 4.5 CPP Curve For Alloy CDA 102 In Actual J-13 Well Water At $80^{\circ} \mathrm{C}$ Run At A Scan Rate Of 3.6 V/hr Following A Fifteen Hour

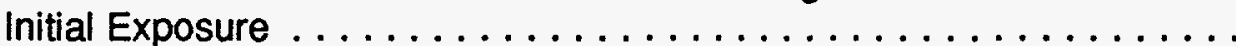




\section{LIST OF FIGURES (Continued)}

Page

Figure 4.6 CPP Curve For Alloy CDA 102 In Simulated J-13 Well Water At $90^{\circ} \mathrm{C}$ Run At A Scan Rate of $0.6 \mathrm{~V} / \mathrm{hr}$ Following A Fifteen Hour

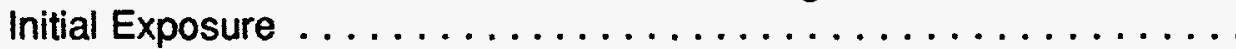

Figure 4.7 CPP Curve For Alloy CDA 715 In Simulated J-13 Well Water At $90^{\circ} \mathrm{C}$ Run At A Scan Rate Of $0.6 \mathrm{~V} / \mathrm{hr}$ Following A Fitteen Hour

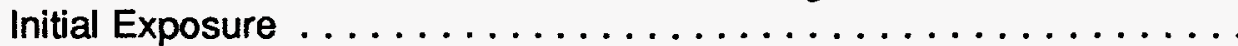

Figure 4.8 CPP Curve For Alloy 304L In Simulated J-13 Well Water At $90^{\circ} \mathrm{C}$ Run At A Scan Rate Of $0.6 \mathrm{~V} / \mathrm{hr}$ Following A Fifteen Hour Initial Exposure ..........................

Figure 4.9 CPP Curve For Alloy 825 In Simulated J-13 Well Water At $90^{\circ} \mathrm{C}$ Run At A Scan Rate Of $0.6 \mathrm{~V} / \mathrm{hr}$ Following A Fifteen Hour Initial

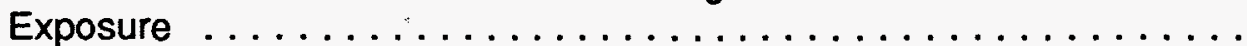

Figure 5.1 CPP Curve For Alloy CDA 102 In Simulated J-13 Well Water At $90^{\circ} \mathrm{C}$ Run At A Scan Rate Of $0.6 \mathrm{~V} / \mathrm{hr}$

Figure 5.2 CPP Curve For Alloy CDA 102 In Simulated J-13 Well Water At $90^{\circ} \mathrm{C}$ With The Chloride Concentration Increased To $1000 \mathrm{mg} / \mathrm{l}$

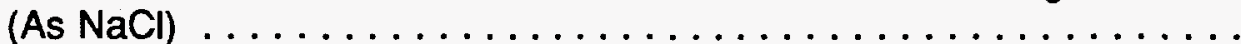

Figure 5.3 CPP Curve For Alloy CDA 715 In Simulated J-13 Well Water At $90^{\circ} \mathrm{C}$ Run At A Scan Rate Of $0.6 \mathrm{~V} / \mathrm{hr}$

Figure 5.4 CPP Curve For Alloy CDA 715 in Simulated J-13 Well Water At $90^{\circ} \mathrm{C}$ With The Chloride Concentration Increased To $1000 \mathrm{mg} / \mathrm{l}$

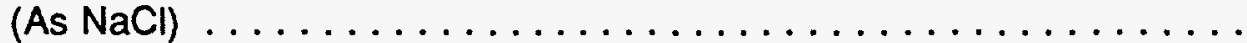

Figure 5.5 CPP Curve For Alloy 304L In Simulated J-13 Well Water At $90^{\circ} \mathrm{C}$ Run At A Scan Rate Of $0.6 \mathrm{~V} / \mathrm{hr}$

Figure 5.6 CPP Curve For Alloy 304L in Simulated J-13 Well Water At $90^{\circ} \mathrm{C}$ With The Chloride Concentration Increased To $1000 \mathrm{mg} / \mathrm{l}$

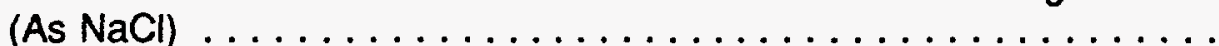

Figure 5.7 CPP Curve For Alloy 825 In Simulated J-13 Well Water At $90^{\circ} \mathrm{C}$

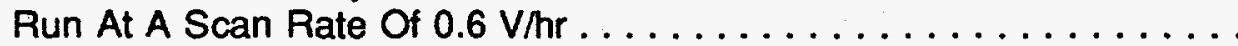

Figure 5.8 CPP Curve For Alloy 1825 In Simulated J-13 Well Water At $90^{\circ} \mathrm{C}$ With The Chloride Concentration Increased To $1000 \mathrm{mg} /$ (As

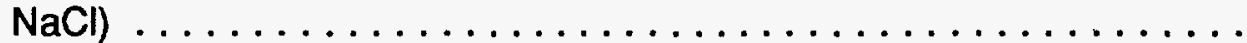




\section{LIST OF FIGURES (Continued)}

Page

Figure 6.1 CPP Curve For Alloy CDA 102 In Test Solution Number 8. No Pitting, But Locally Active Attack And Oxide Growth Observed During Post-Test Evaluation . . . . . . . . . . . . . . . . . . .

Figure 6.2 CPP Curve For Alloy CDA 102 In Test Solution Number 15. Pitting Observed During Post-Test Evaluation . . . . . . . . . . .

Figure 6.3 CPP Curve For Alloy CDA 102 In Test Solution Number 10. No Pitting, But Locally Active Attack Observed During Post-Test Evaluation

Figure 6.4

CPP Curve For Alloy CDA 102 In Test Solution Number 12. Pitting As Well As Active Corrosion Observed During Post-Test Evaluation . . . . . . . . . . . . . . . . . . . . .

Figure 6.5 CPP Curve For Alloy CDA 102 In Test Solution Number 7. Active Corrosion Observed During Post-Test Evaluation . . . . . . . . .

Figure 6.6 CPP Curves For Alloy CDA 102 In Test Solution Numbers 33 Through 36 (Identical Solutions With Average Concentrations Of Environmental Variables) . . . . . . . . . . . . . . . . .

Figure 6.7 CPP Curve For Alloy CDA 715 In Test Solution Number 7. Active Corrosion Observed During Post-Test Evaluation . . . . . . . .

Figure 6.8 CPP Curve For Alloy CDA 715 In Test Solution Number 8. Pitting And Local Active Corrosion Observed During Post-Test

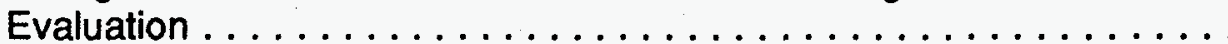

Figure 6.9 CPP Curve For Alloy CDA 715 In Test Solution Number 15. Active Corrosion, No Pitting Observed During Post-Test Evaluation

Figure 6.10 CPP Curve For Alloy CDA 715 In Test Solution Number 24. No Pitting Observed During Post-Test Evaluation; Dark Shiny Oxide

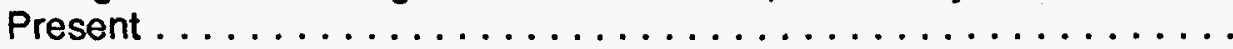

Figure 6.11 CPP Curve For Alloy CDA 715 In Test Solution Number 6. Local Active Corrosion, No Pitting Observed During Post-Test Evaluation ............................... 


\section{LIST OF FIGURES (Continued)}

Page

Figure 6.12 CPP Curve For Alloy CDA 715 In Test Solution Number 17. No Pitting Observed During Post-Test Evaluation; Surface Remained Bright And Shiny, Free of Any Visible Oxide ...........

Figure 6.13 CPP Curves For Alloy CDA 715 In Test Solution Numbers 33 Through 36 (Identical Solutions With Average Concentrations Of Environmental Variables) ..........................

Figure 7.1 CPP Curves For Alloy 304L In Test Solution Numbers 33 Through 36 (Identical Solutions With Average Concentrations Of Environmental Variables) . . . . . . . . . . . . . . . . . .

Figure 7.2. CPP Curves For Alloy 825 in Test Solution Numbers 33 Through 36 (Identical Solutions With Average Concentrations Of Environmental Variables)..$\ldots \ldots \ldots \ldots \ldots \ldots \ldots \ldots \ldots$

Figure 8.1 CPP Curves For Alloy CDA 102 In Simulated J-13 Well Water

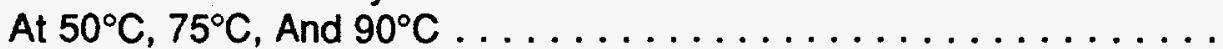

Figure 8.2 CPP Curves For Alloy CDA 715 In Simulated J-13 Well Water

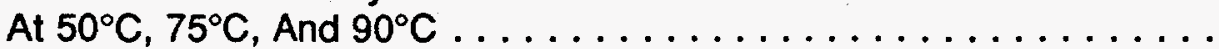

Figure 8.3. CPP Curves For Alloy 304L in Simulated J-13 Well Water At $50^{\circ} \mathrm{C}, 75^{\circ} \mathrm{C}$, And $90^{\circ} \mathrm{C}$

Figure 8.4. CPP Curves For Alloy 825 In Simulated J-13 Well Water At $50^{\circ} \mathrm{C}, 75^{\circ} \mathrm{C}$, And $90^{\circ} \mathrm{C}$

Figure 9.1 Schematic of The Heat-Transfer Specimen $\ldots \ldots \ldots \ldots \ldots$

Figure 9.2 Electrochemical Cell For Ambient Pressure PotentiodynamicPolarization Experiments On Heat-Transfer Specimens ...........

Figure 11.1 The Effects Of Solution Variables, Over The Defined Concentration Ranges, On The Corrosion Parameters For Alloy CDA 102 in Solution Numbers 1 through $36 \ldots \ldots . \ldots 100$

Figure 11.2 The Effects Of Solution Variables, Over The Defined Concentration Ranges, On The Corrosion Parameters For Alloy CDA 102 In Solution Numbers 39 Through 42; 80\% Confidence Level 


\section{LIST OF FIGURES (Continued)}

Page

Figure 11.3 The Effects Of Solution Variables, Over The Defined Concentration Ranges, On The Corrosion Parameters For Alloy CDA 715 In Solution Numbers 1 Through $36 \ldots \ldots \ldots \ldots$

Figure 11.4 The Effects Of Solution Variables, Over The Defined Concentration Ranges, On Corrosion Parameters For Alloy CDA 715 In Solution Numbers 39 Through 42; $80 \%$ Confidence Level

Figure 11.5 The Effects Of Solution Variables, Over The Defined Concentration Ranges, On The Corrosion Parameters For Alloy $304 \mathrm{~L}$ In Solution Numbers 1 through $36 \ldots \ldots \ldots \ldots \ldots$.

Figure 11.6 The Effects Of Solution Variables, Over The Defined Concentration Ranges, On The Corrosion Parameters For Alloy 304L In Solution Numbers 39 Through 42; $80 \%$ Confidence

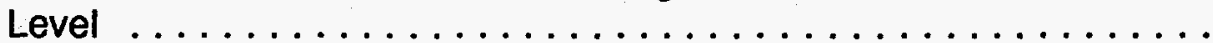

Figure 11.7 The Effects Of Solution Variables, Over The Defined Concentration Ranges, On The Corrosion Parameters For Alloy 825 In Solution Numbers 1 Through 36; 80\% Confidence

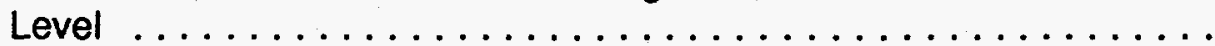

Figure 11.8 The Effects Of Solution Variables, Over The Defined Concentration Ranges, On The Corrosion Parameters For Alloy 825 In Solution Numbers 39 Through $42 ; 80 \%$ Confidence

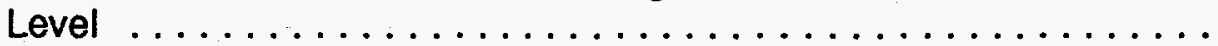




\section{LIST OF TABLES}

Page

Table 2.1 Percentages Of Major Constituents In Topopah Springs Tuff, Drill Core USW GU-3, Samples 60, 61 And 62. $\mathrm{Fe}_{2} \mathrm{O}_{3}$ Represents Total Iron (Schuraytz-1985) . . . . . . . . . . .

Table 2.2 Chemical Composition Of Test Solutions At The End Of Corrosion Tests $(\mu \mathrm{g} / \mathrm{ml})$ (Undiluted And Filtered Solution) (Abraham-1986)

Table 3.1 Chemical Composition Of Simulated Tuff Groundwater And J-13

Well Water From Yucca Mountain, Nevada (For Comparison) . . . . . .

Table 3.2 Concentration Ranges For Environmental Species In Tuff

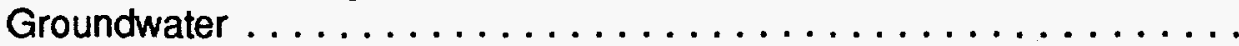

Table 3.3 List Of Variables Included In The Matrix Of Potentiodynamic

Polarization Tests In Task $2 \ldots \ldots \ldots \ldots \ldots \ldots \ldots \ldots \ldots$

Table 3.4 Series Of Tests Included in The Matrix Of Potentiodynamic

Polarization Tests In Task $2 \ldots \ldots \ldots \ldots \ldots \ldots \ldots \ldots$

Table 4.1 Polarization Parameters For The Candidate Alloys in Actual And

Simulated $\mathrm{J}-13$ Well Water . . . . . . . . . . . . . . . . . .

Table 5.1 Polarization Parameters For The Candidate Alloys In Simulated $\mathrm{J}-13$ Well Water At $90^{\circ} \mathrm{C}$, With And Without Salt . . . . . . . . .

Table 6.1 Polarization Parameters For The Test Solutions In The Statistically-Designed Matrix Of Experiments For Alloy CDA 102

Table 6.2

Polarization Parameters For The Test Solutions In The Statistically-Designed Matrix Of Experiments For Alloy CDA 715

Table 7.1

Polarization Parameters For The Test Solutions In The Statistically-Designed Matrix Of Experiments For Alloy 304L

Table 7.2

Polarization Parameters For The Test Solutions In The Statistically-Designed Matrix Of Experiments For Alloy $825 \ldots \ldots$. . . .

Table 8.1 Compositions Of Selected Solutions From The Experimental Matrix Used In The Temperature-Effect Studies Of The CopperBase Alloys . . . . . . . . . . . . . . . . . . . . . . . 


\section{LIST OF TABLES (Continued)}

Page

Table 8.2 Effect Of Temperature On The Polarization Parameters Taken From CPP Curves On Copper-Base Alloys In Simulated J-13 Well Water And In Selected Solutions From The Test Matrix

Table 8.3 Compositions Of Selected Solutions From The Experimental Matrix Used in The Temperature-Effect Studies Of $\mathrm{Fe}-\mathrm{Cr}-\mathrm{Ni}$ Alloys ................................

Table 8.4 Effect Of Temperature On The Polarization Parameters Taken From CPP Curves On Fe-Cr-Ni Alloys In Simulated J-13 Well Water And in Selected Solutions From The Test Matrix . . . . . . . . . . .

Table 9.1 Composition Of J-13 Well Water And Solution Number 22 Used For The Heat-Transfer Studies Of The Copper-Base Alloys . . . . . . .

Table 9.2

Comparison Of CPP Parameters For Isothermal And HeatTransfer Specimens Of Alloy CDA 102 And Alloy CDA 715

Table 9.3 Composition Of J-13 Well Water And Solution Number 7 Used For The Heat-Transfer Studies of The Fe-Cr-Ni Alloys . . . . . . . . .

Table 9.4 Comparison Of CPP Parameters For Isothermal And HeatTransfer Specimens Of Alloy 304L And Alloy 825 . . . . . . . . . . . .

Table 10.1 Compositions Of $\mathrm{J}-13$ Well Water And Selected Solutions From The Experimental Matrix Used In The Welding-Effect Studies Of The Copper-Base Alloys . . . . . . . . . . . . . . . . . .

Table 10.2 Comparison Of CPP Parameters For Wrought And Welded Specimens Of The Copper-Base Alloys ...............

Table 10.3 Compositions Of J-13 Well Water And Selected Solutions From The Experimental Matrix Used In The Welding-Effect Studies Of The Fe-Cr-Ni Alloys . . . . . . . . . . . . . . . . . . .

Table 10.4 Comparison Of CPP Parameters For Wrought And Welded Specimens of The Fe-Cr-Ni Alloys . . . . . . . . . . . . . .

Table 11.1 Summary Of The Statistical Analysis For Alloy CDA 102. Coefficients Were Selected Based On $80 \%$ Confidence Level. 


\section{LIST OF TABLES (Continued)}

Page

Table 11.2 Summary Of The Statistical Analysis For Alloy CDA 715. Coefficients Were Selected Based On $80 \%$ Confidence Level. (Solution Numbers 1 Through 36. )

Table 11.3 Summary Of The Statistical Analysis For Alloy 304L. Coefficients Were Selected Based On $80 \%$ Confidence Level. (Solution Numbers 1 Through 36.)

Table 11.4 Summary Of The Statistical Analysis For Alloy 825 . Coefficients Were Selected Based On $80 \%$ Confidence Level. (Solution Numbers 1 Through 36.)

Table 11.5 Summary Of The Statistical Analysis For Each Of The Four Alloys In Solution Numbers 39 Through 42. Coefficients Were Selected Based On $80 \%$ Confidence Level 


\section{EXECUTIVE SUMMARY}

CC Technologies is investigating the long-term performance of container materials used for highlevel radioactive waste packages as part of the information needed by the Nuclear Regulatory Commission to assess the Department of Energy's application to construct a geologic repository for the high-level radioactive waste. The scope of work consists of employing short-term techniques, such as electrochemical and mechanical techniques to examine a wide range of possible failure modes. Long-term tests are being used to verify and further examine specific failure modes identified as important by the short-term studies.

This report summarizes the results of cyclic-potentiodynamic-polarization (CPP) studies performed in Task 2 of the program on candidate container materials for the Tuff Repository. The CPP technique was used to provide an understanding of how specific variables such as environmental composition, temperature, alloy composition, and welding affect both the general- and localizedcorrosion behavior of the alloys in simulated repository environments.

Two classes of alloys were evaluated in this study for use as container materials for the Tuff Repository; $\mathrm{Fe}-\mathrm{Cr}-\mathrm{Ni}$ alloys and copper-base alloys. The candidate $\mathrm{Fe}-\mathrm{Cr}-\mathrm{Ni}$ alloys were Type 304L Stainless Steel (Alloy 304L) and Incoloy Alloy 825 (Alloy 825). The candidate copper-base alloys were CDA 102 Copper (Alloy CDA 102) and Copper-30 Nickel (Alloy CDA 715).

Cyclic-potentiodynamic-polarization (CPP) tests were performed with each of the four candidate alloys in simulated $\mathrm{J}-13$ well water and in 42 synthetic environments. These synthetic environments were developed using a statistical model specifically designed to examine corrosion behavior in complex environments. The solution variables of interest and their lower and upper limits were selected from compositional ranges reported in the literature for the Tuff well water, Tuff groundwater heated in the presence of Tuff rock, and Tuff groundwater heated in the presence of radiation. The corrosion behavior of the alloys in these simulated repository environments, as determined by the CPP technique, was then used as the foundation for further studies to examine a wide range of possible failure modes included in Task 2 of the program and in other tasks.

The effects of temperature on the corrosion behavior were evaluated in Task 2 by two test methods; temperature and temperature gradients. The first temperature-studies experiments examined changes in corrosion behavior when CPP tests were performed with each of the alloys in selected environments at $50^{\circ} \mathrm{C}, 75^{\circ} \mathrm{C}$, and $90^{\circ} \mathrm{C}$. The environments selected for this study were based upon the results of the corrosion behavior of the alloys as determined previously by the CPP technique. The following solutions were selected from the experimental test matrix for evaluation:

(1) Simulated $\mathrm{J}-13$ well water,

(2) Solution Number 7, an active-corrosion solution, for the copper-base alloys, and one that promoted pitting of the $\mathrm{Fe}-\mathrm{Cr}-\mathrm{Ni}$ alloys,

(3) Solution Number 10, which promoted passivation and pitting of the copper-base alloys, and

(4) Solution Number 20, which promoted passivation and pitting of the $\mathrm{Fe}-\mathrm{Cr}-\mathrm{Ni}$ alloys. 
The results of these CPP experiments indicated that no systematic trends were evident for the alloy-environment systems which were evaluated, further indicating that there is not a strong temperature dependence on the corrosion behavior over the limited temperature range of $50^{\circ} \mathrm{C}$ to $90^{\circ} \mathrm{C}$.

The second temperature-studies test method was developed to examine the effects of temperature gradients on the corrosion behavior when CPP tests were performed utilizing a specimen which was internally heated to $90^{\circ} \mathrm{C}$ while maintaining the test solution at $50^{\circ} \mathrm{C}$. The environments selected for this study were also based upon the results of the corrosion behavior of the alloys as previously determined by the CPP technique. The following solutions were selected from the experimental test matrix for evaluation:

Simulated J-13 well water, Solution Number 7 ,

(3) Solution Number 22, which promoted pitting of the copper-base alloys.

The results of these CPP experiments indicated that, in simulated $\mathrm{J}-13$ well water, heat transfer appeared to have an effect on the corrosion behavior of each of the four alloys. Optical examination of the specimens revealed more severe etching and pitting after heat-transfer experiments as compared with observations made following isothermal tests in simulated $\mathrm{J}-13$ well water. Temperature gradients did not appear to have a major effect on CPP behavior in test Solution Numbers 7 and 22.

Task 2 also examined the effect of welding on the corrosion behavior of the candidate alloys by the CPP technique. In preparation for these tests, V-shaped grooves were machined longitudinally in $6^{\prime \prime} \times 12^{\prime \prime}$ plates of each of the four alloys. Rods having the same alloy composition were welded in these grooves. A welder who is licensed for welding nuclear power plant vessels performed the actual welding. Cylindrical electrochemical specimens were then machined longitudinally from the weld and evaluated by the CPP technique.

The environments selected for this study were based upon the results of the corrosion behavior of the wrought material as previously determined by the CPP technique. The following solutions were selected from the experimental test matrix for evaluation:

(1) Simulated J-13 well water,

(2) Solution Number 7 ,

(3) Solution Number 25, an active-corrosion solution for the $\mathrm{Fe}-\mathrm{Cr}-\mathrm{Ni}$ alloys, and

(4) Solution Number 29, which promoted pitting of the copper-base alloys.

The results of the CPP experiments indicated that the copper-base welds appear to be somewhat more susceptible to localized corrosion than the wrought alloys in the simulated $\mathrm{J}-13$ environment. In the case of Alloy 825, the CPP curve did not exhibit hysteresis, but some etching was found around bubbles that formed on the welded specimen during the test with simulated $\mathrm{J}-13$ well water. Neither wrought nor welded specimens of Alloy $304 \mathrm{~L}$ showed any attack in the J-13 environment.

In Solution Number 7, no appreciable change in polarization parameters was observed for either the welded $\mathrm{Fe}-\mathrm{Cr}$-Ni or copper-base alloys. The welded Alloy CDA 102 exhibited a hysteresis 
loop, which typically indicates localized attack. However, only etching was evident on the specimen. No hysteresis loop was evident in the data of the wrought alloy.

In Solution Number 29, both of the welded copper-base alloys generally exhibited lower freecorrosion potentials, higher corrosion currents, and lower protection potentials than the unwelded specimens. Optical examination of the welded specimens revealed only oxide growth. No pitting was observed as in testing with the wrought alloys. These observations, along with the actual shaped of the CPP curves, suggest that the welds in the copper-base alloys exhibited less of a tendency to passivate than the wrought material. This behavior could lead to galvanic corrosion of the welds and warrants further study.

For the Fe-Cr-Ni alloys, the welds performed as well as, and in some cases slightly better than, the wrought material in Solution Number 25. There was no indication that the welds were more susceptible to attack than the wrought material. Variation in the corrosion parameters between the welded and wrought specimens is probably attributed to scatter in the data. 



\section{INTRODUCTION}

The Department of Energy (DOE) is conducting a program for the disposal of high-level radioactive waste in a deep-mined geologic repository. The Nuclear Regulatory Commission (NRC), which is responsible for regulating high-level radioactive waste disposal, will review DOE's application for the construction and operation of the repository. To assist in evaluating DOE's application, the NRC's Office of Nuclear Regulatory Research is developing an understanding of the long-term performance of the geologic repository. As part of this effort, Cortest Columbus Technologies has been awarded a contract to investigate the long-term performance of container materials used for high-level waste packages. At the direction of the NRC, the program is focused on the Tuff Repository.

The scope of work consists of employing relatively short-term electrochemical techniques to examine a wide range of possible failure modes. Long-term tests (1-2 years) are being used to verify the short-term studies.

This report summarizes the results of cyclic-potentiodynamic-polarization (CPP) studies performed in Task 2 of the program on candidate container materials for the Tuff Repository. The purpose of Task 2 was to examine the effects of environmental and metallurgical variables on the electrochemical behavior of the candidate materials to provide an understanding of how these variables affect both the general- and localized-corrosion behavior of the alloys in simulated repository environments. Specifically, the effects of environmental composition, temperature, alloy composition and welding were evaluated in simulated environments between $50^{\circ} \mathrm{C}$ and $90^{\circ} \mathrm{C}$. 



\section{BACKGROUND - THE TUFF REPOSITORY ENVIRONMENT}

\subsection{Nominal Environment}

The Tuff repository will be located in the Topopah Spring Member of the Paintbrush Tuff under Yucca Mountain, 100 miles northwest of Las Vegas, Nevada in the Nevada Test Site (NTS). The site is located in an extremely arid zone with about $15 \mathrm{~cm} / \mathrm{year}$ annual precipitation. The evaporation-transpiration rates also are very high so the net water percolating down from the surface is of the order of a few millimeters per year (Montazer - 1984).

Tuff is an igneous rock of volcanic origin and is composed of volcanic rock fragments (shards) and ash. The structure of the tuff deposits depends on the cooling rate and degree of compaction after the volcanic eruption. The rock shards weld together and the compacted material may remain glassy or may devitrify. A layered structure develops; a densely welded core surrounded above and below by zones of material decreasing in density and strength. In the postdepositional period, alteration of the tuff layers occurs. Crystallization transforms the glassy material to feldspar plus quartz or cristobalite. Zeolitization produces hydrous silicates by reaction of the glassy material with groundwater. A typical stratigraphy of the tuff at the NTS is shown in Figure 2.1. A more detailed description of these tuff layers is found in Johnstone-1981.

The potential repository horizon is in the lower, densely welded and devitrified portion of the Topopah Spring Member located 700 to 1400 feet above the static water table. The bulk rock at the horizon is composed of rhyolite with a small range in composition as shown in Table 2.1. This small variation in geochemistry demonstrates that the host rock may be considered uniform, according to Glassley-1986.

A reference water used in many repository studies has been taken from Well $\mathrm{J}-13$. That well is located near the repository site and produces water which has flowed through the Topopah Spring Member, where it lies at a lower elevation and is in the saturated zone. The $\mathrm{J}-13$ well water is the best available source of water from the Topopah Spring Member, but may not be a good approximation of the actual water that will be present in the repository.

The location of the repository above the static water table has a major impact on the anticipated environment. First of all, the environment will be aerated; the $\mathrm{J}-13$ well water contains $5.7 \mathrm{ppm}$ dissolved oxygen which probably represents a lower limit for oxygen. This condition is unique in that the plans for all other repositories, either in the United States or elsewhere, have called for locations below the static water table where conditions are deaerated (anoxic).

A second feature of the location of the repository above the water table is the elimination of the hydrostatic head on the waste container. At the repository elevation, the boiling point for water is about $95^{\circ} \mathrm{C}$, and thus the environment at the waste package surface will be steam and air during the early life of the repository. 


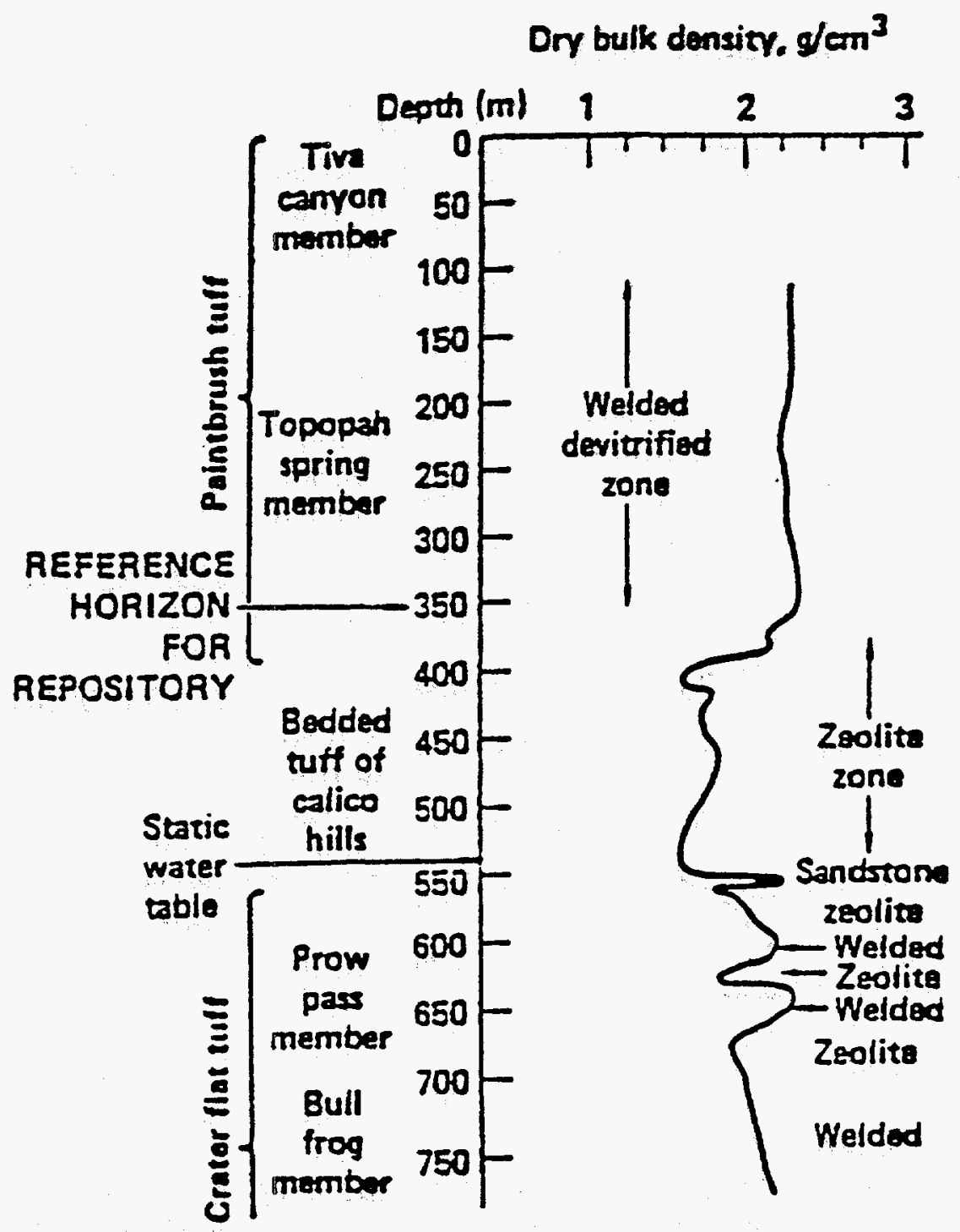

(Drilthole UE 25 a-1)

Figure 2.1 Representative Stratigraphic Section In Nevada Tuff (Drillhole UE25 a-1) (McCright-1984). 
Table 2.1 Percentages Of Major Constituents In Topopah Springs Tuff, Drill Core USW GU-3, Samples 60, 61 And 62. $\mathrm{Fe}_{2} \mathrm{O}_{3}$ Represents Total Iron (Schuraytz-1985).

\begin{tabular}{||l|l|l|l|l|l||}
\hline Constituent & 60 & 61 & 62 & Average & Std Dev \\
\hline $\mathrm{SiO}_{2}$ & 78.4 & 78.9 & 78.9 & 78.73 & 0.24 \\
$\mathrm{Al}_{2} \mathrm{O}_{3}$ & 12.0 & 12.3 & 12.2 & 12.17 & 0.12 \\
$\mathrm{Fe}_{2} \mathrm{O}_{3}$ & 1.016 & 0.973 & 1.000 & 0.996 & 0.018 \\
$\mathrm{CaO}$ & 0.492 & 0.451 & 0.480 & 0.474 & 0.017 \\
$\mathrm{MgO}$ & 0.1271 & 0.1281 & 0.1126 & 0.123 & 0.007 \\
$\mathrm{TiO}_{2}$ & 0.1108 & 0.0927 & 0.0984 & 0.101 & 0.008 \\
$\mathrm{Na} 2 \mathrm{O}$ & 4.07 & 3.92 & 4.25 & 4.08 & 0.13 \\
$\mathrm{~K}_{2} \mathrm{O}$ & 3.71 & 3.18 & 2.94 & 3.28 & 0.32 \\
$\mathrm{P}_{2} \mathrm{O}_{2}$ & 0.01 & 0.01 & 0.03 & 0.02 & 0.01 \\
$\mathrm{MnO}$ & 0.0624 & 0.0455 & 0.0488 & 0.052 & 0.007 \\
\hline
\end{tabular}




\subsection{Thermal Effects}

The repository is being designed for two types of waste packages; spent fuel and processed defense high level waste in the form of borosilicate glass. The spent fuel will have the highest thermal output of between 1.3 and $3.3 \mathrm{Kw}$ per container, while the glass will have an output of 0.25 to $0.47 \mathrm{Kw}$ per container. The temperature histories of the waste packages are sensitive functions of the thermal properties of the near-field rock, the specific configuration of boreholes and emplacement drifts, heat transfer mode as well as container output power; none of these factors has been precisely defined. Comparative canister surface temperatures as a function of time are shown in Figure 2.2 for one set of conditions. Note that the canister surface for spent fuel remains above the boiling temperature over at least a 300 year period following emplacement.

These elevated temperatures should exclude liquid water from the near field of the repository for several hundred years, although liquid water may be present in the pores in the rock up to $140^{\circ} \mathrm{C}$. It is also possible that vadose water may come in contact with some of the waste packages during periods of liquid water movement through the repository.

A consequence of the elevated temperature in the repository will be the interaction of groundwater with the host rock in the vicinity of the waste package. A number of interaction studies has been performed over temperatures ranging from $90-250^{\circ} \mathrm{C}$ with core wafers, crushed core wafers in gold-bags and polytetrafluoroethylene (PTFE)-lined autoclaves. Rapid shifts in chemistry occurred with crushed rock as opposed to wafers because of the higher surface area with the former. Changes in solution concentration at $90^{\circ} \mathrm{C}$ were minor; whereas, more pronounced shifts occurred at $150^{\circ} \mathrm{C}$. Results obtained by Knauss $-1985 \mathrm{a}$ for crushed core material at $150^{\circ} \mathrm{C}$ are given in Figures 2.3 and 2.4. These data show that the silicon ( $\mathrm{Si}$ ) concentrations increased from about $30 \mathrm{ppm}$ to around $150 \mathrm{ppm}$ within 60 days, while the sodium $(\mathrm{Na})$ concentration only increased slightly over the test period. The concentrations of aluminum* (Al), magnesium (Mg) and calcium (Ca) decreased with time while that of potassium* (K) was not greatly affected by thermal interaction; the $\mathrm{pH}$ decreased very slightly.

Another consequence of the elevated temperatures in the repository will be the boiling of groundwater in the vicinity of the waste package. This will lead to the concentration of the species, both beneficial and deleterious in the groundwater. Abraham (1986) has performed some solution analyses on boiling J-13 groundwaters at Brookhaven National Laboratory. The solutions were boiled in the presence of tuft rock and specimens of several stainless steels. The results are summarized in Table 2.2. These data show that the composition of $\mathrm{J}-13$ well water changed quite dramatically as a result of boiling. The stable concentrations of most species after one year were more than an order of magnitude higher than those in the $\mathrm{J}-13$ well water. Some species, such as $\mathrm{SO}_{4}{ }^{2-}, \mathrm{NO}_{3}{ }^{-}, \mathrm{Ca}^{2+}$ and $\mathrm{K}^{+}$exhibited a maximum in concentration after only a few months which suggests the precipitation of compounds such as $\mathrm{CaSO}_{4}$, etc.

*Both aluminum and potassium exhibited initial transient increases in concentrations. 


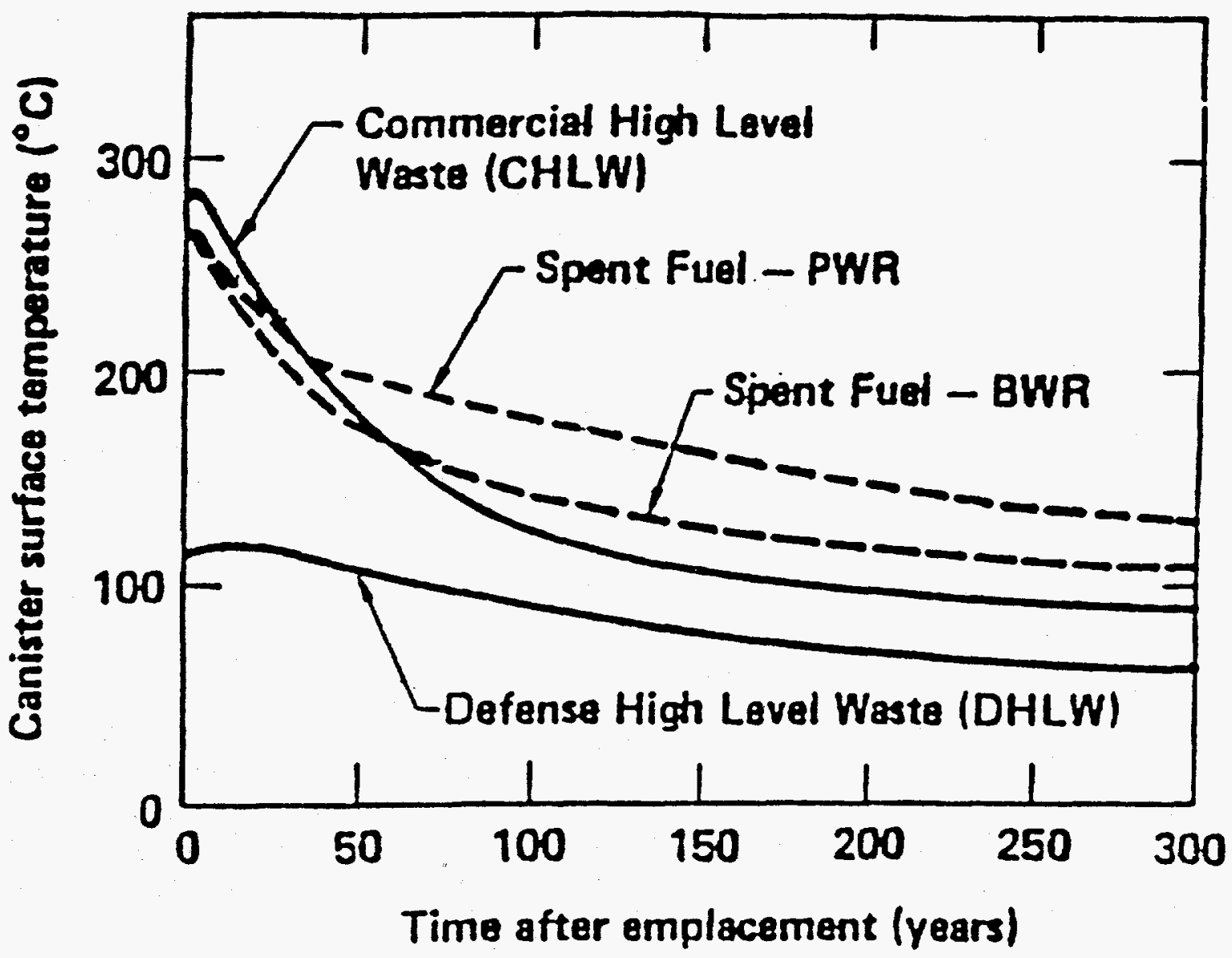

Figure 2.2 Comparative Canister Surface Temperature-Time Profiles For Different Waste Packages In A Tuff Repository (Vertical Emplacement, $50 \mathrm{~kW} / \mathrm{acre}$ Areal Loading) (McCright-1984). 


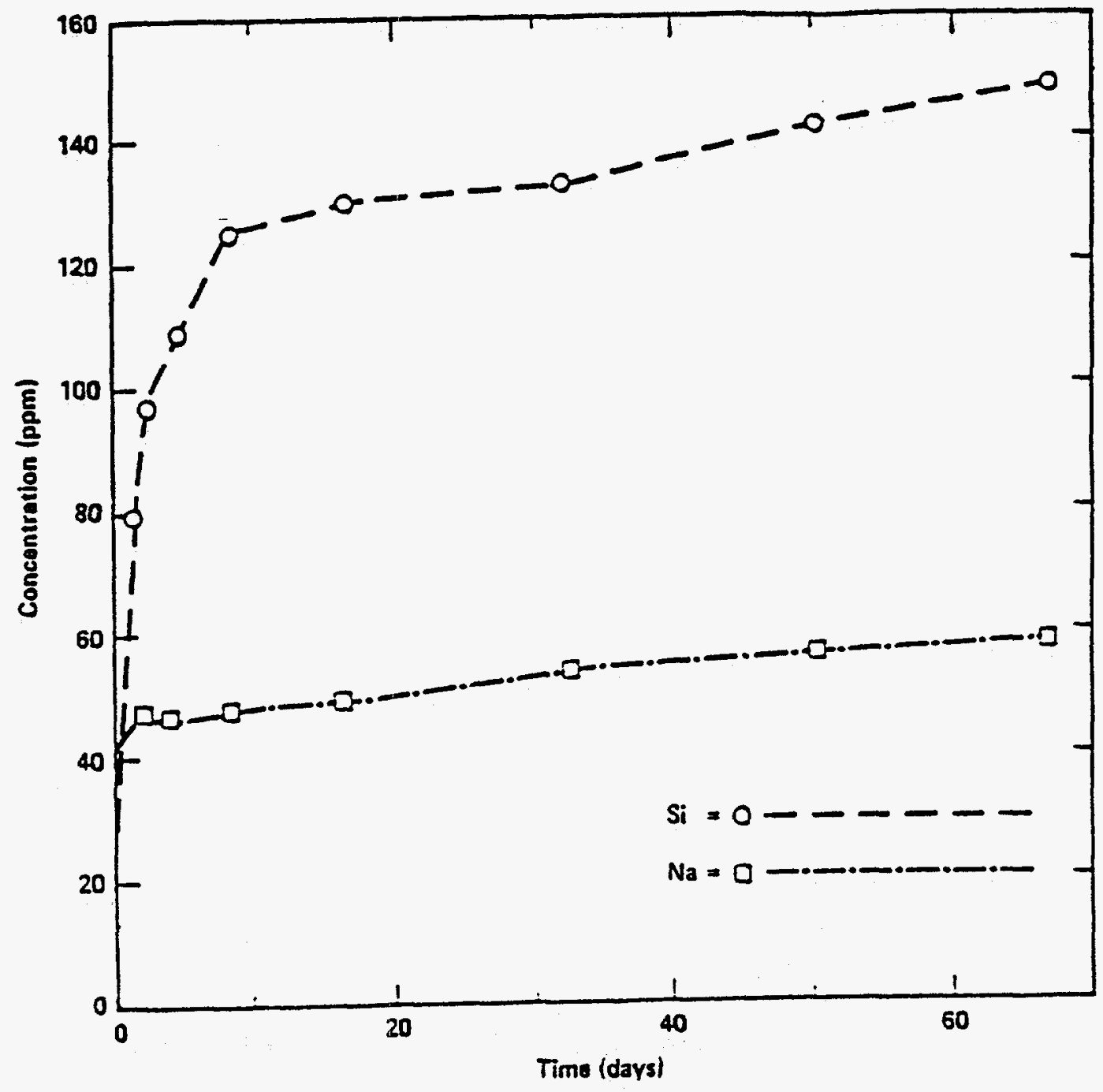

Figure 2.3 Silicon And Sodium Concentrations in J-13 Well Water Reacted With Crushed G-1 Material At $150^{\circ} \mathrm{C}$ As A Function Of Time In Days (Knauss-1985a). 


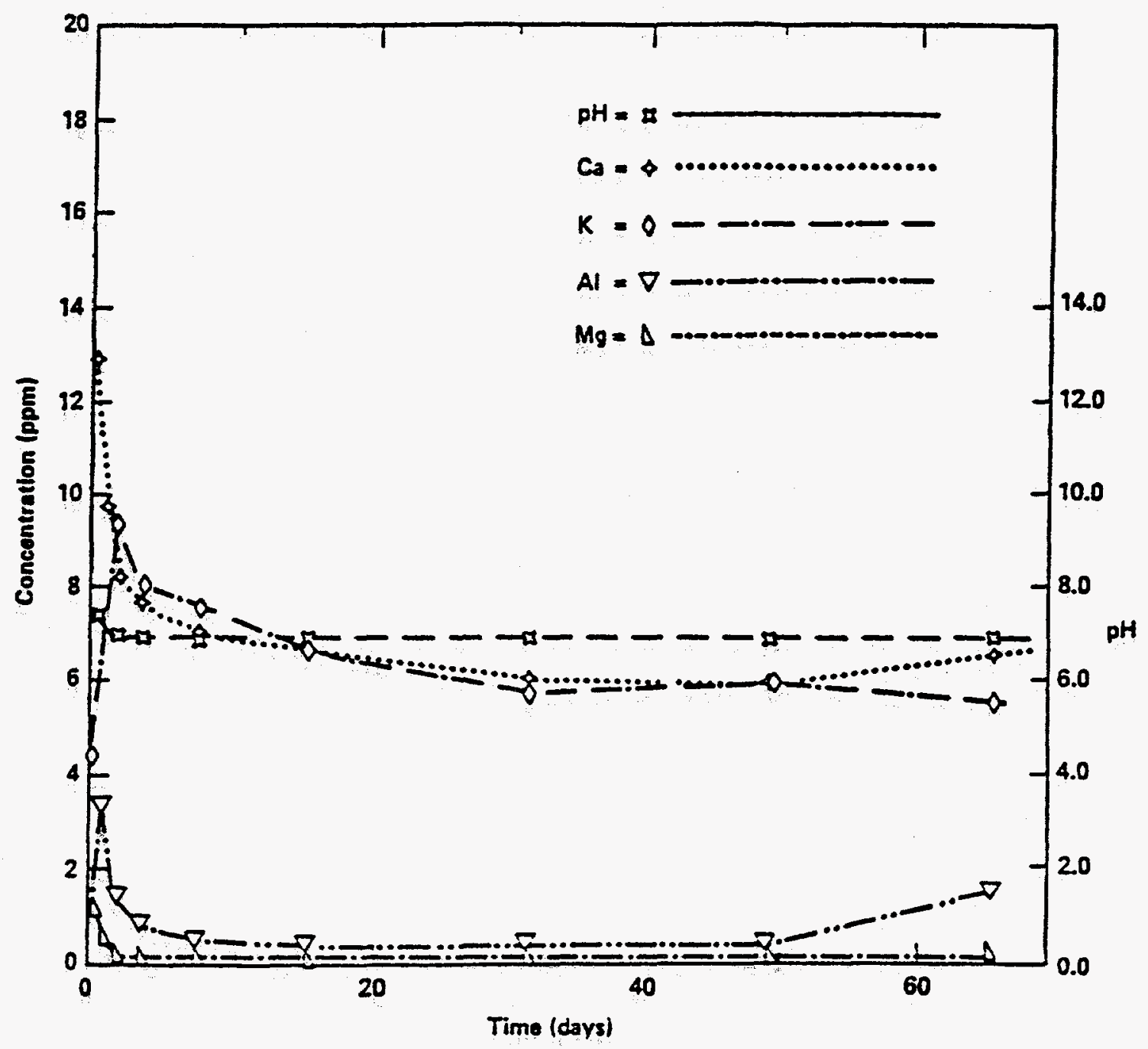

Figure 2.4 Aluminum, Potassium, Calcium, Magnesium, And pH Analyses From J-13 Well Water Reacted With Crushed G-1 Material At $150^{\circ} \mathrm{C}$ As A Function Of Time In Days (Knauss-1985a). 
Table 2.2 Chemical Composition Of Test Solutions At The End Of Corrosion Tests $(\mu \mathrm{g} / \mathrm{ml})$ (Undiluted And Filtered Solution) (Abraham-1986).

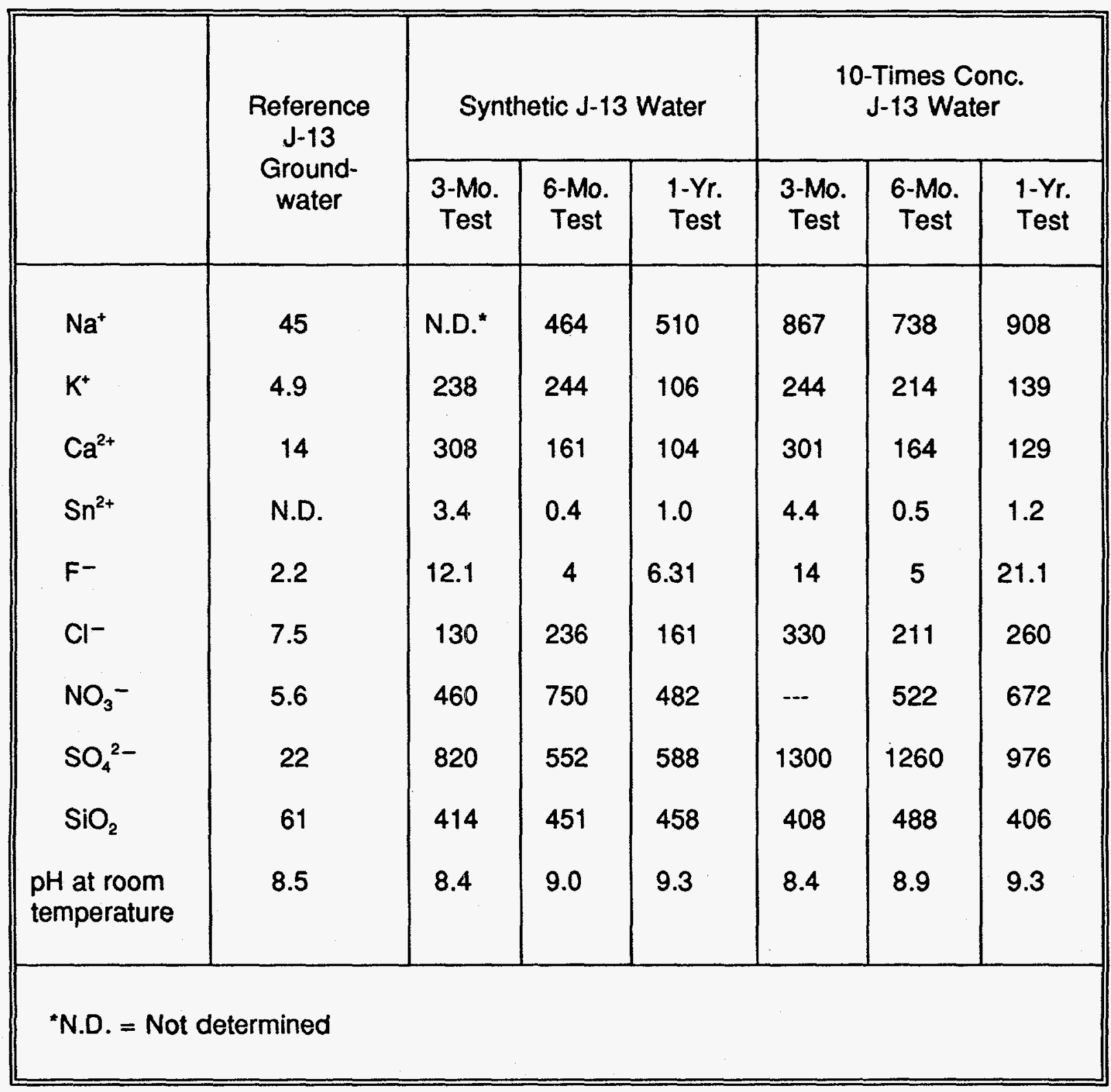


The concentration of the species in the $10 \mathrm{X} \mathrm{J-13}$ well water also increased with exposure time in these tests. Although the magnitudes of the increases were smaller than those observed for the $\mathrm{J}-13$ well water, the actual final concentrations of the species in the tests with the $10 \mathrm{XJ}-13$ well water were higher than those in the standard $\mathrm{J}-13$ well water. As in the $\mathrm{J}-13$ well water, maximum concentrations were observed for some species in the boiling $10 \mathrm{X} \mathrm{J-13}$ well water after a few months.

\subsection{Radiation Effects}

Relatively little research has been performed on the influence of the radiation field on the environment in the Tuff Repository. On the other hand, a number of articles discuss, in general terms, the anticipated role of radiation in altering the repository environment while research on the effects of radiation on water and dilute aqueous solutions is much more extensive. As described by McCright-1984, the highest levels of radiation will occur on emplacement and the levels will begin to decay. The radiation of interest with regard to container corrosion will be gamma radiation. Interaction of the gamma radiation with either the container or the host rock is also expected to be minimal. Thus, the primary problem is the interaction of the gamma radiation field with the liquid and gas phases in the repository. Although most of the fission products responsible for gamma radiation decay rapidly, the repository environment will consist of air and water vapor during the time period when radiation levels will be high.

Radiolysis products expected in the moist-air system are not well established. Some experimental research regarding the temperature effects on radiolysis products has been performed by Van Konynenburg (1986) and others. Their research indicates that, above $135^{\circ} \mathrm{C}$, the dominant species are $\mathrm{NO}, \mathrm{N}_{2} \mathrm{O}$, and $\mathrm{O}_{3}$. Between $120^{\circ} \mathrm{C}$ and $135^{\circ} \mathrm{C}, \mathrm{NO}_{2}, \mathrm{~N}_{2} \mathrm{O}_{4}, \mathrm{H}_{2} \mathrm{O}$, and $\mathrm{O}_{3}$ are the dominant products, while below $120^{\circ} \mathrm{C}$, the most abundant products are $\mathrm{HNO}_{3}$ and $\mathrm{H}_{2} \mathrm{O}$ with small amounts of $\mathrm{O}_{3}$.

In liquid water at high radiation levels, small amounts of nitrates and nitrites will also be produced. However, the simultaneous presence of liquid water and high radiation fields are possible only intermittently during periods of liquid water movement through the repository.

Glass (1985 and 1986) reviewed the literature and performed electrochemical studies in irradiated $\mathrm{J}-13$ well water. These studies concluded that the primary effect of radiation of $\mathrm{J}-13$ well water is to produce the dominant oxidizing species $\mathrm{O}_{2}$ and $\mathrm{H}_{2} \mathrm{O}_{2}$ with smaller concentrations of $\mathrm{O}_{2}$ and still smaller concentrations of $\mathrm{HO}_{2}$. Irradiation of water containing $\mathrm{CO}_{2}$ or $\mathrm{HCO}_{3}$ with $\mathrm{O}_{2}$ was found to produce carboxylic acids (formic and oxalic).

Studies focused on the effects of radiation on water and dilute aqueous solutions concluded that a host of transient radicals, ions, and stable molecular species is created by gamma radiation. Some of these species are as follows: $\mathrm{H}, \mathrm{OH}, \mathrm{e}-\mathrm{aq}, \mathrm{H}_{3} \mathrm{O}^{+}, \mathrm{OH}^{-}, \mathrm{H}_{2}, \mathrm{H}_{2} \mathrm{O}_{2}, \mathrm{O}_{2}, \mathrm{O}_{2}^{-}$and $\mathrm{HO}_{2}$. While these species only consider the breakdown of the water molecule, many other species are generated by reactions with other species in the groundwater. 


\section{EXPERIMENTAL APPROACH}

\subsection{Test Technique}

The cyclic-potentiodynamic-polarization (CPP) technique was used in this project to provide an understanding of how the specific variables such as environmental composition, temperature, alloy composition, and welding affect the general- and pitting-corrosion behavior of the alloys in simulated repository environments.

In the CPP procedure, the polarity and magnitude of the current flow between a specimen of the material of interest and an inert counter electrode are measured as a function of electrochemical potential. For the anodic portions of the curve, the current measured is equal to the corrosion rate of the specimen if two conditions are met: (1) The electrochemical potential is far enough away from the open-circuit potential that the rate of the cathodic reaction is negligible; and (2) The rates of spurious oxidation reactions are negligible.

Schematics of anodic polarization curves showing several types of behavior are given in Figure 3.1. For the active-corrosion case, the anodic curve is linear on an E-log i plot, and the forward and reverse scans are coincident. The presence of a peak in the anodic portion of the curve, followed by decreasing current, is generally indicative of the onset of passivation. The occurrence of hysteresis between the forward and reverse scans is indicative of pitting. Where the hysteresis loop is very large, the protection potential may be very close to the open-circuit potential, indicating a high probability of pitting in that particular environment.

The polarization behavior of the alloys was determined using conventional polarization techniques. The specific polarization equipment used for these experiments included a Princeton Applied Research Model 273 potentiostat coupled to a computer data-acquisition system or a Santron Electrochemical Measuring System. A two-compartment electrochemical cell was employed that utilized a saturated-calomel reference electrode (SCE) and a platinum counter electrode (Figure 3.2). Originally, it was planned to use a three-compartment cell (working, counter, and reference electrode compartments), but the relatively high resistance of several of the solutions prevented its use, and the two-compartment cell was used for all tests. The working electrode specimens were cylindrical rods that were drilled, tapped at one end, and sealed off using PTFE gaskets. The specimens were typically $1.3 \mathrm{~cm}$ in length with the diameter depending on the metal being tested. The electrodes were polished with successively finer grades of silicon carbide paper, finishing with a 600 -grit grade.

A typical experiment consisted of setting up the electrochemical cell containing the test solution. The test solution was slowly brought up to the desired temperature while being sparged with the desired gas. The specimen was immersed in the heated solution after sparging for one to two hours. The specimen was exposed to the test solution under freely-corroding conditions for 16-24 hours to permit steady-state conditions to be achieved.

The working electrode lead was connected to the test specimen while the auxiliary (counter) electrode lead was connected to an inert electrode (platinum wire) placed in the test cell. The 


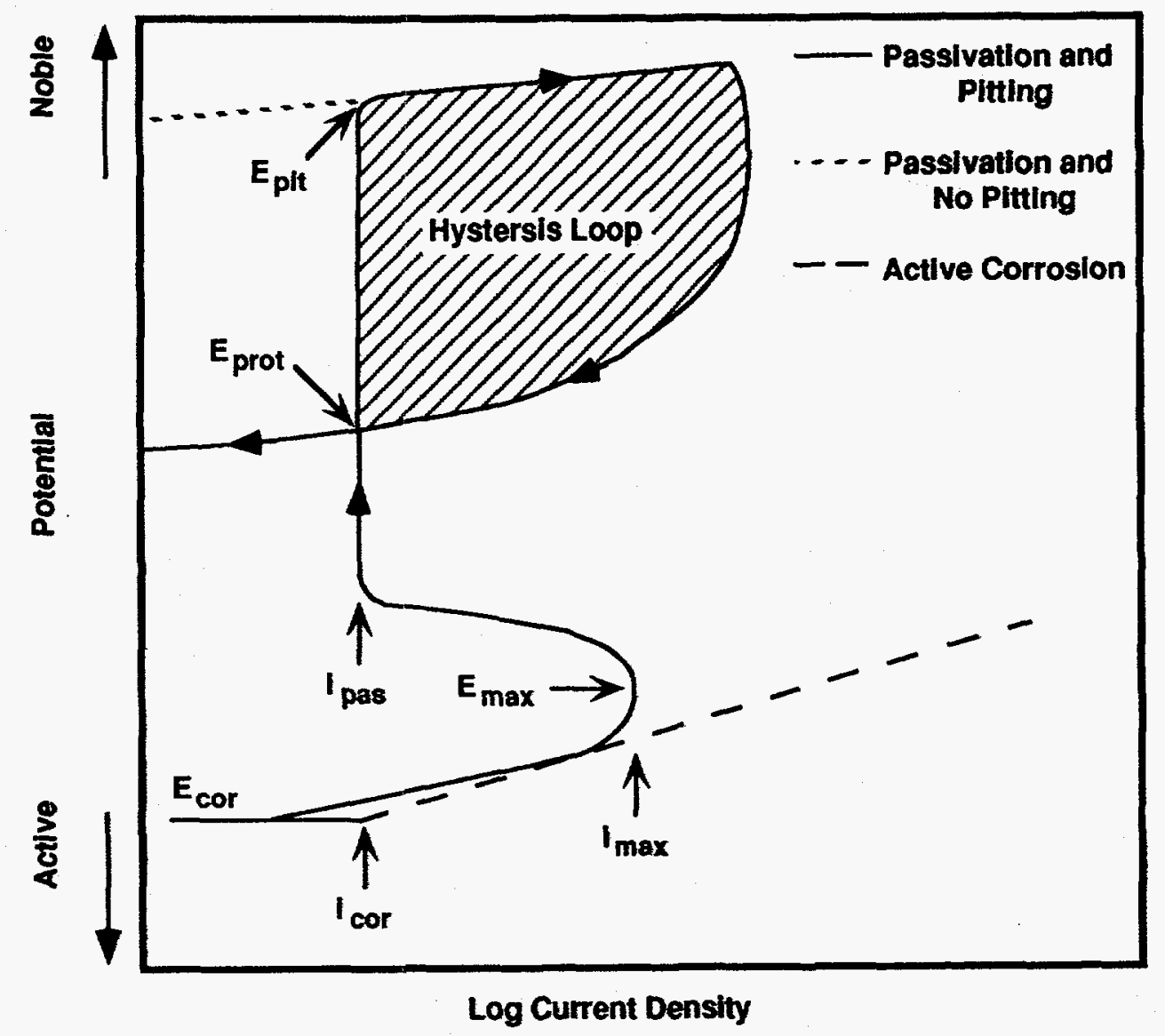

Figure 3.1 Schematic Of Typical Cyclic Potentiodynamic Polarization Curve.

$E_{c o r}=$ corrosion potential; $E_{p i t}=$ potential at which pits initiate on forward scan; $E_{\text {prot }}$ $=$ potential at which pits repassivate on reverse scan; $i_{c o r}=$ current density at the free-corrosion potential; $i_{\max }=$ current density at active peak; $i_{\text {pas }}=$ current density in passive range. 


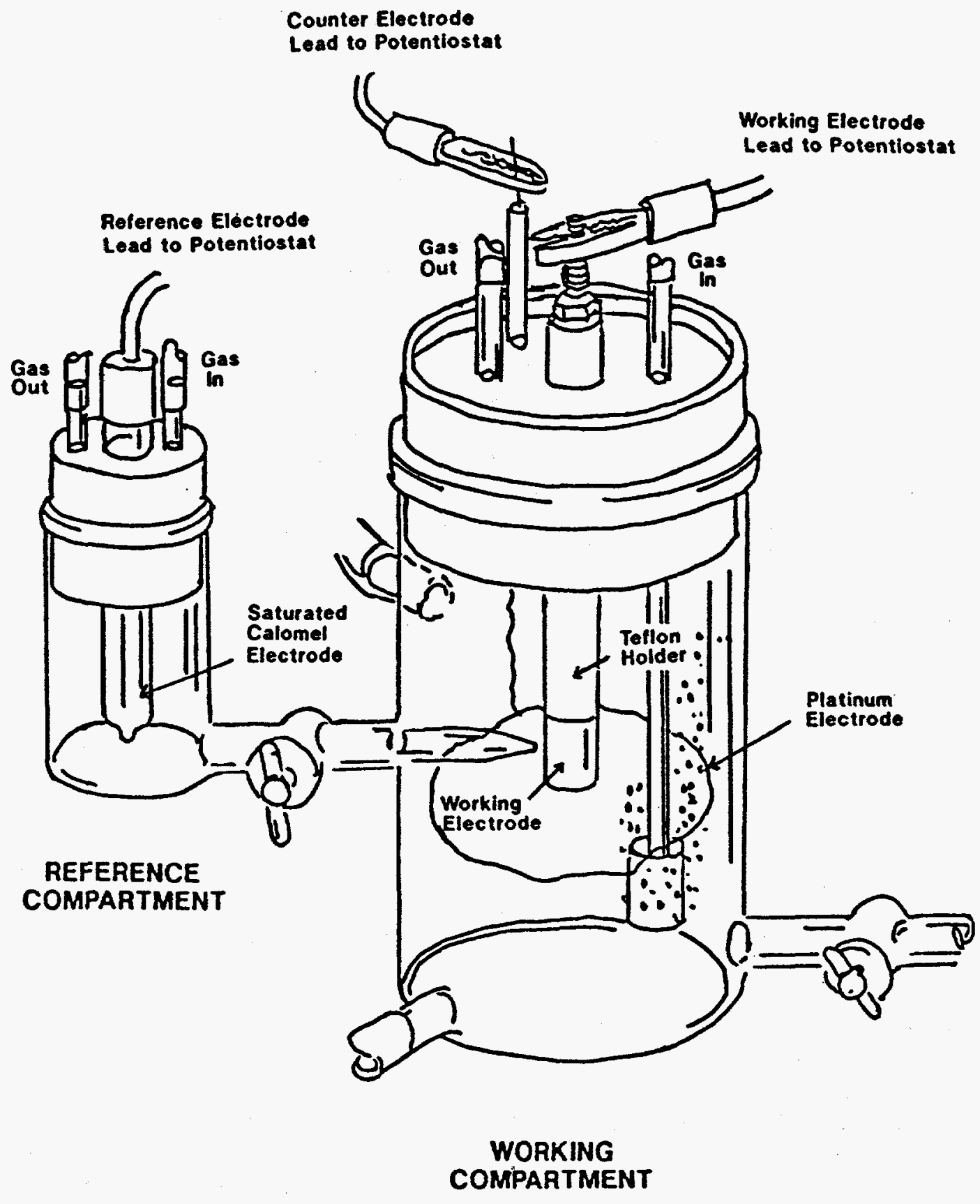

Figure 3.2 Electrochemical Cell Used For Ambient Pressure Potentiodynamic Polarization Experiments. 
reference electrode lead was connected to the reference electrode which communicates with the test cell electrolyte through a small diameter tube filled with electrolyte, referred to as a Luggin probe or salt bridge. The tip of the probe is placed near the test specimen to minimize measurement errors due to ohmic potential drops.

Partial cathodic and full anodic polarization curves were obtained by scanning at a rate of $0.6 \mathrm{~V} / \mathrm{hr}$ and beginning the scan approximately $100 \mathrm{mV}$ more negative than the free-corrosion potential. The current for the anodic curve was scanned until a current density of approximately $2 \times 10^{-3}$ $A / \mathrm{cm}^{2}$ was attained; the potential scan was then reversed until repassivation occurred and the current changed polarity, becoming cathodic. In those cases in which the current density did not attain $2 \times 10^{-3} \mathrm{Acm}^{2}$, the potential scan was reversed at a potential of 1.2 volts.

After completion of the polarization scans, the following polarization parameters were obtained from the CPP curves of potential (E) versus logarithm of current density (log $i)$ when applicable: $i_{c o r}, E_{c o r}, i_{p a s}, E_{p i t}$ or $E_{b}, E_{\text {prot }}$ or $E_{r p}, i_{\max }$ and $E_{\max }$. Tafel slopes were obtained from the CPP curves by extrapolating tangents to the anodic and cathodic portions of the curves at +75 and $-75 \mathrm{mV}$ from $E_{c o r}$, respectively. The specimens were also optically examined at $30 \mathrm{X}$ magnification following testing to confirm the predictions from the CPP curves.

\subsection{Candldate Alloys Evaluated}

Two classes of alloys were evaluated in this study; Fe-Cr-Ni alloys and copper-base alloys. The candidate Fe-Cr-Ni alloys evaluated were Type 304L Stainless Steel (Alloy 304L) and Incoloy Alloy 825 (Alloy 825). The candidate copper-base alloys evaluated were CDA 102 Copper (Alloy CDA 102) and Copper-30 Nickel (Alloy CDA 715). The compositions of the candidate alloys are given in Appendix I.

\subsection{Test Environments}

A large number of test environments was used in this study. The environments include simulated and actual $\mathrm{J}-13$ well water, simulated $\mathrm{J}-13$ well water containing chloride additions, and a matrix of test environments designed to cover the compositional ranges for important environmental species. The actual $\mathrm{J}-13$ well water used in this program was obtained from Oak Ridge National Laboratories. Due to the difficulty in obtaining actual $\mathrm{J}-13$ well water, required over the duration of the program, a simulated $\mathrm{J}-13$ well water was used. This simulated $\mathrm{J}-13$ well water was previously developed by Battelle Memorial Institute. The composition of the simulated J-13 well water is given in Table 3.1. Details of the environments and analysis techniques used in the test matrix are given below. 
Table 3.1 Chemical Composition Of Simulated Tuff Groundwater And J-13 Well Water From Yucca Mountain, Nevada (For Comparison).

\begin{tabular}{|c|c|c|c|}
\hline $\begin{array}{c}\text { Environmental } \\
\text { Varlable }\end{array}$ & $\begin{array}{c}\text { Actual Chemical } \\
\text { Used }\end{array}$ & $\begin{array}{l}\mathrm{J}-13^{*} \\
\text { ppm }\end{array}$ & $\begin{array}{c}\text { Simulated } \mathrm{J}-13 \ddagger \\
\text { ppm }\end{array}$ \\
\hline $\mathrm{Na}^{+}$ & $\mathrm{NaHCO}_{3}$ & 44.0 & 46.0 \\
\hline $\mathrm{K}^{+}$ & $\mathrm{KCl}, \mathrm{KF}$ & 5.1 & 5.5 \\
\hline $\mathrm{Mg}^{2+}$ & $\mathrm{MgCl}_{2} \cdot 6 \mathrm{H}_{2} \mathrm{O}$ & 1.9 & 1.7 \\
\hline $\mathrm{Ca}^{2+}$ & $\mathrm{Ca}\left(\mathrm{NO}_{3}\right)_{2} \cdot 4 \mathrm{H}_{2} \mathrm{O}, \mathrm{CaSO}_{4} \cdot 1 / 2 \mathrm{H}_{2} \mathrm{O}$ & 12.5 & 12.0 \\
\hline $\mathrm{SiO}_{2}$ & $\mathrm{H}_{2} \mathrm{SiO}_{3}$ & 58. & 64.2 \\
\hline $\mathbf{F}^{-}$ & KF & 2.2 & 1.7 \\
\hline $\mathrm{Cl}^{-}$ & $\mathrm{KCl}, \mathrm{MgCl}_{2} \cdot 6 \mathrm{H}_{2} \mathrm{O}$ & 6.9 & 6.4 \\
\hline $\mathrm{HCO}_{3}^{-}$ & $\mathrm{NaHCO}_{3}$ & 125. & 121. \\
\hline $\mathrm{NO}_{3}^{-}$ & $\mathrm{Ca}\left(\mathrm{NO}_{3}\right)_{2} \cdot 4 \mathrm{H}_{2} \mathrm{O}$ & 9.6 & 12.4 \\
\hline $\mathrm{SO}_{4}^{2-}$ & $\mathrm{CaSO}_{4} \cdot 1 / 2 \mathrm{H}_{2} \mathrm{O}$ & 18.7 & 19.2 \\
\hline pH & & 7.6 & $7.0 \pm 0.2$ \\
\hline TDS & & 291.5 & 290.3 \\
\hline
\end{tabular}

"Knauss, 1985

‡Beavers, 1987 
Synthetic environments which, historically, have been used to simulate field conditions in laboratory corrosion studies are usually relatively simple. More often than not, the effects of variables are studied by varying a single variable at a time. Such an approach does not account for the dependency of effects among multiple variables. In this project, a statistical approach was used that was specifically designed to examine corrosion behavior in complex environments (Koch, 1988). By using a statistically-based experimental design, a mathematical expression was developed that relates a dependent variable or response, such as corrosion rate, to a number of independent solution variables or factors, such as species concentration, temperature, and pH. In such an analysis, the mathematical expressions can include main-effect terms (linear), two factor interactions (cross products), and quadratic terms. High-order terms, such as three-factor interactions, can also be evaluated but their physical significance is often difficult to explain and the magnitude of the terms are expected to be much smaller than the main-effect terms or twofactor interaction terms. Because of the large number of solution variables (15), and the large number of alloys (4) examined in this study, it was decided that the most effective approach was to determine the main-effect terms for each of the variables free and clear of two-factor interactions but not to perform the much larger matrix of experiments required to determine the two-factor interactions and quadratic terms. To estimate the main-effect terms of the variables, a Resolution IV experimental design was selected. In this design, each environmental variable has a high and low level.

The initial step was to define the solution variables of interest for inclusion into the test matrix. Table 3.2 presents the compositional ranges of important environmental species for (1) Tuff well water, (2) Tuff groundwater heated to temperatures from $90-250^{\circ} \mathrm{C}$ in the presence of Tuff rock, and (3) Tuff groundwater heated to $90-150^{\circ} \mathrm{C}$ in the presence of radiation. The references from which the data were obtained are indicated in Table 3.2.

The fifteen environmental variables that were included in the experimental matrix and their high and low concentrations are given in Table 3.3. The fitteen variables selected for examination in the Task 3 tests included twelve variables associated with the J-13 groundwater and three variables produced by radiolysis. Nitrogen, sulfate, and sodium were chosen as the gas, anion and cation, respectively, used for balancing the solution chemistry. One variable that is missing from the fifteen environmental variables listed in Table 3.3 is the radiolysis product hydrogen. Because of the experimental difficulties in mixing hydrogen and oxygen, it was decided to remove hydrogen from the matrix of experiments and to perform a few experiments separately to establish its effect. A complete summary of the solution matrix investigated during the program is outlined in Table 3.4.

In the following paragraphs, each variable is briefly discussed and justification for inclusion of the variable into the matrix and the concentrations selected are presented based on a review of the literature (Knauss-1985a, Glass-1986, Oversby-1983, Yunker-1986a, et al.).

Silicon dioxide, $\mathrm{SiO}_{2}$, is present in the $\mathrm{J}-13$ well water at a concentration of $58 \mathrm{mg} /$. Data by Knauss-1985a and Oversby- 1983 indicate that, at $90^{\circ} \mathrm{C}$, this is the approximate steady-state concentration which likely represents the solubility limit of $\mathrm{SiO}_{2}$ at $90^{\circ} \mathrm{C}$. During radiation, Yunker$1986 \mathrm{a}$ found that the concentration of $\mathrm{SiO}_{2}$ decreased to a value of 1.1 to $3.2 \mathrm{mg} /$. Because of 
Table 3.2 Concentration Ranges For Environmental Species In Tuff Groundwater.

\begin{tabular}{|c|c|c|c|c|c|}
\hline \multirow{2}{*}{$\begin{array}{c}\text { Environmental Varlable } \\
\mathrm{pH}\end{array}$} & \multirow{2}{*}{$\begin{array}{c}\begin{array}{c}\text { Nominal Concentration of } \\
\text { Well Water, }{ }^{(2)} \mathrm{mgn}\end{array} \\
7.6\end{array}$} & \multicolumn{2}{|c|}{$\begin{array}{l}\text { Concentration Range of } \\
\text { Groundwater Heated To } \\
\text { 90-250 } \mathrm{C} \text { With Tuff } \\
\text { Rock, }\end{array}$} & \multicolumn{2}{|c|}{$\begin{array}{c}\text { Concentration Range O } \\
\text { Groundwater Heated To } \\
\text { s0-150 } \mathrm{C} \text { In Presence } 0 \\
\text { Radiation }{ }^{(4)}, \mathrm{mg} /\end{array}$} \\
\hline & & 5.8 & $\begin{array}{l}-\quad 8.3 \\
\end{array}$ & 7.6 & - $\quad 9.0$ \\
\hline $\mathrm{SiO}_{2}$ & 58 & 29 & - 394 & 1.05 & - $\quad 3.10$ \\
\hline $\mathrm{HCO}_{3}^{-}$ & 125 & 45 & - 195 & 8.1 & -21 \\
\hline$F^{-}$ & 2.2 & 2.2 & $\begin{array}{l}-\quad 4.4 \\
\end{array}$ & 0.38 & $-\quad 1.4$ \\
\hline $\mathrm{Cl}^{-}$ & 6.9 & 6.5 & 8.9 & 2.5 & - $\quad 5.8$ \\
\hline $\mathrm{NO}_{3}^{-}$ & 9.6 & 8.5 & $-\quad 16.8$ & 2.5 & -18.8 \\
\hline $\mathrm{SO}_{4}^{2-}$ & 18.7 & 13.3 & - 22 & 1.8 & - $\quad 6.2$ \\
\hline $\mathrm{NO}_{2}^{-}$ & - & 0.7 & $-\quad 1.5$ & 1.2 & $\begin{array}{l}-\quad 3.8 \\
\end{array}$ \\
\hline $\mathrm{H}_{2} \mathrm{O}_{2}$ & - & & - & 0 & $-4.8^{10}$ \\
\hline $\mathrm{Al}^{3+}$ & .012 & 0.016 & 4.8 & $<0.15$ & - $\quad 0.18$ \\
\hline $\mathrm{Fe}^{2+}$ & 0.006 & & - & $<0.02$ & $-\quad 0.04$ \\
\hline $\mathrm{Ca}^{2+}$ & 12.5 & 0.21 & $-\quad 13.2$ & 2.7 & - $\quad 9.8$ \\
\hline $\mathrm{Mg}^{2+}$ & 1.9 & 0.009 & 2.0 & 0.6 & - $\quad 1.1$ \\
\hline $\mathrm{K}^{+}$ & 5.1 & 3.2 & - $\quad 19.4$ & 2.4 & $\begin{array}{l}-\quad 4.8 \\
\end{array}$ \\
\hline $\mathrm{Na}^{+}$ & 44 & 35 & . 74 & 2.8 & -36 \\
\hline
\end{tabular}

(a) Knauss, 1985.

(b) Oversby, 1983.

(c) Yunker, 1986.

(d) Glass, 1985. 
Table 3.3 List Of Variables Included In The Matrix Of Potentiodynamic Polarization Tests In Task 2.

\begin{tabular}{|c|c|c|c|c|c|}
\hline $\begin{array}{l}\text { Varlable } \\
\text { Number }\end{array}$ & $\begin{array}{l}\text { Variable } \\
\text { Name }\end{array}$ & Origin & $\begin{array}{c}\text { Test Mattix } \\
\text { High Concentration } \\
\text { mgl }\end{array}$ & $\begin{array}{l}\text { Test Matrix } \\
\text { Low Concentration } \\
\text { mg } /\end{array}$ & $\begin{array}{c}\text { Nominal } \\
\text { Concentration } \\
\text { Of } \mathrm{J}-13, \mathrm{mg} /\end{array}$ \\
\hline 1 & $\mathrm{SiO}_{2}$ & $J-13$ & 215 & 2.2 & 58 \\
\hline 2 & $\mathrm{HCO}_{3}^{-}$ & $J-13$ & 2000 & 0.4 & 125 \\
\hline 3 & $F^{-}$ & $J-13$ & 200 & 0.04 & 2.2 \\
\hline 4 & $\mathrm{Cl}^{-}$ & $J-13$ & 1000 & 0.2 & 6.9 \\
\hline 5 & $\mathrm{NO}_{3}^{-}$ & $J-13$ & 1000 & 0.2 & 9.6 \\
\hline 6 & $\mathrm{NO}_{2}^{-}$ & Radiolysis & 200 & 0 & - \\
\hline 7 & $\mathrm{H}_{2} \mathrm{O}_{2}$ & Radiolysis & 200 & 0 & - \\
\hline 8 & $\mathrm{Ca}^{2+}$ & $J-13$ & 20 & 0.004 & 12 \\
\hline 9 & $\mathrm{Mg}^{2+}$ & $J-13$ & 20 & 0.004 & 1.9 \\
\hline 10 & $\mathrm{Al}^{3+}$ & $J-13$ & 0.8 & 0.0004 & 0.01 \\
\hline 11 & $\mathrm{PO}_{4}^{3-}$ & $J-13$ & 2.0 & 0.01 & $0.12^{*}$ \\
\hline 12 & Oxalic Acid & Radiolysis & 172 & 0 & - \\
\hline 13 & $\mathrm{O}_{2}$ & $\begin{array}{l}\text { Open Repository } \\
\text { and Radiolysis }\end{array}$ & $30^{* *}$ & $5^{* *}$ & - \\
\hline 14 & Temp & $J-13$ & $90^{\circ} \mathrm{C}$ & $50^{\circ} \mathrm{C}$ & - \\
\hline 15 & pH & $J-13$ & 10 & 5 & 7.6 \\
\hline
\end{tabular}

- McCright, R. D. FY 1985 Status Report, UCID-20509, September 30, 1985.

** Volume \%. 
Table 3.4 Series Of Tests Included In The Matrix Of Potentiodynamic Polarization Tests in Task 2.

\begin{tabular}{|c|c|c|c|c|c|c|c|c|c|c|c|c|c|c|c|}
\hline $\begin{array}{l}\text { Test } \\
\text { No. }\end{array}$ & $\mathrm{SiO}_{2}$ & $\mathrm{HCO}_{3}^{-}$ & $\mathbf{F}^{-}$ & $\mathrm{Cl}^{-}$ & $\mathrm{NO}_{3}^{-}$ & $\mathrm{NO}_{2}^{-}$ & $\mathrm{H}_{2} \mathrm{O}_{2}$ & $\mathrm{Ca}^{2+}$ & $\mathrm{Mg}^{2+}$ & $\mathrm{Al}^{3+}$ & $\mathrm{PO}_{4}{ }^{3-}$ & $\begin{array}{c}\text { Oxalic } \\
\text { Acld }\end{array}$ & $\mathbf{O}_{2}$ & $\begin{array}{c}\text { Temp } \\
{ }^{\circ} \mathrm{C}\end{array}$ & pH \\
\hline 1 & 2.2 & 0.4 & 200 & 1000 & 1000 & 200 & 200 & 0.8 & 0.004 & 0.0004 & 0.01 & 0 & 5 & 90 & 5 \\
\hline 2 & 2.2 & 2000 & 200 & 1000 & 1000 & 0 & 0 & 0.004 & 0.004 & 0.8 & 2.0 & 172 & 5 & 50 & 5 \\
\hline 3 & 215 & 0.4 & 0.04 & 0.2 & 1000 & 200 & 0 & 0.8 & 0.004 & 0.8 & 2.0 & 0 & 30 & 50 & 5 \\
\hline 4 & 215 & 2000 & 0.04 & 0.2 & 1000 & 0 & 200 & 0.004 & 0.004 & $\mid 0.0004$ & 0.01 & 172 & 30 & 90 & 5 \\
\hline 5 & 2.2 & 0.4 & 200 & 0.2 & 0.2 & 0 & 200 & 0.8 & 0.8 & 0.8 & 0.01 & 172 & 30 & 50 & 5 \\
\hline 6 & 2.2 & 2000 & 200 & 0.2 & 0.2 & 200 & 0 & 0.004 & 0.8 & 0.0004 & 2.0 & 0 & 30 & 90 & 5 \\
\hline 7 & 215 & 0.4 & 0.04 & 1000 & 0.2 & 0 & 0 & 0.8 & 0.8 & 0.0004 & 2.0 & 172 & 5 & 90 & 5 \\
\hline 8 & 215 & 2000 & 0.04 & 1000 & 0.2 & 200 & 200 & 0.004 & 0.8 & 0.8 & 0.01 & 0 & 5 & 50 & 5 \\
\hline 9 & 2.2 & 0.4 & 0.04 & 1000 & 0.2 & 200 & 200 & 0.004 & 0.004 & 0.0004 & 2.0 & 172 & 30 & 50 & 10 \\
\hline 10 & 2.2 & 2000 & 0.04 & 1000 & 0.2 & 0 & 0 & 0.8 & 0.004 & 0.8 & 0.01 & 0 & 30 & 90 & 10 \\
\hline 11 & 215 & 0.4 & 200 & 0.2 & 0.2 & 200 & 0 & 0.004 & 0.004 & 0.8 & 0.01 & 172 & 5 & 90 & 10 \\
\hline 12 & 215 & 2000 & 200 & 0.2 & 0.2 & 0 & 200 & 0.8 & 0.004 & $\mid 0.0004$ & 2.0 & 0 & 5 & 50 & 10 \\
\hline 13 & 2.2 & 0.4 & 0.04 & 0.2 & 1000 & 0 & 200 & 0.004 & 0.8 & 0.8 & 2.0 & 0 & 5 & 90 & 10 \\
\hline 14 & 2.2 & 2000 & 0.04 & 0.2 & 1000 & 200 & 0 & 0.8 & 0.8 & 0.0004 & 0.01 & 172 & 5 & 50 & 10 \\
\hline 15 & 215 & 0.4 & 200 & 1000 & 1000 & 0 & 0 & 0.004 & 0.8 & 0.0004 & 0.01 & 0 & 30 & 50 & 10 \\
\hline 16 & 215 & 2000 & 200 & 1000 & 1000 & 200 & 200 & 0.8 & 0.8 & 0.8 & 2.0 & 172 & 30 & 90 & 10 \\
\hline 17 & 215 & 2000 & 0.04 & 0.2 & 0.2 & 0 & 0 & 0.004 & 0.8 & 0.8 & 2.0 & 172 & 30 & 50 & 10 \\
\hline 18 & 215 & 0.4 & 0.04 & 0.2 & 0.2 & 200 & 200 & 0.8 & 0.8 & $|0.0004|$ & 0.01 & 0 & 30 & 90 & 10 \\
\hline 19 & 2.2 & 2000 & 200 & 1000 & 0.2 & 0 & 200 & 0.004 & 0.8 & 0.0004 & 0.01 & 172 & 5 & 90 & 10 \\
\hline 20 & 2.2 & 0.4 & 200 & 1000 & 0.2 & 200 & 0 & 0.8 & 0.8 & 0.8 & 2.0 & 0 & 5 & 50 & 10 \\
\hline 21 & 215 & 2000 & 0.04 & 1000 & 1000 & 200 & 0 & 0.004 & 0.004 & 0.0004 & 2.0 & 0 & 5 & 90 & 10 \\
\hline 22 & 215 & 0.4 & 0.04 & 1000 & 1000 & 0 & 200 & 0.8 & 0.004 & 0.8 & 0.01 & 172 & 5 & 50 & 10 \\
\hline 23 & 2.2 & 2000 & 200 & 0.2 & 1000 & 200 & 200 & 0.004 & 0.004 & 0.8 & 0.01 & 0 & 30 & 50 & 10 \\
\hline 24 & 2.2 & 0.4 & 200 & 0.2 & 1000 & 0 & 0 & 0.8 & 0.004 & 0.0004 & 2.0 & 172 & 30 & 90 & 10 \\
\hline 25 & 215 & 2000 & 200 & 0.2 & 1000 & 0 & 0 & 0.8 & 0.8 & 0.8 & 0.01 & 0 & 5 & 90 & 5 \\
\hline 26 & 2.2 & 0.4 & 200 & 0.2 & 1000 & 200 & 200 & 0.004 & 0.8 & 0.0004 & 2.0 & 172 & 5 & 50 & 5 \\
\hline 27 & 2.2 & 2000 & 0.04 & 1000 & 1000 & 0 & 200 & 0.8 & 0.8 & 0.0004 & 2.0 & 0 & 30 & 50 & 5 \\
\hline 28 & 2.2 & 0.4 & 0.04 & 1000 & 1000 & 200 & 0 & 0.004 & 0.8 & 0.8 & 0.01 & 172 & 30 & 90 & 5 \\
\hline 29 & 215 & 2000 & 200 & 1000 & 0.2 & 200 & 0 & 0.8 & 0.004 & 0.0004 & 0.01 & 172 & 30 & 50 & 5 \\
\hline 30 & 215 & 0.4 & 200 & 1000 & 0.2 & 0 & 200 & 0.004 & 0.004 & 0.8 & 2.0 & 0 & 30 & 90 & 5 \\
\hline 31 & 2.2 & 2000 & 0.04 & 0.2 & 0.2 & 200 & 200 & 0.8 & 0.004 & 0.8 & 2.0 & 172 & 5 & 90 & 5 \\
\hline 32 & 2.2 & 0.4 & 0.04 & 0.2 & 0.2 & 0 & 0 & 0.004 & 0.8 & 0.0004 & 0.01 & 0 & 5 & 50 & 5 \\
\hline $33^{*}$ & 108 & 500 & 50 & 250 & 250 & 50 & 50 & 0.2 & 0.2 & 0.2 & 1.3 & 43 & 15 & 70 & 7.5 \\
\hline $34^{*}$ & 108 & 500 & 50 & 250 & 250 & 50 & 50 & 0.2 & 0.2 & 0.2 & 1.3 & 43 & 15 & 70 & 7.5 \\
\hline $35^{*}$ & 108 & 500 & 50 & 250 & 250 & 50 & 50 & 0.2 & 0.2 & 0.2 & 1.3 & 43 & 15 & 70 & 7.5 \\
\hline $36^{*}$ & 108 & 500 & 50 & 250 & 250 & 50 & 50 & 0.2 & 0.2 & 0.2 & 1.3 & 43 & 15 & 70 & 7.5 \\
\hline $37 \pm$ & 64.2 & 121 & 1.7 & 6.4 & 12.4 & 0 & 0 & 12 & 1.7 & 0 & 0 & 0 & 0 & 90 & 7.0 \\
\hline $38+$ & 64.2 & 121 & 1.7 & 1000 & 12.4 & 0 & 0 & 12 & 1.7 & 0 & 0 & 0 & 0 & 90 & 7.0 \\
\hline 39 & 108 & 500 & 50 & 250 & 250 & 50 & 50 & 0.1 & 0.1 & 0.5 & 1.3 & 50 & 15 & 70 & 5 \\
\hline 40 & 108 & 500 & 50 & 250 & 250 & 50 & 50 & 20 & 20 & 0.5 & 1.3 & 50 & 15 & 70 & 5 \\
\hline 41 & 108 & 500 & 50 & 250 & 250 & 50 & 50 & 20 & 0.1 & 0.5 & 1.3 & 50 & 15 & 70 & 10 \\
\hline 42 & 108 & 500 & 50 & 250 & 250 & 50 & 50 & 0.1 & 20 & 0.5 & 1.3 & 50 & 15 & 70 & 10 \\
\hline
\end{tabular}

- Tests 33 through 36 are quadruplicate midpoint tests which help to establish the degree of reproducibility of the CPP Tests.

\pm Simulated J-13 well water.

+ Simulated $\mathrm{J}-13$ well water containing $1000 \mathrm{ppm} \mathrm{Cl}-$. 
this, a low concentration of $2.2 \mathrm{mg} / \mathrm{l}$ was selected. A high concentration of $215 \mathrm{mg} / \mathrm{provides}$ a factor of $100 \mathrm{X}$ between the low and high concentration examined. Also, the $100 \mathrm{mg} / \mathrm{l}$ concentration is likely to exceed the solubility limit such that the high concentration primarily insures that saturation is attained during the high concentration tests. Silicon dioxide was added to the test solutions as silicic acid.

Bicarbonate, $\mathrm{HCO}_{3}^{-}$, is present in the $\mathrm{J}-13$ well water at a concentration of $125 \mathrm{mg} /$. Heating the $\mathrm{J}-13$ well water in the presence of Tuff rock at $90^{\circ} \mathrm{C}$ produced an increase in the concentration to $190 \mathrm{mg} / \mathrm{l}$ while radiation tended to decrease the concentration to $8-20 \mathrm{mg} /$. Therefore, a low concentration of $0.4 \mathrm{mg} /$ was selected and a factor of $5000 \mathrm{X}$ was used to provide a high concentration of $2000 \mathrm{mg} / \mathrm{l}$. Bicarbonate was added to the test solutions as sodium bicarbonate.

Fluoride, $\mathrm{F}^{-}$, is present in the $\mathrm{J}-13$ well water at a concentration of $2.2 \mathrm{mg} /$. Heating in the presence of Tuff rock resulted in a very slight increase in fluoride concentration. Radiation produced a slight decrease in fluoride concentration to $0.4-1.4 \mathrm{mg} /$. Based on these results, a $0.04 \mathrm{mg} /$ low concentration was selected and a factor of $500 \mathrm{X}$ provides a high concentration of $200 \mathrm{mg} /$. Fluoride was added to the test solutions as potassium fluoride.

Chloride, $\mathrm{Cl}^{-}$, is present in the $\mathrm{J}-13$ well water at a concentration of $7 \mathrm{mg} /$. Heating of the $\mathrm{J}-13$ well water in the presence of Tuff rock produced little or no change in the chloride concentration. The effect of radiation was to produce a slight decrease in the chloride concentration to 2.5-5.8 $\mathrm{mg} / \mathrm{l}$. The low concentration was selected at $0.2 \mathrm{mg} /$ and a factor of $5000 \mathrm{X}$ increase provides a high concentration of $1000 \mathrm{mg} / \mathrm{l}$. Chloride was added to the test solution as sodium chloride.

Nitrate, $\mathrm{NO}_{3}{ }^{-}$, is present in the $\mathrm{J}-13$ well water at a concentration of $10 \mathrm{mg} / \mathrm{l}$. Very little change was observed in the nitrate concentration upon heating in the presence of Tuff rock. In the presence of radiation, the nitrate concentration varied from 2.5 to $19 \mathrm{mg} /$. Thereby, no systematic increase or decrease in the nitrate concentration was observed. The low concentration for nitrate was selected at $0.2 \mathrm{mgh}$ and a factor of $200 \mathrm{X}$ provides a high concentration of $1000 \mathrm{mg} /$. Nitrate was added to the test solutions as sodium nitrate.

Nitrite, $\mathrm{NO}_{2}^{-}$, is a radiolysis product which has been shown to achieve concentrations from 0.7 to $3.8 \mathrm{mg} / \mathrm{l}$. The low concentration for nitrite is zero. A high concentration of $200 \mathrm{mg} / \mathrm{l}$ was selected and is approximately 50X the concentration indicated by Yunker (1986a). Nitrite was added to the test solutions as sodium nitrite.

Peroxide, $\mathrm{H}_{2} \mathrm{O}_{2}$, is a radiolysis product and was shown to achieve a concentration of $5 \mathrm{mg} / \mathrm{l}$ in the presence of radiation. The low concentration was selected as zero and a high concentration was selected at $200 \mathrm{mg} / \mathrm{l}$ which provides a factor of approximately $40 \mathrm{X}$ over the concentration indicated by Glass (1986).

Calcium, $\mathrm{Ca}^{2+}$, is present in the $\mathrm{J}-13$ well water at a concentration of $12 \mathrm{mg} / \mathrm{l}$. The concentration of calcium changed little when the $\mathrm{J}-13$ well water was heated in the presence of Tuff rock at $90^{\circ} \mathrm{C}$. At higher temperatures, the calcium concentration decreased to $0.2 \mathrm{mg} /$. In the presence of radiation, the concentration of calcium decreased to $2-9.8 \mathrm{mg} /$. The low concentration for calcium was selected at $0.004 \mathrm{mg} / \mathrm{l}$ and a factor of $5000 \mathrm{X}$ provides a high concentration of 20 $\mathrm{mg} / \mathrm{l}$. Calcium was added to the test solutions as calcium sulfate, one-half hydrate. 
Magnesium, $\mathrm{Mg}^{2+}$, is present in the $\mathrm{J}-13$ well water at a concentration of $1.9 \mathrm{mg} /$. The concentration of magnesium changed little when the $\mathrm{J}-13$ well water was heated in the presence of Tuff rock and showed only a slight decrease in concentration in the presence of radiation. The low concentration for magnesium was selected at $0.004 \mathrm{mg} /$ and a factor of $5000 \mathrm{X}$ provides a high concentration of $20 \mathrm{mg} /$. Magnesium was added to the test solutions as magnesium sulfate, seven hydrate.

Aluminum, $\mathrm{Al}^{3+}$, is present in the $\mathrm{J}-13$ well water at a concentration of $0.01 \mathrm{mg}$. Upon heating the $\mathrm{J}-13$ well water in the presence of Tuff rock, the aluminum concentration increased to $2-3$ $\mathrm{mg} /$. In the presence of radiation, the aluminum increased to $0.18 \mathrm{mg} /$. Therefore, a much larger range of concentration was observed for aluminum than was observed for other species. Thereby, a low concentration of 0.0004 was selected and a factor of $2000 \mathrm{X}$ provides a high concentration of $0.8 \mathrm{mg} /$. Aluminum was added to the test solutions as aluminum sulfate, 16 hydrate.

Phosphate, $\mathrm{PO}_{4}{ }^{3-}$, has been reported at a concentration of $0.12 \mathrm{mg} / \mathrm{in} \mathrm{J}-13$ well water (McCright-1985) and has not been reported, at all, in other referenced J-13 well waters. The low concentration for phosphate was selected to be $0.01 \mathrm{mg} / \mathrm{l}$ and a factor of 200X provides a high concentration of $2.0 \mathrm{mg} /$. Phosphate was added to the test solutions as phosphoric acid.

Organic acids have been reported as naturally occurring in groundwaters and have been indicated as possible radiolysis products. For this study, oxalic acid was selected as the organic acid to examine. The low concentration of oxalic acid will be zero and the high concentration for oxalic acid will be $172 \mathrm{mg} / \mathrm{l}$ which approximates to the concentration range of other radiolysis products.

Oxygen, $\mathrm{O}_{2}$, is present in the repository because of its location above the water table and because no airtight sealing arrangement is proposed for the repository. It is likely that the concentration of $\mathrm{O}_{2}$ could be somewhat less than that normally occurring in air and, on the high side, could be greater than that occurring in air due to radiolysis. The low concentration of $\mathrm{O}_{2}$ was selected at 5 volume percent and the high concentration at 30 volume percent.

Because the repository design will not permit any significant pressure buildup, the aqueous phase corrosion, which is being examined in this task, has a limiting temperature at the boiling point of the $\mathrm{J}-13$ well water. The low temperature to be examined was selected at $50^{\circ} \mathrm{C}$ and the high temperature was selected at $90^{\circ} \mathrm{C}$. The high temperature of $90^{\circ} \mathrm{C}$ was selected to provide a temperature near boiling but that can be controlled relatively easily and accurately in the laboratory.

The $\mathrm{pH}$ of the $\mathrm{J}-13$ well water is slightly alkaline, having been reported at $\mathrm{pH}$ 7.6. Upon heating of the J-13 well water in the presence of Tuff rock, the pH varied only slightly when heated at $90^{\circ} \mathrm{C}$ and decreased down to 6.0 when heated at $250^{\circ} \mathrm{C}$. In the presence of radiation, the $\mathrm{pH}$ has been observed to increase to 9.0. To provide a somewhat larger range of $\mathrm{pH}$ for the test matrix, the low pH was selected at 5 and the high pH was selected at 10.

The high concentration of $\mathrm{Ca}, \mathrm{Mg}$, and $\mathrm{Al}$ were inadvertently added to the test matrix at a lower than desired value. Accordingly, several additional tests were added to the test matrix (Tests 3942 in Table 3.4) to assess the effects of these species on the corrosion behavior. 



\section{CPP TESTS IN J-13 WELL WATER}

Upon initiation of the overall program, several CPP tests were performed to (1) reproduce results by McCright at Lawrence Livermore Laboratories (LLL), (2) to compare behavior of candidate alloys in simulated and actual $\mathrm{J}-13$ well water, and (3) to evaluate the effects of changing the CPP test parameters, from those used at LLL, on the polarization behavior. To reproduce the behavior observed by McCright (Figure 4.1), the following test conditions were used: Actual J-13 well water, a scan rate of $3.6 \mathrm{~V} / \mathrm{hr}$, temperature of $80^{\circ} \mathrm{C}$, aerated conditions, and an initial exposure of 1-2 hours prior to performing the CPP test. For comparison purposes, CPP tests were performed under these test conditions in simulated $\mathrm{J}-13$ well water. The results of CPP experiments performed on Alloy CDA 102 under the above conditions are summarized in Table 4.1. The actual curves are shown in Figures 4.2 and 4.3, respectively. The curves are similar, with slight differences in the polarization parameters of breakdown potential $\left(E_{b}\right)$, repassivation potential $\left(E_{r p}\right)$, and corrosion current $\left(i_{c o s}\right)$. Repetition of these experiments verified the similarities between these curves. Although the passive current density is lower for the curves produced in this study, as compared to McCright's data, the polarization behavior reasonably reproduces the behavior shown by McCright in Figure 4.1. The above results produce two important findings that are critical to the remaining work performed in this project:

Prepared solutions can reasonably simulate actual well waters extracted from the Tuff site, and

The experimental procedures used for the NRC project are capable of reproducing the polarization behavior observed at Lawrence Livermore National Laboratory under similar test conditions.

There were three test conditions employed in the NRC program that were different than those used for the curves discussed above: (1) The period of exposure to the environment was 15-20 hours compared to 1-2 hours, (2) The scan rate was $0.6 \mathrm{~V} / \mathrm{hr}$ compared to $3.6 \mathrm{~V} / \mathrm{hr}$ and (3) the test temperature was $90^{\circ} \mathrm{C}$ compared to $80^{\circ} \mathrm{C}$. Both the longer exposure period and slower scan rate help insure nearer steady-state conditions. This, in turn, improves reproducibility and provides better estimates of corrosion rates and free-corrosion potentials. Tests were performed to examine the effects of these changes in procedures on the polarization behavior. In the first test, the scan rate was left unchanged at $3.6 \mathrm{~V} / \mathrm{hr}$ and a longer exposure time prior to performing the CPP test was permitted. Figures 4.4 and 4.5 show the CPP curves for alloy CDA 102 for simulated and actual $\mathrm{J}-13$ well water, respectively, with the longer initial exposure times. Comparisons to Figures 4.2 and 4.3 show that slight changes in the corrosion parameters occurred. The polarization behavior in Figures 4.4 and 4.5 should represent nearer steady-state initial test conditions.

The other conditions that were varied from the curves shown in Figures 4.2 and 4.3 were scan rate and temperature. Figure 4.6 shows a CPP curve for Alloy CDA 102 in simulated J-13 well water with an initial exposure period of fifteen hours, a scan rate of $0.6 \mathrm{~V} / \mathrm{hr}$, and a temperature of $90^{\circ} \mathrm{C}$ instead of $80^{\circ} \mathrm{C}$. The $90^{\circ} \mathrm{C}$ temperature was selected to coincide with the matrix of tests. These conditions are identical to those for Figure 4.4 except that the $0.6 \mathrm{~V} / \mathrm{hr}$ scan rate is six times slower than for the curve shown in Figure 4.4 and the temperature is 10 degrees higher. 


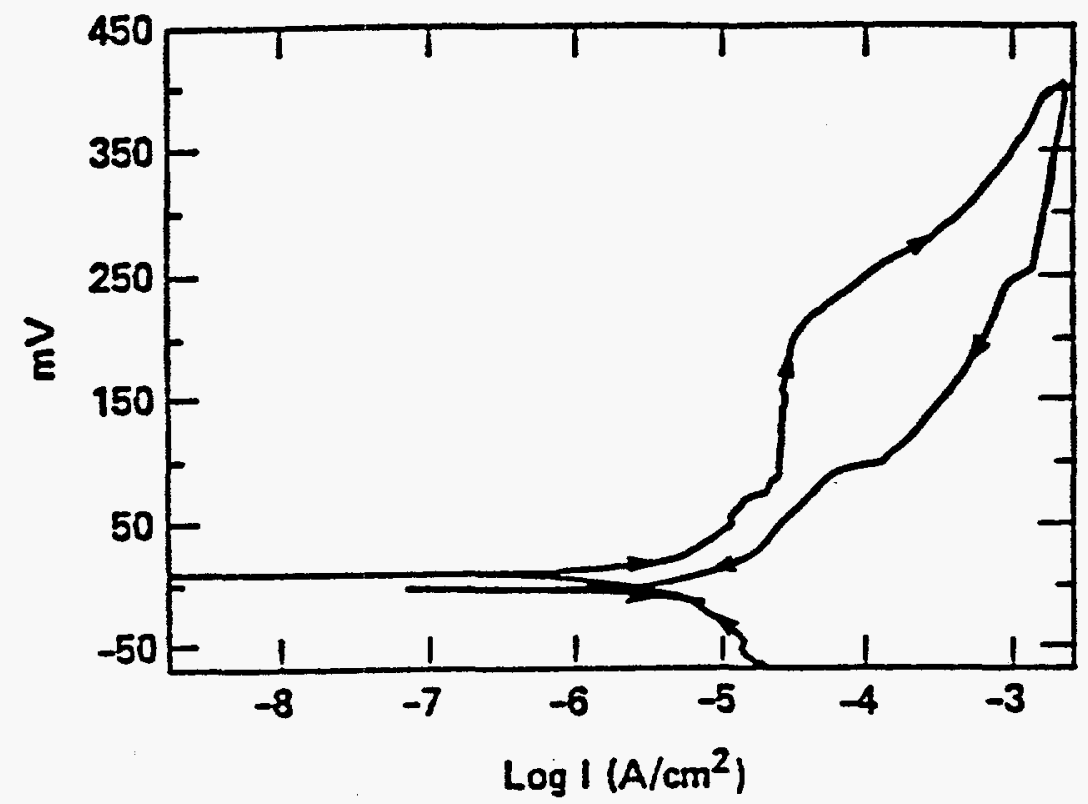

Figure 4.1 CPP Curve For Alloy CDA 102 in Actual J-13 Well Water At $80^{\circ} \mathrm{C}$ Run At A Scan Rate Of 3.6 V/hr Following A One To Two Hour Initial Exposure. (McCright-1985). 
Table 4.1 Polarization Parameters For The Candidate Alloys In Actual And Simulated J-13 Well Water.

\begin{tabular}{|c|c|c|c|c|c|c|c|c|}
\hline Alloy & $\begin{array}{l}\mathrm{J}-13 \\
\text { Water }\end{array}$ & $\begin{array}{c}\text { Temperature } \\
.{ }^{\circ} \mathrm{C}\end{array}$ & $\begin{array}{c}\text { Inittal } \\
\text { Exposure } \\
\text { Hours }\end{array}$ & $\begin{array}{l}\text { Scan } \\
\text { Rate } \\
\text { V/hr }\end{array}$ & $\begin{array}{c}E_{\infty x} \\
V, \text { SCE }\end{array}$ & $\begin{array}{c}\mathrm{l}_{\cos } \\
\mu \mathrm{A} \mathrm{cm}^{2}\end{array}$ & $\begin{array}{l}E_{p N} / E_{0} \\
V, S C E\end{array}$ & $\begin{array}{l}E_{p o v e} / E_{p p} \\
V, S C E\end{array}$ \\
\hline CDA 102 & Actual * & 80 & 1.2 & 3.6 & -0.011 & 5.78 & +0.201 & +0.092 \\
\hline CDA 102 & Simulated & 80 & 1 & 3.6 & -0.015 & 0.13 & +0.161 & -0.140 \\
\hline CDA 102 & Actual & 80 & 1 & 3.6 & +0.004 & 0.31 & +0.212 & -0.179 \\
\hline CDA 102 & Simulated & 80 & 15 & 3.6 & -0.030 & 0.80 & +0.256 & -0.046 \\
\hline CDA 102 & Actual & 80 & 15 & 3.6 & -0.017 & 0.35 & +0.242 & -0.085 \\
\hline CDA 102 & Simulated & 90 & 15 & 0.6 & -0.030 & 2.0 & +0.140 & -0.035 \\
\hline CDA 715 & Simulated & 90 & 15 & 0.6 & -0.265 & 0.41 & +0.180 & +0.080 \\
\hline 304L & Simulated & 90 & 15 & 0.6 & -0.125 & 0.12 & +0.800 & +0.800 \\
\hline 1825 & Simulated & 90 & 15 & 0.6 & -0.650 & 0.08 & +0.700 & +0.700 \\
\hline
\end{tabular}

- McCright - 1985. 


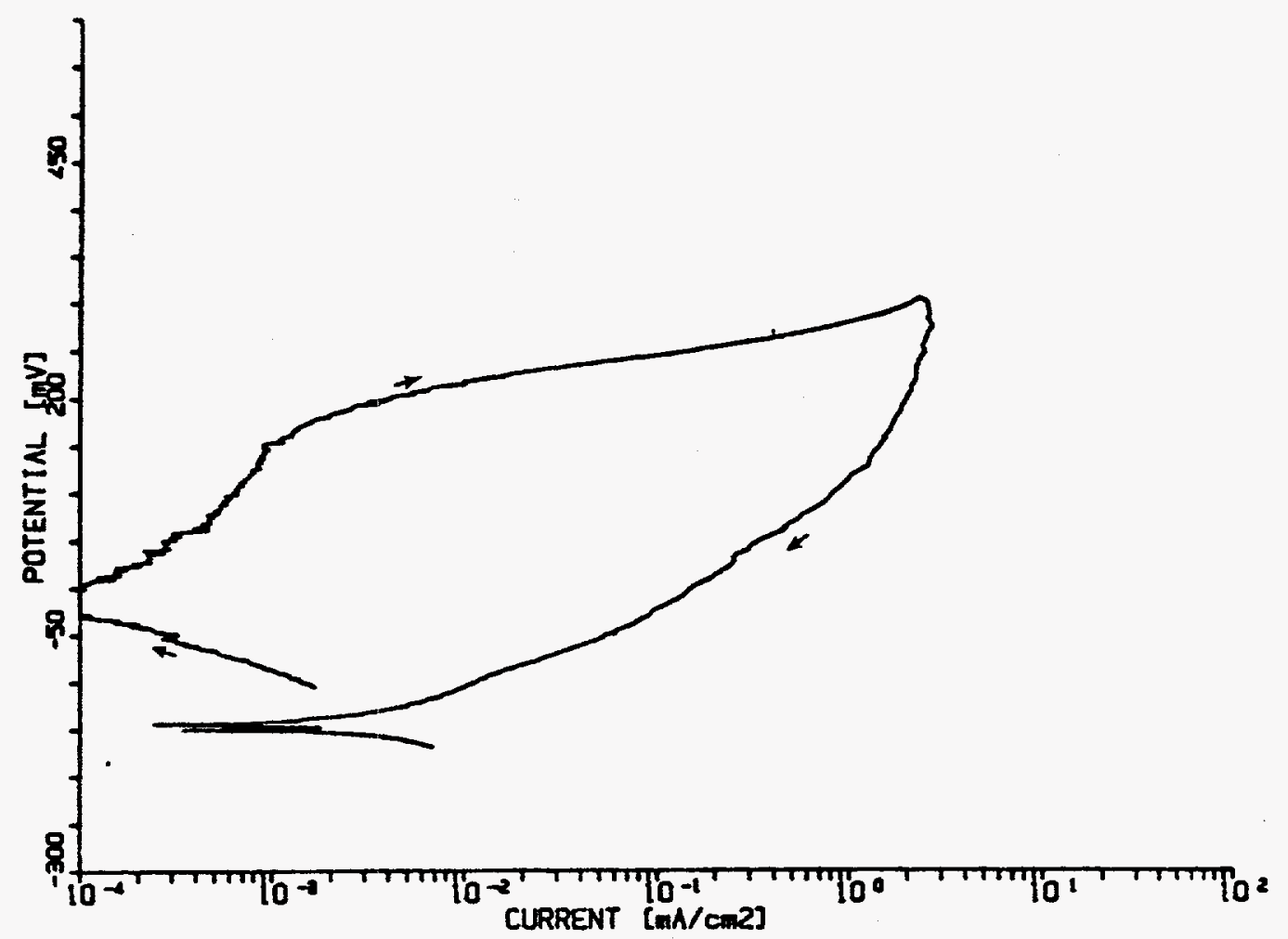

Figure 4.2 CPP Curve For Alloy CDA 102 In Simulated J-13 Well Water At $80^{\circ} \mathrm{C}$ Run At A Scan Rate Of 3.6 V/hr Following A One Hour Initial Exposure.

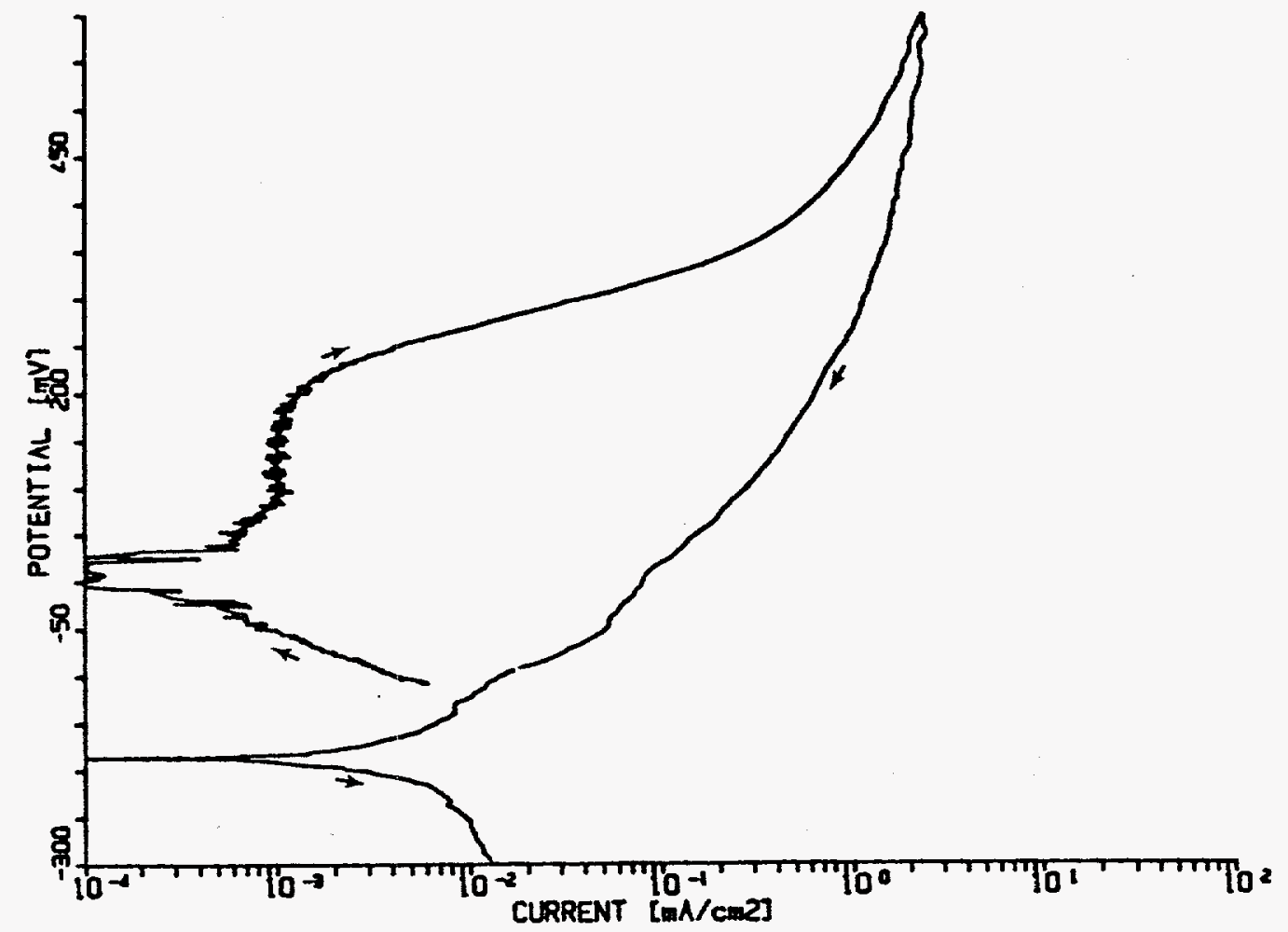

Figure 4.3 CPP Curve For Alloy CDA 102 In Actual J-13 Well Water At $80^{\circ} \mathrm{C}$ Run At A Scan Rate Of 3.6 V/hr Following A One Hour Initial Exposure. 


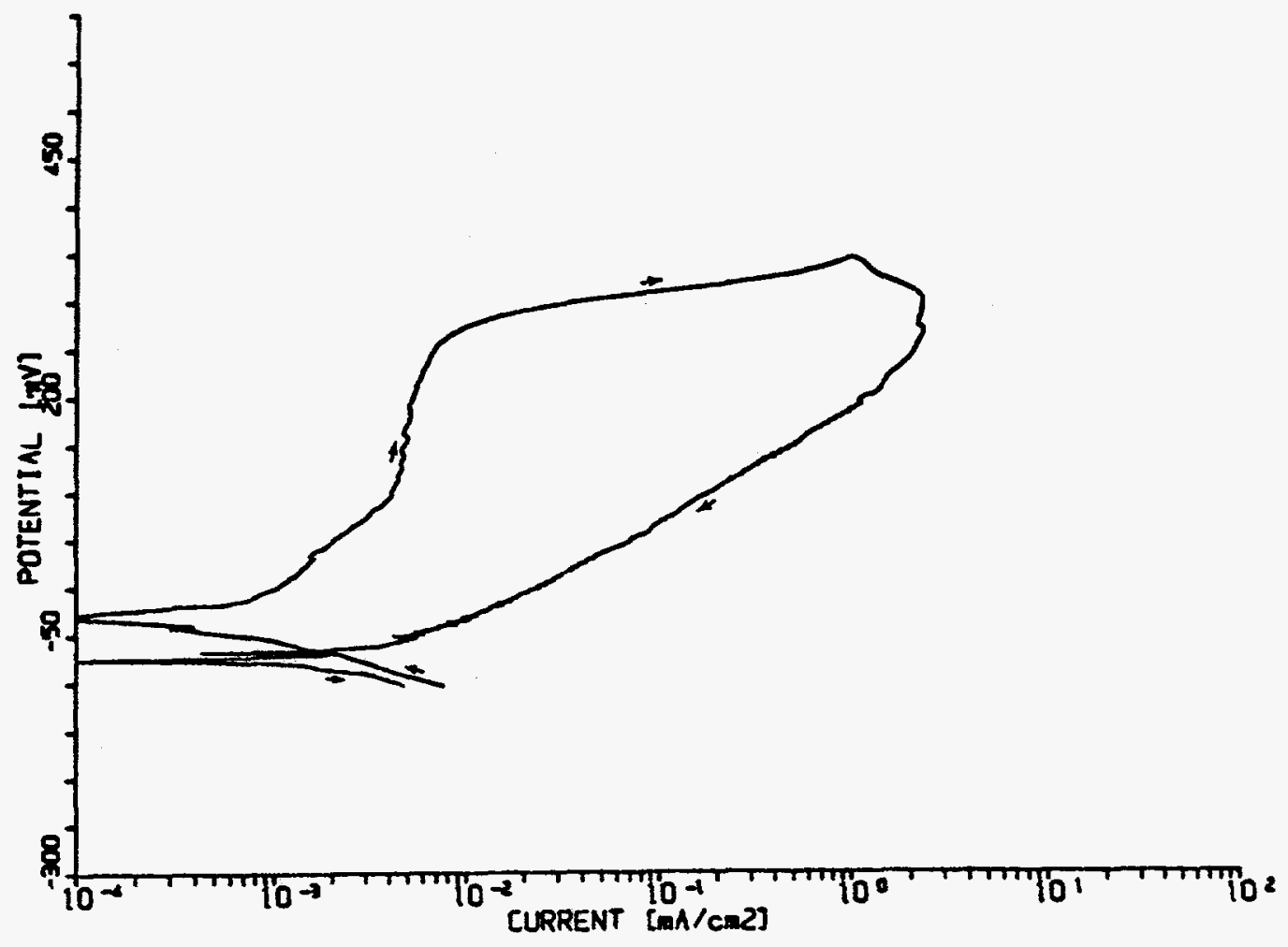

Figure 4.4 CPP Curve For Alloy CDA 102 In Simulated J-13 Well Water At $80^{\circ} \mathrm{C}$ Run At A Scan Rate Of 3.6 V/hr. Following A Fifteen Hour Initial Exposure.

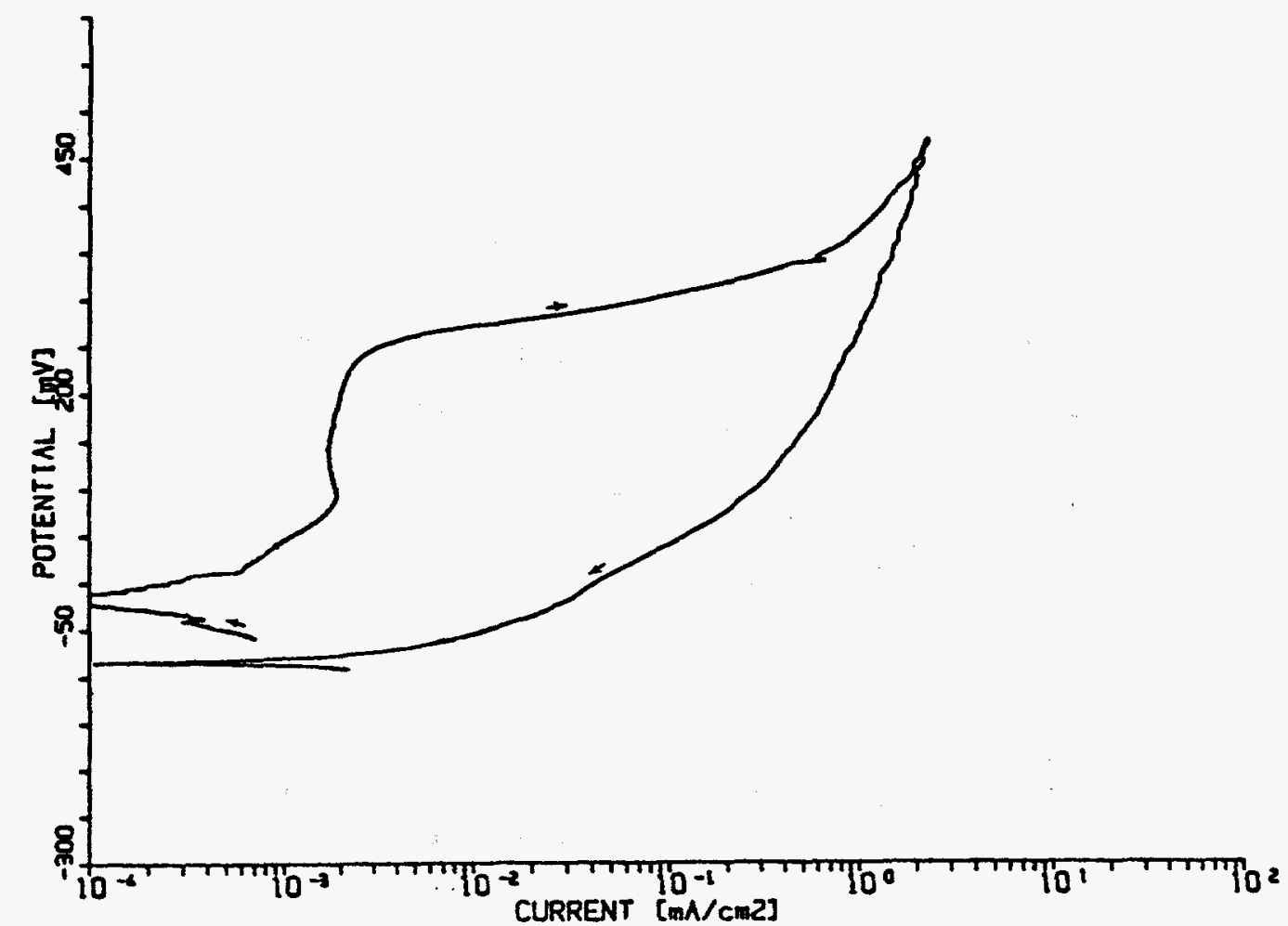

Figure 4.5 CPP Curve For Alloy CDA 102 In Actual J-13 Well Water At $80^{\circ} \mathrm{C}$ Run At A Scan Rate Of 3.6 V/hr Following A Fifteen Hour Initial Exposure. 


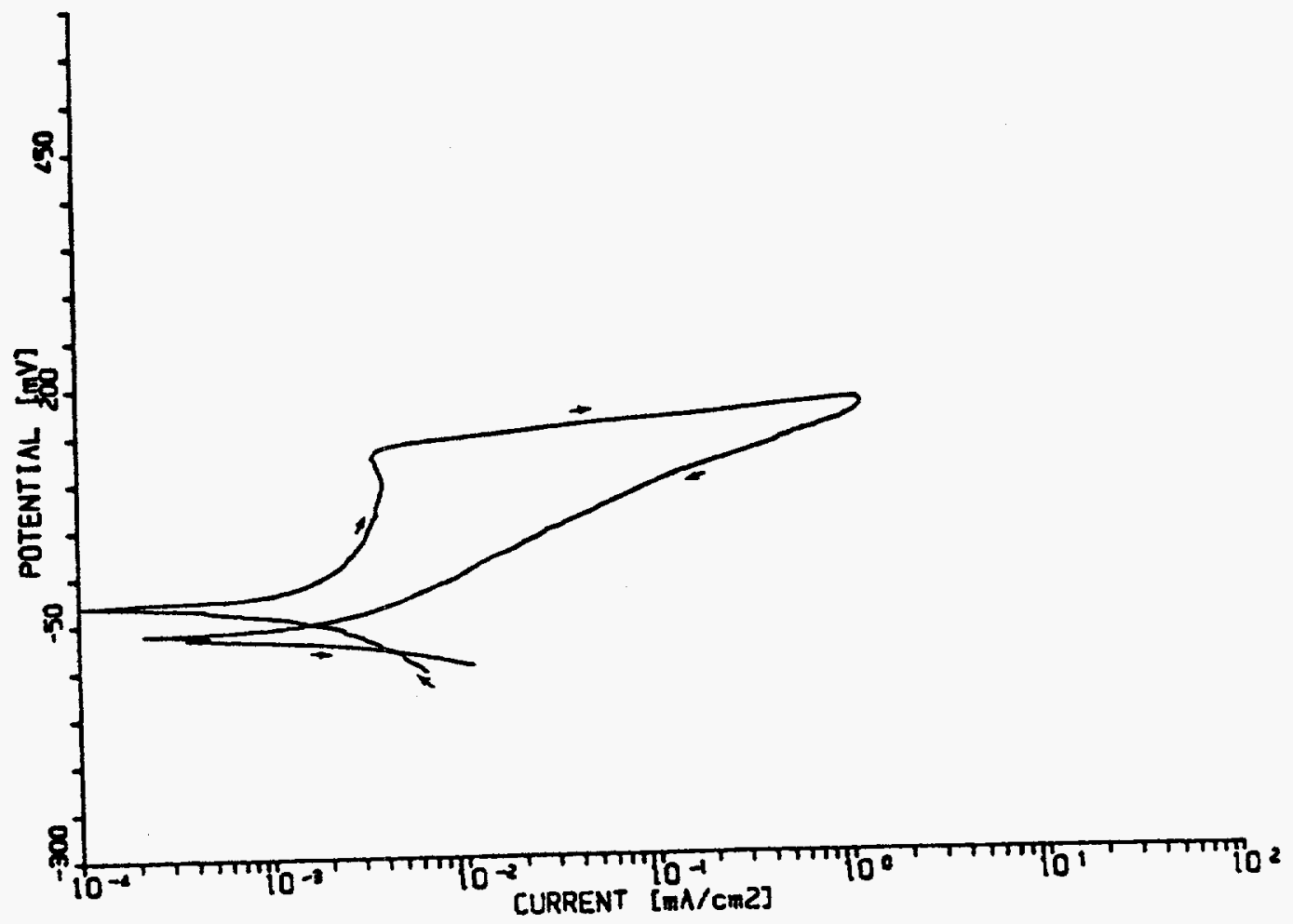

Figure 4.6 CPP Curve For Alloy CDA 102 In Simulated J-13 Well Water At $90^{\circ} \mathrm{C}$ Run At A Scan Rate of $0.6 \mathrm{~V} / \mathrm{hr}$ Following A Fifteen Hour Initial Exposure. 
Figures 4.7 - 4.9 show the CPP curves for Alloy CDA 715, Alloy 304L and Alloy 825 in simulated $\mathrm{J}-13$ well water under the same conditions as for Figure 4.6.

Comparing the behavior seen in Figure 4.6 (slow scan rate) to Figure 4.4 (fast scan rate), the only significant difference is in the value of the breakdown potential, $E_{b}$. The much more negative value for $E_{b}$ for the slower scan rate is not unusual since pitting has some initiation time associated with it and this behavior has been seen in other alloy-environmental combinations. It should be noted that the increase in temperature also would produce a similar trend. The behavior for the slower scan rate is nearer steady-state conditions and predicts actual field situations more closely. Therefore, all subsequent CPP testing used a $0.6 \mathrm{~V} / \mathrm{hr}$ scan rate and an initial exposure time of 15-20 hours prior to performing the CPP test. 


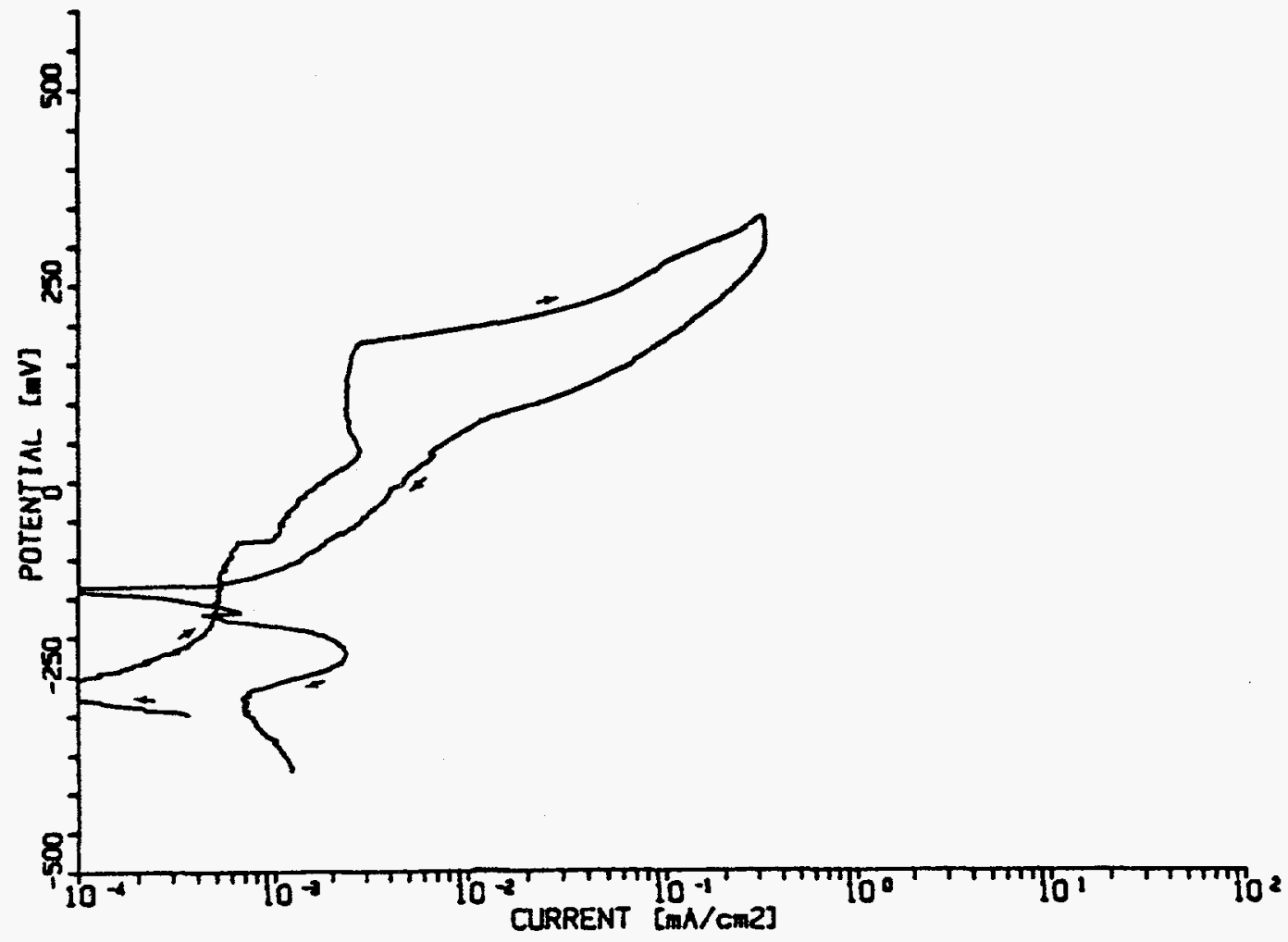

Figure 4.7 CPP Curve For Alloy CDA 715 in Simulated J-13 Well Water At $90^{\circ} \mathrm{C}$ Run At A Scan Rate Of $0.6 \mathrm{~V} / \mathrm{hr}$ Following A Fifteen Hour Initial Exposure.

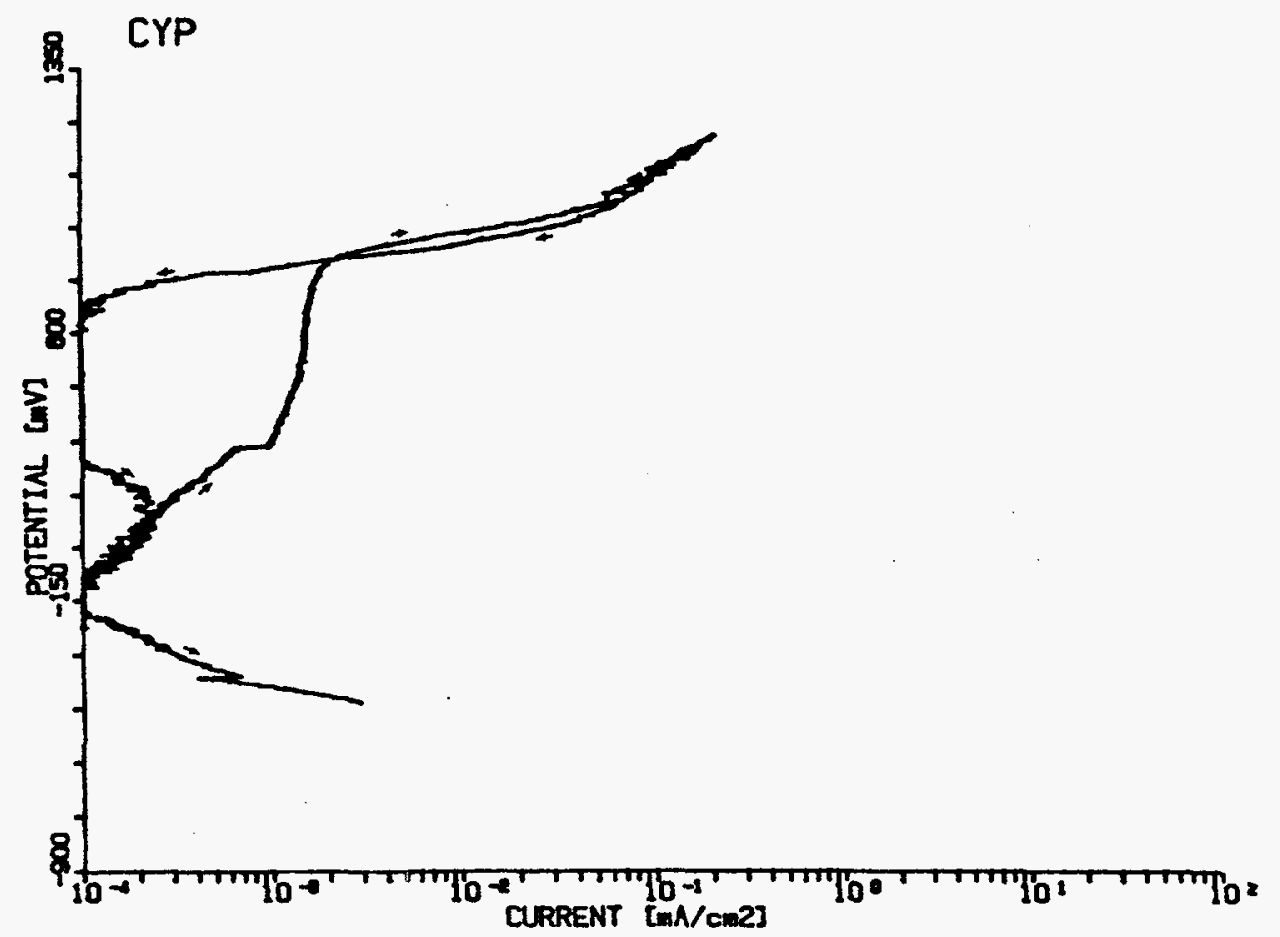

Figure 4.8 CPP Curve For Alloy $304 \mathrm{~L}$ In Simulated J-13 Well Water At $90^{\circ} \mathrm{C}$ Run At A Scan Rate Of 0.6 V/hr Following A Fifteen Hour Initial Exposure. 


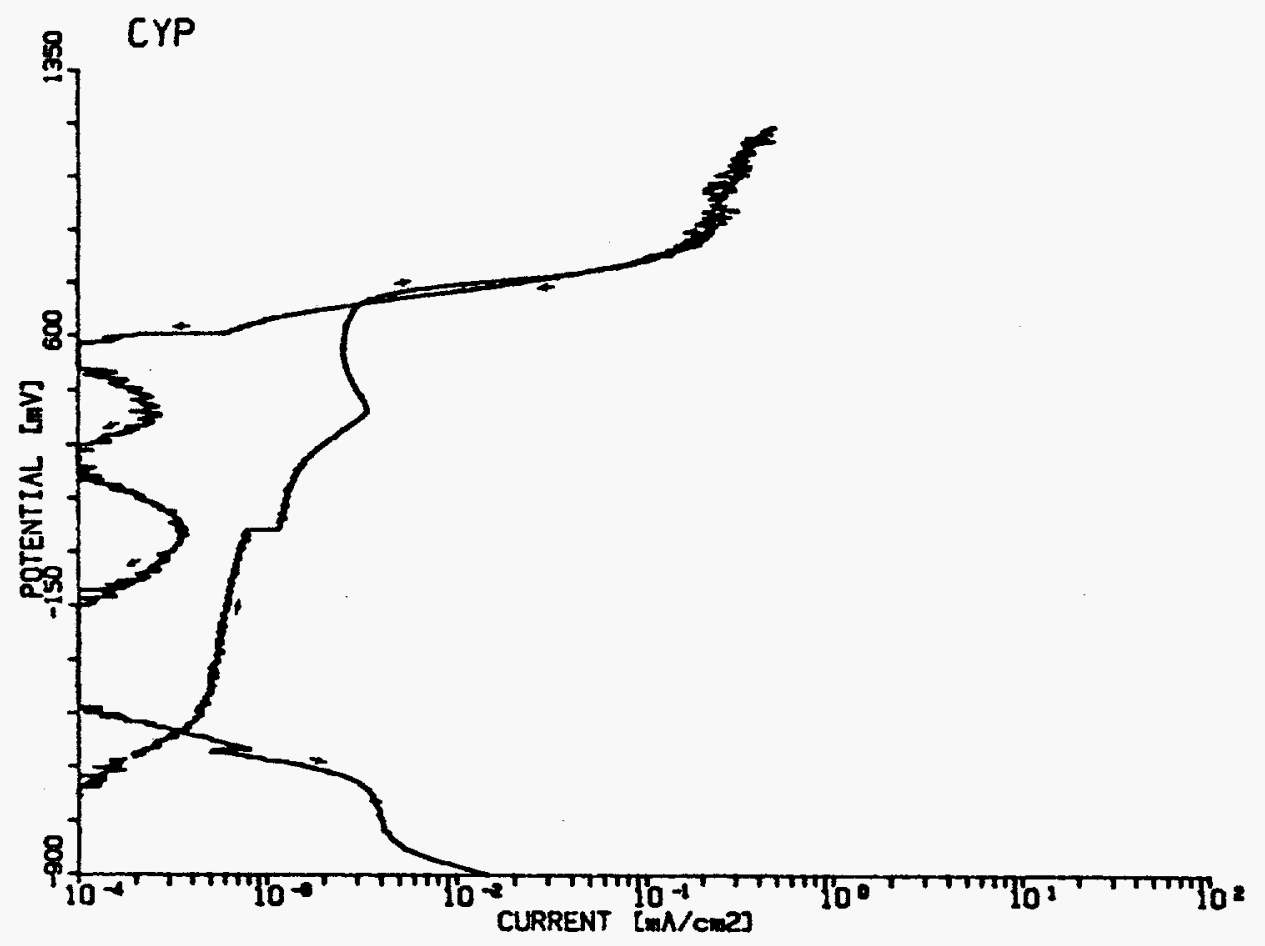

Figure 4.9 CPP Curve For Alloy 825 in Simulated J-13 Well Water At $90^{\circ} \mathrm{C}$ Run At A Scan Rate Of $0.6 \mathrm{~V} / \mathrm{hr}$ Following A Fifteen Hour Initial Exposure. 



\section{CPP TESTS IN CHLORIDE SOLUTIONS}

The composition of the groundwater that comes in contact with the waste container is expected to be much more concentrated than that of the J-13 well water as a result of thermal concentration. Cyclic-potentiodynamic-polarization tests were performed with each of the candidate container alloys in simulated $\mathrm{J}-13$ well water with the chloride $(\mathrm{Cl})$ concentration increased to $1000 \mathrm{mgl}$ (as sodium chloride, $\mathrm{NaCl}$ ), the maximum $\mathrm{Cl}$ concentration from the environmental test matrix. Table 5.1 summarizes the polarization parameters for each of the four alloys in both simulated $\mathrm{J}-13$ well water and in simulated $\mathrm{J}-13$ well water containing $1000 \mathrm{mg} /$ chloride.

Figures 5.1 and 5.2 compare the polarization behavior of Alloy CDA 102 in simulated J-13 well water with low and high chlorides, respectively. The most significant difference in the curves is the loss of the passive region with the chloride addition. A dark film also was present on the specimen in the high chloride solution prior to starting the CPP scan. Both curves exhibit hysteresis on the reverse scans that typically indicates the occurrence of pitting on the specimen. However, post-test optical examination of the specimens indicated no pitting; only local changes in film coloration on the specimens with no observable depth of attack. This behavior was observed in many instances of the program and is discussed in greater detail below.

Cyclic-potentiodynamic-polarization curves for Alloy CDA 715 in simulated $\mathrm{J}-13$ well water and simulated $\mathrm{J}-13$ well water with $1000 \mathrm{mg} / \mathrm{l}$ of chloride are given in Figures 5.3 and 5.4 respectively. The increased chloride concentration significantly decreased the breakdown and $\left(E_{b}\right)$ repassivation $\left(E_{m}\right)$ potentials. However, as was observed for Alloy CDA 102, typical pitting was not found. Instead of local deep pits, which were expected because of the hysteresis observed, local areas of very shallow active corrosion and local changes in the oxide film occurred.

Figures 5.3 and 5.4 also demonstrate two different types of curves with respect to repassivation during the reverse scan. In Figure 5.4, $E_{\mathrm{p}}$ was selected at the potential where the current during the reverse scan equaled the original passive current density. Figure 5.3 exhibits different behavior, where the very shallow slope typically observed during repassivation changes to a steeper slope which is believed to represent the bulk surface conditions. Note that $E_{\mathrm{rp}}$ in Figure 5.3 was selected at the point of this slope change. Also shown in Figure 5.3 is a peak in the cathodic curve during the return scan (" $A$ " in Figure 5.3). This will also be apparent in several curves in the matrix of experiments for Alloy CDA 715. It was observed that any time this phenomenon occurred, a copper film was present at the active sites or pits on the specimen surface. Therefore, it is believed that the cathodic current peak represents reduction of copper ions and the plating of copper back on the specimen surface.

Because CPP tests performed under Task 2 of the program indicated that the copper-base alloys did not always exhibit classical pitting behavior, the distinction in the electrochemical terms was made to reflect this fact. Thus, the terms $E_{b}$ and $E_{p p}$ were used to describe the breakdown potential and repassivation potential for the copper-base alloys. On the other hand, the classical terms $E_{p h}$ and $E_{\text {prot }}$ were used for the pitting potential and the protection potential, respectively, for the Fe-Cr-Ni alloys. 
Table 5.1 Polarization Parameters For The Candidate Alloys In Simulated J-13 Well Water At $90^{\circ} \mathrm{C}$, With And Without Salt.

\begin{tabular}{|c|c|c|c|c|c|c|}
\hline Alloy & $\begin{array}{c}\text { Test } \\
\text { Solution }\end{array}$ & $\begin{array}{c}E_{\infty} \\
V, S C E\end{array}$ & $\mu \mathrm{low}_{\mathrm{cm}}^{2}$ & $\begin{array}{l}E_{p R} / E_{0} \\
V, S C E\end{array}$ & $\begin{array}{l}E_{p r o t} / E_{p p} \\
V, S C E\end{array}$ & Comments \\
\hline $\begin{array}{l}\text { CDA } 102 \\
\text { CDA } 102\end{array}$ & $\begin{array}{c}\mathrm{J}-13 \\
\mathrm{~J}-13+1000 \mathrm{ppm} \mathrm{Cl}\end{array}$ & $\begin{array}{l}-0.030 \\
-0.075\end{array}$ & $\begin{array}{l}2.0 \\
2.2\end{array}$ & $\begin{array}{l}+0.140 \\
-0.050\end{array}$ & $\begin{array}{l}-0.035 \\
-0.218\end{array}$ & $\begin{array}{l}\text { Local changes in oxide. } \\
\text { Local changes in oxide. }\end{array}$ \\
\hline $\begin{array}{l}\text { CDA } 715 \\
\text { CDA } 715\end{array}$ & $\begin{array}{c}J-13 \\
J-13+1000 \text { ppm Cl }\end{array}$ & -0.400 & 0.02 & -0.040 & $\begin{array}{l}+0.080 \\
-0.028\end{array}$ & $\begin{array}{l}\text { Local changes in oxide, } \\
\text { local active attack with } \\
\text { few shallow pits. } \\
\text { Local changes in oxide, } \\
\text { local active attack. }\end{array}$ \\
\hline $\begin{array}{l}304 L \\
304 L\end{array}$ & $\begin{array}{c}\mathrm{J}-13 \\
\mathrm{~J}-13+1000 \mathrm{ppm} \mathrm{Cl}\end{array}$ & $\begin{array}{l}-0.125 \\
-0.250\end{array}$ & 0.12 & $\begin{array}{l}+0.800 \\
+0.160\end{array}$ & $\begin{array}{l}+0.800 \\
-0.180\end{array}$ & $\begin{array}{l}\text { No pitting or active } \\
\text { attack. } \\
\text { Pitting. }\end{array}$ \\
\hline 825 & $\begin{array}{c}J-13 \\
J-13+1000 p p m ~ C l\end{array}$ & -0.480 & 0.14 & $\begin{array}{l}+0.700 \\
+0.700\end{array}$ & $\begin{array}{l}+0.700 \\
+0.160\end{array}$ & $\begin{array}{l}\text { No pitting or active } \\
\text { attack. } \\
\text { Pitting. }\end{array}$ \\
\hline
\end{tabular}

NOTE: $\quad$ Chloride added as sodium chloride. 


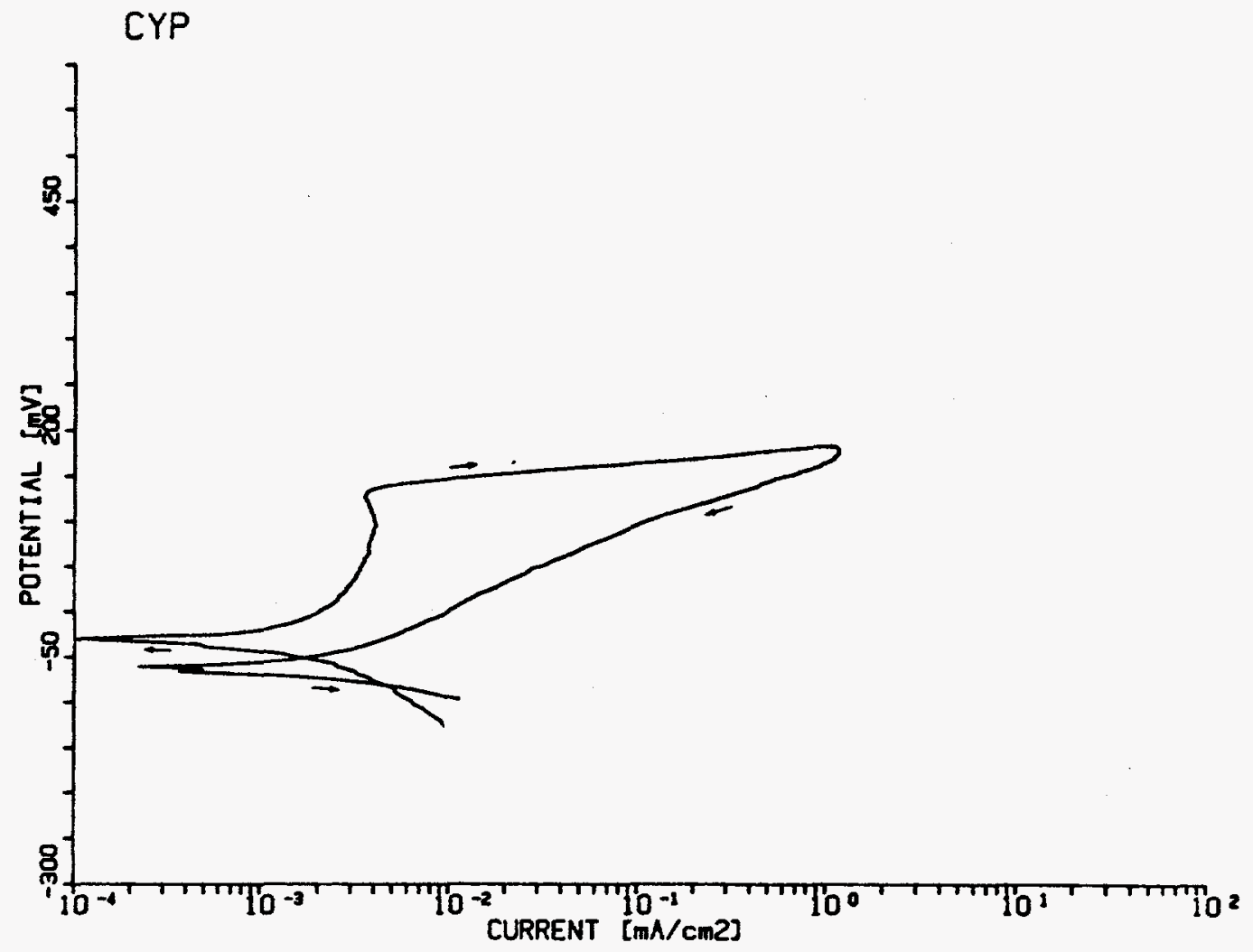

Figure 5.1 CPP Curve For Alloy CDA 102 in Simulated J-13 Well Water At $90^{\circ} \mathrm{C}$ Run At A Scan Rate Of $0.6 \mathrm{~V} / \mathrm{hr}$.

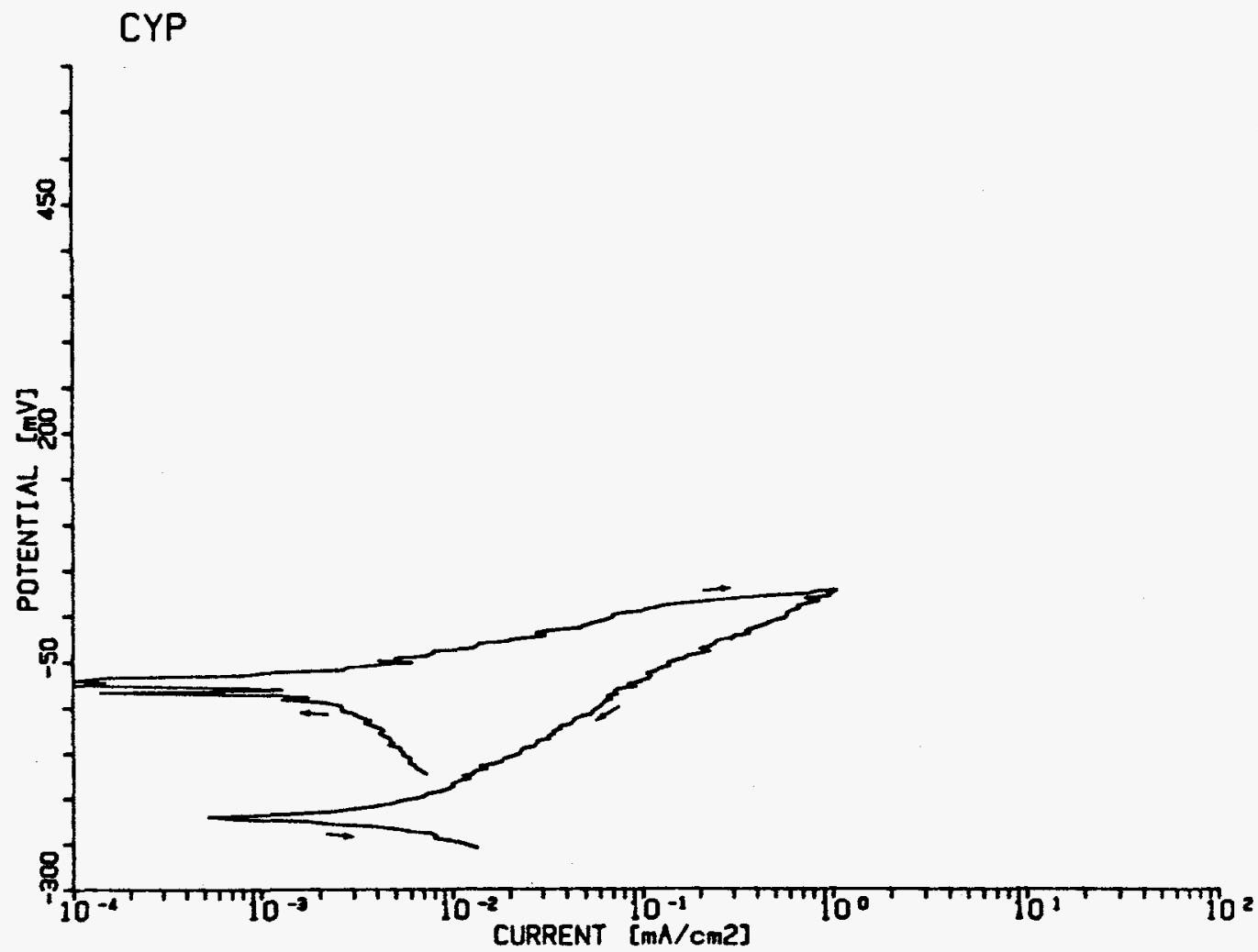

Figure 5.2 CPP Curve For Alloy CDA 102 In Simulated J-13 Well Water At $90^{\circ} \mathrm{C}$ With The Chloride Concentration Increased To $1000 \mathrm{mg} / \mathrm{As} \mathrm{NaCl}$ ). 


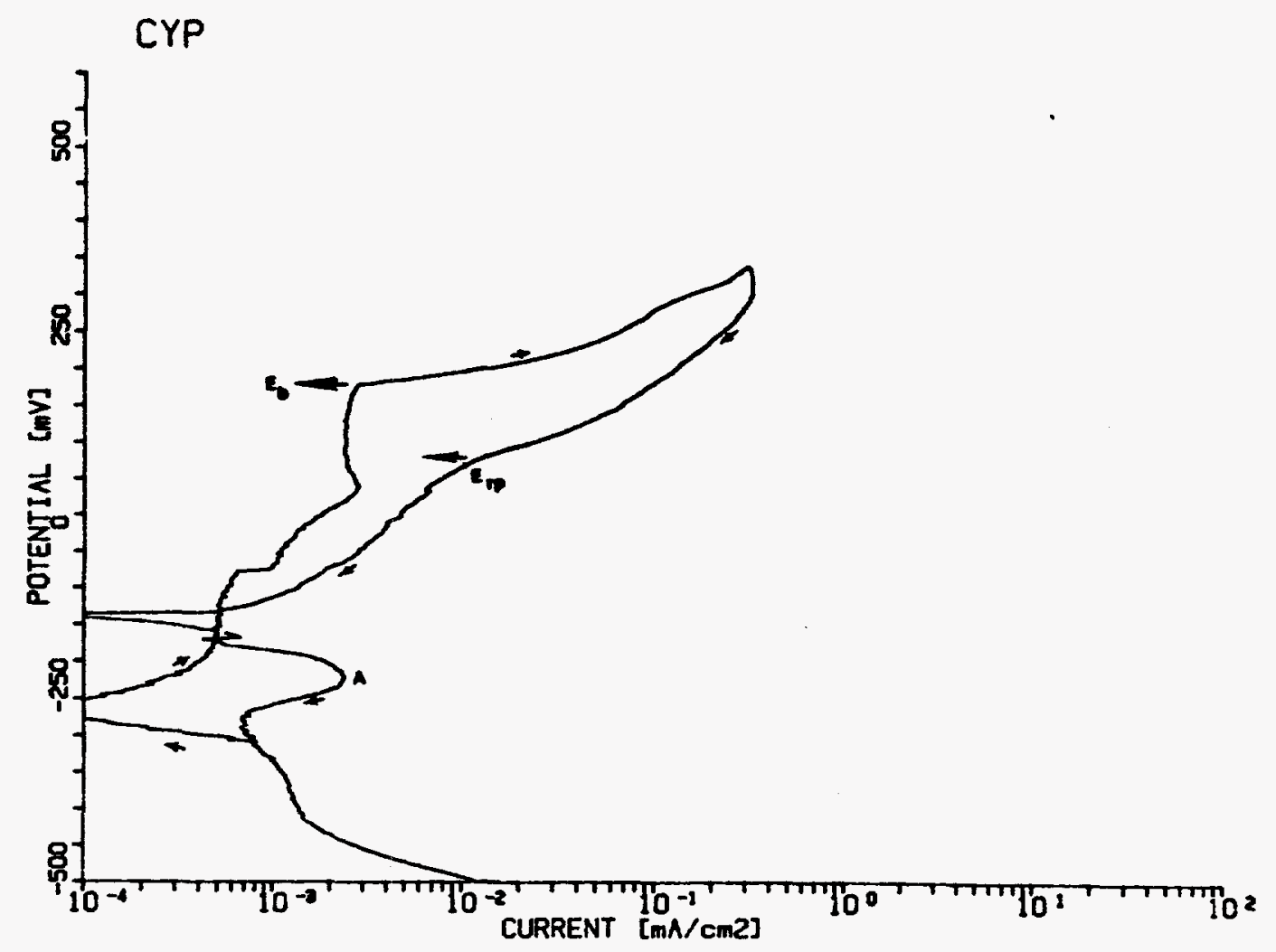

Figure 5.3 CPP Curve For Alloy CDA 715 in Simulated J-13 Well Water At $90^{\circ} \mathrm{C}$ Run At A Scan Rate Of $0.6 \mathrm{~V} / \mathrm{hr}$.

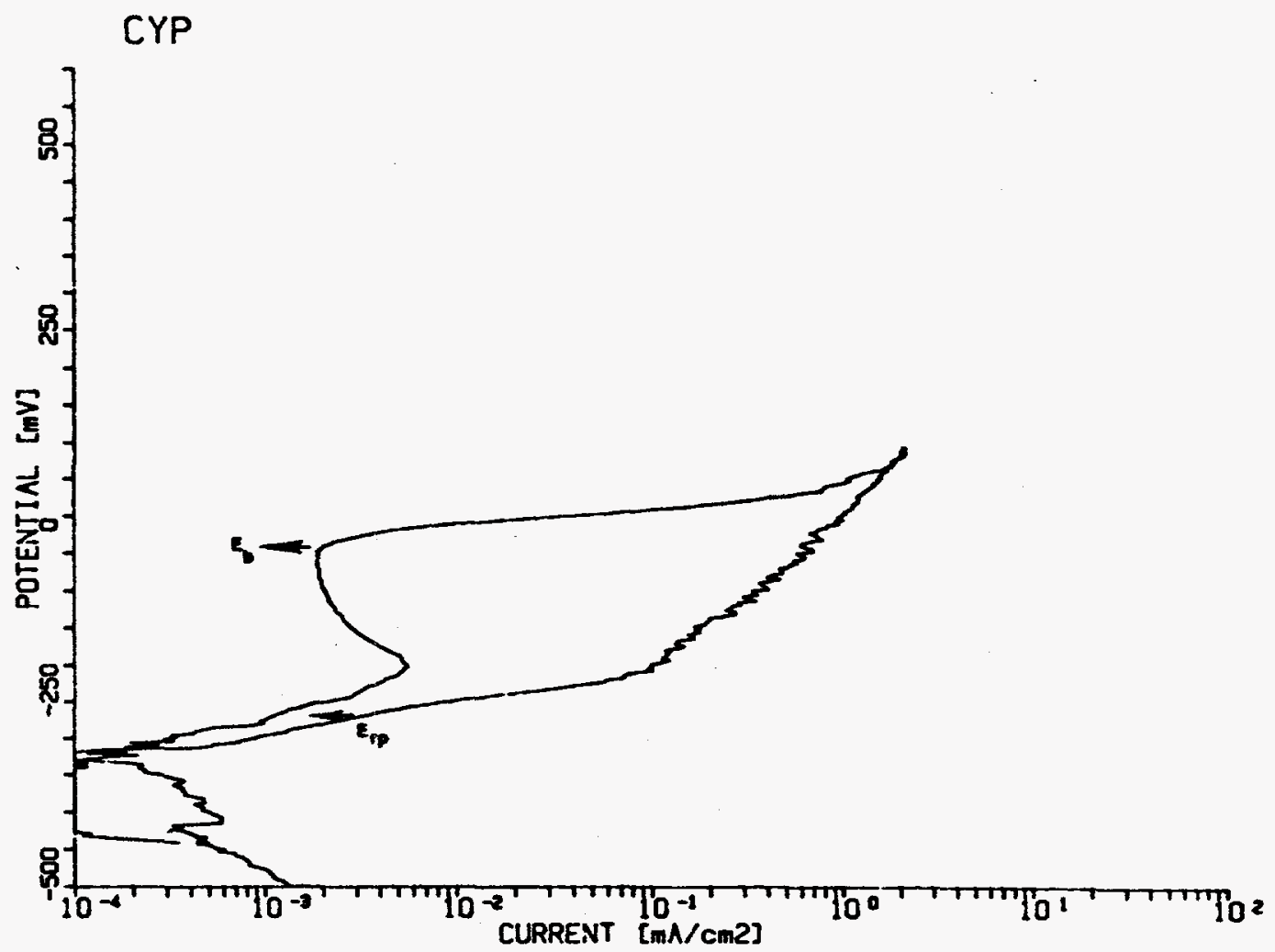

Figure 5.4 CPP Curve For Alloy CDA 715 In Simulated J-13 Well Water At $90^{\circ} \mathrm{C}$ With The Chloride Concentration Increased To $1000 \mathrm{mg} /$ (As $\mathrm{NaCl}$ ). 
CPP tests were performed on Alloy $304 \mathrm{~L}$ and Alloy 825 in simulated J-13 well water and in the simulated J-13 well water with the addition of $1000 \mathrm{mg} /$ chloride. The tests were run at $90^{\circ} \mathrm{C}$ under naturally aerated conditions. Figures 5.5 and 5.6 compare CPP curves for Alloy $304 \mathrm{~L}$ in simulated J-13 well water and simulated J-13 well water with $1000 \mathrm{mg} / \mathrm{l}$ chloride added as well. Figure 5.5 shows that Alloy $304 \mathrm{~L}$ in simulated $\mathrm{J}-13$ well water exhibited passive behavior with no indication of pitting corrosion (no hysteresis loop). Examination of the sample during post-test evaluation indicated no pitting or other form of corrosion or observable oxide formation on the surface.

Figure 5.6 shows that Alloy $304 \mathrm{~L}$, in simulated $\mathrm{J}-13$ well water containing $1000 \mathrm{mg} /$ chloride, exhibited passive behavior at the free-corrosion potential, a pitting potential of approximately $+0.160 \mathrm{~V}$ (SCE) and a protection potential of approximately $-0.180 \mathrm{~V}$ (SCE). Post-test evaluation of the sample indicated significant pitting over the entire surface, which corresponded well with the large hysteresis observed during the CPP experiment. Furthermore, in the simulated J-13 well water containing the increased chloride content, the protection potential is relatively close to the free-corrosion potential $(-0.25 \mathrm{~V}$ (SCE). Conventional wisdom and the above results indicate that Alloy $304 \mathrm{~L}$ is, at best, a marginal alloy for application in an environment similar to $\mathrm{J}-13$ well water with an elevated chloride concentration.

Figure 5.7 shows a CPP curve for Alloy 825 in simulated $\mathrm{J}-13$ well water at $90^{\circ} \mathrm{C}$. As is seen from the curve, no hysteresis is present during the return scan, indicating no pitting corrosion. Post-test examination of the specimen indicated no signs of corrosion of any kind. Therefore, Alloy 825 would not be expected to corrode significantly in $\mathrm{J}-13$ well water at $90^{\circ} \mathrm{C}$, which is similar to the results observed for Alloy $304 \mathrm{~L}$ in the simulated $\mathrm{J}-13$ well water.

Figure 5.8 shows a CPP curve for Alloy 825 in simulated $\mathrm{J}-13$ well water at $90^{\circ} \mathrm{C}$ with $1000 \mathrm{mg} / \mathrm{l}$ chloride added (as $\mathrm{NaCl}$ ). In the presence of the added chloride, a significant hysteresis loop is observed, which is an indication of pitting/crevice corrosion. Post-test examination indicated the specimen underwent pitting corrosion. The addition of $1000 \mathrm{mg} / \mathrm{chloride}$ was sufficient to sustain pitting in a potential range of +0.160 to $+0.70 \mathrm{~V}$ (SCE). For the simulated $\mathrm{J}-13$ well water with $1000 \mathrm{mg} / \mathrm{l}$ chloride added, the pitting range is some $600-700 \mathrm{mV}$ more positive than the freecorrosion potential. This indicates that, for these conditions, pitting of Alloy $\mathbf{8 2 5}$ is highly unlikely unless the free-corrosion potential becomes significantly more positive with time, which may be possible in the presence of radiolysis products. Although pitting is unlikely, at the free corrosion potential, in the $\mathrm{J}-13$ well water or the $\mathrm{J}-13$ well water with $1000 \mathrm{mg} /$ chloride added, pitting was observed to be quite likely in other solutions examined in the statistical matrix; see the discussion of potentiodynamic-polarization studies of the Fe-Cr-Ni alloys in Section 7. 


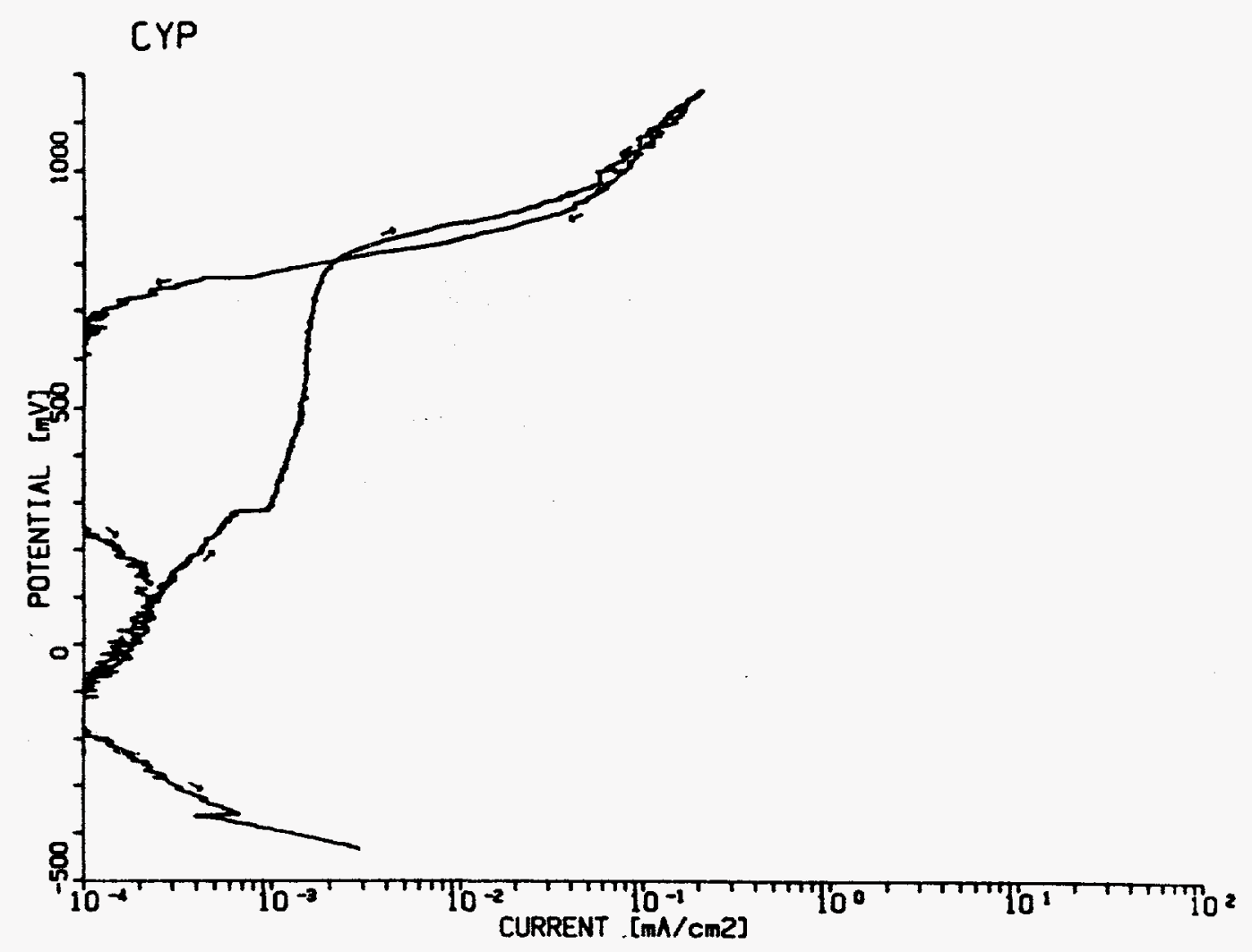

Figure 5.5 CPP Curve For Alloy $304 \mathrm{~L}$ in Simulated J-13 Well Water At $90^{\circ} \mathrm{C}$ Run At A Scan Rate of $0.6 \mathrm{~V} / \mathrm{hr}$.

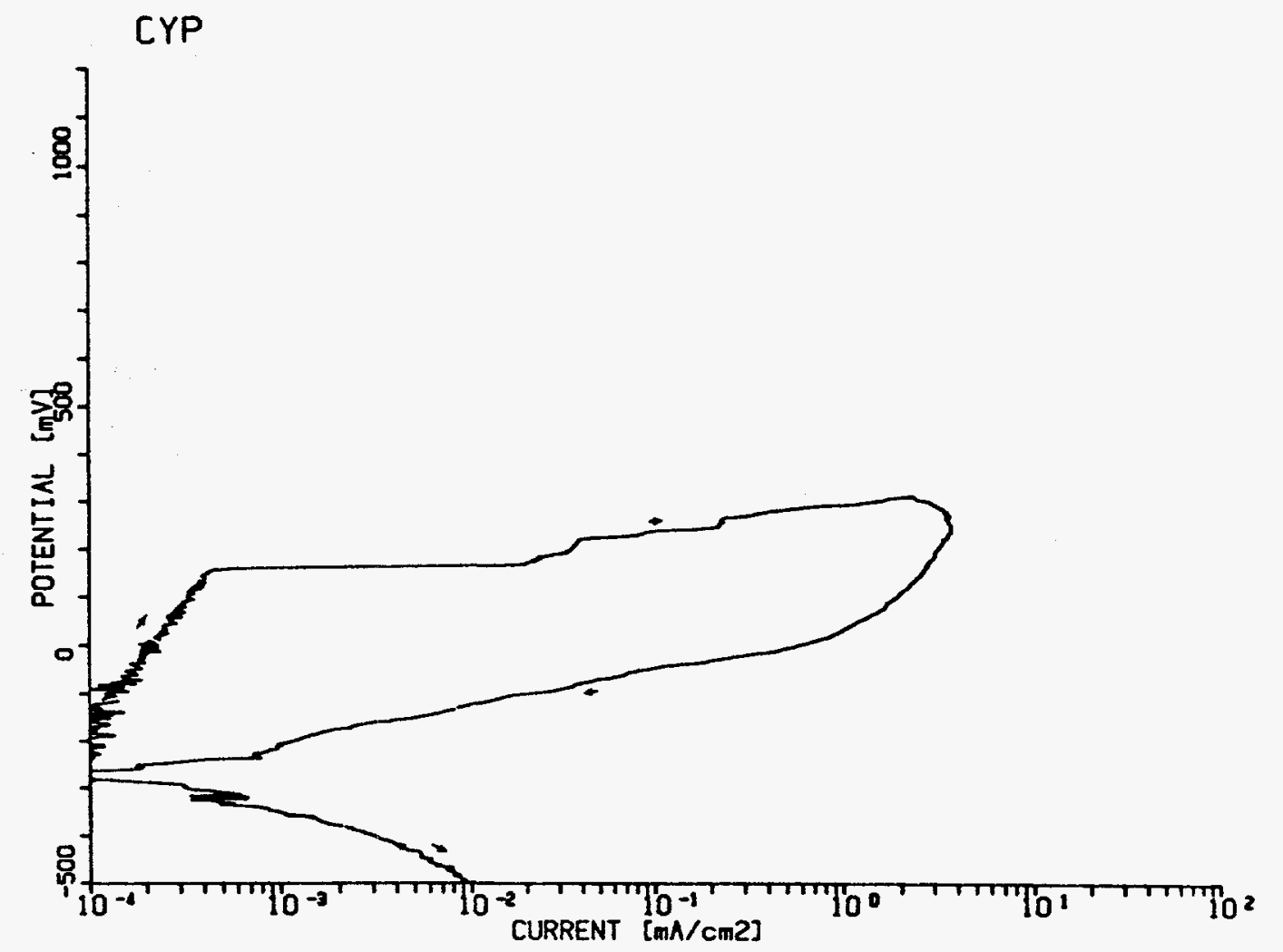

Figure 5.6 CPP Curve For Alloy $304 \mathrm{~L}$ In Simulated J-13 Well Water At $90^{\circ} \mathrm{C}$ With The Chloride Concentration Increased To $1000 \mathrm{mg} /$ (As $\mathrm{NaCl}$ ). 


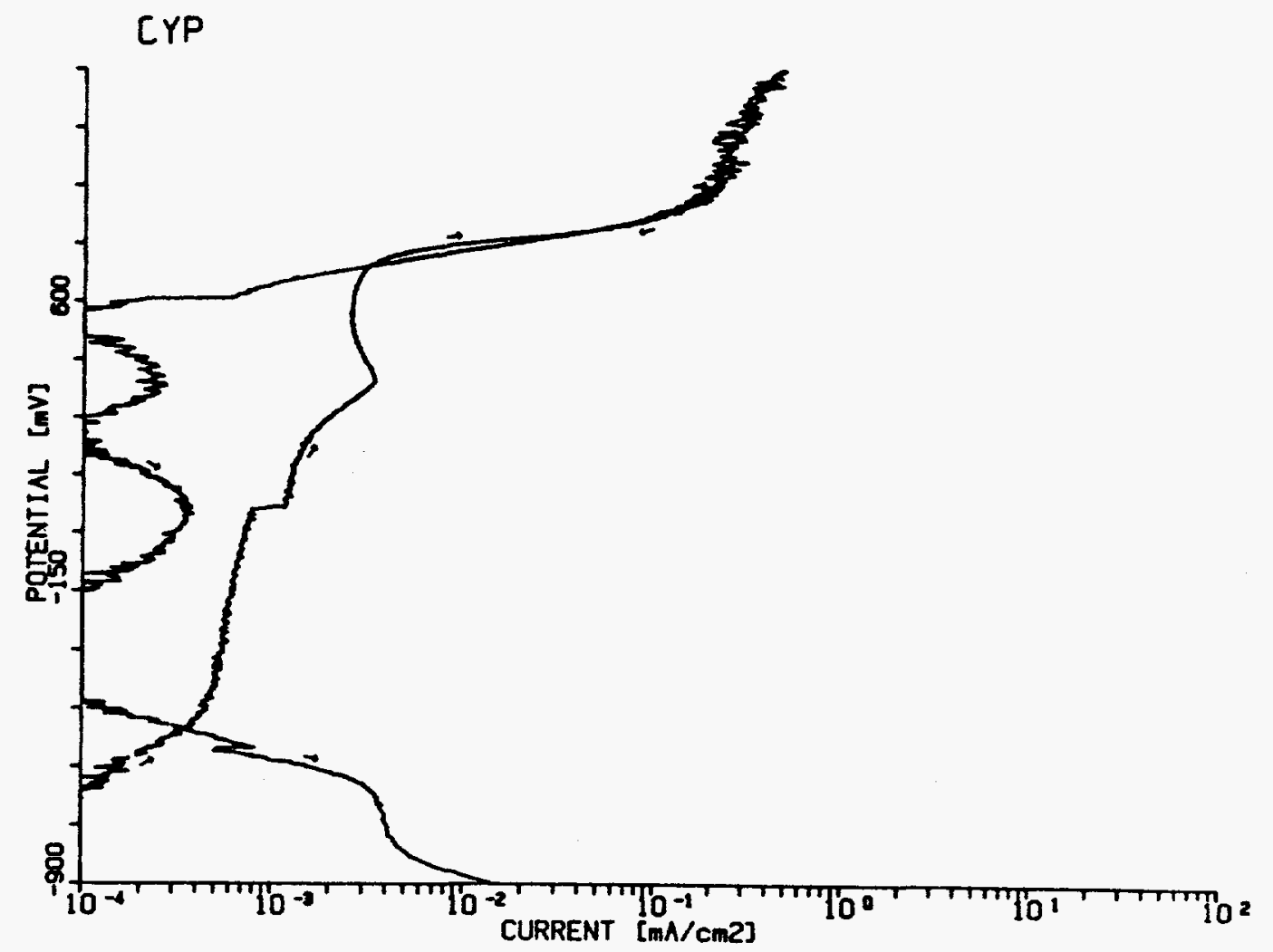

Figure 5.7 CPP Curve For Alloy 825 In Simulated J-13 Well Water At $90^{\circ} \mathrm{C}$ Run At A Scan Rate Of $0.6 \mathrm{~V} / \mathrm{hr}$.

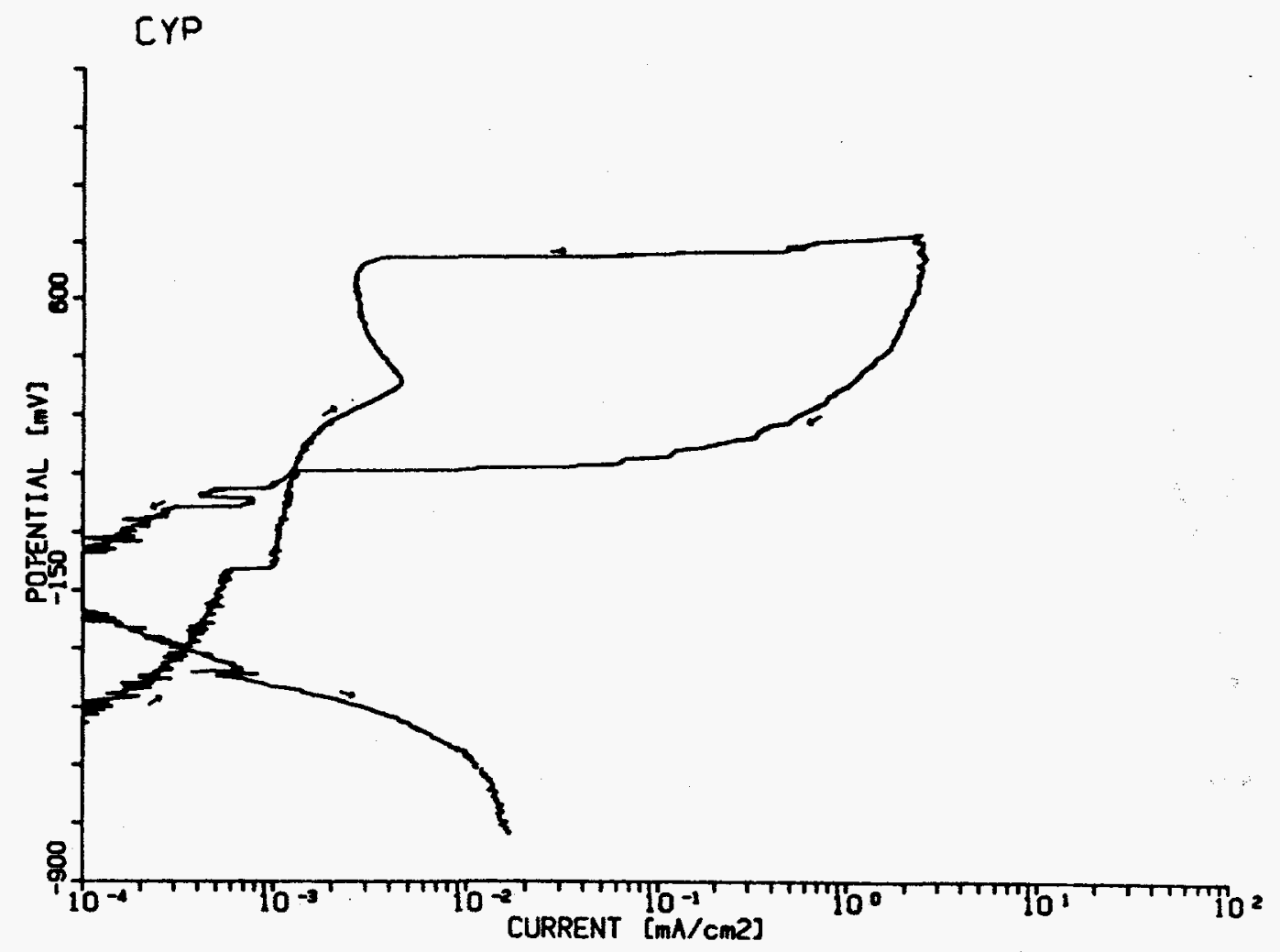

Figure 5.8 CPP Curve For Alloy 825 in Simulated J-13 Well Water At $90^{\circ} \mathrm{C}$ With The Chloride Concentration Increased To $1000 \mathrm{mg} /$ (As NaCl). 



\section{STATISTICAL MATRIX - CPP TESTS FOR COPPER-BASE ALLOYS}

The statistical matrix of CPP curves for Alloy CDA 102 and Alloy CDA 715 in each of the test solutions are given in Appendix A and Appendix B, respectively.

\subsection{Alloy CDA 102}

As discussed in Section 5, classical pitting was not always observed for copper-base alloys when hysteresis was present in the CPP curves. Therefore, the terms pitting and protection potentials were replaced with breakdown, $E_{b}$, and repassivation, $E_{r p}$, potentials, respectively, for the copperbase alloys to better characterize the observed behavior. In the following paragraphs, several CPP curves are shown which exhibit the different types of behavior observed for Alloy CDA 102.

Figures 6.1 and 6.2 show the polarization behavior for Alloy CDA 102 in test Solutions 8 and 15, respectively. Both tests exhibited an immediate breakdown of the initial oxide and hysteresis in the reverse scan. For both curves, the forward anodic scan had much too small of a siope $(<0.02$ V/decade) for it to represent a general active dissolution phenomenon. Therefore, the anodic portion of the curves probably represents a breakdown of the original oxide. As shown in the figures, the breakdown potential was set to equal $E_{c o r}$.

Figures 6.1 and 6.2 also show the selection of the corrosion currents. Typically, no linear region existed over any significant current range making Tafel extrapolation difficult. The procedure used was as follows: (1) select a potential range 0.075-0.100 $\mathrm{V}$ more negative (cathodic curve) than $E_{c o r},(2)$ extrapolate the tangent to the curve back to $E_{c o r}$, and (3) the intersection was the estimate for $I_{c o r}$ (see Figures 6.1 and 6.2). The same procedure was repeated for a potential 0.075-0.100V more positive (anodic curve) and the average of the two predictions was used for $I_{\text {cor. }}$ It should be noted that, for Figures 6.1 and 6.2, the anodic extrapolation was not possible because the breakdown potential was approximately equal to $E_{c o r}$.

Although the polarization behavior for CDA 102 copper was similar in both Solution Numbers 8 and 15, pitting was observed in Solution Number 15 and only local active sites were observed in Solution Number 8 . This relatively confusing behavior (similar CPP curves but different corrosion morphologies) warrants further investigation.

Figures 6.3 and 6.4 show CPP curves for Alloy CDA 102 in Solution Numbers 10 and 12, respectively. The shapes of the curves are very similar and exhibit passive regions followed by breakdown of the original oxide film and a large hysteresis loop in the reverse scan. Alloy CDA 102 in Solution Number 12, shown in Figure 6.4, exhibited pitting as well as areas of active corrosion while, in Solution Number 10, only local areas of active corrosion (no pitting) was observed. These curves illustrate why a "breakdown" potential is used, as opposed to a "pitting" potential, to describe the observed behavior. Also, the selection of $E_{r p}$ was difficult because $E_{r p}$ values were selected with consideration given to a slope change, recall Figures 5.3 and 6.1 . Point " $A$ " in Figure 6.4 is possibly such a slope change, but it was so slight that $E_{\mathrm{rp}}$ was selected where the return scan intersected the passive current of the forward scan. 


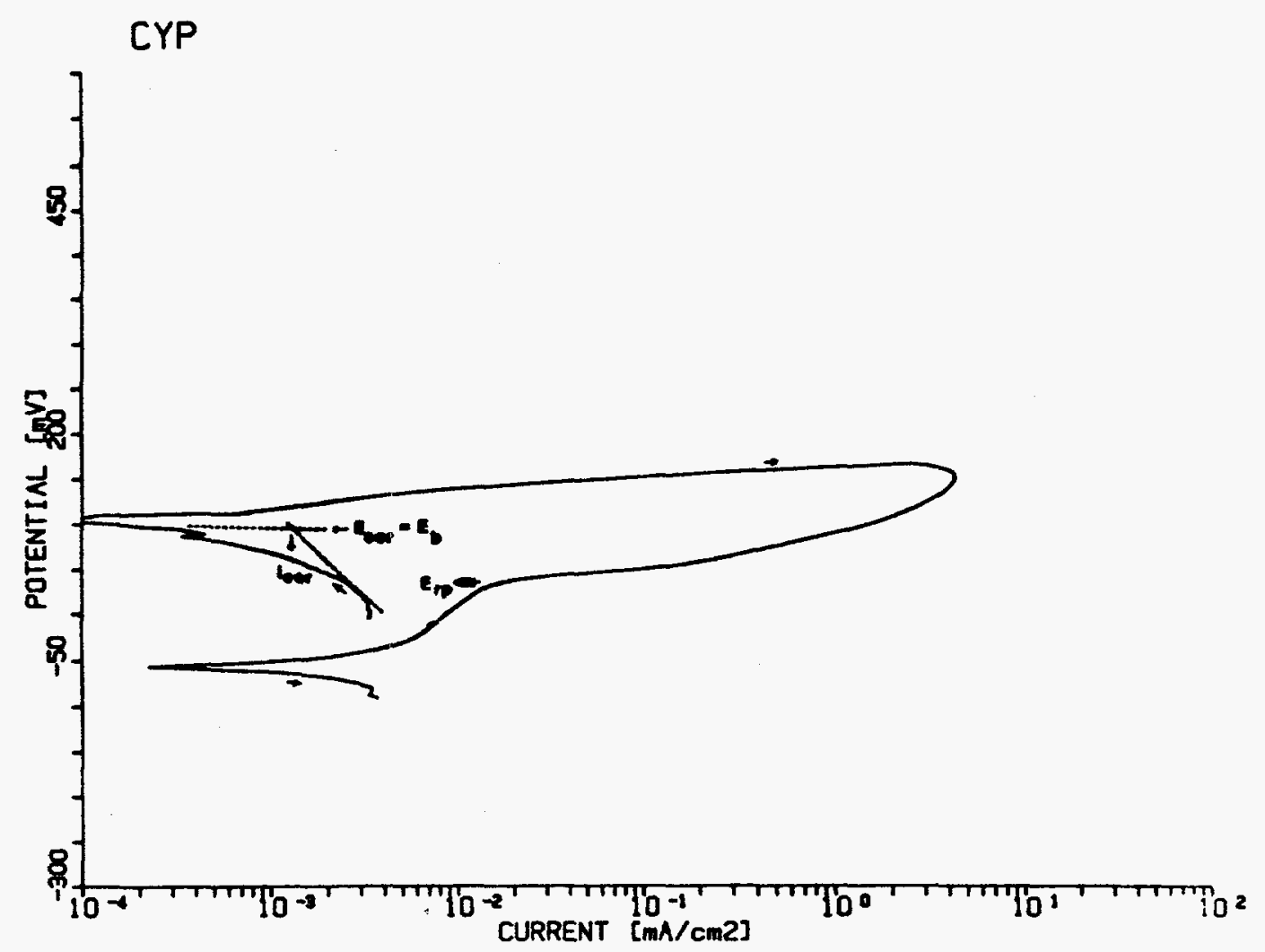

Figure 6.1 CPP Curve For Alloy CDA 102 In Test Solution Number 8. No Pitting, But Locally Active Attack And Oxide Growth Observed During Post-Test Evaluation.

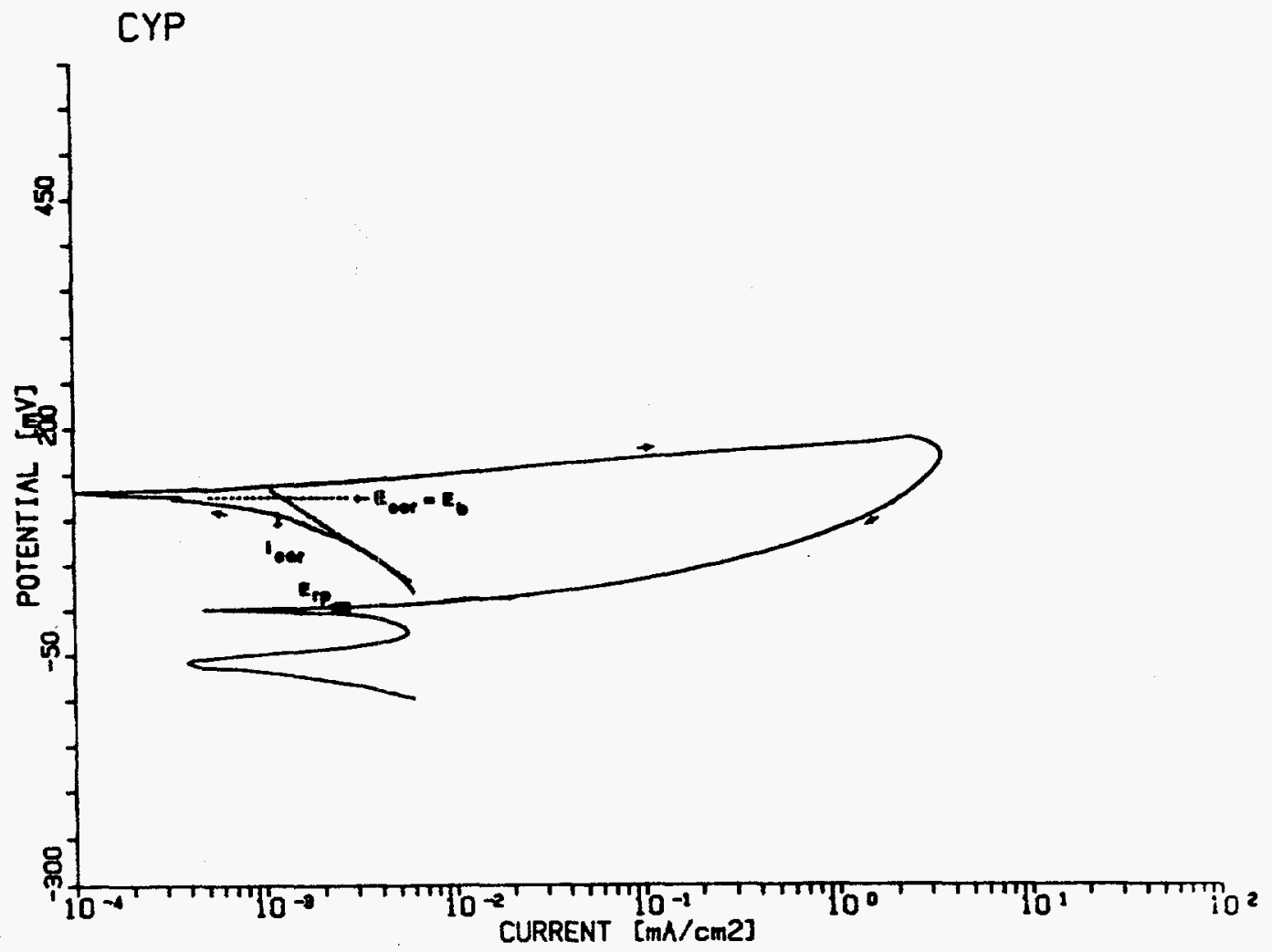

Figure 6.2 CPP Curve For Alloy CDA 102 In Test Solution Number 15. Pitting Observed During Post-Test Evaluation. 


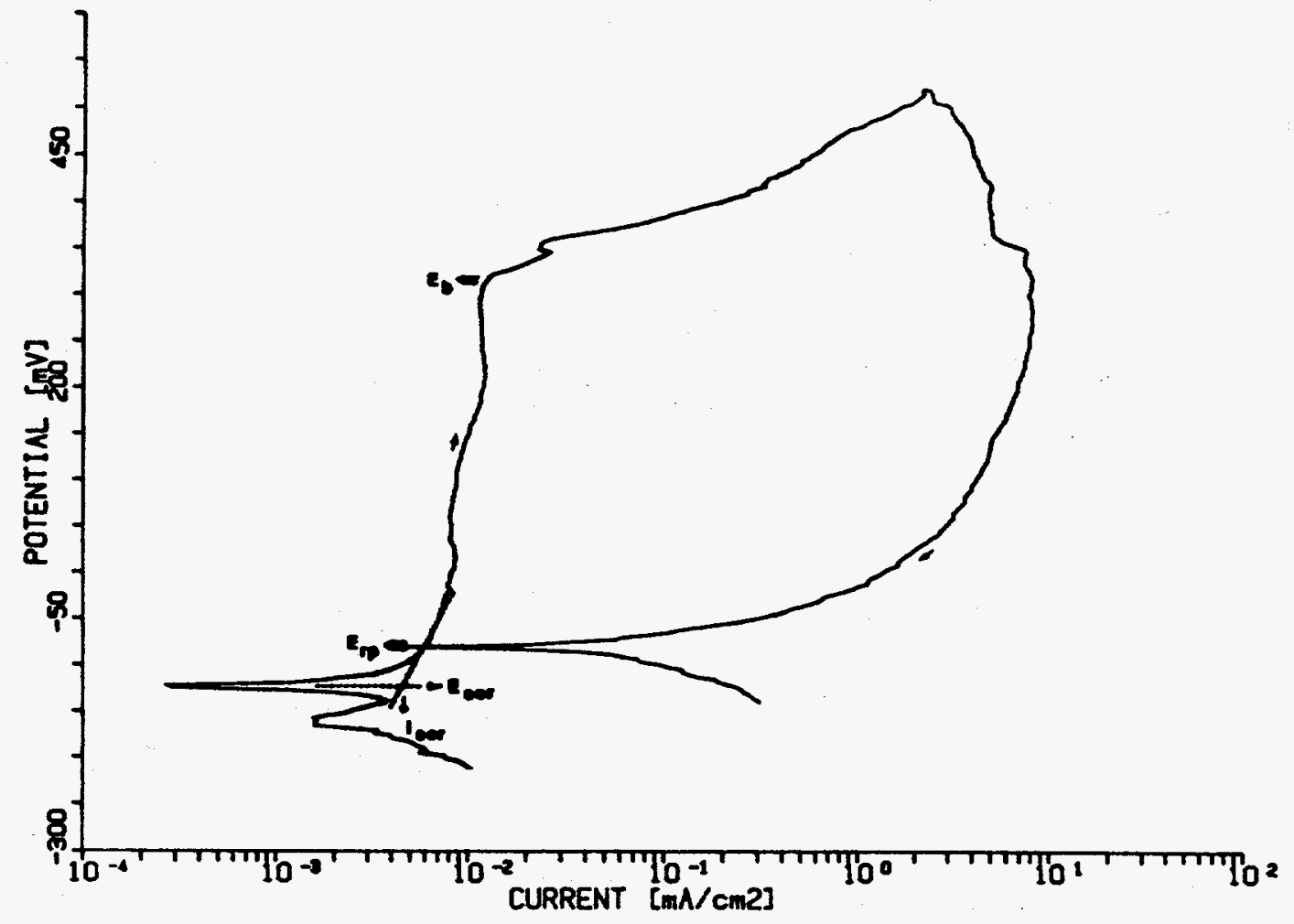

Figure 6.3 CPP Curve For Alloy CDA 102 In Test Solution Number 10. No Pitting, But Locally Active Attack Observed During Post-Test Evaluation.

CYP

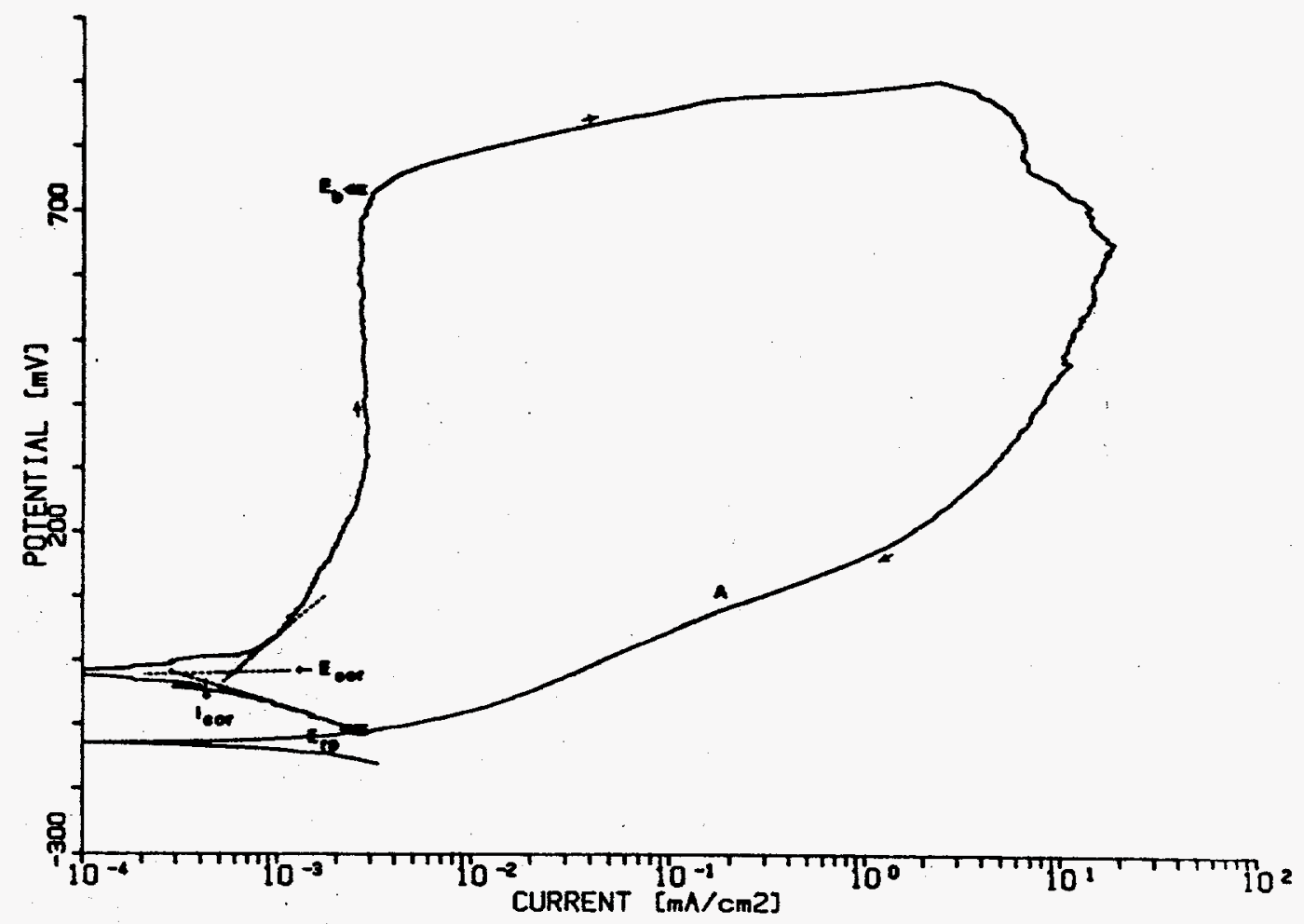

Figure 6.4 CPP Curve For Alloy CDA 102 In Test Solution Number 12. Pitting As Well As Active Corrosion Observed During Post-Test Evaluation. 
Figure 6.5 shows the polarization behavior for Alloy CDA 102 in Solution 7. The post-test evaluation of the specimen indicated active corrosion as suggested by the CPP curve. For the purpose of selecting data for use in the statistical analysis, $E_{c o r}$ is equal to $E_{b}$ which is equal to $E_{r p}$ when active corrosion occurs.

Table 6.1 gives the CPP parameters for Alloy CDA 102 in the test solutions of the statistical matrix of experiments. The parameters selected from each curve included $E_{c o r}, i_{c o r}$, $E_{b}$, and $E_{r p}$; $i_{\text {pas }}$ was selected where a passive range was present. Comments on the type of corrosion observed also are included. As previously discussed, $E_{c o r}=E_{0} \neq E_{p p}$ indicates immediate film breakdown and some degree of hysteresis, while $E_{c o r}=E_{b}=E_{r p}$ indicates active corrosion behavior.

Test Solution Numbers 33-36 have identical solution variables and the polarization behavior for these four tests defined the reproducibility of the data. Figure 6.6 shows the CPP curves for Alloy CDA 102 in Solution Numbers 33-36. As shown in Figure 6.6 and Table 6.1, the data for the four tests are very similar; except that in Solution Number $34, i_{c o r}$ was slightly greater and $E_{b}$ was somewhat more negative than that observed in the other three solutions. The values for $E_{c o r}$ and $E_{r p}$ were very reproducible and post-test examination indicated that the type of attack (locally active corrosion sites with no pitting) was the same for all specimens. Tests in Solutions 39-42 were performed to evaluate the effects of high levels of $\mathrm{Ca}^{+2}$ and $\mathrm{Mg}^{+2}$ on CPP behavior.

It is obvious that a very wide range of behavior is possible depending on the variation in solution variables used in these tests. The solution composition typically was varied by a factor of $200 \mathrm{X}$ to 5000X for each species and is not out of the ordinary for the concentrating of species at a heated metal surface.

\subsection{Alloy CDA 715}

The statistical matrix of CPP tests previously discussed and given in Table 3.4 also was performed for Alloy CDA 715. As discussed for Alloy CDA 102, hysteresis was present but classical pitting was not always observed. Therefore, the pitting and protection potentials were replaced by breakdown, $E_{b}$ and repassivation, $E_{i p}$, potentials, respectively. The CPP curves corresponding to the test solutions from the matrix are given in Appendix B. Table 6.2 gives the CPP parameters for Alloy CDA 715 in the test solutions. In the following paragraphs, several CPP curves are shown which exhibit the different types of behavior measured for Alloy CDA 715.

Figure 6.7 shows the CPP curve for Alloy CDA 715 in Solution Number 7. It should be noted that the selection of a corrosion current based on anodic extrapolation and cathodic extrapolation provided different results and the corrosion current reported is: the average of the two extrapolations. The polarization behavior shown in Figure 6.7 indicates active corrosion with no tendency for passivation and with no hysteresis in the return scan. This behavior is somewhat different than exhibited in most of the test solutions and a greater amount of "noise" is present at high currents than is normally observed. For these reasons, the CPP test was repeated in Solution Number 7. The test results were identical to those shown in Figure 6.7 with only a slightly different free-corrosion potential. Away from $\mathrm{E}_{\text {cor }}$, the CPP curves were coincident. This demonstrates the excellent reproducibility of the polarization behavior determined by the CPP test 


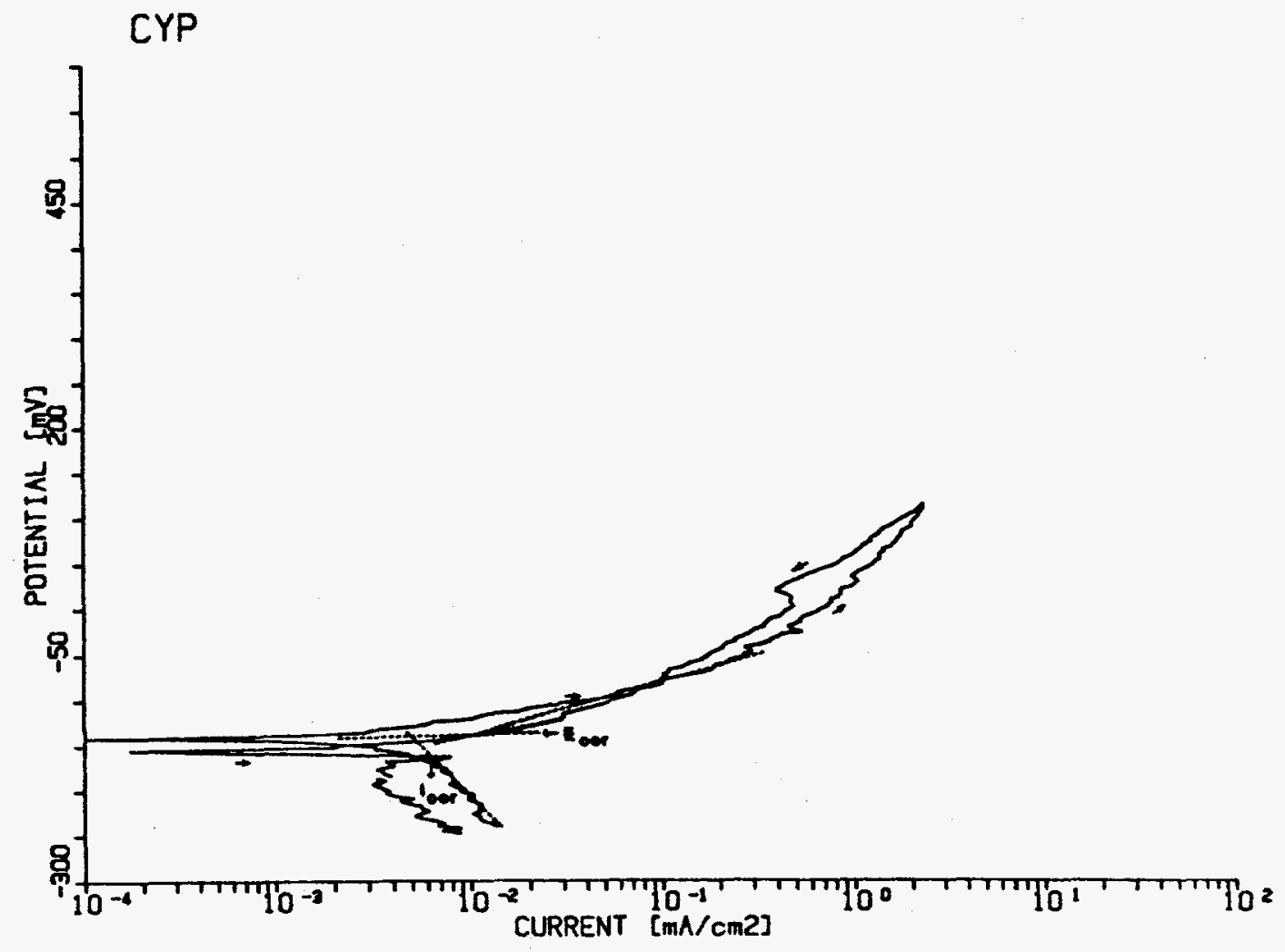

Figure 6.5 CPP Curve For Alloy CDA 102 In Test Solution Number 7. Active Corrosion Observed During Post-Test Evaluation. 
Table 6.1 Polarization Parameters For The Test Solutions In The Statistically-Designed Matrix Of Experiments For Alloy CDA 102.

\begin{tabular}{|c|c|c|c|c|c|c|}
\hline $\begin{array}{c}\text { Test } \\
\text { Solution }\end{array}$ & $\begin{array}{c}\mathrm{E}_{\text {cor' }} \\
\mathrm{V}, \mathrm{SCE}\end{array}$ & $\begin{array}{c}I_{\cos } \\
\mu A \\
\mathrm{~cm}^{2}\end{array}$ & $\begin{array}{c}I_{\text {paes }} \\
\mu \mathrm{Acm}^{2}\end{array}$ & $v, \begin{array}{c}E_{b,} \\
\text { SCE }\end{array}$ & $\begin{array}{c}E_{p p} \\
V, \text { SCE }\end{array}$ & Comments \\
\hline $\begin{array}{r}1 \\
2 \\
3 \\
4 \\
5 \\
6 \\
7 \\
8 \\
9 \\
10 \\
11 \\
12 \\
13 \\
14 \\
15 \\
16 \\
17 \\
18 \\
19 \\
20 \\
21 \\
22 \\
23 \\
24 \\
25 \\
26 \\
27 \\
28 \\
29 \\
30 \\
31 \\
32 \\
33 \\
34 \\
35 \\
36 \\
37 \\
38 \\
39 \\
40 \\
41 \\
42\end{array}$ & $\begin{array}{l}+0.005 \\
+0.095 \\
+0.050 \\
+0.095 \\
+0.145 \\
-0.100 \\
-0.140 \\
+0.105 \\
+0.050 \\
-0.115 \\
-0.105 \\
-0.020 \\
-0.035 \\
-0.120 \\
+0.130 \\
-0.100 \\
-0.110 \\
+0.145 \\
-0.170 \\
-0.085 \\
-0.150 \\
+0.060 \\
-0.075 \\
-0.060 \\
-0.120 \\
+0.110 \\
+0.025 \\
-0.050 \\
-0.070 \\
-0.150 \\
-0.085 \\
+0.015 \\
-0.070 \\
-0.050 \\
-0.075 \\
-0.075 \\
-0.030 \\
-0.075 \\
-0.073 \\
+0.090 \\
-0.128 \\
-0.109\end{array}$ & $\begin{array}{c}1.5 \\
1.0 \\
0.52 \\
9.0 \\
16 \\
5.0 \\
6.6 \\
1.3 \\
7.5 \\
4.7 \\
0.98 \\
0.52 \\
0.60 \\
2.6 \\
1.2 \\
4.5 \\
1.4 \\
0.18 \\
6.2 \\
0.33 \\
3.0 \\
5.6 \\
3.0 \\
4.3 \\
1.6 \\
15 \\
2.4 \\
9.2 \\
2.2 \\
9.7 \\
3.0 \\
0.37 \\
1.7 \\
3.5 \\
1.0 \\
1.3 \\
2.0 \\
2.2 \\
1.3 \\
3.8 \\
2.3 \\
6.8\end{array}$ & \begin{tabular}{|c}
9.0 \\
5.5 \\
2.6 \\
1.2 \\
12 \\
\\
4.2 \\
2.0 \\
\\
8.0 \\
0.82 \\
4.1 \\
\\
3.0 \\
23 \\
7.6 \\
\\
\\
3.3 \\
470 \\
8.8 \\
0.80 \\
1.6 \\
2.0 \\
1.5 \\
1.5
\end{tabular} & $\begin{array}{l}+0.16 \\
+0.07 \\
+0.16 \\
+0.10 \\
+0.14 \\
+0.18 \\
+0.14 \\
+0.10 \\
+0.05 \\
+0.33 \\
+0.16 \\
+0.72 \\
+0.12 \\
+0.20 \\
+0.13 \\
+0.50 \\
+0.74 \\
+0.16 \\
+0.48 \\
-0.04 \\
+0.32 \\
+0.06 \\
+0.28 \\
+0.12 \\
+0.13 \\
+0.11 \\
+0.02 \\
-0.05 \\
+0.16 \\
+0.15 \\
+0.10 \\
+0.10 \\
+0.18 \\
+0.14 \\
+0.20 \\
+0.20 \\
+0.14 \\
-0.05 \\
+0.09 \\
+0.15 \\
+0.21 \\
+0.15\end{array}$ & $\begin{array}{r}+0.00 \\
+0.05 \\
+0.08 \\
+0.02 \\
+0.10 \\
+0.17 \\
-0.14 \\
+0.04 \\
+0.03 \\
-0.07 \\
+0.16 \\
-0.10 \\
0.00 \\
+0.06 \\
0.00 \\
-0.04 \\
-0.02 \\
+0.12 \\
-0.05 \\
-0.02 \\
+0.12 \\
+0.02 \\
+0.08 \\
+0.04 \\
+0.13 \\
+0.11 \\
0.00 \\
+0.02 \\
0.00 \\
+0.15 \\
0.04 \\
-0.05 \\
0.08 \\
0.10 \\
0.10 \\
0.10 \\
-0.04 \\
-0.22 \\
+0.02 \\
+0.03 \\
+0.08 \\
+0.06\end{array}$ & $\begin{array}{l}\text { No pitting (oxide growth) } \\
\text { No pitting (oxide growth) } \\
\text { No pitting (oxide growth) } \\
\text { No pitting (local oxide growth/active areas) } \\
\text { No pitting (oxide growth) } \\
\text { No pitting (tarnish) } \\
\text { No pitting (local oxide growth/active areas) } \\
\text { No pitting (local active attack/oxide growth) } \\
\text { No pitting (local oxide growth) } \\
\text { No pitting (local oxide growth/active areas) } \\
\text { No pitting (oxide growth/active areas) } \\
\text { Pitting (oxide growth/active areas) } \\
\text { No pitting } \\
\text { Pitting (oxide growth) } \\
\text { Pitting (oxide growth) } \\
\text { No pitting (tarnished/active areas) } \\
\text { Pitting (oxide growth) } \\
\text { Pitting (oxide growth) } \\
\text { No pitting (tarnished/active areas) } \\
\text { No pitting (active areas) } \\
\text { No pitting (tarnished/active areas) } \\
\text { Pitting (oxide growth) } \\
\text { No pitting (tarnished/active areas) } \\
\text { No pitting (oxide growth/active areas) } \\
\text { No pitting (tarnished/active areas) } \\
\text { No pitting (tarnished) } \\
\text { No pitting (local oxide growth) } \\
\text { No pitting (oxide growth/active areas) } \\
\text { Pitting (oxide growth/active areas) } \\
\text { No pitting (oxide growth/active areas) } \\
\text { Pitting (oxide growth/active areas) } \\
\text { No pitting (oxide growth/active areas) } \\
\text { No pitting (oxide growth/active areas) } \\
\text { No pitting (oxide growth/active areas) } \\
\text { No pitting (oxide growth/active areas) } \\
\text { No pitting (oxide growth/active areas) } \\
\text { Local changes in oxide } \\
\text { Local changes in oxide } \\
\text { No pitting (oxide growth/etching) } \\
\text { No pitting (oxide growth) } \\
\text { No pitting (localized etching) } \\
\text { Localized etching, incipient pitting } \\
\text { Lo }\end{array}$ \\
\hline
\end{tabular}




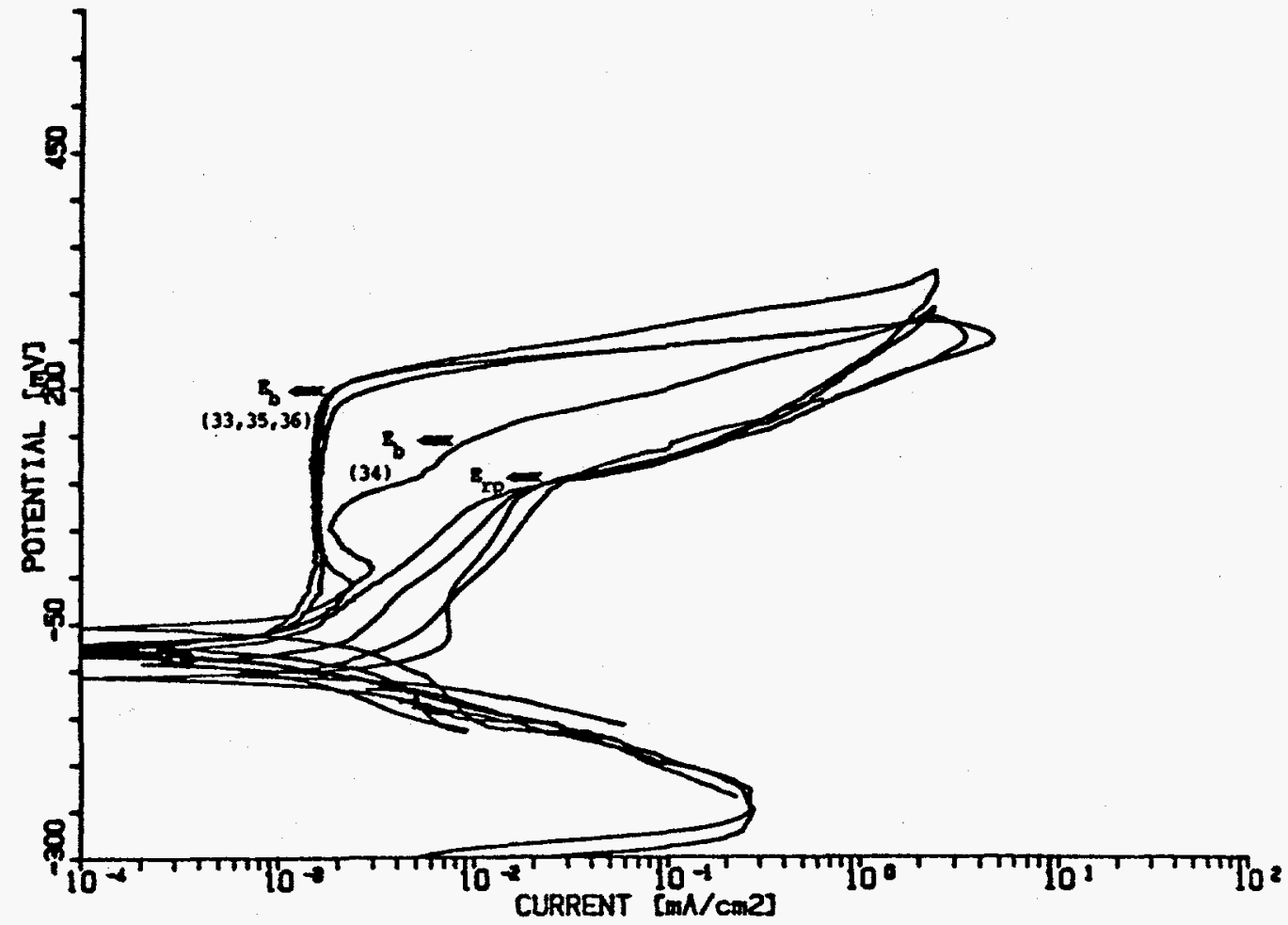

Figure 6.6 CPP Curves For Alloy CDA 102 in Test Solution Numbers 33 Through 36 (Identical Solutions With Average Concentrations Of Environmental Variables). 
Table 6.2 Polarization Parameters For The Test Solutions in The Statistically-Designed Matrix Of Experiments For Alloy CDA 715.

\begin{tabular}{|c|c|c|c|c|c|c|}
\hline $\begin{array}{c}\text { Test } \\
\text { Solution }\end{array}$ & $\begin{array}{c}E_{\operatorname{cor}} \\
\mathbf{V}, \mathbf{S C E}\end{array}$ & $\begin{array}{l}\mu \mathrm{A} / \mathrm{cm}^{2} \\
\times 10^{-6} \\
\end{array}$ & $\begin{array}{c}\mu \mathrm{Acm}^{2} \\
\times 10^{-}\end{array}$ & $\begin{array}{c}E_{b s} \\
V, \text { SCE }\end{array}$ & $\mathrm{v}, \mathrm{E}_{\mathrm{SP}}$ & Comments \\
\hline $\begin{array}{r}1 \\
2 \\
3 \\
4 \\
5 \\
6 \\
7 \\
8 \\
9 \\
10 \\
11 \\
12 \\
13 \\
14 \\
15 \\
16 \\
17 \\
18 \\
19 \\
20 \\
21 \\
22 \\
23 \\
24 \\
25 \\
26 \\
27 \\
28 \\
29 \\
30 \\
31 \\
32 \\
33 \\
34 \\
35 \\
36 \\
37 \\
38 \\
39 \\
40 \\
41 \\
42\end{array}$ & $\begin{array}{r}-0.188 \\
-0.075 \\
0.000 \\
-0.130 \\
+0.095 \\
-0.175 \\
-0.150 \\
-0.105 \\
0.050 \\
-0.155 \\
-0.100 \\
+0.025 \\
+0.150 \\
+0.240 \\
-0.160 \\
-0.250 \\
-0.225 \\
-0.065 \\
-0.140 \\
-0.250 \\
-0.400 \\
+0.073 \\
-0.030 \\
-0.100 \\
-0.125 \\
+0.120 \\
-0.015 \\
-0.050 \\
-0.060 \\
-0.170 \\
-0.105 \\
0.000 \\
+0.065 \\
+0.045 \\
+0.080 \\
+0.080 \\
-0.265 \\
-0.400 \\
+0.090 \\
+0.156 \\
-0.155 \\
-0.008\end{array}$ & $\begin{array}{l}2.5 \\
0.15 \\
0.29 \\
0.09 \\
7.2 \\
0.30 \\
23 \\
1.6 \\
7.6 \\
0.08 \\
0.03 \\
0.06 \\
0.09 \\
4.0 \\
0.07 \\
0.09 \\
0.34 \\
1.1 \\
0.08 \\
0.19 \\
0.23 \\
1.0 \\
0.45 \\
0.10 \\
0.56 \\
2.0 \\
1.5 \\
7.8 \\
0.91 \\
9.0 \\
0.83 \\
0.18 \\
0.3 \\
0.76 \\
0.75 \\
1.6 \\
0.41 \\
0.02 \\
13.0 \\
5.0 \\
0.11 \\
1.8\end{array}$ & $\begin{array}{c}1.8 \\
0.38 \\
1.5 \\
\\
2.0 \\
18 \\
1.3 \\
0.4 \\
15 \\
0.24 \\
\\
0.32 \\
1.0 \\
1.5 \\
11 \\
1.0 \\
0.70 \\
1.0 \\
4.3 \\
6.3 \\
4.6 \\
3.0 \\
1.6 \\
30 \\
5.3 \\
1.8 \\
7.3 \\
2.2 \\
16 \\
36\end{array}$ & $\begin{array}{r}-0.19 \\
+0.30 \\
0.00 \\
+0.26 \\
1 \\
+0.63 \\
-0.15 \\
+0.63 \\
+0.18 \\
+0.63 \\
+0.27 \\
+0.78 \\
+0.28 \\
+0.24 \\
+0.20 \\
+0.66 \\
+0.68 \\
+0.16 \\
+0.65 \\
+0.11 \\
+0.61 \\
+0.17 \\
+0.38 \\
+0.14 \\
+0.22 \\
+0.12 \\
+0.34 \\
+0.20 \\
+0.28 \\
-0.17 \\
+0.66 \\
0.00 \\
+0.48 \\
+0.32 \\
+0.35 \\
+0.38 \\
+0.18 \\
-0.04 \\
+0.09 \\
+0.37 \\
+0.44 \\
+0.33\end{array}$ & $\begin{array}{r}-0.19 \\
+0.02 \\
-0.10 \\
+0.06 \\
-0.20 \\
-0.15 \\
0.00 \\
-0.14 \\
-0.02 \\
+0.15 \\
-0.05 \\
-0.10 \\
+0.02 \\
-0.20 \\
-0.05 \\
+0.58 \\
+0.08 \\
0.00 \\
-0.05 \\
-0.02 \\
+0.02 \\
-0.06 \\
-0.18 \\
+0.09 \\
+0.05 \\
+0.01 \\
-0.02 \\
+0.02 \\
-0.17 \\
+0.08 \\
-0.02 \\
+0.04 \\
0.00 \\
+0.03 \\
+0.05 \\
+0.08 \\
-0.03 \\
-0.09 \\
+0.37 \\
+0.44 \\
+0.33\end{array}$ & $\begin{array}{l}\text { No pitting (oxide growth/active areas) } \\
\text { Pitting (active areas) } \\
\text { Pitting } \\
\text { Pitting (oxide growth/active areas) } \\
\text { No pitting (oxide growth/active areas) } \\
\text { Pitting (oxide growth/active areas) } \\
\text { No pitting (active) } \\
\text { Pitting (active areas) } \\
\text { Pitting (active areas) } \\
\text { Pitting (active areas) } \\
\text { Pitting (oxide growth/active areas) } \\
\text { Pitting (active areas) } \\
\text { No pitting } \\
\text { Pitting (oxide growth) } \\
\text { No pitting (active areas) } \\
\text { Pitting (oxide growth/active areas) } \\
\text { No pitting } \\
\text { No pitting (oxide growth) } \\
\text { Pitting (oxide growth/active areas) } \\
\text { Pitting (oxide growth/active areas) } \\
\text { Pitting (active areas) } \\
\text { Pitting (active areas) } \\
\text { Pitting (active areas) } \\
\text { Pitting (tarnished) } \\
\text { Pitting (active areas) } \\
\text { Pitting (active areas) } \\
\text { Pitting (active areas) } \\
\text { No pitting (active attack) } \\
\text { Pitting (tarnish/active areas) } \\
\text { No pitting (active attack) } \\
\text { Pitting (active areas) } \\
\text { Pitting (oxide growth/active areas) } \\
\text { Pitting (active areas) } \\
\text { Pitting (active areas) } \\
\text { Pitting (active areas) } \\
\text { Pitting (active areas) } \\
\text { Pitting (oxide growth/active areas) } \\
\text { No pitting (oxide growth/active areas) } \\
\text { Incipient pitting, localized etching } \\
\text { Pitting } \\
\text { Pitting } \\
\text { Pitting }\end{array}$ \\
\hline
\end{tabular}




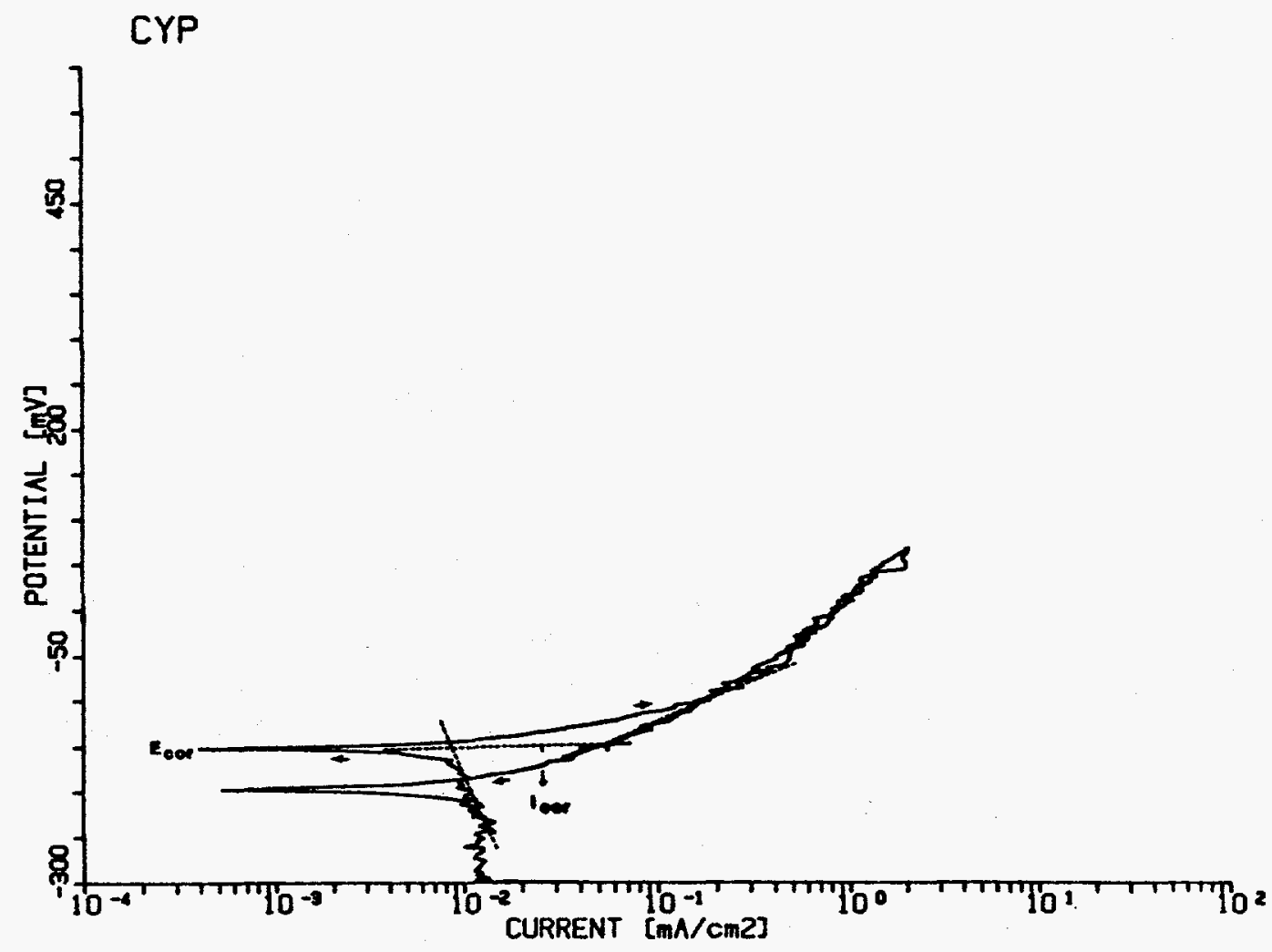

Figure 6.7 CPP Curve For Alloy CDA 715 in Test Solution Number 7. Active Corrosion Observed During Post-Test Evaluation. 
for this solution. Post-test examination showed that active corrosion had occurred over the entire surface of the specimen.

Figures 6.8 through 6.11 show CPP curves for Alloy CDA 715 in Solution Numbers 8, 15, 24, and 6 , respectively. Although no active peaks are present, the curves indicate varying degrees of passive behavior followed by breakdown of the passive film and repassivation upon reversing the potential scan. Typically, this behavior would be representative of deep localized pitting corrosion. Post-test examination of the specimens, however, indicated greatly varying types of attack. In Solution Number 8 (Figure 6.8), pitting was observed along with local areas of active corrosion. In Solution Number 15 (Figure 6.9), the specimen underwent what appears to be general active attack with the entire specimen surface etched and no observable pitting. In Solution Number 24 (Figure 6.10), the specimen had a very dark (black) shiny oxide present with no observable pitting corrosion. In Solution Number 6 (Figure 6.11), the specimen had local areas of active corrosion but no observable pitting.

Figures 6.8 and 6.9 exhibited cathodic peaks during the reverse scan. In Figure 6.9, the cathodic peak is represented by a cathodic loop which occurred during the hysteresis portion of the reverse scan. As mentioned in the discussion or the miscellaneous experiments, any time a cathodic peak was observed during the reverse scan, a copper colored product was observed at the active corrosion sites on the specimens. This cathodic peak is believed to be a redeposition of copper back on the surface of the specimen.

It should also be noted that, at low currents (less than $1 \mu \mathrm{A} / \mathrm{cm}^{2}$ ), a jog in current occasionally was observed (see Figures 6.10 and 6.11). This shift in current is created by a change in scales in the software of the potentiostat and the actual output of the potentiostat remains steady. Independent measurements indicate that the higher current value of the jog accurately represents the current to the specimen, as opposed to the low current value. This is an inherent problem for the potentiostat system being used but has no effect on the results of the tests being reported in this document.

Figure 6.12 shows the polarization behavior for Alloy CDA 715 in Solution Number 17. A small hysteresis was observed following the breakdown potential. Based on the post-test evaluation, no pitting had occurred and the specimen surface remained bright and shiny and free of any visible oxide.

Test Solution Numbers 33 through 36 had identical solution variables and the polarization behavior for these four tests helped define the reproducibility of the data. Figure 6.13 shows the CPP curves for Alloy CDA 715 in Solution Numbers 33-36. Figure 6.13 and Table 6.2 indicate that some variation occurs in the passive current density and the values of $E_{b}$. The general shape of the curves and the type of corrosion observed, based on post-test examination, were very similar. These data provided the statistical analysis with an estimation of the variation that can be expected for the different corrosion parameters.

In summary, data for Alloy CDA 102 and Alloy CDA 715 indicates that several different types of corrosion are possible depending upon the solution composition. These data also show that various combinations of solution variables produced localized corrosion for both of the copperbase alloys in some regions of the factor space. 


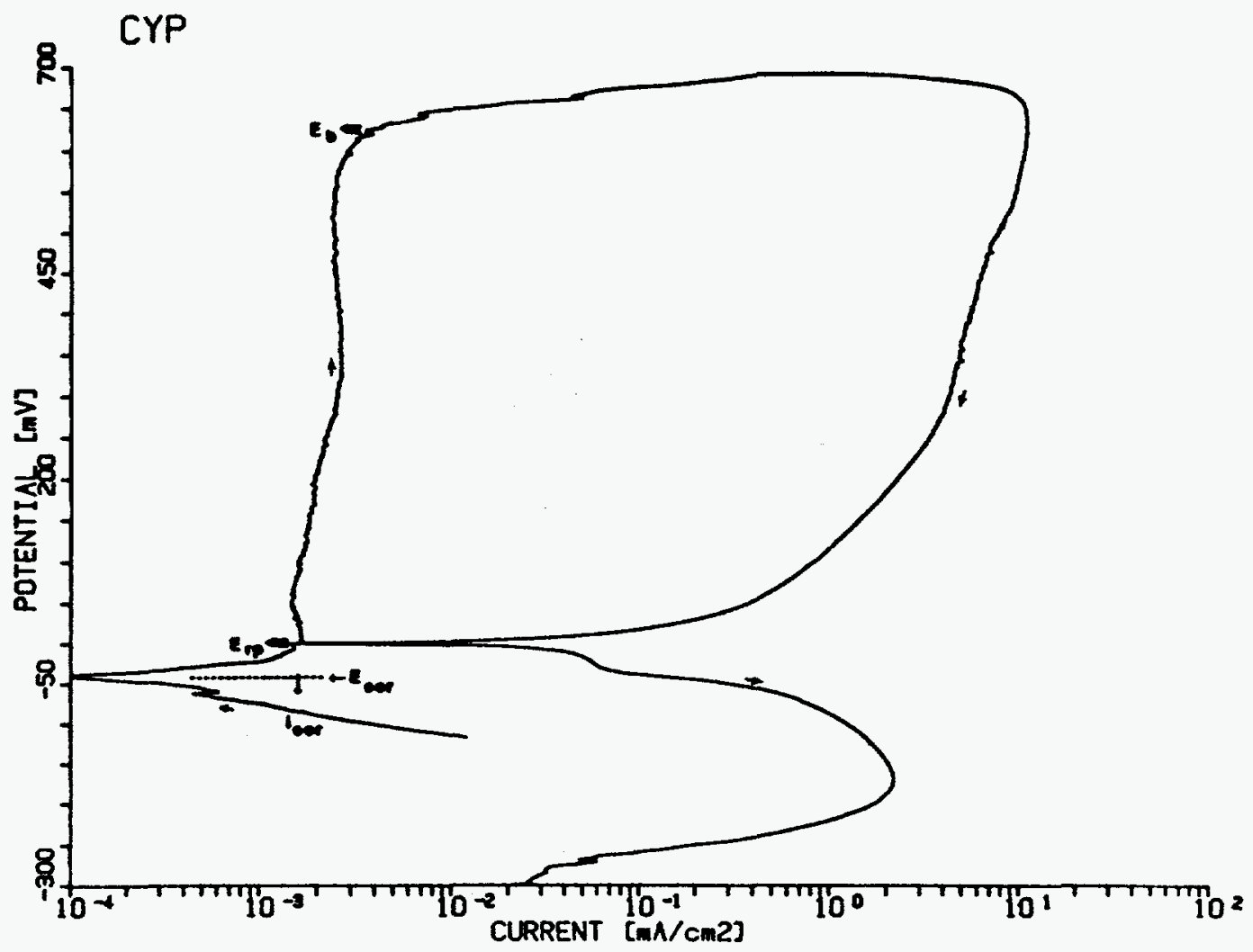

Figure 6.8 CPP Curve For Alloy CDA 715 In Test Solution Number 8. Pitting And Local Active Corrosion Observed During Post-Test Evaluation.

$$
\text { CYP }
$$

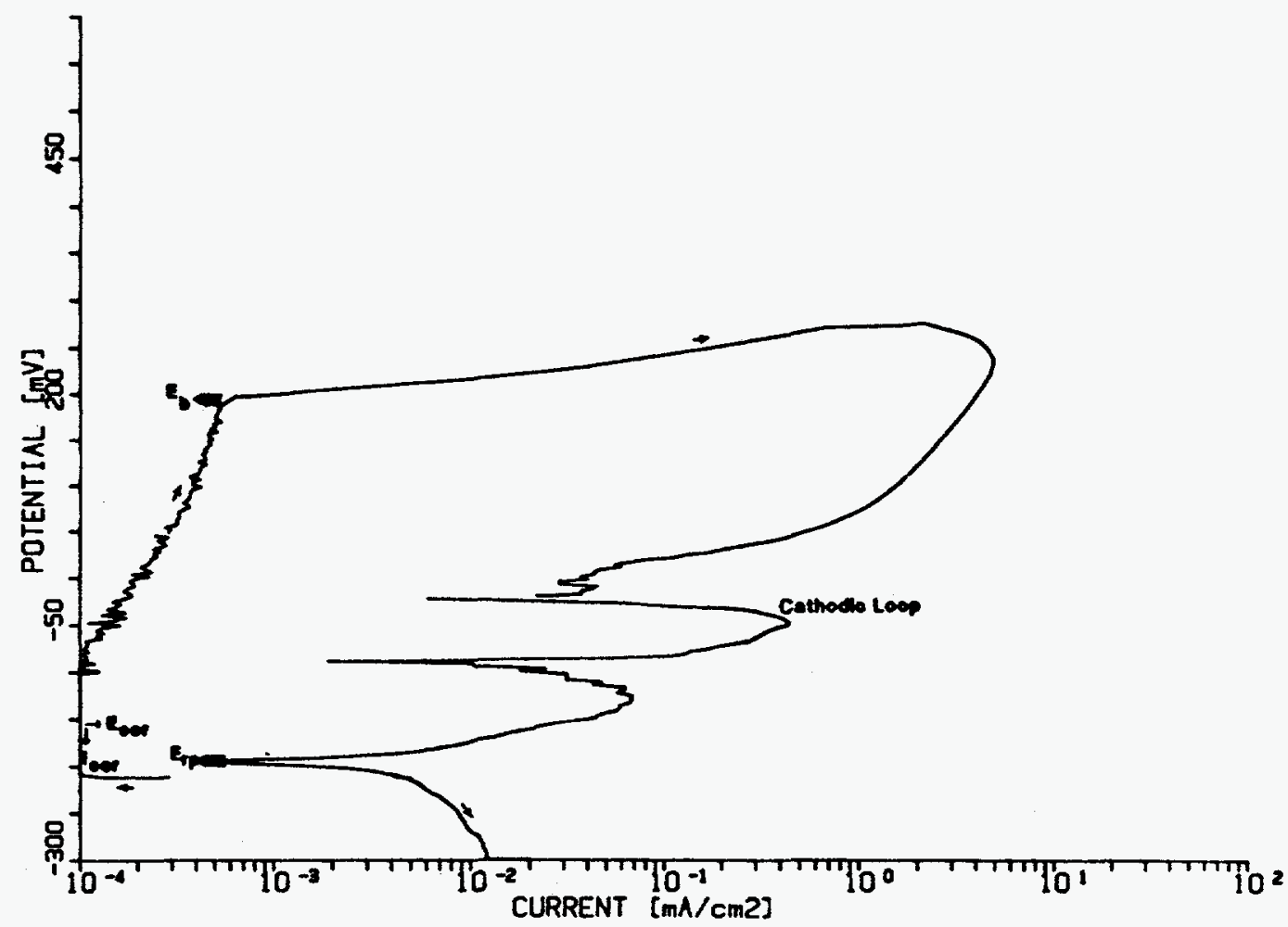

Figure 6.9 CPP Curve For Alloy CDA 715 In Test Solution Number 15. Active Corrosion, No Pitting Observed During Post-Test Evaluation. 


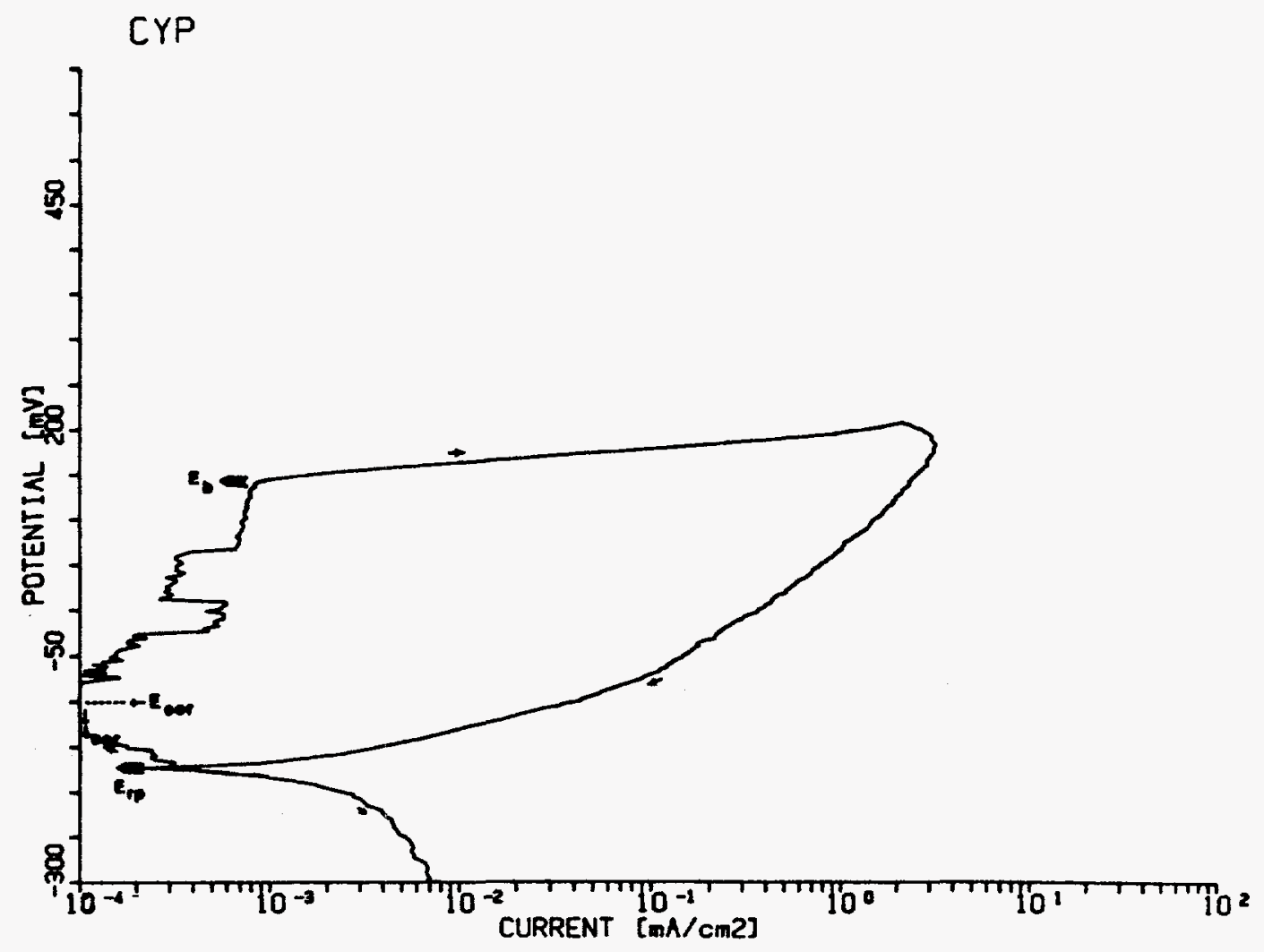

Figure 6.10 CPP Curve For Alloy CDA 715 In Test Solution Number 24. No Pitting Observed During Post-Test Evaluation; Dark Shiny Oxide Present.

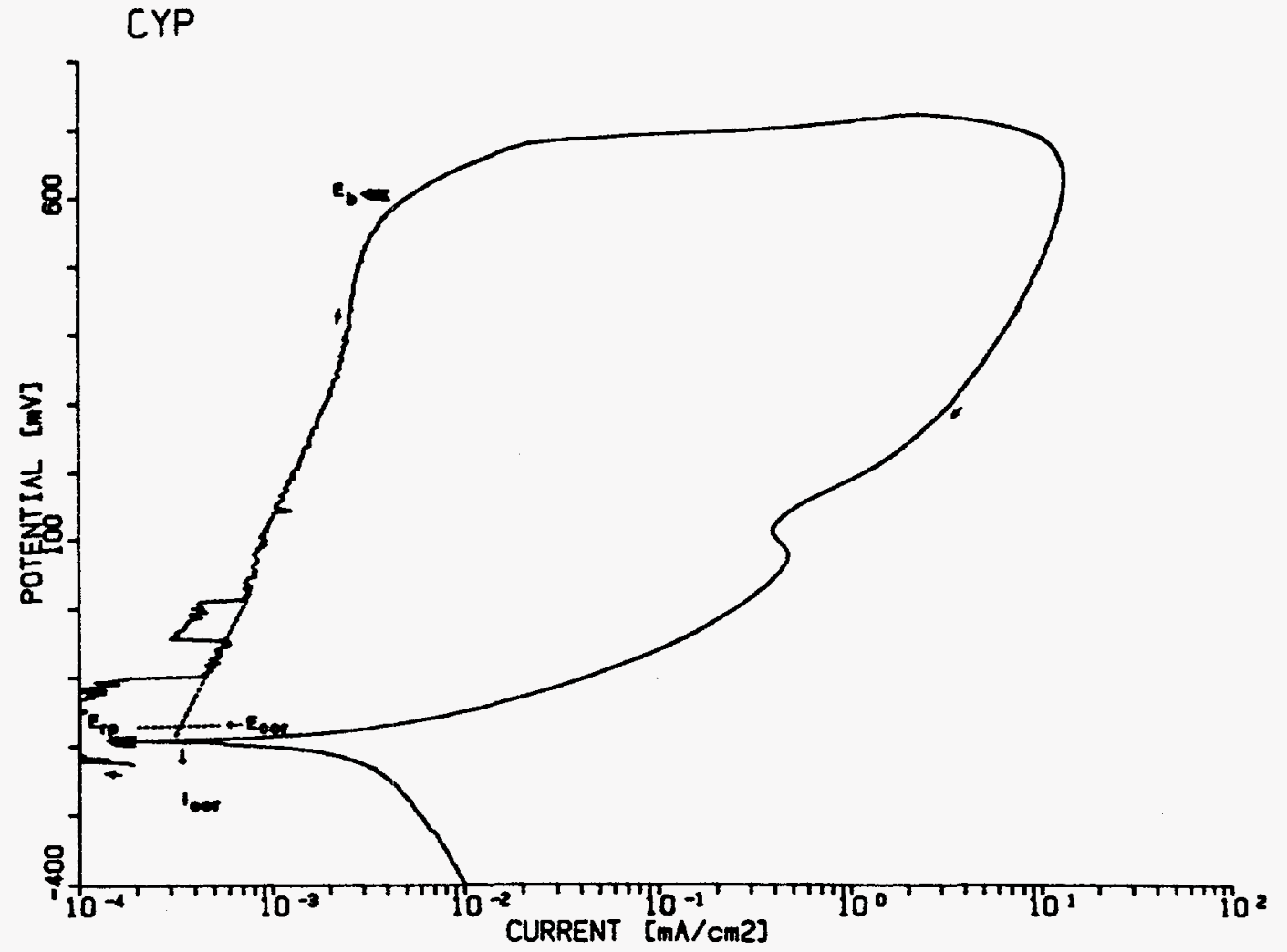

Figure 6.11 CPP Curve For Alloy CDA 715 In Test Solution Number 6. Local Active Corrosion, No Pitting Observed During Post-Test Evaluation. 


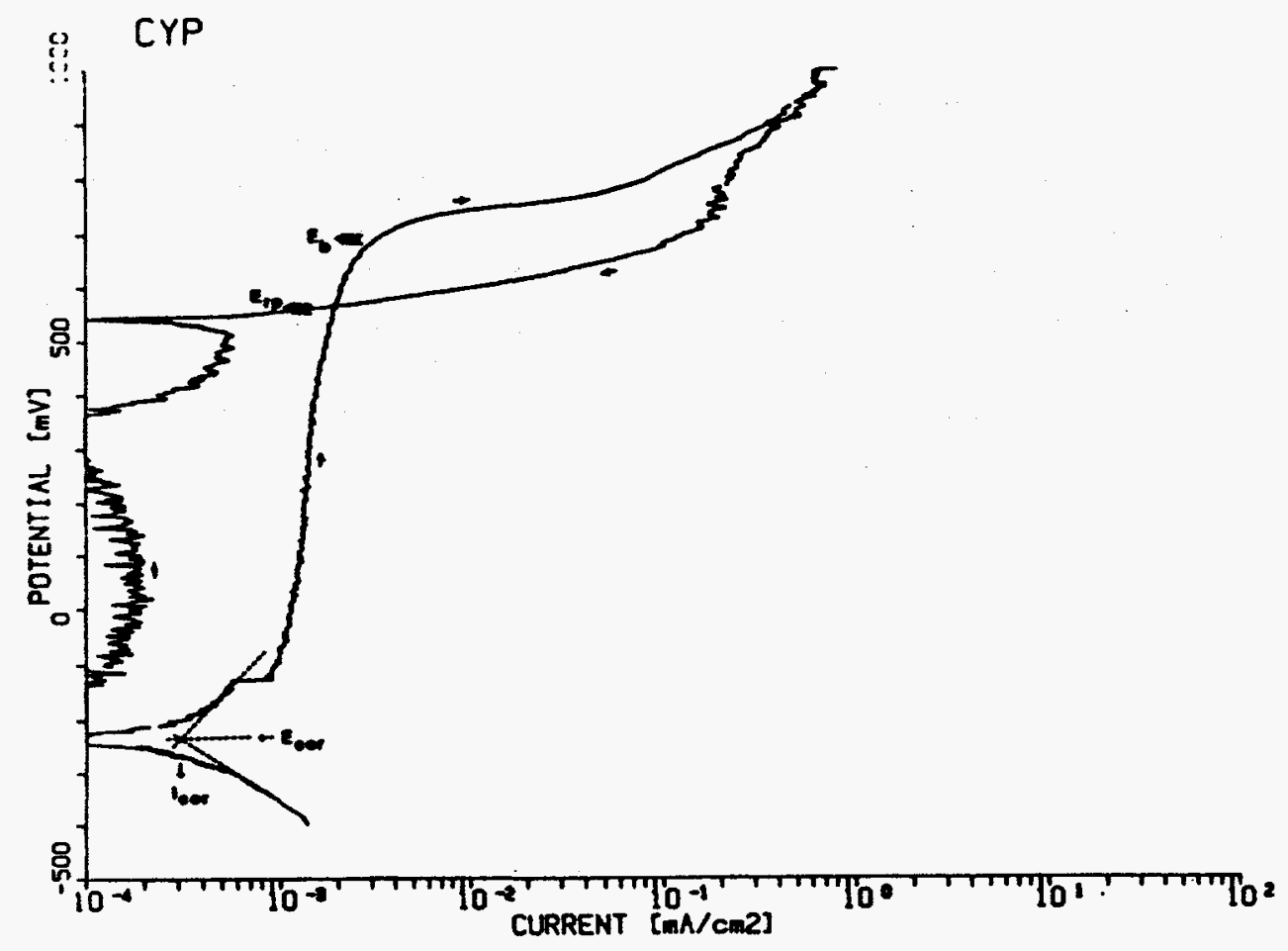

Figure 6.12 CPP Curve For Alloy CDA 715 In Test Solution Number 17. No Pitting Observed During Post-Test Evaluation; Surface Remained Bright And Shiny, Free of Any Visible Oxide.

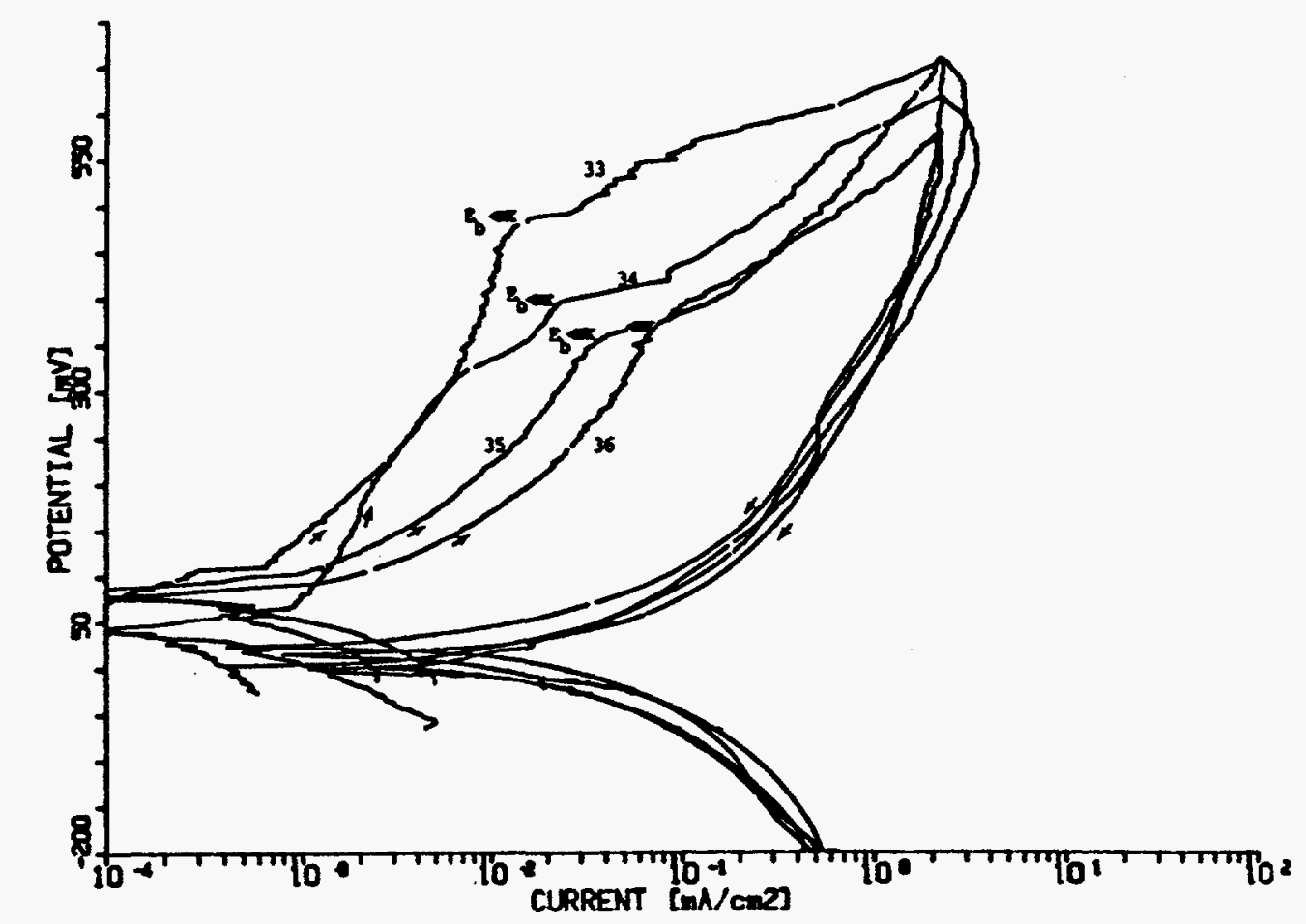

Figure 6.13 CPP Curves For Alloy CDA 715 in Test Solution Numbers 33 Through 36 (Identical Solutions With Average Concentrations Of Environmental Variables). 
The results of our research also indicate that great care should be taken in interpreting the results of electrochemical studies performed on the copper-base alloys in Tuff environments. Two distinct types of corrosion processes have been associated with essentially identical CPP curves. In several of the environments, the hysteresis on the reverse scan was correlated with classical pitting. However, in several other environments, the hysteresis was associated with regions of a oxide film color change on the specimen, with apparent active corrosion sites beneath the thick oxide. This color change may be associated with a change in oxidation state of the film (e.g. from $\mathrm{Cu}^{+}$to $\mathrm{Cu}^{2+}$ ) and/or may represent the early stages of film breakdown. Further research is needed to investigate this phenomenon. 


\section{STATISTICAL MATRIX - CPP TESTS FOR FE-Cr-NI ALLOYS}

The statistical matrix of CPP tests for Alloy 304L and Alloy 825 in each of the test solutions is given in Appendix $\mathrm{C}$ and Appendix $\mathrm{D}$ respectively. In contrast to the unusual behavior of the copper-base alloys, the results of the Fe-Cr-Ni alloys were found to conform with a conventional interpretation of the CPP curves.

\subsection{Alloy $304 \mathrm{~L}$}

The full matrix of CPP tests was completed on Alloy 304L and the actual CPP curves are given in Appendix C. Although the results were found to conform with a conventional interpretation of the CPP curves, a slight hysteresis was present for some of the tests in which no pitting occurred. In these cases, a surface tarnishing (thin oxide growth) occurred at the higher potentials. This behavior has beem observed for other alloy-solution combinations in previous studies. Therefore, some interpretation is required in analyzing the CPP curves, as is always the case.

For Alloy 304L, significant hysteresis in the CPP curves corresponded to pitting on the specimen surface and the absence of hysteresis or only slight hysteresis corresponded to no observable pitting. A wide range of behavior was observed for Alloy $304 \mathrm{~L}$ in the test solutions including passive behavior with no pitting, passive behavior with pitting, and active corrosion behavior. Table 7.1 presents the polarization parameters selected from the matrix of CPP tests. Also included in the table is a brief description of the specimen condition following testing. These data were used in the statistical analysis to establish the significance of each of the environmental variables on each polarization parameter. Test Solution Numbers 33 through 36 exhibited identical solution variables and the polarization behavior of these tests helped to provide an indication of the reproducibility of the data. The comparison of CPP curves in these four solutions is shown in Figure 7.1.

It should be noted that several of the CPP tests for Alloy 304L resulted in polarization behavior which appears to indicate active corrosion (test Solution Numbers $5,12,13,18,22,26,27,33$, 34, 35, and 36). Although slight attack and/or tamishing was observed for many of these specimens, experience indicates that the amount of attack does not correspond to the currents observed. Therefore, it is believed that a "spurious" oxidation reaction, a reaction other than corrosion, resulted in the high currents and, for the most part, these tests resulted in no pitting and the specimens remaining passive over the potential range examined.

\subsection{Alloy 825}

The full matrix of CPP tests was also completed on Alloy 825 using the same experimental procedure previously outlined. The resulting curves are given in Appendix D. Interpretation of the CPP curves conformed with a conventional interpretation as was the case for Alloy 304L. 
Table 7.1 Polarization Parameters For The Test Solutions In The Statistically-Designed Matrix Of Experiments For Alloy 304L.

\begin{tabular}{|c|c|c|c|c|c|c|}
\hline $\begin{array}{c}\text { Test } \\
\text { Solution } \\
\end{array}$ & $\mathrm{E}_{\mathrm{cog}}$ & $\begin{array}{r}\mu \mathrm{A} \mathrm{cm}^{2} \\
\times 10^{-1} \\
\end{array}$ & $\begin{array}{l}\mu \mathrm{A} / \mathrm{cm}^{2} \\
\times 10^{-6} \\
\end{array}$ & V, ScE & 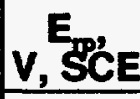 & Comments \\
\hline $\begin{array}{c}1 \\
1 \text { repeat } \\
1 \text { repeat } \\
2 \\
3 \\
4 \\
5 \\
6 \\
7 \\
8 \\
9 \\
10 \\
11 \\
12 \\
13 \\
14 \\
14 \text { repeat } \\
15 \\
16 \\
17 \\
18 \\
19 \\
19 \text { repeat } \\
20 \\
21 \\
22 \\
23 \\
24 \\
25 \\
26 \\
27 \\
28 \\
29 \\
30 \\
31 \\
32 \\
33 \\
34 \\
35 \\
36 \\
37 \\
38 \\
39 \\
40 \\
41 \\
42 \\
14\end{array}$ & $\begin{array}{l}+0.200 \\
+0.245 \\
-0.220 \\
-0.030 \\
+0.070 \\
+0.030 \\
+0.305 \\
-0.140 \\
-0.035 \\
+0.160 \\
+0.200 \\
-0.050 \\
-0.170 \\
+0.090 \\
+0.195 \\
+0.075 \\
-0.155 \\
-0.195 \\
-0.075 \\
-0.140 \\
+0.160 \\
+0.065 \\
+0.075 \\
-0.150 \\
-0.110 \\
+0.130 \\
-0.050 \\
-0.500 \\
-0.075 \\
+0.275 \\
+0.185 \\
-0.080 \\
-0.020 \\
+0.020 \\
+0.140 \\
-0.010 \\
+0.195 \\
+0.200 \\
+0.160 \\
+0.195 \\
-0.125 \\
-0.250 \\
+0.230 \\
+0.168 \\
+0.080 \\
+0.048\end{array}$ & $\begin{array}{l}0.40 \\
0.30 \\
0.09 \\
0.13 \\
0.07 \\
0.17 \\
0.24 \\
0.13 \\
0.35 \\
0.50 \\
0.31 \\
0.14 \\
0.16 \\
0.26 \\
0.28 \\
0.14 \\
0.10 \\
0.12 \\
0.13 \\
0.09 \\
0.27 \\
0.30 \\
0.30 \\
0.25 \\
0.12 \\
0.14 \\
0.16 \\
0.18 \\
0.23 \\
0.47 \\
0.50 \\
0.20 \\
0.12 \\
2.00 \\
0.27 \\
0.10 \\
0.13 \\
0.14 \\
0.24 \\
0.14 \\
0.12 \\
0.12 \\
0.03 \\
0.11 \\
0.32 \\
0.32\end{array}$ & $\begin{array}{c}0.5 \\
1.6 \\
1.2 \\
2.6 \\
1.5 \\
23 \\
22 \\
0.8 \\
2.6 \\
1.6 \\
1.3 \\
1.5\end{array}$ & $\begin{array}{l} \\
+0.82 \\
+0.75 \\
+0.80 \\
+0.70 \\
+0.76 \\
\\
+0.70 \\
+0.30 \\
+0.40 \\
+0.72 \\
\\
+0.64 \\
+0.73 \\
+0.82 \\
\\
\\
+0.53 \\
+0.57 \\
+0.20 \\
+0.83 \\
+0.95\end{array}$ & $\begin{array}{r} \\
+0.73 \\
+0.73 \\
+0.66 \\
+0.67 \\
+0.72 \\
\\
-0.08 \\
0.00 \\
-0.15 \\
+0.68 \\
+0.60 \\
+0.65 \\
+0.79 \\
\\
\\
-0.10 \\
-0.17 \\
-0.08 \\
+0.80 \\
+0.98\end{array}$ & $\begin{array}{l}\text { Pitting/thin oxide over surface } \\
\text { Pitting/thin oxide over surface } \\
\text { Pitting/thin oxide over surface } \\
\text { No pitting/local tarnishing } \\
\text { No pitting } \\
\text { No pitting } \\
\text { No pitting/very slight tarnishing } \\
\text { No pitting } \\
\text { Pitting } \\
\text { Pitting } \\
\text { Pitting } \\
\text { Pitting } \\
\text { No pitting/tarnished } \\
\text { No pitting/local tarnishing } \\
\text { No pitting/local tarnishing } \\
\text { No pitting } \\
\text { No pitting } \\
\text { No pitting/local tarnishing } \\
\text { No pitting } \\
\text { No pitting } \\
\text { Very slight localized etched areas } \\
\text { Pitting } \\
\text { Pitting/local active corrosion } \\
\text { Pitting/tarnishing } \\
\text { No pitting } \\
\text { No pitting/slight attack at mount } \\
\text { No pitting/local tarnishing } \\
\text { No pitting/heaving tarnishing } \\
\text { No pitting } \\
\text { No pitting/slight tarnishing } \\
\text { No pitting/local tarnishing } \\
\text { Pitting } \\
\text { Pitting } \\
\text { Pitting/tarnishing } \\
\text { No pitting } \\
\text { No pitting } \\
\text { No pitting/local tarnishing/slight attack at mount } \\
\text { No pitting/local tarnishing/slight attack at mount } \\
\text { No pitting/local tarnishing/slight attack at mount } \\
\text { No pitting/local tarnishing/slight attack at mount } \\
\text { No pitting } \\
\text { Pitting } \\
\text { Pitting } \\
\text { Slight Pitting } \\
\text { No attack } \\
\text { No attack }\end{array}$ \\
\hline
\end{tabular}




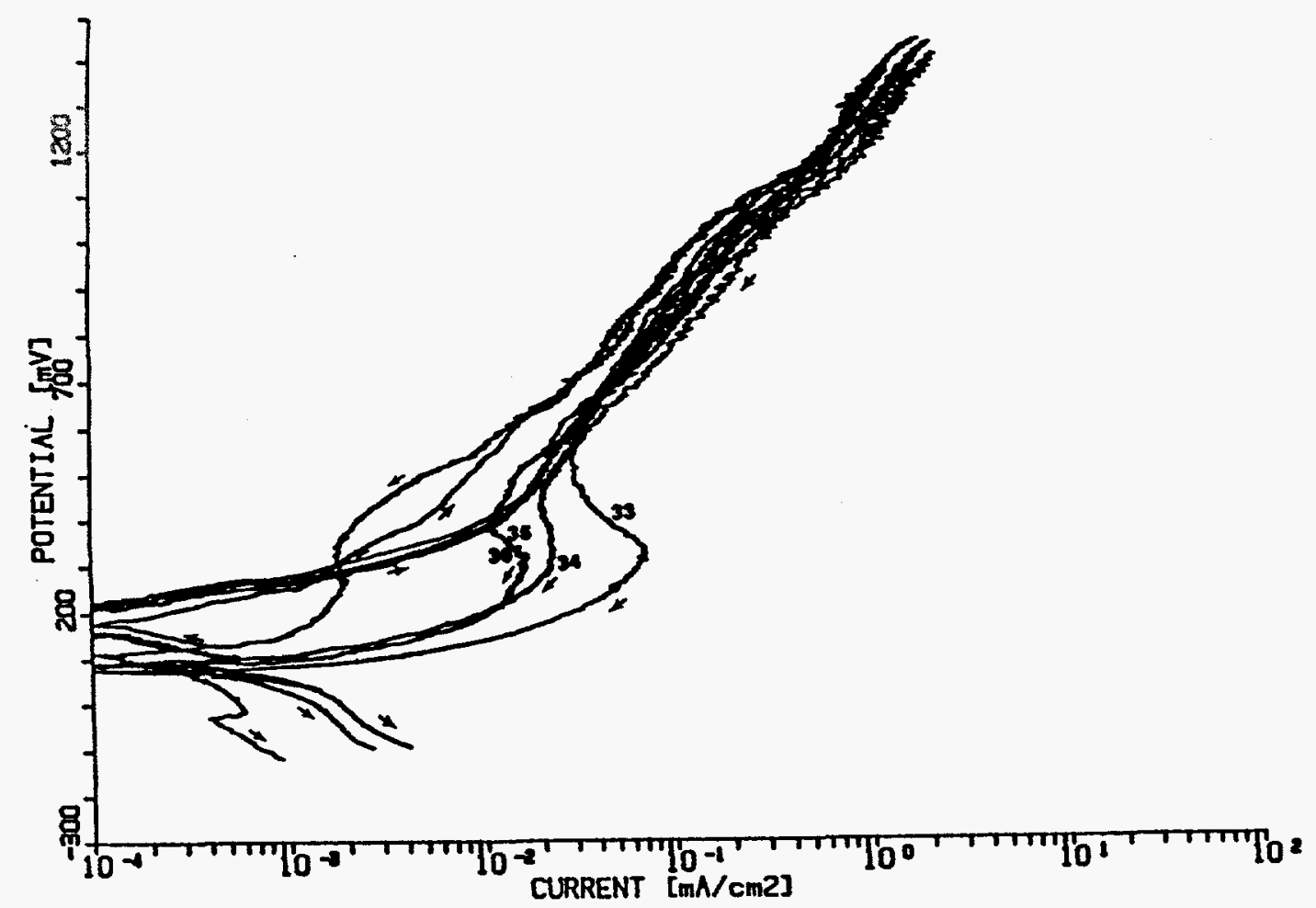

Figure 7.1 CPP Curves For Alloy 304L In Test Solution Numbers 33 Through 36 (Identical Solutions With Average Concentrations Of Environmental Variables). 
Again, care is required in interpreting the polarization behavior in two areas: (1) some slight hysteresis was present due to tamishing, thin oxide formation, and (2) seemingly active behavior might be the result of spurious oxidation reactions on the specimen surface and not representative of corrosion. It should be noted that the above two areas of caution in interpreting CPP curves are not unique to this study and special attention to these details is given to all CPP tests performed at CC Technologies.

Crevice corrosion at the PTFE holder-specimen interface was more prevalent for Alloy 825 than for Alloy 304L. This is probably due to the Alloy 825 being inherently more resistant to pitting, thereby making the presence of crevices more important as pit-initiation sites. Also, the pits were much smaller in diameter and, in general, more shallow for Alloy 825 as compared to Alloy 304L. For four Alloy 825 CPP tests (test Solution Numbers 8, 13, 18, and 27), this crevice corrosion and possibly the very small pits resulted in a very high passive current density. However, post-test examination suggested a different interpretation; that is, the apparent passive current was actually a pseudo-limiting current density for pitting/crevice attack. For these tests, the breakdown potential for pitting/crevice and the protection potential were selected at the point at which the forward and reverse scans, respectively, crossed at $10 \mu \mathrm{A} / \mathrm{cm}^{2}$ current density. The $10 \mu \mathrm{A} / \mathrm{cm}^{2}$ current density was selected somewhat arbitrarily, but corresponds to the highest passive current density expected.

As was observed with Alloy 304L tests, Alloy 825 exhibited pitting behavior in several of the test solutions. The primary question is whether the range of solution variables tested realistically simulated long-term conditions which may develop in a repository.

Table 7.2 presents a summary of the polarization parameters selected from the matrix of CPP tests. Also included in the table is a brief description of the specimen condition following the testing. Test Solution Numbers 33 through 36 were performed in the same solution and provide an indication of the reproducibility of the polarization behavior; the four curves are illustrated in Figure 7.2.

In summary, data for Alloy 304L and Alloy 825 indicate that several different types of corrosion behavior are possible depending upon the solution composition. These data also show that various combinations of solution variables produced localized corrosion for both of the $\mathrm{Fe}-\mathrm{Cr}-\mathrm{Ni}$ alloys in some regions of the factor space. The results of our research showed that although the interpretation of the CPP curves conformed with conventional interpretation, care is required in these interpretations when thin oxide films develop over the specimen surface and when spurious oxidation reactions, which are not actually representative of corrosion, occur at the specimen. 
Table 7.2 Polarization Parameters For The Test Solutions In The Statistically-Designed Matrix Of Experiments For Alloy 825.

\begin{tabular}{|c|c|c|c|c|c|c|}
\hline $\begin{array}{c}\text { Test } \\
\text { Solution }\end{array}$ & $\mathrm{V}, \mathrm{E}_{\mathrm{gOE}}$ & $\begin{array}{r}\mu \mathrm{Am}^{2} \\
\times 10^{-8} \\
\end{array}$ & $\begin{array}{r}\mu \mathrm{APm}^{2} \\
\times 10^{-6} \\
\end{array}$ & & $v$, Śg'E & Comments \\
\hline $\begin{array}{c}1 \\
2 \\
3 \\
4 \\
5 \\
6 \\
7 \\
8 \\
8 \text { repeat } \\
8 \text { repeat } \\
9 \\
10 \\
11 \\
12 \\
13 \\
14 \\
15 \\
16 \\
17 \\
18 \\
19 \\
20 \\
21 \\
22 \\
23 \\
24 \\
25 \\
26 \\
27 \\
28 \\
28 \text { repeat } \\
29 \\
30 \\
31 \\
32 \\
33 \\
34 \\
35 \\
36 \\
37 \\
38 \\
39 \\
40 \\
41 \\
42 \\
\end{array}$ & $\begin{array}{l}+0.225 \\
-0.325 \\
-0.005 \\
+0.030 \\
+0.225 \\
-0.400 \\
-0.090 \\
+0.105 \\
+0.100 \\
-0.070 \\
+0.260 \\
-0.320 \\
-0.465 \\
-0.010 \\
+0.180 \\
-0.250 \\
-0.205 \\
-0.070 \\
-0.190 \\
+0.135 \\
-0.070 \\
-0.320 \\
-0.450 \\
-0.040 \\
+0.020 \\
-0.180 \\
-0.420 \\
+0.200 \\
+0.120 \\
-0.020 \\
-0.125 \\
-0.070 \\
+0.180 \\
+0.080 \\
-0.270 \\
+0.095 \\
+0.100 \\
+0.090 \\
+0.170 \\
-0.650 \\
-0.480 \\
+0.267 \\
+0.189 \\
-0.255 \\
+0.026\end{array}$ & $\begin{array}{l}0.40 \\
0.24 \\
0.10 \\
0.37 \\
0.50 \\
0.13 \\
0.27 \\
0.14 \\
0.41 \\
0.55 \\
0.30 \\
0.14 \\
0.17 \\
0.12 \\
0.31 \\
0.24 \\
0.13 \\
0.22 \\
0.12 \\
0.32 \\
0.10 \\
0.10 \\
0.14 \\
0.16 \\
0.26 \\
0.16 \\
0.11 \\
0.14 \\
0.22 \\
0.16 \\
0.15 \\
0.08 \\
0.68 \\
0.39 \\
<0.08 \\
0.15 \\
0.33 \\
0.16 \\
0.32 \\
0.08 \\
0.14 \\
0.14 \\
0.13 \\
0.02 \\
0.33\end{array}$ & $\begin{array}{c}3.0 \\
1.6 \\
2.0 \\
10 \\
1.5 \\
2.0\end{array}$ & $\begin{array}{l}+0.72 \\
+0.78 \\
+0.94 \\
\\
+0.65 \\
+0.60 \\
+0.35 \\
+0.28 \\
+0.24 \\
+0.58 \\
+0.68 \\
+0.67 \\
\\
+0.36 \\
+0.69 \\
+0.75 \\
+0.73 \\
+0.29 \\
+0.72 \\
+0.69 \\
+0.67\end{array}$ & $\begin{array}{l}+0.48 \\
+0.68 \\
+0.80 \\
+0.53 \\
+0.15 \\
+0.12 \\
+0.09 \\
+0.09 \\
+0.10 \\
+0.63 \\
+0.54 \\
+0.33 \\
+0.67 \\
+0.57 \\
+0.70 \\
+0.14 \\
+0.15 \\
+0.09 \\
+0.60\end{array}$ & $\begin{array}{l}\text { No pitting/tarnished } \\
\text { Very shallow pitting } \\
\text { Pitting } \\
\text { No pitting/slight tarnishing } \\
\text { No pitting/slight tarnishing } \\
\text { No pitting/tarnished } \\
\text { Pitting } \\
\text { Pitting/crevice/intergranular attack } \\
\text { Pitting/crevice corrosion } \\
\text { Pitting/crevice corrosion } \\
\text { Pitting/crevice/intergranular attack } \\
\text { No pitting/tarnished } \\
\text { No pitting/tarnished } \\
\text { No pitting/tarnished } \\
\text { Pitting } \\
\text { No pitting } \\
\text { No pitting/tarnished/(possible very slight pitting) } \\
\text { No pitting/local tarnishing/slight crevice crack } \\
\text { No pitting } \\
\text { Pitting/crevice attack } \\
\text { Pitting/crevice attack } \\
\text { Pitting/crevice attack } \\
\text { No pitting } \\
\text { No pitting/local tarnishing/slight etching } \\
\text { No pitting/local tarnishing/slight etching } \\
\text { No pitting/slight tarnishing } \\
\text { No pitting/tarnishing/local active attack } \\
\text { No pitting/tarnishing/very shallow local active attack } \\
\text { Pitting/tocal active attack } \\
\text { No pitting/tarnishing } \\
\text { No pitting/tarnishing } \\
\text { Very shallow pitting } \\
\text { Pitting } \\
\text { No pitting/local tarnishing/slight active attack } \\
\text { No pitting } \\
\text { No pitting/heavy tarnishing } \\
\text { No pitting/heavy tarnishing } \\
\text { No pitting/heavy tarnishing } \\
\text { Pitting//shallow)/heavy tarnishing } \\
\text { No Pitting } \\
\text { Pitting } \\
\text { Pitting } \\
\text { Pitting/crevice attack } \\
\text { No attack } \\
\text { No pitting/etching at crevice } \\
\text { al }\end{array}$ \\
\hline
\end{tabular}




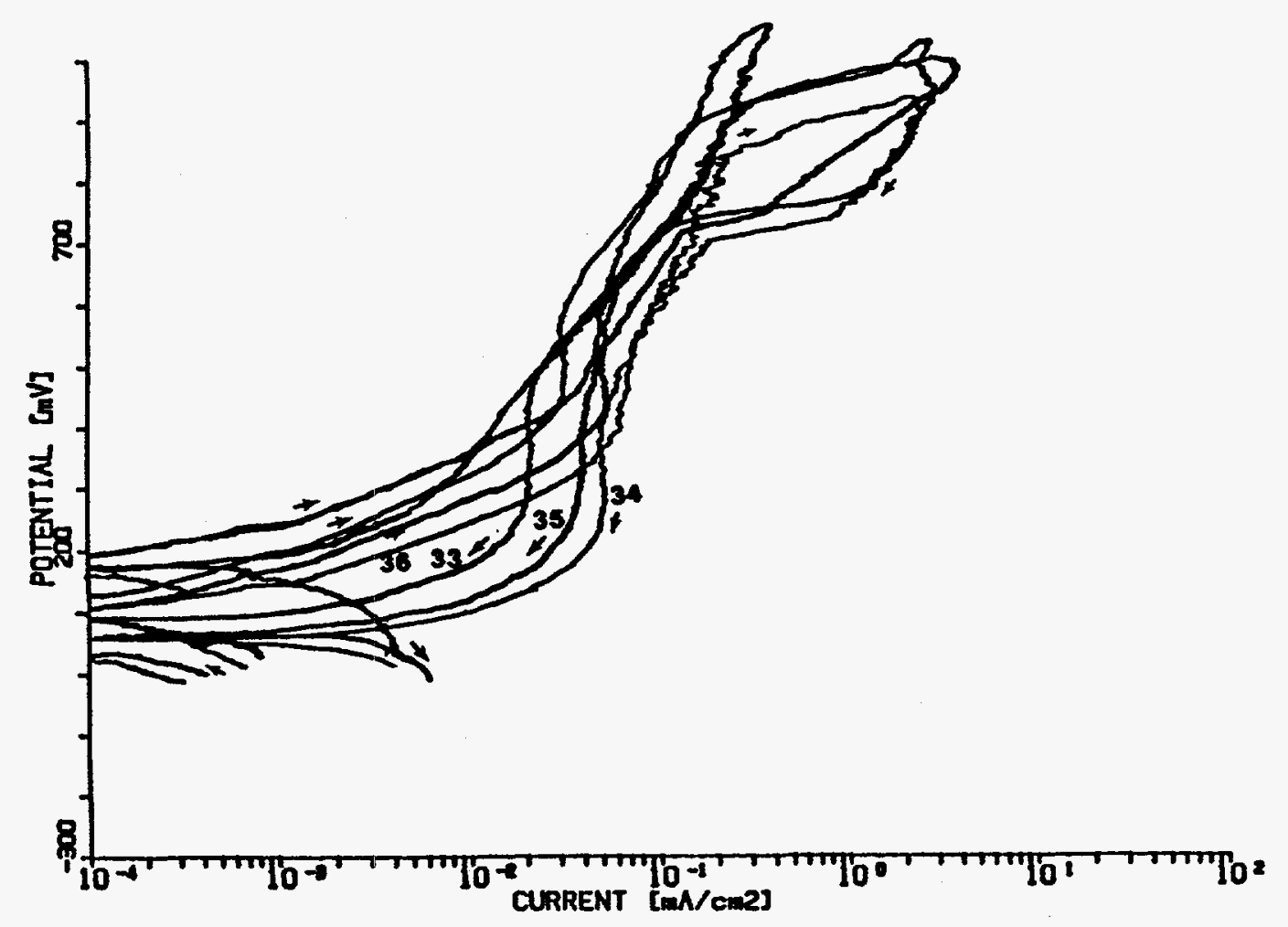

Figure 7.2. CPP Curves For Alloy 825 In Test Solution Numbers 33 Through 36 (Identical Solutions With Average Concentrations Of Environmental Variables). 


\section{EFFECTS OF TEMPERATURE ON CPP BEHAVIOR}

Cyclic-potentiodynamic-polarization (CPP) experiments were performed on Alloys CDA 102, CDA $715,304 \mathrm{~L}$, and 825 in simulated $\mathrm{J}-13$ well water and in three other solutions selected from the statistical matrix at $50^{\circ} \mathrm{C}, 75^{\circ} \mathrm{C}$, and $90^{\circ} \mathrm{C}$. The purpose of these experiments was to provide a better indication of the effect of temperature on the corrosion behavior of these alloys. The experimental conditions were similar to those previously used for each alloy as described in Section 3. The tests were run at a scan rate of $0.17 \mathrm{mV} / \mathrm{sec}(0.6 \mathrm{~V} / \mathrm{hr})$. Each of the CPP curves obtained in this subtask is given in Appendix $E$.

\subsection{Copper-Base Alloys}

Each of the copper-base alloys was evaluated at $50^{\circ} \mathrm{C}, 75^{\circ} \mathrm{C}$, and $90^{\circ} \mathrm{C}$ in the following solutions:

(1) Simulated J-13 well water,

(2) Solution No. 7, in which the copper-base alloys exhibited active-corrosion behavior (in the CPP test matrix), and

(3) Solution No. 10, which promoted passivation and pitting of the copper-base alloys.

The compositions of these solutions are given in Table 8.1.

The CPP curves for Alloy CDA 102 and Alloy CDA 715 in simulated J-13 well water at each of the three temperatures are shown in Figures 8.1 and 8.2 , respectively. Table 8.2 presents the polarization parameters selected from these curves.

For Alloy CDA 102 in simulated $\mathrm{J}-13$ well water, it is seen that the corrosion current density, $\mathrm{i}_{\text {corr }}$, increased with increasing temperature while no significant change in free-corrosion potential, $E_{c o r}$, was observed. The breakdown potential, $E_{b}$, varied only slightly with temperature. Although significant differences in the repassivation potential, $E_{r p}$, were observed for the different tests, no temperature-dependent trends were evident. In all cases, post-test examination indicated local variations in the oxide coloration. Some active corrosion also was observed for the specimen tested at $75^{\circ} \mathrm{C}$. As discussed previously, the hysteresis in the CPP curves for Alloy CDA 102 appears to be related to the oxide-layer irregularities, as opposed to the pitting-repassivation phenomena to which hysteresis is normally attributed. It is possible that the wide range of $E_{p}$ values observed can be attributed to variation in the nature of the oxide from test to test.

For Alloy CDA 715 in simulated $J-13$ well water, the values of $E_{c o r}$ became more negative as the temperature increased while the corrosion rates were similar for all temperatures. This behavior is indicative of a passive alloy, i.e. $E_{c o r}$ varies but $i_{c o r}$ remains unchanged. The values of $E_{b}$ and $E_{r p}$ did not show a systemic trend for Alloy 715 in simulated J-13 well water. Post-test examination of the test specimens indicated similar behavior at all three temperatures. That is, local oxide changes as well as locally active attack, with a few shallow pits in the active regions. The local oxide changes and the shallow pits probably account for the hysteresis in the CPP curves. 
Table 8.1 Compositions Of Selected Solutions From The Experimental Matrix Used in The Temperature-Effect Studies Of The Copper-Base Alloys.

\begin{tabular}{|c|c|c|c|c|}
\hline $\begin{array}{c}\text { Environmental } \\
\text { Specles }\end{array}$ & $\begin{array}{c}\text { J-13 Well Water } \\
\text { mg/l }\end{array}$ & $\begin{array}{c}\text { Simulated } \\
\text { J-13 Well Water } \\
\text { mg/l }\end{array}$ & $\begin{array}{c}\text { Solution } N^{2} 7 \\
\mathrm{mg} / \mathrm{l}\end{array}$ & $\begin{array}{c}\text { Solution Ne } 10 \\
\mathrm{mg} /\end{array}$ \\
\hline $\mathrm{pH}$ & 7.6 & $7.0 \pm 0.2$ & 5.0 & 10 \\
\hline $\mathrm{SiO}_{2}$ & 58 & 64.2 & 215 & 2.2 \\
\hline $\mathrm{HCO}_{3}^{-}$ & 125 & 121 & 0.4 & 2000 \\
\hline$F^{-}$ & 2.2 & 1.7 & 0.04 & 0.04 \\
\hline $\mathrm{Cl}^{-}$ & 6.9 & 6.4 & 1000 & 1000 \\
\hline $\mathrm{NO}_{3}^{-}$ & 9.6 & 12.4 & 0.2 & 0.2 \\
\hline $\mathrm{SO}_{4}{ }^{2-}$ & 18.7 & 19.2 & $\bullet$ & $\bullet$ \\
\hline $\mathrm{NO}_{2}^{-}$ & - & - & 0.0 & 0.0 \\
\hline $\mathrm{H}_{2} \mathrm{O}_{2}$ & - & - & 0.0 & 0.0 \\
\hline $\mathrm{Al}^{3+}$ & 0.012 & - & 0.0004 & 0.8 \\
\hline $\mathrm{Fe}^{2+}$ & 0.006 & - & 0.0 & 0.0 \\
\hline $\mathrm{Ca}^{2+}$ & 12.5 & 12.0 & 0.8 & 0.8 \\
\hline $\mathrm{Mg}^{2+}$ & 1.9 & 1.7 & 0.8 & 0.004 \\
\hline $\mathrm{K}^{+}$ & 5.1 & 5.5 & 0.08 & 0.08 \\
\hline $\mathrm{Na}^{+}$ & 44 & 46 & $\bullet$ & * \\
\hline $\mathrm{PO}_{4}^{3-}$ & 0.12 & - & 2.0 & 0.01 \\
\hline Oxalic Acid & - & - & 172 & 0 \\
\hline
\end{tabular}

- $\mathrm{Na}^{+}$and $\mathrm{SO}_{4}^{2-}$ were used to balance the composition. 


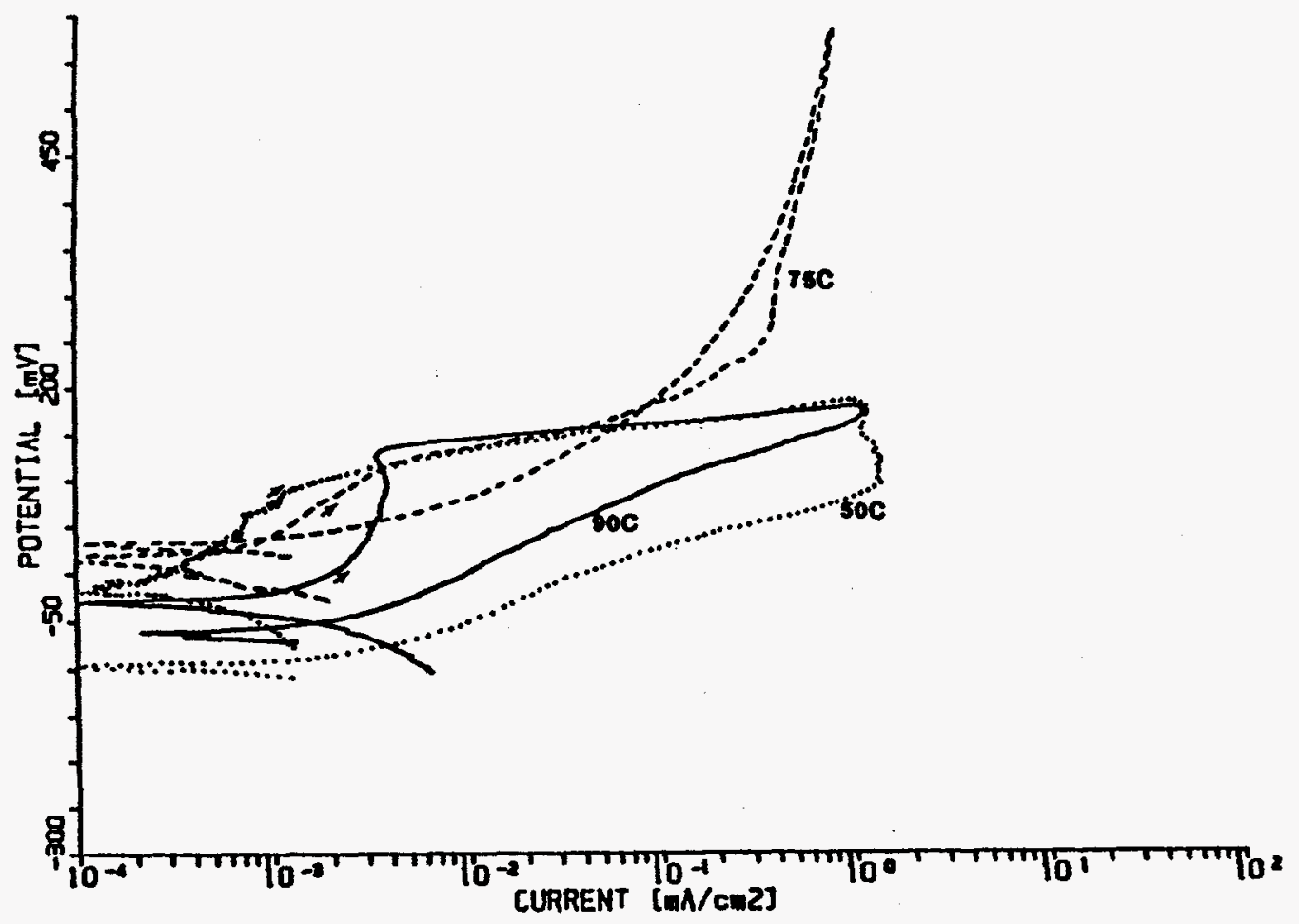

Figure 8.1 CPP Curves For Alloy CDA 102 In Simulated J-13 Well Water At $50^{\circ} \mathrm{C}, 75^{\circ} \mathrm{C}$, And $90^{\circ} \mathrm{C}$.

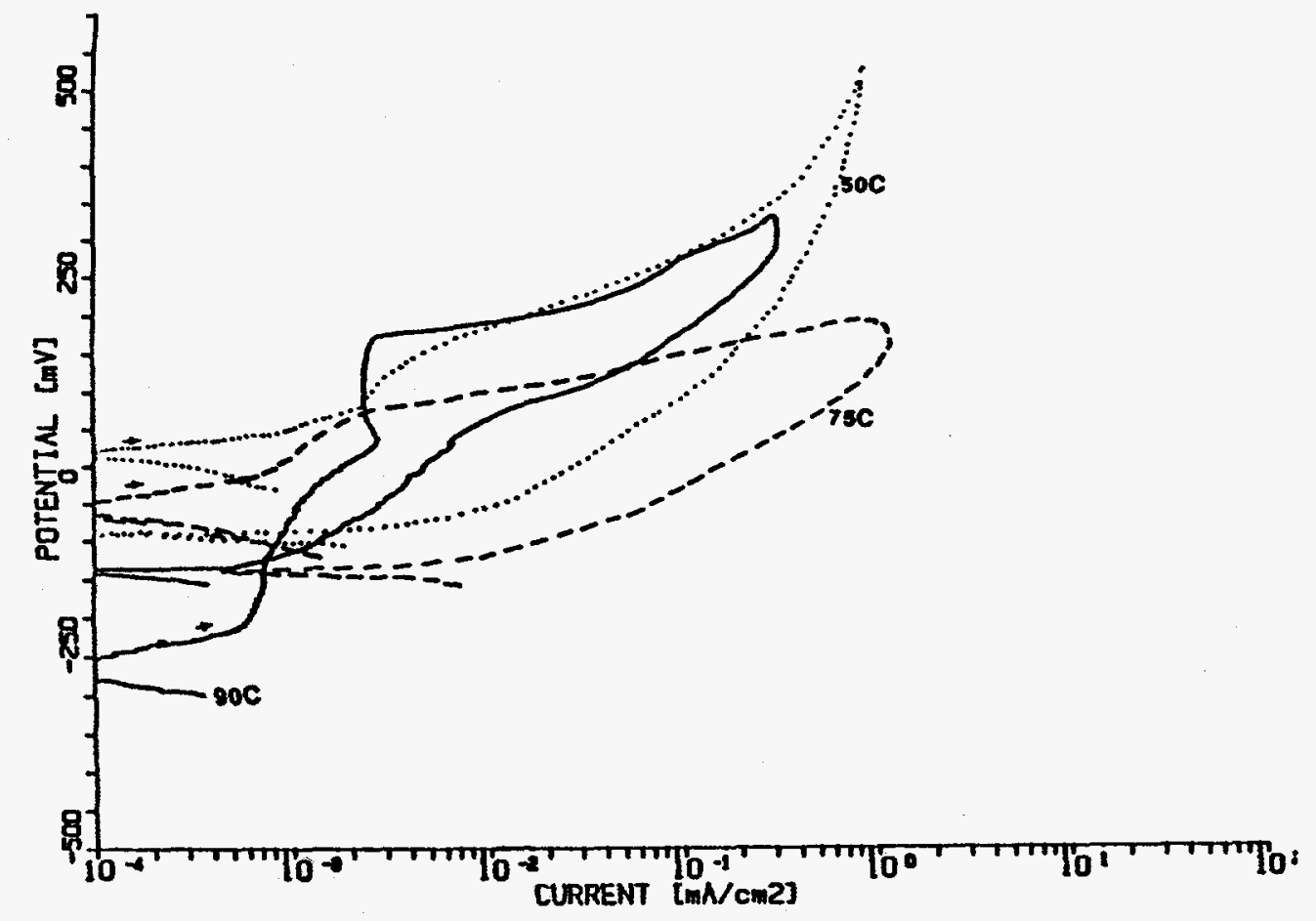

Figure 8.2 CPP Curves For Alloy CDA 715 in Simulated J-13 Well Water At $50^{\circ} \mathrm{C}, 75^{\circ} \mathrm{C}$, And $90^{\circ} \mathrm{C}$. 
Table 8.2 Effect Of Temperature On The Polarization Parameters Taken From CPP Curves On Copper-Base Alloys In Simulated $\mathrm{J}-13$ Well Water And In Selected Solutions From The Test Matrix.

\begin{tabular}{|c|c|c|c|c|c|c|c|}
\hline Alloy & $\begin{array}{c}\text { Solution } \\
\text { Temperature }\end{array}$ & $\begin{array}{c}\text { Test } \\
\text { Solution }\end{array}$ & $\begin{array}{c}E_{\text {cor }} \\
\mathbf{V}, \mathbf{S C E}\end{array}$ & $\begin{array}{c}I_{\operatorname{cor}} \\
\mu A \mathrm{~cm}^{2}\end{array}$ & $\mathrm{~V}, \mathrm{E}_{\mathrm{b}} \mathrm{SCE}$ & $\begin{array}{c}E_{T p} \\
V, \text { SCE }\end{array}$ & Comments \\
\hline $\begin{array}{l}\text { CDA } 102 \\
\text { CDA } 102 \\
\text { CDA } 102 \\
\end{array}$ & $\begin{array}{l}50^{\circ} \mathrm{C} \\
75^{\circ} \mathrm{C} \\
90^{\circ} \mathrm{C} \\
\end{array}$ & $\begin{array}{l}J-13 \\
J-13 \\
J-13\end{array}$ & $\begin{array}{r}-0.020 \\
+0.020 \\
-0.030 \\
\end{array}$ & $\begin{array}{l}0.30 \\
0.60 \\
2.0 \\
\end{array}$ & $\begin{array}{r}+0.110 \\
+0.125 \\
+0.140 \\
\end{array}$ & $\begin{array}{r}-0.090 \\
+0.045 \\
-0.035 \\
\end{array}$ & $\begin{array}{l}\text { Local changes in oxide. } \\
\text { Active corrosion beneath partially loose-adherent oxide. } \\
\text { Local changes in oxide. }\end{array}$ \\
\hline $\begin{array}{l}\text { CDA } 715 \\
\text { CDA } 715 \\
\text { CDA } 715\end{array}$ & $\begin{array}{l}50^{\circ} \mathrm{C} \\
75^{\circ} \mathrm{C} \\
90^{\circ} \mathrm{C}\end{array}$ & $\begin{array}{l}J-13 \\
J-13 \\
J-13\end{array}$ & $\begin{array}{r}+0.025 \\
-0.040 \\
-0.265 \\
\end{array}$ & $\begin{array}{l}0.60 \\
0.56 \\
0.41\end{array}$ & $\begin{array}{l}+0.190 \\
+0.085 \\
+0.180 \\
\end{array}$ & $\begin{array}{l}-0.080 \\
-0.125 \\
+0.080\end{array}$ & $\begin{array}{l}\text { Local changes in oxide, local active attack } w / \text { few shallow pits. } \\
\text { Local changes in oxide, local active attack } w / \text { few shallow pits. } \\
\text { Local changes in oxide, local active attack } w / \text { few shallow pits. }\end{array}$ \\
\hline \begin{tabular}{ll|} 
CDA 102 \\
CDA 102 \\
CDA 102 \\
\end{tabular} & $\begin{array}{l}50^{\circ} \mathrm{C} \\
75^{\circ} \mathrm{C} \\
90^{\circ} \mathrm{C}\end{array}$ & $\begin{array}{l}7 \\
7 \\
7\end{array}$ & $\begin{array}{l}-0.120 \\
-0.105 \\
-0.140 \\
\end{array}$ & $\begin{array}{r}3.9 \\
130.0 \\
6.6 \\
\end{array}$ & - & $\begin{array}{l}- \\
- \\
-\end{array}$ & $\begin{array}{l}\text { Local changes in oxide, local active attack. } \\
\text { Local changes in oxide, active corrosion over entire surface. } \\
\text { Local oxide growth, active areas. }\end{array}$ \\
\hline $\begin{array}{l}\text { CDA } 715 \\
\text { CDA } 715 \\
\text { CDA } 715 \\
\end{array}$ & $\begin{array}{l}50^{\circ} \mathrm{C} \\
75^{\circ} \mathrm{C} \\
90^{\circ} \mathrm{C}\end{array}$ & $\begin{array}{l}7 \\
7 \\
7\end{array}$ & $\begin{array}{l}-0.050 \\
-0.190 \\
-0.150 \\
\end{array}$ & $\begin{array}{l}2.4 \\
59.0 \\
23\end{array}$ & $\begin{array}{l}- \\
-\end{array}$ & $\begin{array}{l}- \\
-\end{array}$ & $\begin{array}{l}\text { Local changes in oxide, active corrosion over entire surface, } \\
\text { shallow pitting. } \\
\text { Local changes in oxide, active corrosion over entire surface. } \\
\text { Active corrosion. }\end{array}$ \\
\hline $\begin{array}{l}\text { CDA } 715 \\
\text { CDA } 715 \\
\text { CDA } 715\end{array}$ & $\begin{array}{l}50^{\circ} \mathrm{C} \\
75^{\circ} \mathrm{C} \\
90^{\circ} \mathrm{C}\end{array}$ & $\begin{array}{l}10 \\
10 \\
10\end{array}$ & $\begin{array}{l}-0.105 \\
-0.150 \\
-0.155\end{array}$ & $\begin{array}{l}0.13 \\
0.08 \\
0.08\end{array}$ & $\begin{array}{l}+0.670 \\
+0.660 \\
+0.630\end{array}$ & $\begin{array}{l}+0.020 \\
+0.010 \\
-0.020\end{array}$ & $\begin{array}{l}\text { Pitting, active attack. } \\
\text { Pitting, active attack. } \\
\text { Pitting, active attack. }\end{array}$ \\
\hline
\end{tabular}

" No passive behavior observed. 
In Solution Number 7 and Solution Number 10 neither of the copper-base alloys appeared to show any systematic trends in the polarization parameters. Optical examination of the specimens following these CPP tests also failed to show any observable differences as a result of temperature differences. These data indicate that there is not a strong temperature dependence of the corrosion behavior of the copper-base alloys in the synthetic environments evaluated over the limited temperature range of $50^{\circ} \mathrm{C}$ to $90^{\circ} \mathrm{C}$.

\subsection{Fe-Cr-NI Alloys}

Each of the $\mathrm{Fe}-\mathrm{Cr}-\mathrm{Ni}$ alloys was evaluated at $50^{\circ} \mathrm{C}, 70^{\circ} \mathrm{C}$, and $90^{\circ} \mathrm{C}$ in the following solutions:

(1) Simulated J-13 well water,

(2) Solution Number 7, which promoted pitting of the Fe-Cr-Ni alloys (in the CPP test matrix), and

(3) Solution Number 20, which promoted passivation and pitting of the $\mathrm{Fe}-\mathrm{Cr}-\mathrm{Ni}$ alloys.

The compositions of these solutions are given in Table 8.3.

The CPP curves for Alloy $304 \mathrm{~L}$ and Alloy 825 in simulated J-13 well water at each of the three temperatures are shown in Figures 8.3 and 8.4 , respectively. Table 8.4 presents the polarization parameters selected from these curves.

For Alloy $304 \mathrm{~L}$ in simulated $\mathrm{J}-13$ well water, the forward scans for each of the three curves were very similar and very little difference in the passive-current density was observed for the different temperatures. As observed for CDA 715, the free-corrosion potential of Alloy $304 \mathrm{~L}$ at $90^{\circ} \mathrm{C}$ was significantly more negative than at $50^{\circ} \mathrm{C}$ or $75^{\circ} \mathrm{C}$. The CPP tests performed at $50^{\circ} \mathrm{C}$ and $90^{\circ} \mathrm{C}$ in simulated $\mathrm{J}-13$ well water exhibited no hysteresis and the specimens showed no signs of pitting or other attack during post-test examination. Table 8.4 shows that the $E_{\text {prit }}$ and $E_{\text {prot }}$ values for Alloy $304 \mathrm{~L}$ were similar at $50^{\circ} \mathrm{C}$ and $90^{\circ} \mathrm{C}$ in simulated $\mathrm{J}-13$ well water. However, hysteresis was observed for Alloy $304 \mathrm{~L}$ at $75^{\circ} \mathrm{C}$ and pits were observed on the bottom of the specimen. This hysteresis was reflected in a very negative value for $E_{\text {prot }}$. It should be noted that the CPP tests at $50^{\circ} \mathrm{C}$ and $75^{\circ} \mathrm{C}$ were performed using the same batch of simulated $\mathrm{J}-13$ well water. Therefore, the difference in behavior between $50^{\circ} \mathrm{C}$ and $75^{\circ} \mathrm{C}$ cannot be attributed to differences in the makeup of the simulated J-13 well water. Also, the Alloy $304 \mathrm{~L}$ test specimens came from the same batch of material for all three tests. The question remains as to the cause of the pitting observed at $75^{\circ} \mathrm{C}$.

For Alloy 825 in simulated J-13 well water, very little difference was observed in the CPP behavior at the three temperatures. The free-corrosion potential was more negative at higher temperatures. No hysteresis was observed at any of the temperatures and post-test examination showed that negligible attack of the samples had occurred.

In Solution Number 7 and Solution Number 20, however, neither of the $\mathrm{Fe}-\mathrm{Cr}-\mathrm{Ni}$ alloys appeared to show any systematic trends in the polarization parameters. Optical examination of the specimens showed pitting of both alloys in both of the solutions with no observable differences as a result of changes in the solution temperature. The apparent lack of any systematic trends 
Table 8.3. Compositions Of Selected Solutions From The Experimental Matrix Used In The Temperature-Effect Studies Of Fe-Cr-Ni Alloys.

\begin{tabular}{|c|c|c|c|c|}
\hline $\begin{array}{c}\text { Environmental } \\
\text { Species }\end{array}$ & $\begin{array}{c}\text { J-13 Well Water } \\
\text { mg/l }\end{array}$ & $\begin{array}{c}\text { Simulated } \\
\text { J-13 Well Water } \\
\text { mg/l }\end{array}$ & $\begin{array}{c}\text { Solution } N^{2} 7 \\
\mathrm{mg} / \mathrm{l}\end{array}$ & $\begin{array}{c}\text { Solution } N^{2} 20 \\
\mathrm{mg} / \mathrm{l}\end{array}$ \\
\hline $\mathrm{pH}$ & 7.6 & $7.0 \pm 0.2$ & 5.0 & 10.0 \\
\hline $\mathrm{SiO}_{2}$ & 58 & 64.2 & 215 & 2.2 \\
\hline $\mathrm{HCO}_{3}^{-}$ & 125 & 121 & 0.4 & 0.4 \\
\hline $\mathrm{F}^{-}$ & 2.2 & 1.7 & 0.04 & 200 \\
\hline $\mathrm{Cl}^{-}$ & 6.9 & 6.4 & 1000 & 1000 \\
\hline $\mathrm{NO}_{3}^{-}$ & 9.6 & 12.4 & 0.2 & 0.2 \\
\hline $\mathrm{SO}_{4}{ }^{2-}$ & 18.7 & 19.2 & * & * \\
\hline $\mathrm{NO}_{2}^{-}$ & - & - & 0.0 & 200 \\
\hline $\mathrm{H}_{2} \mathrm{O}_{2}$ & - & - & 0.0 & 0.0 \\
\hline $\mathrm{Al}^{3+}$ & 0.012 & - & 0.0004 & 0.8 \\
\hline $\mathrm{Fe}^{2+}$ & 0.006 & - & 0.0 & 0.0 \\
\hline $\mathrm{Ca}^{2+}$ & 12.5 & 12.0 & 0.8 & 0.8 \\
\hline $\mathrm{Mg}^{2+}$ & 1.9 & 1.7 & 0.8 & 0.8 \\
\hline $\mathrm{K}^{+}$ & 5.1 & 5.5 & 0.08 & 408 \\
\hline $\mathrm{Na}^{+}$ & 44 & 46 & * & * \\
\hline $\mathrm{PO}_{4}^{3-}$ & 0.12 & - & 2.0 & 2.0 \\
\hline Oxalic Acid & - & - & 172 & 0 \\
\hline
\end{tabular}

* $\mathrm{Na}^{+}$and $\mathrm{SO}_{4}{ }^{2-}$ were used to balance the composition. 


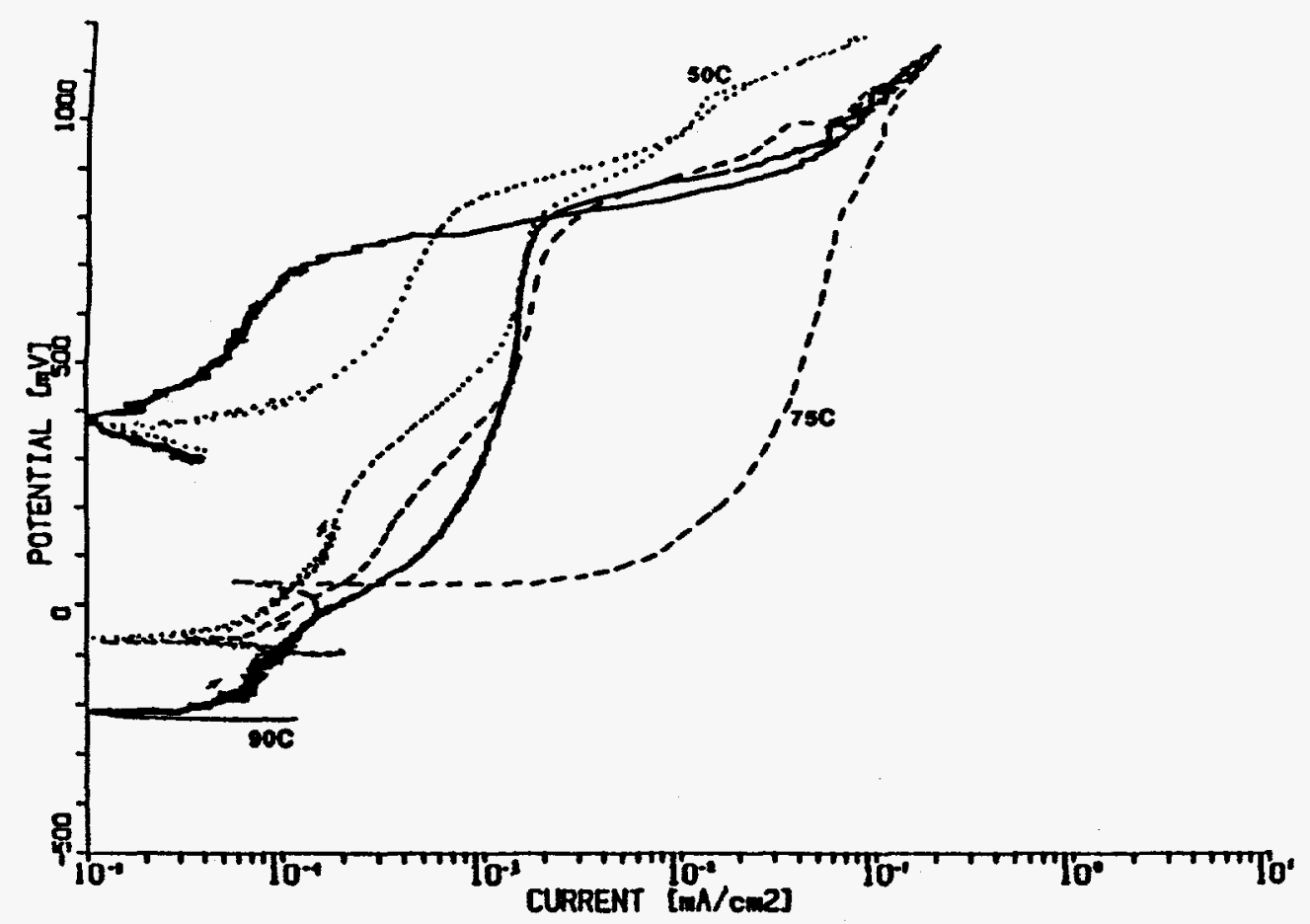

Figure 8.3. CPP Curves For Alloy $304 \mathrm{~L}$ In Simulated J-13 Well Water At $50^{\circ} \mathrm{C}, 75^{\circ} \mathrm{C}$, And $90^{\circ} \mathrm{C}$.

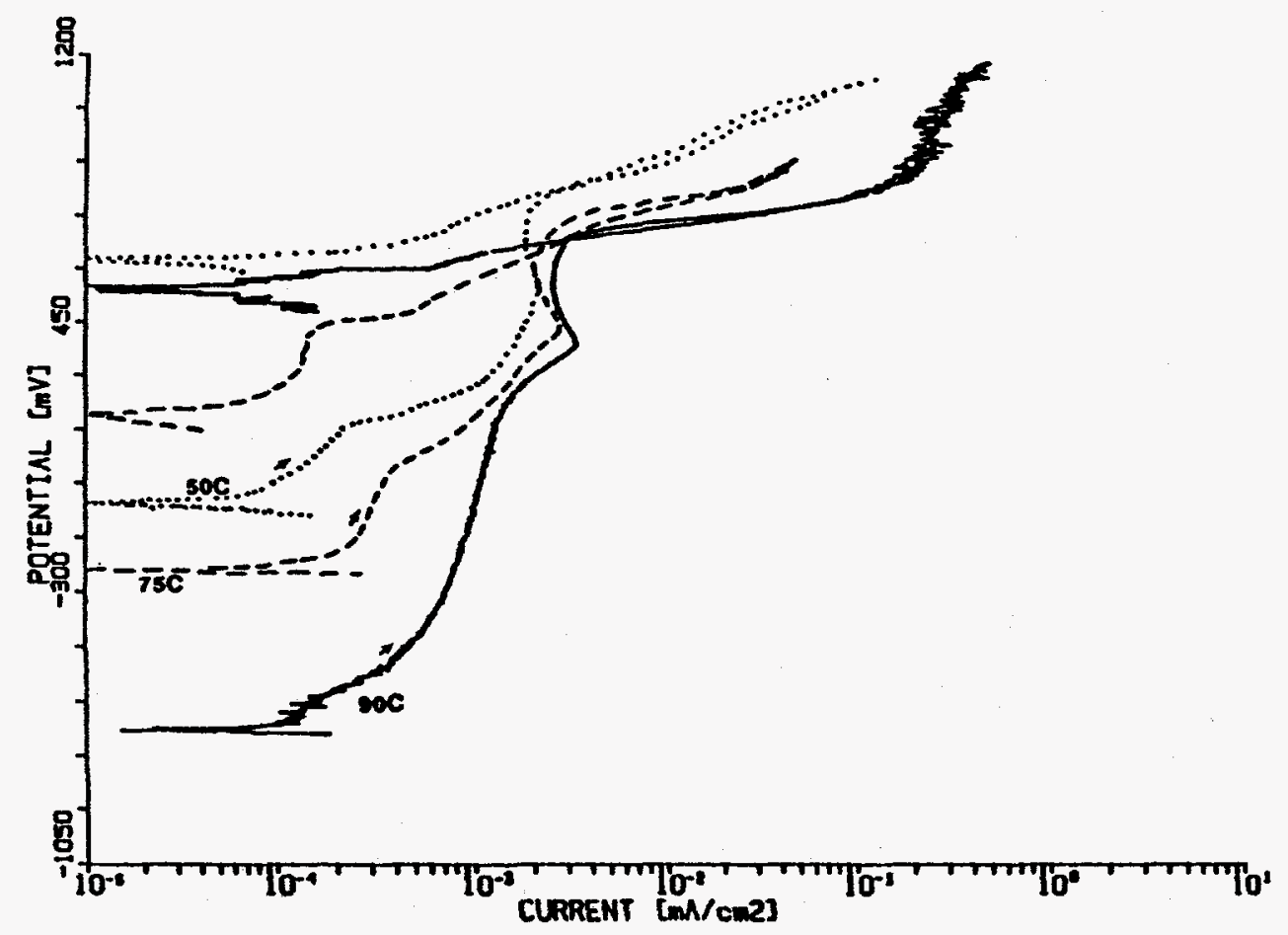

Figure 8.4. CPP Curves For Alloy 825 in Simulated J-13 Well Water At $50^{\circ} \mathrm{C}, 75^{\circ} \mathrm{C}$, And $90^{\circ} \mathrm{C}$. 
Table 8.4 Effect Of Temperature On The Polarization Parameters Taken From CPP Curves On Fe-Cr-Ni Alloys In Simulated J-13 Well Water And In Selected Solutions From The Test Matrix.

\begin{tabular}{|c|c|c|c|c|c|c|c|}
\hline Alloy & $\begin{array}{c}\text { Solution } \\
\text { Temperature }\end{array}$ & $\begin{array}{c}\text { Test } \\
\text { Solution }\end{array}$ & $\begin{array}{c}E_{c o r} \\
V, \text { SCE }\end{array}$ & $\begin{array}{c}l_{\text {cor }} \\
\mu \mathrm{Am}^{2}\end{array}$ & $v, \mathbf{s}_{\mathrm{ph}}$ & $\mathrm{V}, \mathrm{E}_{\mathrm{prot}}$ & Comments \\
\hline $\begin{array}{l}304 L \\
304 L \\
304 L\end{array}$ & $\begin{array}{l}50^{\circ} \mathrm{C} \\
75^{\circ} \mathrm{C} \\
90^{\circ} \mathrm{C}\end{array}$ & $\begin{array}{l}J-13 \\
J-13 \\
J-13\end{array}$ & $\begin{array}{l}-0.075 \\
-0.060 \\
-0.210\end{array}$ & $\begin{array}{l}0.05 \\
0.07 \\
0.05\end{array}$ & $\begin{array}{l}+0.825 \\
+0.825 \\
+0.815 \\
\end{array}$ & $\begin{array}{l}+0.825 \\
+0.040 \\
+0.815\end{array}$ & $\begin{array}{l}\text { Passive, no pitting or active attack. } \\
\text { Few pits on bottom of specimen, othenwise no attack. } \\
\text { Passive, no pitting or active attack. }\end{array}$ \\
\hline $\begin{array}{l}825 \\
825 \\
825\end{array}$ & $\begin{array}{l}50^{\circ} \mathrm{C} \\
75^{\circ} \mathrm{C} \\
90^{\circ} \mathrm{C}\end{array}$ & $\begin{array}{l}J-13 \\
J-13 \\
J-13\end{array}$ & $\begin{array}{r}-0.060 \\
-0.230 \\
-0.675\end{array}$ & $\begin{array}{l}0.05 \\
0.14 \\
0.10\end{array}$ & $\begin{array}{l}+0.840 \\
+0.815 \\
+0.710 \\
\end{array}$ & $\begin{array}{l}+0.840 \\
+0.815 \\
+0.710 \\
\end{array}$ & $\begin{array}{l}\text { Passive, no pitting or active attack. } \\
\text { Passive, no pitting or active attack. } \\
\text { Passive, no pitting or active attack. }\end{array}$ \\
\hline $\begin{array}{l}304 L \\
304 L \\
304 L\end{array}$ & $\begin{array}{l}50^{\circ} \mathrm{C} \\
75^{\circ} \mathrm{C} \\
90^{\circ} \mathrm{C}\end{array}$ & $\begin{array}{l}7 \\
7 \\
7 \\
\end{array}$ & $\begin{array}{l}-0.080 \\
-0.150 \\
-0.035\end{array}$ & $\begin{array}{l}0.09 \\
0.13 \\
0.35\end{array}$ & $\begin{array}{l}+0.170 \\
+0.080 \\
+0.900 \\
\end{array}$ & $\begin{array}{r}-0.010 \\
-0.150 \\
-0.120 \\
\end{array}$ & $\begin{array}{l}\text { Pitting. } \\
\text { Pitting. } \\
\text { Pitting. }\end{array}$ \\
\hline $\begin{array}{l}825 \\
825 \\
825\end{array}$ & $\begin{array}{l}50^{\circ} \mathrm{C} \\
75^{\circ} \mathrm{C} \\
90^{\circ} \mathrm{C}\end{array}$ & $\begin{array}{l}7 \\
7 \\
7\end{array}$ & $\begin{array}{r}-0.190 \\
-0.165 \\
-0.090\end{array}$ & $\begin{array}{l}0.08 \\
0.17 \\
0.27\end{array}$ & $\begin{array}{l}+0.460 \\
+0.420 \\
+0.600 \\
\end{array}$ & $\begin{array}{l}+0.070 \\
+0.230 \\
+0.150 \\
\end{array}$ & $\begin{array}{l}\text { Pitting. } \\
\text { Pitting, very slight etching. } \\
\text { Pitting. }\end{array}$ \\
\hline $\begin{array}{l}304 L \\
304 L \\
304 L\end{array}$ & $\begin{array}{l}50^{\circ} \mathrm{C} \\
75^{\circ} \mathrm{C} \\
90^{\circ} \mathrm{C}\end{array}$ & $\begin{array}{l}20 \\
20 \\
20\end{array}$ & $\begin{array}{r}-0.150 \\
-0.120 \\
-0.205\end{array}$ & $\begin{array}{l}0.25 \\
0.06 \\
0.13\end{array}$ & $\begin{array}{l}+0.400 \\
+0.280 \\
+0.210 \\
\end{array}$ & $\begin{array}{r}-0.150 \\
-0.110 \\
-0.110\end{array}$ & $\begin{array}{l}\text { Pitting, tarnishing. } \\
\text { Pitting, iridescent oxide. } \\
\text { Pitting and active attack. Iridescent oxide. }\end{array}$ \\
\hline $\begin{array}{l}825 \\
825 \\
825\end{array}$ & $\begin{array}{l}50^{\circ} \mathrm{C} \\
75^{\circ} \mathrm{C} \\
90^{\circ} \mathrm{C}\end{array}$ & $\begin{array}{l}20 \\
20 \\
20\end{array}$ & $\begin{array}{l}-0.320 \\
-0.160 \\
-0.250\end{array}$ & $\begin{array}{l}0.10 \\
0.10 \\
0.05\end{array}$ & $\begin{array}{l}+0.690 \\
+0.650 \\
+0.610\end{array}$ & $\begin{array}{l}+0.090 \\
-0.010 \\
+0.150\end{array}$ & $\begin{array}{l}\text { Pitting, crevice attack. } \\
\text { Pitting, iridescent oxide. } \\
\text { Pitting, iridescent oxide. }\end{array}$ \\
\hline
\end{tabular}


in the data or in the post-test evaluation suggest that there is not a strong temperature dependence of the corrosion behavior of the $\mathrm{Fe}-\mathrm{Cr}-\mathrm{Ni}$ alloy/synthetic environment systems evaluated over the limited temperature range of $50^{\circ} \mathrm{C}$ to $90^{\circ} \mathrm{C}$. 



\section{EFFECTS OF HEAT TRANSFER ON CPP BEHAVIOR}

Cyclic-potentiodynamic-polarization experiments were performed on heat-transfer specimens of the four candidate alloys. The purpose of these experiments was to examine the effects of temperature gradients on the corrosion behavior of the alloys. These tests simulate conditons at the heated canister surface. For each of the alloys, testing was conducted in simulated J-13 well water and in one additional solution, selected from the experimental matrix.

The experimental set-up and procedures for the heat-transfer testing were similar to those previously used for each alloy as described in Section 3. The heat-transfer specimen, illustrated in Figure 9.1, was inserted through the bottom of a glass test cell, as shown in Figure 9.2. The cell was filled with the test solution and heated to $50^{\circ} \mathrm{C}$. The heat-transfer specimen was internally heated to $90^{\circ} \mathrm{C}$. The test cell was sparged with the required gas for approximately 16 hours to $100 \mathrm{mV}$ more negative than the free-corrosion potential and the potential was scanned anodically at a rate of $0.6 \mathrm{~V} / \mathrm{hr}$ until a critical potential or current had been attained; the potential was then reversed until a cathodic current was obtained. Each of the CPP experiments performed in this subtask is given in Appendix $F$. These figures compare the heat-transfer CPP behavior with the isothermal CPP behavior in the same environments at both $90^{\circ} \mathrm{C}$ and $50^{\circ} \mathrm{C}$.

\subsection{Copper-Base Alloys}

Each of the copper-base alloys was evaluated in simulated J-13 well water and in Solution Number 22, which was found to promote pitting of these alloys in the CPP test matrix. The compositions of these solutions are give in Table 9.1. A summary of the polarization parameters $E_{c o r}, i_{c o r}, E_{b}$, and $E_{r p}$, as determined from the CPP curves, is given in Table 9.2. In simulated J-13 well water, a significant effect of heat transfer on the polarization parameters for the copper-base alloys is not evident from the data. On the other hand, optical examination of the specimens indicated that heat transfer promoted more severe attack. Alloy CDA 102 exhibited pitting only in the heat-transfer tests; whereas, more severe pitting of Alloy 715 occurred in the presence of heat transfer than in isothermal tests performed at either $50^{\circ} \mathrm{C}$ or $90^{\circ} \mathrm{C}$. Two additional replicate tests of Alloy CDA 102 were performed and the behavior was duplicated.

In Solution Number 22, a significant effect of heat transfer on corrosion behavior was not evident from the data or from optical examination of the test specimen. The values of $E_{c o r}$ for both copper-base alloys did appear to be shifted in the noble direction in Solution Number 22 as a result of the heat transfer, although this effect may have been a result of the higher temperature of the heat-transfer specimen; CPP tests in Solution 22 at $90^{\circ} \mathrm{C}$ were not performed.

\section{$9.2 \mathrm{Fe}-\mathrm{Cr}-\mathrm{Nl}$ Alloys}

Each of the Fe-Cr-Ni alloys was evaluated in simulated $\mathrm{J}-13$ well water and in Solution Number 7 , which was found to promote pitting of these alloys in the CPP test matrix. The compositions of 


\section{HEAT-TRANSFER SPECIMEN}

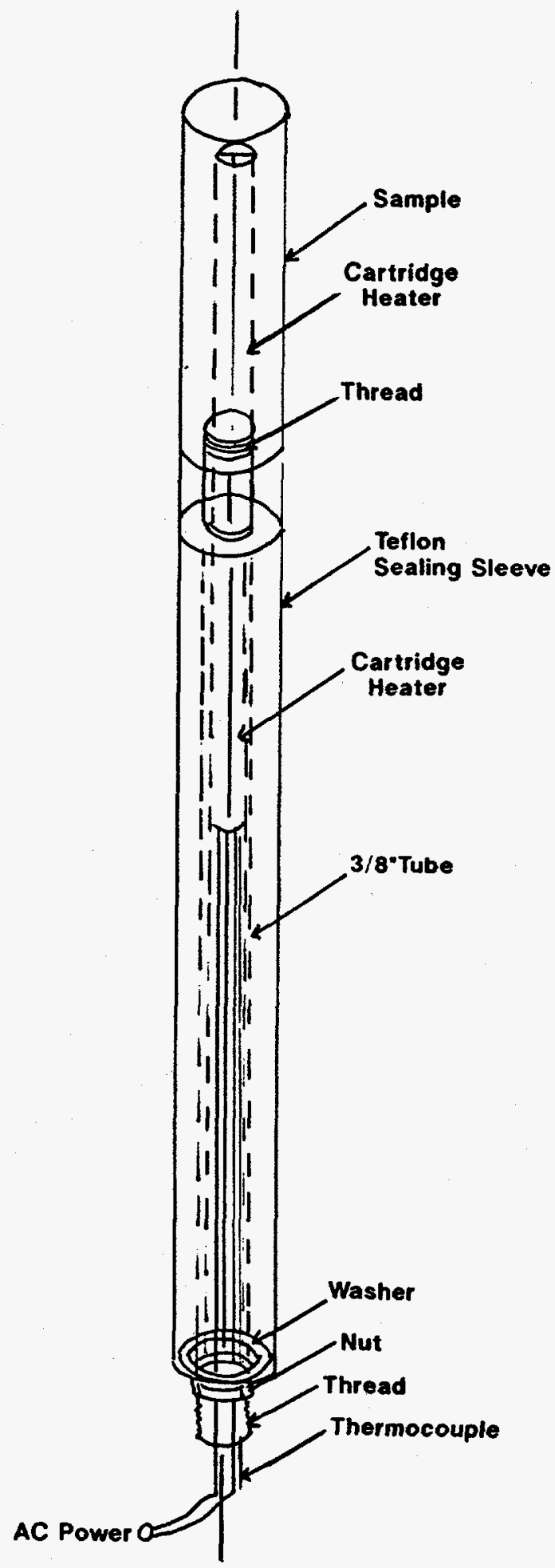

Figure 9.1 Schematic Of The Heat-Transfer Specimen. 


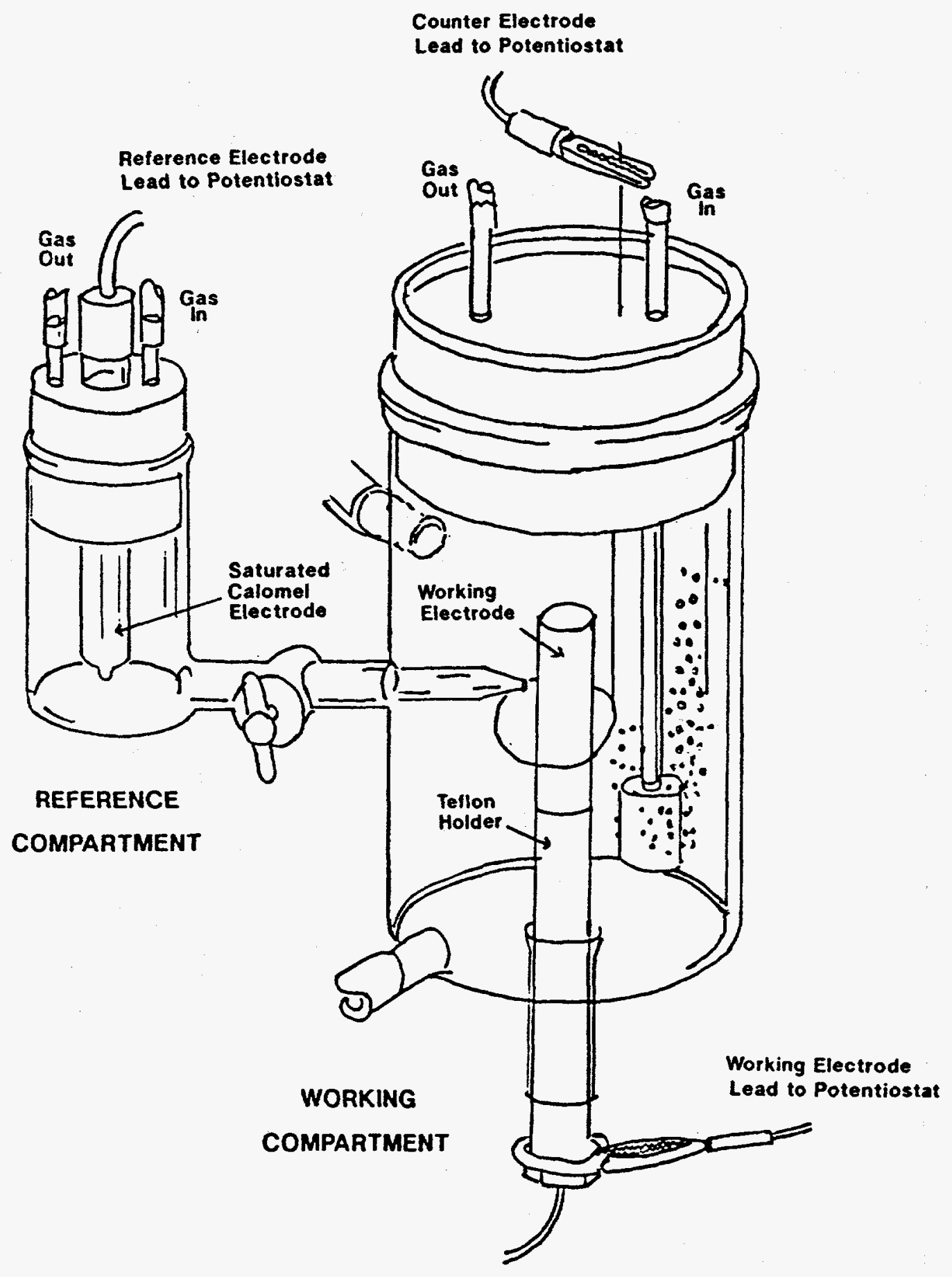

Figure 9.2 Electrochemical Cell For Ambient Pressure Potentiodynamic-Polarization Experiments On Heat-Transfer Specimens. 
Table 9.1 Composition Of J-13 Well Water And Solution Number 22 Used For The HeatTransfer Studies Of The Copper-Base Alloys.

\begin{tabular}{|c|c|c|c|}
\hline $\begin{array}{l}\text { Environmental } \\
\text { Specles }\end{array}$ & $\begin{array}{c}\text { J-13 Well Water } \\
\text { mg/l }\end{array}$ & $\begin{array}{c}\text { Simulated } \\
\mathrm{J}-13 \text { Well Water } \\
\mathrm{mg} / \mathrm{l}\end{array}$ & $\begin{array}{c}\text { Solution } \mathrm{N}^{2} 22 \\
\mathrm{mg} / \mathrm{l}\end{array}$ \\
\hline $\mathrm{pH}$ & 7.6 & $7.0 \pm 0.2$ & 10.0 \\
\hline $\mathrm{SiO}_{2}$ & 58 & 64.2 & 215 \\
\hline $\mathrm{HCO}_{3}^{-}$ & 125 & 121 & 0.4 \\
\hline $\mathrm{F}^{-}$ & 2.2 & 1.7 & 0.04 \\
\hline $\mathrm{Cl}^{-}$ & 6.9 & 6.4 & 1000 \\
\hline $\mathrm{NO}_{3}^{-}$ & 9.6 & 12.4 & 1000 \\
\hline $\mathrm{SO}_{4}^{2-}$ & 18.7 & 19.2 & • \\
\hline $\mathrm{NO}_{2}^{-}$ & - & - & 0.0 \\
\hline $\mathrm{H}_{2} \mathrm{O}_{2}$ & - & - & 200 \\
\hline $\mathrm{Al}^{3+}$ & 0.012 & - & 0.8 \\
\hline $\mathrm{Fe}^{2+}$ & 0.006 & - & 0.0 \\
\hline $\mathrm{Ca}^{2+}$ & 12.5 & 12.0 & 0.8 \\
\hline $\mathrm{Mg}^{2+}$ & 1.9 & 1.7 & 0.004 \\
\hline $\mathrm{K}^{+}$ & 5.1 & 5.5 & 0.08 \\
\hline $\mathrm{Na}^{+}$ & 44 & 46 & $*$ \\
\hline $\mathrm{PO}_{4}^{3-}$ & 0.12 & - & 0.01 \\
\hline Oxalic Acid & - & - & 172 \\
\hline
\end{tabular}

- $\mathrm{Na}^{+}$and $\mathrm{SO}_{4}{ }^{2-}$ were used to balance the composition. 
Table 9.2 Comparison Of CPP Parameters For Isothermal And Heat-Transfer Specimens Of Alloy CDA 102 And Alloy CDA 715.

\begin{tabular}{|c|c|c|c|c|c|c|c|}
\hline Alloy & $\begin{array}{c}\text { Solution } \\
\text { Temperature }\end{array}$ & $\begin{array}{c}\text { Test } \\
\text { Solution }\end{array}$ & $\begin{array}{c}E_{\text {cor }} \\
V, \text { SCE }\end{array}$ & $\begin{array}{c}I_{\text {cor }} \\
\mu \mathbf{A m}^{2}\end{array}$ & $\begin{array}{c}E_{\mathrm{b}} \\
V, \text { SCE }\end{array}$ & $v, E_{m p E}$ & Comments \\
\hline CDA 102 & $90^{\circ} \mathrm{C}$ & $J-13$ & -0.030 & 2.00 & +0.140 & -0.035 & Changes in oxide \\
\hline CDA 102 & $50^{\circ} \mathrm{C}$ & $J-13$ & -0.020 & 0.30 & +0.110 & -0.090 & Changes in oxide \\
\hline CDA 102* & $50^{\circ} \mathrm{C}$ & $J-13$ & -0.021 & 0.48 & +0.103 & -0.078 & Pitting \\
\hline CDA 102† & $50^{\circ} \mathrm{C}$ & $J-13$ & -0.015 & 0.43 & +0.119 & -0.015 & Pitting \\
\hline CDA 102† & $50^{\circ} \mathrm{C}$ & $J-13$ & -0.028 & 0.31 & +0.113 & -0.075 & Pitting \\
\hline CDA 715 & $90^{\circ} \mathrm{C}$ & $J-13$ & -0.265 & 0.41 & +0.180 & +0.080 & Pitting \\
\hline CDA 715 & $50^{\circ} \mathrm{C}$ & $J-13$ & +0.025 & 0.60 & +0.190 & -0.080 & Pitting \\
\hline $\operatorname{CDA} 715^{*}$ & $50^{\circ} \mathrm{C}$ & $J-13$ & -0.015 & 0.18 & +0.180 & -0.050 & Pitting \\
\hline CDA 102 & $50^{\circ} \mathrm{C}$ & 22 & +0.060 & 5.60 & +0.060 & - & Pitting, oxide growth \\
\hline CDA $102^{*}$ & $50^{\circ} \mathrm{C}$ & 22 & +0.100 & 0.62 & +0.013 & - & Pitting \\
\hline CDA 715 & $50^{\circ} \mathrm{C}$ & 22 & +0.073 & 1.00 & +0.020 & - & Pitting, active areas \\
\hline CDA $715^{*}$ & $50^{\circ} \mathrm{C}$ & 22 & +0.113 & 1.40 & +0.038 & - & Pitting, etching \\
\hline
\end{tabular}

\footnotetext{
* Heat Transfer Specimen, $90^{\circ} \mathrm{C}$

$\dagger \quad$ Heat Transfer Specimen, $90^{\circ} \mathrm{C}$, Repeat Test
} 
these solutions are given in Table 9.3. A summary of the polarization parameters, as determined from the CPP curves, is given in Table 9.4. Table 9.4 also shows the results of the optical examinations of the CPP specimens following testing. The actual CPP curves are given in Appendix F. For Alloy $304 \mathrm{~L}$ in simulated $\mathrm{J}-13$ well water, heat transfer promoted some local etching but the CPP behavior was very similar to that observed under isothermal condition at $90^{\circ} \mathrm{C}$. For Alloy 825 in simulated $\mathrm{J}-13$ well water, heat transfer promoted some hysteresis in the CPP behavior and pitting on the specimen. This occurrence of pitting was quite surprising and the test was repeated. In the replicate test, pitting also was observed although the extent of hysteresis was less.

In Solution Number 7, however, the data and optical examination of the specimens revealed that no significant changes in corrosion behavior occurred as a result of temperature gradients. As with the copper-base alloys, the values of $E_{\text {cor }}$ and $E_{\text {pit }}$ did appear to be shifted in the noble direction as a result of the heat transfer, although this effect may have been a result of the higher temperature of the heat-transfer specimen; CPP tests in Solution Number 7 at $90^{\circ} \mathrm{C}$ were not performed. 
Table 9.3 Composition Of J-13 Well Water And Solution Number 7 Used For The HeatTransfer Studies Of The Fe-Cr-Ni Alloys.

\begin{tabular}{|c|c|c|c|}
\hline $\begin{array}{l}\text { Environmental } \\
\text { Specles }\end{array}$ & $\begin{array}{c}\text { J-13 Well Water } \\
\mathrm{mg} /\end{array}$ & $\begin{array}{c}\text { SImulated } \\
\text { J-13 Well Water } \\
\text { mg/l }\end{array}$ & $\begin{array}{c}\text { Solution } N^{\circ} 7 \\
\mathrm{mg} /\end{array}$ \\
\hline $\mathrm{pH}$ & 7.6 & $7.0 \pm 0.2$ & 5.0 \\
\hline $\mathrm{SiO}_{2}$ & 58 & 64.2 & 215 \\
\hline $\mathrm{HCO}_{3}^{-}$ & 125 & 121 & 0.4 \\
\hline$F^{-}$ & 2.2 & 1.7 & 0.04 \\
\hline $\mathrm{Cl}^{-}$ & 6.9 & 6.4 & 1000 \\
\hline $\mathrm{NO}_{3}^{-}$ & 9.6 & 12.4 & 0.2 \\
\hline $\mathrm{SO}_{4}^{2-}$ & 18.7 & 19.2 & - \\
\hline $\mathrm{NO}_{2}^{-}$ & - & - & 0.0 \\
\hline $\mathrm{H}_{2} \mathrm{O}_{2}$ & - & - & 0.0 \\
\hline$A l^{3+}$ & 0.012 & - & 0.0004 \\
\hline $\mathrm{Fe}^{2+}$ & 0.006 & - & 0.0 \\
\hline $\mathrm{Ca}^{2+}$ & 12.5 & 12.0 & 0.8 \\
\hline $\mathrm{Mg}^{2+}$ & 1.9 & 1.7 & 0.8 \\
\hline $\mathrm{K}^{+}$ & 5.1 & 5.5 & 0.08 \\
\hline $\mathrm{Na}^{+}$ & 44 & 46 & • \\
\hline $\mathrm{PO}_{4}^{3-}$ & 0.12 & - & 2.0 \\
\hline Oxalic Acid & - & - & 172 \\
\hline
\end{tabular}

- $\mathrm{Na}^{+}$and $\mathrm{SO}_{4}^{2-}$ were used to balance the composition. 
Table 9.4 Comparison Of CPP Parameters For Isothermal And Heat-Transfer Specimens Of Alloy 304 L And Alloy 825.

\begin{tabular}{|c|c|c|c|c|c|c|c|}
\hline Alloy & $\begin{array}{c}\text { Solution } \\
\text { Temperature }\end{array}$ & $\begin{array}{c}\text { Test } \\
\text { Solution }\end{array}$ & $V, E_{\text {cor }}$ & $\begin{array}{c}I_{\text {oor }} \\
\mu \mathrm{A}^{2} \mathrm{~cm}^{2}\end{array}$ & $\begin{array}{c}E_{\mathrm{b}} \\
v, \mathrm{SCE}\end{array}$ & $\mathrm{E}, \mathrm{E}_{\mathrm{SP}}$ & Comments \\
\hline $304 \mathrm{~L}$ & $90^{\circ} \mathrm{C}$ & $J-13$ & -0.125 & 0.12 & +0.800 & +0.800 & No pitting \\
\hline $304 \mathrm{~L}$ & $50^{\circ} \mathrm{C}$ & $J-13$ & -0.075 & 0.05 & +0.825 & +0.825 & No pitting \\
\hline $304 L^{*}$ & $50^{\circ} \mathrm{C}$ & $J-13$ & -0.050 & 0.90 & +0.845 & +0.815 & Local etching \\
\hline 825 & $90^{\circ} \mathrm{C}$ & $J-13$ & -0.650 & 0.08 & +0.700 & +0.700 & No pitting \\
\hline 825 & $50^{\circ} \mathrm{C}$ & $J-13$ & -0.060 & 0.05 & +0.840 & +0.840 & No pitting \\
\hline $825^{\star}$ & $50^{\circ} \mathrm{C}$ & $J-13$ & -0.050 & 0.08 & +0.820 & +0.700 & Pitting \\
\hline $825 t$ & $50^{\circ} \mathrm{C}$ & $J-13$ & -0.015 & 0.08 & +0.870 & +0.870 & Pitting \\
\hline $304 \mathrm{~L}$ & $90^{\circ} \mathrm{C}$ & 7 & -0.035 & 0.21 & +0.090 & -0.120 & Pitting \\
\hline $304 \mathrm{~L}$ & $50^{\circ} \mathrm{C}$ & 7 & -0.080 & 0.09 & +0.170 & -0.010 & Pitting \\
\hline 304L" & $50^{\circ} \mathrm{C}$ & 7 & -0.013 & 0.43 & +0.200 & -0.006 & Pitting \\
\hline 825 & $90^{\circ} \mathrm{C}$ & 7 & -0.090 & 0.27 & +0.600 & +0.150 & Pitting \\
\hline 825 & $50^{\circ} \mathrm{C}$ & 7 & -0.190 & 0.08 & +0.460 & +0.070 & Pitting \\
\hline 825 * & $50^{\circ} \mathrm{C}$ & 7 & -0.080 & 0.20 & +0.435 & +0.280 & Pitting \\
\hline
\end{tabular}

* Heat Transfer Specimen, $90^{\circ} \mathrm{C}$

$\dagger \quad$ Heat Transfer Specimen, $90^{\circ} \mathrm{C}$, Repeat Test 


\section{EFFECTS OF WELDING ON CPP BEHAVIOR}

Cyclic-potentiodynamic-polarization experiments were performed on welded specimens of the four candidate alloys. The purpose of these experiments was to examine the effects of welding on the corrosion behavior of these alloys. For each of the alloys, testing was conducted in simulated $\mathrm{J}-13$ well water and in two other solutions selected from the experimental matrix. For the copperbase alloys, testing was performed in Solution Number 7 and Solution Number 29. For the Fe-Cr$\mathrm{Ni}$ alloys, testing was performed in Solution Number 7 and Solution Number 25 . The experimental set-up and conditions were similar to those previously used for each of the alloys, as described in Chapter 3 . The tests were all run at a scan rate of $0.17 \mathrm{mV} / \mathrm{sec}(0.6 \mathrm{~V} / \mathrm{hr})$. CPP curves from each of the experiments performed in this subtask are given in Appendix $G$.

Professor R. G. Thompson of the University of Alabama at Birmingham (UAB) was retained as a consultant in the preparation of the welds. Justifications for the welding procedures and welding parameter data sheets were prepared for each of the four alloys and are given in Appendix $\mathrm{H}$. These procedures were based on current recommended industrial practices. It was our understanding that the DOE had not yet prepared welding procedures for the waste container at the time of specimen preparation. Plate and rod material of each of the four alloys was obtained and shipped to UAB for welding. Prior to welding, V-shaped grooves were machined longitudinally in each of the plates, which measured $152.4 \mathrm{~mm}(6 \mathrm{in}$.) $\times 304.8 \mathrm{~mm}(12 \mathrm{in}$.) $\times$ $6.35 \mathrm{~mm}$ (0.25 in.). A welder, who is licensed for welding nuclear power plant vessels, performed the actual welding. Cylindrical electrochemical specimens were then machined longitudinally from the actual weld and evaluated by the cyclic-potentiodynamic-polarization (CPP) technique.

\subsection{Copper-Base Alloys}

Each of the copper-base alloys was evaluated in simulated J-13 well water and in Solution Number 7 at $90^{\circ} \mathrm{C}$. Solution Number 7 was selected as it was previously shown to exhibit activecorrosion behavior of the wrought material. Solution Number 29 was also evaluated with the copper-base alloys at $50^{\circ} \mathrm{C}$. Solution Number 29 was previously shown to promote pitting of the wrought copper-base alloys. The compositions of these solutions are given in Table 10.1 .

Table 10.2 is a comparison of the polarization parameters $E_{c o r}, i_{c o r}, E_{b}$, and $E_{p p}$ as determined from the CPP curves. These data, in addition to the optical examinations, show that the welded copper-base alloys were somewhat more susceptible to localized corrosion than the wrought alloys in the simulated $\mathrm{J}-13$ environment. In Solution Number 7 , no appreciable change in polarization parameters, as a result of welding, was observed for Alloy CDA 715. CPP curves for welded specimens of Alloy CDA 102, shown in Figures G10 and G11, exhibited a hysteresis loop which typically indicates localized attack. However, optical examination of the welded Alloy CDA 102 specimen revealed very slight etching. No hysteresis loop was evident in the data for the wrought alloy, shown in Figure G9. Again, these observations help to illustrate that the copper-base alloys do not appear to exhibit CPP classical behavior. 
Table 10.1 Compositions Of J-13 Well Water And Selected Solutions From The Experimental Matrix Used In The Welding-Effect Studies Of The Copper-Base Alloys.

\begin{tabular}{|c|c|c|c|c|}
\hline $\begin{array}{c}\text { Environmental } \\
\text { Specles }\end{array}$ & $\begin{array}{c}\mathrm{J}-13 \text { Well Water } \\
\mathrm{mg} /\end{array}$ & $\begin{array}{c}\text { Simulated } \\
\text { J-13 Well Water } \\
\text { mg/l }\end{array}$ & $\begin{array}{c}\text { Solution } N^{2} 7 \\
\mathbf{m g} / 1\end{array}$ & $\begin{array}{c}\text { Solution } N 229 \\
\text { mg/l }\end{array}$ \\
\hline $\mathrm{pH}$ & 7.6 & $7.0 \pm 0.2$ & 5.0 & 5.0 \\
\hline $\mathrm{SiO}_{2}$ & 58 & 64.2 & 215 & 215 \\
\hline $\mathrm{HCO}_{3}^{-}$ & 125 & 121 & 0.4 & 2000 \\
\hline$F^{-}$ & 2.2 & 1.7 & 0.04 & 200 \\
\hline $\mathrm{Cl}^{-}$ & 6.9 & 6.4 & 1000 & 1000 \\
\hline $\mathrm{NO}_{3}^{-}$ & 9.6 & 12.4 & 0.2 & 0.2 \\
\hline $\mathrm{SO}_{4}^{2-}$ & 18.7 & 19.2 & * & * \\
\hline $\mathrm{NO}_{2}^{-}$ & - & - & 0.0 & 200 \\
\hline $\mathrm{H}_{2} \mathrm{O}_{2}$ & - & - & 0.0 & 0.0 \\
\hline $\mathrm{Al}^{3+}$ & 0.012 & - & 0.0004 & 0.0004 \\
\hline $\mathrm{Fe}^{2+}$ & 0.006 & - & 0.0 & 0.0 \\
\hline $\mathrm{Ca}^{2+}$ & 12.5 & 12.0 & 0.8 & 0.8 \\
\hline $\mathrm{Mg}^{2+}$ & 1.9 & 1.7 & 0.8 & 0.004 \\
\hline $\mathrm{K}^{+}$ & 5.1 & 5.5 & 0.08 & 408 \\
\hline $\mathrm{Na}^{+}$ & 44 & 46 & $*$ & 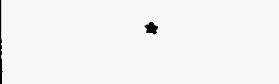 \\
\hline $\mathrm{PO}_{4}^{3-}$ & 0.12 & - & 2.0 & 0.01 \\
\hline Oxalic Acid & - & - & 172 & 172 \\
\hline
\end{tabular}

- $\mathrm{Na}^{+}$and $\mathrm{SO}_{4}{ }^{2-}$ were used to balance the composition. 
Table 10.2 Comparison Of CPP Parameters For Wrought And Welded Specimens Of The Copper-Base Alloys.

\begin{tabular}{|c|c|c|c|c|c|c|c|}
\hline Alloy & $\begin{array}{c}\text { Solution } \\
\text { Temperature }\end{array}$ & $\begin{array}{c}\text { Test } \\
\text { Solution }\end{array}$ & $\begin{array}{c}E_{\text {cor }} \\
\text { SCE }\end{array}$ & $\mu \mathrm{ANCm}^{2}$ & $\begin{array}{c}E_{b} \\
V, S C E\end{array}$ & $\begin{array}{c}E_{r p} \\
v, S C E\end{array}$ & Comments \\
\hline $\begin{array}{l}\text { CDA } 102 \\
\text { CDA } 102^{*}\end{array}$ & $\begin{array}{l}90^{\circ} \mathrm{C} \\
90^{\circ} \mathrm{C}\end{array}$ & $\begin{array}{l}J-13 \\
J-13\end{array}$ & $\begin{array}{l}-0.030 \\
-0.052\end{array}$ & $\begin{array}{l}2.00 \\
0.33\end{array}$ & $\begin{array}{l}+0.140 \\
+0.153\end{array}$ & $\begin{array}{l}-0.035 \\
-0.109\end{array}$ & $\begin{array}{l}\text { Changes in oxide. } \\
\text { Incipient pitting. }\end{array}$ \\
\hline $\begin{array}{l}\text { CDA } 715 \\
\text { CDA } 715^{*}\end{array}$ & $\begin{array}{l}90^{\circ} \mathrm{C} \\
90^{\circ} \mathrm{C}\end{array}$ & $\begin{array}{l}J-13 \\
J-13\end{array}$ & $\begin{array}{l}-0.265 \\
-0.115 \\
\end{array}$ & $\begin{array}{l}0.41 \\
0.08\end{array}$ & $\begin{array}{l}+0.180 \\
+0.130\end{array}$ & $\begin{array}{l}+0.080 \\
-0.150\end{array}$ & $\begin{array}{l}\text { Pitting. } \\
\text { Pitting. }\end{array}$ \\
\hline CDA 102 & $90^{\circ} \mathrm{C}$ & 7 & -0.140 & 6.60 & - & - & No pitting, local oxide growth. \\
\hline $\begin{array}{l}\text { CDA } 102^{*} \\
\text { CDA 102* } \\
\text { Repeat }\end{array}$ & $\begin{array}{l}90^{\circ} \mathrm{C} \\
90^{\circ} \mathrm{C}\end{array}$ & $\begin{array}{l}7 \\
7\end{array}$ & $\begin{array}{l}-0.127 \\
-0.138\end{array}$ & $\begin{array}{r}11.00 \\
1.30\end{array}$ & $\begin{array}{l}-0.100 \\
-0.100\end{array}$ & $\begin{array}{l}-0.210 \\
-0.210\end{array}$ & $\begin{array}{l}\text { No pitting, possible very slight etching. } \\
\text { No pitting, possible very slight etching. }\end{array}$ \\
\hline $\begin{array}{l}\text { CDA } 715 \\
\text { CDA } 715^{*} \\
\end{array}$ & $\begin{array}{l}90^{\circ} \mathrm{C} \\
90^{\circ} \mathrm{C} \\
\end{array}$ & $\begin{array}{l}7 \\
7\end{array}$ & $\begin{array}{l}-0.150 \\
-0.169 \\
\end{array}$ & $\begin{array}{l}23.00 \\
12.00 \\
\end{array}$ & - & - & $\begin{array}{l}\text { No pitting, active corrosion. } \\
\text { No pitting, possible very slight etching. }\end{array}$ \\
\hline $\begin{array}{l}\text { CDA } 102 \\
\text { CDA } 102^{*}\end{array}$ & $\begin{array}{l}50^{\circ} \mathrm{C} \\
50^{\circ} \mathrm{C}\end{array}$ & $\begin{array}{l}29 \\
29 \\
\end{array}$ & $\begin{array}{l}-0.070 \\
-0.126\end{array}$ & $\begin{array}{r}2.20 \\
10.00\end{array}$ & $\begin{array}{l}+0.160 \\
+0.100 \\
\end{array}$ & $\begin{array}{r}0.000 \\
+0.100 \\
\end{array}$ & $\begin{array}{l}\text { Pitting and oxide growth. } \\
\text { Oxide growth. }\end{array}$ \\
\hline $\begin{array}{l}\text { CDA } 715 \\
\text { CDA } 715\end{array}$ & $\begin{array}{l}50^{\circ} \mathrm{C} \\
50^{\circ} \mathrm{C}\end{array}$ & $\begin{array}{l}29 \\
29\end{array}$ & $\begin{array}{l}-0.060 \\
-0.113\end{array}$ & $\begin{array}{l}0.91 \\
7.00\end{array}$ & $\begin{array}{l}+0.280 \\
-0.50\end{array}$ & $\begin{array}{l}+0.020 \\
-0.188\end{array}$ & $\begin{array}{l}\text { Pitting and active attack. } \\
\text { Oxide and darker spotting. }\end{array}$ \\
\hline
\end{tabular}

"Welded specimens.

NOTE: $J-13$ is simulated $\mathrm{J}-13$ well water. 
In Solution Number 29, both of the welded copper-base alloys generally exhibited lower freecorrosion potentials and higher corrosion currents, unwelded specimens. Optical examination of the welded specimens revealed only oxide growth and no pitting; some pitting of the wrought specimens was observed. These observations, along with the actual shapes of the CPP curves, suggest that the welds in the copper-base alloys exhibited less of a tendency to passivate than the wrought material. This behavior could lead to galvanic corrosion of the weids and warrants further study.

\subsection{Fe-Cr-Ni Alloys}

Each of the $\mathrm{Fe}-\mathrm{Cr}-\mathrm{Ni}$ alloys were evaluated at $90^{\circ} \mathrm{C}$ in the following test solutions:

(1) Simulated $\mathrm{J}-13$ well water,

(2) Solution Number 7, which promoted pitting of the Fe-Cr-Ni alloys, and

(3) Solution Number 25, an active-corrosion solution for the $\mathrm{Fe}-\mathrm{Cr}-\mathrm{Ni}$ alloys.

The compositions of these solutions are given in Table 10.3.

The CPP curves for the wrought and welded specimens of Alloy 304L and Alloy 825 are given in Appendix $G$. Table 10.4 is a comparison of the polarization parameters $E_{c o r}, i_{c o r}, E_{p i l}$ and $E_{p r o t}$ as determined from these CPP curves.

These data, in addition to the optical examinations of the specimens, show that, in simulated $\mathrm{J}-13$ well water, neither wrought nor welded specimens of Alloy 304L exhibited any attack. In the case of Alloy 825, the CPP curve for the welded specimens did not exhibit hysteresis, but some etching was found around bubbles that formed on the specimen.

In Solution Number 7, no appreciable effect of welding on the polarization parameters was observed for either of the Fe-Cr-Ni alloys. Optical examination revealed pitting in both the wrought and welded specimens. In Solution Number 25, the welds performed as well as, and in some cases slightly better than, the wrought material. There was no indication that the welds were more susceptible to attack than the wrought material. Variation in the corrosion parameters between the welded and wrought specimens is probably attributable to scatter in the data. 
Table 10.3 Compositions Of J-13 Well Water And Selected Solutions From The Experimental Matrix Used In The Welding-Effect Studies Of The Fe-Cr-Ni Alloys.

\begin{tabular}{|c|c|c|c|c|}
\hline $\begin{array}{c}\text { Environmental } \\
\text { Specles }\end{array}$ & $\begin{array}{c}\text { J-13 Well Water } \\
\mathrm{mg} / \mathrm{l}\end{array}$ & $\begin{array}{c}\text { Simulated } \\
\text { J-13 Well Water } \\
\text { mg/l }\end{array}$ & $\begin{array}{c}\text { Solution } N^{\circ} 7 \\
\mathrm{mg} / \mathrm{l}\end{array}$ & $\begin{array}{c}\text { Solution } N 25 \\
m g /\end{array}$ \\
\hline $\mathrm{pH}$ & 7.6 & $7.0 \pm 0.2$ & 5.0 & 5.0 \\
\hline $\mathrm{SiO}_{2}$ & 58 & 64.2 & 215 & 215 \\
\hline $\mathrm{HCO}_{3}^{-}$ & 125 & 121 & 0.4 & 2000 \\
\hline$F^{-}$ & 2.2 & 1.7 & 0.04 & 200 \\
\hline $\mathrm{Cl}^{-}$ & 6.9 & 6.4 & 1000 & 0.2 \\
\hline $\mathrm{NO}_{3}^{-}$ & 9.6 & 12.4 & 0.2 & 1000 \\
\hline $\mathrm{SO}_{4}{ }^{2-}$ & 18.7 & 19.2 & * & * \\
\hline $\mathrm{NO}_{2}^{-}$ & - & - & 0.0 & 0.0 \\
\hline $\mathrm{H}_{2} \mathrm{O}_{2}$ & - & - & 0.0 & 0.0 \\
\hline $\mathrm{Al}^{3+}$ & 0.012 & - & 0.0004 & 0.8 \\
\hline $\mathrm{Fe}^{2+}$ & 0.006 & - & 0.0 & 0.0 \\
\hline $\mathrm{Ca}^{2+}$ & 12.5 & 12.0 & 0.8 & 0.8 \\
\hline $\mathrm{Mg}^{2+}$ & 1.9 & 1.7 & 0.8 & 0.8 \\
\hline $\mathrm{K}^{+}$ & 5.1 & 5.5 & 0.08 & 408 \\
\hline $\mathrm{Na}^{+}$ & 44 & 46 & * & * \\
\hline $\mathrm{PO}_{4}^{3-}$ & 0.12 & - & 2.0 & 0.01 \\
\hline Oxalic Acid & - & - & 172 & 0.0 \\
\hline
\end{tabular}

* $\mathrm{Na}^{+}$and $\mathrm{SO}_{4}{ }^{2-}$ were used to balance the composition. 
Table 10.4 Comparison Of CPP Parameters For Wrought And Welded Specimens Of The Fe-Cr-Ni Alloys.

\begin{tabular}{|c|c|c|c|c|c|c|c|}
\hline Alloy & $\begin{array}{c}\text { Solution } \\
\text { Temperature }\end{array}$ & $\begin{array}{c}\text { Test } \\
\text { Solution }\end{array}$ & $\begin{array}{c}E_{c o r} \\
V, S C E\end{array}$ & $\begin{array}{c}I_{\text {cor }} \\
\mu A \mathrm{~cm}^{2}\end{array}$ & $\begin{array}{c}E_{p k} \\
V, \text { SCE }\end{array}$ & $\begin{array}{c}E_{\text {prot }} \\
\text {, SCE }\end{array}$ & Comments \\
\hline $304 \mathrm{~L}$ & $90^{\circ} \mathrm{C}$ & $J-13$ & -0.125 & 0.12 & +0.800 & +0.800 & No pitting. \\
\hline $304 L^{*}$ & $90^{\circ} \mathrm{C}$ & $\mathrm{J}-13$ & -0.226 & 0.06 & +0.821 & +0.821 & No attack. \\
\hline 825 & $90^{\circ} \mathrm{C}$ & $\mathrm{J}-13$ & -0.650 & 0.08 & +0.700 & +0.700 & No pitting. \\
\hline $825^{\star}$ & $90^{\circ} \mathrm{C}$ & $\mathrm{J}-13$ & -0.142 & 0.03 & +0.744 & +0.744 & Slight etching. \\
\hline $304 \mathrm{~L}$ & $90^{\circ} \mathrm{C}$ & 7 & -0.035 & 0.21 & +0.090 & -0.120 & Pitting. \\
\hline $304 L^{*}$ & $90^{\circ} \mathrm{C}$ & 7 & -0.150 & 0.06 & +0.100 & -0.100 & Pitting. \\
\hline 825 & $90^{\circ} \mathrm{C}$ & 7 & -0.090 & 0.27 & +0.600 & +0.150 & Pitting. \\
\hline $825^{\star}$ & $90^{\circ} \mathrm{C}$ & 7 & -0.123 & 0.12 & +0.691 & +0.136 & Pitting. \\
\hline $304 \mathrm{~L}$ & $90^{\circ} \mathrm{C}$ & 25 & -0.075 & 0.23 & +0.820 & +0.790 & No pitting. \\
\hline $304 L^{*}$ & $90^{\circ} \mathrm{C}$ & 25 & 0.000 & 0.09 & +0.989 & +0.989 & No attack. \\
\hline 825 & $90^{\circ} \mathrm{C}$ & 25 & -0.420 & 0.11 & +0.700 & +0.600 & Local active attack. \\
\hline 825 & $90^{\circ} \mathrm{C}$ & 25 & -0.063 & 0.05 & +0.690 & +0.620 & Iridescent oxide. \\
\hline
\end{tabular}

*Welded specimens.

NOTE: $J-13$ is simulated $J-13$ well water. 


\section{DISCUSSION}

The overall objective of Task 2 of the research program was to examine the effects of environmental and metallurgical variables on the electrochemical behavior of the candidate container materials. The intent of the work was not to provide long-term predictive capability but to identify the types of behavior that reasonably could occur in the geologic repository over the life of the canister and the important variables affecting that behavior.

An experimental test matrix was formulated in an effort to evaluate corrosion behavior over the possible range of environmental species that may occur. The major difficulty encountered in designing these synthetic test solutions is in defining the geochemistry and the actual environments to which the canister will be exposed. It is important to recognize that failure of engineered structures by corrosion rarely occur in environments that resemble the nominal environment for which the alloys were selected. In the case of the Tuff Repository, the J-13 well water is probably the most dilute environment that can be expected within the repository since boiling of the groundwater and its interaction with the host rock at elevated temperatures will tend to concentrate most species. The presence of the radiation field will generate new species, such as nitrites, carboxylic acids and hydrogen peroxide. Those species that are not volatile also may concentrate at the surface of the canister as a result of the combination of boiling and radiation.

Accordingly, the simulated $\mathrm{J}-13$ well water is probably too dilute to accurately represent the groundwater which will actually contact the waste canisters. However, exposure testing in this environment provides good base-line information and a confirmation of the extensive research performed by the Department of Energy in $\mathrm{J}-13$ well water. An alloy that performs poorly in the $\mathrm{J}-13$ well water probably can be rejected for further consideration as a container material. On the other hand, it cannot be concluded that an alloy that performs well in $\mathrm{J}-13$ well water is acceptable for construction of the waste containers.

\subsection{CPP Tests in $\mathrm{J}-13$ Well Water}

Cyclic-potentiodynamic-polarization tests were performed in simulated and actual J-13 well water (Tuff groundwater) to reproduce and verify the polarization behavior observed by McCright (1985) at Lawrence Livermore National Laboratory and to establish that the simulated $\mathrm{J}-13$ water produced similar corrosion behavior to the actual groundwater. The results of the experiments performed at Cortest Columbus Technologies, Inc. on Alloy CDA 102 showed that the curves were similar, having only slight differences in the polarization parameters. Repetition of these experiments verified the similarities. This indicates that the prepared solutions can reasonably simulate actual well water extracted from the Tuff site. These data, when compared with McCright's data, also indicate that the experimental procedures used for the NRC project are capable of reproducing the polarization behavior observed at Lawrence Livermore National Laboratory under similar test conditions.

The results of the CPP experiments performed in simulated $\mathrm{J}-13$ well water showed local changes in oxide for both of the copper-base alloys. Alloy CDA 715 was also found to exhibit local active 
attack and shallow pitting in the simulated J-13 well water. Both Alloy $304 \mathrm{~L}$ and Alloy 825 showed the absence of pitting or active attack in the simulated $\mathrm{J}-13$ well water.

CPP tests also were performed on the candidate alloys in simulated $\mathrm{J}-13$ well water with 1000 $\mathrm{mg} / \mathrm{l}$ added chloride to assess the individual effect of chloride concentration on corrosion behavior. For Alloy CDA 102, the chloride addition promoted a loss of passivity; the alloy exhibited active behavior in the chloride containing solution while passive behavior was observed in the simulated $\mathrm{J}-13$ well water in the absence of the added chloride. For Alloy CDA 715, the chloride additions promoted a decrease in the values of $E_{\mathrm{b}}$ and $E_{\mathrm{pp}}$. However, in both the standard simulated $\mathrm{J}-13$ well water and that solution with added chloride, hysteresis in the CPP curve for Alloy CDA 715 was observed yet significant pitting of the specimens was not found in post-test evaluations. Instead, local areas of very shallow pitting and changes in the oxide film occurred.

The chloride addition to simulated J-13 well water promoted pitting of Alloy $304 \mathrm{~L}$ in the CPP tests, hysteresis in the CPP curves and a decrease in the protection and pitting potentials. The value $E_{\text {prot }}$ was very close to $E_{c o r}$ indicating a high probability of pitting in this environment. In the absence of the added chloride, $E_{p h}$ and $E_{\text {prot }}$ values were very noble and equal (no hysteresis was observed) and no pitting occurred. The chloride added to the simulated $\mathrm{J}-13$ well water promoted a similar change in the polarization behavior for Alloy 825 and pitting of the specimen was observed. However, in the case of Alloy 825 , the value of $E_{\text {prot }}$ was $600-700 \mathrm{mV}$ more noble that $E_{c o r}$, indicating that pitting of this alloy is unlikely in this environment in the absence of a significant noble shift in the free-corrosion potential. Such noble shifts may occur as a result of radiolysis in the repository. It also should be pointed out that other environments from the test matrix promoted more severe pitting of Alloy 825, as described below.

\subsection{Statistical Matrix of CPP Tests}

Relatively little corrosion research has been performed in environments designed to simulate the concentration effects on the groundwater in the Tuff Repository and these generally have been performed in uniformly concentrated groundwaters. This has been accomplished either by boiling actual J-13 well water (Pitman-1986 and Abraham-1986) or by preparing a concentrated simulated J-13 well water (Abraham-1986 and McCright-1985). In the latter case, all species were uniformly concentrated. These studies have provided useful information on container materials performance, and are discussed in greater detail in the Task 1 Topical Report (Beavers1990, NUREG/CR-5435) and in the topical report to be issued for Task 7 of this program. In fact, in Task 7, long-term boil-down tests were performed to assess materials performance. However, these tests probably do not accurately simulate actual repository conditions in that it is not likely that the species will uniformly concentrate because of (1) rock-water interactions, (2) corrosion product-water interactions, (3) retrograde solubility of some species and even (4) interaction of the groundwater with species from failed containers. Moreover, these studies have not considered, in general, the effects of the radiation field on the groundwater composition.

The synthetic test environments used in the Task 2 studies were developed using a statistical model specifically designed to examine corrosion behavior in complex environments. The Resolution IV experimental design was selected to evaluate 15 variables; twelve variables associated with the $\mathrm{J}-13$ groundwater and three variables produced by radiolysis. This design 
was a fold-over design of two groups of 16 experiments, with each variable having a high and low level. The 32 high/low level combinations were required to determine the main-effect terms for fifteen variables, giving 32 CPP tests for each alloy. Four additional replicate experiments were also performed for each alloy in an average solution consisting of midpoint concentrations for each variable. These replicate CPP tests were used to estimate the experimental error. A concentration factor of about $200 \mathrm{X}$ was used for many of the species. Although the concentration factor may be too low for some of the species, it is considered to be reasonable for a screening matrix. For example, chloride and nitrate concentrations of $1000 \mathrm{ppm}$ were used in the test matrix, whereas Abraham (1986) reported concentrations of $236 \mathrm{ppm}$ and $750 \mathrm{ppm}$ for chloride and nitrate respectively following six-month boil-down tests. Thus, much higher concentrations are possible for these species within the repository over hundreds of years.

Each individual test solution represents an individual point within the 15 dimensional factor space. While it is not known whether these specific environments will be encountered, the maximum concentrations of the majority of the species within the solutions are thought to be reasonable, based on the above discussion. If the factor space is believed to be reasonable, poor performance by a candidate container alloy in any of the solutions from the test matrix needs to be examined carefully in terms of the expected environment within the repository. Further geochemical research also is needed to better define the repository environment over the life of the canister emplacement.

It should be recognized that the test matrix was designed as a screening matrix to identify important species, or regions of the environmental factor space, with respect to corrosion of the container materials, where additional research is needed. The matrix of tests performed was the absolute minimum necessary to obtain the main-effect terms for each of the variables free and clear of two-factor interactions. The actual data from these tests were not intended to provide predictive capability on long-term corrosion behavior.

For each of the four candidate alloys tested, the CPP data indicated that several types of corrosion were possible depending upon the alloy and the solution composition. The types of corrosion behavior observed for the different alloys included general and localized active attack (etching), pitting, intergranular attack, and crevice corrosion. Each of the four alloys tested was found to undergo localized corrosion in some regions of the factor space.

The results of our research also indicate that great care is required in interpreting the results of the electrochemical studies for both the copper-base and the $\mathrm{Fe}-\mathrm{Cr}$-Ni alloys. For the copperbase alloys, two distinct types of corrosion processes were found to be associated with essentially identical CPP curves. In several of the simulated environments, hysteresis that occurred on the reverse scan was correlated with classical pitting. In several other simulated environments, hysteresis was associated with regions of oxide film color change on the specimen without an apparent increase in the rates of attack. This color change may be associated with a change in oxidation state of the film (e.g. from $\mathrm{Cu}^{+}$to $\mathrm{Cu}^{2+}$ ) and/or may represent the early stages of film breakdown. Further research is needed to investigate this phenomenon.

The Fe-Cr-Ni alloys, on the other hand, were generally found to conform with conventional interpretation of CPP curves. There were, however, a few instances where only a surface tarnishing (thin oxide growth) occurred at the higher potentials. This may have resulted in a different catalysis of the water breakdown reactions which manifested itself as a small amount 
of hysteresis. In other instances, slight attack and/or tarnish was observed, but experience indicated that the amount of attack did not correspond to the currents observed. In these cases, it is believed that a spurious oxidation reaction, a reaction other than corrosion, resulted in the high currents. For the most part, these tests resulted in no pitting and the specimen remaining passive over the potential range examined.

The electrochemical data for the four candidate container alloys were entered in ASCII files. These data were then verified with the original CPP curves and analyzed by Dr. W. R. Harper of Resource International, Inc. in Columbus, Ohio using a SAS (SAS Institute, Cary, NC) statistical package. Summaries of the results of the statistical analyses are presented in Tables 11.1 through 11.4. In these tables, the classical terms $E_{p i t}$ and $E_{\text {prot }}$ were used for the pitting potential and protection potential, respectively, for the $\mathrm{Fe}-\mathrm{Cr}$-Ni alloys. On the other hand, the term $\mathrm{E}_{\mathrm{b}}$ and $E_{r p}$ were used to describe the breakdown potential and repassivation potential for the copper-base alloys. As described previously, the copper-base alloys did not always exhibit classical pitting behavior and the distinction in the electrochemical terms was made to reflect this fact.

The data in Tables 11.1 through 11.4 are based on an 80 percent confidence level, which means that one accepts a 20 percent probability that a variable does not have an effect. This is a typical confidence level for a screening experiment. Variables having a higher confidence level (90 percent) are indicated in the tables with an asterisk. The confidence level is determined from the F statistic for the variable which is a ratio of two variances; i.e., the sum of squares explained by each factor when entered into the regression equation divided by the residual mean square error. In general, when the calculated F statistic is large (corresponding to a high confidence level) it indicates that a large amount of the experimental variation is explained by this term in comparison to the error variation. The statistical error consists of two components; experimental error and error due to the fact that a full factorial experimental design was not performed. For each alloy, four replicate CPP curves were performed at the midpoint concentrations to assess the experimental error. In general, this error was found to be a small component of the overall variation of the measured parameters.

The results in the tables are presented as intercepts and coefficients for the regression equation:

$$
Y=a_{0}+\sum a_{i} x_{i}
$$

where $Y$ is the corrosion parameter, $a_{0}$ is the intercept, $a_{i}$ is the coefficient for the $i_{\text {th }}$ solution variable, and $x_{i}$ is the concentration of variable $i$. It should be cautioned that the Resolution IV design is a screening design to identify important environmental variables and inclusion of a regression equation does not imply a predictive capability.

The units of the coefficients vary depending upon the corrosion parameter and the solution variable and are a ratio of units. For the potential-related parameters, the units of the numerator are $\mathrm{mV}$. For the current parameters, the units of the numerator are $\mu \mathrm{A} / \mathrm{cm}^{2}$. The units for the denominator for most variables are $\mathrm{mg} /$; the units are ${ }^{\circ} \mathrm{C}$ for temperature, volume percent for oxygen and $\mathrm{pH}$ units for $\mathrm{pH}$. Thus, for the corrosion parameter $\mathrm{E}_{\mathrm{pit}}$ and the solution variable $\mathrm{Cl}$, the units of the coefficient are $\mathrm{mV} / \mathrm{mg} /$.

In these tables, a positive sign in front of the coefficient indicates that an increase in the concentration of a variable increases the value of the corrosion parameter. It should be cautioned 
Table 11.1 Summary Of The Statistical Analysis For Alloy CDA 102. Coefficients Were Selected Based On $80 \%$ Confidence Level. (Solution Numbers 1 Through 36.)

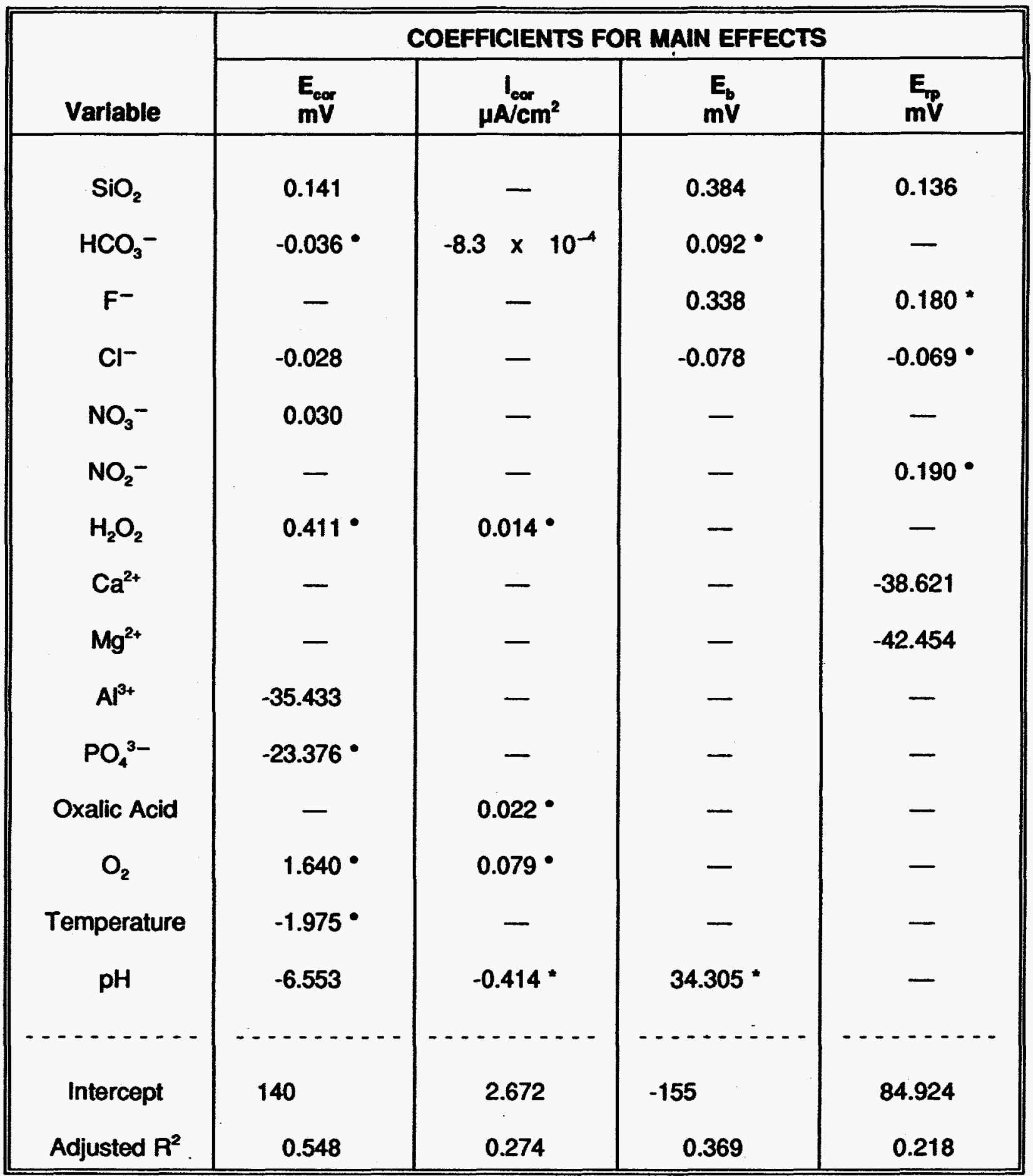

* Based on $90 \%$ confidence level. 
Table 11.2 Summary Of The Statistical Analysis For Alloy CDA 715. Coefficients Were Selected Based On $80 \%$ Confidence Level. (Solution Numbers 1 Through 36. )

\begin{tabular}{|c|c|c|c|c|}
\hline \multirow[b]{2}{*}{ Varlable } & \multicolumn{4}{|c|}{ COEFFICIENTS FOR MAIN EFFECTS } \\
\hline & $\begin{array}{l}E_{\text {cor }} \\
m V\end{array}$ & $\mu \stackrel{I_{\text {eor }}}{I^{2} \mathrm{~cm}^{2}}$ & $\begin{array}{c}\mathbf{E}_{\mathrm{b}} \\
\mathbf{m V}\end{array}$ & $\begin{array}{l}E_{p p} \\
m V\end{array}$ \\
\hline $\mathrm{SiO}_{2}$ & -0.271 & - & - & - \\
\hline $\mathrm{HCO}_{3}^{-}$ & $-0.039^{\bullet}$ & $-1.5 \times 10^{-3 *}$ & $0.191^{*}$ & $0.058^{\bullet}$ \\
\hline $\mathrm{F}^{-}$ & $-0.333^{\bullet}$ & - & - & - \\
\hline $\mathrm{Cl}^{-}$ & $-0.117^{\bullet}$ & $2.6 \times 10^{-3 *}$ & - & $-0.105^{\bullet}$ \\
\hline $\mathrm{NO}_{3}^{-}$ & - & - & $-0.102 *$ & - \\
\hline $\mathrm{NO}_{2}^{-}$ & - & - & - & - \\
\hline $\mathrm{H}_{2} \mathrm{O}_{2}$ & $0.350^{\bullet}$ & - & - & - \\
\hline $\mathrm{Ca}^{2+}$ & - & - & - & - \\
\hline $\mathrm{Mg}^{2+}$ & 一 & - & - & 81.372 \\
\hline $\mathrm{Al}^{3+}$ & - & - & - & 70.568 \\
\hline $\mathrm{PO}_{4}{ }^{3-}$ & -27.707 & - & - & - \\
\hline Oxalic Acid & - & $0.015^{*}$ & - & 0.417 \\
\hline $\mathrm{O}_{2}$ & - & - & - & - \\
\hline Temperature & $-2.781^{\circ}$ & - & - & - \\
\hline $\mathrm{pH}$ & - & $-0.518^{*}$ & 34.036 * & - \\
\hline Intercept & 305 & 2.424 & -116 & -74.880 \\
\hline Adjusted $R^{2}$ & 0.400 & 0.134 & 0.555 & 0.233 \\
\hline
\end{tabular}

* Based on $90 \%$ confidence level. 
Table 11.3 Summary Of The Statistical Analysis For Alloy 304L. Coefficients Were Selected Based On $80 \%$ Confidence Level. (Solution Numbers 1 Through 36.)

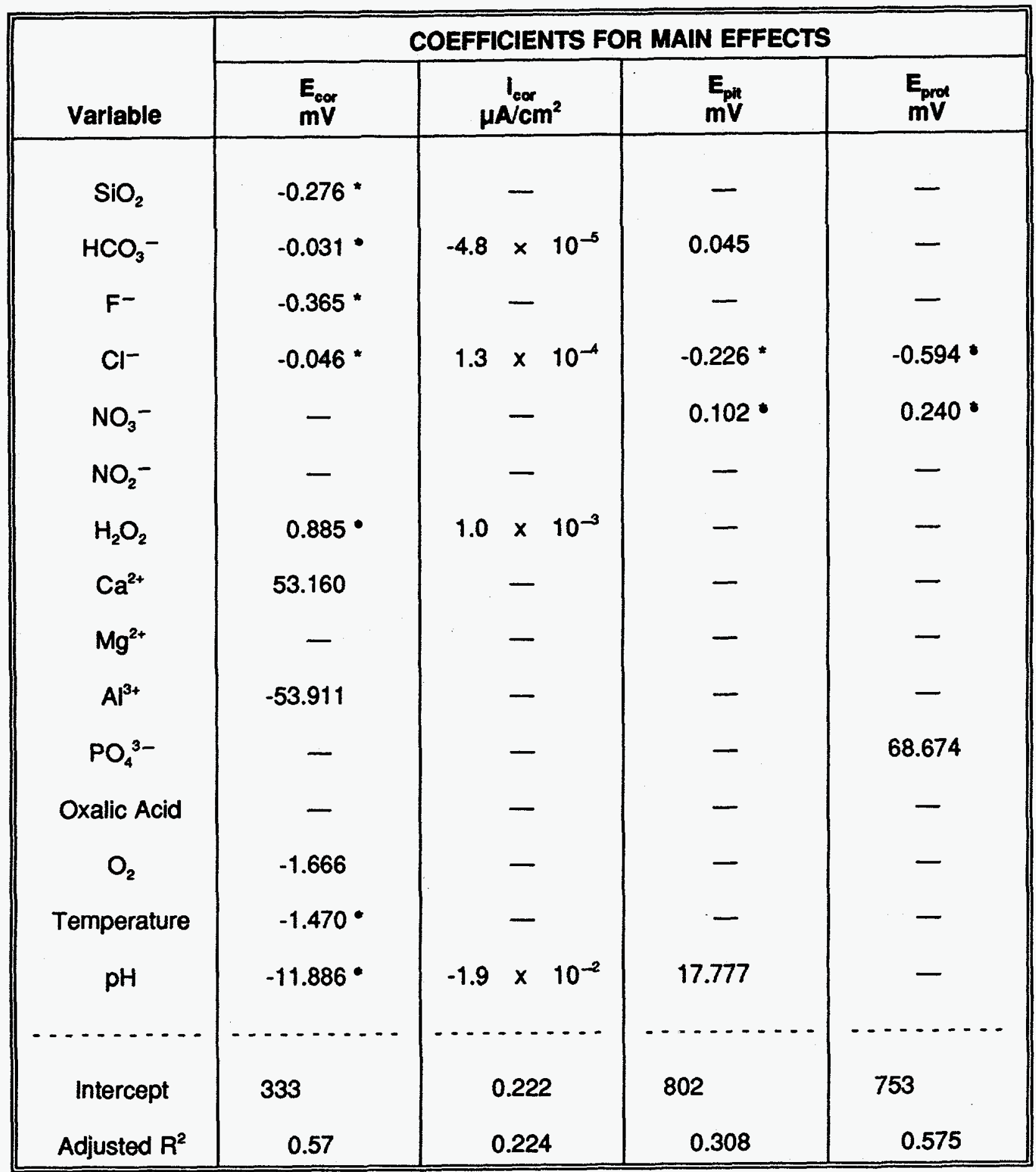

* Based on $90 \%$ confidence level. 
Table 11.4 Summary Of The Statistical Analysis For Alloy 825. Coefficients Were Selected Based On $80 \%$ Confidence Level. (Solution Numbers 1 Through 36.)

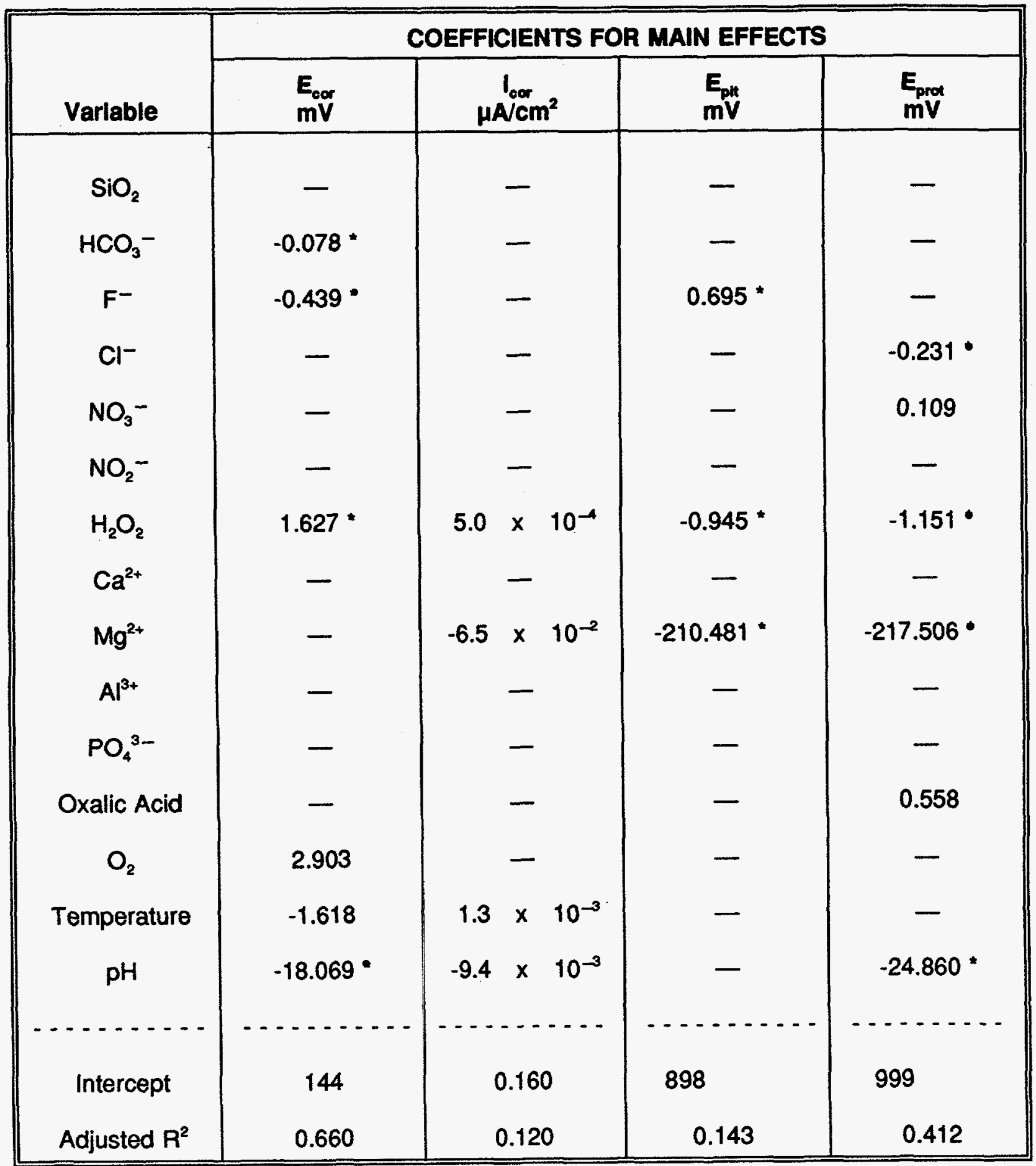

- Based on $90 \%$ confidence level. 
that the magnitude of the coefficient be considered in the context of the range of the variable; the ranges of oxygen, temperature and $\mathrm{pH}$ are much smaller than the ranges for many of the other variables. The coefficient must be multiplied by the range of the solution variable to determine the magnitude of the effect on the parameter. Also included in the tables are the adjusted $\mathbf{R}^{2}$ values, which indicate the percentage of the observed variation for the corrosion parameter that can be explained by the solution variable; an adjustment is made in the $R^{2}$ value for the number of experiments and the number of parameters estimated in the regression.

Further discussion of the coefficients for the copper-base alloys and the $\mathrm{Fe}-\mathrm{Cr}-\mathrm{Ni}$ alloys is given in separate sections below. These sections also present the statistical data in a bar-chart format. The data in these bar charts were re-analyzed to account for the concentration of the variables to clearly portray the important variables, and the magnitude of their effects on specific corrosion parameters for each alloy.

\subsubsection{Copper-Base Alloys}

A summary of the significant main-effect terms for Alloy CDA 102 for each of the four corrosion parameters $\left(E_{c o r}, i_{c o r}, E_{b}\right.$, and $\left.E_{r p}\right)$ is given in Table 11.1. Figure 11.1 gives the direction and magnitude of the effect of the solution variables on these parameters for Alloy CDA 102. These data show that several of the variables affected $\mathrm{E}_{\text {cor }}$ with $\mathrm{H}_{2} \mathrm{O}_{2}$ having the largest positive effect (increased $\mathrm{E}_{\text {cor }}$ ) and temperature and $\mathrm{HCO}_{3}{ }^{-}$having the largest negative effects. The effect of $\mathrm{H}_{2} \mathrm{O}_{2}$ on $\mathrm{E}_{\text {cor }}$ is reasonable since $\mathrm{H}_{2} \mathrm{O}_{2}$ is a strong oxidant while some of the other effects are more difficult to explain. The adjusted $\mathrm{R}^{2}$ value was moderate, 0.55 , indicating that $55 \%$ of the variation in the data was explained.

With regard to $\mathrm{i}_{c o r}$, the data trends were quite reasonable with the oxidants, $\mathrm{H}_{2} \mathrm{O}_{2}$ and $\mathrm{O}_{2}$ increasing $i_{c o r}$ and $\mathrm{HCO}_{3}$, a passivating species, decreasing $\mathrm{i}_{\text {cor; }}$; an increase in $\mathrm{pH}$ also decreased $i_{\text {cor }}$. The adjusted $R^{2}$ value for $i_{\text {cor }}$ was low; 0.274 . Chloride exhibited a negative effect on both $E_{b}$ and $E_{\mathrm{pp}}$ while $\mathrm{SiO}_{2}$ and $\mathrm{F}^{-}$exhibited a positive effect on both parameters. $\mathrm{pH}$ and $\mathrm{HCO}_{3}^{-}$also exhibited positive effects on $E_{b}$ while $\mathrm{NO}_{2}^{-}$exhibited a positive effect on $E_{\mathrm{pp}}$. The adjusted $\mathrm{R}^{2}$ values for both $E_{b}$ and $E_{p p}$ were low at 0.369 and 0.218 respectively.

As previously described, the concentrations of $\mathrm{Al}^{3+}, \mathrm{Mg}^{2+}$, and $\mathrm{Ca}^{2+}$ in the original test matrix were inadvertently prepared at lower than desired concentrations. Accordingly, a small matrix of tests was performed to independently evaluate the effects of these species on corrosion behavior in an average solution (all other species at their average concentrations). Aluminum was excluded from the evaluation since it was determined that its solubility was so low in the test solutions that it was impossible to meet the design concentrations. A summary of the results of this matrix of tests is given in Table 11.5 and data for CDA 102 are given in Figure 11.2. These data show that there was no effect of $\mathrm{Ca}^{2+}, \mathrm{Mg}^{2+}$, or $\mathrm{pH}$ on $\mathrm{E}_{\mathrm{cor}}$ or $\mathrm{E}_{\mathrm{b}}$ while $\mathrm{Mg}^{2+}$ exhibited a positive effect on $\mathrm{i}_{\mathrm{cor}}$ and $\mathrm{pH}$ exhibited a small positive effect on $E_{\mathrm{p}}$. This was a fully saturated design, thus the $\mathrm{R}^{2}$ value is one.

A summary of the significant main-effect terms for Alloy CDA 715 for each of the four corrosion parameters $\left(E_{c o r}, i_{c o r}, E_{b}\right.$, and $\left.E_{T p}\right)$ is given in Table 11.2. Figure 11.3 gives the direction and magnitude of the effect of the solution variables on these parameters for Alloy CDA 715. These 

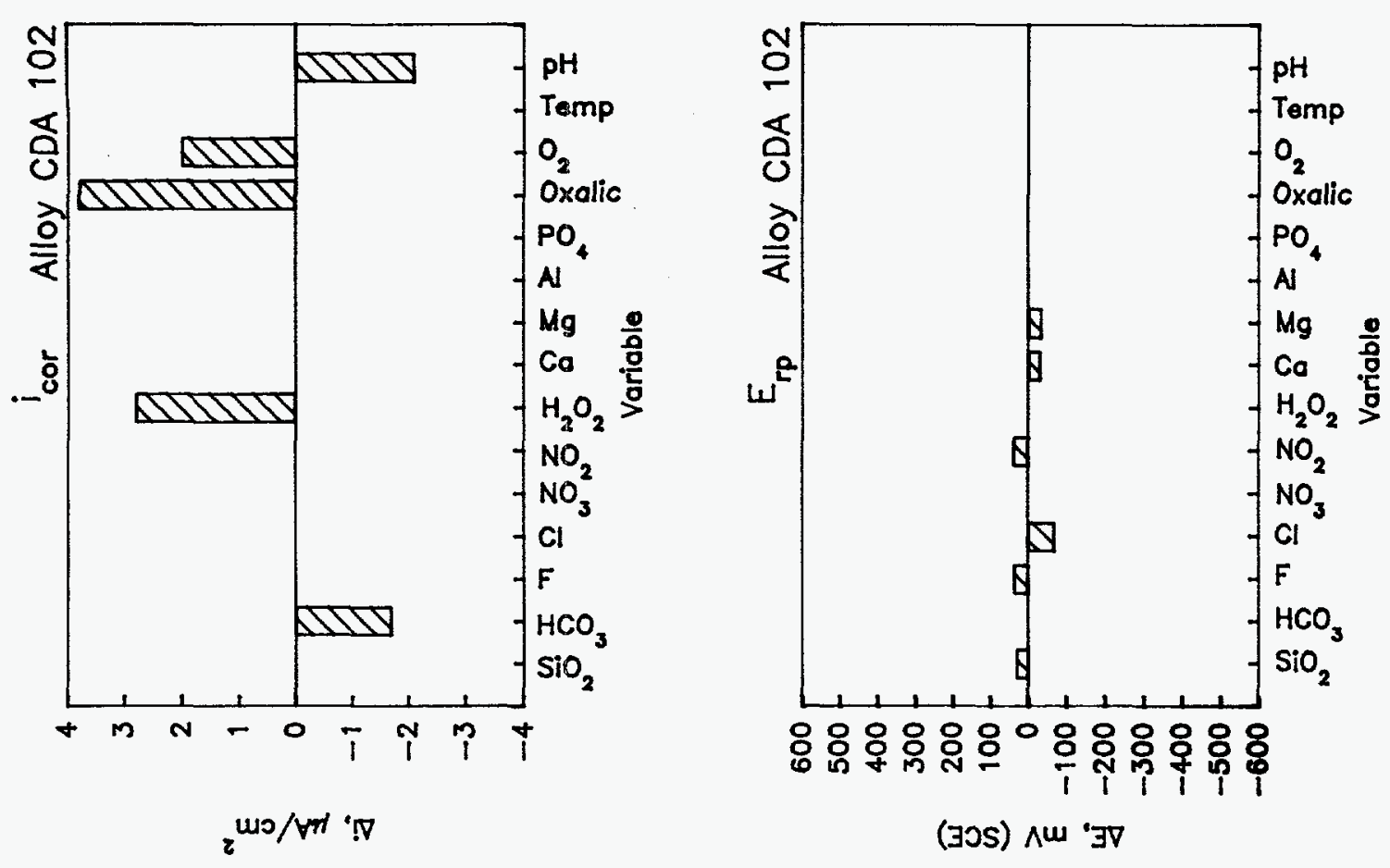

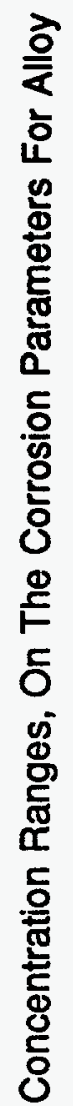

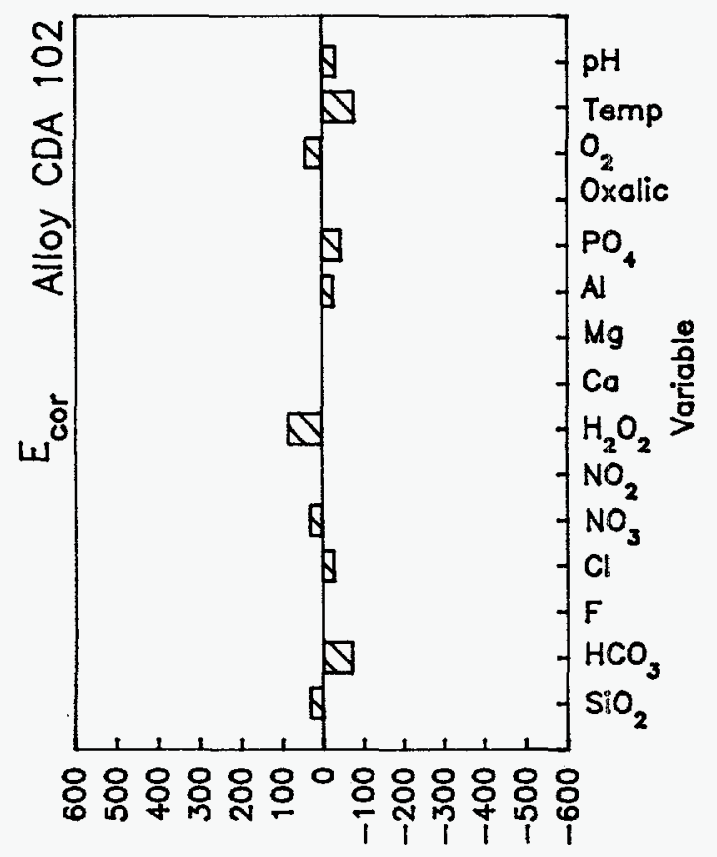

(

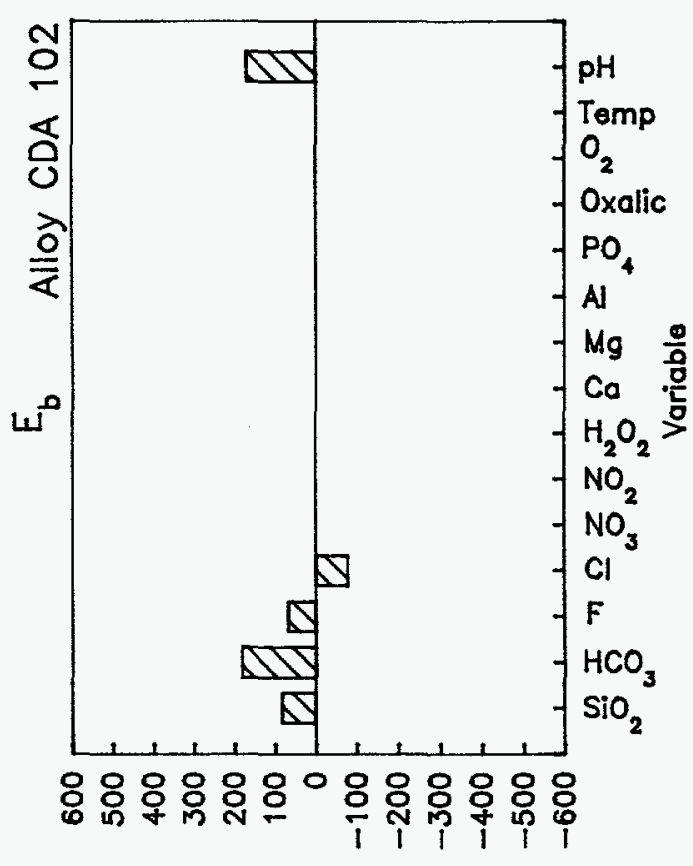

(उOS) A 
Table 11.5 Summary Of The Statistical Analysis For Each Of The Four Alloys In Solution Numbers 39 Through 42 . Coefficients Were Selected Based On $80 \%$ Confidence Level.

\begin{tabular}{|c|c|c|c|c|c|}
\hline \multirow[b]{2}{*}{ ALLOY } & \multirow[b]{2}{*}{ VARIABLE } & \multicolumn{4}{|c|}{ COEFFICIENTS FOR MAIN EFFECT } \\
\hline & & $E_{\text {cor }}$ & $I_{\text {cor }}$ & $E_{p h}$ or $E_{b}$ & $E_{\text {prot }}$ or $E_{\text {pp }}$ \\
\hline 825 & $\begin{array}{c}\mathrm{Ca}^{2+} \\
\mathrm{Mg}^{2+} \\
\mathrm{pH} \\
\text { Intercept } \\
\end{array}$ & $\begin{array}{c}\overline{-} \\
-68.500 \\
-\overline{609.8}\end{array}$ & $\begin{array}{c}\bar{z} \\
\overline{-} \\
-\overline{0.100}\end{array}$ & $\begin{array}{c}\overline{10.377} \\
- \\
652.0\end{array}$ & \begin{tabular}{c}
$\overline{18.794}$ \\
- \\
\hdashline 187.9
\end{tabular} \\
\hline $304 L$ & \begin{tabular}{c}
$\mathrm{Ca}^{2+}$ \\
$\mathrm{Mg}^{2+}$ \\
$\mathrm{pH}$ \\
\hdashline Intercept
\end{tabular} & $\begin{array}{c}\overline{-} \\
-27.000^{*} \\
365.3\end{array}$ & \begin{tabular}{c}
$\bar{z}$ \\
$\overline{0.050}$ \\
\hdashline-0.220
\end{tabular} & $\begin{array}{c}\overline{-} \\
19.100 * \\
--\overline{549.5}\end{array}$ & $\begin{array}{c}\bar{Z} \\
-\overline{-} \\
-451.3\end{array}$ \\
\hline CDA 715 & $\begin{array}{c}\mathrm{Ca}^{2+} \\
\mathrm{Mg}^{2+} \\
\mathrm{pH} \\
\text { Intercept }\end{array}$ & \begin{tabular}{c}
$\overline{-}$ \\
-40.900 \\
\hdashline 294.2
\end{tabular} & $\begin{array}{c}\overline{-} \\
-1.609 \\
--\overline{21.085}\end{array}$ & $\begin{array}{c}\bar{Z} \\
\overline{-} \\
-62.9\end{array}$ & $\begin{array}{c}\bar{Z} \\
\overline{-} \\
-164.6\end{array}$ \\
\hline CDA 102 & $\begin{array}{c}\mathrm{Ca}^{2+} \\
\mathrm{Mg}^{2+} \\
\mathrm{pH} \\
\text { Intercept }\end{array}$ & $\begin{array}{c}\bar{z} \\
\overline{-} \\
-53.2\end{array}$ & $\begin{array}{c}\overline{0.176} \\
0.400 \\
----- \\
-0.713\end{array}$ & \begin{tabular}{c}
$\bar{Z}$ \\
$\overline{-}$ \\
\hdashline 25.2
\end{tabular} & $\begin{array}{c}\bar{z} \\
8.600 \\
--23.0\end{array}$ \\
\hline
\end{tabular}

* Based on $90 \%$ confidence level.

Breakdown potential $\left(E_{b}\right)$ and repassivation potential $\left(E_{\mathrm{T}}\right)$ are used for the copper-base alloys rather than $E_{p i t}$ and $E_{\text {prot }}$ 

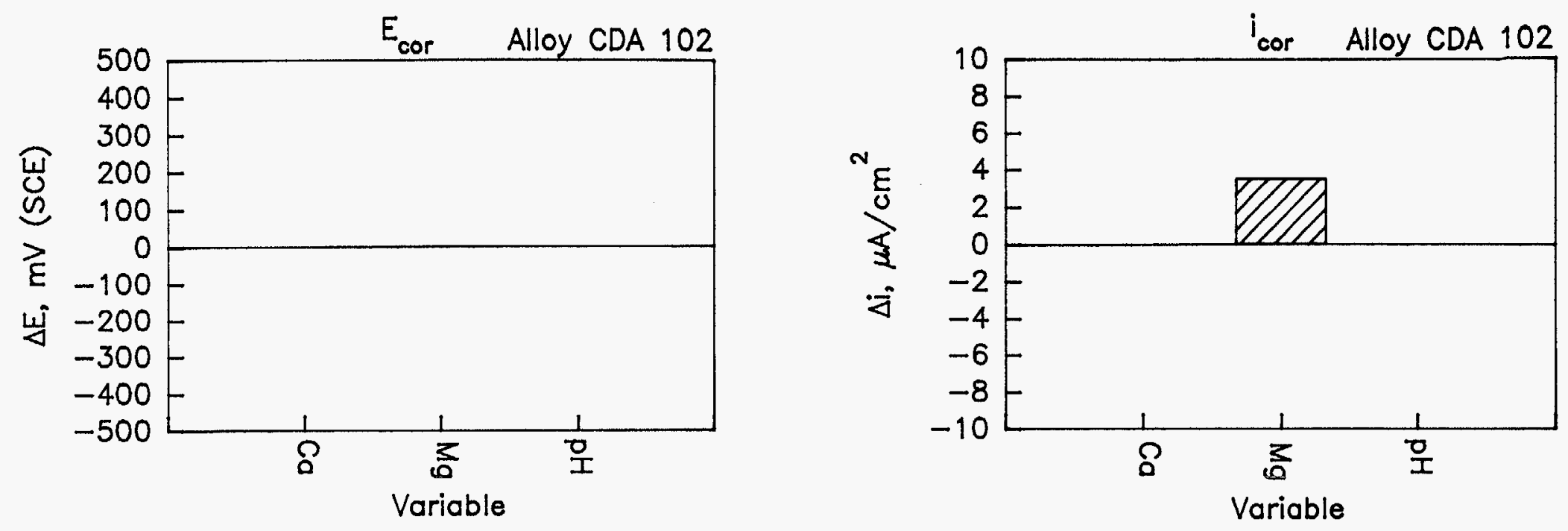

$\overrightarrow{0}$
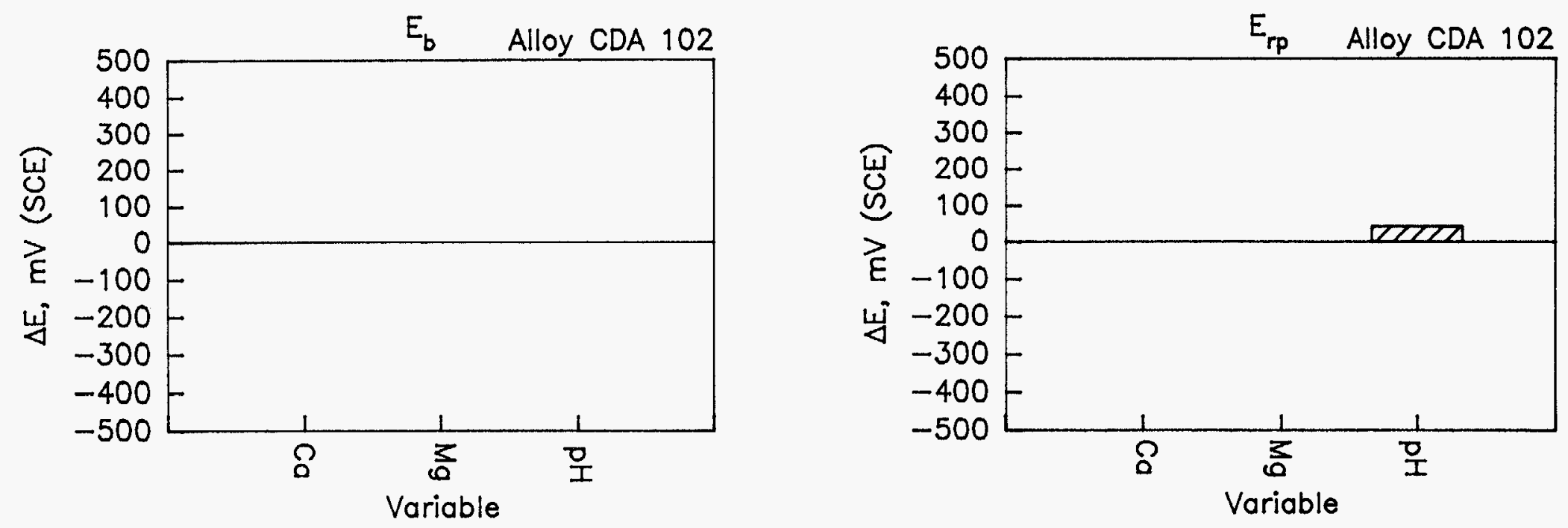

Figure 11.2 The Effects Of Solution Variables, Over The Defined Concentration Ranges, On The Corrosion Parameters For Alloy CDA 102 In Solution Numbers 39 Through 42; 80\% Confidence Level. 

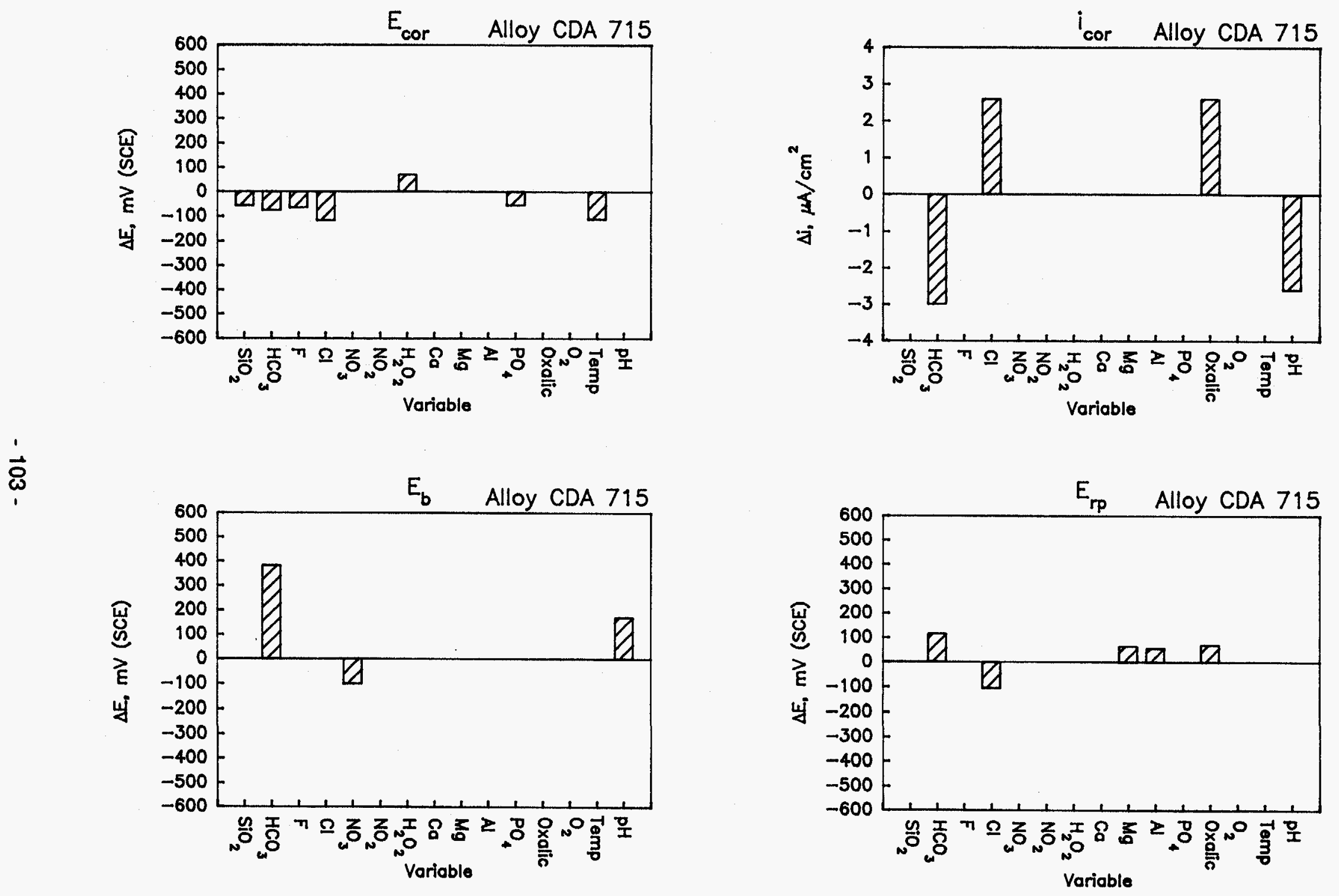

Figure 11.3 The Effects Of Solution Variables, Over The Defined Concentration Ranges, On The Corrosion Parameters For Alloy CDA 715 in Solution Numbers 1 Through 36. 
data show that several of the variables affected $\mathrm{E}_{\mathrm{cor}}$ with $\mathrm{H}_{2} \mathrm{O}_{2}$ having the only positive effect (increased $E_{c o r}$ ) and temperature and $\mathrm{Cl}$ having the largest negative effects. The adjusted $R^{2}$ value was moderately low, 0.40 , indicating that $40 \%$ of the variation in the data was explained.

With regard to $\mathrm{i}_{c o r}, \mathrm{pH}$ and $\mathrm{HCO}_{3}{ }^{-}$had the only negative coefficients, as was observed for Alloy CDA 102, while $\mathrm{Cl}^{-}$and Oxalic acid exhibited positive coefficients, increasing $i_{c o r}$. The adjusted $R^{2}$ value for $i_{c o r}$ was very low; 0.134 . Bicarbonate and $\mathrm{pH}$ exhibited positive effects on $E_{b}$ while the only variable decreasing $\mathrm{E}_{\mathrm{b}}$ was $\mathrm{NO}_{3}^{-}$. The adjusted $\mathrm{R}^{2}$ value for $\mathrm{E}_{\mathrm{b}}$ was moderate at 0.55 . With regard to $\mathrm{E}_{\mathrm{pp}}$, five variables affected the parameter with $\mathrm{Cl}^{-}$exhibiting the only negative effect and $\mathrm{HCO}_{3}{ }^{-}$exhibiting the largest positive effect. The adjusted $\mathrm{R}^{2}$ value for $\mathrm{E}_{\mathrm{b}}$ was low at 0.233 .

A summary of the results of the matrix of tests performed on alloy CDA 715, in which the effects of high levels of $\mathrm{Mg}^{2+}$ and $\mathrm{Ca}^{2+}$ on the CPP behavior was evaluated, is given in Table 11.5 and data for Alloy CDA 715 are given in Figure 11.4. These data show that there was no effect of $\mathrm{Ca}^{2+}$ or $\mathrm{Mg}^{2+}$ on any of the test parameters. pH exhibited a small positive effect on $\mathrm{E}_{\text {cor }}$ and $\mathrm{a}$ negative effect on $i_{\text {cor }}$. This was a fully saturated design, thus the $R^{2}$ value is one.

\subsubsection{Fe-Cr-NI Alloys}

A summary of the significant main-effect terms for Alloy $304 \mathrm{~L}$ for each of the four corrosion parameters $\left(E_{\text {cor, }} i_{\text {cor }}, E_{\text {pit }}, E_{\text {prot }}\right)$ is given in Table 11.3 and Figure 11.5. With regard to $E_{\text {cor, }}$ the negative values for many of the variables indicate that they promoted a decrease in the freecorrosion potential. On the other hand, $\mathrm{H}_{2} \mathrm{O}_{2}$ promoted an increase in $\mathrm{E}_{\text {cor }}$, which is expected based on the known oxidizing strength of $\mathrm{H}_{2} \mathrm{O}_{2}$ (see Figure 11.5). The effect of $\mathrm{O}_{2}$, a negative coefficient, is not fully understood. The $E_{c o r}$ analysis for Alloy $304 \mathrm{~L}$ had an adjusted $R^{2}$ value of 0.57 , which means that the main-effect terms accounted for $57 \%$ of the total variability in the data.

With regard to $\mathrm{i}_{c o r}, \mathrm{HCO}_{3}^{-}$, and $\mathrm{pH}$ were found to decrease $\mathrm{i}_{c o r}$ while $\mathrm{Cl}^{-}$and $\mathrm{H}_{2} \mathrm{O}_{2}$ increased $\mathrm{i}_{c o r}$. This behavior is understandable since $\mathrm{HCO}_{3}{ }^{-}$and elevated $\mathrm{pH}$ tend to promote passivation (corrosion inhibitors) while $\mathrm{Cl}^{-}$attacks the passive film on stainless steels and $\mathrm{H}_{2} \mathrm{O}_{2}$ is an oxidant, which also increased the corrosion potential. The overall adjusted $R^{2}$ value for $i_{c o r}$ was low, 0.224 , when considering main-effect terms only.

The pitting potential, $\mathrm{E}_{\text {pit }}$ for Alloy $304 \mathrm{~L}$ was increased by the passivating agents $\mathrm{HCO}_{3}-\mathrm{NO}_{3}$, and elevated $\mathrm{pH}$, while $\mathrm{Cl}^{-}$decreased $\mathrm{E}_{\mathrm{plr}}$. No other variables were found to be significant. The adjusted $R^{2}$ value for the main-effect term analysis was 0.37 . The protection potential, $E_{\text {prol }}$, for Alloy $304 \mathrm{~L}$ was found to be affected by $\mathrm{Cl}^{-}, \mathrm{NO}_{3}{ }^{-}$, and $\mathrm{PO}_{4}{ }^{3-}$; nitrate and phosphate increased the protection potential while $\mathrm{Cl}^{-}$decreased the protection potential. The adjusted $\mathrm{R}^{2}$ value for the main-effect term analysis for the protection potential was 0.575 . As shown in Figure 11.5, the magnitude of the $\mathrm{Cl}^{-}$and $\mathrm{NO}_{3}{ }^{-}$variables show a significant effect when concentration is considered.

A summary of the results of the matrix of tests performed on Alloy 304L, in which the effects of high levels of $\mathrm{Mg}^{2+}$ and $\mathrm{Ca}^{2+}$ on the CPP behavior was evaluated, is given in Table 11.5 and data for Alloy $304 \mathrm{~L}$ are given in Figure 11.6. These data show that there was no effect of $\mathrm{Ca}^{2+}$ or $\mathrm{Mg}^{2+}$ 

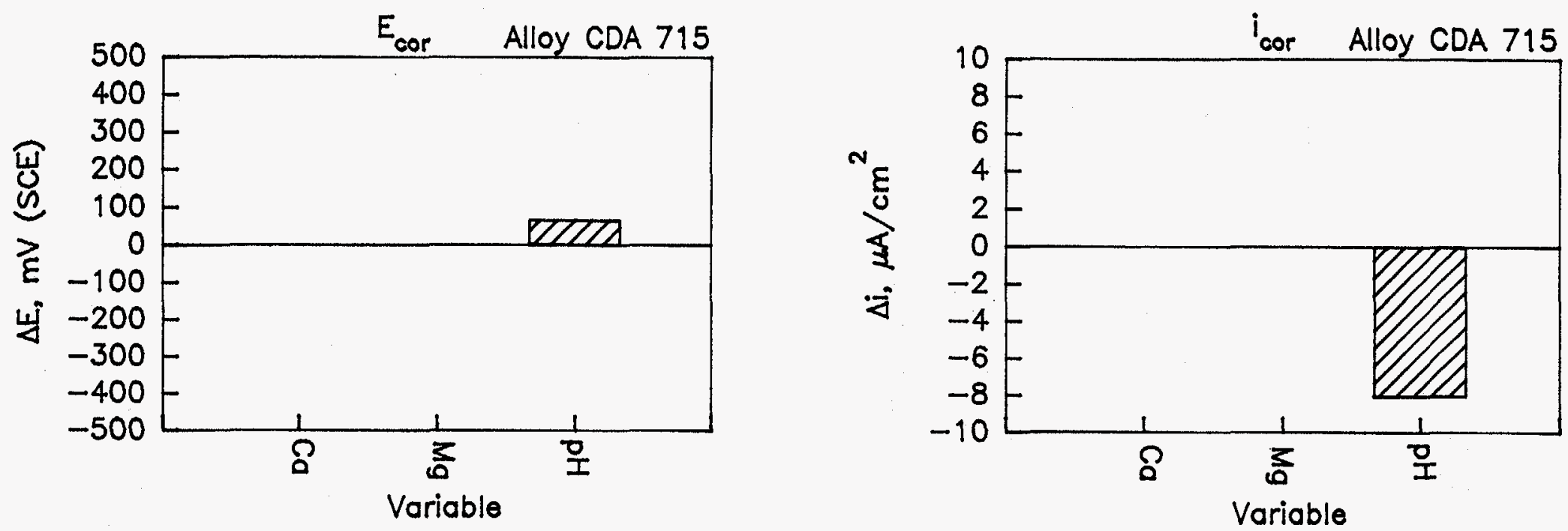

官
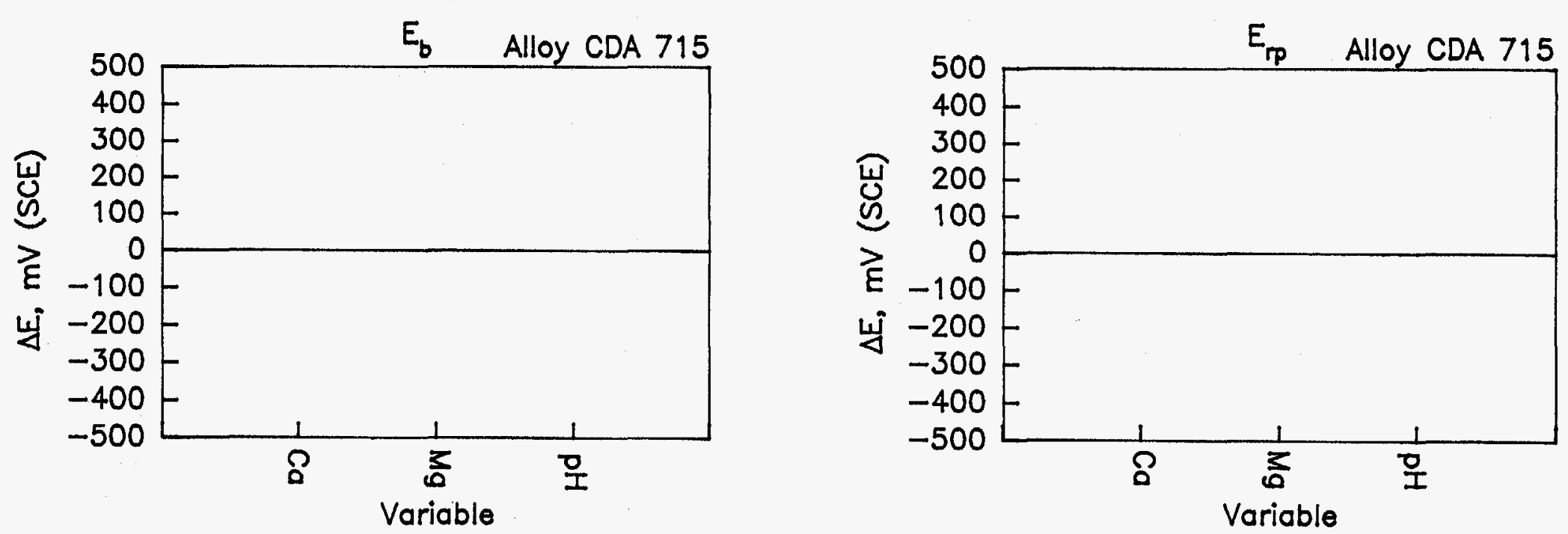

Figure 11.4 The Effects Of Solution Variables, Over The Defined Concentration Ranges, On Corrosion Parameters For Alloy CDA 715 In Solution Numbers 39 Through 42; $80 \%$ Confidence Level. 

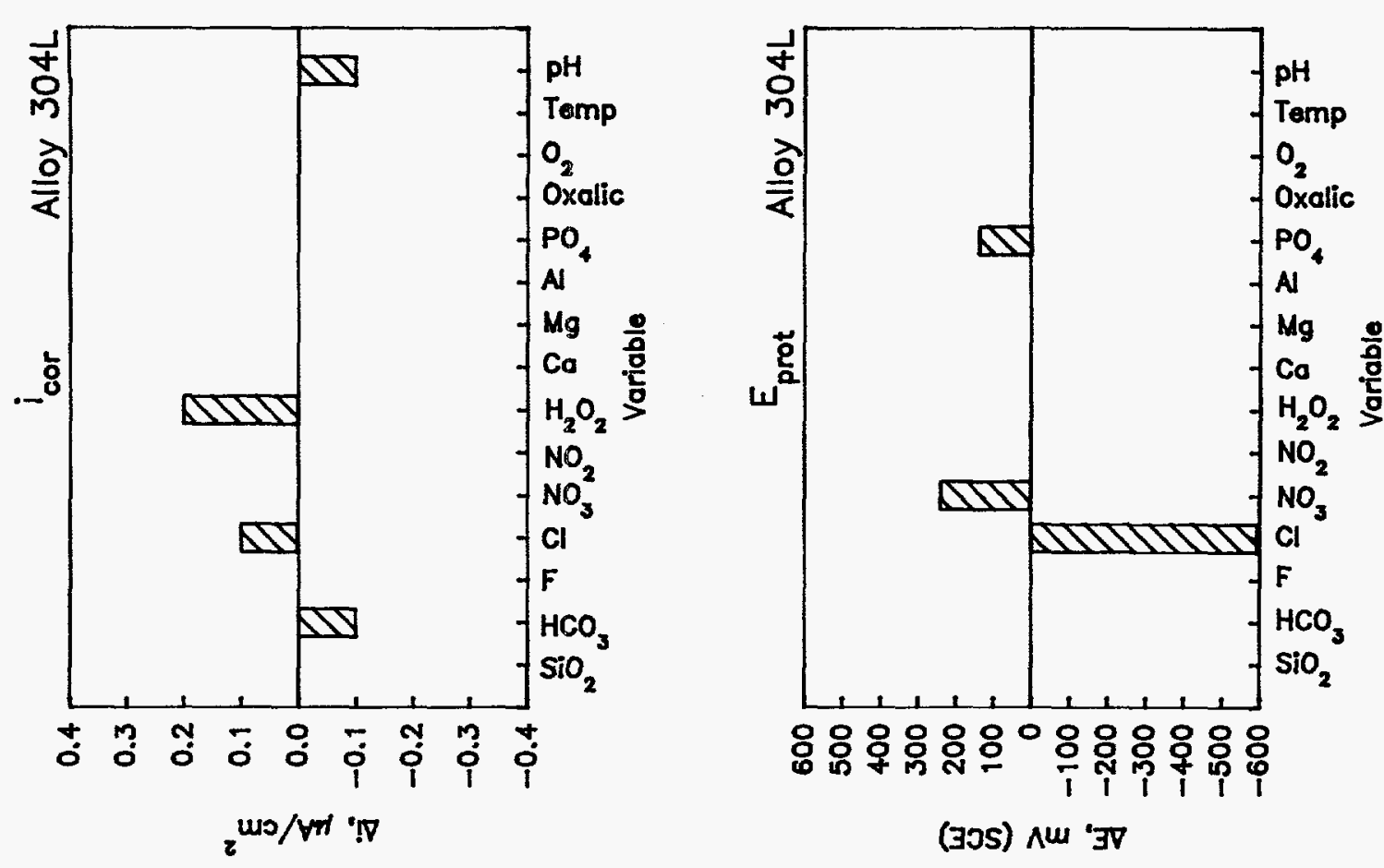

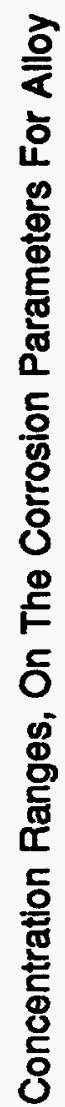
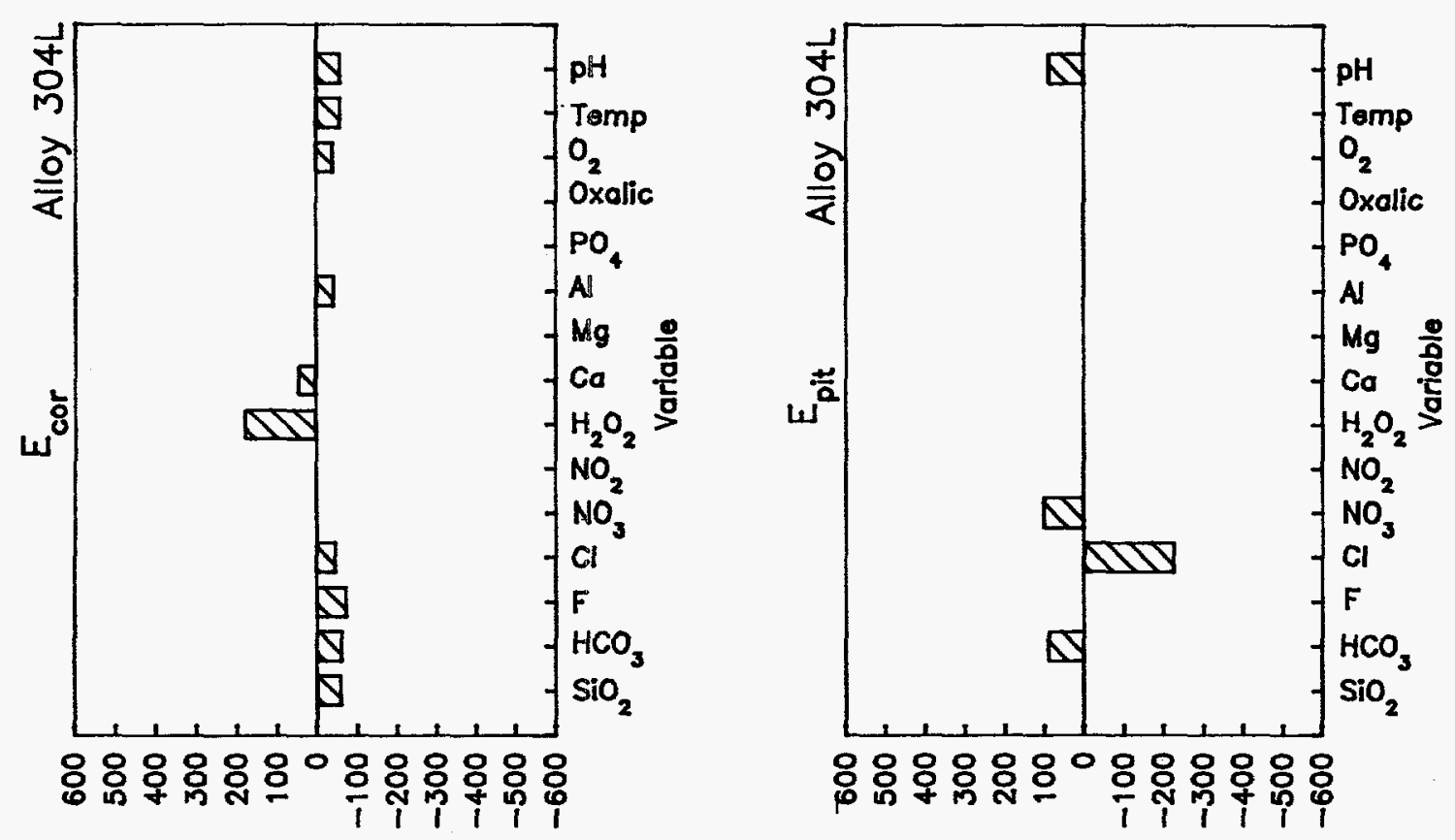

(JOS) $\wedge$ '

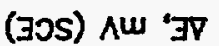



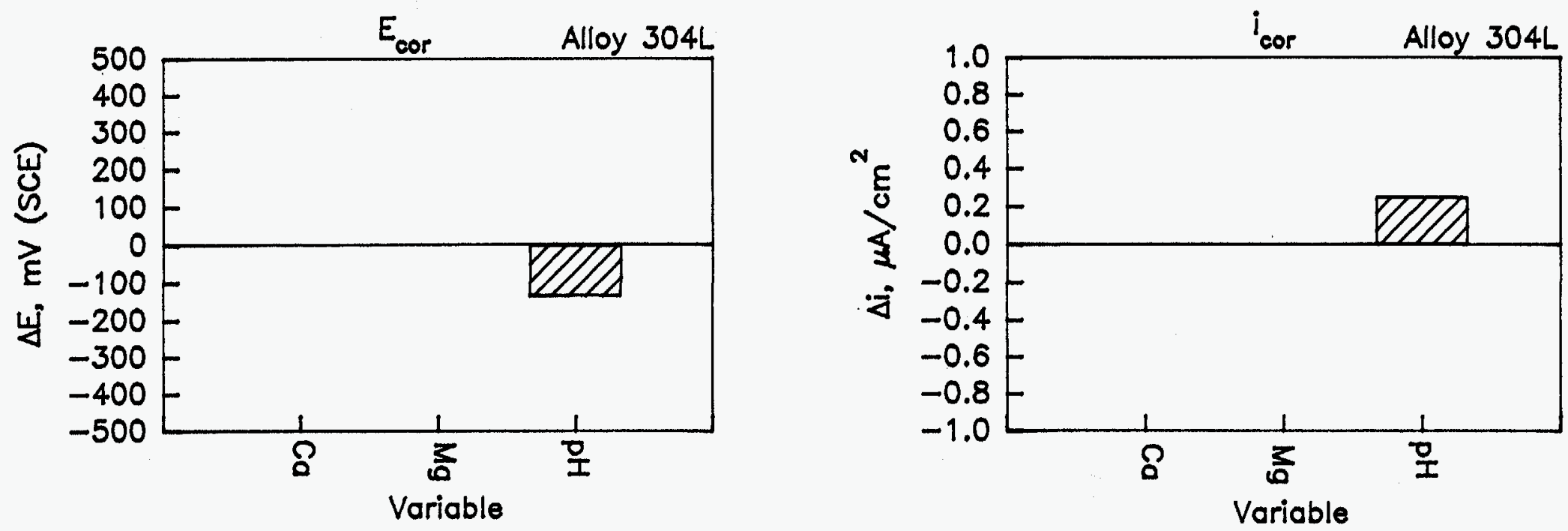

$\stackrel{1}{0}_{1}^{1}$
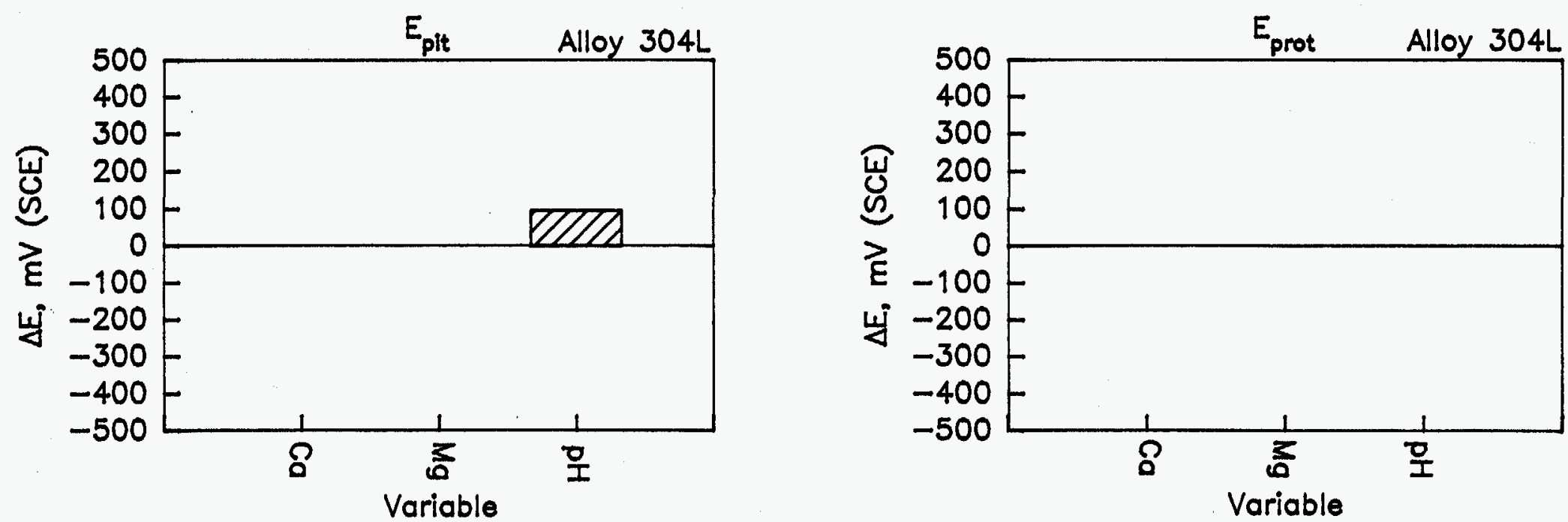

Figure 11.6 The Effects Of Solution Variables, Over The Defined Concentration Ranges, On The Corrosion Parameters For Alloy 304L in Solution Numbers 39 through 42; $80 \%$ Confidence Level. 
on any of the test parameters. $\mathrm{pH}$ exhibited a small negative effect on $\mathrm{E}_{\mathrm{cor}}$ and small positive effects on $I_{c o r}$ and $E_{\text {pir }}$. This was a fully saturated design, thus the $R^{2}$ value is one.

Table 11.4 and Figure 11.7 are a summary of the significant main effects for Alloy 825 for each of the four parameters. With regard to $E_{\text {cor }}$, the general trends with Alloy 825 were similar to those observed with Alloy 304L, but fewer variables were found to be important for Alloy 825 . In addition, the oxygen coefficient for Alloy 825 was positive instead of a negative coefficient, which was observed with Alloy $304 \mathrm{~L}$. The adjusted $R^{2}$ value for $E_{\text {cor }}$ of Alloy 825 was moderately high; 0.66. Only three variables were found to affect $i_{\text {cor }}$ for Alloy $825 ; \mathrm{H}_{2} \mathrm{O}_{2}, \mathrm{Mg}^{2+}$, and temperature. $\mathrm{H}_{2} \mathrm{O}_{2}$ and temperature had positive effects on $\mathrm{i}_{c o r}$ while $\mathrm{Mg}$ had a negative effect. The adjusted $R^{2}$ value for $i_{c o r}$ of Alloy 825 also was very low; 0.120 . The data for $E_{p h t}$ for Alloy 825 were quite peculiar; only three variables were found to affect $E_{\text {pit }}\left(F-, \mathrm{H}_{2} \mathrm{O}_{2}\right.$, and $\left.\mathrm{Mg}^{2+}\right)$. The $\mathrm{Mg}^{2+}$ effect was quite large, while the coefficient for $\mathrm{F}$ was found to be positive and no $\mathrm{Cl}^{-}$effect was found. In addition, the adjusted $R^{2}$ value was low 0.143 . This behavior may reflect the fact that the pitting potential for Alloy 825 were very high in many cases and the measured value may indicate water breakdown as opposed to actual pit initiation.

The protection potential for Alloy 825 was affected by six solution variables. Chloride exhibited a negative effect while $\mathrm{NO}_{3}$ - was beneficial, increasing $\mathrm{E}_{\text {prol. }}$. Similar effects were observed for Alloy $304 \mathrm{~L}$ and are reasonable based on the behavior of these species. The effects of the other species on $\mathrm{E}_{\text {pit }}$ are not readily explainable. Both $\mathrm{Mg}^{2+}$ and $\mathrm{H}_{2} \mathrm{O}_{2}$ both exhibited negative effects on $E_{\text {prot }}$, which were similar in magnitude to their effects on $E_{\text {pir }}$. The adjusted $R^{2}$ value for $E_{\text {prot }}$ of Alloy 825 was moderate at $\mathbf{0 . 4 1 2}$.

A summary of the results of the matrix of tests performed on Alloy 825, in which the effects of high levels of $\mathrm{Mg}^{2+}$ and $\mathrm{Ca}^{2+}$ on the CPP behavior was evaluated,is given in Table 11.5 and data for Alloy 825 are given in Figure 11.8. These data indicate that $\mathrm{Mg}^{2+}$ exhibited positive effects on $E_{\text {pit }}$ and $E_{\text {prot }}$. These trends are the opposite of those observed at the lower concentration levels in the main matrix, as described above. The only other effect evident in the small matrix was $\mathrm{pH}$ which exhibited a negative effect on $E_{\text {cor. }}$. This was a fully saturated design, thus the $\mathrm{R}^{2}$ value is one.

For passive alloys such as Alloy 304L and Alloy 825, the most important parameters in predicting long-term performance are $E_{\text {cor }}, E_{\text {pity }}$ and $E_{\text {prot }}$. General corrosion rates are usually quite low for passive alloys and decrease with time. Those solution species that cause noble (positive) shifts in $E_{c o r}$ or negative shifts in $E_{p i t}$ or $E_{\text {prot }}$ may promote localized corrosion while solution species that tend to separate $E_{\text {cor }}$ from $E_{p l t}$ or $E_{\text {prot }}$ are beneficial. Based on this analysis, $\mathrm{HCO}_{3}-\mathrm{NO}_{3}{ }^{-}$, and $\mathrm{pH}$ are beneficial for Alloy $304 \mathrm{~L}$ and warrant further study. Similarly, detrimental variables for Alloy $304 \mathrm{~L}$ are $\mathrm{Cl}^{-}$and $\mathrm{H}_{2} \mathrm{O}_{2}$.

For Alloy 825, the expected detrimental effects of $\mathrm{Cl}^{-}$and $\mathrm{H}_{2} \mathrm{O}_{2}$ on corrosion behavior were found, along with the beneficial effect of $\mathrm{NO}_{3}-$. However, many of the other effects are difficult to understand. This may be a reflection of our poor understanding of solution chemistry effects on corrosion or the generally low values of $R^{2}$ found in the study for all four alloys. This poor predictive capability is probably the result of three factors; (1) the limited number of tests run for the large number of experimental variables, introducing a large amount of statistical error in the results, (2) interaction among the solution variables, such that they are not truly independent variables, and (3) variation due to factors other than main effect terms (two- or three-factor 

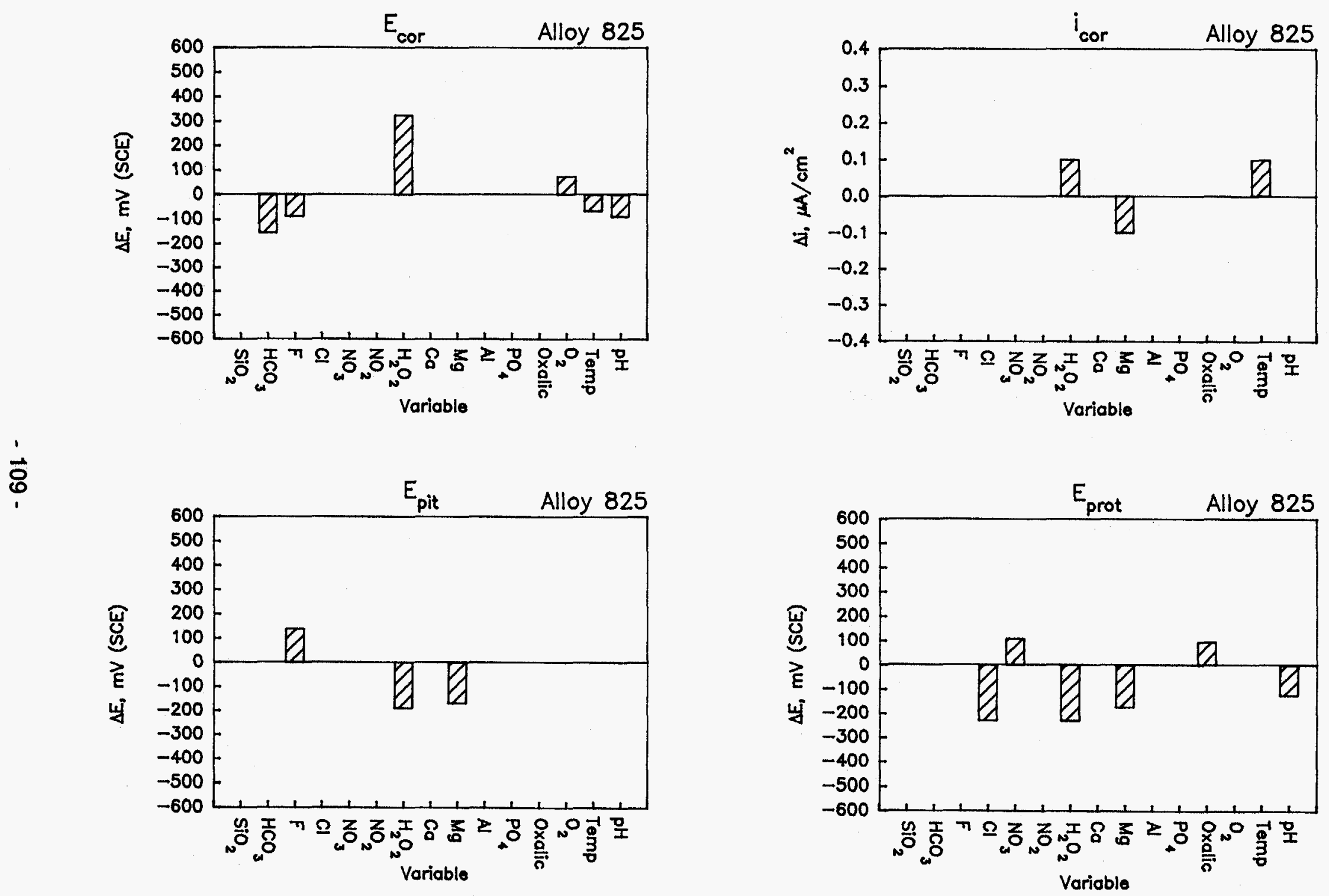

Figure 11.7 The Effects Of Solution Variables, Over The Defined Concentration Ranges, On The Corrosion Parameters For Alloy 825 In Solution Numbers 1 Through 36; 80\% Confidence Level. 

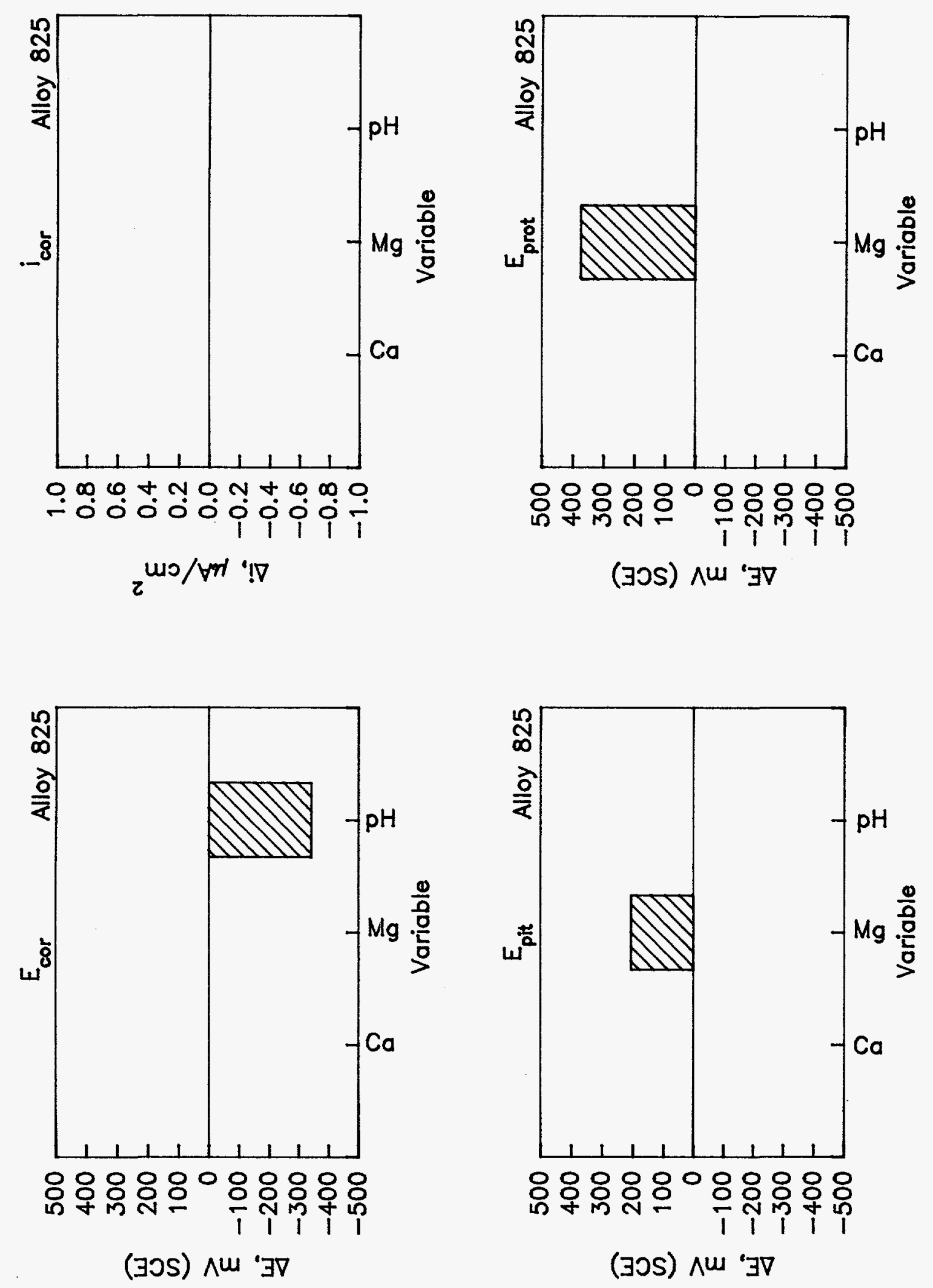
interactions and quadratic terms). Nevertheless, the statistical matrix of CPP tests provided an increase in our understanding of the types of behavior that are possible and identified important variables for further study.

\subsection{Thermal Effects on CPP Behavior}

The thermal effects on the corrosion behavior of the four candidate alloys were evaluated by the cyclic-potentiodynamic-polarization technique with two different test methods. The first series of thermal-effects experiments examined the changes in corrosion behavior when CPP tests were performed with each of the alloys at $50^{\circ} \mathrm{C}, 75^{\circ} \mathrm{C}$, and $90^{\circ} \mathrm{C}$ in selected environments. The second series of thermal-effects experiments examined the effects of heat transfer on the corrosion behavior by the CPP technique utilizing specimens which were internally heated to $90^{\circ} \mathrm{C}$ while maintaining the selected test solutions at $50^{\circ} \mathrm{C}$. The environments selected for each of these studies were based on the results of the CPP tests from the experimental matrix. For comparative purposes, all four alloys were evaluated in simulated $\mathrm{J}-13$ well water.

\subsubsection{Isothermal Tests}

The results of the research performed in simulated $\mathrm{J}-13$ well water showed that the effect of temperature on the CPP behavior at the free-corrosion potential to be similar for each of the four alloys. With the exception of Alloy CDA 102, the values for $E_{\text {cor }}$ for each alloy were found to become more negative as the temperature was increased while the corrosion rates were similar for all three temperatures. This behavior is indicative of passive alloys. For Alloy CDA 102, the corrosion current density increased with increasing temperature while no significant change in the corrosion potential was observed. This behavior is indicative of an actively corroding alloy.

For Alloys CDA 102 and CDA 715 in simulated J-13 well water, there was no systematic effect of temperature on the values of $E_{b}$ and $E_{r p}$. The CPP curve for Alloy CDA 715 exhibited a limited passive range prior to film breakdown in the simulated $\mathrm{J}-13$ well water. Optical examination of Alloy CDA 715 revealed localized changes in the oxide film and a few shallow pits corresponded with these localized active areas at all three temperatures. Optical examination of Alloy CDA 102 following the CPP tests showed localized variations in the oxide coloration. Although significant differences in the repassivation potential were also noted for Alloy CDA 102 at the different temperatures, no temperature-dependent trends were evident. It is possible that the wide range of repassivation potentials can be attributed to the irregularities in the oxide layer from test to test.

For Alloy 825 in simulated $\mathrm{J}-13$ well water, values of $E_{p l t}$ and $E_{p r o t}$ decrease with increasing temperatures. However, no pitting or hysteresis was observed in the tests.

Alloy $304 \mathrm{~L}$ was found to exhibit anomalous CPP behavior at $75^{\circ} \mathrm{C}$. Hysteresis occurred in the CPP curve for Alloy $304 \mathrm{~L}$ in the simulated $\mathrm{J}-13$ well water at only $75^{\circ} \mathrm{C}$ and optical examination revealed pits on the bottom of the specimen following the test. No pitting or hysteresis was evident at either $50^{\circ} \mathrm{C}$ or $90^{\circ} \mathrm{C}$. Glass (Glass-1984) also observed a slight increase in corrosion rate at $70^{\circ} \mathrm{C}$ as compared to rates obtained at $50^{\circ} \mathrm{C}$ and $90^{\circ} \mathrm{C}$ in Tuff-conditioned $\mathrm{J}-13$ well water. 
CPP tests were also performed in three other environments selected from the experimental test matrix to aid in further evaluating the effects of temperature on corrosion behavior. The copperbase alloys were evaluated in Solution Numbers 7 and 10, and the $\mathrm{Fe}-\mathrm{Cr}-\mathrm{Ni}$ alloys were evaluated in Solution Numbers 7 and 20. Solution Number 7 was selected for evaluation as it was shown to promote active corrosion of the copper-base alloys and pitting of the $\mathrm{Fe}-\mathrm{Cr}-\mathrm{Ni}$ alloys. Solution Number 10 was also chosen as it was found to promote passivation and pitting of the copper-base alloys whereas Solution Number 20 promoted this same corrosion behavior of the Fe-Cr-Ni alloys. Both Solution Number 10 and Number 20 had a pH of 10. Each of the three test solutions contained $1000 \mathrm{ppm}$ chloride. Solution Number 10 also contained $1000 \mathrm{ppm}$ bicarbonate whereas Solution Number 20 contained 200 ppm nitrite.

The results of the CPP experiments in Solution Numbers 7 and 10 showed that neither of the copper-base alloys appeared to show any systematic trends in the polarization parameters. Optical examination of the specimens following the CPP tests also failed to show any observable differences as a result of the temperature differences. These data suggest that there is not a strong temperature dependence of the corrosion behavior of the copper-base alloy/synthetic environment systems evaluated over the limited temperature range of $50^{\circ} \mathrm{C}$ to $90^{\circ} \mathrm{C}$.

The results of the CPP experiments with the Fe-Cr-Ni alloys in Solution Numbers 7 and 20 showed that neither of the alloys exhibited any systematic trends in the polarization parameters. Optical examination of the specimens revealed pitting of both alloys in both of the selected environments with no observable differences as a result of the change in the solution temperature. Again, the apparent lack of any systematic trends in the CPP data or in the posttest evaluation suggest that there is not a strong temperature dependence of the corrosion behavior of the $\mathrm{Fe}-\mathrm{Cr}-\mathrm{Ni}$ alloy/synthetic environment systems evaluated over the limited temperature range of $50^{\circ} \mathrm{C}$ to $90^{\circ} \mathrm{C}$.

\subsubsection{Temperature Gradient Tests}

The effects of temperature gradients were evaluated by the CPP technique using heat-transfer specimens of the candidate alloys. All of the tests were performed in $50^{\circ} \mathrm{C}$ simulated solutions selected from the experimental matrix while maintaining the temperature of the specimen at $90^{\circ} \mathrm{C}$. Each of the four alloys was evaluated in simulated $\mathrm{J}-13$ well water. The copper-base alloys were further evaluated in Solution Number 22 and the $\mathrm{Fe}-\mathrm{Cr}-\mathrm{Ni}$ alloys were evaluated in Solution Number 7. Each of these environments contained $1000 \mathrm{ppm}$ chloride and $172 \mathrm{ppm}$ oxalic acid and had a pH of 10 and 5 respectively. These solutions were found to promote pitting of the alloys in earlier CPP testing.

The results of the research and optical examination following testing in simulated $\mathrm{J}-13$ well water showed that temperature gradients appeared to be detrimental to the corrosion behavior of each of the four alloys as evidenced by the more severe etching and pitting that occurred during the testing. Testing was repeated with Alloy CDA 102 to reconfirm the corrosion behavior. The data from the repeat tests showed the CPP curves and corrosion behavior to be reproducible. The occurrence of pitting of Alloy 825 was quite surprising and that particular test was also repeated. Again, the data from that repeat test showed the CPP curve to be reproducible. 
The results of the experiments performed with the copper-base alloys in Solution Number 22 and the $\mathrm{Fe}-\mathrm{Cr}$-Ni alloys in Solution Number 7 all revealed that no significant changes occurred in the corrosion behavior as a result of the temperature gradients. Optical examination of the alloys following the CPP tests in Solution Numbers 22 and 7 revealed pitting of the heat-transfer specimen which was no more severe than the pitting that occurred in earlier CPP testings in the absence of heat transfer. For each of the alloy/simulated environment systems tested, the values of $E_{c o r}$ and $E_{b} / E_{p i t}$ did appear to be shifted in the noble direction as a result of the heat transfer; however, this effect may have been a result of the increased temperature of the heat-transfer specimens.

The CPP behavior of the candidate alloy is interesting in that the heat transfer was detrimental only in the simulated $\mathrm{J}-13$ well water, which was the least aggressive environment tested. The non-aggressive behavior of the simulated $\mathrm{J}-13$ well water can be attributed to the relatively high concentration of corrosion inhibitors, in comparison to aggressive species such as chloride. It may be speculated that the detrimental behavior of the alloys in the presence of heat transfer is the result of concentration of the aggressive species at the metal surface. The inhibitors, such as carbonates or silicates, tend to be less soluble than the aggressive species and thus would be expected to achieve lower concentrations at the metal surface in the presence of heat transfer.

\subsection{Effects Of Welding On CPP Behavior}

The effects of welding on the corrosion behavior of the four candidate alloys were evaluated by the CPP techrique. Each of the CPP tests was performed on cylindrical electrochemical specimens machined from the actual weld and the results of the tests were compared with CPP curves for the wrought material. Testing was performed in simulated J-13 well water for each of the alloys and in one environment that promoted pitting and in one that promoted active corrosion of the wrought alloys.

The results of the research in simulated $\mathrm{J}-13$ water showed that the copper-base welds appeared to be somewhat more susceptible to localized corrosion than the wrought alloys. For Alloy 825 , the CPP curve for the weld did not exhibit hysteresis, but some etching was observed around bubbles that formed on the specimen during the test in simulated $\mathrm{J}-13$ well water. Neither the wrought nor welded specimens of Alloy $304 \mathrm{~L}$ showed any attack in the simulated J-13 well water environment.

Solution Number 7 was evaluated as it was found to be an active-corrosion solution for the copper-base alloys and promoted pitting of the $\mathrm{Fe}-\mathrm{Cr}$-Ni alloys. As previously discussed, Solution Number 7 contained 1000 ppm chlorides, 172 ppm oxalic acid, and had a pH of 5 . The results of the experimentation showed no appreciable effect of welding on the polarization parameters for either the welded Fe-Cr-Ni or CDA Alloy 715. The welded Alloy CDA 102 specimens were found to exhibit hysteresis loops; however, only etching was evident on the specimen. No hysteresis loop was evident in the data for the wrought Alloy CDA 102.

Solution Number 29 was evaluated with the welded copper-base alloys as it was found to promote pitting of the wrought alloys. Solution Number 29 contained high concentrations of bicarbonate, chloride, and oxalic acid and had a pH of 5 . Results of the tests in this environment 
showed that both of the welded copper-base alloys generally exhibited higher corrosion currents and lower free-corrosion potentials than the unwelded specimens. The post-test examinations of the welded specimen revealed changes in the oxide growth and the absence of pitting. On the other hand, the unwelded specimen exhibited hysteresis in the CPP curves and pitting. These data suggest that the copper-base welds exhibited less of a tendency to passivate than the wrought material in this particular environment. This behavior could possibly lead to galvanic corrosion of the welds and warrants further investigation.

Finally, Solution Number 25 was evaluated with the welded $\mathrm{Fe}-\mathrm{Cr}$-Ni alloys as it was found to be an active-corrosion environment for the wrought materials. Solution Number 25 contained high concentrations of bicarbonate and nitrate, a low concentration of chloride, and had a pH of 5 . Results of the CPP tests performed in Solution Number 25 suggest that the welds performed as well as, and in some cases slightly better than, the wrought material. There was no indication that the welds were more susceptible to attack than the wrought material. The variations observed in the corrosion parameters between the wrought and welded specimens are probably attributable to scatter in the data.

Once the geochemistry of the repository and the actual welding procedures for the canisters are finally determined, further research of the welded alloys needs to be performed. These include testing in more realistic environments and long-term exposures of welded specimens. 


\section{CONCLUSIONS}

Based on the preceding data and discussions, the following conclusions can be drawn:

- The polarization behavior reported by Lawrence Livermore Laboratories in J-13 well water was reproducible.

- Laboratory simulations of J-13 well water produced comparable CPP behavior to actual $\mathrm{J}-13$ well water.

- For each of the alloys, CPP data indicated that several different types of corrosion were possible depending upon the solution composition.

- All of the candidate alloys tested underwent localized corrosion in some regions of the factor space. Further research is needed to better define the geochemistry of the repository environment.

- For the copper-base alloys, hysteresis in the CPP curves was not always associated with pitting. This confusing behavior (similar polarization curves having different corrosion morphologies) warrants further investigation.

- For the $\mathrm{Fe}-\mathrm{Cr}-\mathrm{Ni}$ alloys, the CPP data was found to conform with a conventional interpretation of CPP curves.

- Results of the temperature-effect studies do not indicate a strong temperature dependence on the corrosion behavior of the alloy-synthetic environment systems evaluated over the limited temperature range of $50^{\circ} \mathrm{C}$ to $90^{\circ} \mathrm{C}$.

- Temperature gradients (heat transfer) were detrimental to the corrosion behavior of all four alloys in simulated $\mathrm{J}-13$ well water.

- In more aggressive solutions, no significant effects of temperature gradients on corrosion behavior were observed.

- In the welding-effect studies, relatively little effect of welding was observed on the CPP behavior of the Fe-Cr-Ni alloys in the alloy-synthetic environment; systems evaluated.

- Welding was found to be detrimental to the performance of the copper-base alloys in both simulated J-13 well water and in a solution known to promote pitting of the wrought copper-base alloys. 



\section{RECOMMENDATIONS FOR FURTHER RESEARCH}

- The statistical matrix of synthetic test environments was based on data obtained from a thorough review of the literature. Further geochemical research is needed to better define the repository environment and the effects of radiation on the environment.

- The CPP results from the screening test matrix need to be used as guidelines to identify the appropriate factor space for additional research. In particular, the variables that promoted both beneficial and deleterious effects on the candidate alloys need to be investigated further.

- Interpretation of the CPP data from the copper-base alloys did not conform to conventional interpretation. In numerous cases, similar polarization curves were found to have completely different corrosion morphologies. In some cases, hysteresis occurred and optical examination of the species revealed pitting. In other cases, similar hysteresis revealed only changes in the oxide and no pitting occurred. The atypical behavior of the copper-base alloys warrants further testing.

- In the temperature-effect studies, Alloy $304 \mathrm{~L}$ exhibited pitting at $75^{\circ} \mathrm{C}$ in simulated $\mathrm{J}-13$ well water, but not at $50^{\circ} \mathrm{C}$ or $90^{\circ} \mathrm{C}$. Long-term testing at various temperatures is needed to help assess the long-term corrosion behavior of this alloy.

- Temperature gradients (heat transfer) were found to affect the corrosion behavior of all of the candidate alloys in simulated $\mathrm{J}-13$ well water. Long-term testing of heat-transfer specimens should be performed.

- In the welding-effect studies, welded specimens were prepared based on current recommended practices. It was our understanding that in 1989 , the DOE had not yet prepared welding procedures for the waste container at the time of specimen preparation Welding procedures need to be established for the waste containers and further testing of the welds needs to be performed.

- In the studies performed to evaluate welded specimens, the welded copper-base alloys showed less of a tendency to passivate than the wrought alloys in a solution that was previously shown to promote pitting of the wrought copper-base alloys. This behavior could lead to galvanic corrosion of the welds and warrants further study. 



\section{REFERENCES}

Abraham-1986 - Abraham, T., Jain, H., and Soo, P., "Stress-corrosion Cracking Tests On HighLevel-Waste Container Materials In Simulated Tuff Repository Environments," Brookhaven National Laboratory, NUREG/CR-4619, BNL-NUREG-51996, June, 1986.

Beavers-1987 - Beavers, J. A. and Thompson, N. G., et al., "Long-Term Performance of Container Materials for High-Level Waste," NUREG/CR-4955, BMI-2155, September, 1987.

Beavers-1989 - Beavers, J. A., Thompson, N. G., and Harper, W. V., "PotentiodynamicPolarization Studies Of Candidate Container Materials in Simulated Tuff Repository Environments," Cortest Columbus, Inc., Columbus, Ohio, November, 1989.

Beavers-1990 - Beavers, J. A. and Thompson, N. G., "Environmental Effects On Corrosion in The Tuff Repository," Cortest Columbus, Inc., Columbus, Ohio, NUREG/CR-5435.

Glass-1985 - Glass, R. S., Overturf, G. E., Van Konynenburg, R. A., and McCright, R. D., "Gamma Radiation Effects On Corrosion: I Electrochemical Mechanisms For The Aqueous Corrosion Processes Of Austenitic Stainless Steels," Lawrence Livermore National Laboratory, Livermore, CA, UCRL-92311, February, 1985.

Glass-1986 - Glass, R. S., Van Konynenburg, R. A., and Overturf, G. E., "Corrosion Processes Of Austenitic Stainless Steels And Copper-Based Materials In Gamma-Irradiated Aqueous Environments," Corrosion-86, Paper No. 258 and Lawrence Livermore National Laboratory, Livermore, CA, UCRL-92941, September, 1985.

Glassley-1986 - Glassley, W. E., "Reference Waste Package Environment Report," Lawrence Livermore National Laboratory, Livermore, CA, UCRL-53726, October 1, 1986.

Johnstone-1981 - Johnstone, J. K. and Wolfsberg, K., editors, "Evaluation Of Tuff As A Medium For A Nuclear Waste Repository: Interim Status Report On The Properties Of Tuff," Sandia National Laboratories, SAND80-1464, July, 1981.

Knauss-1985a - Knauss, K. G., Beiriger, W. J. and Peifer, D. W., "Hydrothermal Interaction Of Crushed Topopah Spring Tuff and J-13 Water At 90,150 , and $250^{\circ} \mathrm{C}$ Using Dickson-Type, GoldBag Rocking Autoclaves, "Lawrence Livermore National Laboratory, Livermore, CA, UCRL-53630, DE86-014752, May, 1985.

Knauss-1985b - Knauss, K. G., Beiriger, W. B., Peifer, D. W. and Piwinskii, A., "Reaction of Solid Wafers Of Topopah Spring Tuff With J-13 Water At 90,150 , and $250^{\circ} \mathrm{C}$ In Dickson-Type, GoldBag Rocking Autoclaves: 1. Short-Term Experiments," Lawrence Livermore National Laboratory, Livermore, CA, UCRL-53645. 
Koch-1988 - Koch, G. H., Spangler, J. M., and Thompson, N. G., "Corrosion Studies In Complex Environments," The Use Of Synthetic Environments For Corrosion Testing, ASTM STP970, P. E. Francis And T. S. Lee, Eds., American Society For Testing And Materials, Philadelphia, PA, 1988, pp. 3-17.

McCright-1984 - McCright, R. D., Weiss, H., Juhas, M. C., and Logan, R. W., "Selection Of Candidate Canister Materials For High-Level Nuclear Waste Containment in A Tuff Repository," Lawrence Livermore National Laboratory, Livermore, CA, UCRL 89988 and Corrosion '84, Paper No. 198, April, 1984.

McCright-1985 - McCright, R. D., "FY 1985 Status Report On Feasibility Assessment Of CopperBase Waste Package Container Materials In A Tuff Repository," Lawrence Livermore National Laboratory, Livermore, CA, UCID-20509, September, 1985.

Montazer-1984 - Montazer, P. and Wilson, W. E., "Conceptual Hydrologic Model Of Flow in The Unsaturated Zone, Yucca Mountain, Nevada," U. S. Geological Survey - Water Resources Investigation Report, USGS-WRI-84-4345, 1984.

Oversby-1983 - Oversby, V. M., Knauss, K. G., "Reaction Of Bullfrog Tuff With J-13 Well Water At $90^{\circ} \mathrm{C}$ and $150^{\circ} \mathrm{C}$," Lawrence Livermore National Laboratory, Livermore, CA, UCRL-53442, DE84-000659, September, 1983.

Pitman-1986 - Pitman, S. G., Westerman, R. E., Haberman, J. H., "Corrosion And Slow Strain Rate Testing Of Type 304L Stainless Steel in Tuff Groundwater Environments, " Pacific Northwest Laboratory, Richland, WA, PNL-SA-14396, DE87-006404, October, 1986.

Schuraytz-1985 - Schuraytz, B., "Geochemical Gradients In The Topopah Spring Member Of The Paintbrush Tuff: Evidence For Eruption Across A Magmatic Interface," Lawrence Livermore National Laboratory, Livermore, CA, UCRL-53698.

Van Konynenburg-1986 - Van Konynenburg, R. A., "Radiation Chemical Effects In Experiments To Study. The Reaction Of Glass In A Gamma-Irradiated Air, Groundwater, And Tuff Environment," Lawrence Livermore National Laboratory, Livermore, CA, UCRL-53719.

Yunker-1986a - Yunker, W. H., "Corrosion. Of Copper-Based Materials In Gamma Radiation," Westinghouse Hanford Company, HEDL-7612, DE87-005494, June, 1986.

Yunker-1986b - Yunker, W. H., Westinghouse Hanford Company, and Glass, R. S., Lawrence Livermore National Laboratory, "Long-Term Corrosion Behavior Of Copper-Base Materials in A Gamma-Irradiated Environment," UCRL-94500, DE87-007098, December, 1986. 
APPENDIX A

CYCLIC POTENTIODYNAMIC POLARIZATION CURVES

FOR ALLOY CDA 102

IN TEST SOLUTIONS FROM THE

RESOLUTION IV MATRIX 


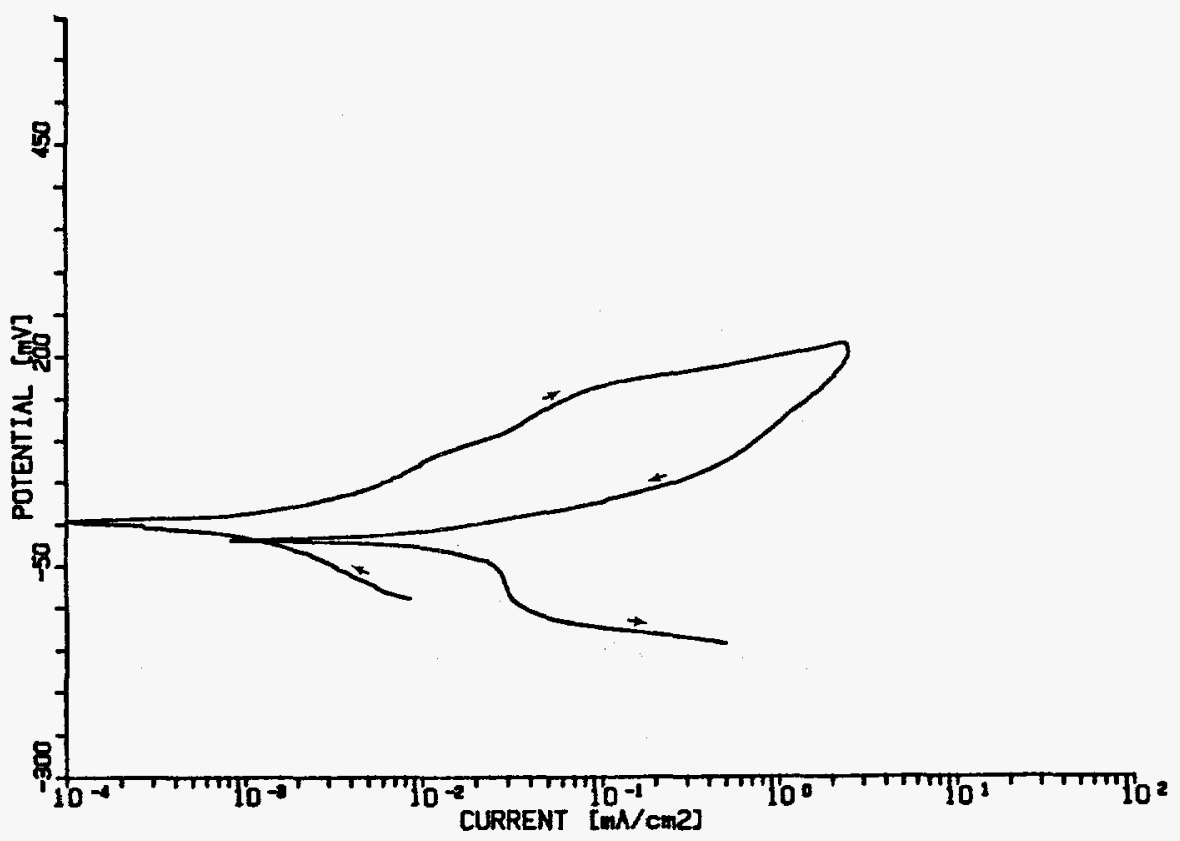

Figure Al. Potent lodynamic Polerization Curve For Alloy CDA 102 In Solut lon No. 1 At $90^{\circ} \mathrm{C}$.

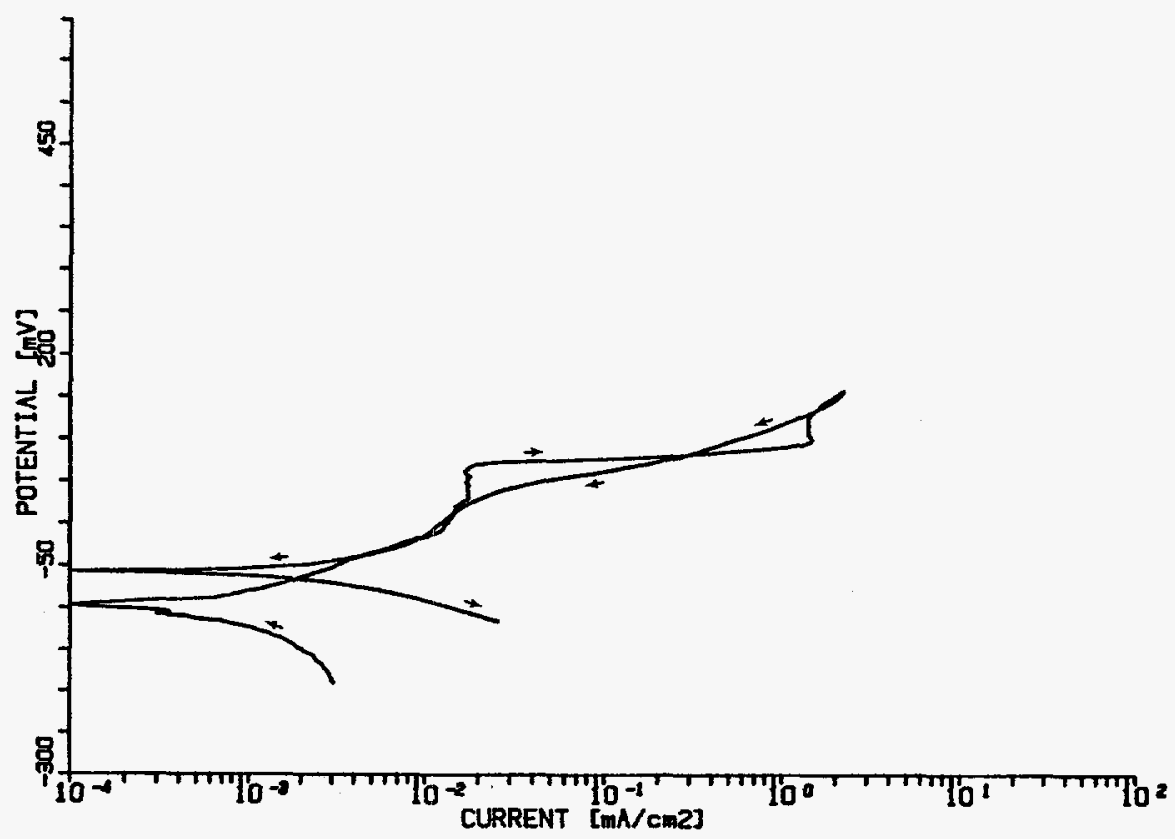

Figure A2. Potentlodynamic Rolarization Curve For Alloy CDA 102 In Solution No. 2 At $50^{\circ} \mathrm{C}$. 


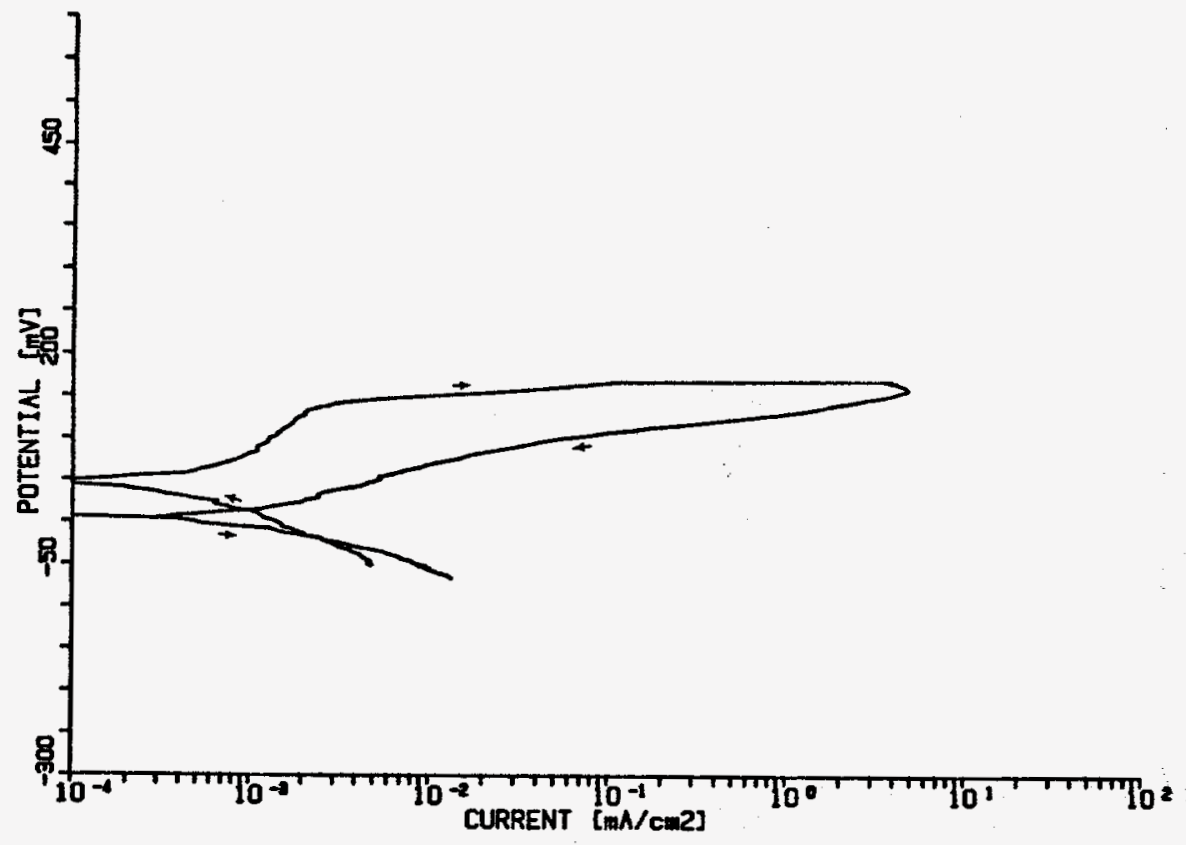

Figure A3. Potentlodynamic Polarization Curve For Alloy CDA 102 In Solution No. 3 At $50^{\circ} \mathrm{C}$.

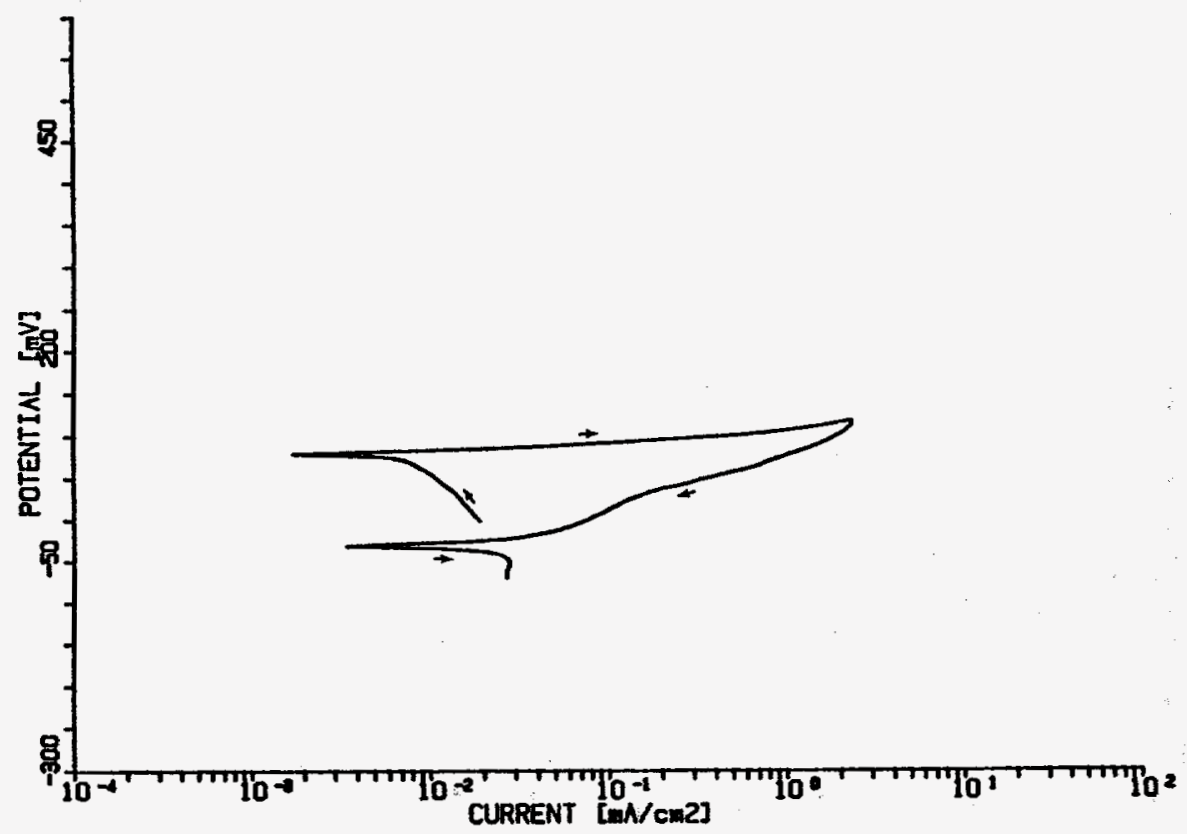

Figure A4. Potentiodrnemic Polarlzation Curve For Alloy CDA 102 In Solution No. At $90^{\circ} \mathrm{C}$. 


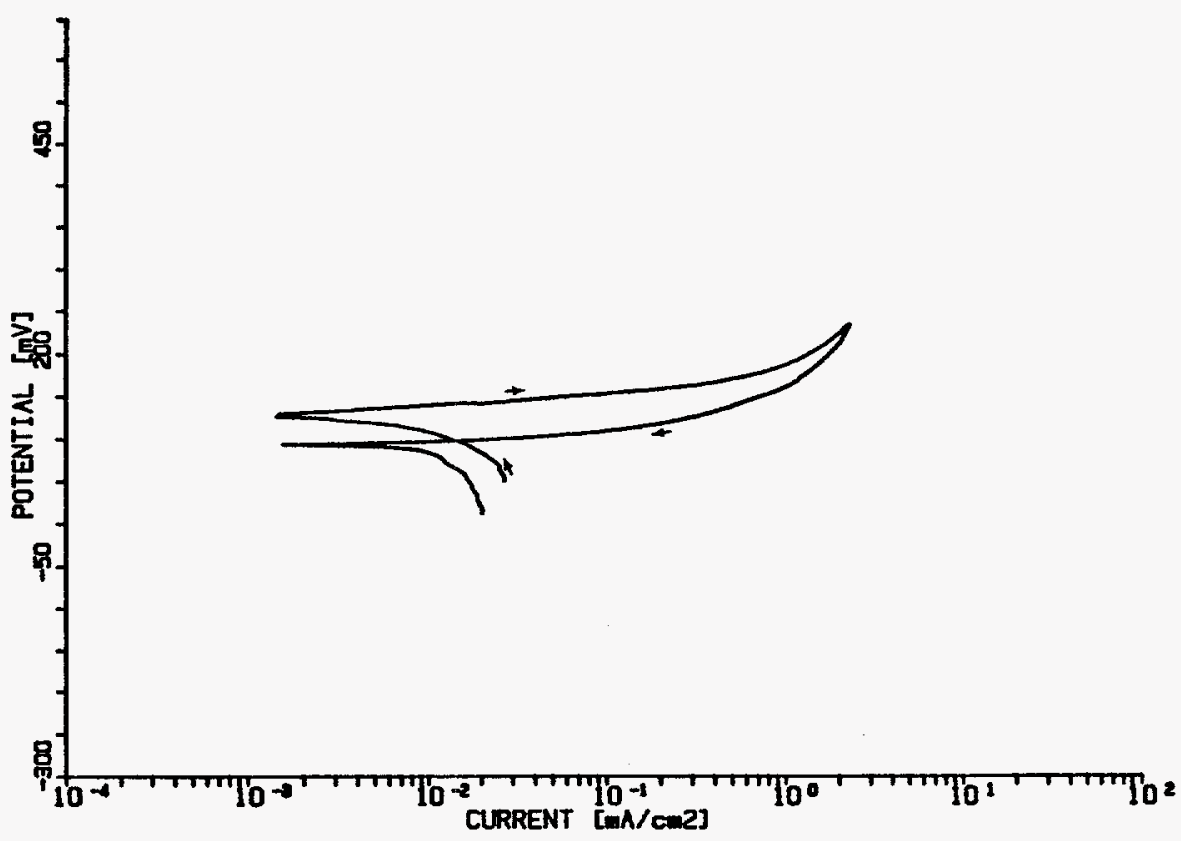

Figure A5. Potentlodynamic Rolerization Curve For Alloy CDA 102 In Solution No. 5 At $50^{\circ} \mathrm{C}$.

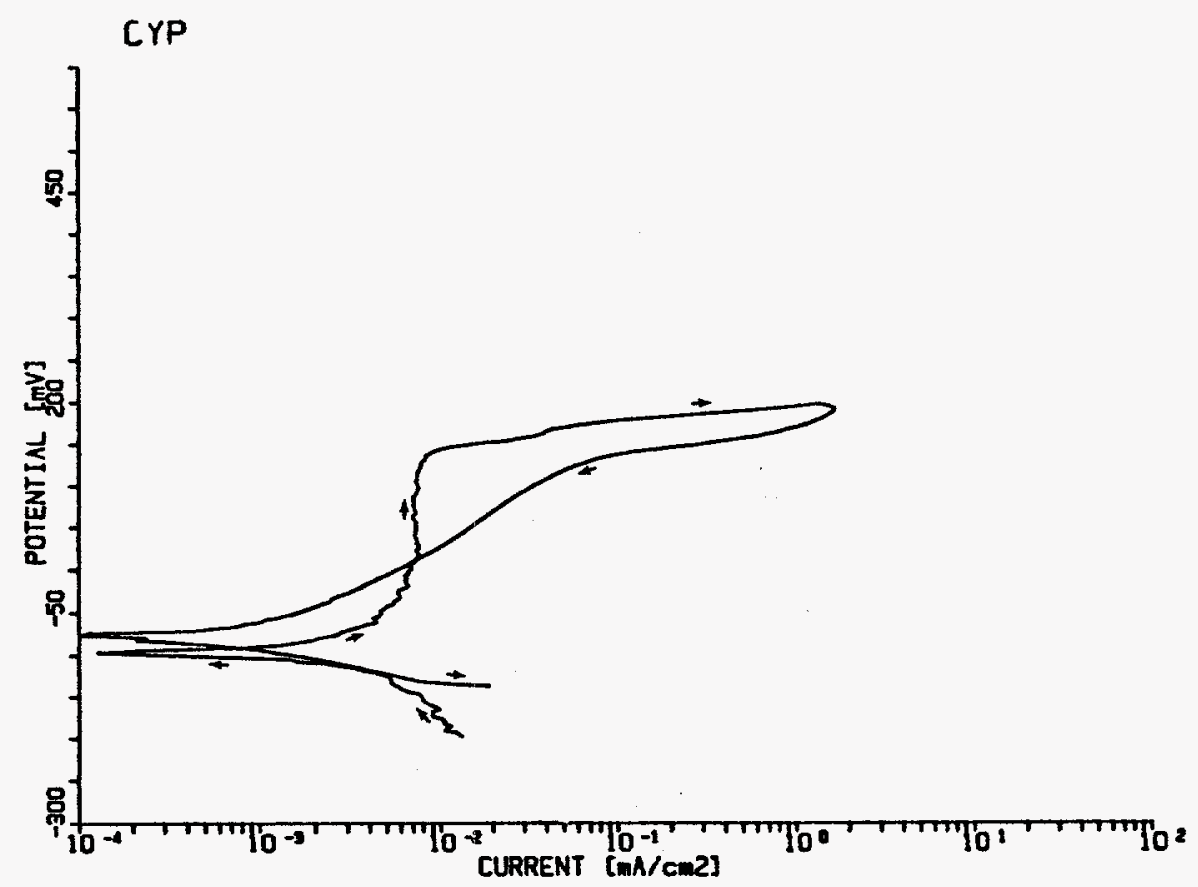

Figure A6. Potent lodynamie Polarization Curve For Allos CDA 102 In Solution No. 6 At $90^{\circ} \mathrm{C}$. 


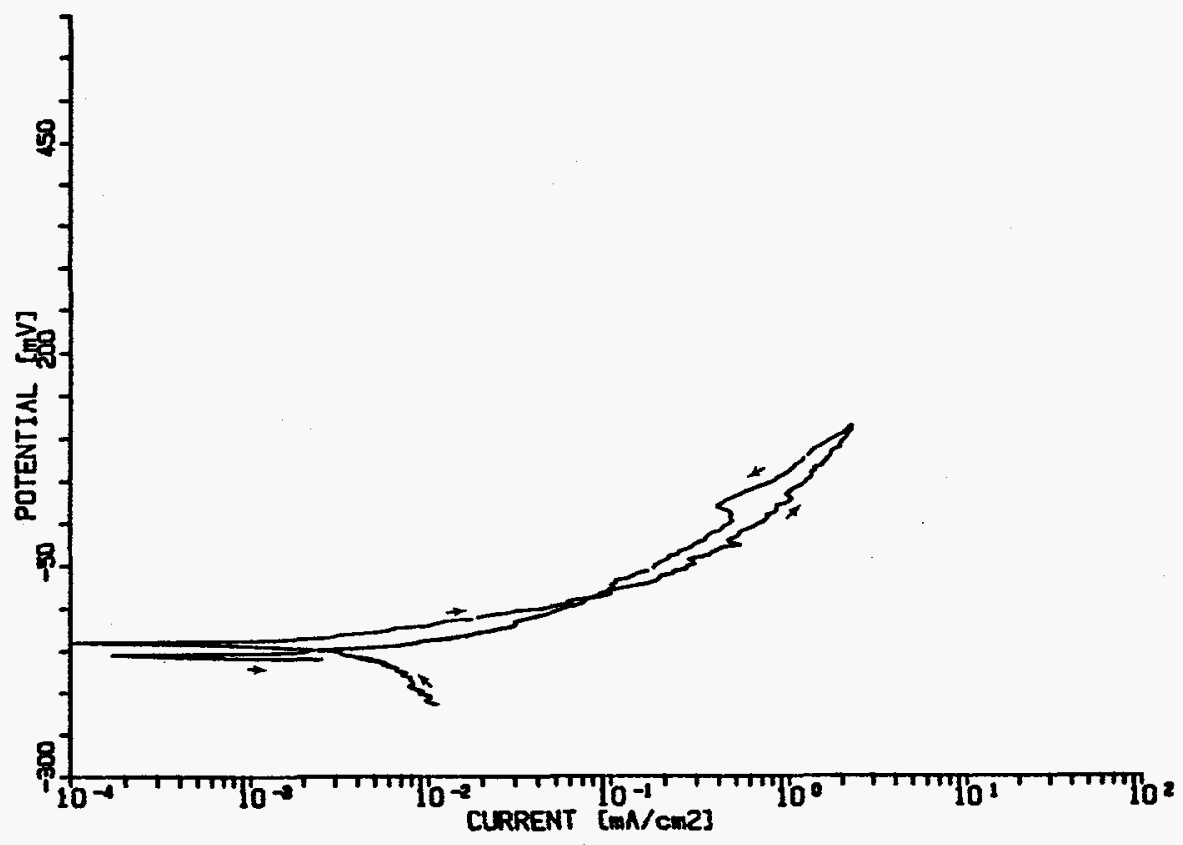

Figure 17. Potentlodjnamle Polarization Curve For Alloy CDA 102 In Solution No. 7 At $90^{\circ} \mathrm{C}$.

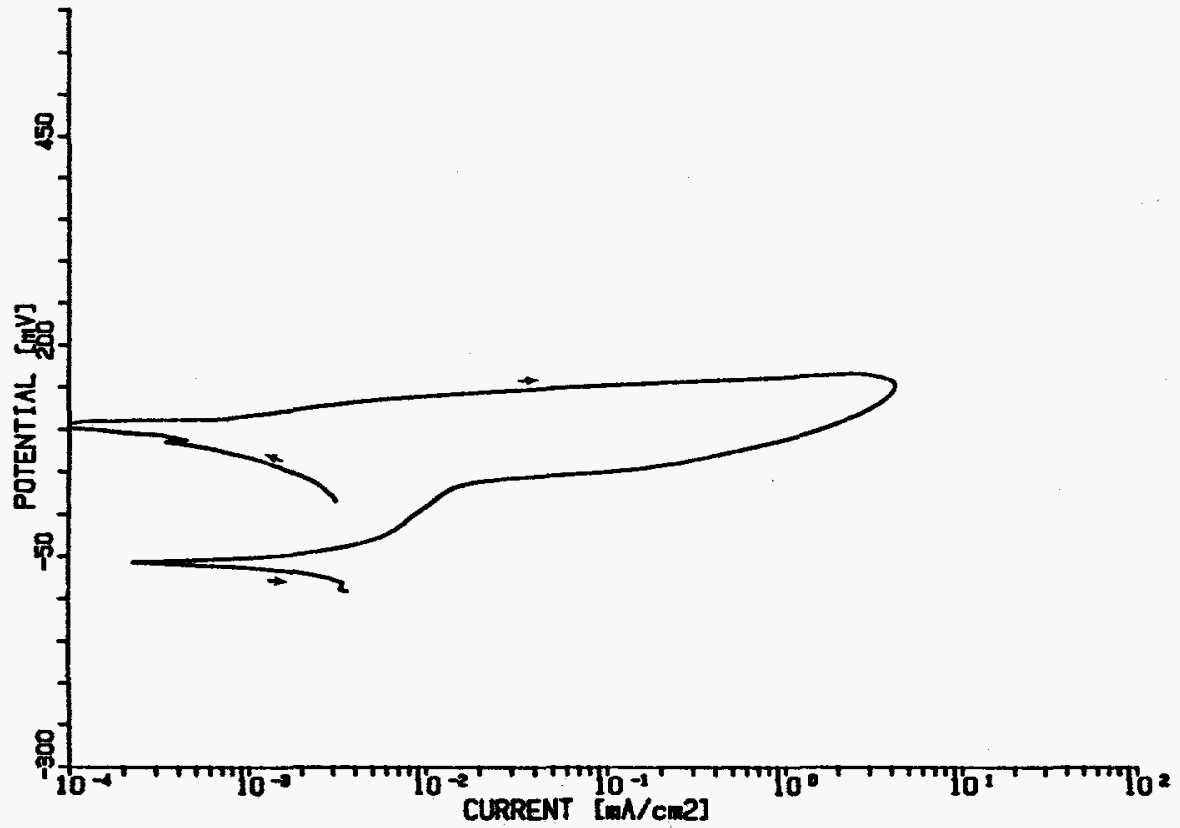

F1gure A8. Potentlodynamic Polarization Curve For Alloy CDA 102 In Solution Mo. 8 At $50^{\circ} \mathrm{C}$. 


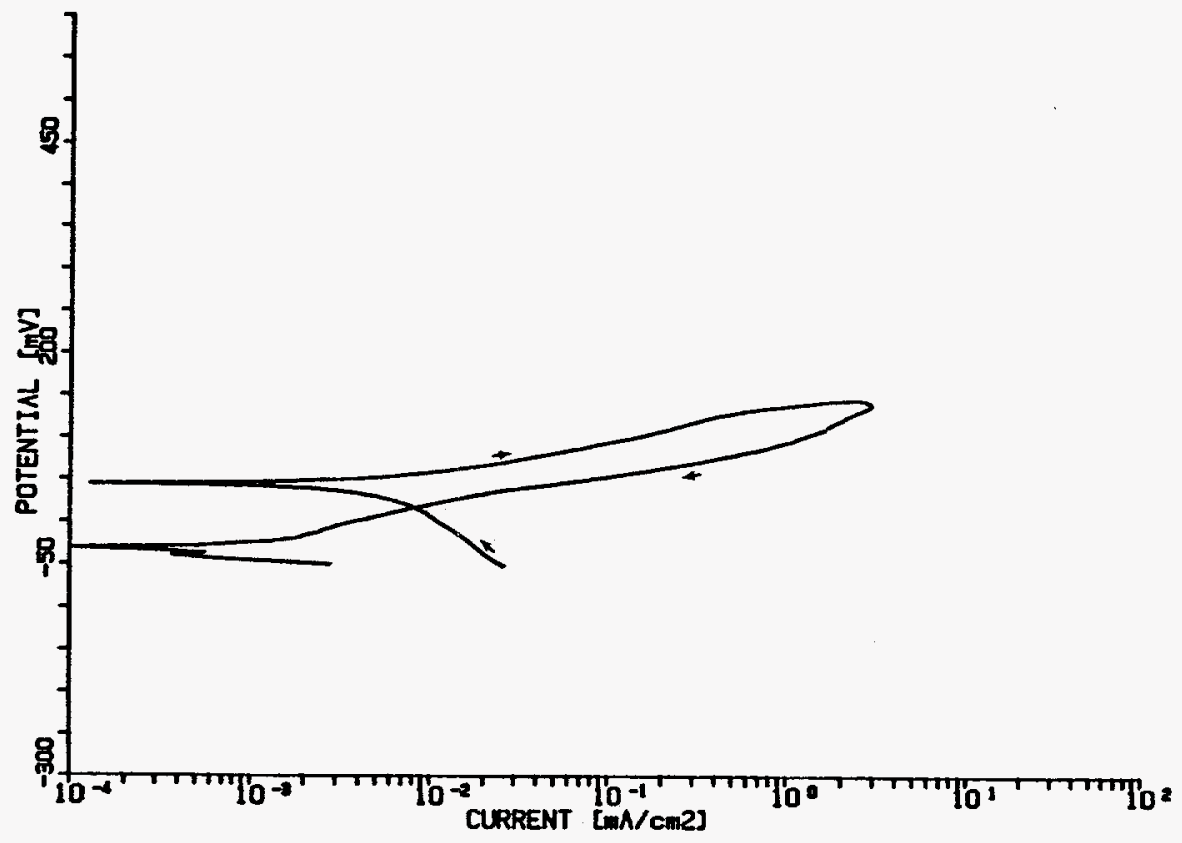

Figure A9. Potentlodynamle Rolerization Curve For Alloy CDA 102 In Solution No. 9 At $50^{\circ} \mathrm{C}$.

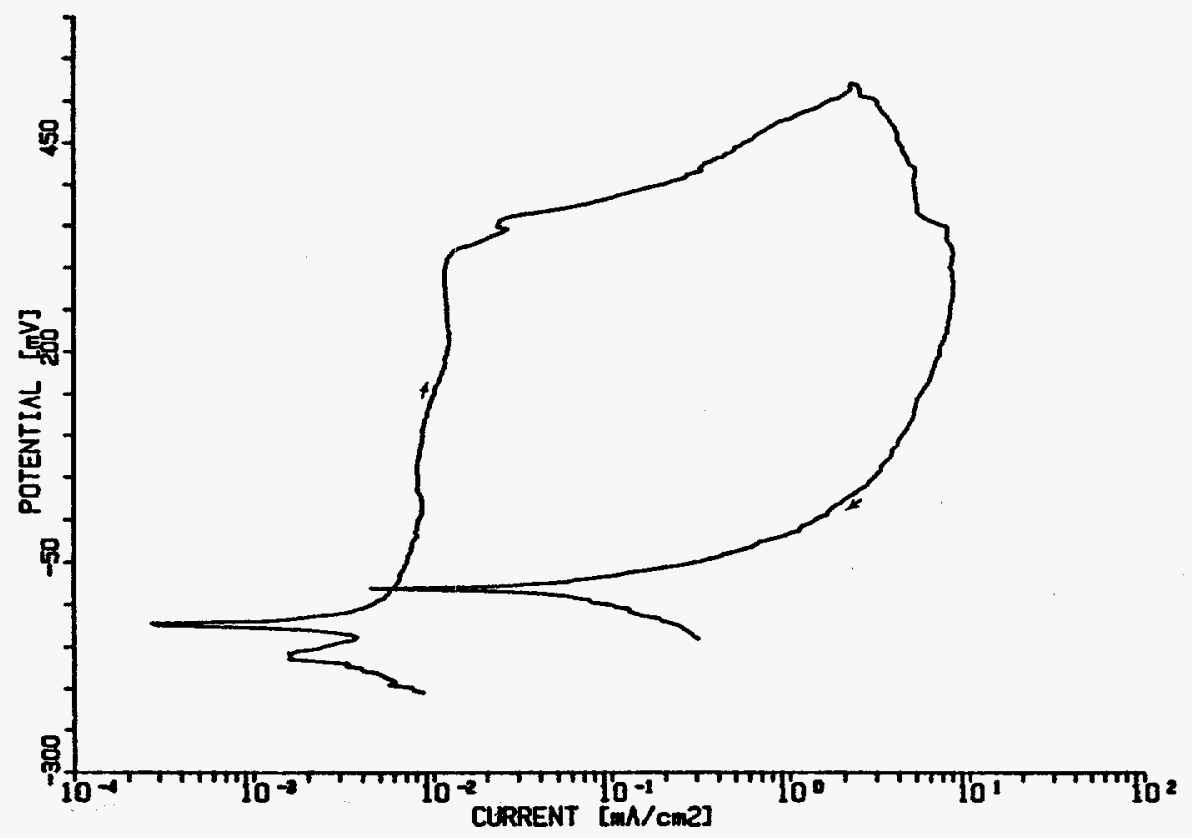

Flgure AlO. Potentiodynamic Polarization Curve For Alloy CDA 102 In Solution No. $10^{\circ}$ at $90^{\circ} \mathrm{C}$. 


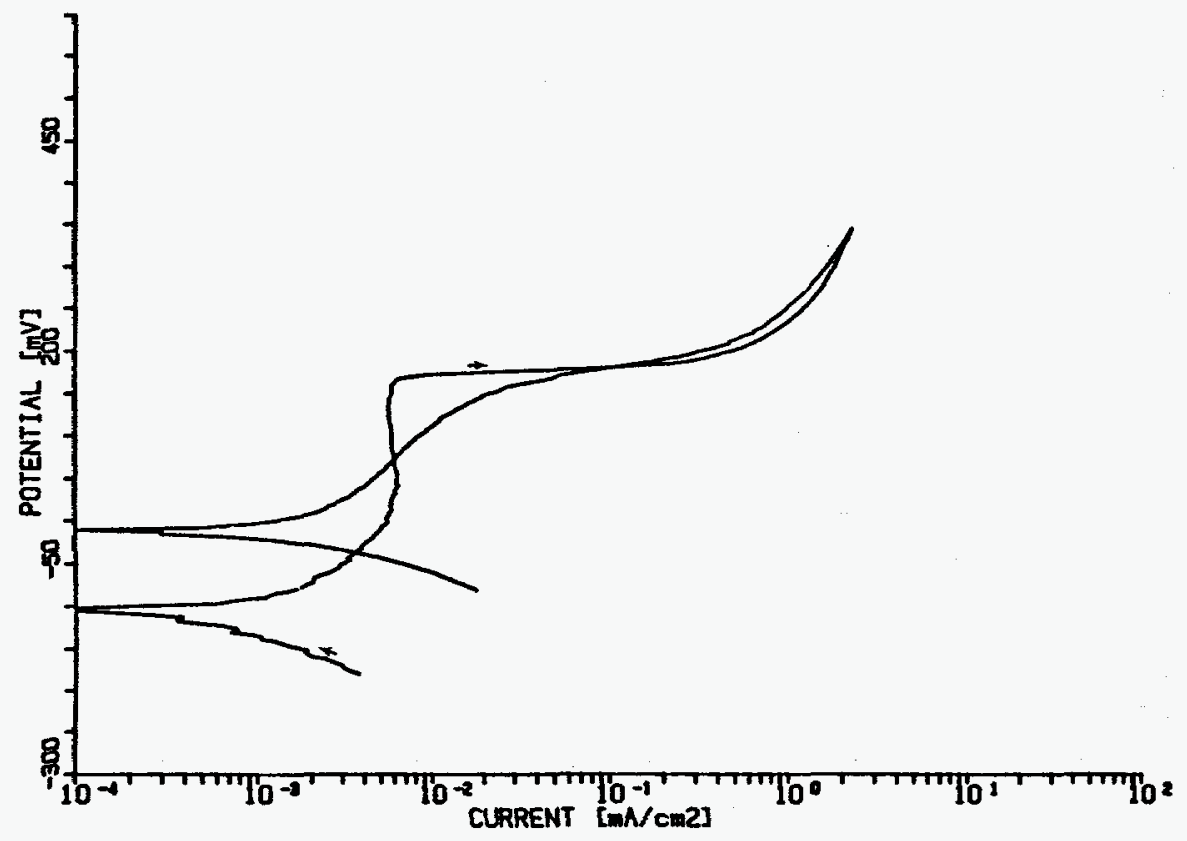

Figure All. Potentlodganic Polarization Curve For Alloy CDA 102 In Solution Ho. 11 at $90^{\circ} \mathrm{C}$.

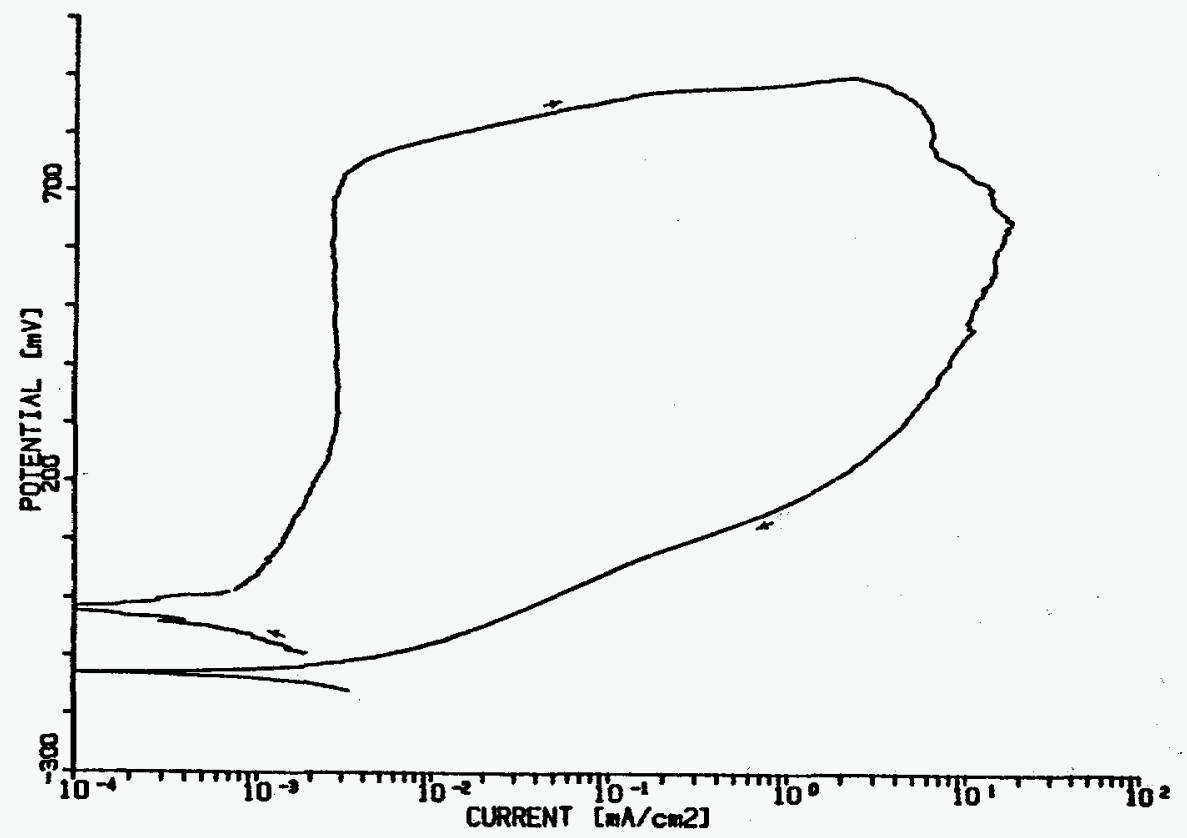

F1gure A12. Potentiodynamic Polarization Curve For Alloy CDA 102 In Solution No. 12 At $50^{\circ} \mathrm{c}$. 


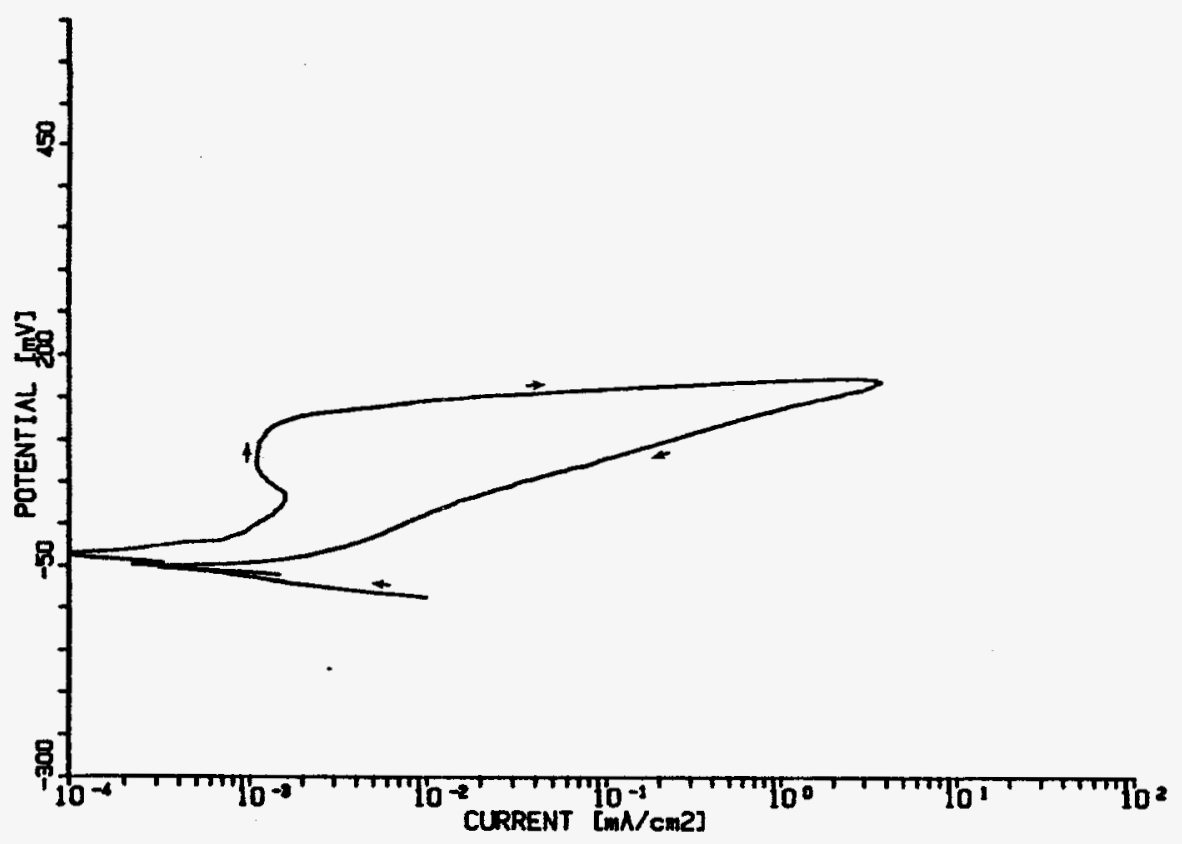

Figure A13. Potentlodynamle Rolarization Curve For Alloy CDA 102 In Solution No. 13 at $90^{\circ} \mathrm{C}$.

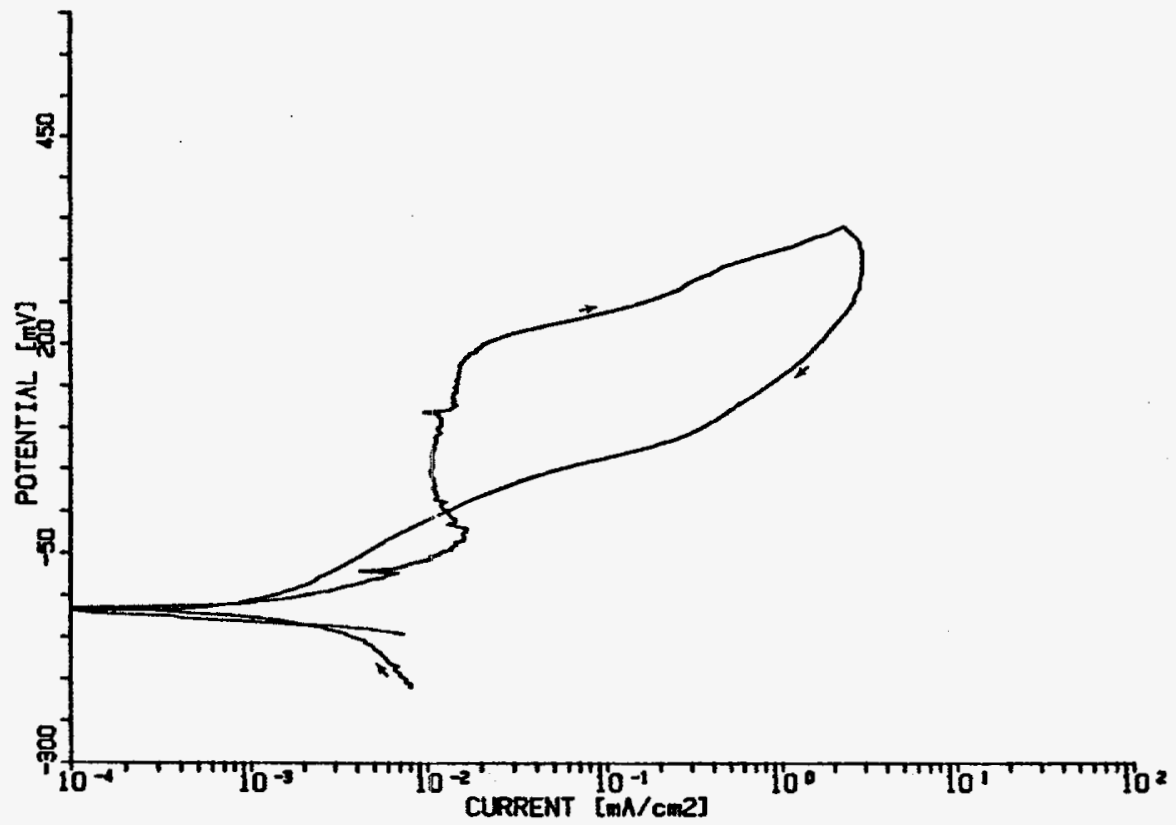

Figure A14. Potent lodynaric Polarization Curvo For Alloy CDA 102 In Solution No. 14 At $50^{\circ} \mathrm{C}$. 


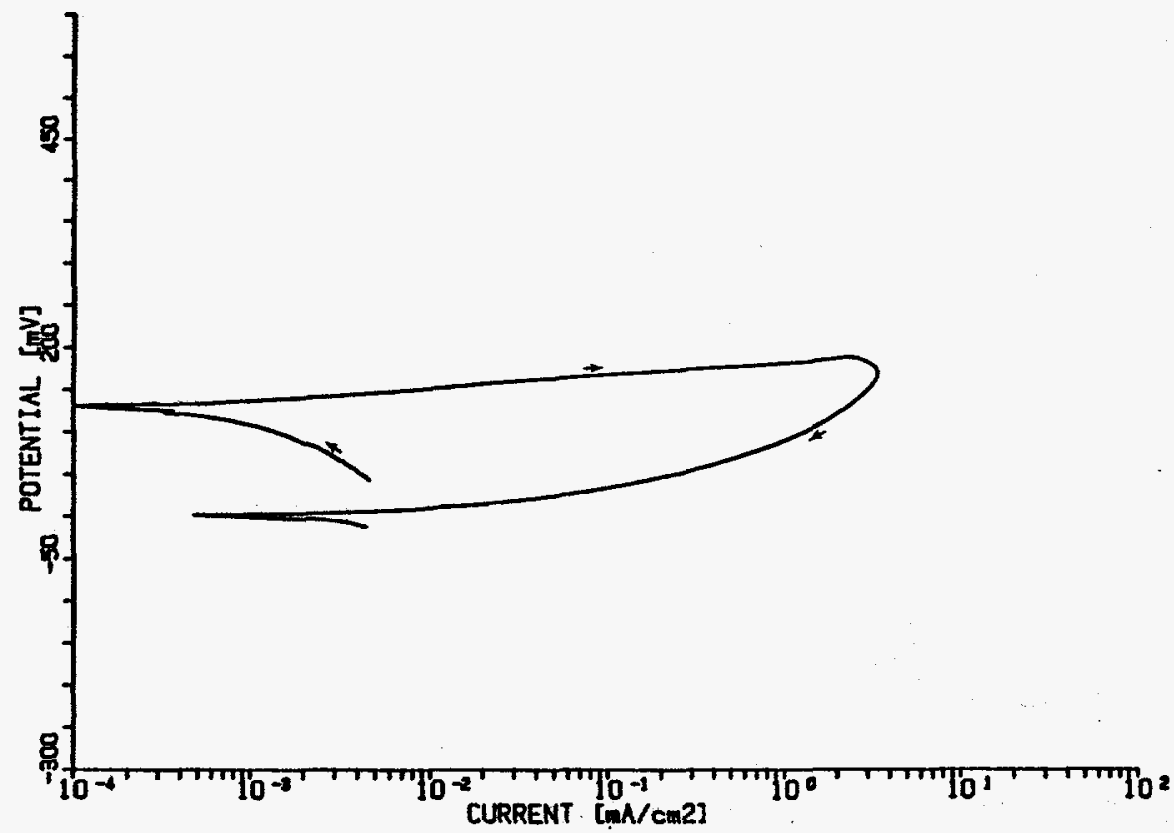

Figure 115. Rotentiodynamic Polarization Curve For Alloy CDA 102 In Solution No. 15 At $50^{\circ} \mathrm{C}$.

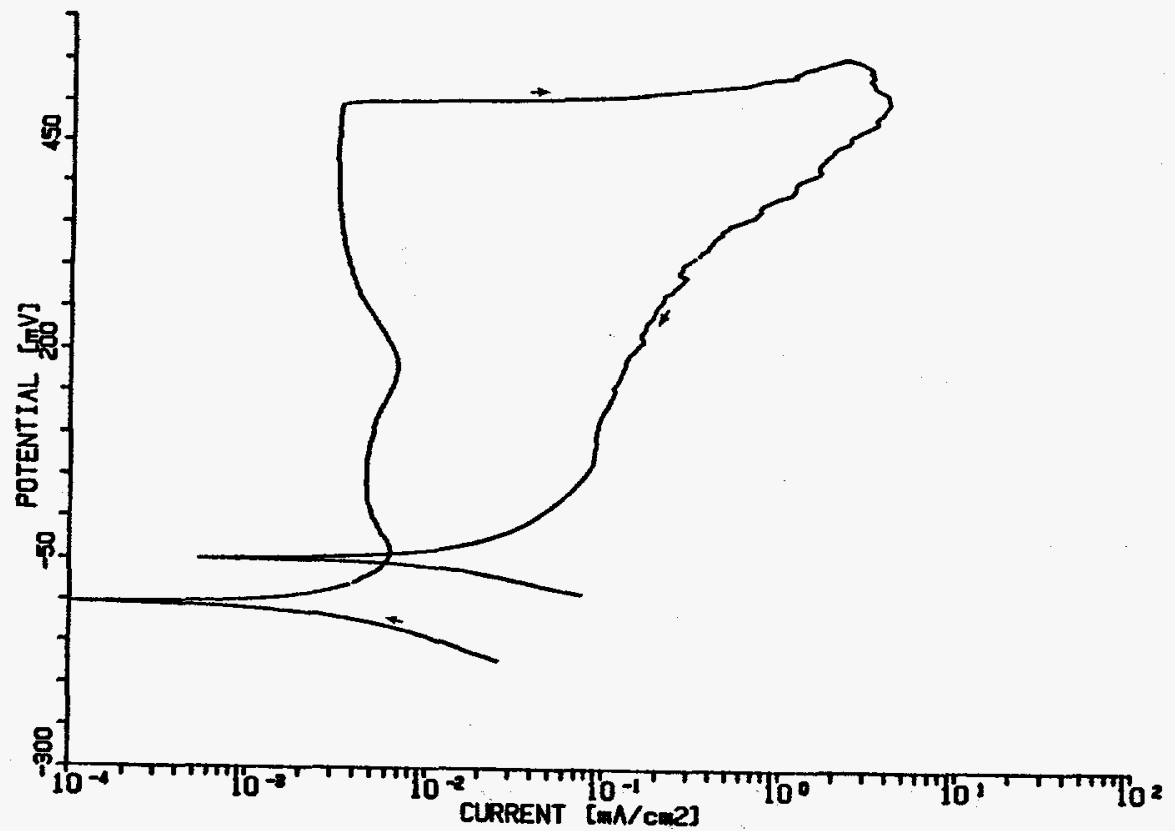

Figure A16. Rotentlodynamic Polarization Curve For Alloy CDA 102 In Solution No. 16 At $90^{\circ} \mathrm{C}$. 


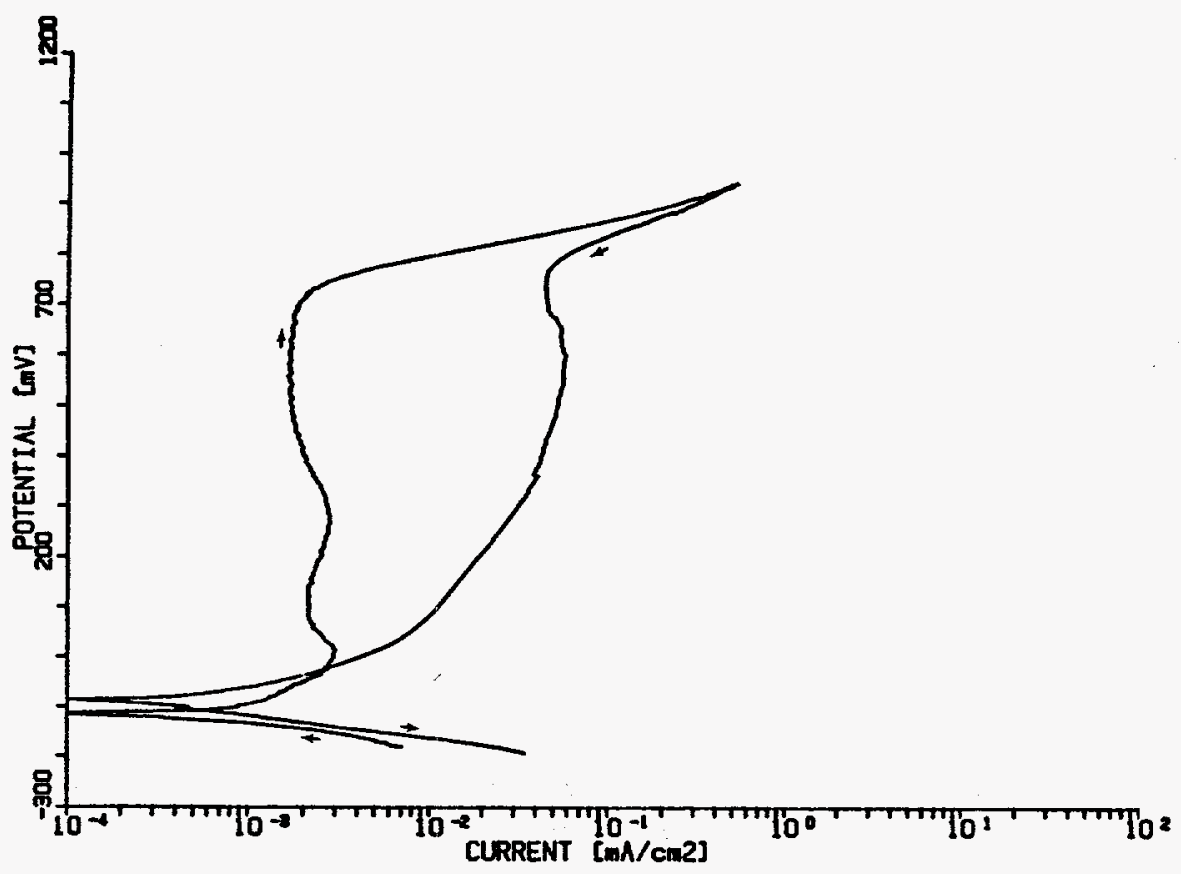

Figure A17. Fotentlodynamic Polarization Curve For Alloy CDA 102 In Solution No. 17 At $50^{\circ} \mathrm{C}$.

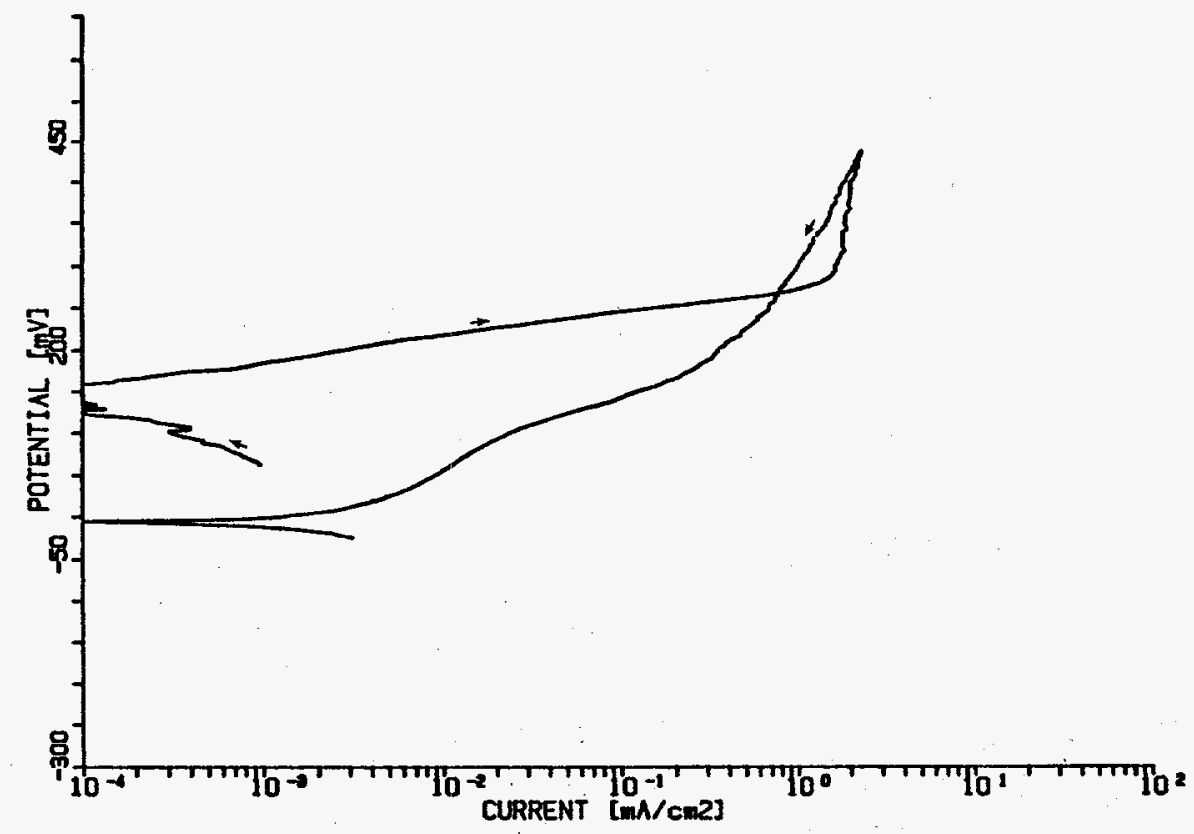

Figure Al8, Potentlodynamie Polarization Curve For Alloy CDA 102 In Solution No. 18 At $90^{\circ} \mathrm{C}$. 


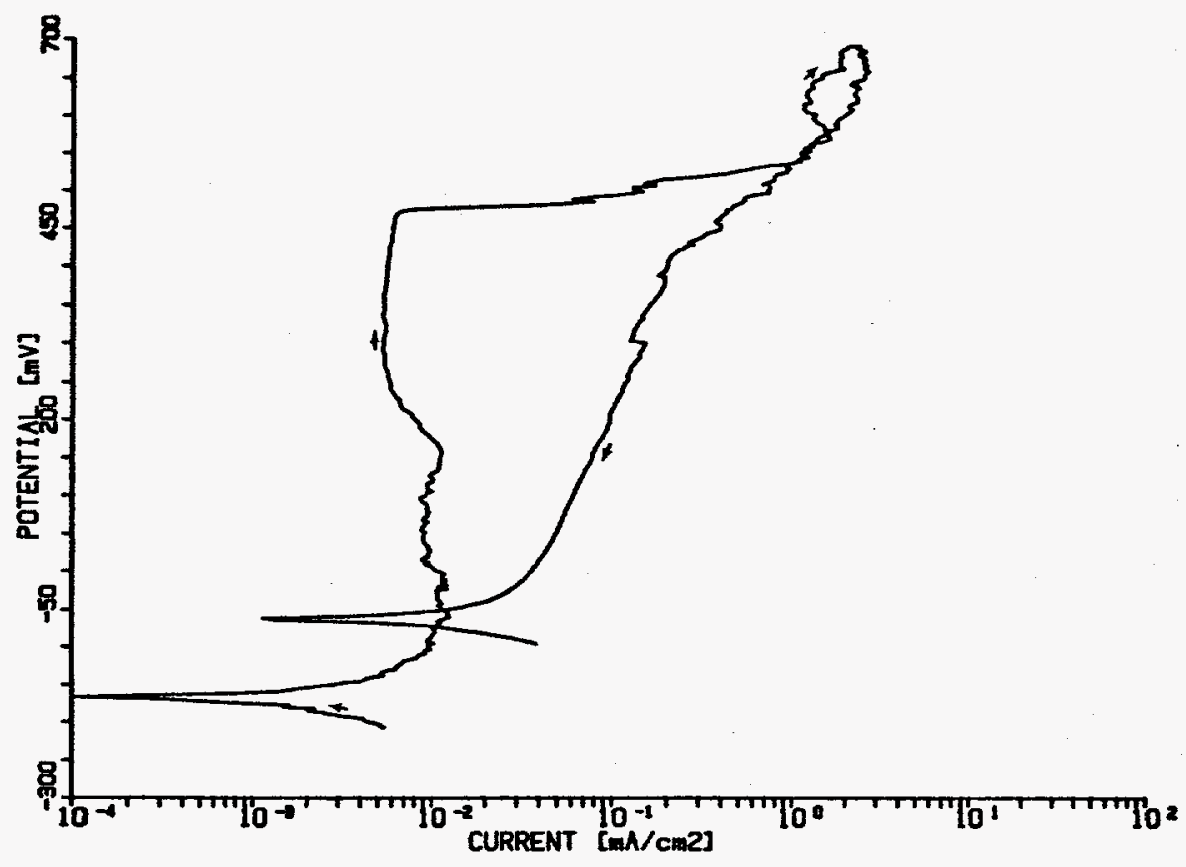

F1gure A19. Potentiodynamic Folarization Curve For Alloy CDA 102 In Solution No. 19 At $90^{\circ} \mathrm{C}$.

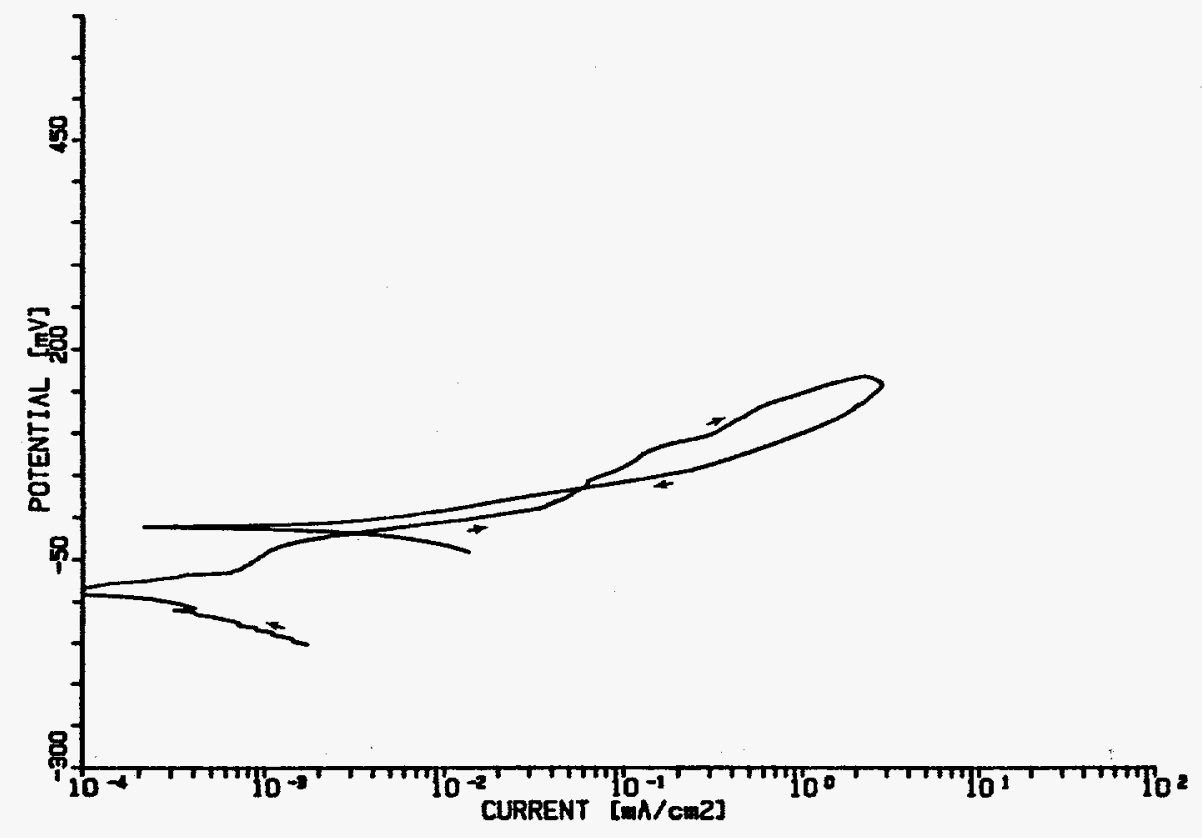

T1gure A20. Potentlodynamic Polarizetion Curve For Alloy CDA 102 In Solution No. 20 At $50^{\circ} \mathrm{C}$. 


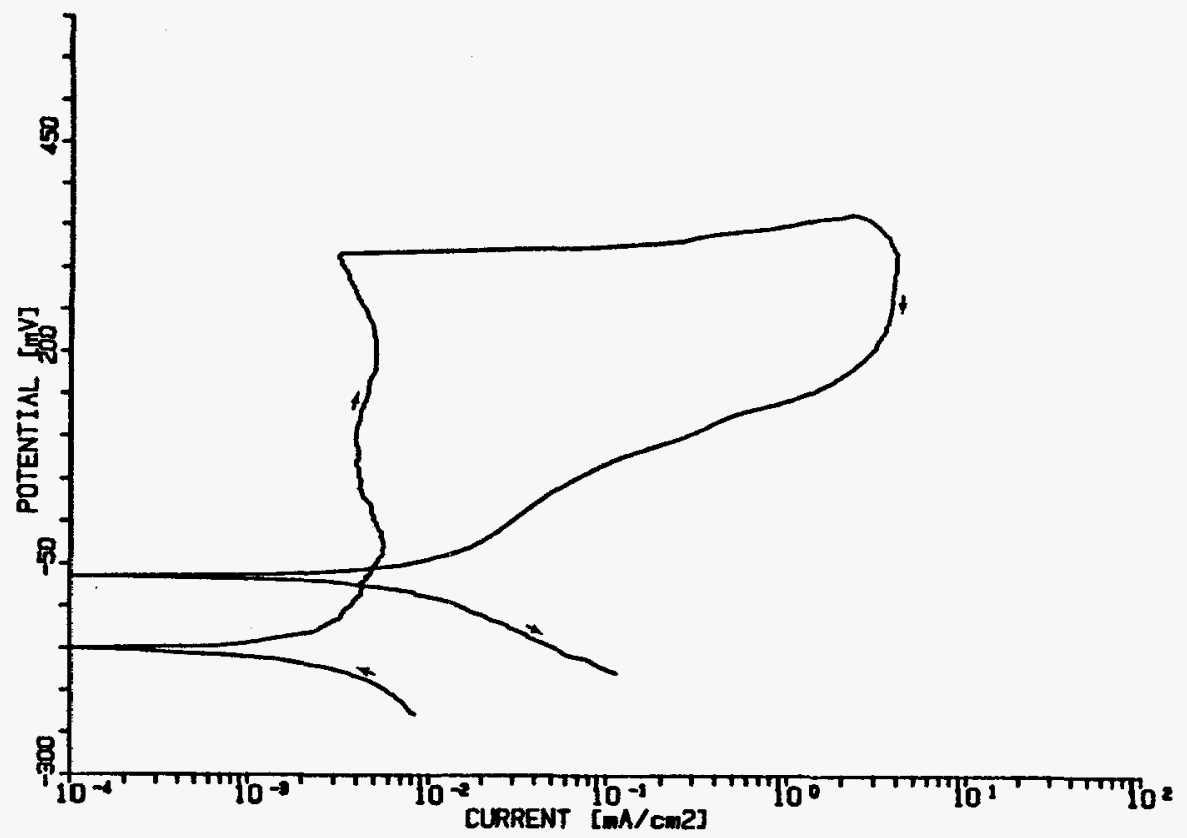

F1gure A21. Potentlodynanic Rolarization Curve For Alloy CDA 102 In Solution No. 21 At $90^{\circ} \mathrm{C}$.

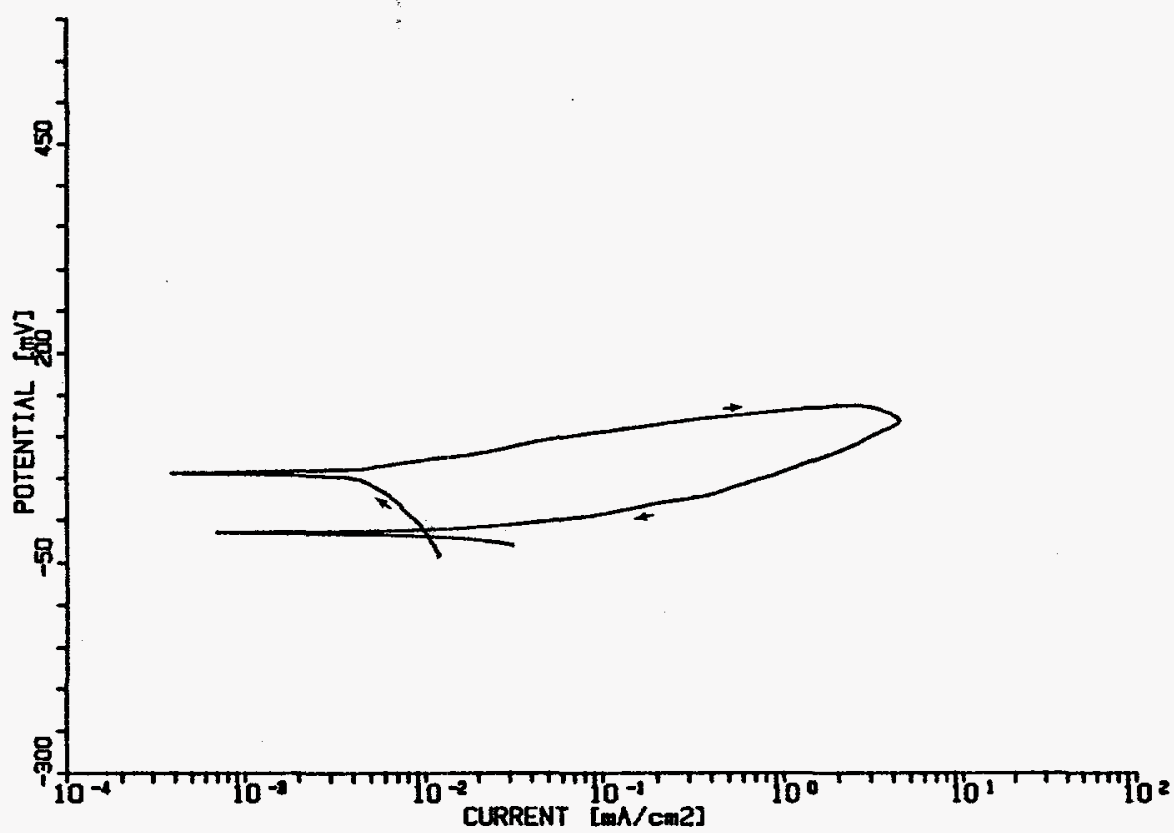

Figure A22. Potentlodynamic Polarlzation Curve For A1loy CDA 102 In Solution No. 22 at $50^{\circ} \mathrm{C}$. 


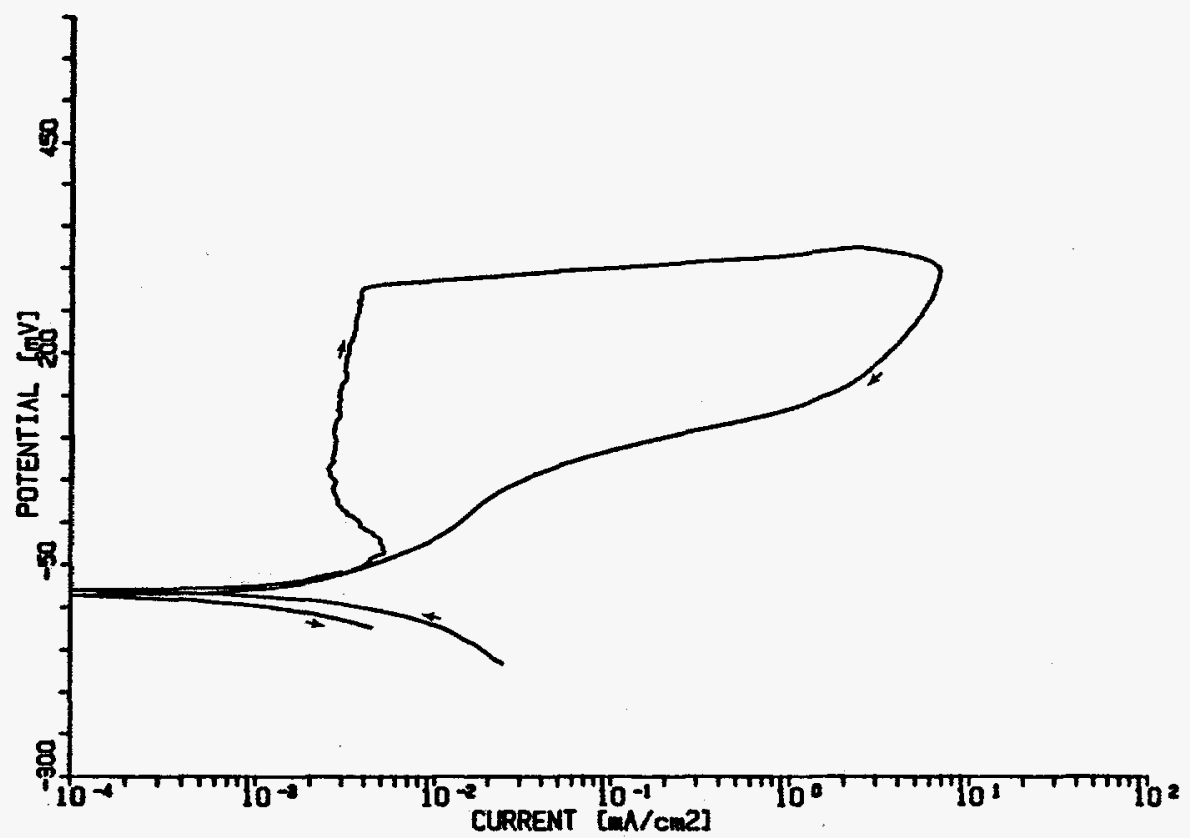

Figure A23. Potentiodynanic Polarizetion Curve For Alloy CDA 102 In Solution No, 23 At $50^{\circ} \mathrm{C}$.

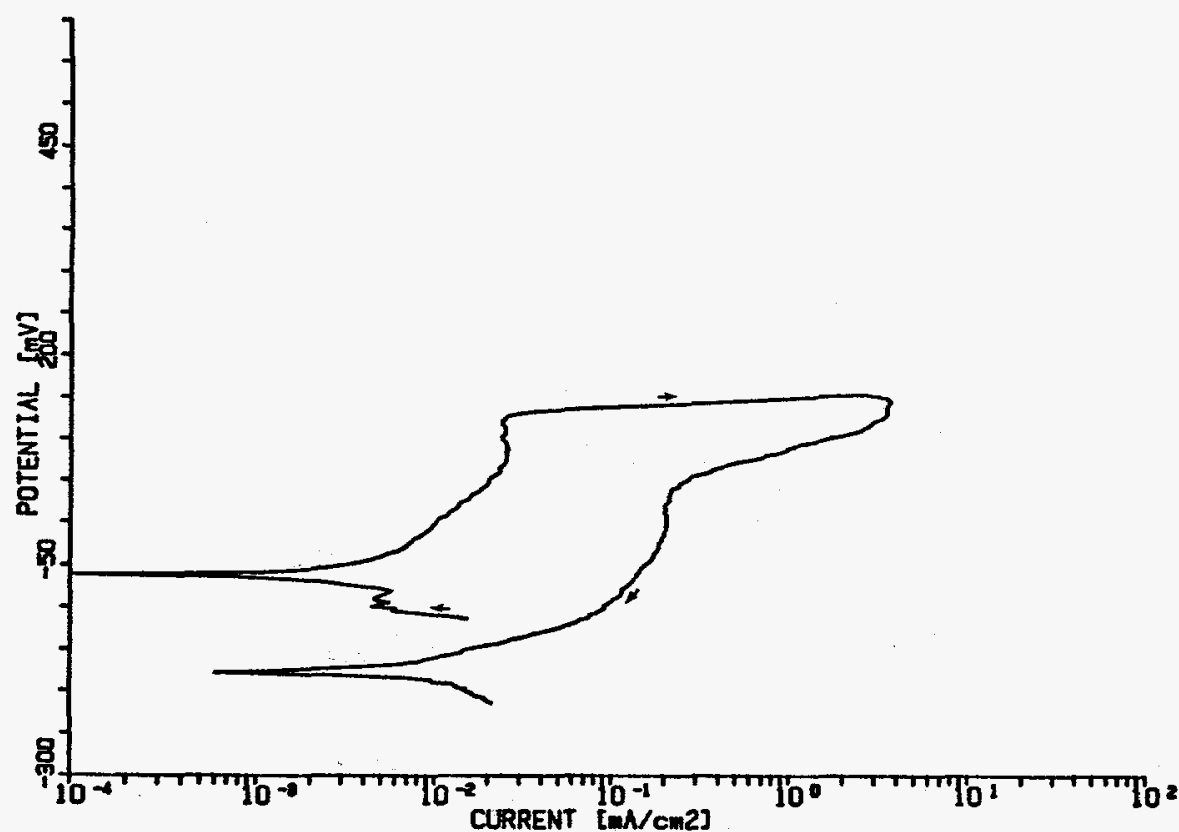

F1gure A24. Potentiodynamic Polarization Curve For A1loy CDA 102 In Solution No. 24 At $90^{\circ} \mathrm{C}$. 


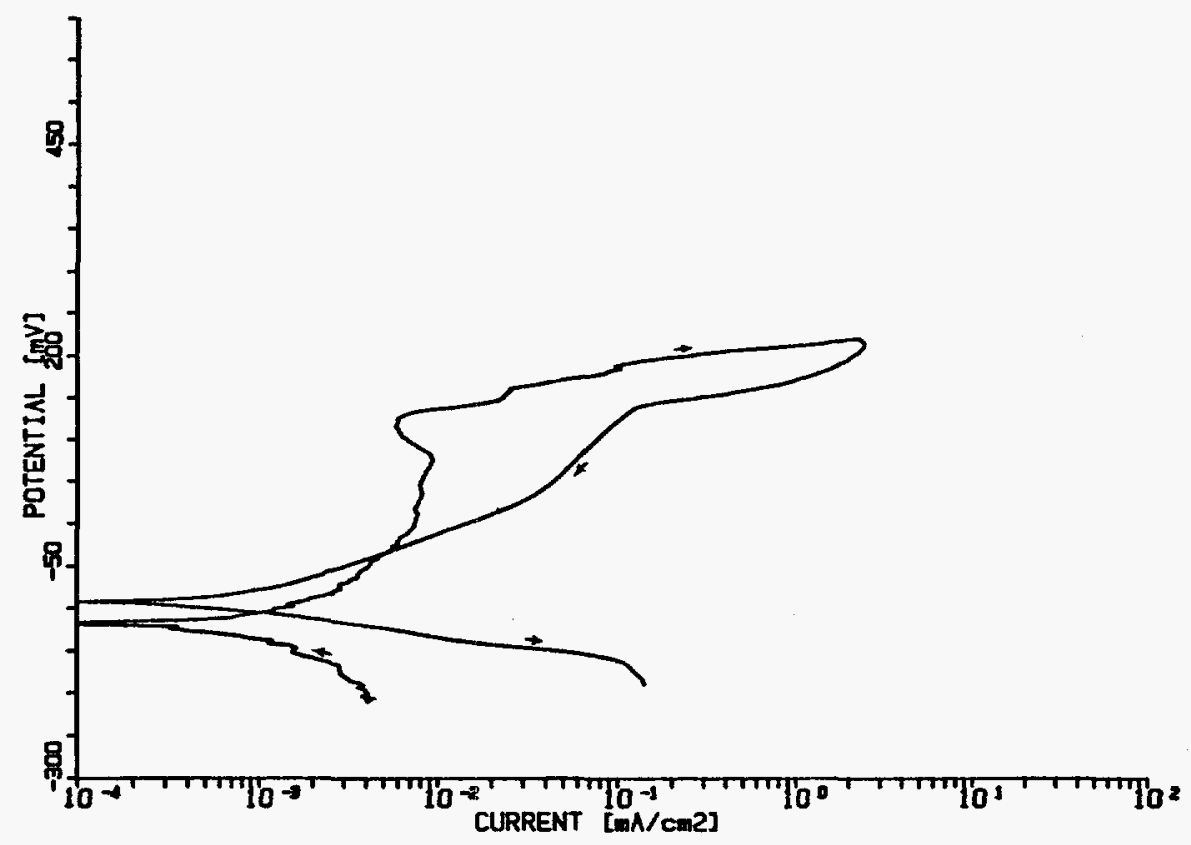

Figure A25. Potentlodynamle Polarization Curve For Alloy CDA 102 In Solut lon No. 25 At $90^{\circ} \mathrm{C}$.

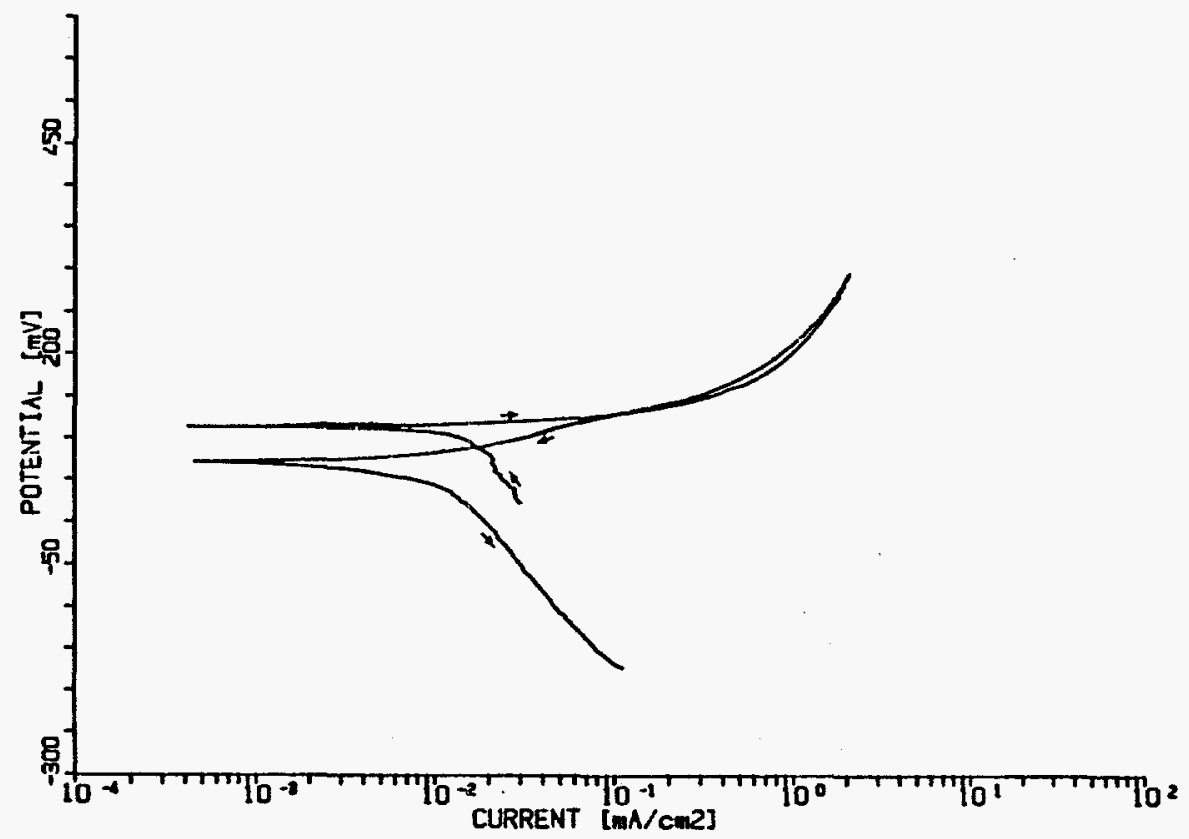

Figure A26. Potentfodynamic Polarfzation Curve For Alloy CDA 102 In Solution No. 26 At $50^{\circ} \mathrm{C}$. 


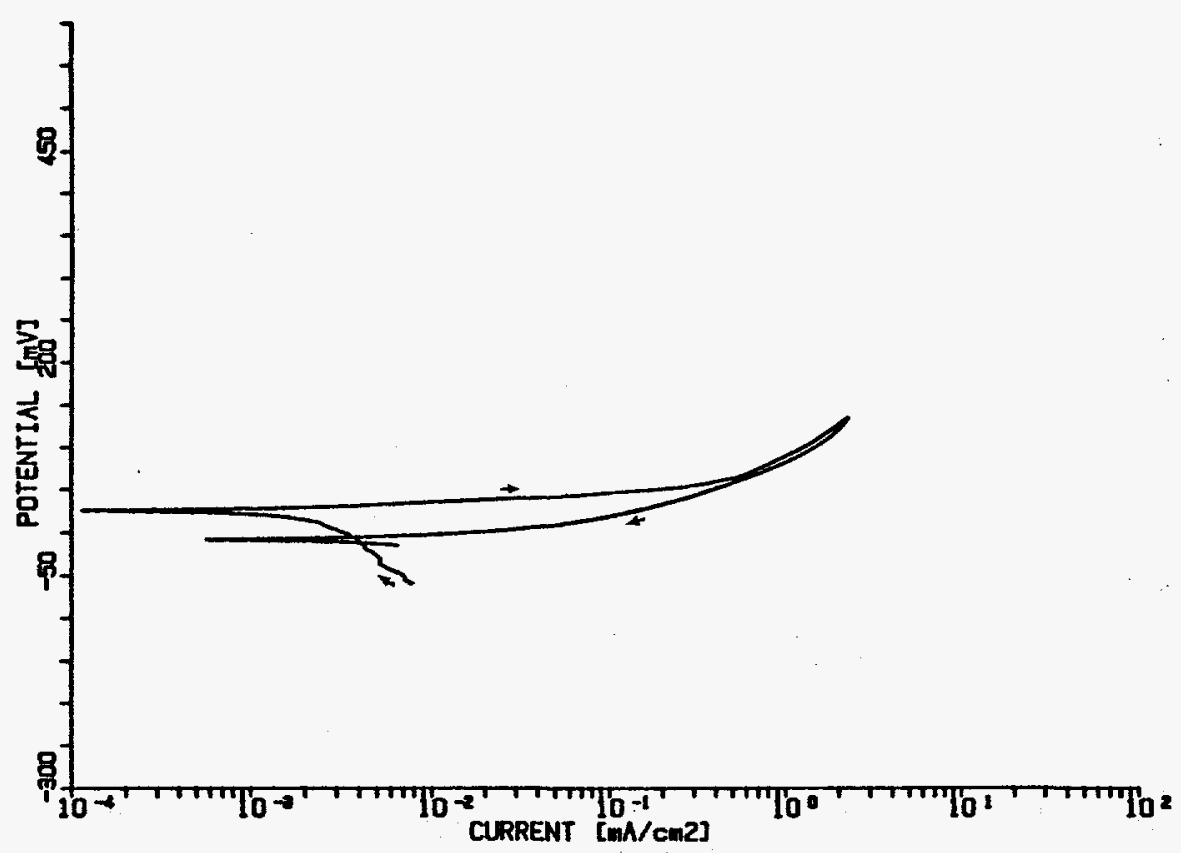

Figure A27. Potent lodynamic Polarization Curve For Alloy CDA 102 In Solution No. 27 at $50^{\circ} \mathrm{C}$.

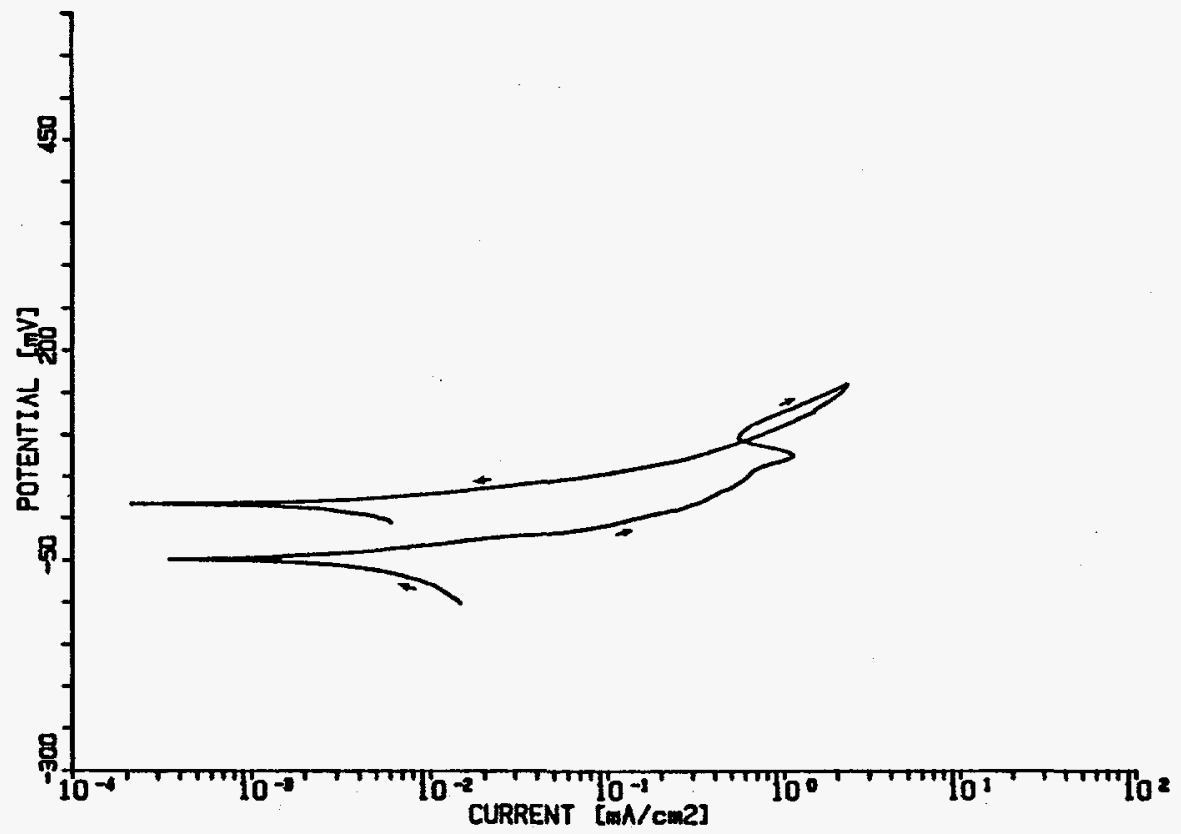

Figure A28. Potentlodynamic Polarization Curve For A1loy CDA 102 In Solution No. 28 At $90^{\circ} \mathrm{C}$. 


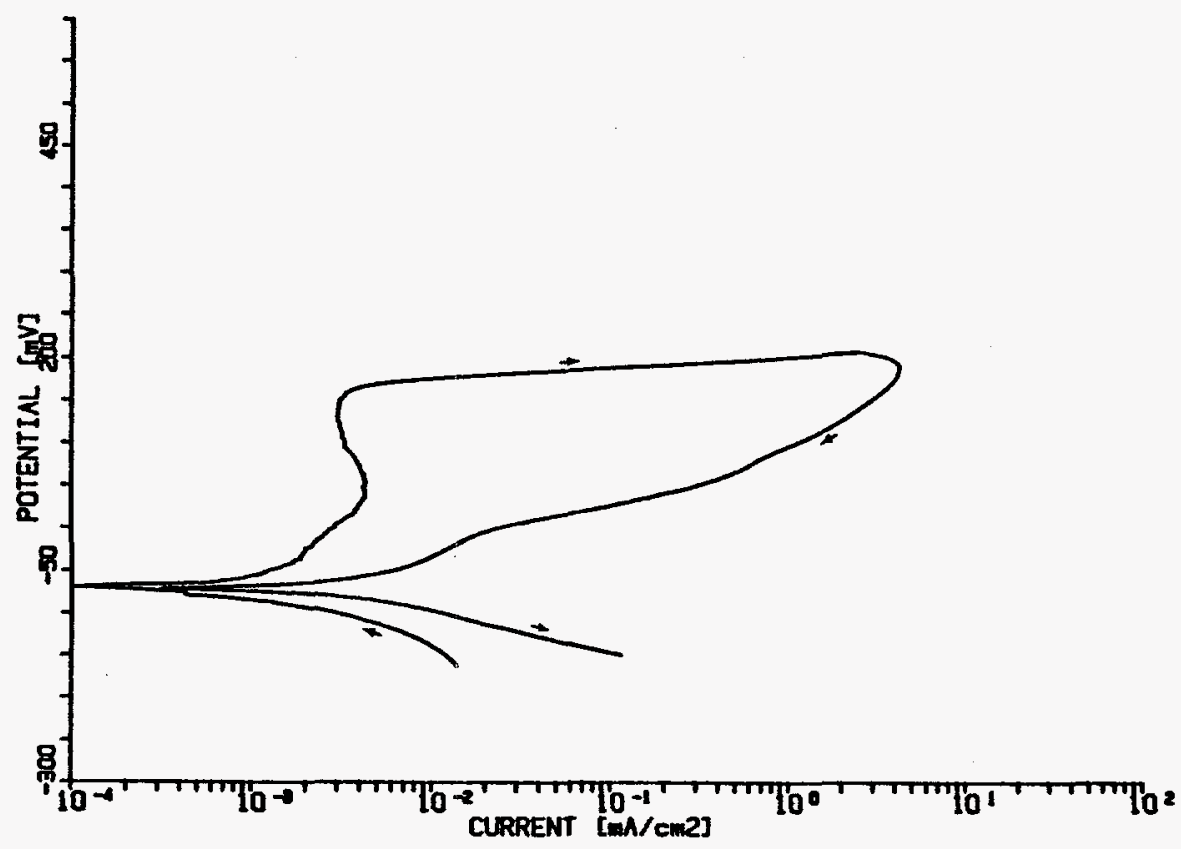

Fleure 129. Potentiodynamle Folerleation Curve For Alloy CDA 102 In Solution No. 29 At $50^{\circ} \mathrm{C}$.

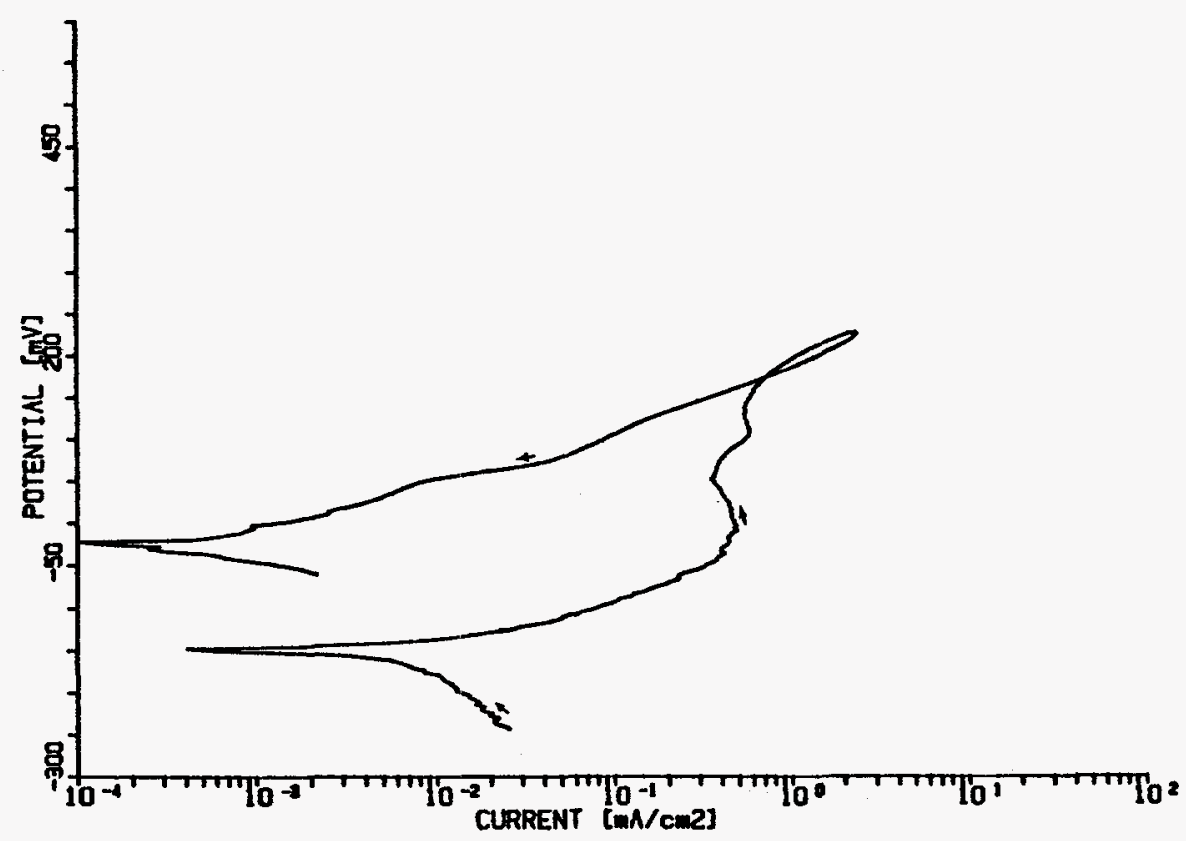

Figure A30. Fotentlodynamic Polerlzation Curve For Alloy CDA 102 In Solution No. 30 at $90^{\circ} \mathrm{C}$. 


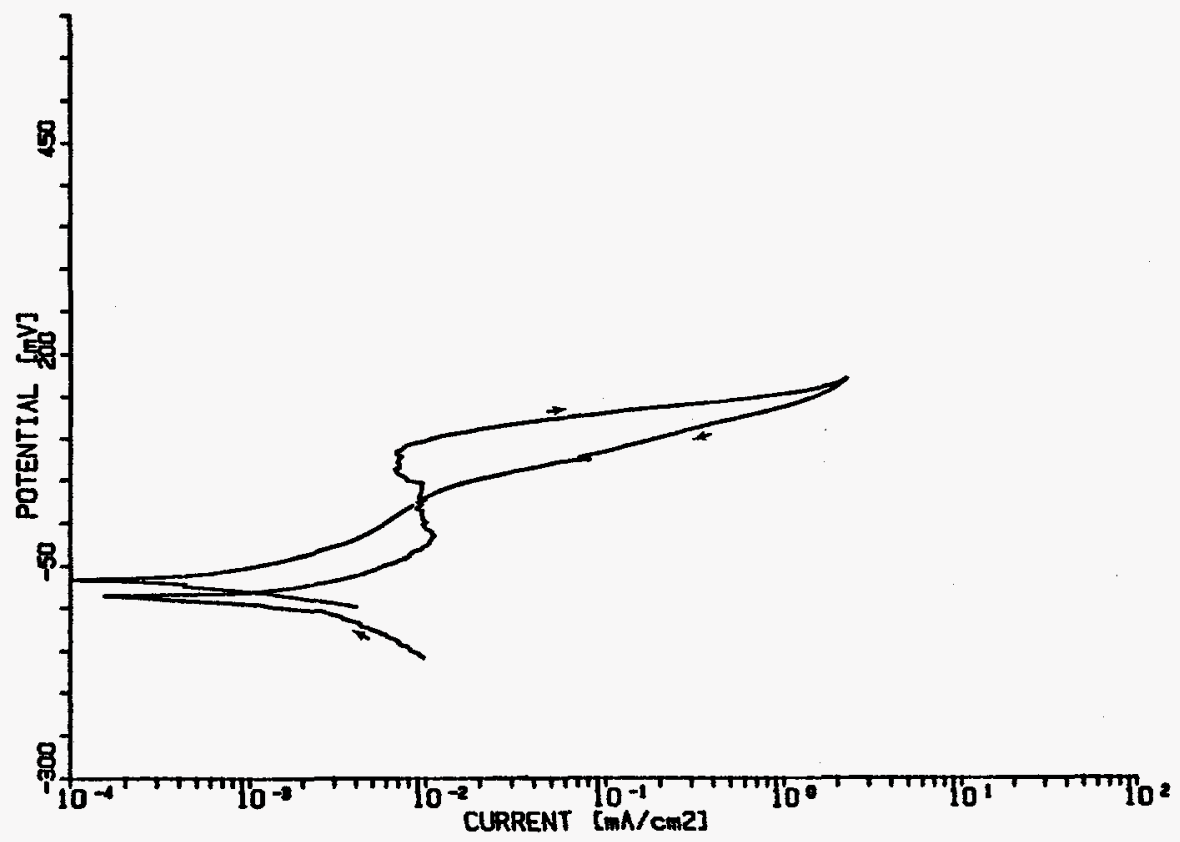

Figure A31. Potentiodynamlc Polarizetion Curvo For Alloy CDA 102 In Solution No. 31 At $90^{\circ} \mathrm{C}$.

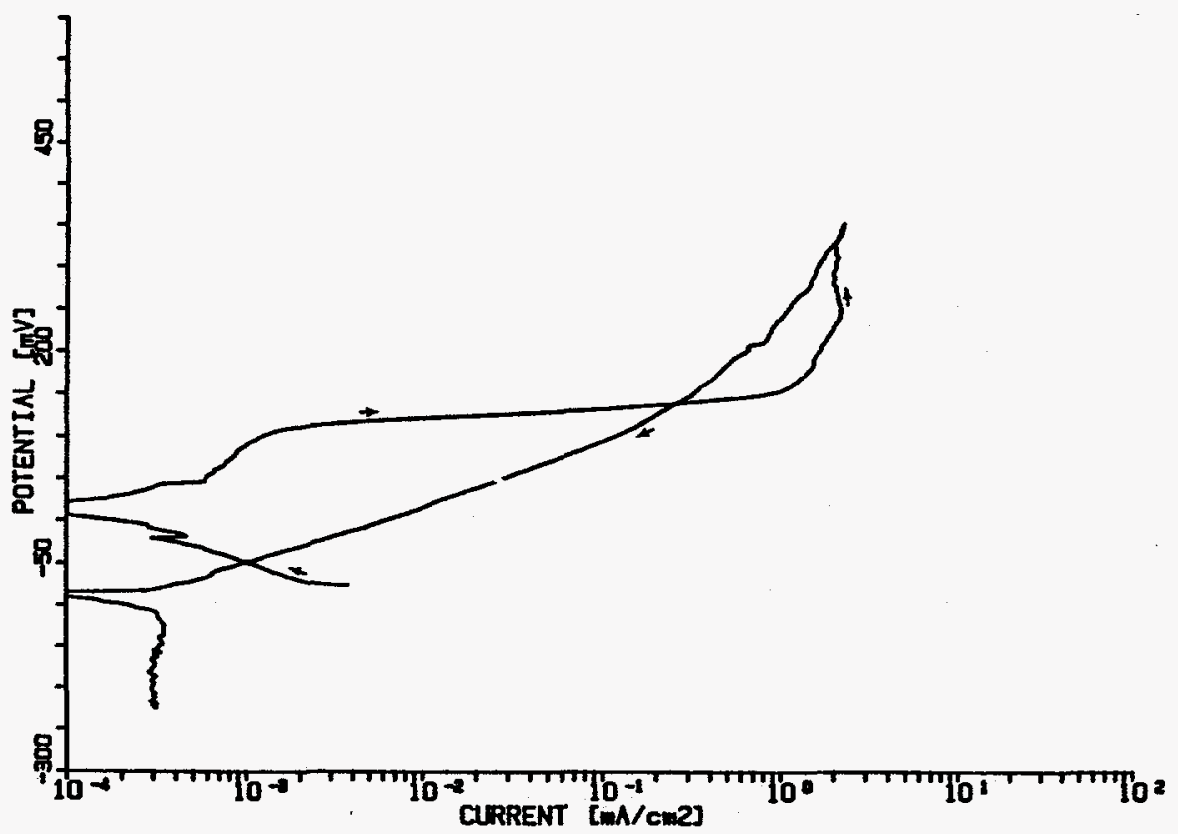

Figure A32. Potentlodynanic Polarization Curve For Allog CDA 102 In Solution Ho. 32 at $50^{\circ} \mathrm{C}$. 


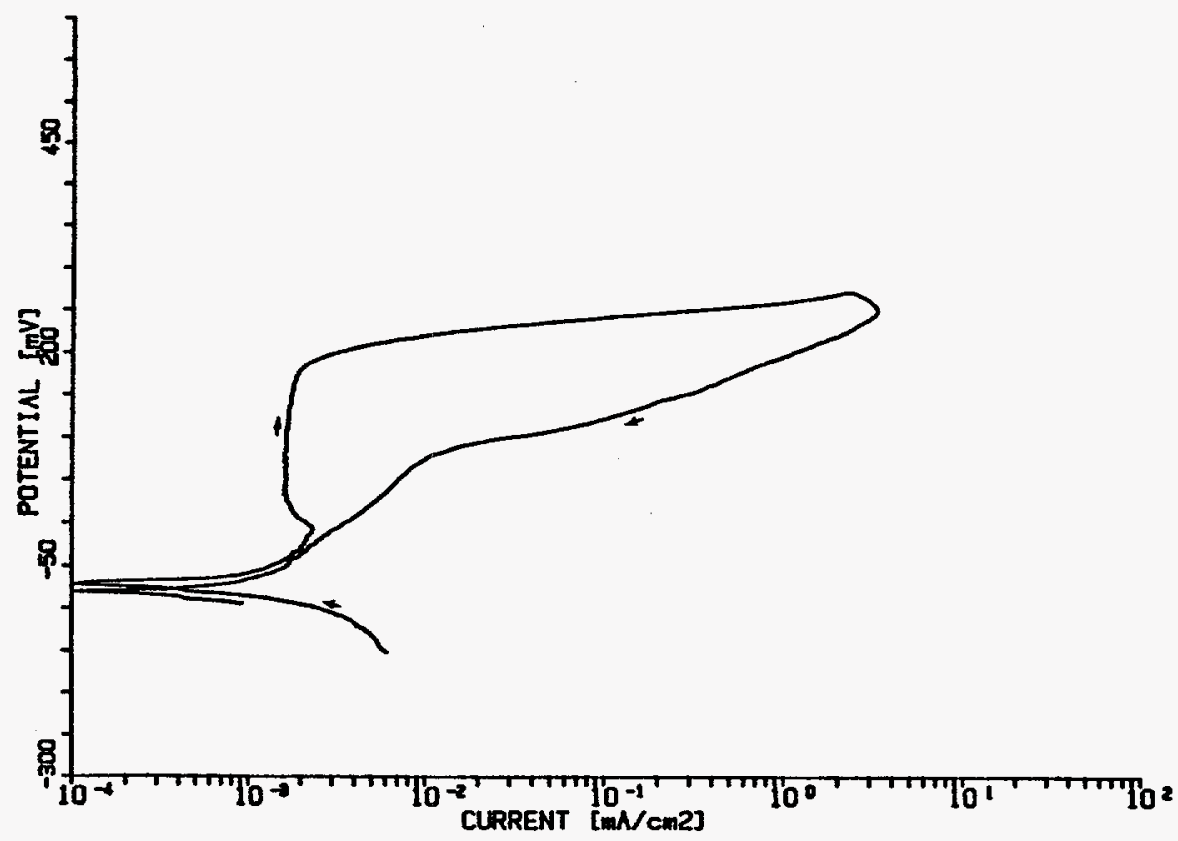

Figure A33. Potent lodynamic Polarization Curve Por Alloy CDA 102 In Solution Mo. 33 At $70^{\circ} \mathrm{C}$.

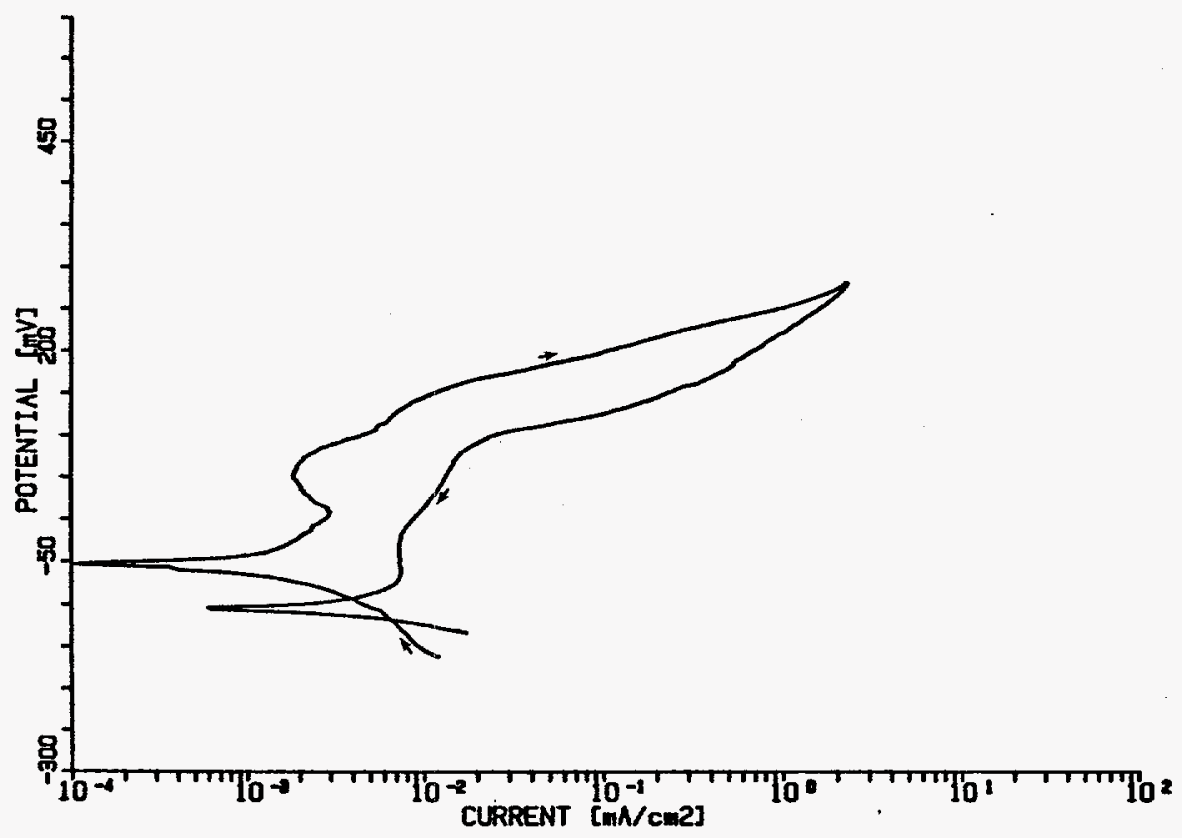

Figure A34. Potentlodynamic Polerization Curve For Allog CDA 102 In Solution No. 34 At $70^{\circ} \mathrm{C}$. 


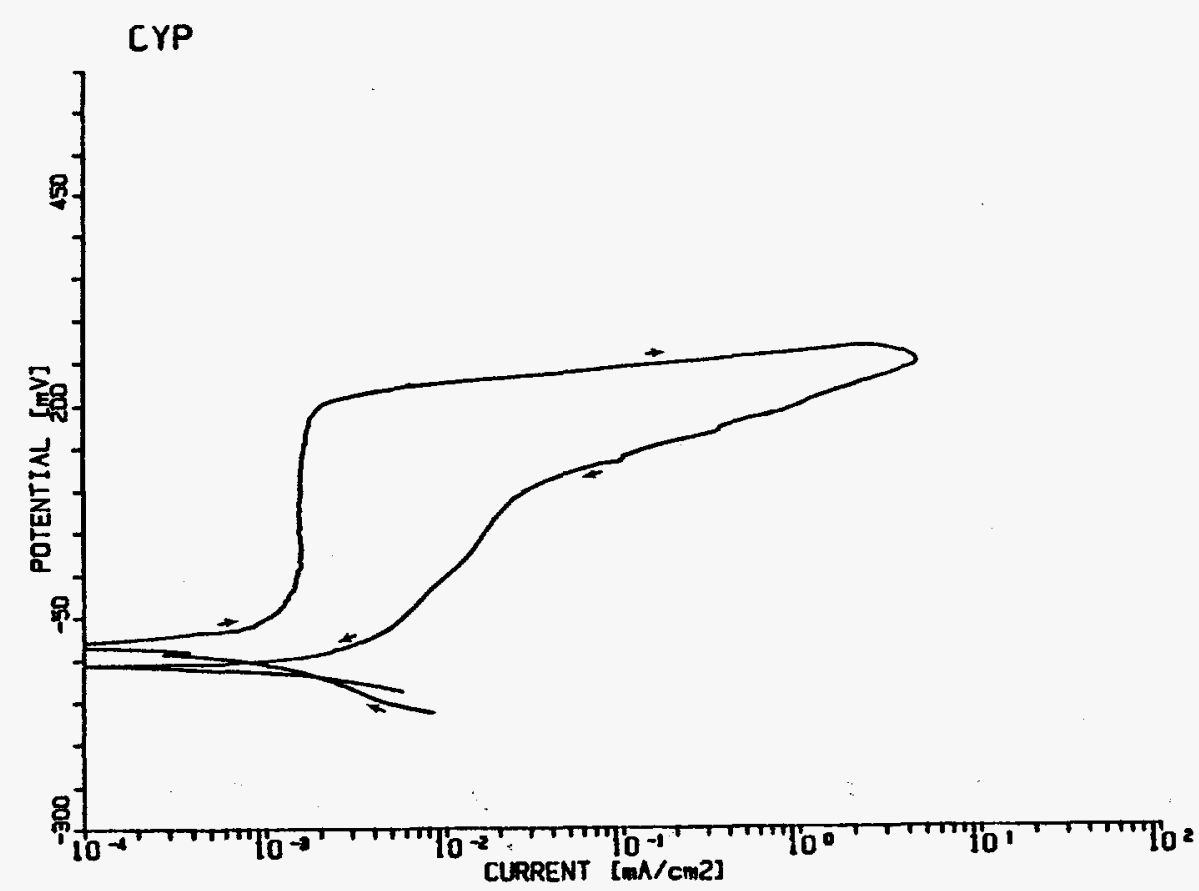

Figure A35. Potentlodynamic Polarization Curve For Alloy CDA 102 In Solution Ho. 35 At $70^{\circ} \mathrm{C}$.

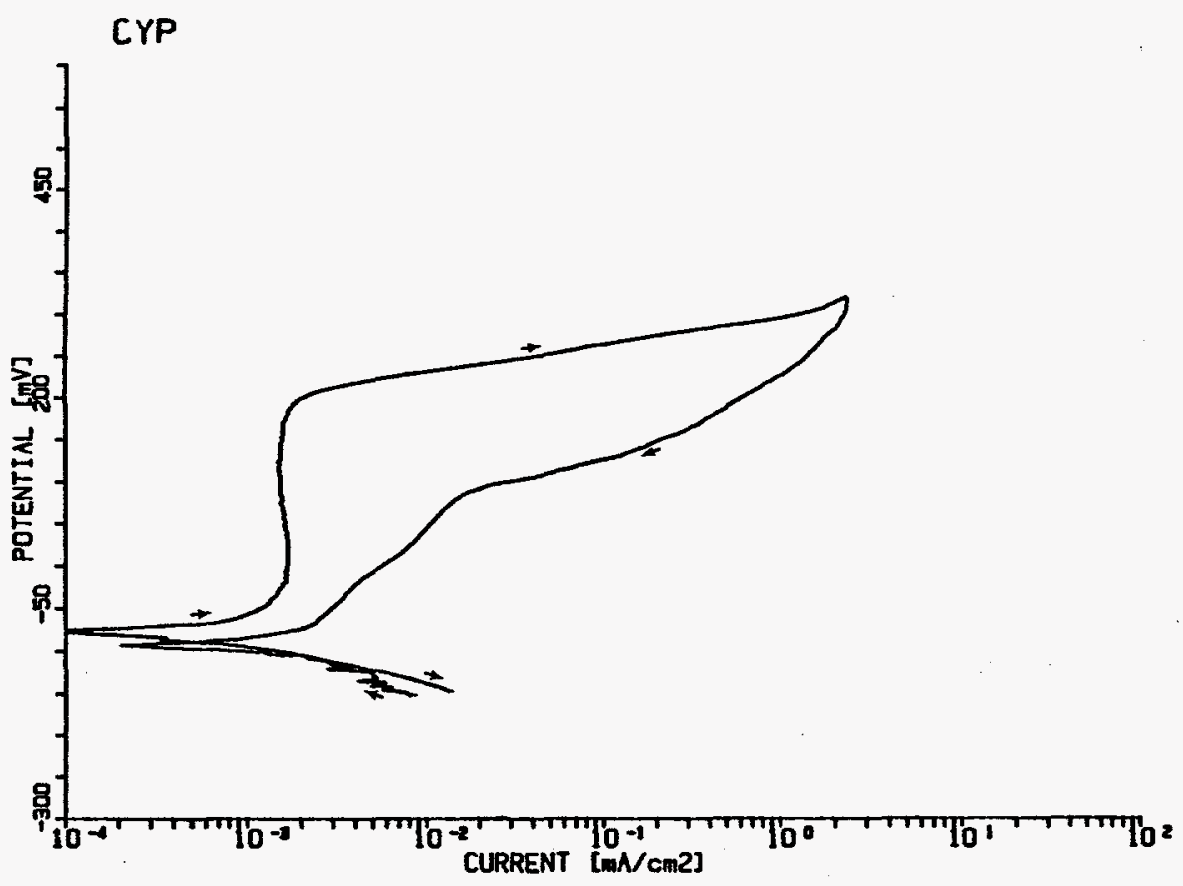

F1eure 436. Fotent lodynalc Folarization Curve For Alloy CDA 102 In Solution 13o. 36 at $70^{\circ} \mathrm{C}$. 


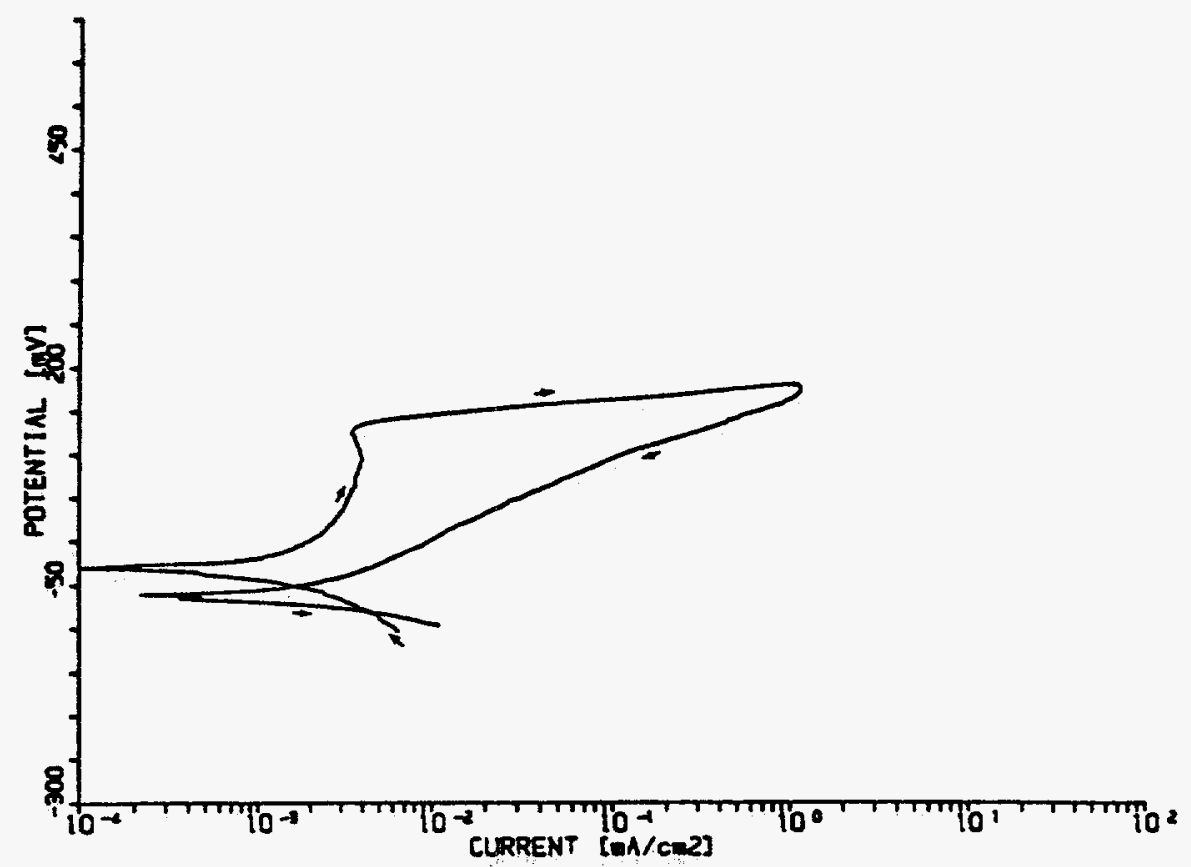

Figure 137. Rotentiodynamic Polerization Curve For Alloy CDA 102 In Simulated J-13 vell Vater at $90^{\circ} \mathrm{C}$.

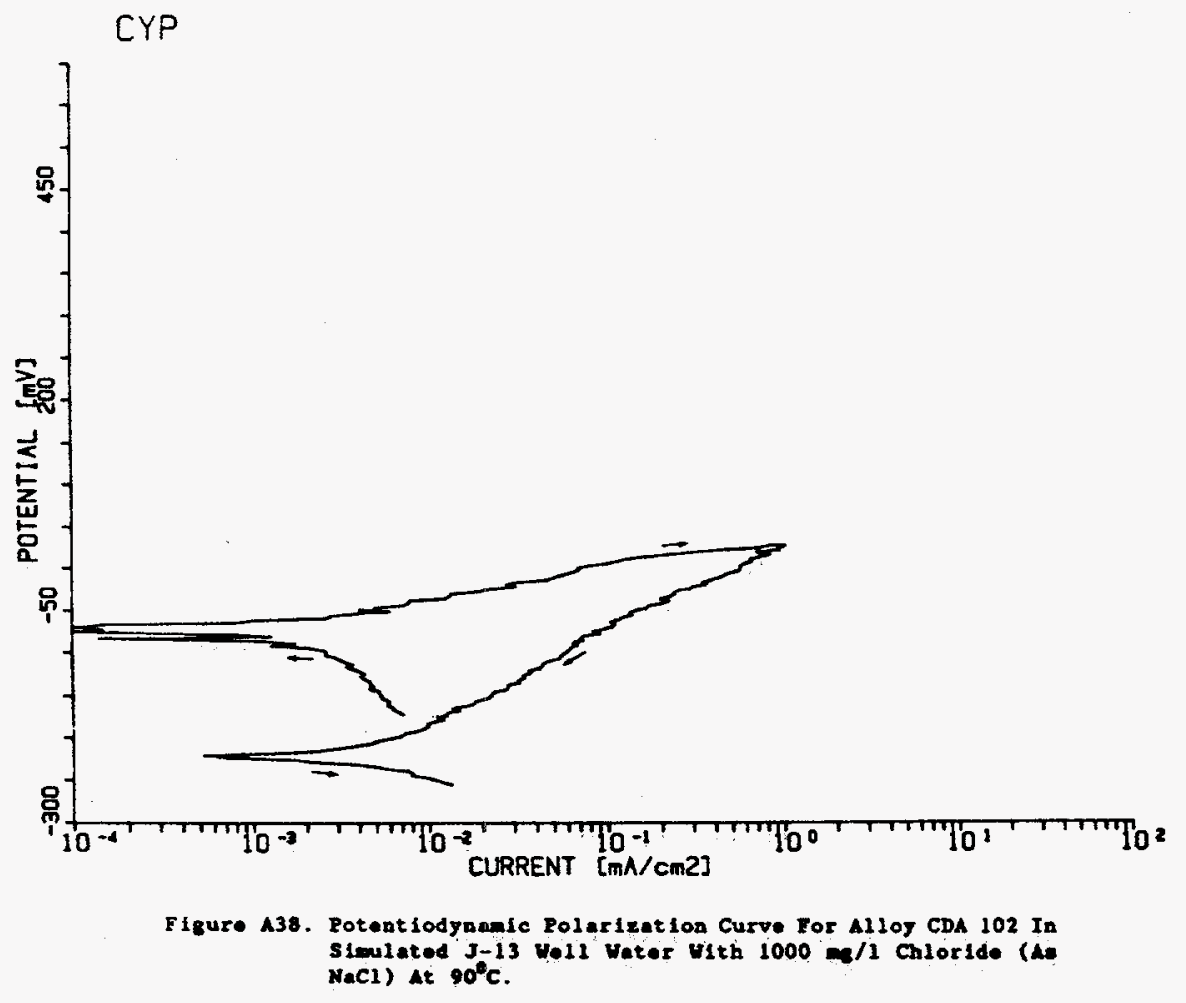




\section{CYP}

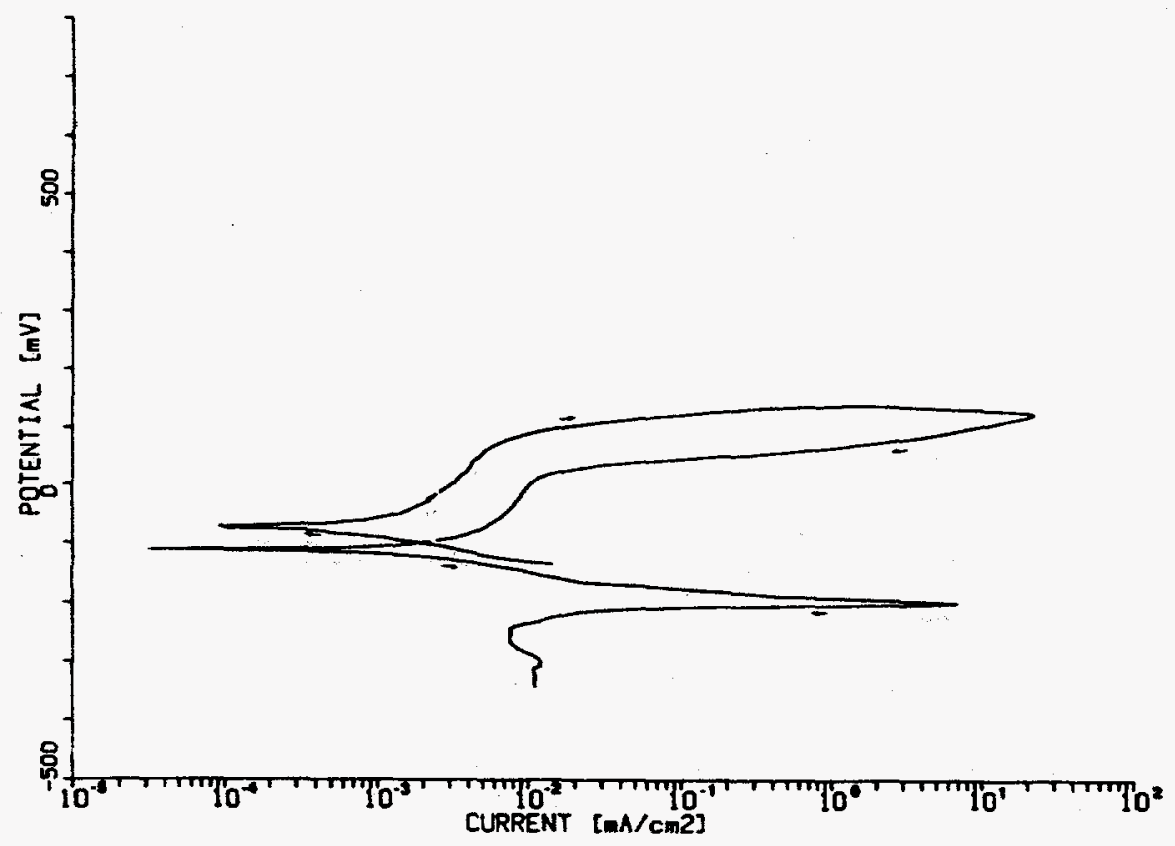

Figure A39. Potent lodynamic Folerization Curve For Alloy CDA 102 In
Solution Mo. 39 At $70^{\circ} \mathrm{C}$.

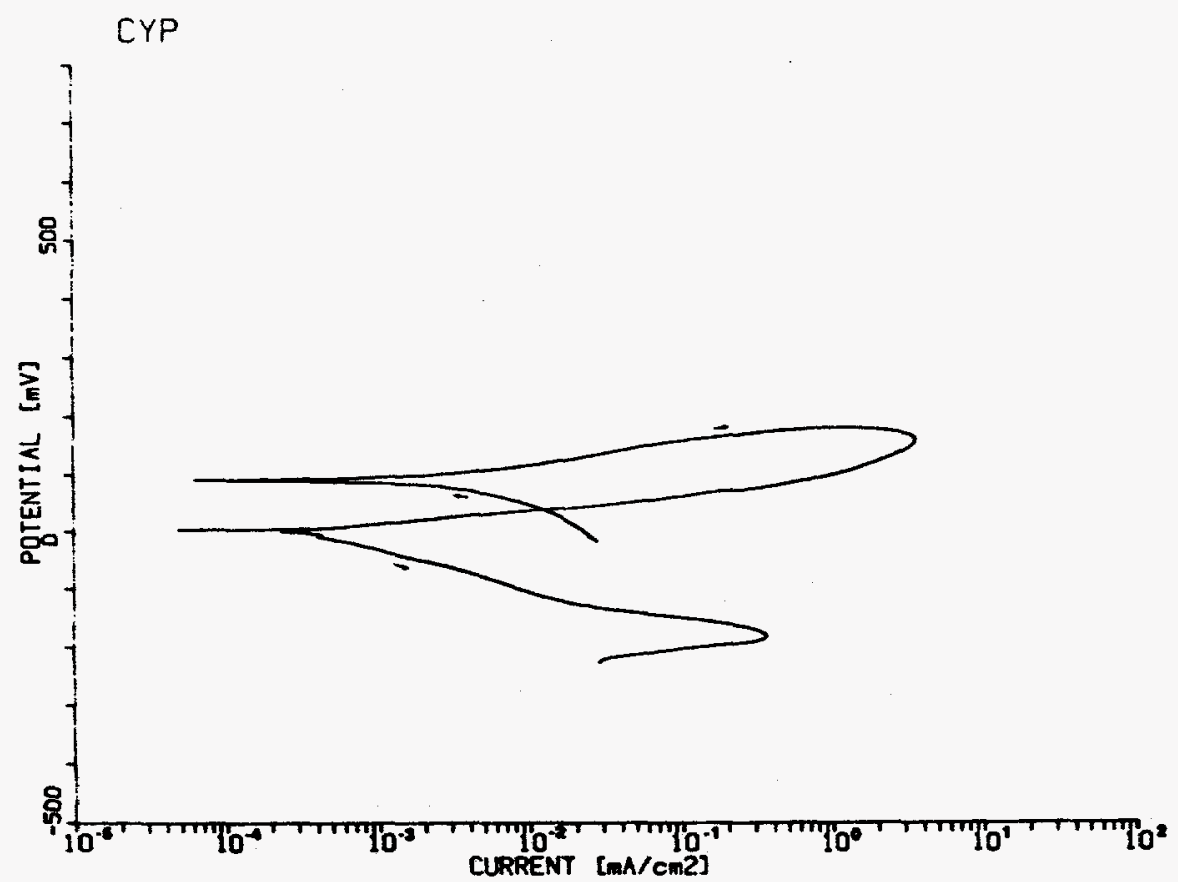

Figure M40. Potent1odyanic Polariention Curve For Allos CDA 102 In Solut lon Wo. 40 at $70^{\circ} \mathrm{C}$. 


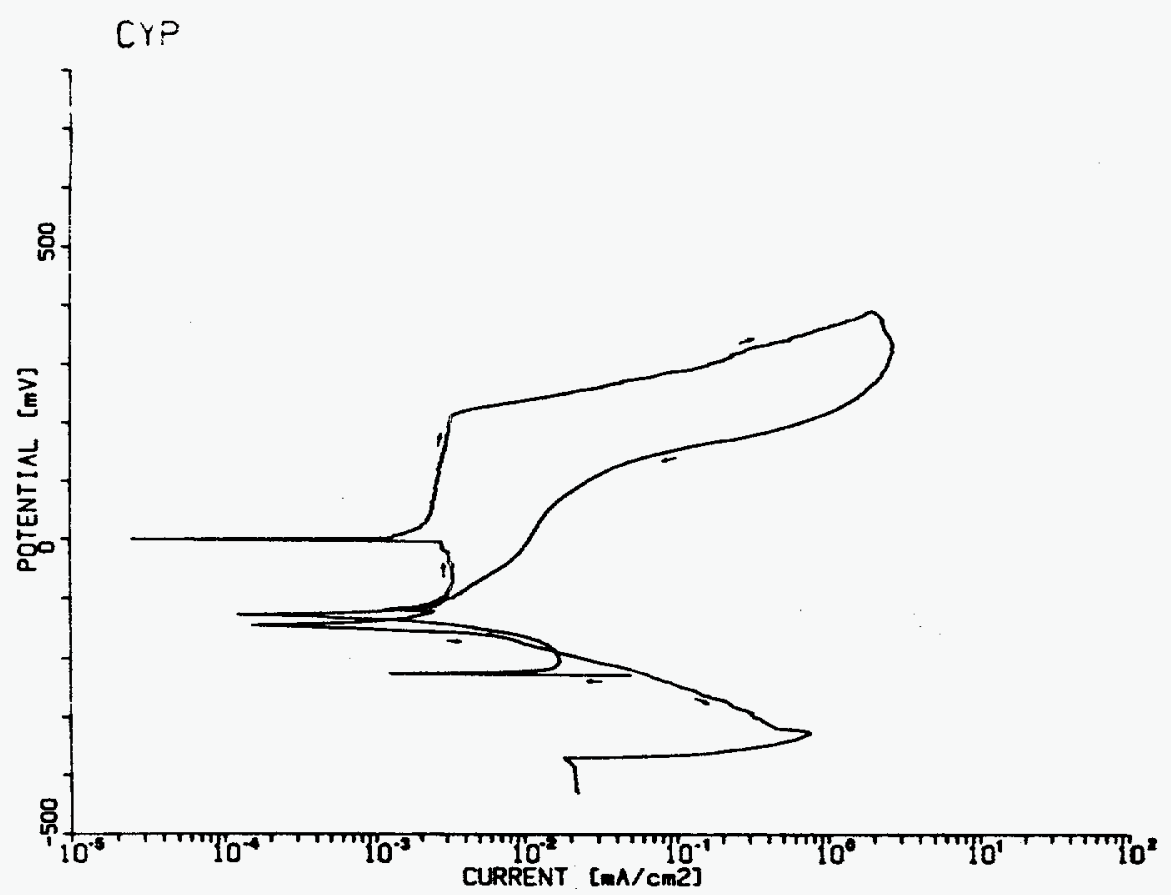

Figure A41. Rotentlodyanic Poleriestion Curve For Alloy CDA 102 In Solution Mo. il at $10^{\circ} \mathrm{C}$.

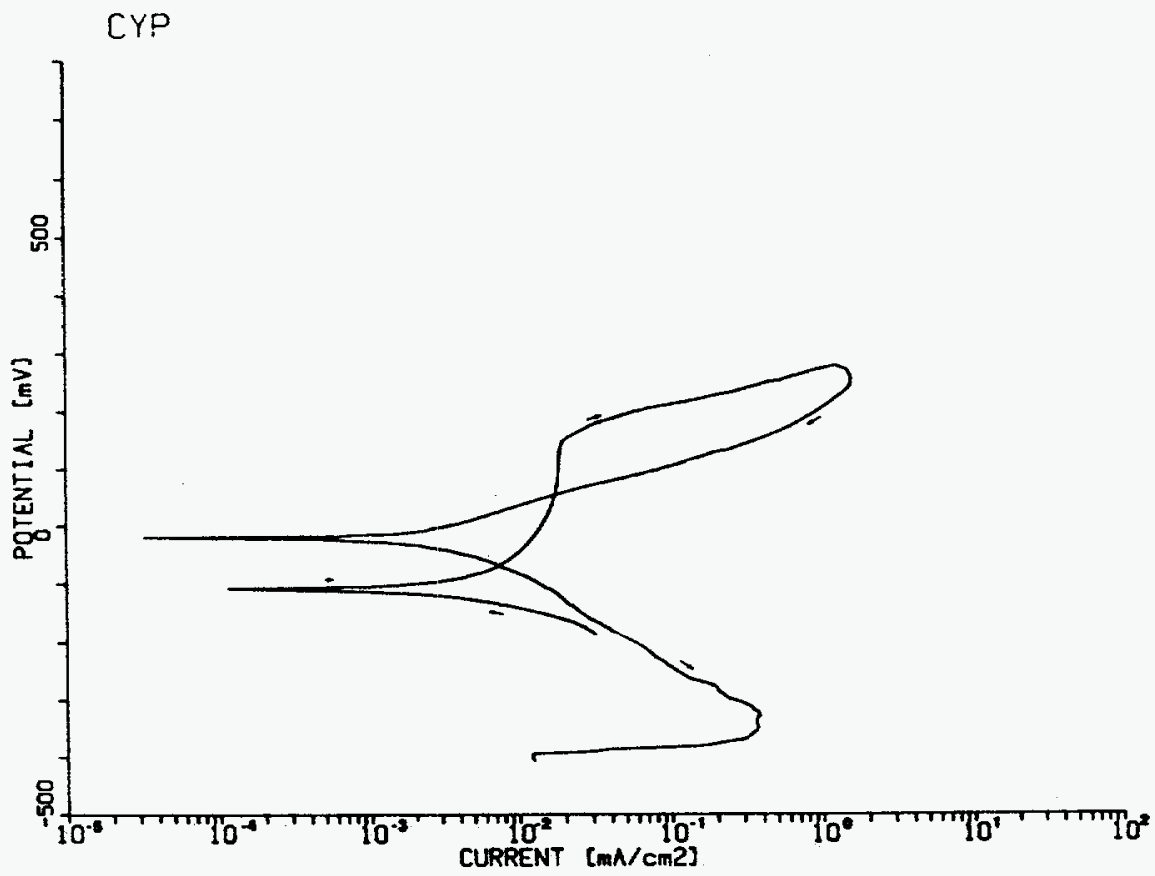

Eigure 442, Rotentlodjnamic Rolarization Curve For Alloy CDA 102 In Solution Ho. 42 At $70^{\circ} \mathrm{C}$. 
APPENDIX B

CYCLIC POTENTIODYNAMIC POLARIZATION CURVES

FOR ALLOY CDA 715

IN TEST SOLUTIONS FROM THE

RESOLUTION IV MATRIX 


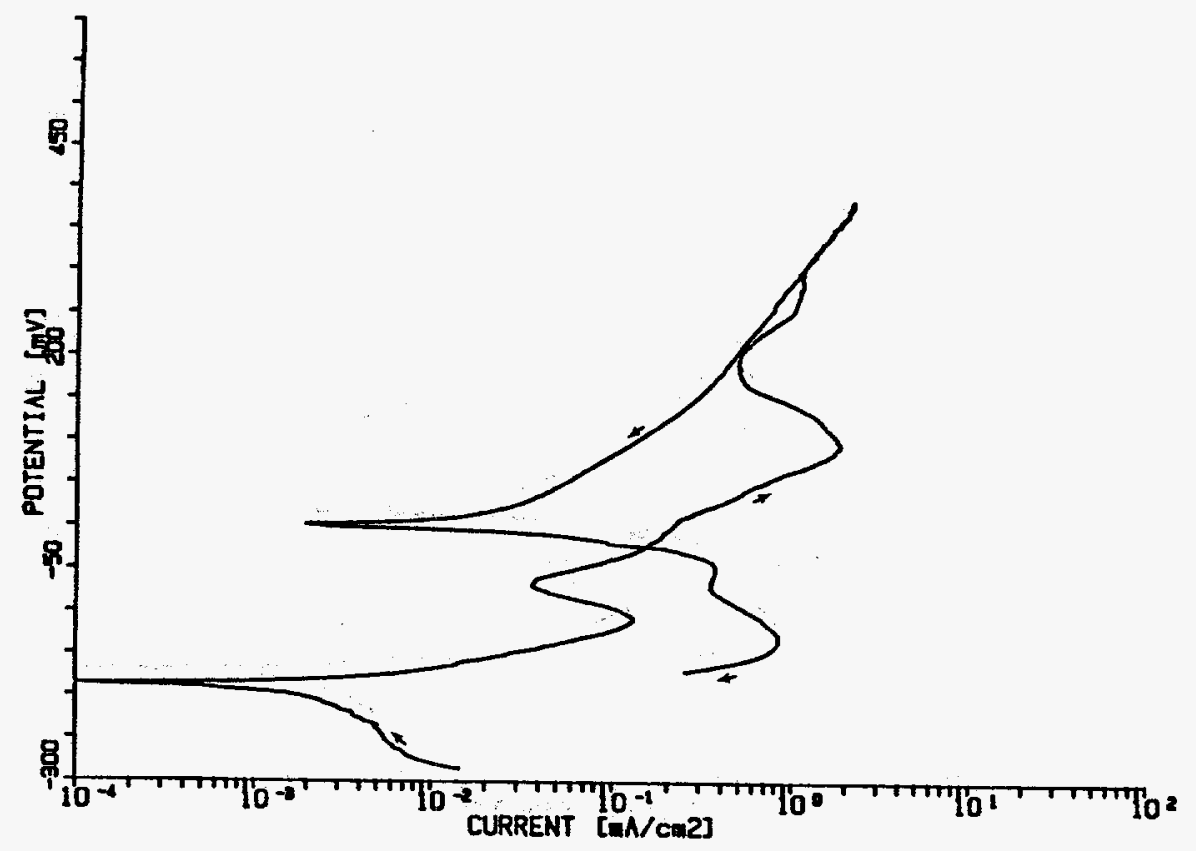

Figure B1. Rotentiodynamic Polarization Curve For Alloy CDa 715 In Solution Ho. 1 at $90^{\circ} \mathrm{C}$.

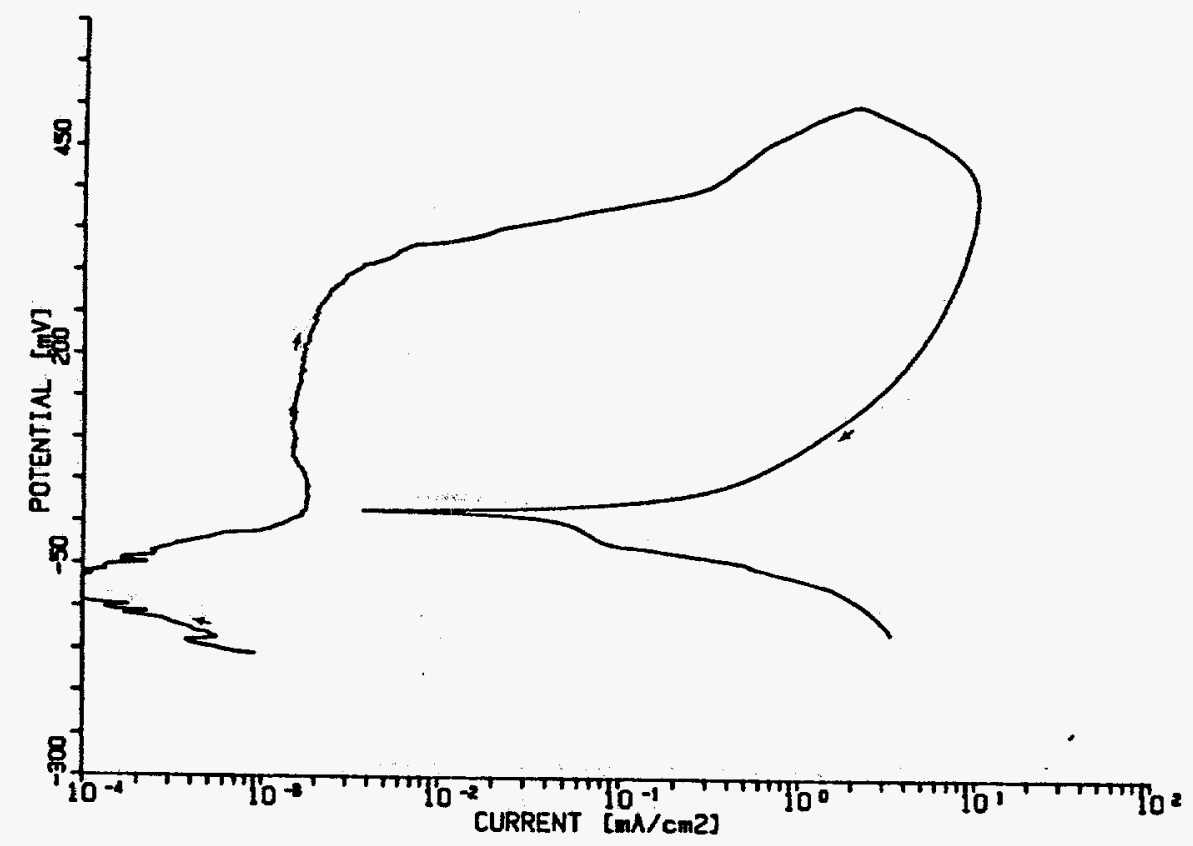

Ffgure B2. Potentiodynemic Polarization Curve For Allog CDA 715 In Solution No. 2 at $50^{\circ} \mathrm{C}$. 


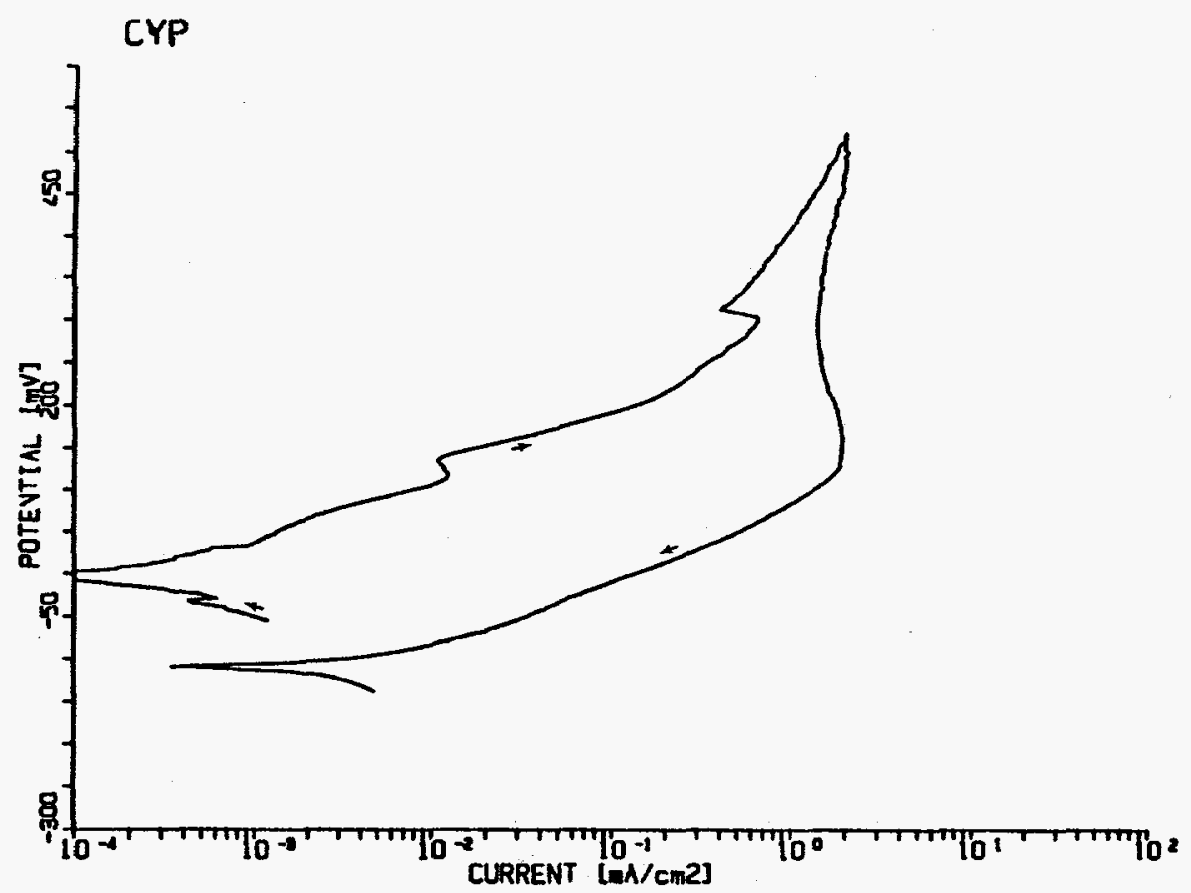

F1gure B3. Potentlodynamic Polarization Curve For Allog CDA 715 In Solution No. 3 At $50^{\circ} \mathrm{C}$.

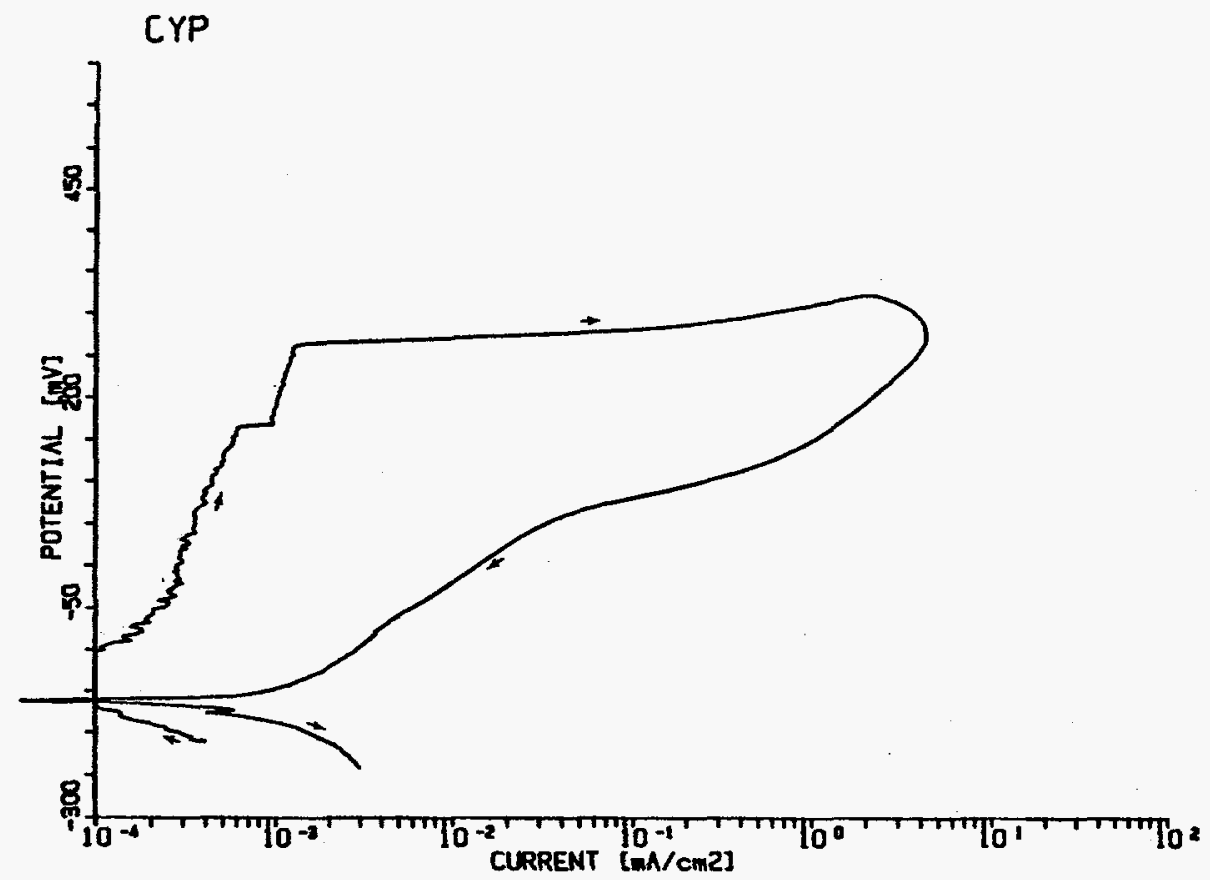

Figure B4. Poteatlodynamic Polerization Curve For Alloy CDA 715 In Solution Ho. It it $90^{\circ} \mathrm{C}$. 


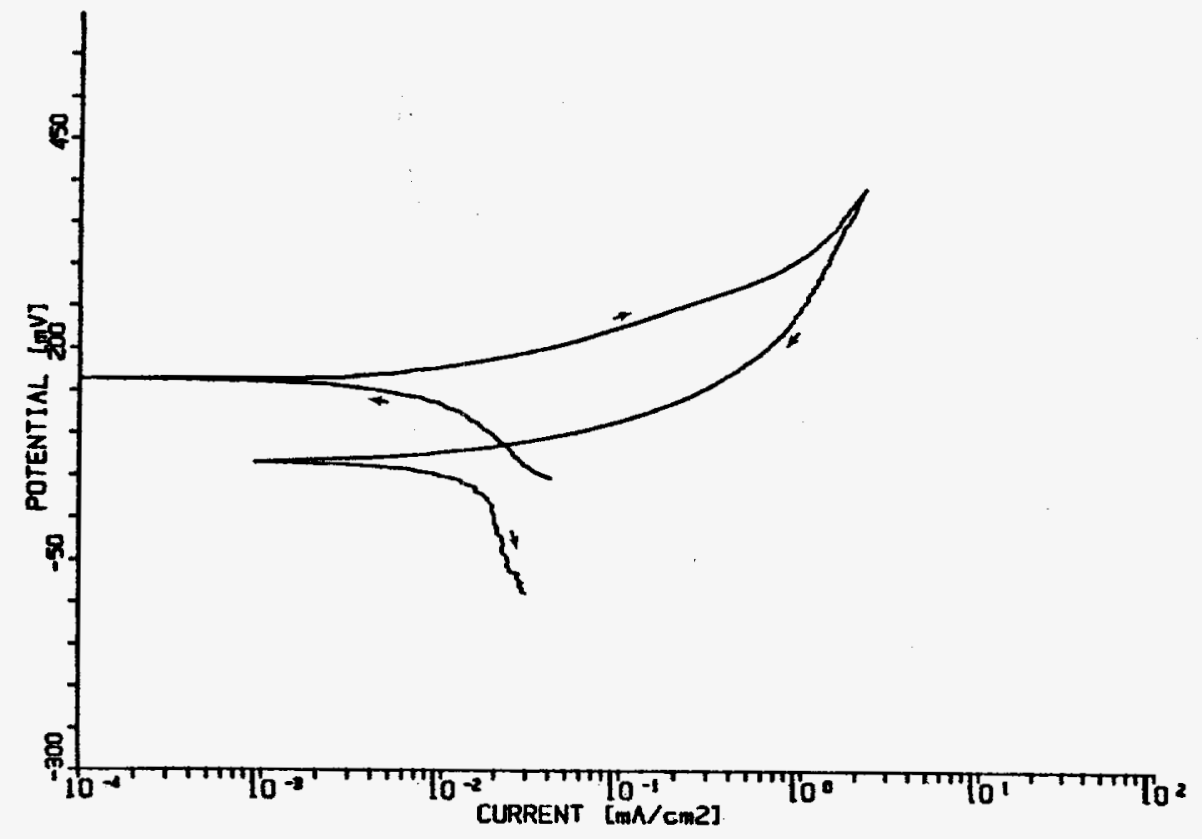

Figure B5. Rotentlodynanic Polarization Curve For Alloy CDA 715 In Solution No. 5 At $50^{\circ} \mathrm{C}$.

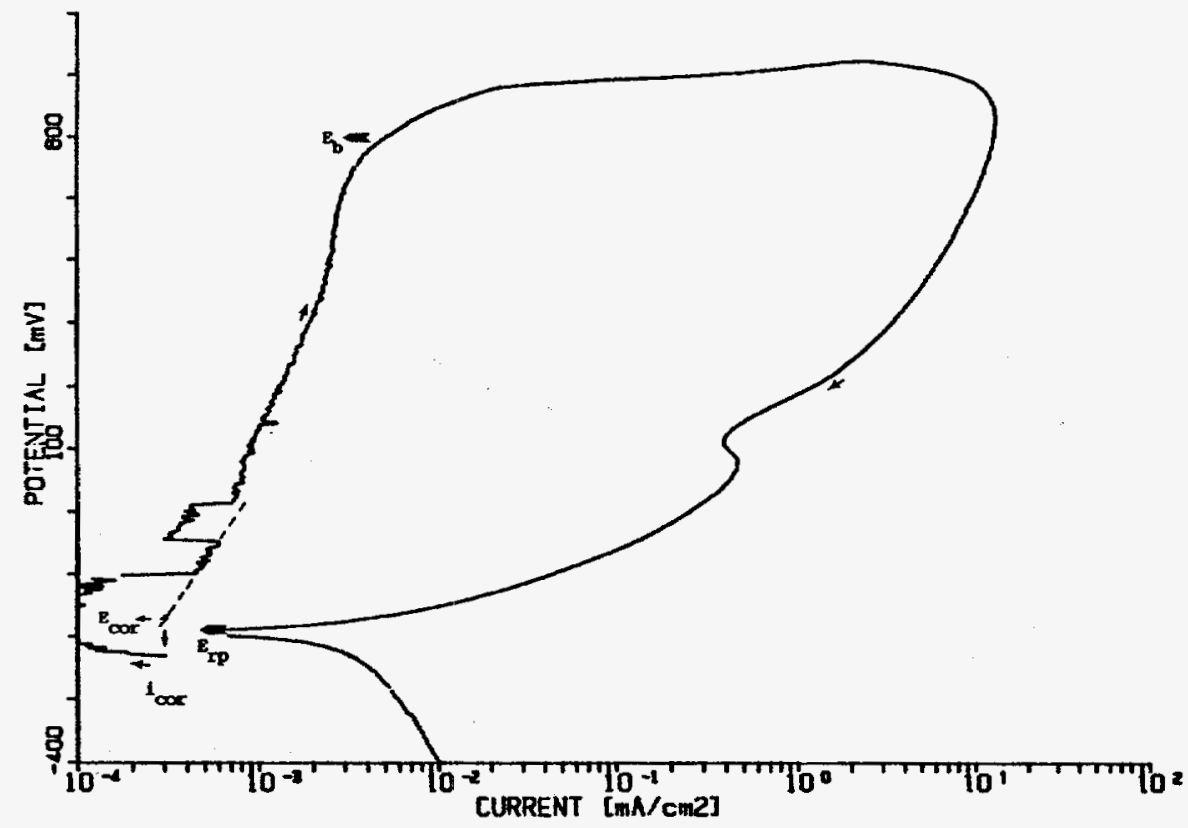

Figure B6. Potentiodynanic Polarization Curvo Foz Allog CDA 715 In Solution No. 6 at $90^{\circ} \mathrm{C}$. 


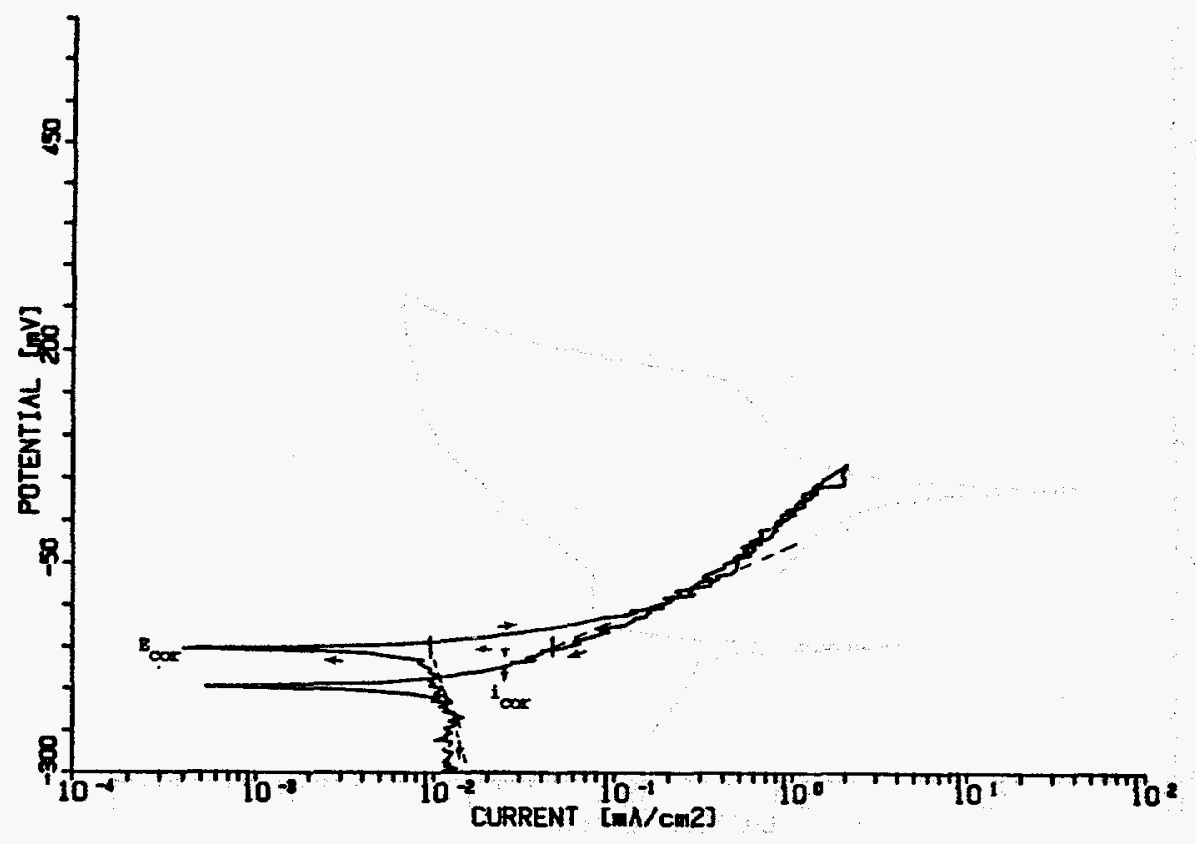

Figure B7. Potentlodynamic Rolarization Curve For Allog CDA 715 In Solution Ho. 7 at $90^{\circ} \mathrm{C}$

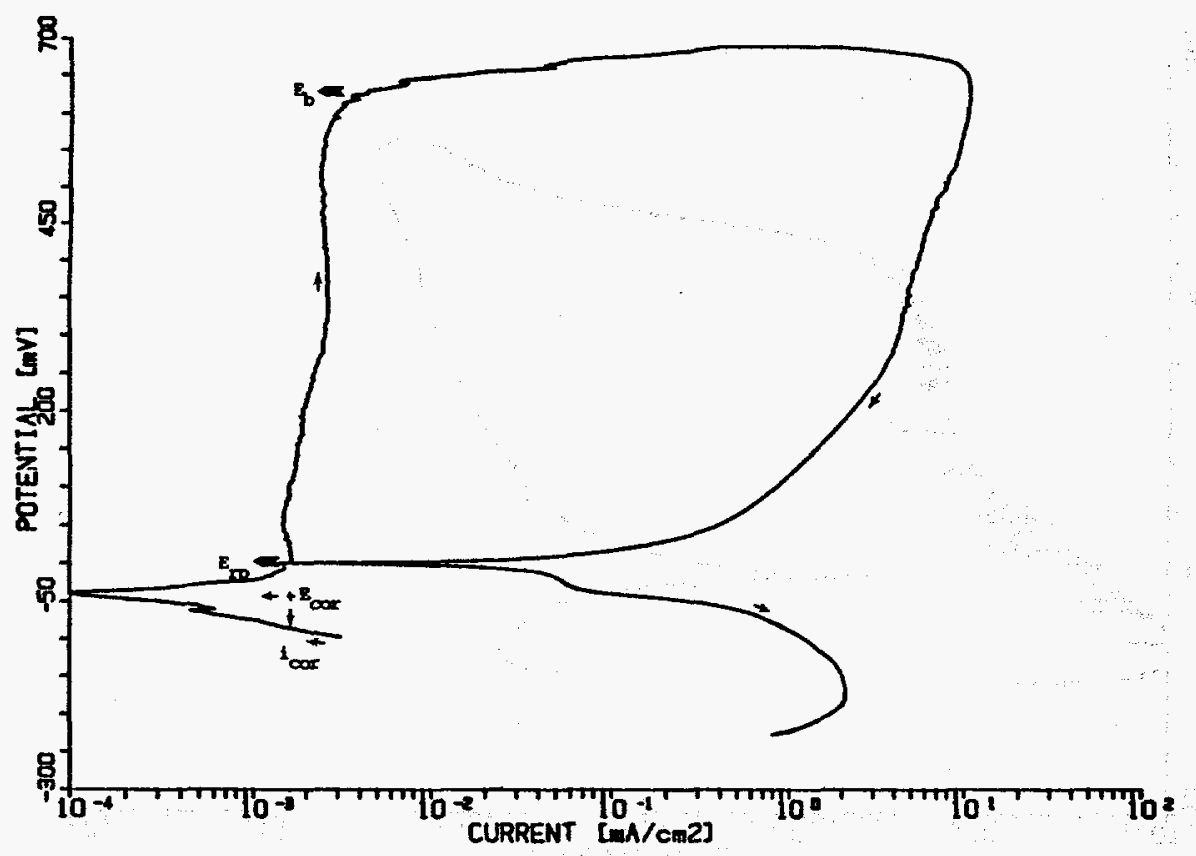

Flgure B8. Potentiodynamic Folarizetion Curve For Alloy CDA 715 In Solution No, At $50^{\circ} \mathrm{C}$. 


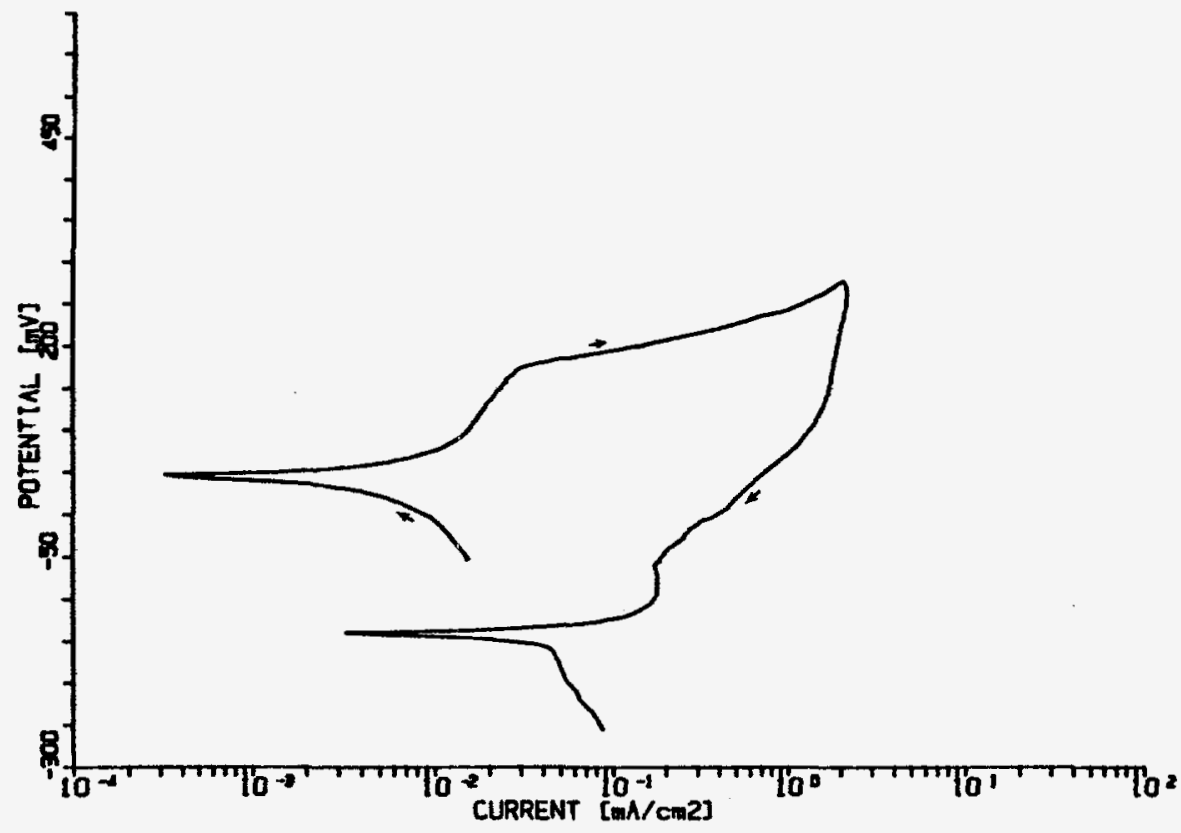

Fisure 89. Potentlodyatic Polezization Curve For Alloy CDA 715 In Solution No. I lt $50^{\circ} \mathrm{C}$.

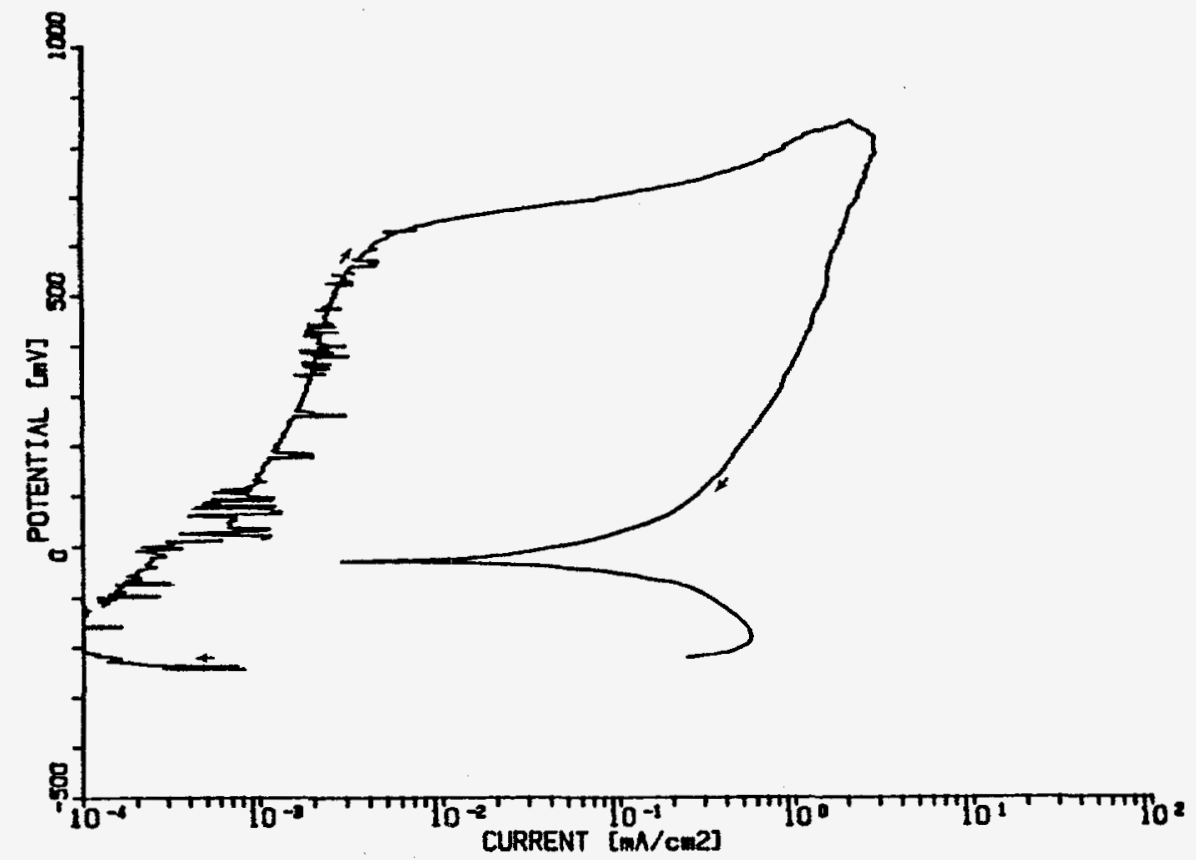

Figure B10. Potentlodynamic Polarization Curve For alloy CDA 715 In Solution No. 10 At $90^{\circ} \mathrm{C}$ 


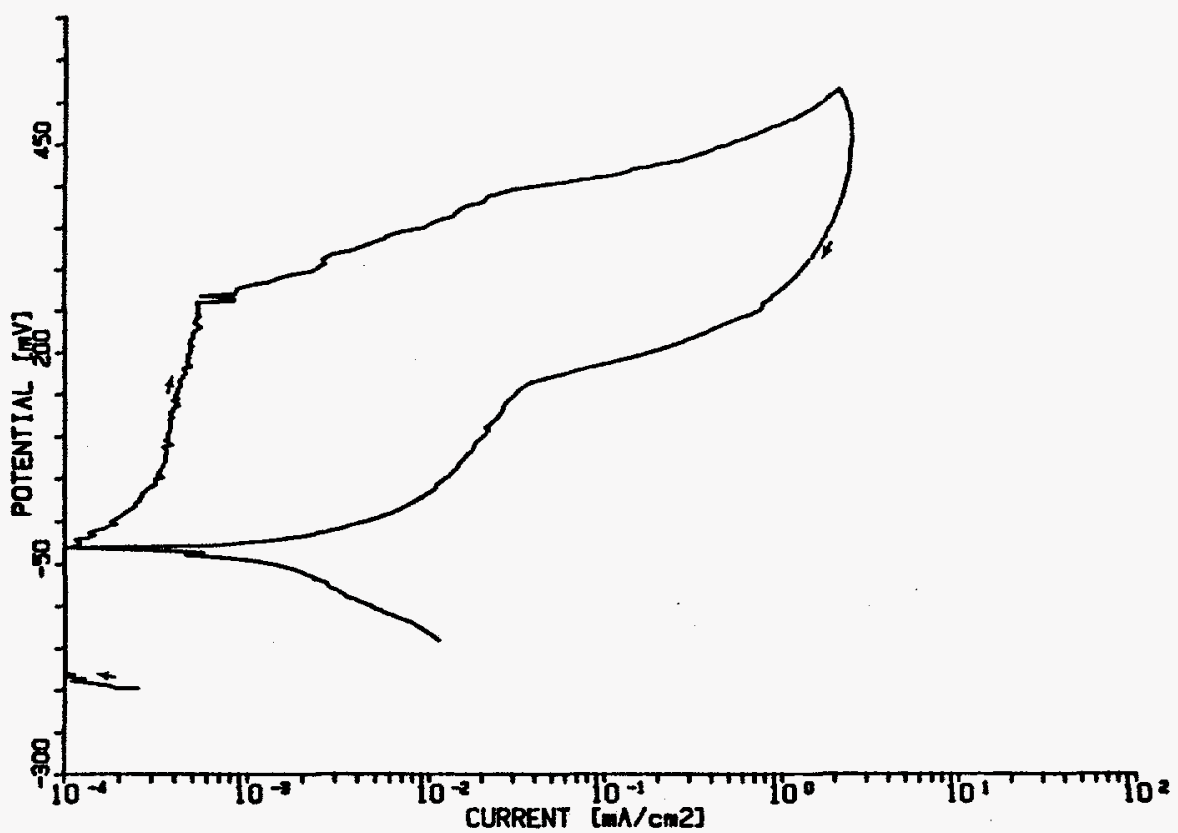

Figure B11. Potentlodynaic Polarization Curve For Alloy CDA 715 In Solution Ho. 11 At $90^{\circ} \mathrm{C}$

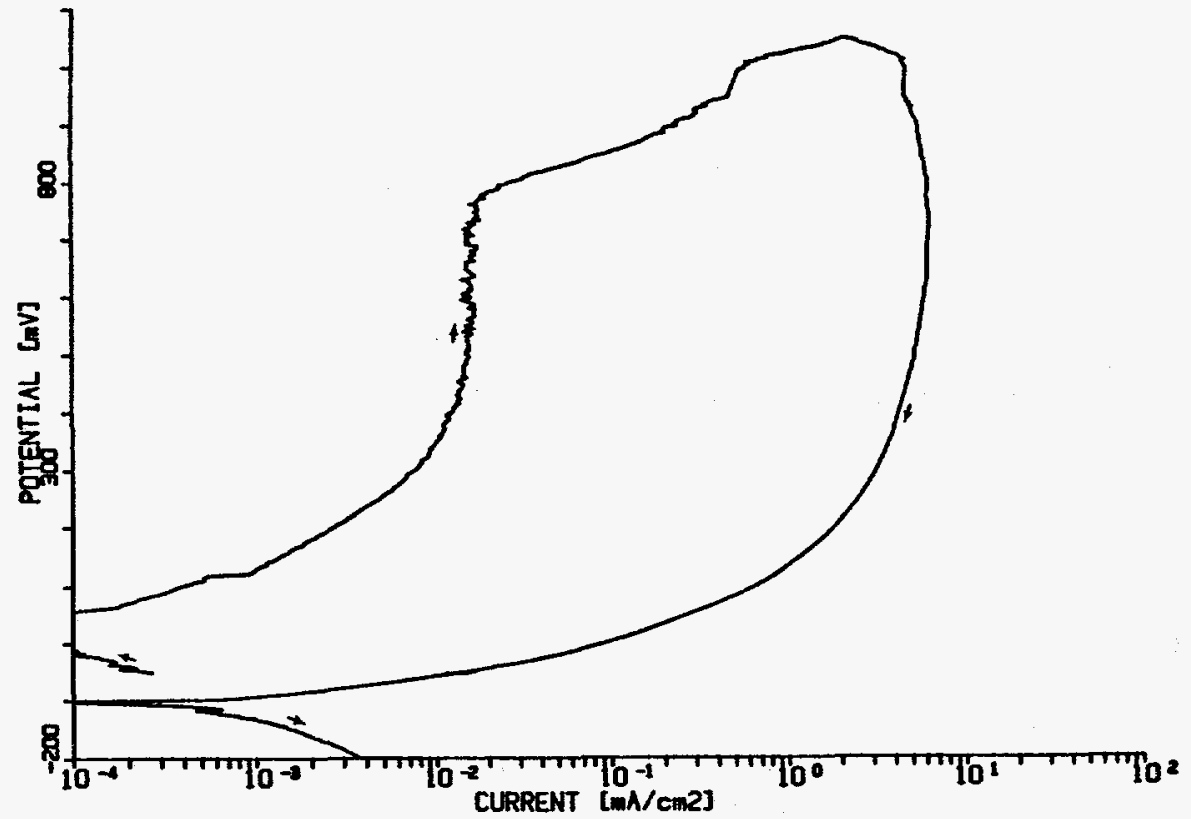

Figure B12. Potentlodyenic Eolerization Curve For Alloy CDA 715 Ia Solution Ho. 12 At $50^{\circ} \mathrm{C}$. 


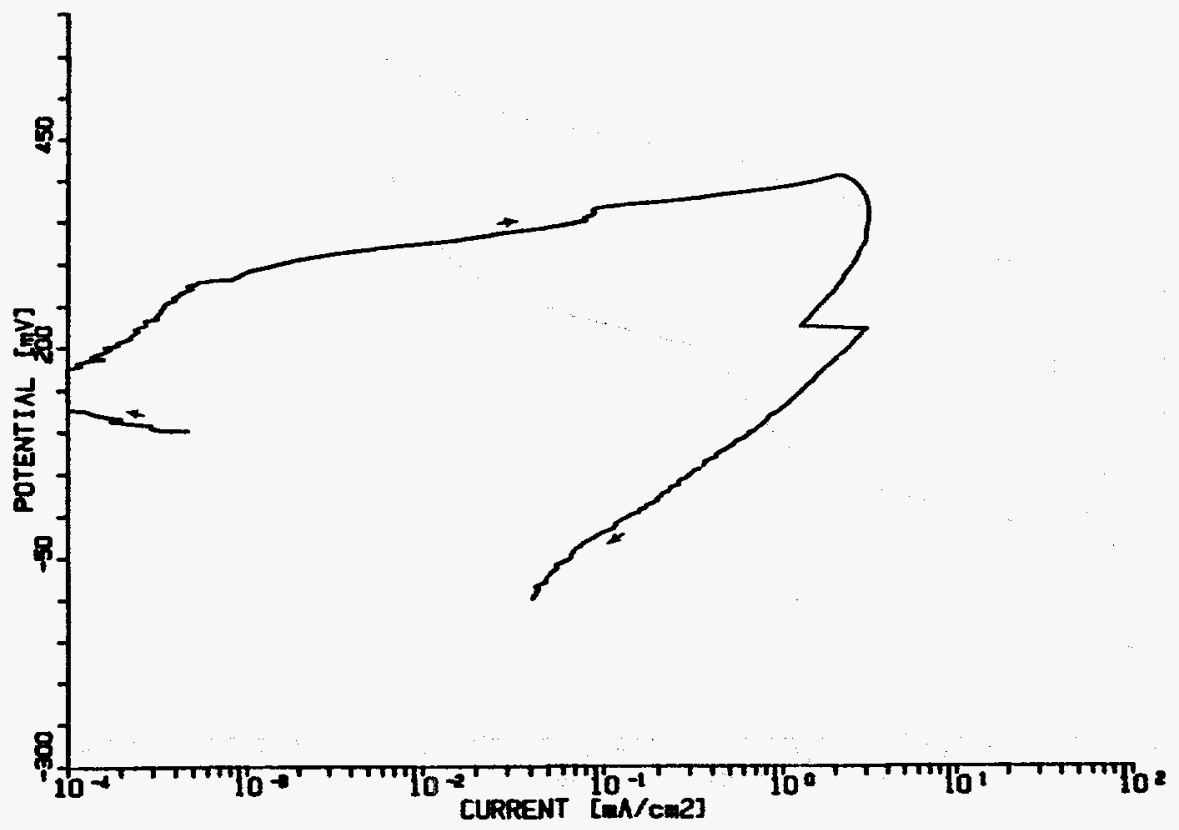

Figure 813. Fotent lodynanic Polerisation Curve For Allog CDA 115 In Solut Iop Ho. 13 At $90^{\circ} \mathrm{C}$.

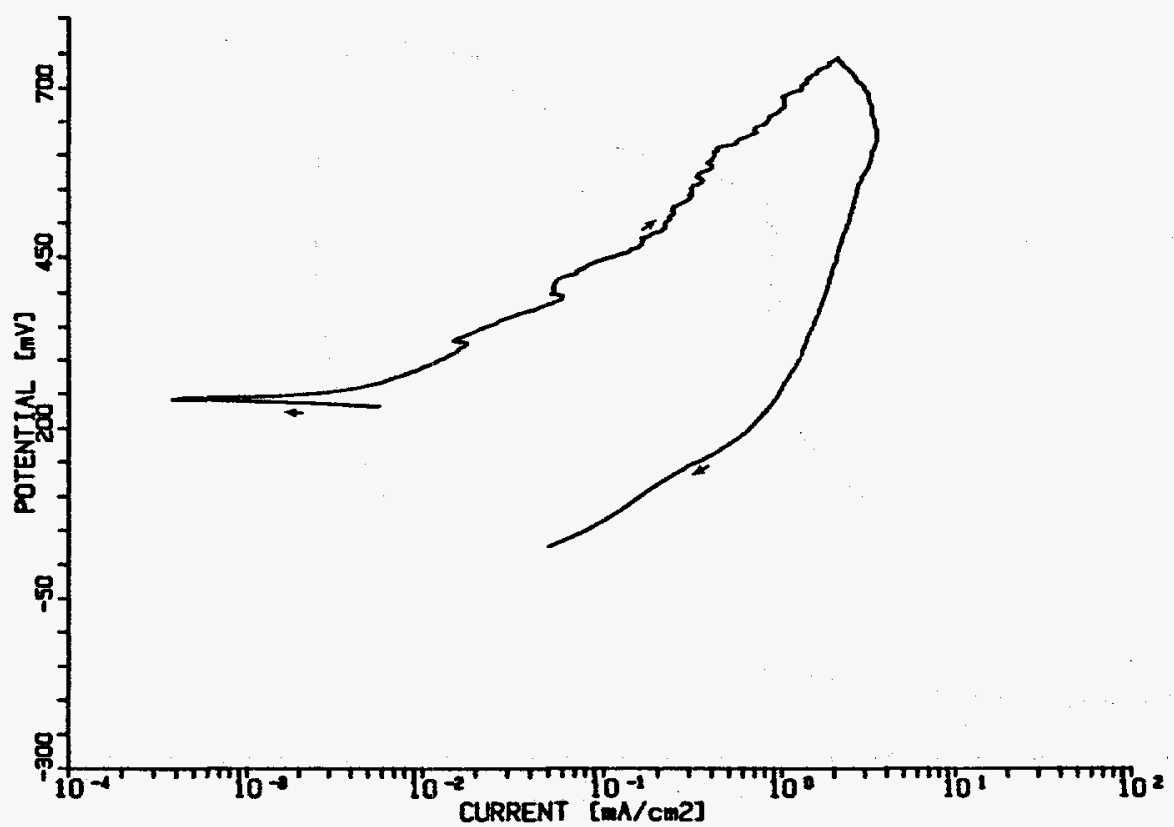

Figure B14. Potentlodynamic Polarization Curve For Alloy CDA 715 In Solution Ho. It At $50^{\circ} \mathrm{C}$. 


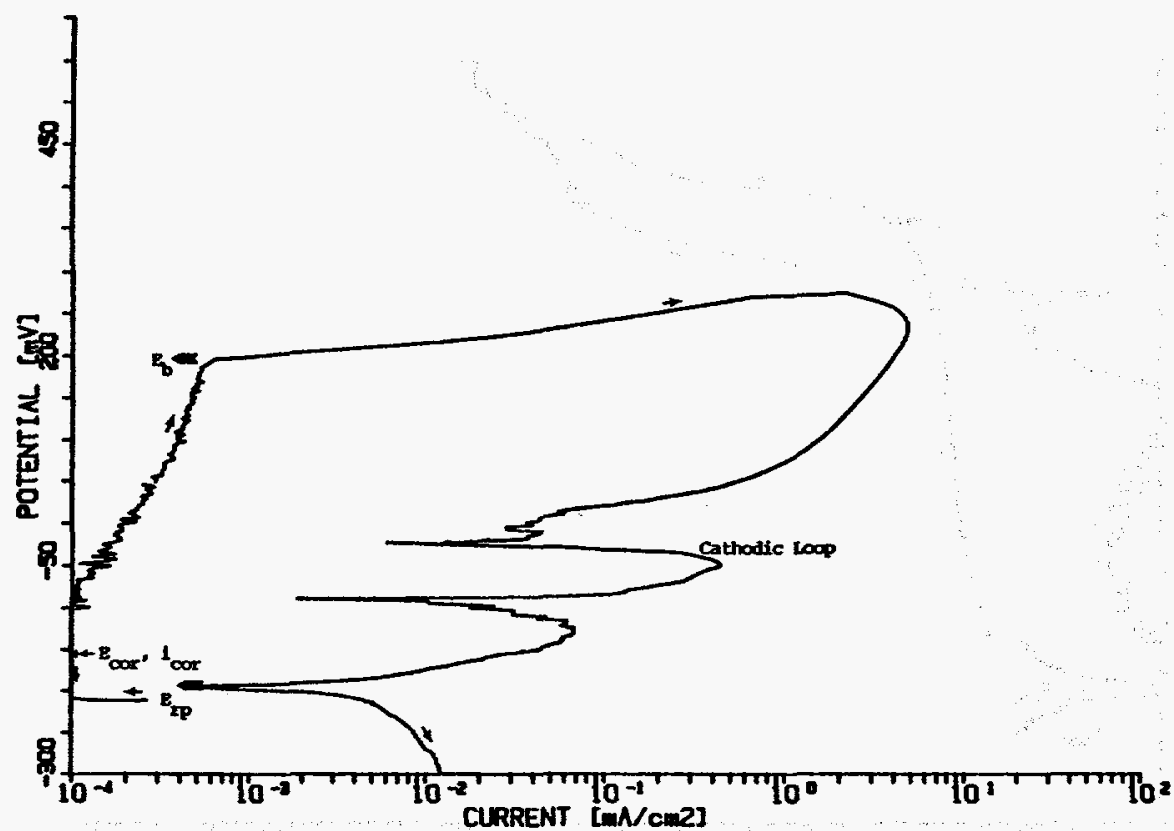

F18ure 815. Potentlodynamic Polarization Curve For Allog CDA 115 In Solution No. 15 At $50^{\circ} \mathrm{C}$

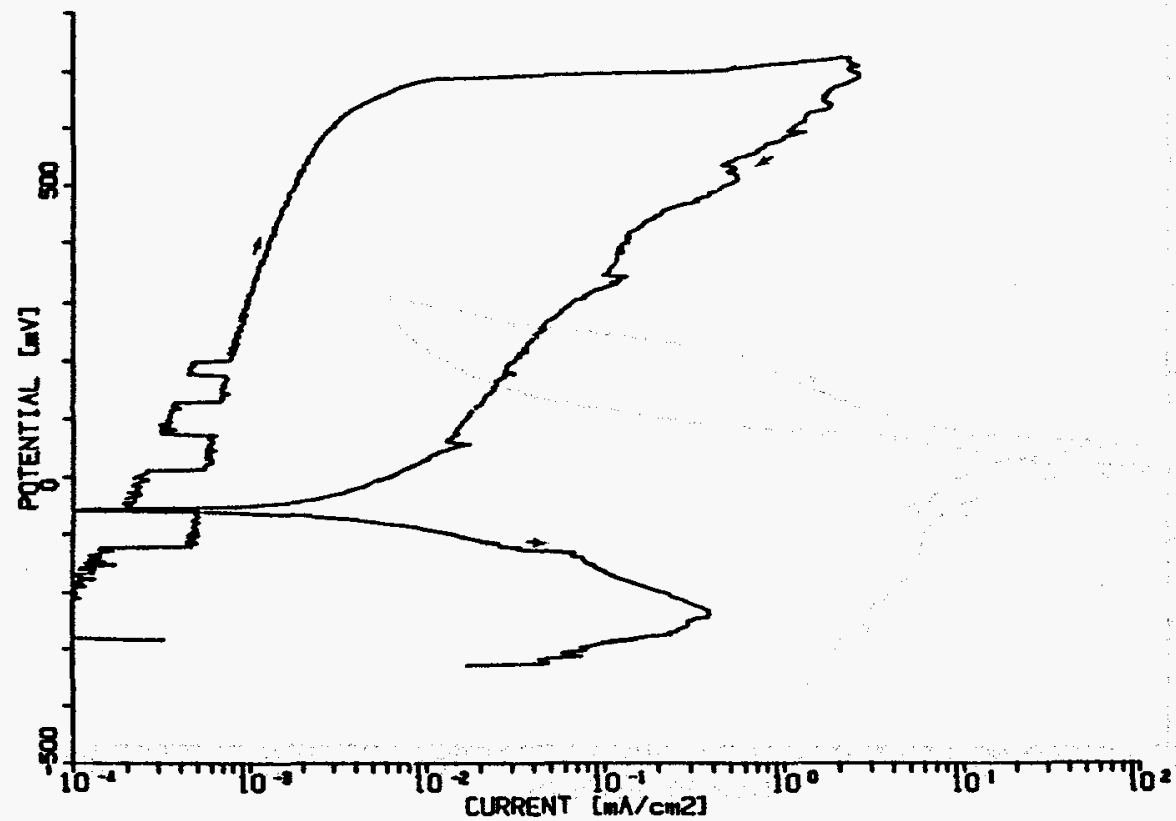

Figure B16. Potentlodynamle Polarization Curve For A110\% CDA 715 In Solueton No. 16 At $90^{\circ} \mathrm{C}$. 


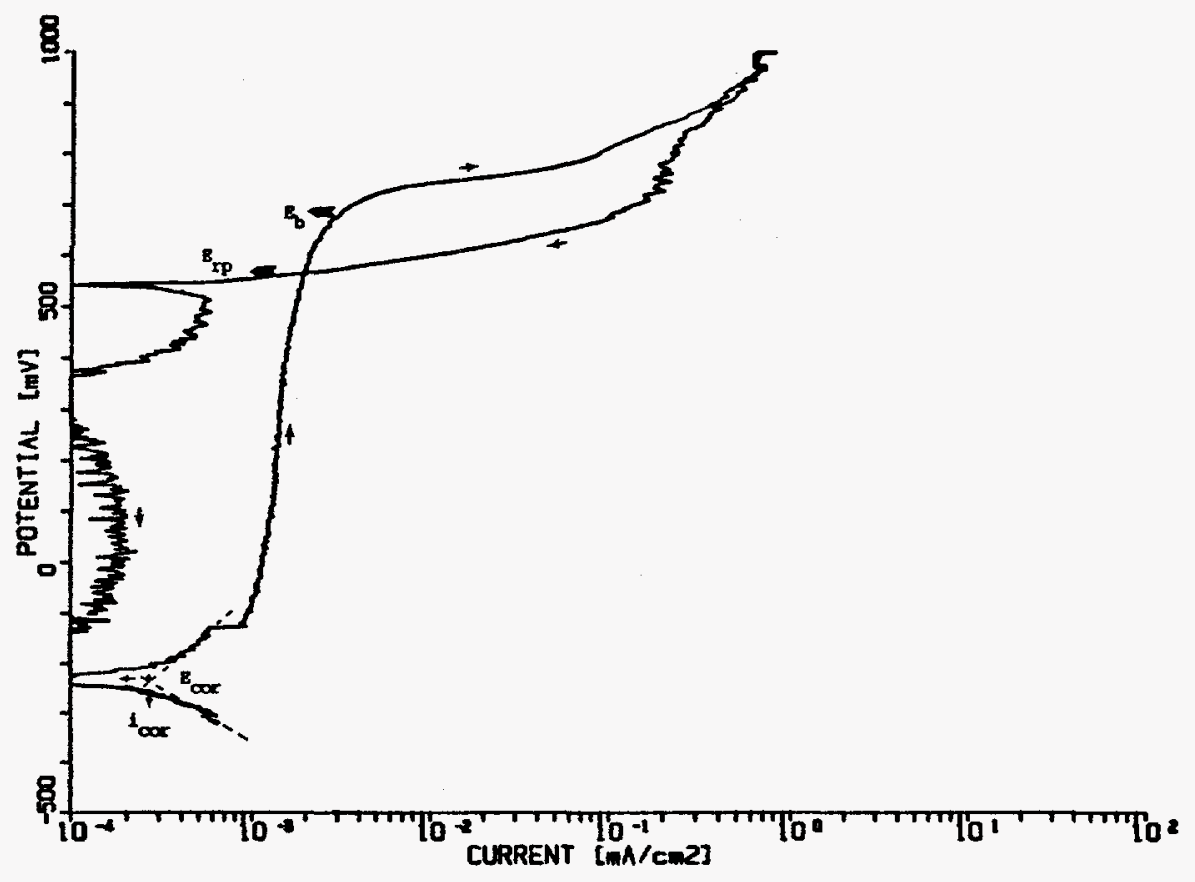

Figure B17. Fotentlodynamic Polerization Curve For Alloy CDA 715 In Solution Ho. 17 At $30^{\circ} \mathrm{C}$.

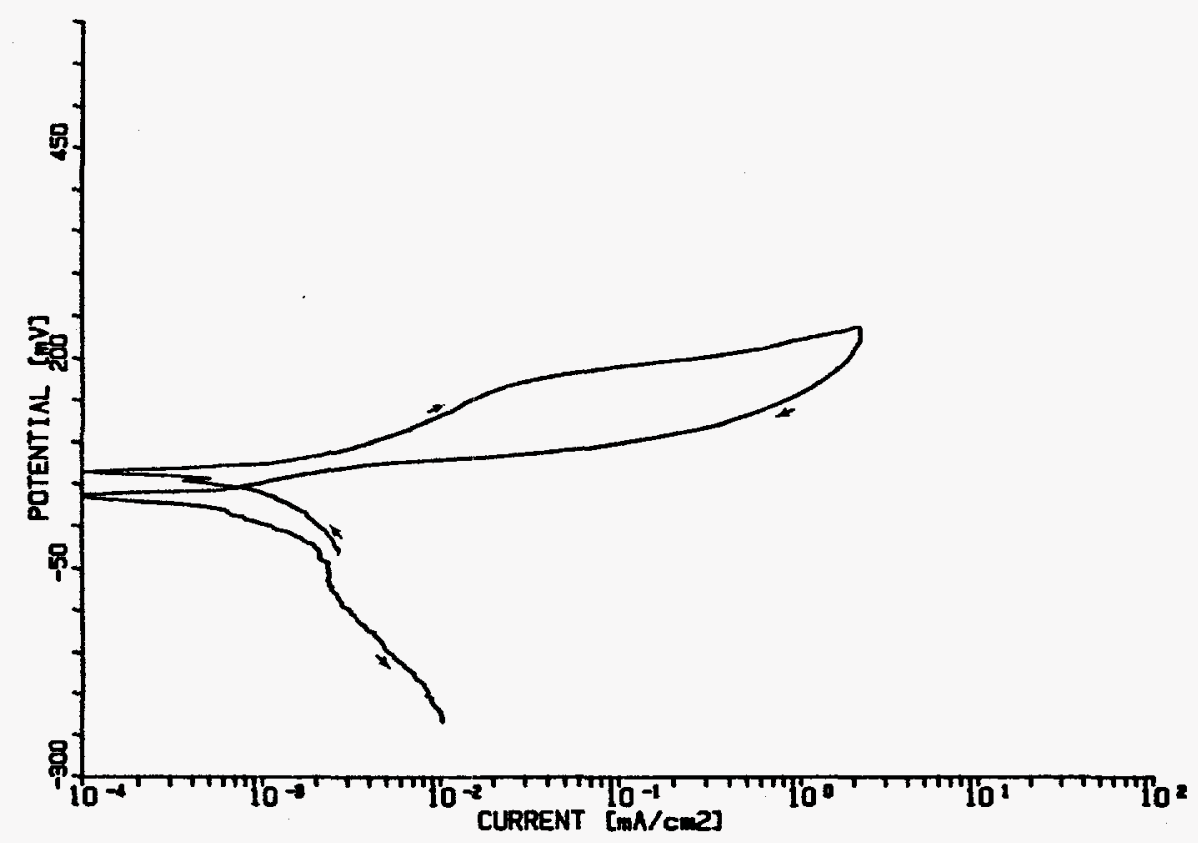

Figure s10. Fotentlodynanie Eolerization Curve For Alloy CDA 115 In Solution Ho. 18 at $90^{\circ} \mathrm{C}$. 


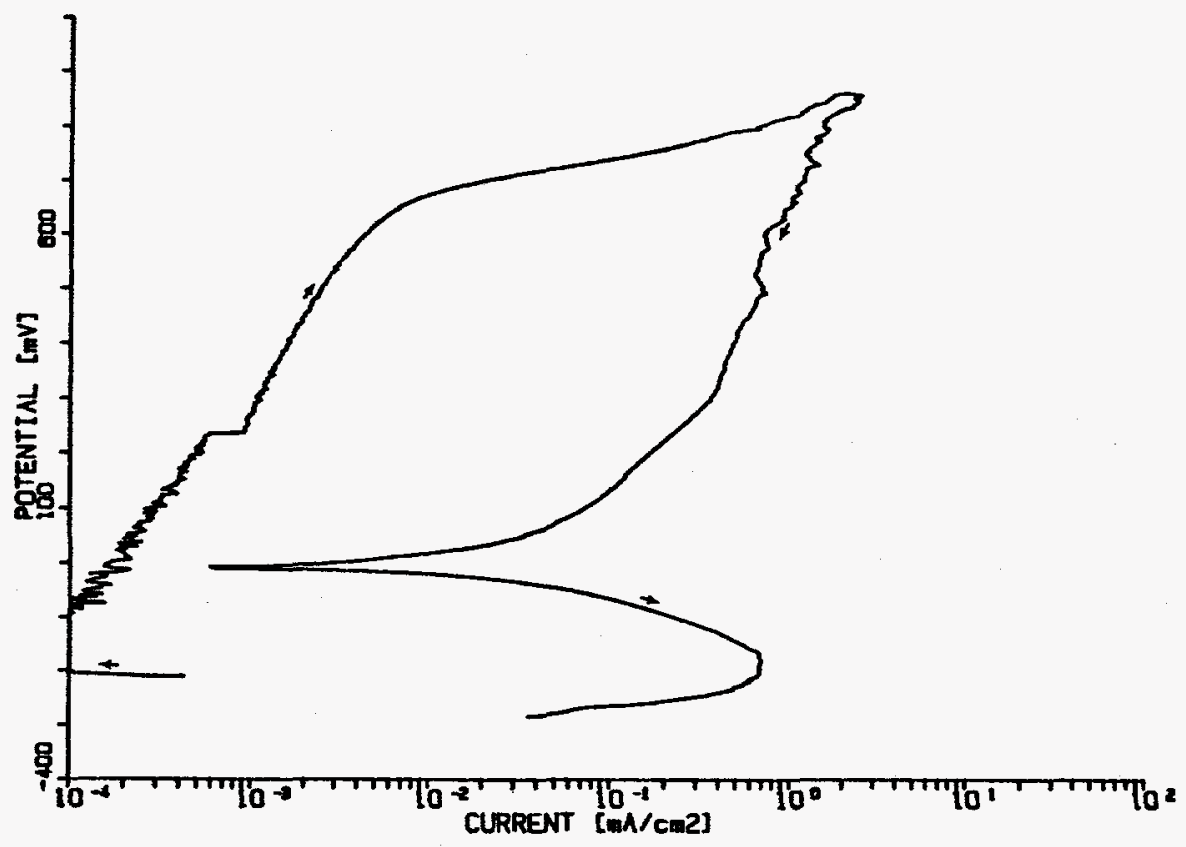

Figure B19. Potentlodynamic Rolerization Curve For Allog CDA 715 In Solution No. 19 At $90^{\circ} \mathrm{C}$

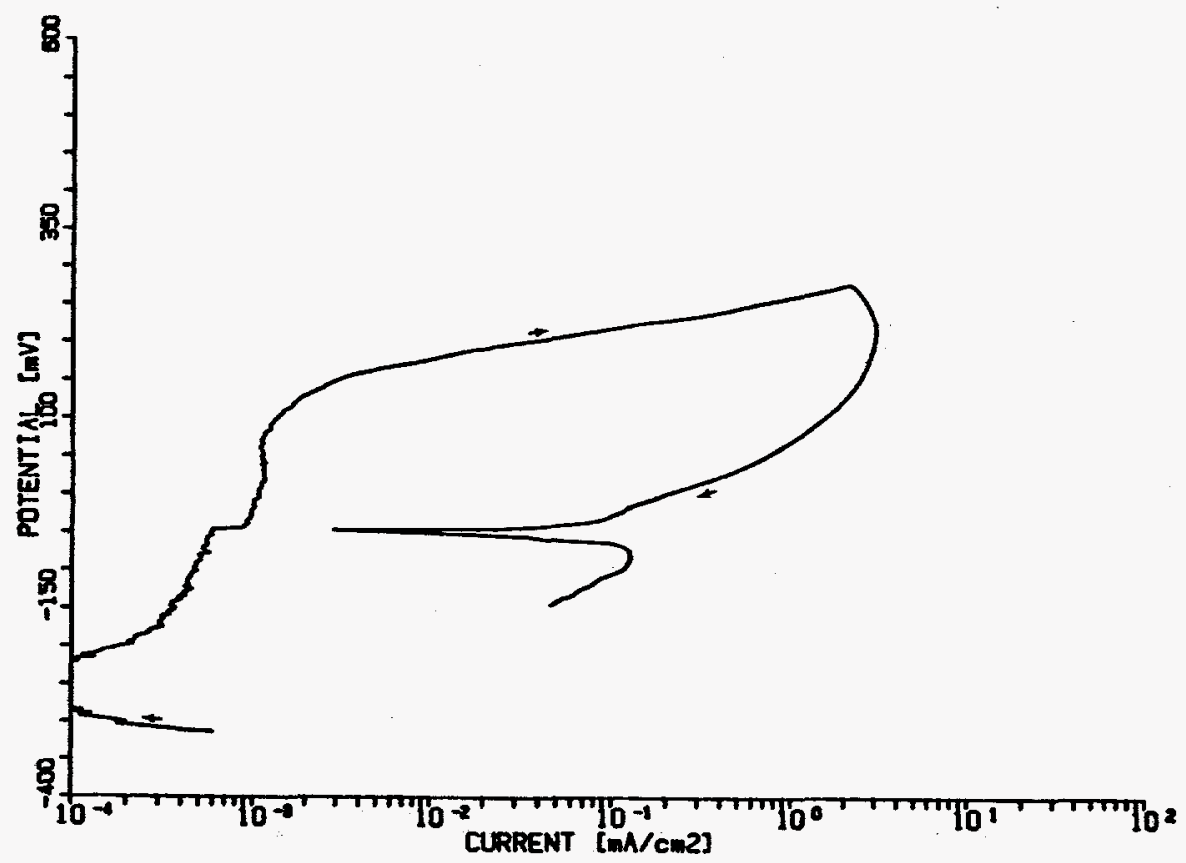

Figure 820. Potentfodynamle Polarization Curve For Alloy CDA 715 In Solution No. 20 at $50^{\circ} \mathrm{C}$. 


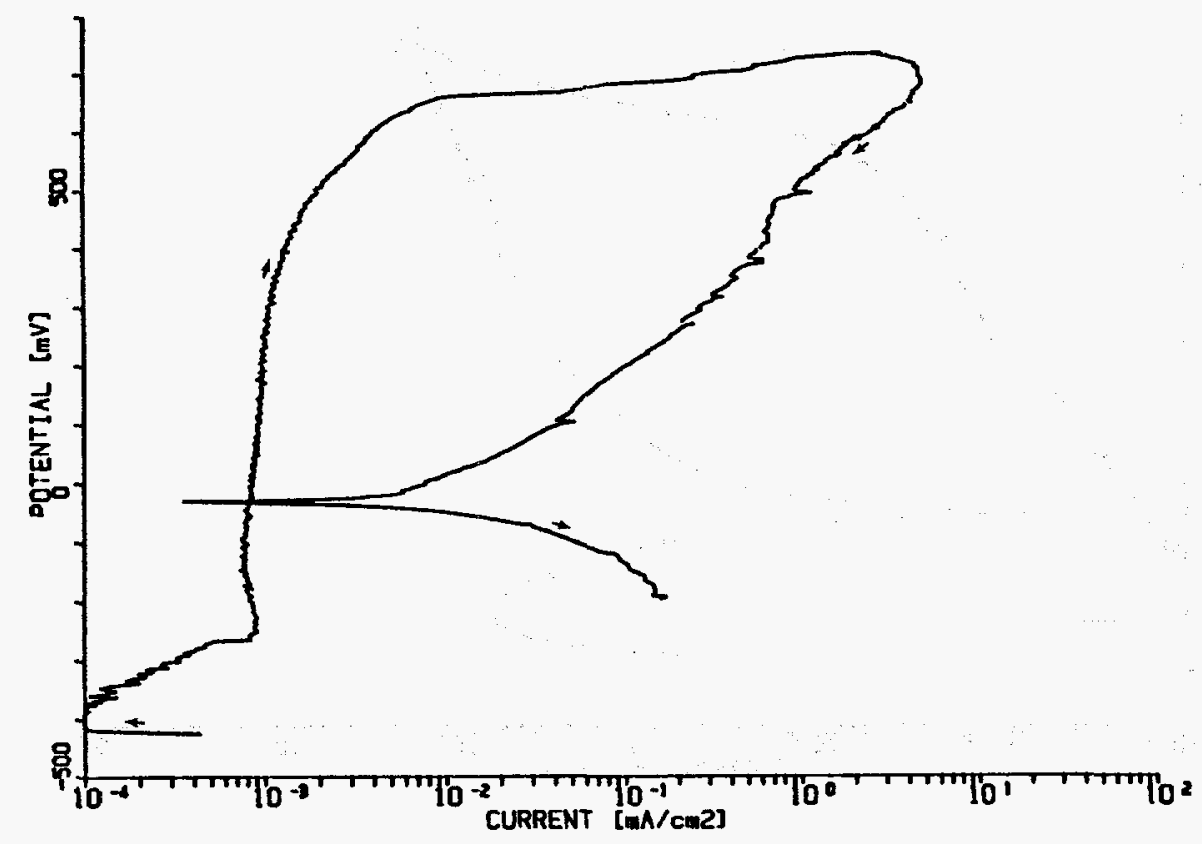

Figure 821. Potentiodynamic Polarization Curve For Alloy CDA 715 In Solution No. 21 at $90^{\circ} \mathrm{C}$.

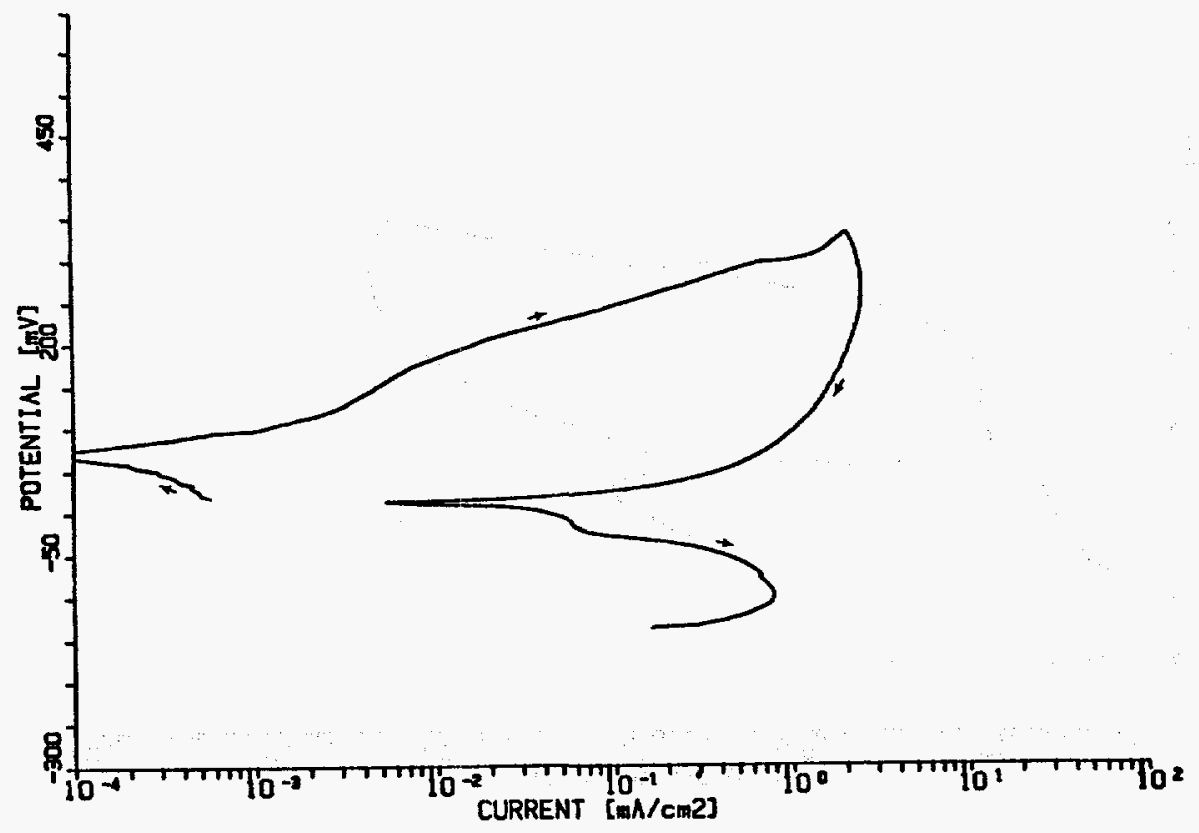

Figure B22. Potentlodynamic Polarization Curve For A1loy CDA 715 In Solution Ho. 22 at $50^{\circ} \mathrm{C}$. 


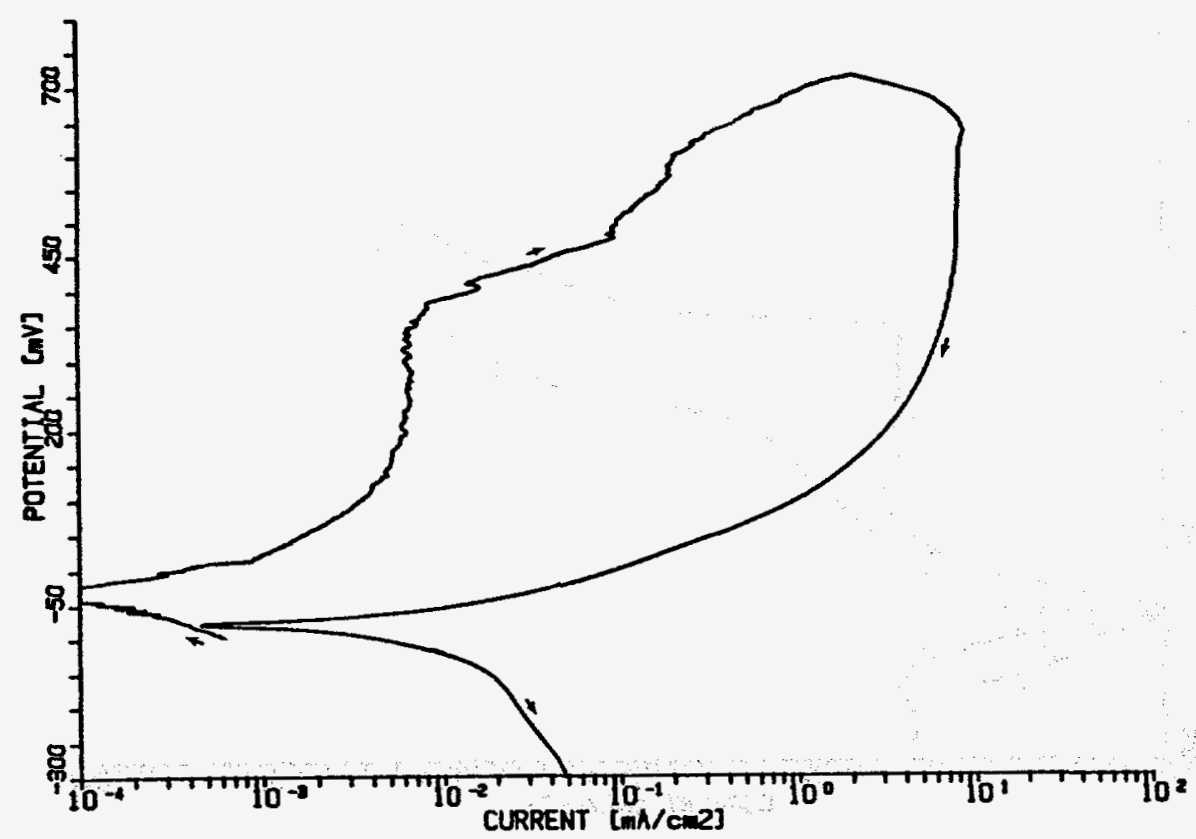

Figure 823. Potent 1odynamle Polarization Curve For Alloy CDA 715 In Solution No. 23 At $50^{\circ} \mathrm{C}$.

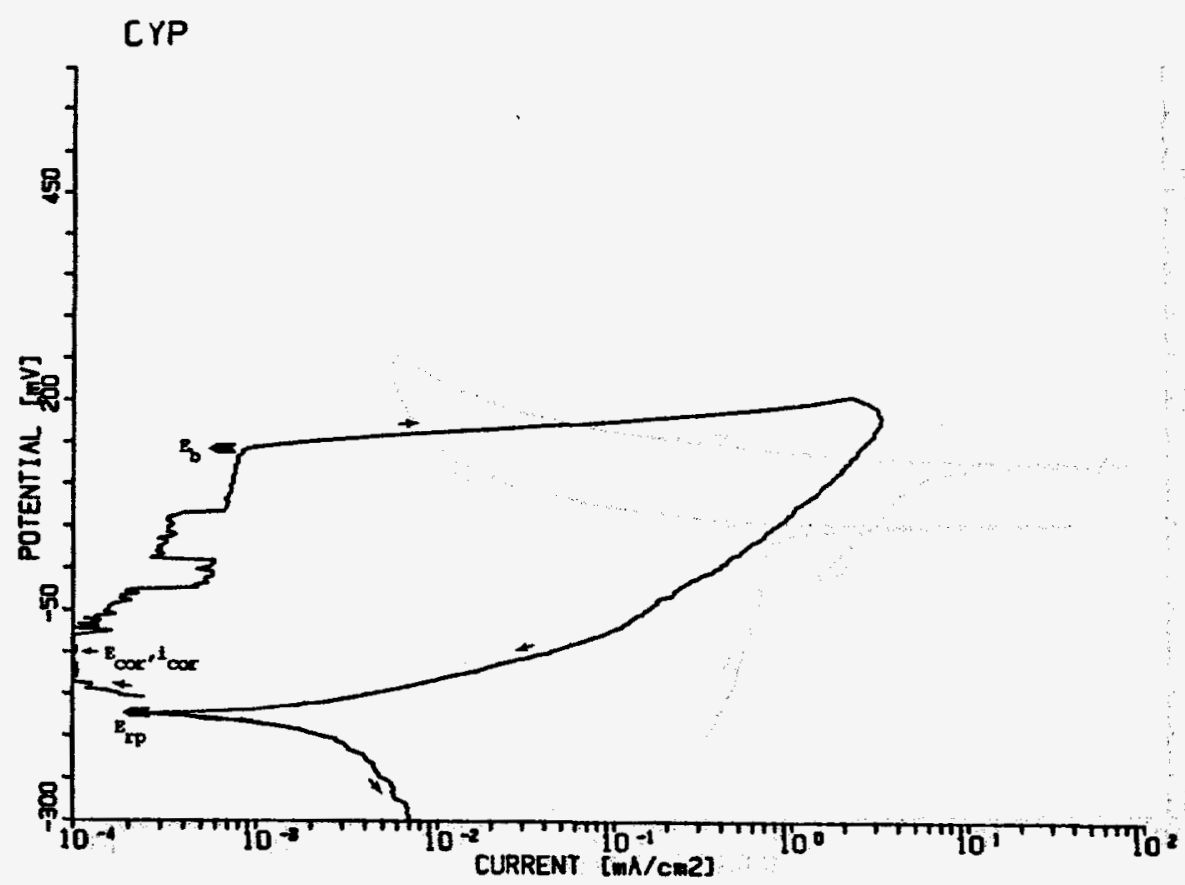

Figure B24. Potentiodynamic Polerlzation Curve For Alloy CDA 713 In Solution No. 24 at $90^{\circ} \mathrm{C}$. 


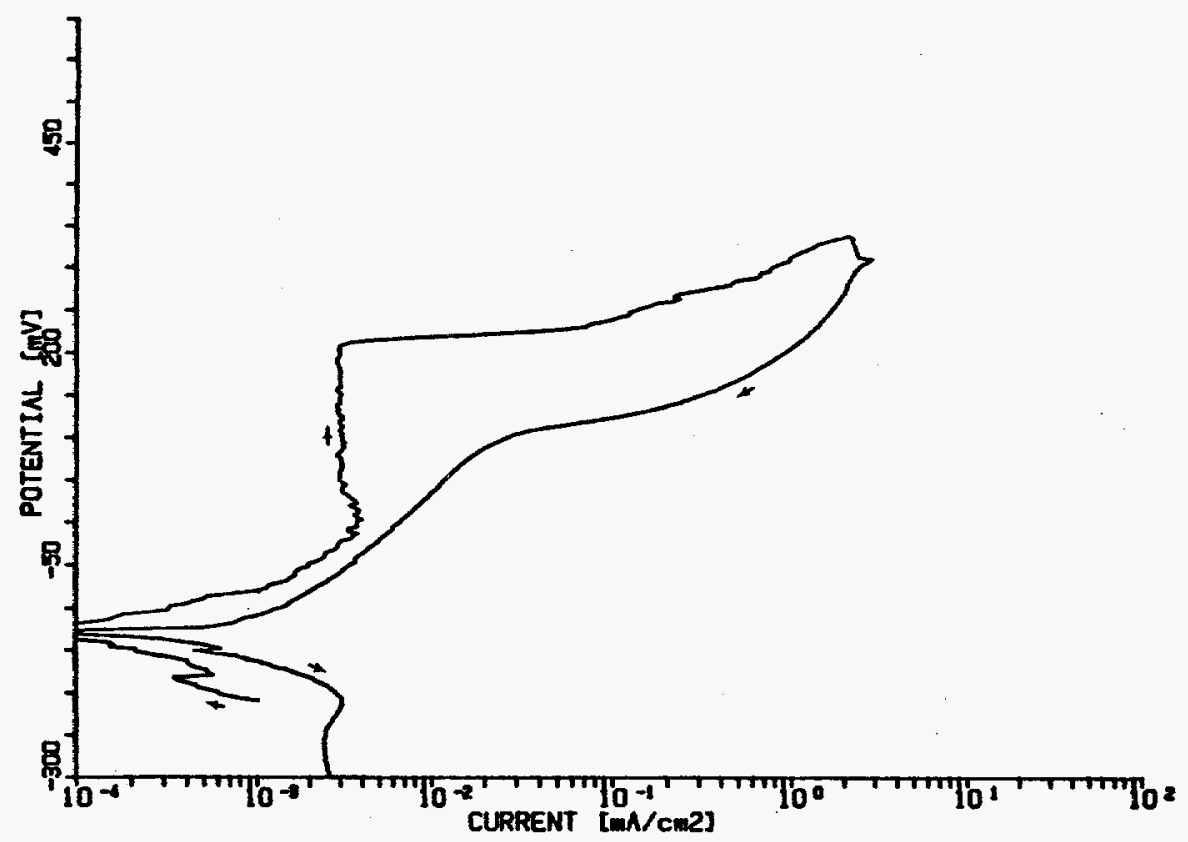

Fizure B25. Rotentiodranic Polarizetioa Curve For Alloy CDA 715 In Solution Ho. 25 At $90^{\circ} \mathrm{C}$.

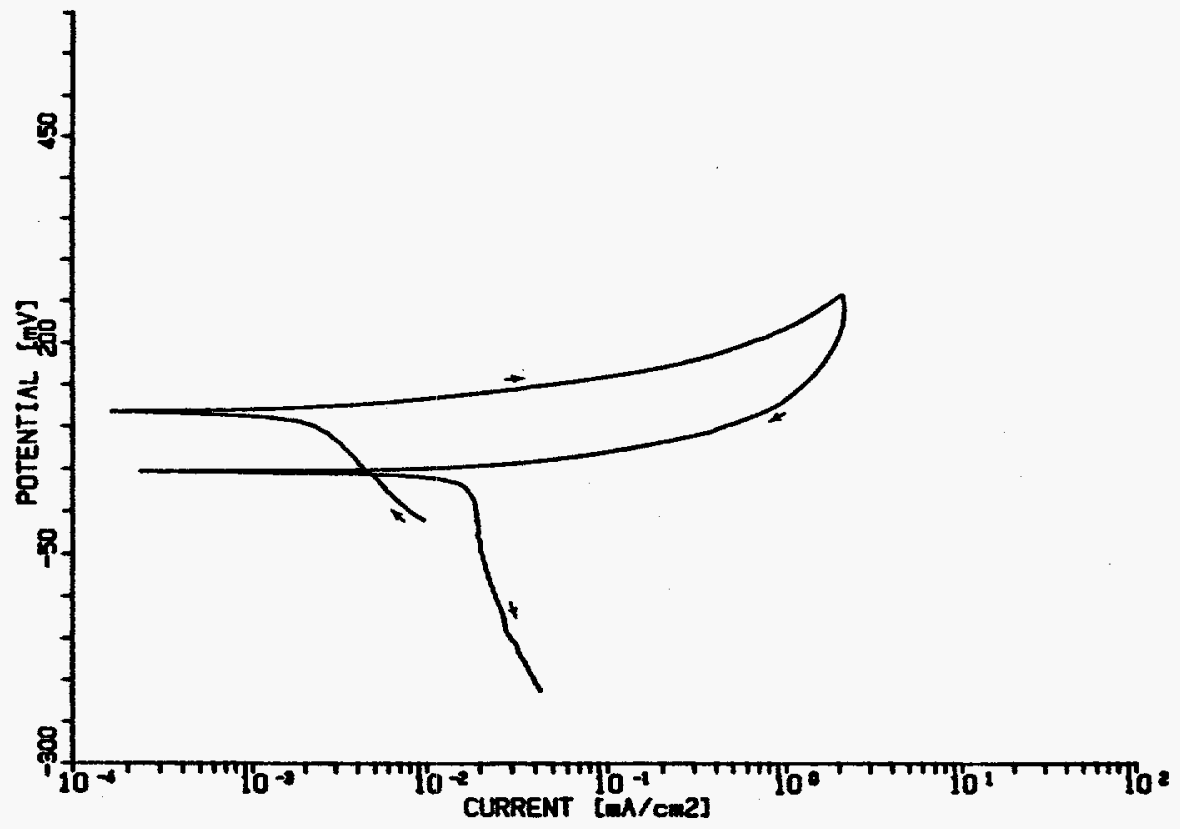

F1gure 826. Potentiodyanic Polerization Curve For Alloy CDA 715 In Solution Ho. 26 At $30^{\circ} \mathrm{C}$. 


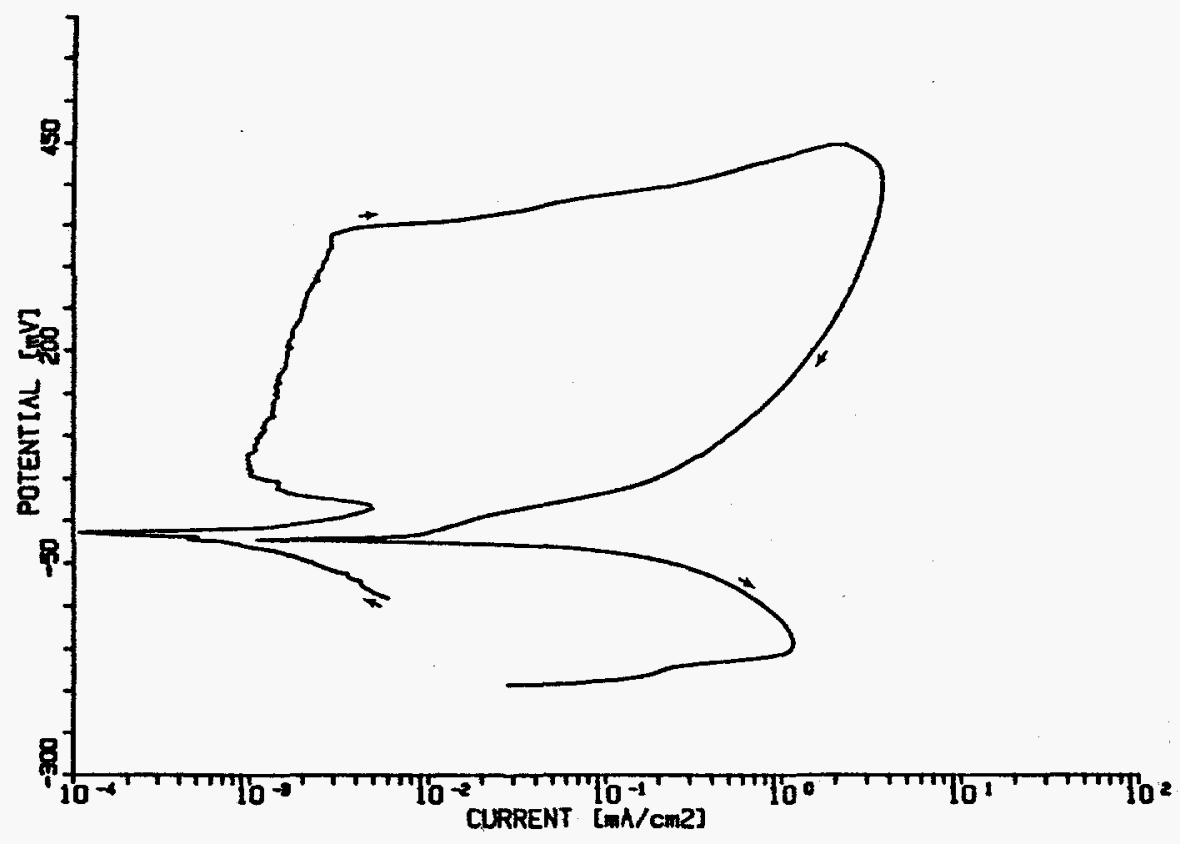

Figure 827. Potentlodynamle Polarization Curve For Alloy CDA 715 In Solution No. 27 at $50^{\circ} \mathrm{C}$

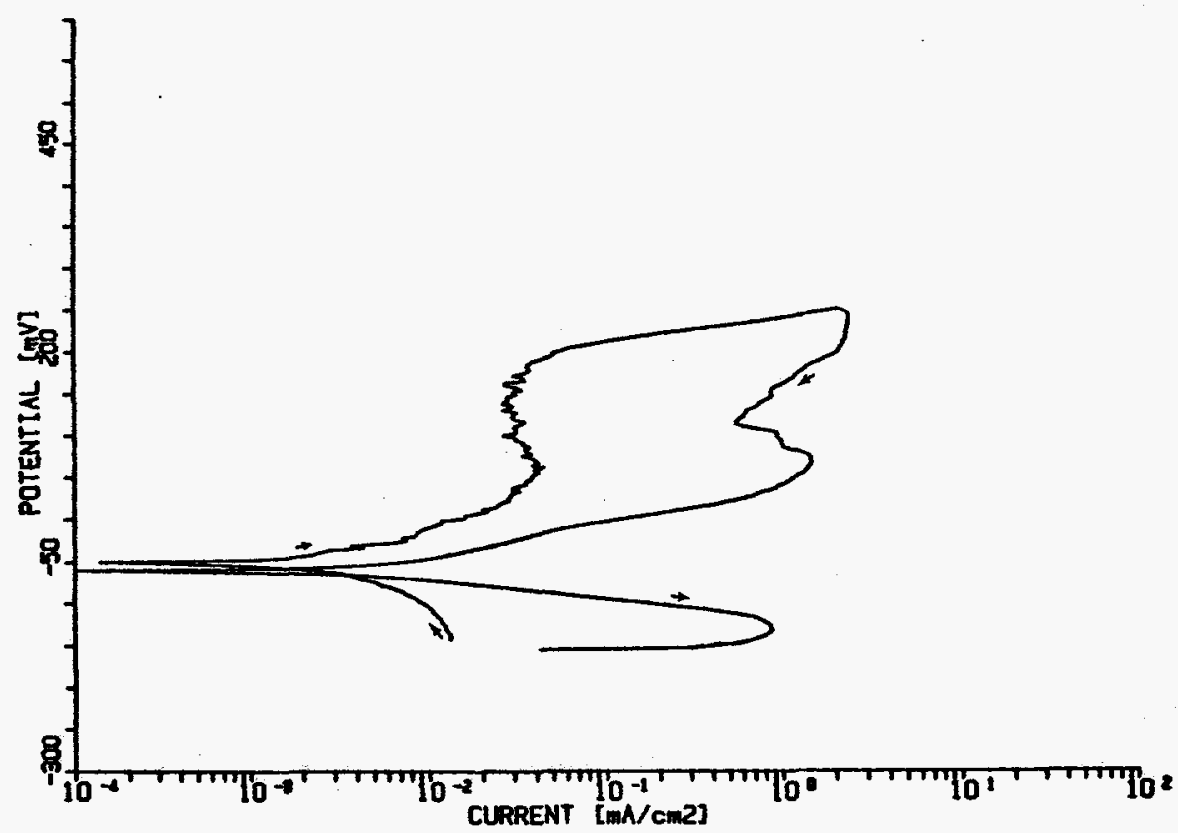

Floure 328. Potentlodyanic Polarizetion Curve For Alloy CDA 715 In Solution No. 28 At $90^{\circ} \mathrm{C}$. 


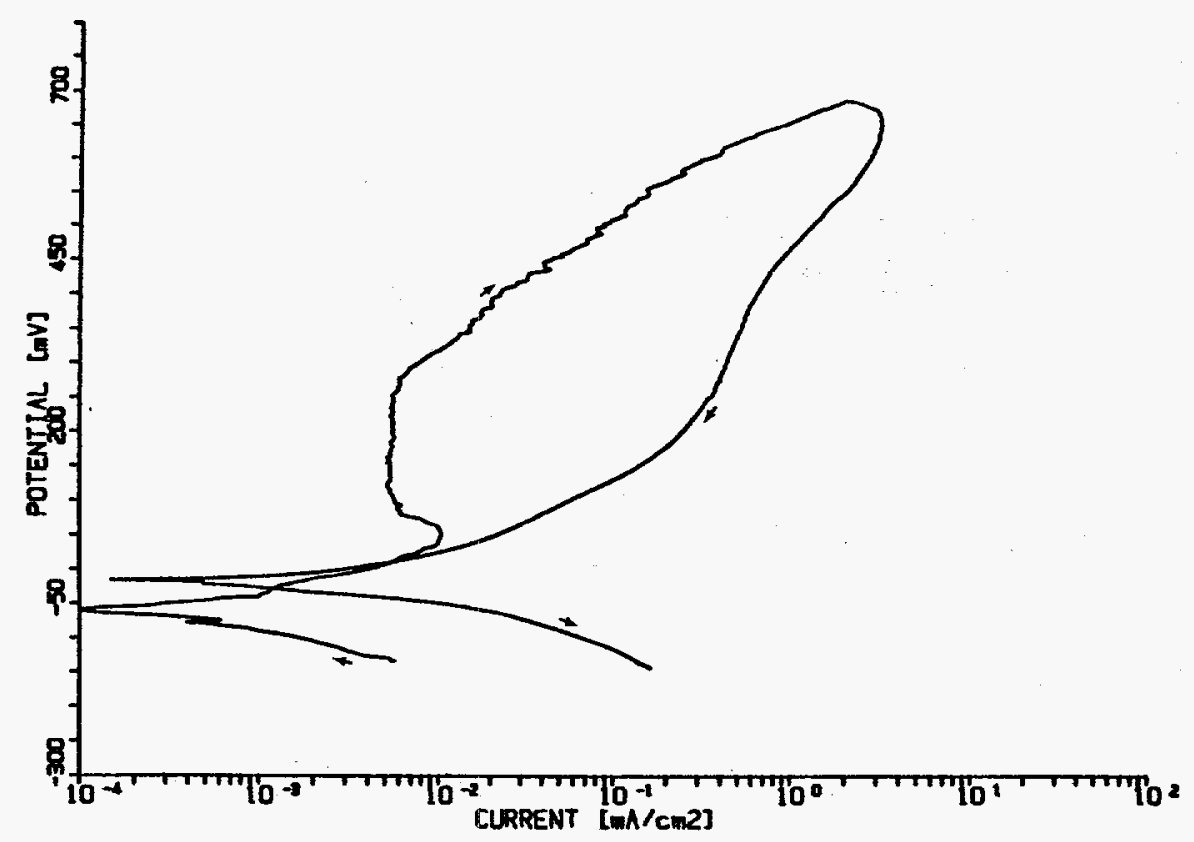

Eigure 829. Potentiodjnamie Polerization Curve For Alloy CDA 715 In Solution No. 29 at $50^{\circ} \mathrm{C}$.

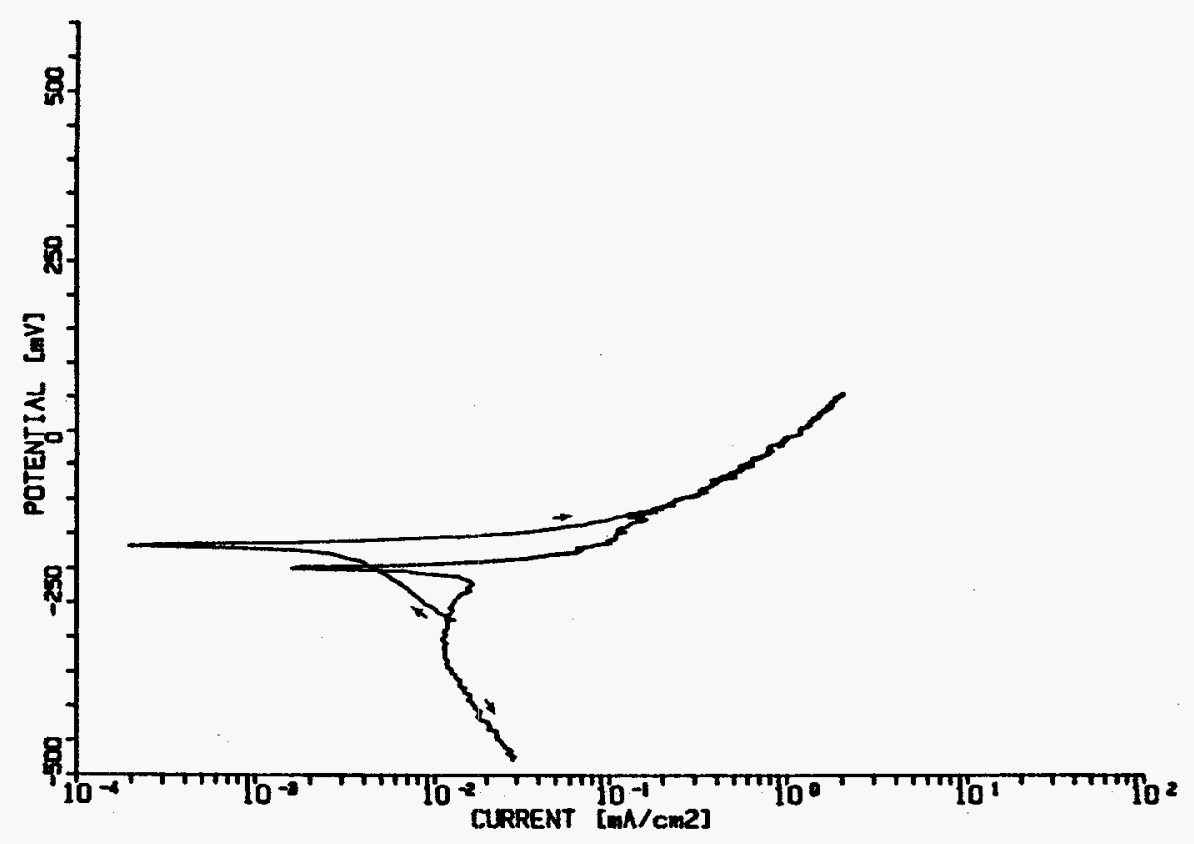

FIgure B30. Rotentlodynalic Rolerization Curve For Alloy CDA 715 In Solution No. 30 At $90^{\circ} \mathrm{C}$. 


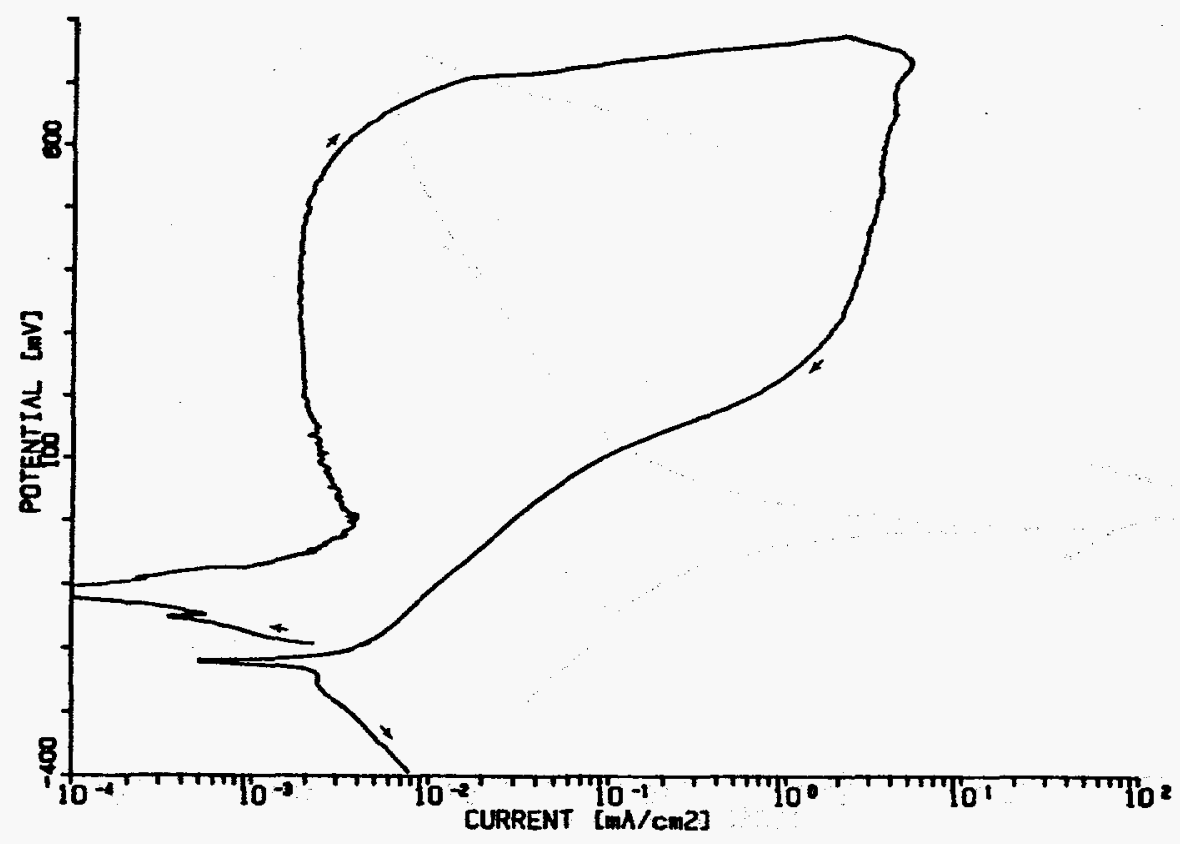

Figura B31. Potentlodynamic Polezization Curve For Alloy CDA 115 In Solution no. 31 at $90^{\circ} \mathrm{C}$.

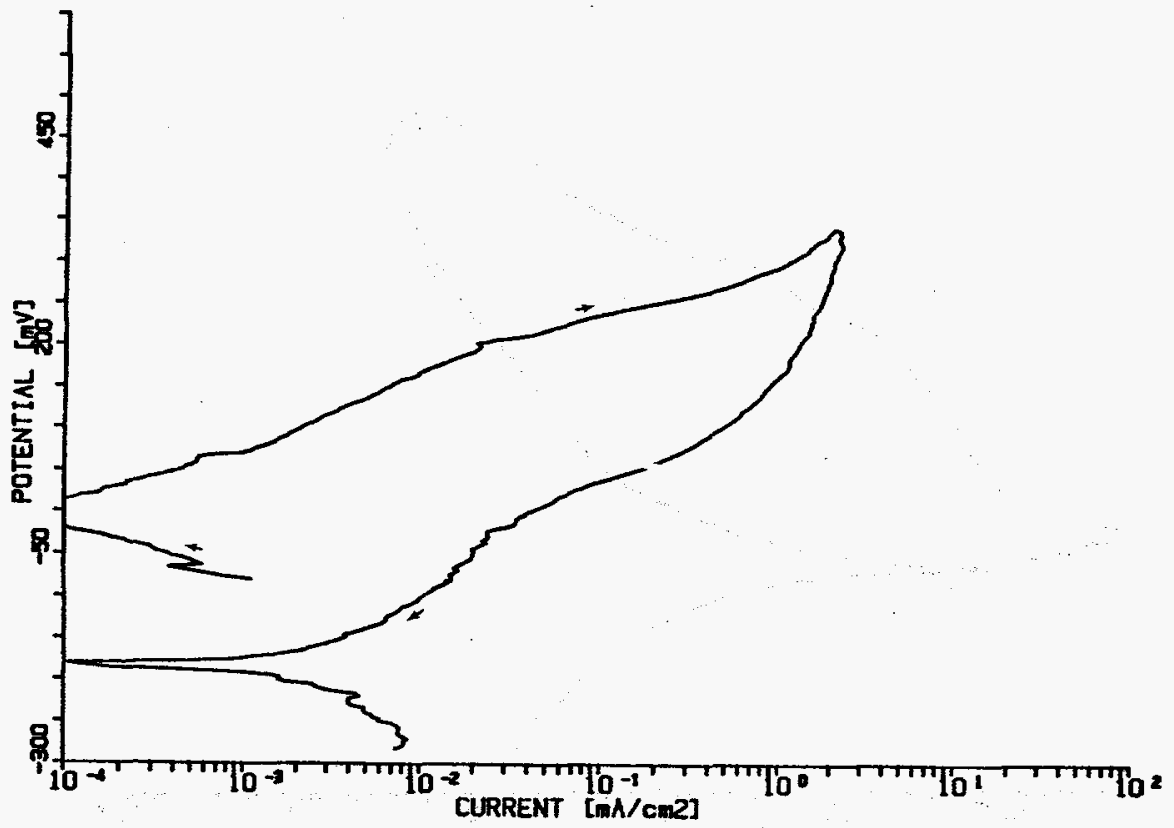

Figure B32. Potentlodynamie Polarization Curve For Alloy CDA 715 In Solution No. 32 At $50^{\circ} \mathrm{C}$. 


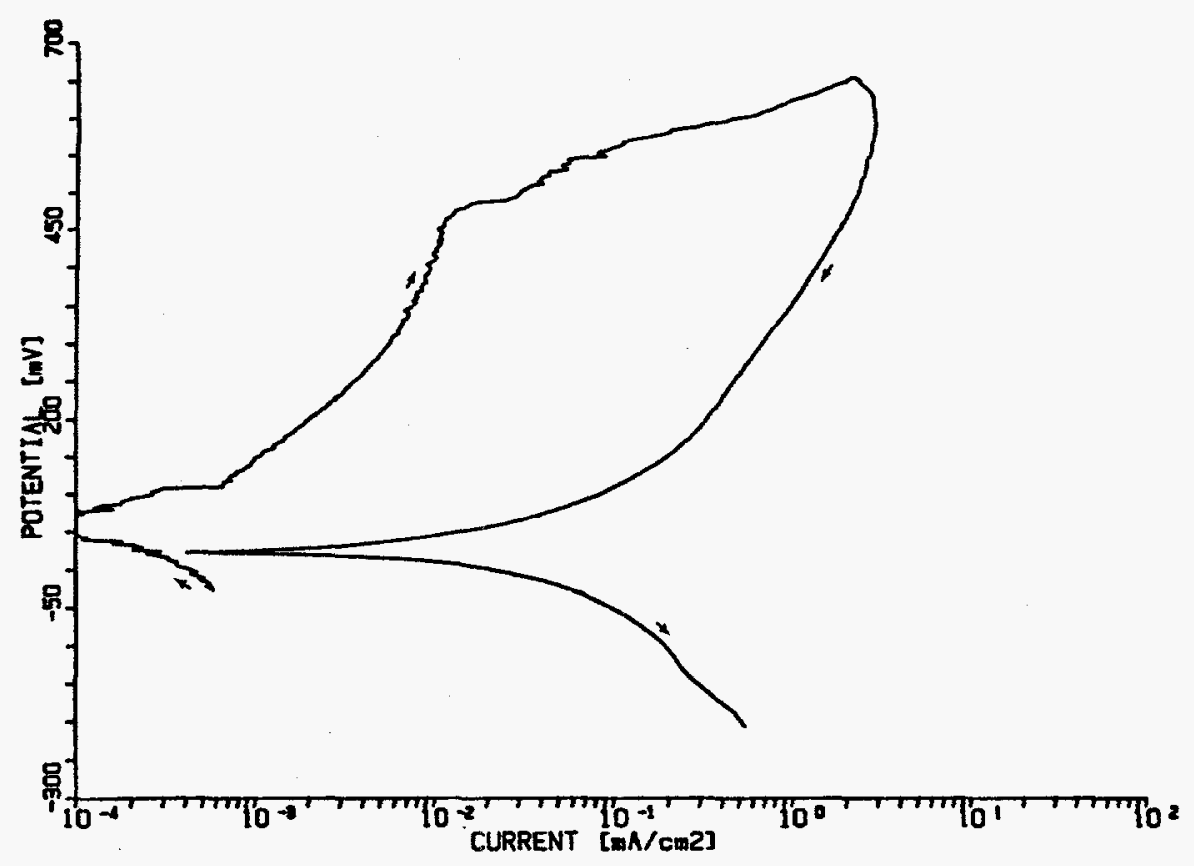

F1gure B33. Potentiodynamic Polarization Curve For Alloy CDA 715 In Solution Ho. 33 at $70^{\circ} \mathrm{C}$.

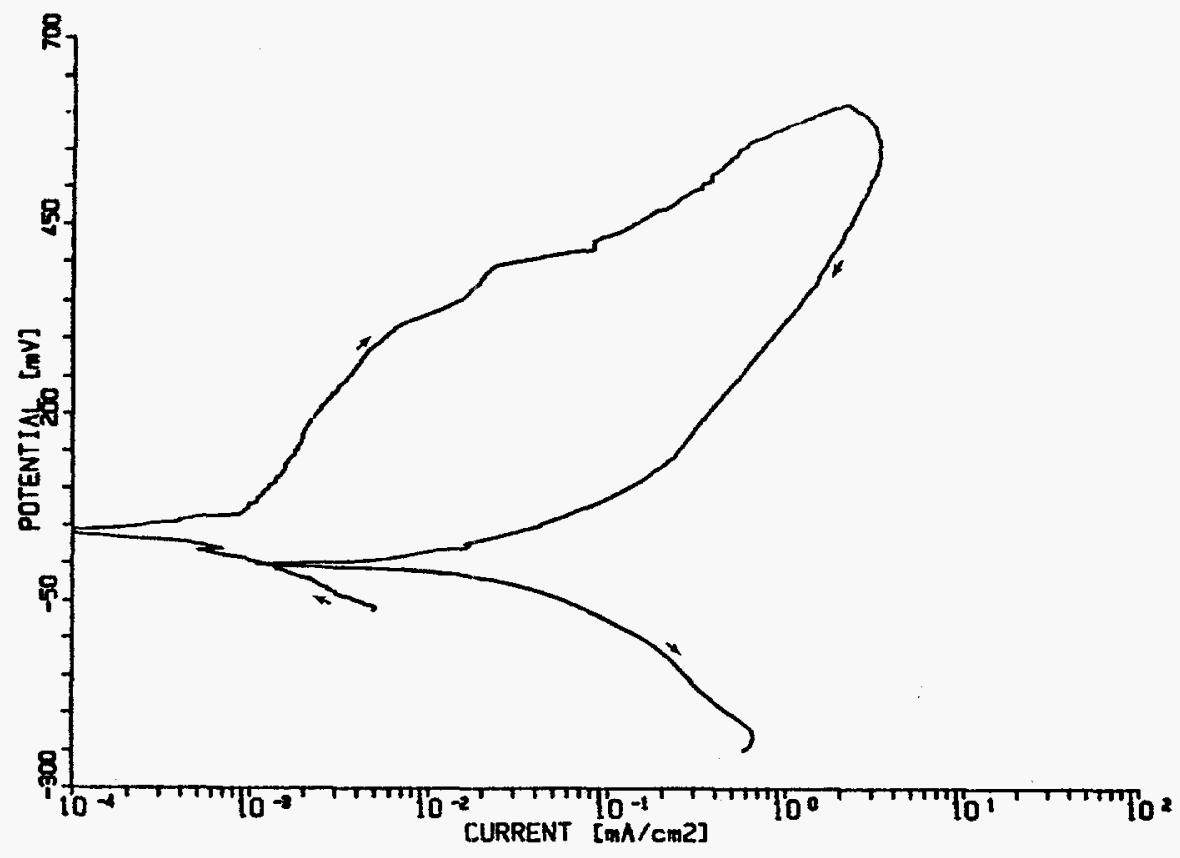

Figure B34. Eotent lodynaric Polerization Curve For Allog CDA 715 In Solution No. 34 at $70^{\circ} \mathrm{C}$. 


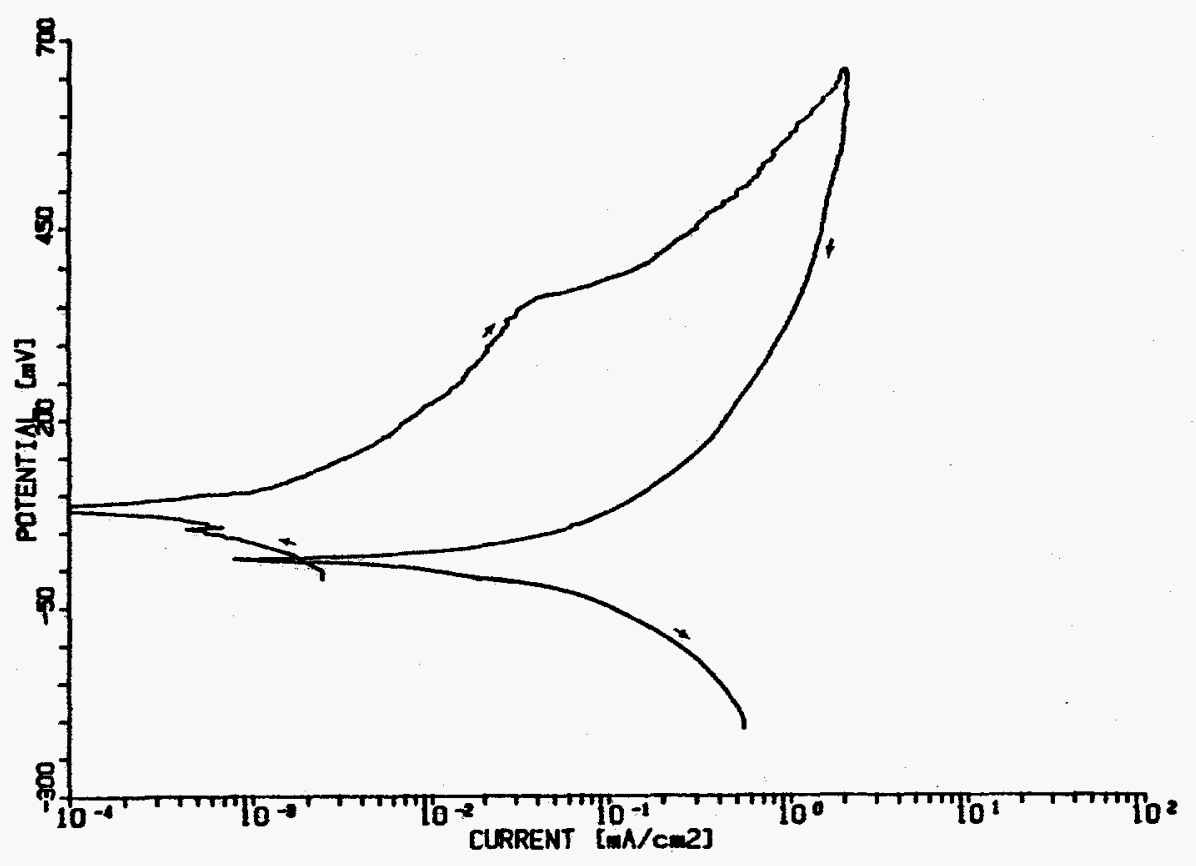

Figure B35. Fotentlodynamic Polerlzetion Curve For Alloy CDA 715 In Solution Ho. 35 at $70^{\circ} \mathrm{C}$.

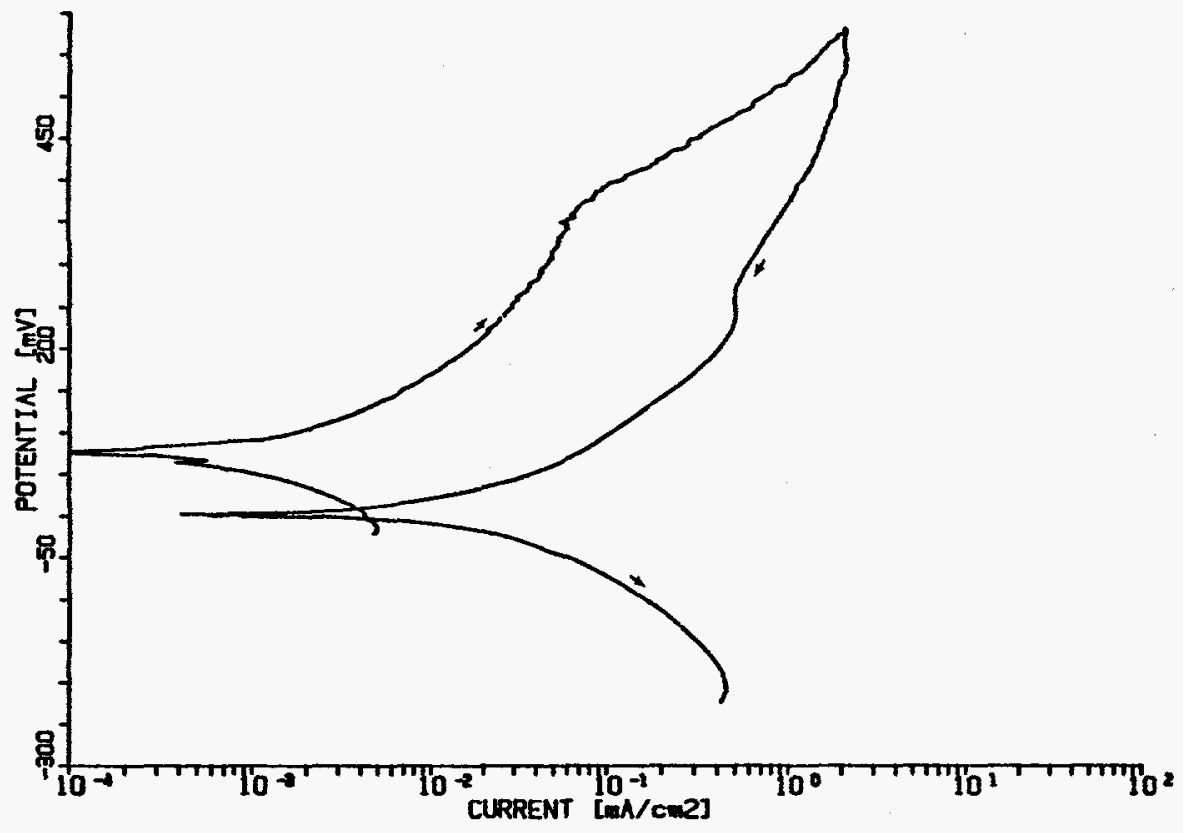

rigure B36. Potentlodynamic Polerizetion Curve For Alloy CDA 715 In Solution No. 36 at $70^{\circ} \mathrm{C}$. 


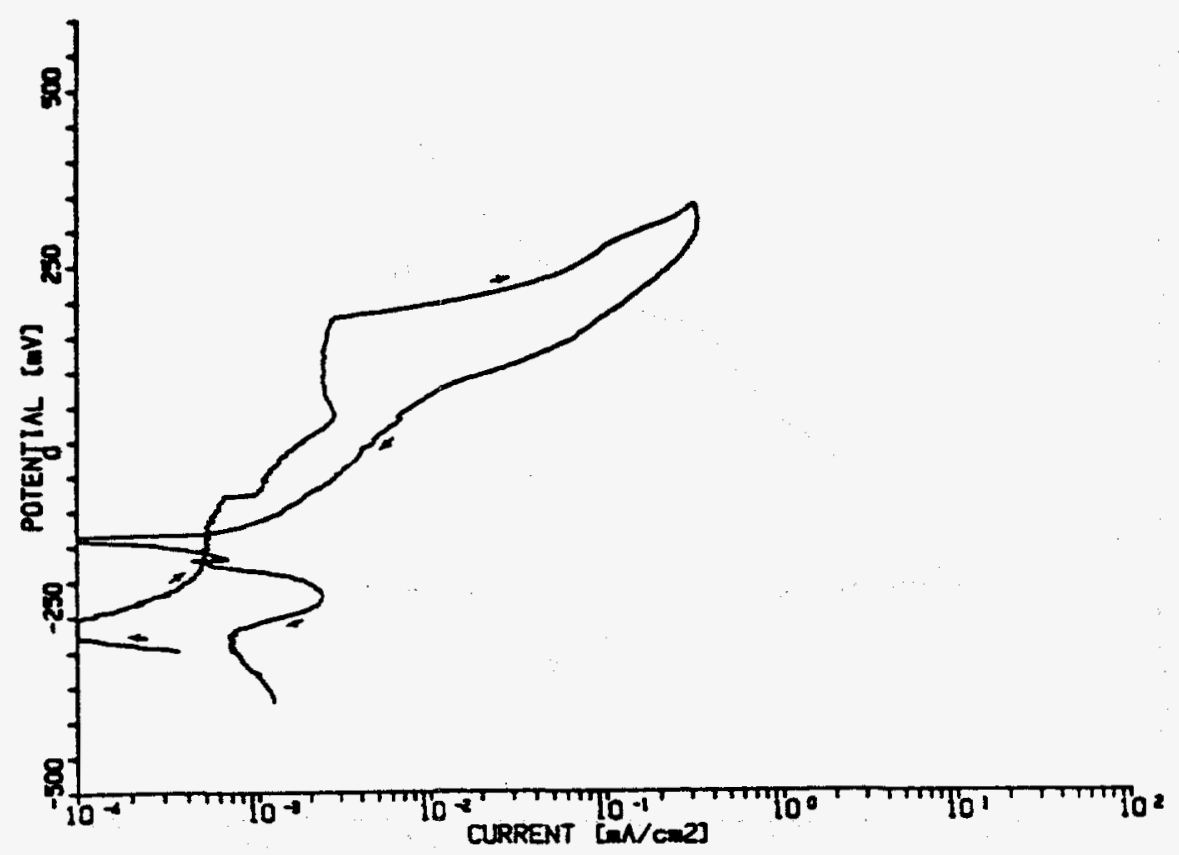

Tigure B37. Rotentiodynamic Polarization Curve For Alloy CDA 715 In Simulated $\mathrm{J}-13$ Voll Water $\Delta t 90^{\circ} \mathrm{C}$.

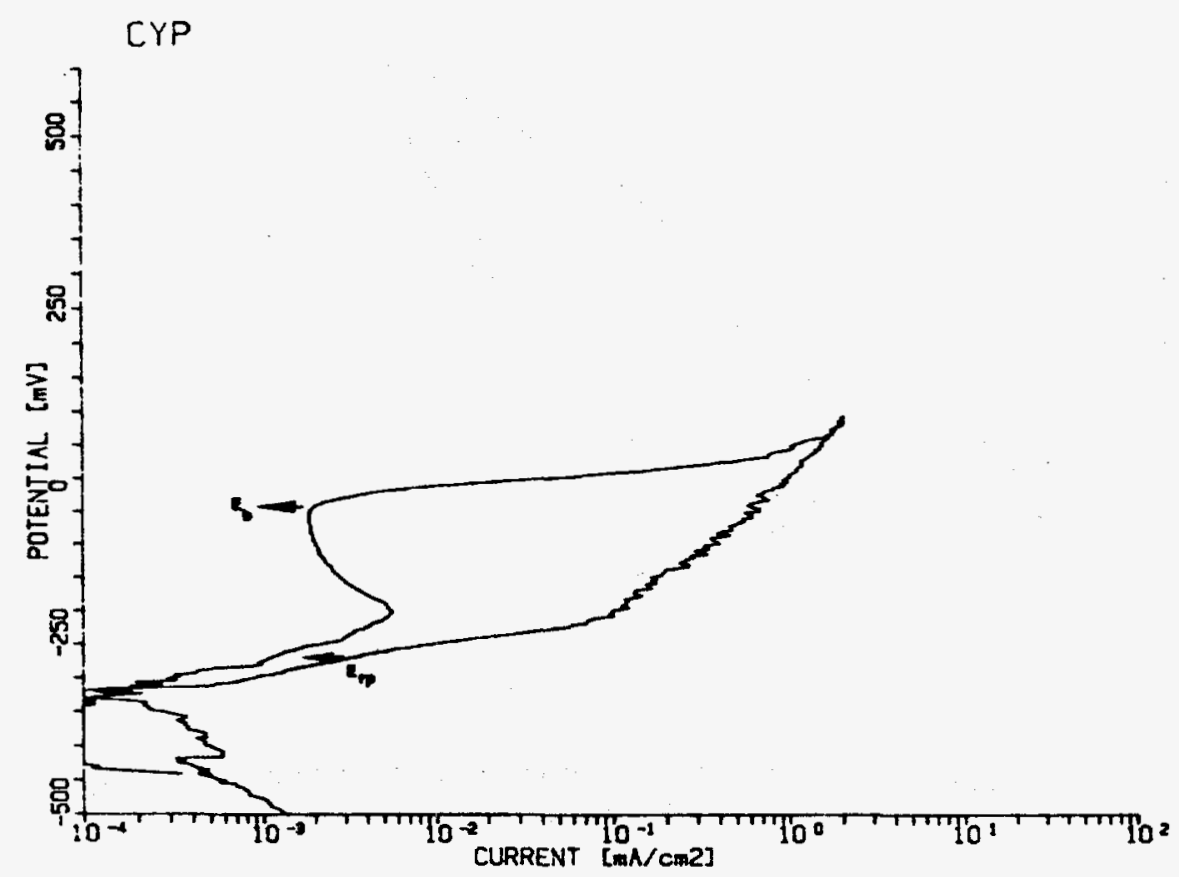

Figure B38. Fotentiodynanie Rolerization Curve For Alloy CDA 715 In Simulatad J-13 Wall Water With $1000 \mathrm{ma/1}$ Chloride (As sac1) at $90^{\circ} \mathrm{C}$. 


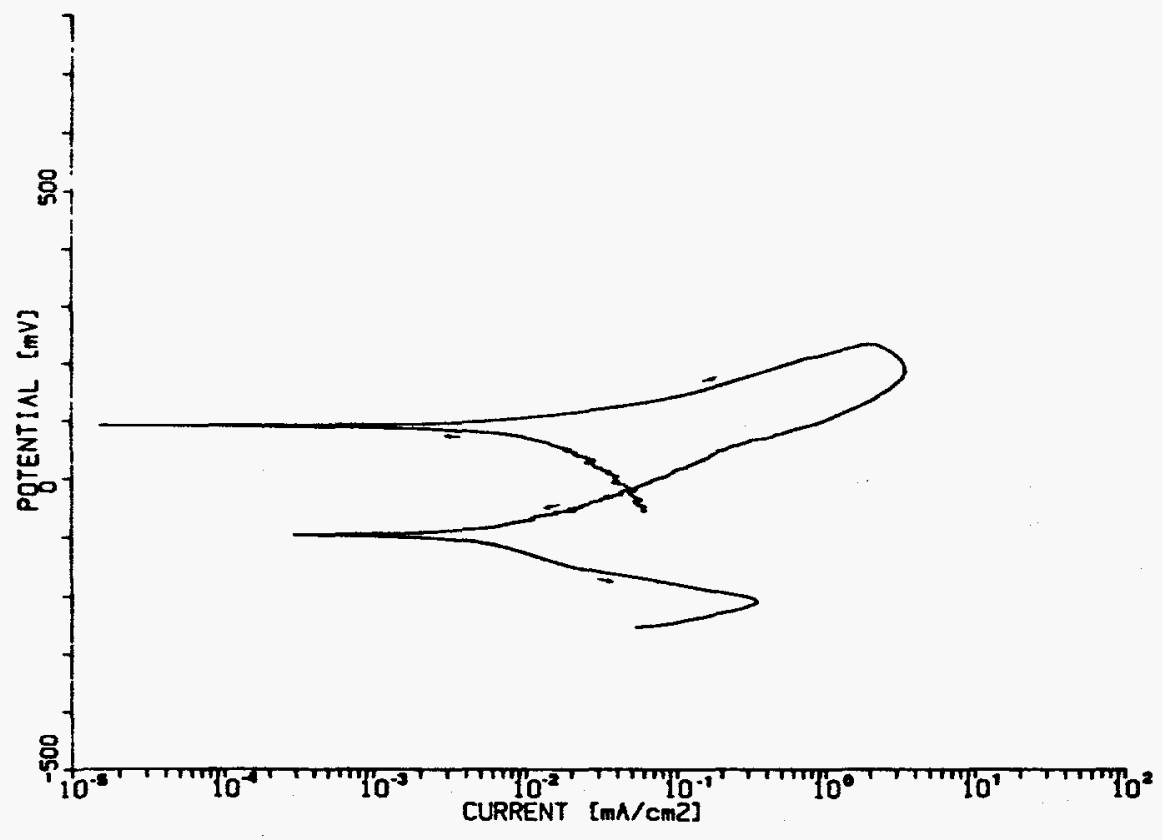

Plgure 839. Potentiodyanic Polarization Curve For Mlloy CDA 71S In Solution Mo. 39 at $10^{\circ} \mathrm{C}$.

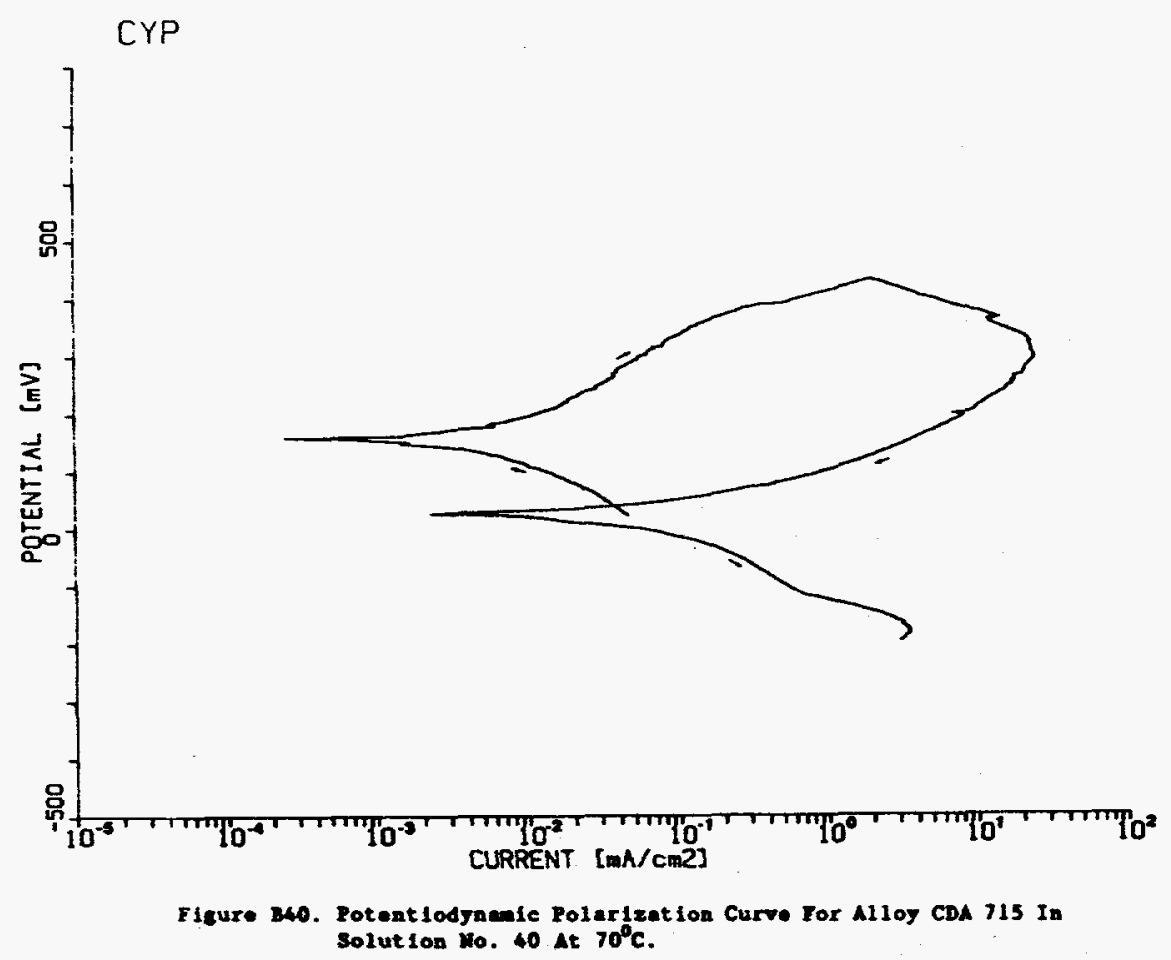




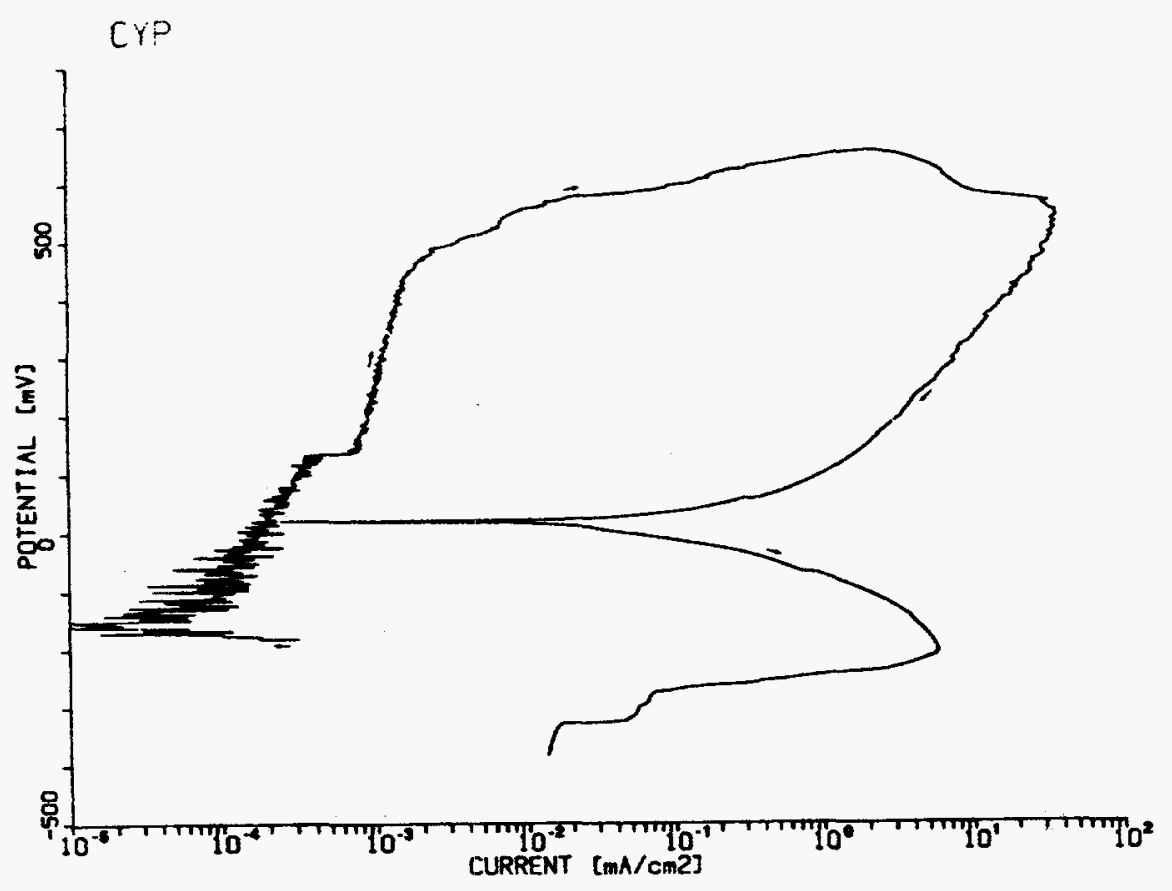

Figure B41. Potentiodynase Folerization Curve For Allog CDA 715 In Solution No. 11 at $70^{\circ} \mathrm{C}$.

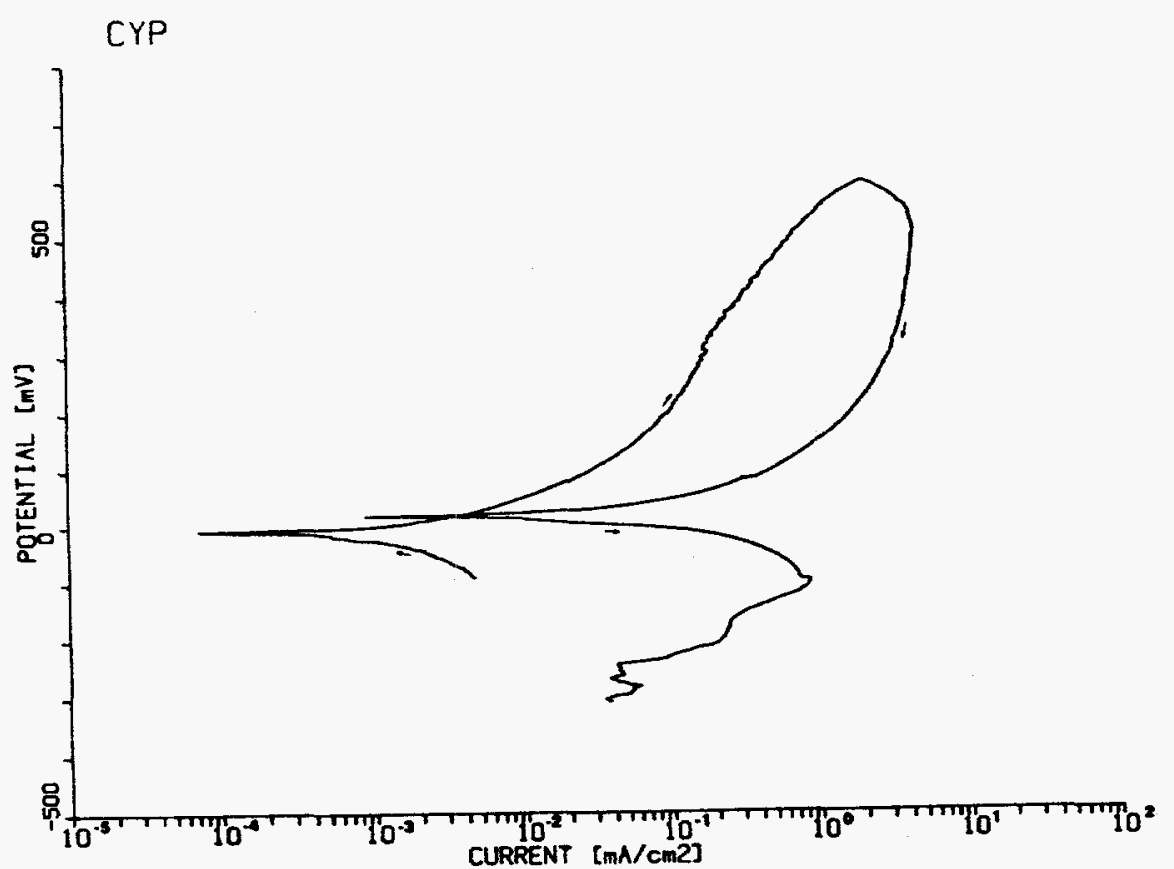

Figure 42. Potent lodjanale Polerization Curve For Alloy CDA 115 In solution No. 42 at $70^{\circ} \mathrm{C}$. 
APPENDIX C

CYCLIC POTENTIODYNAMIC POLARIZATION CURVES

FOR ALLOY 304L

IN TEST SOLUTIONS FROM THE

RESOLUTION IV MATRIX

$-165-$ 


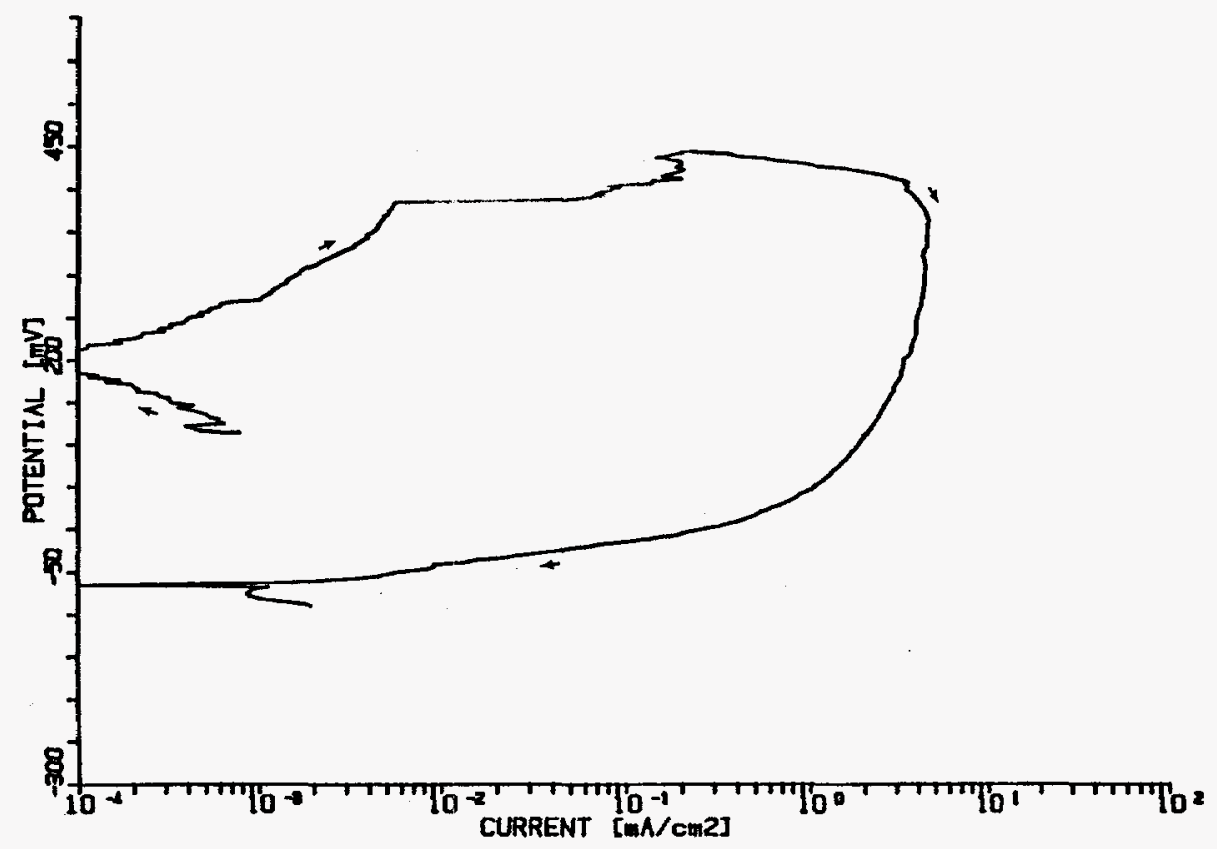

Figure C1. Potentlodynanic Polerization Curve For Alloy 304L In Solution Ho. 1 At $90^{\circ} \mathrm{C}$.

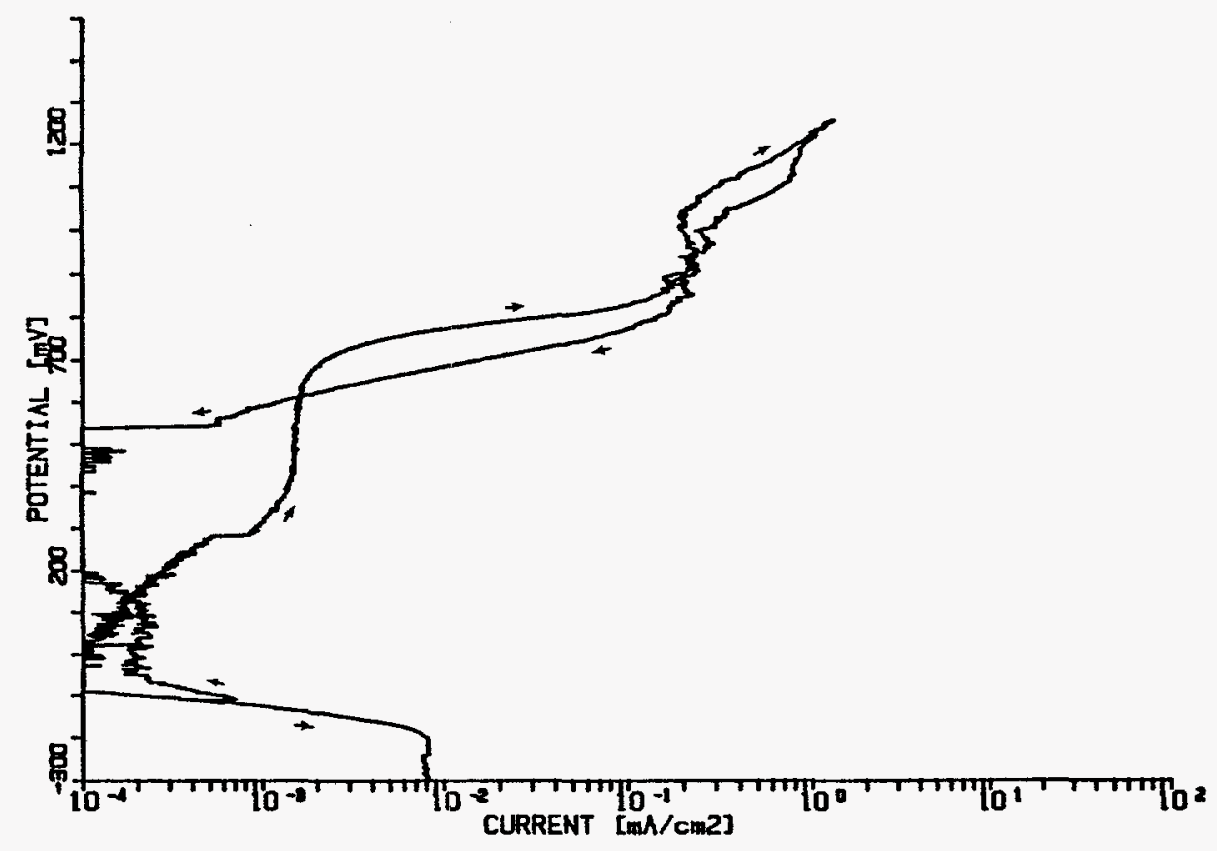

Figure C2. Potentlodynamic Polerleation Curve For Alloy $304 \mathrm{~L}$ In Solution No. 2 at $50^{\circ} \mathrm{C}$. 


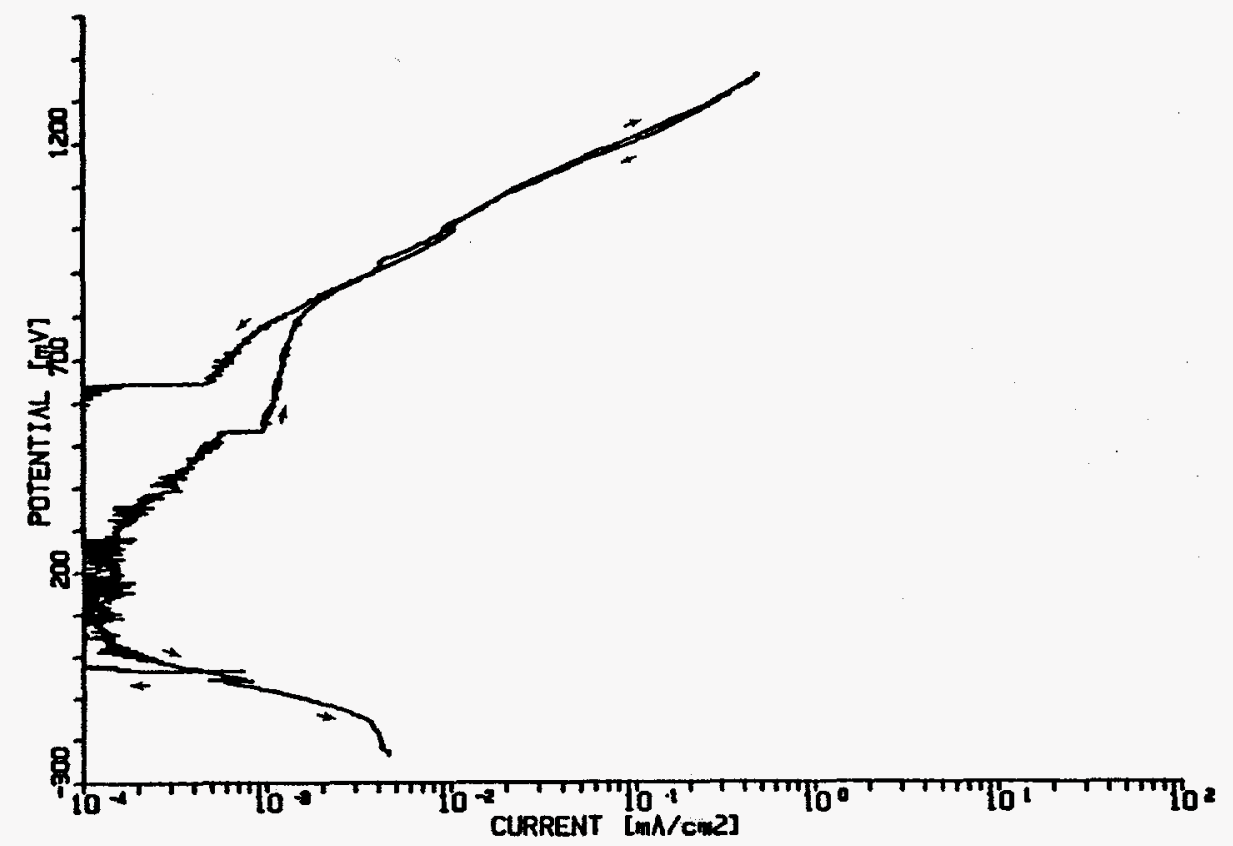

Figure C3. Potentlodynamic Polarization Curve For Alloy 304L In Solution No. 3 at $50^{\circ} \mathrm{C}$.

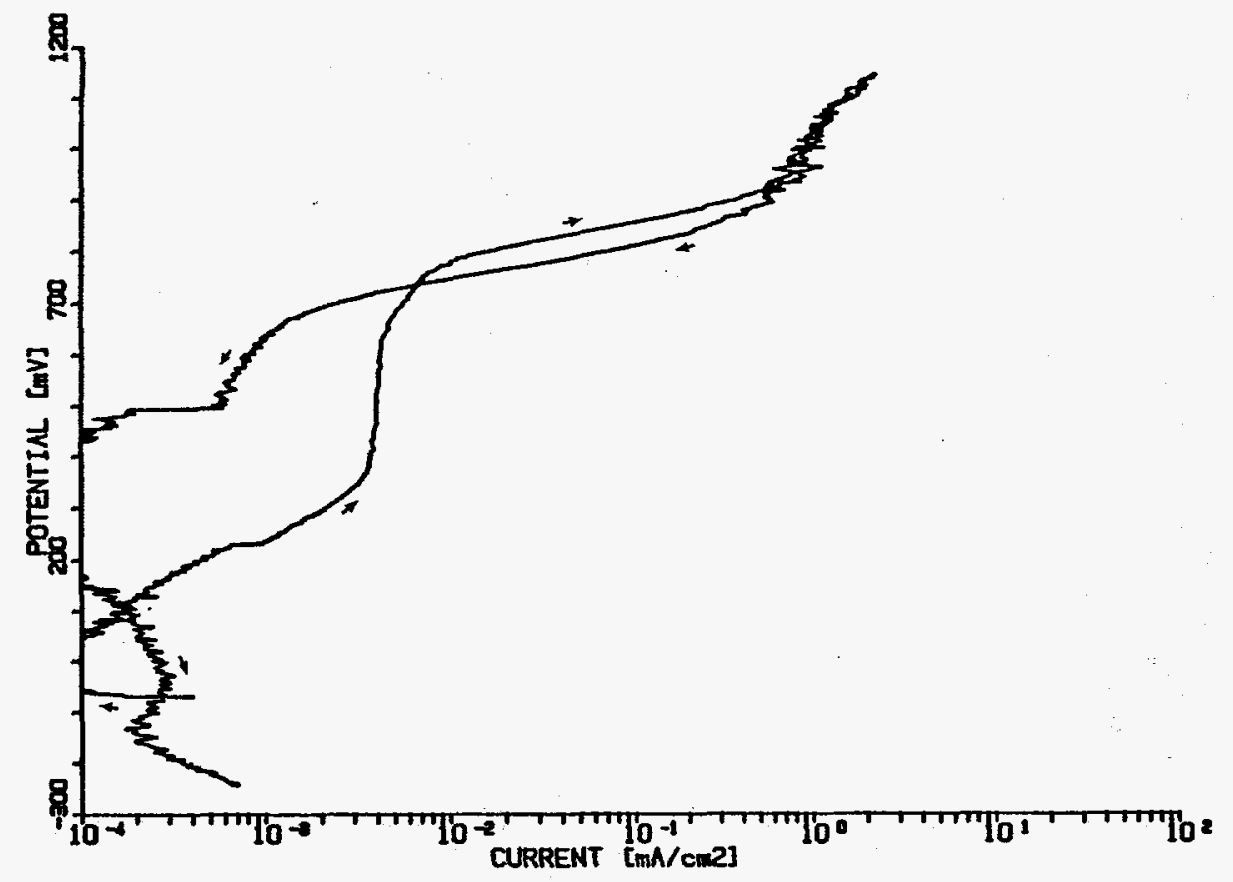

Eigure C4. Potentiodynamic Polarization Curve For Alloy $304 \mathrm{~L}$ In Solution 110. 4 st $90^{\circ} \mathrm{C}$. 


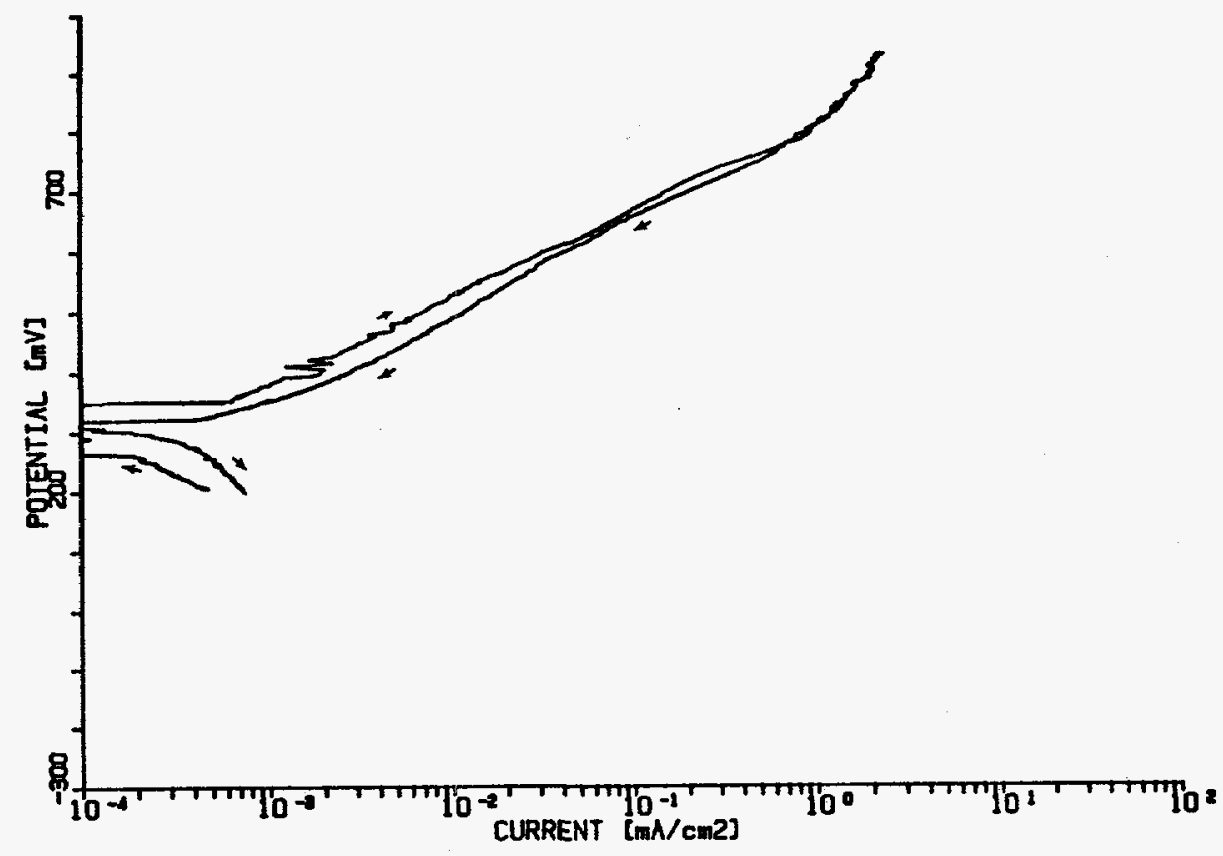

Tigure C5. Potentiodynamic Polarizetion Curve For Alloy $304 \mathrm{~L}$ In Solution No. 3 At $50^{\circ} \mathrm{C}$.

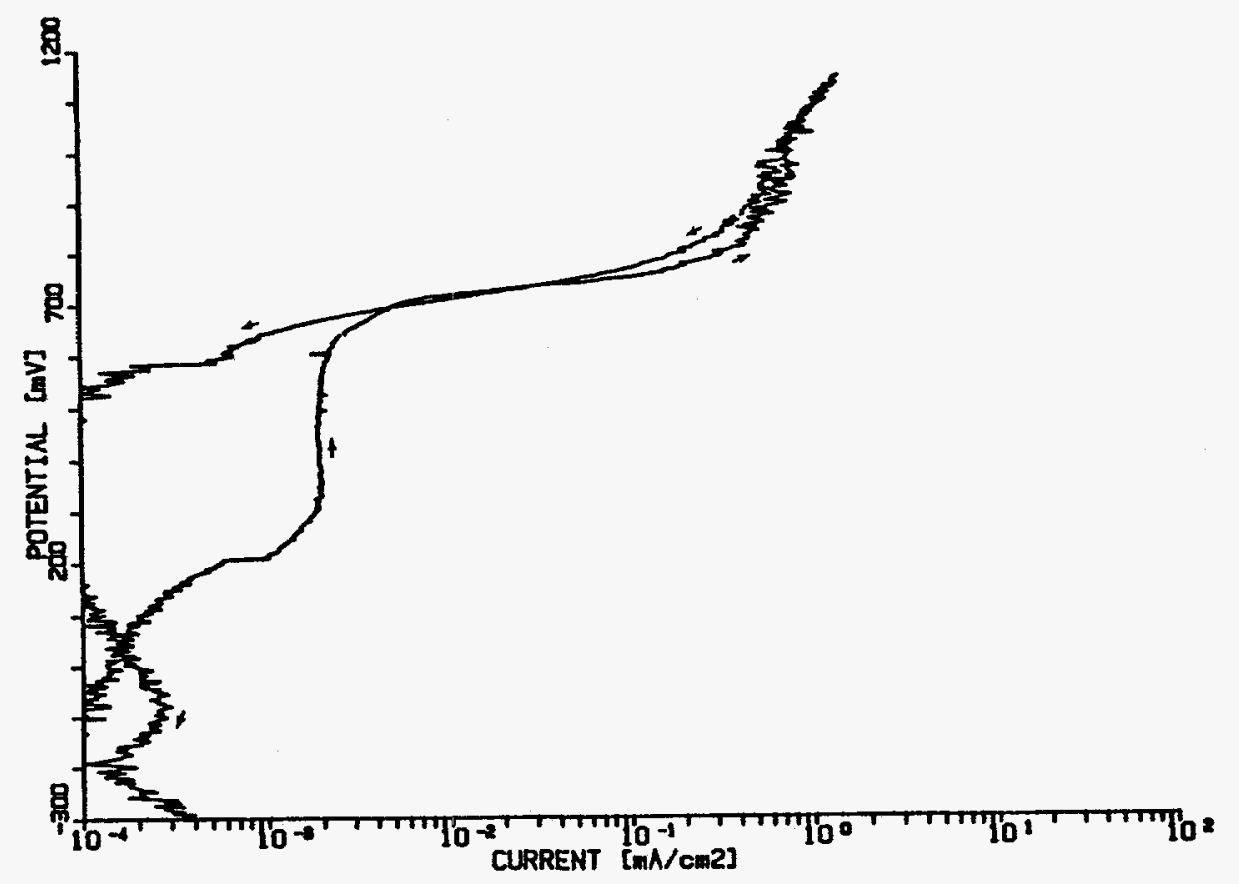

Figure C6. Fotentiodynamic Polertzation Curve For Alloy $304 \mathrm{~L}$ In Solution Ho. 6 at $90^{\circ} \mathrm{C}$. 


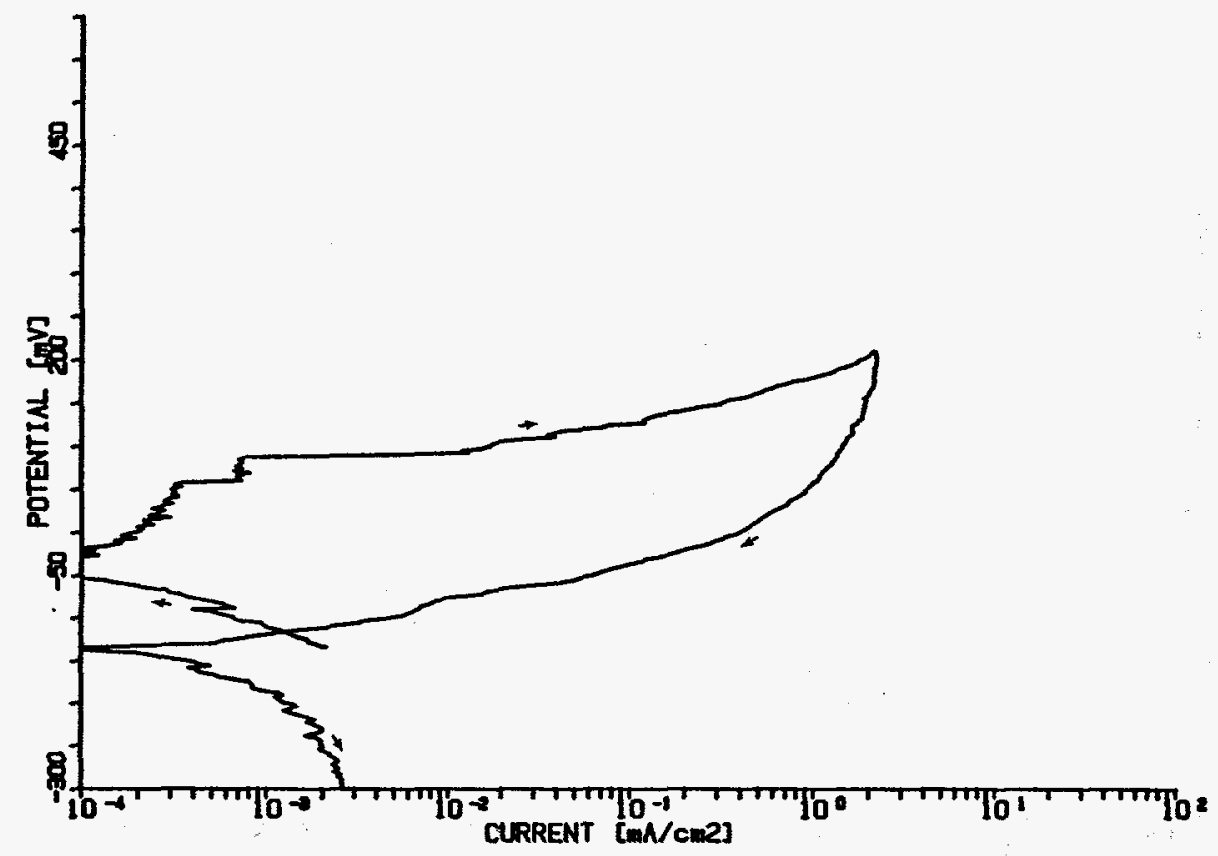

Figure C7. Rotent1odyamic Polarization Curve For Alloy 304L In solution Ho. 7 at $90^{\circ} \mathrm{C}$.

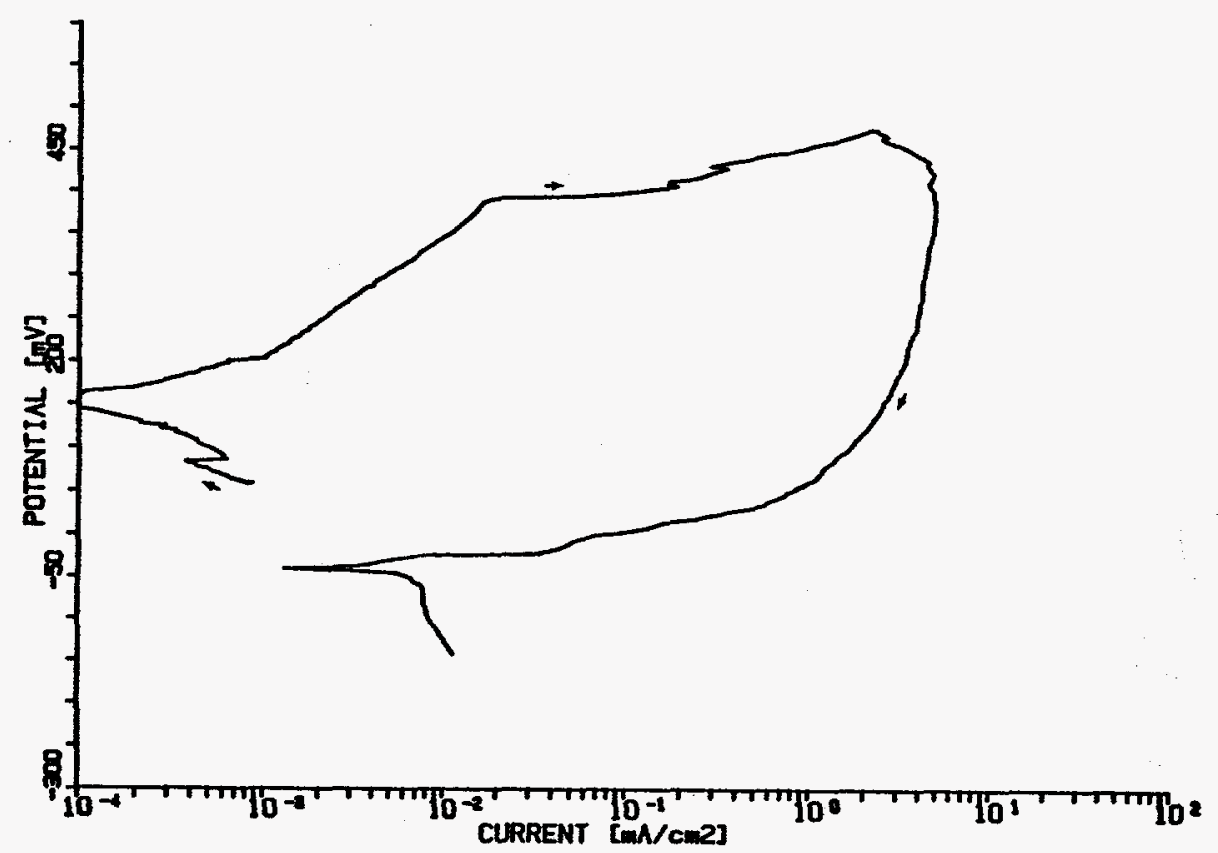

Figure Ce. Potentiodyamic Polarization Curve For 1110 g $304 \mathrm{~L}$ In Solution No. at $50^{\circ} \mathrm{C}$. 


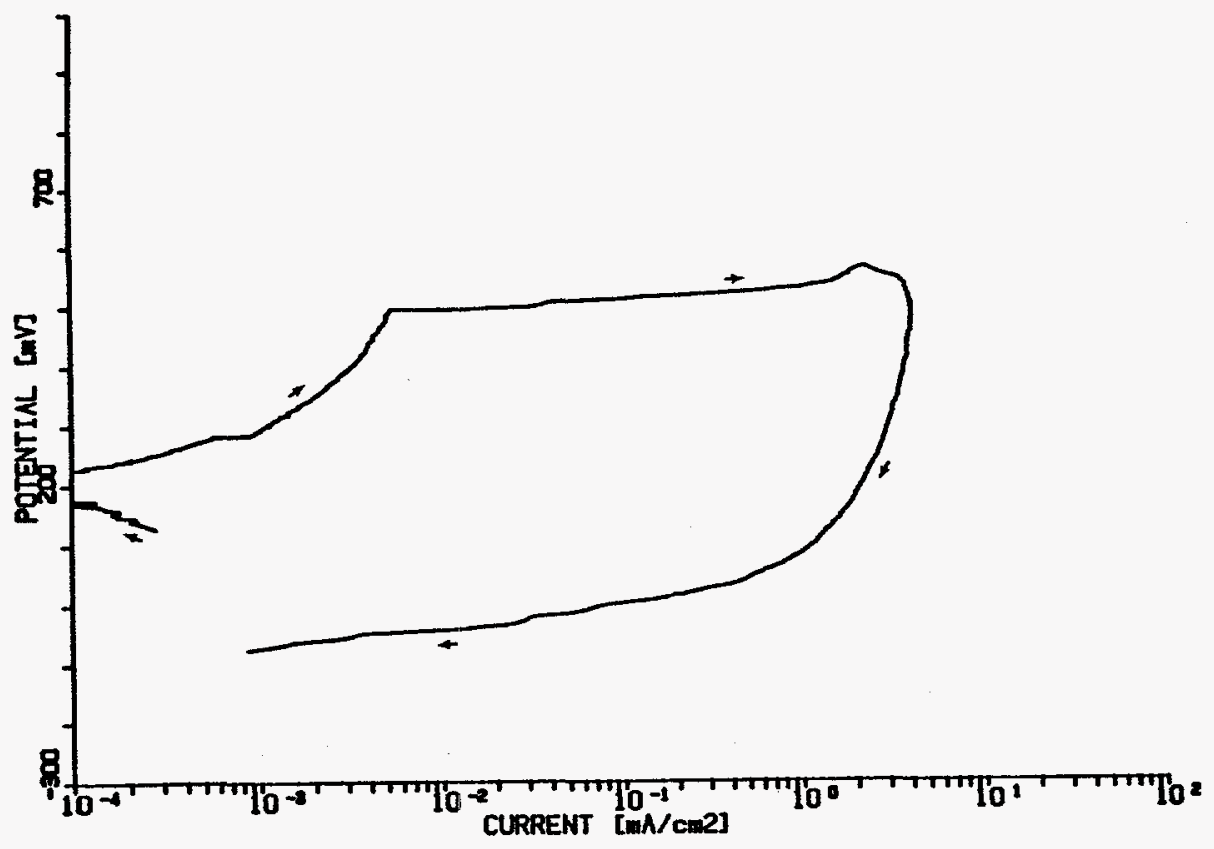

Figure c9. Potentiodynamic Polarlzation Curve For Alloy 304L In Solution No. 9 at $50^{\circ} \mathrm{C}$.

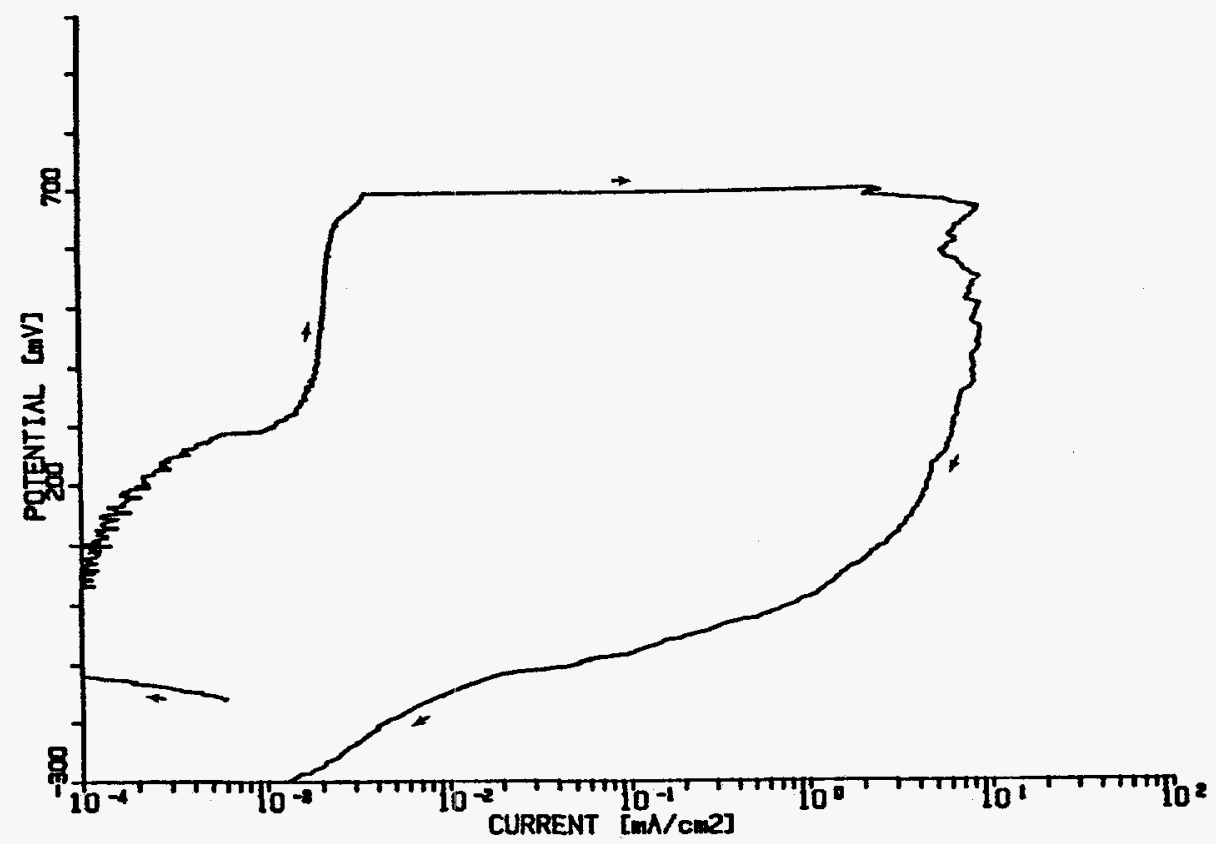

Figure C10. Potentiodynanic Polarization Curve For Alloy $304 \mathrm{~L}$ In Solution Ho. 10 At $90^{\circ} \mathrm{C}$. 


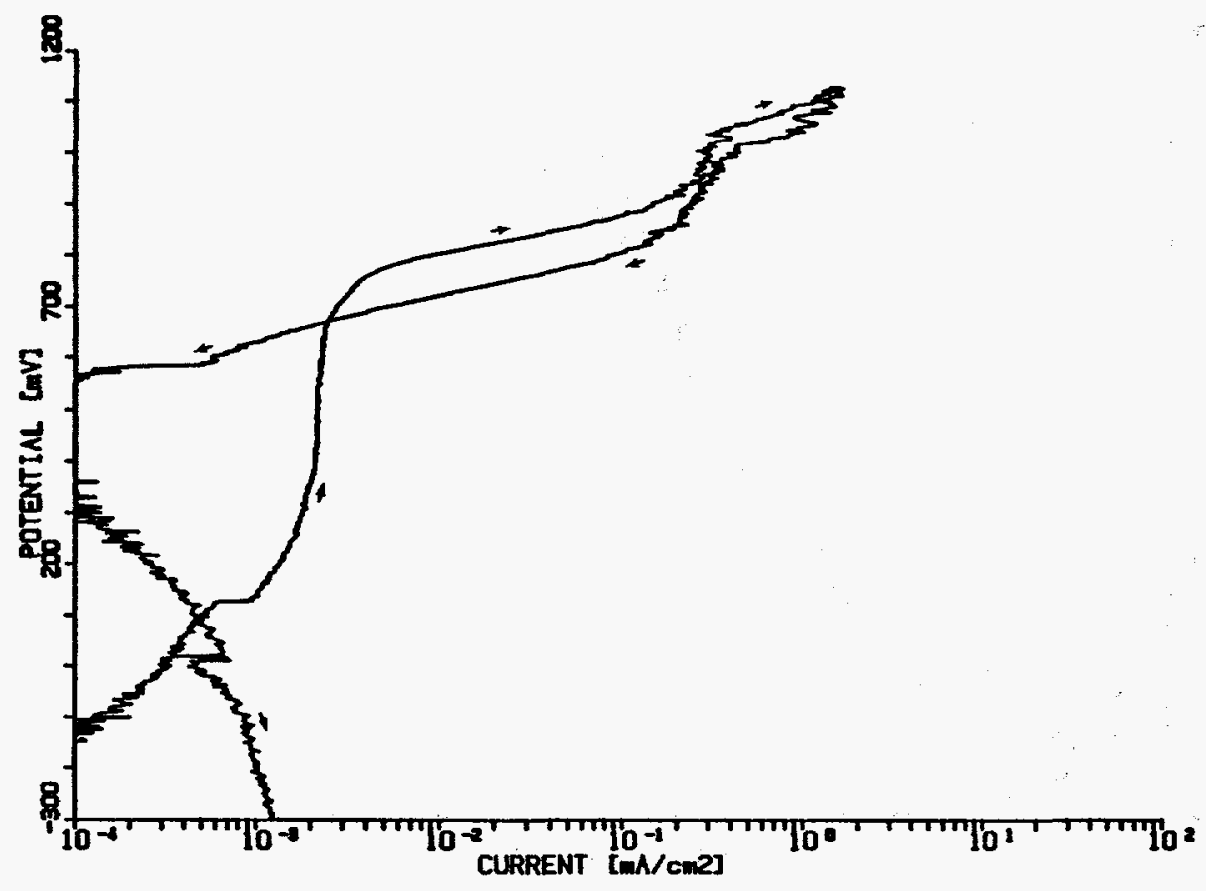

Figure C11. Potentlodynamic Polarizat ion Curve Por Alloy 304L in Solution No. II At $90^{\circ} \mathrm{C}$.

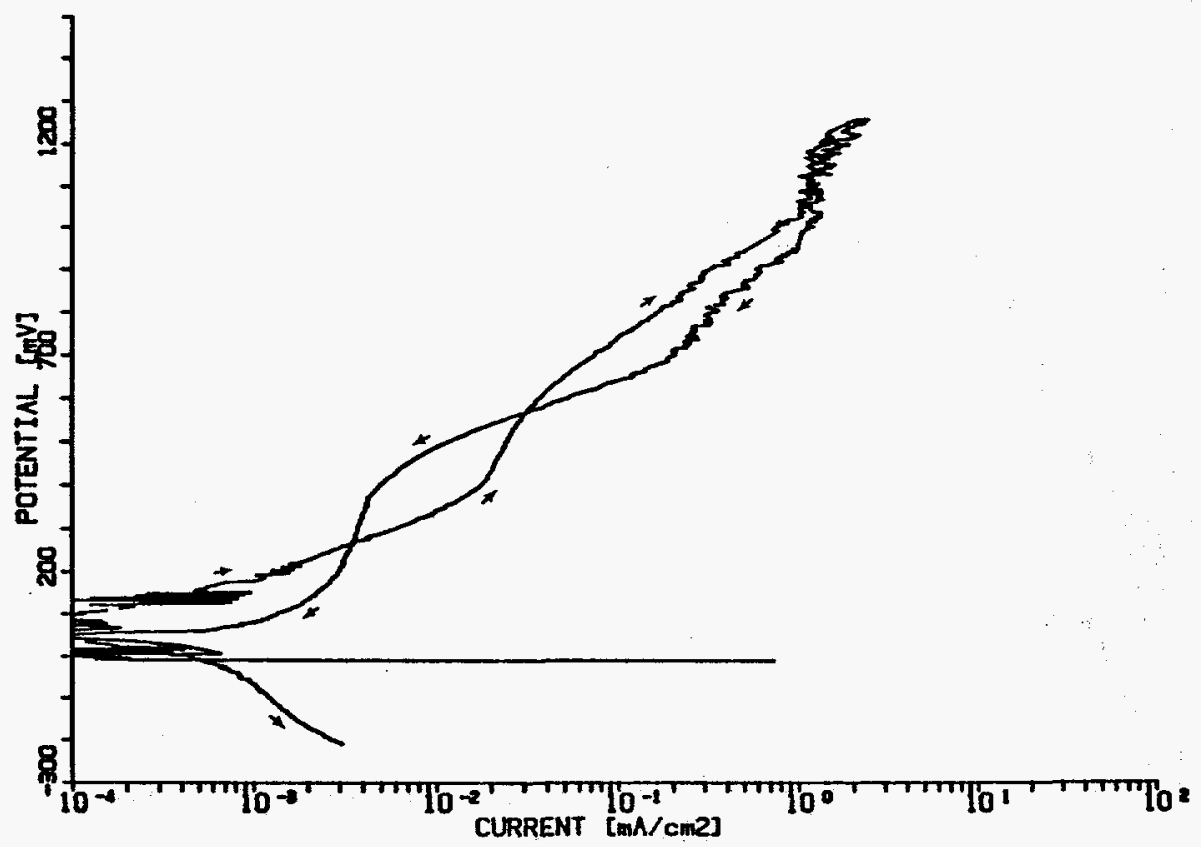

Figure C12. Potentlodyanic Polarization Curve For Alloy 304L In Solution No. 12 at $50^{\circ} \mathrm{C}$. 


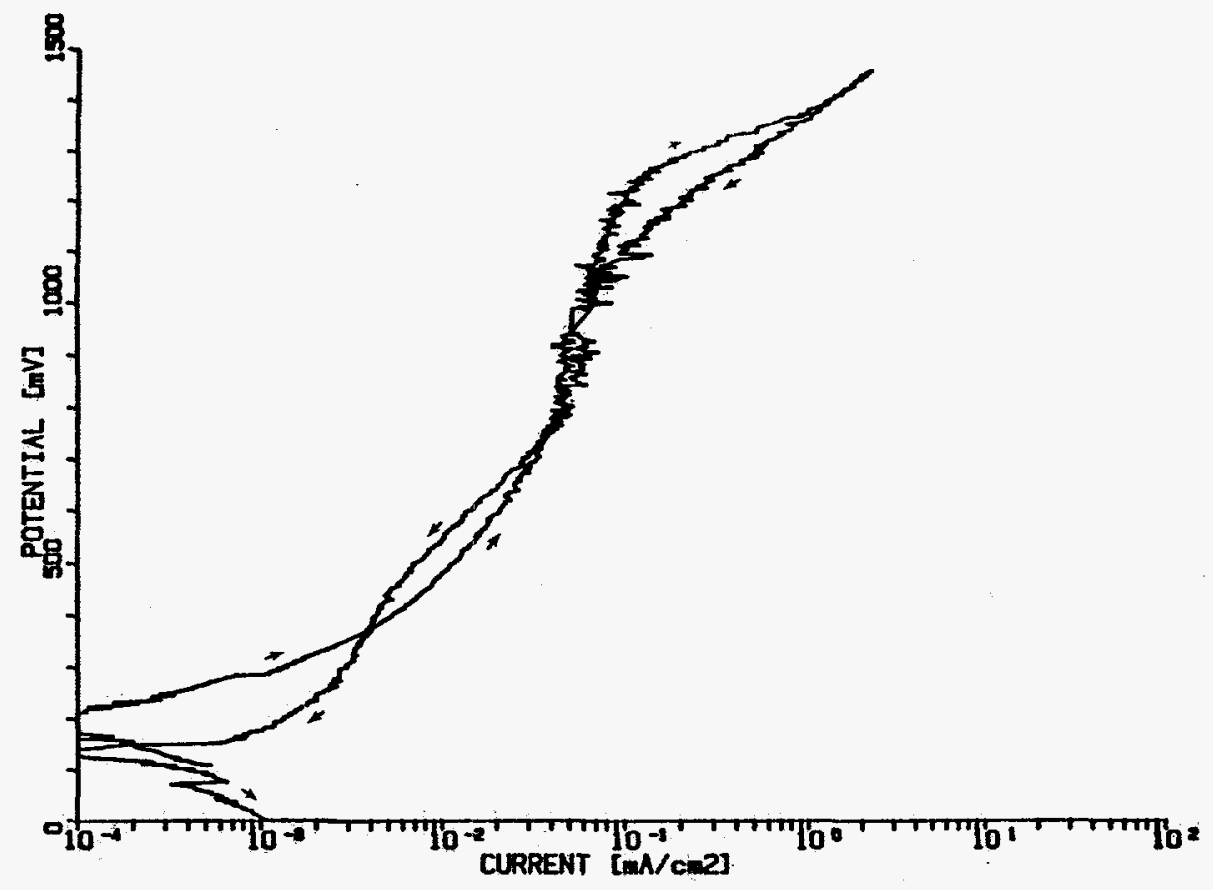

F1gure C13. Rotentlodyanic Polarization Curve for Alloy 304L In Solution Ho. 13 at $90^{\circ} \mathrm{C}$.

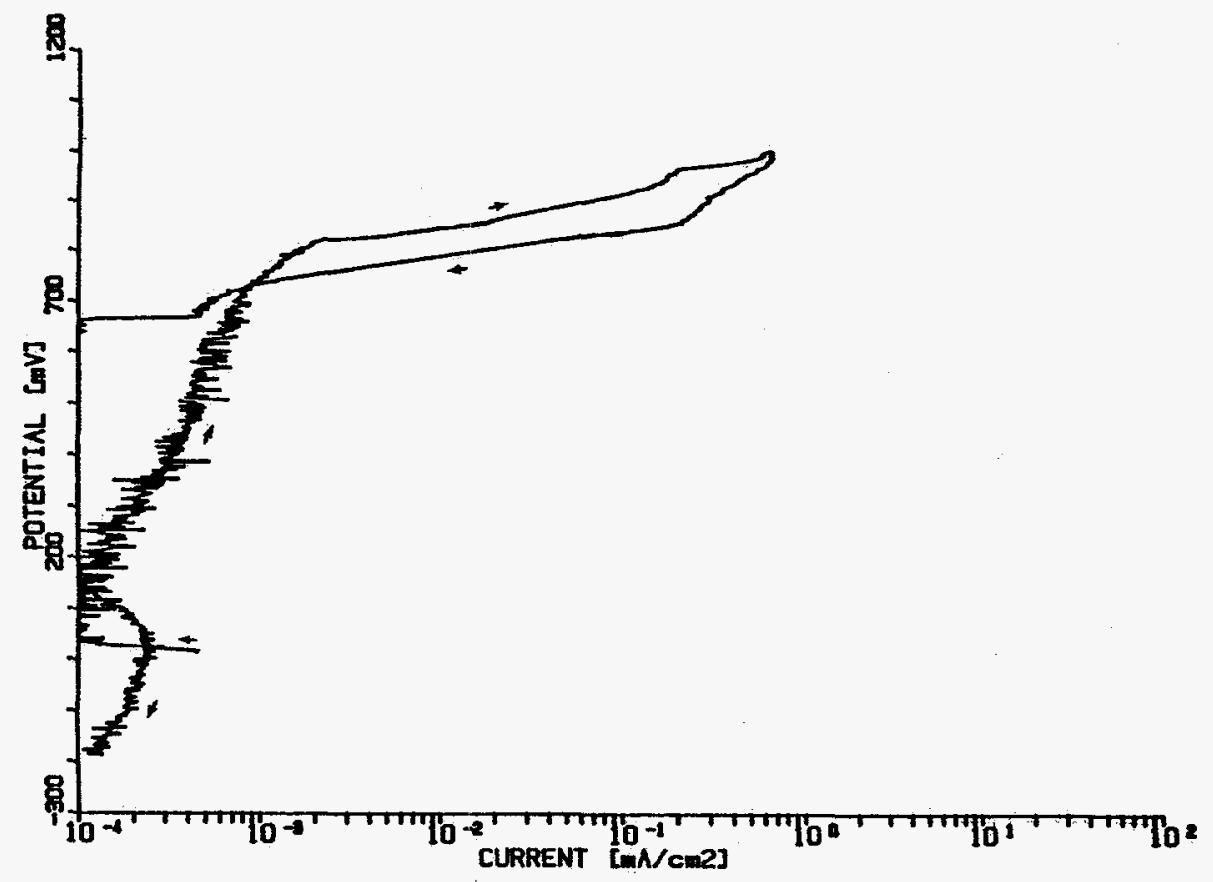

Figure C14. Potent lodynamic Polarization Curve For Alloy 304L Ia Solutiod No. 14 At $50: \mathrm{C}$. 


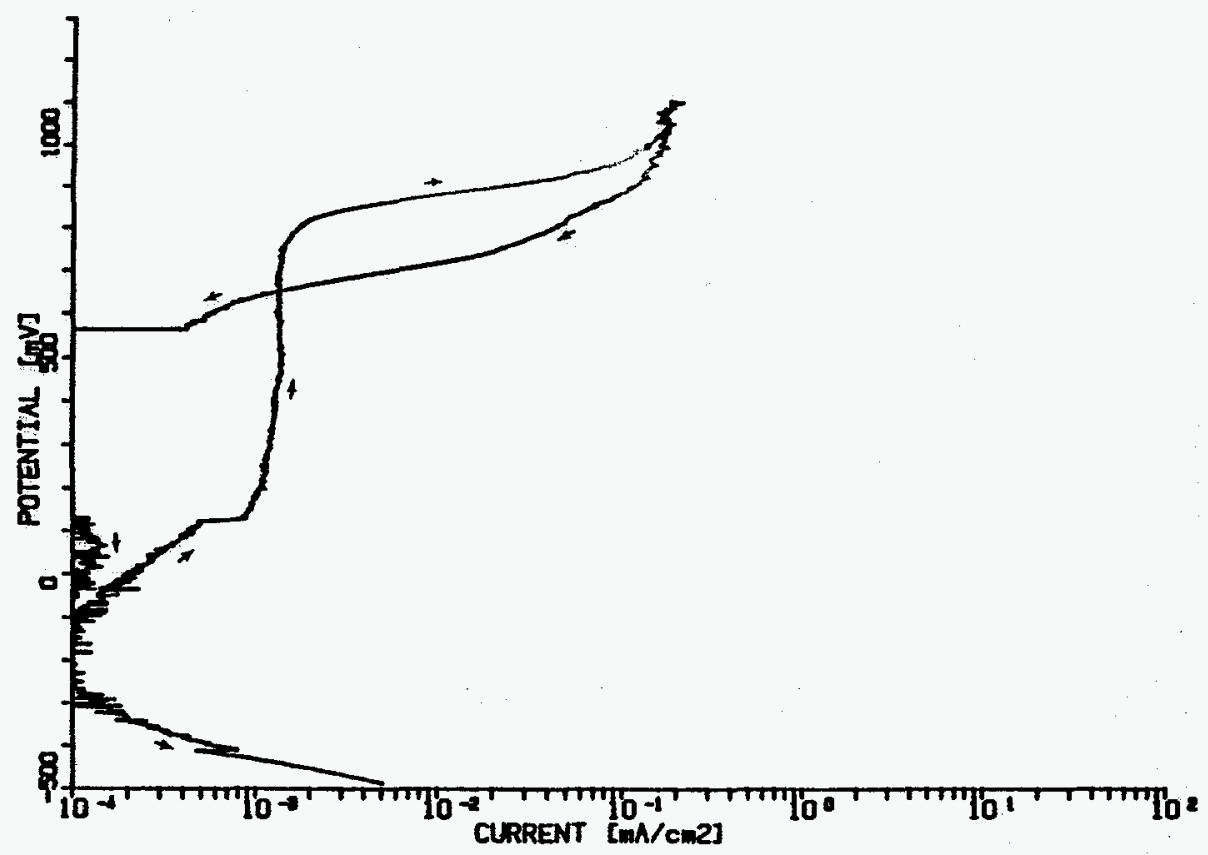

Figure ClS. Potentlodynaic Polerieation Curve For Alloy 304L In Solution Mo. IS at $50^{\circ} \mathrm{C}$.

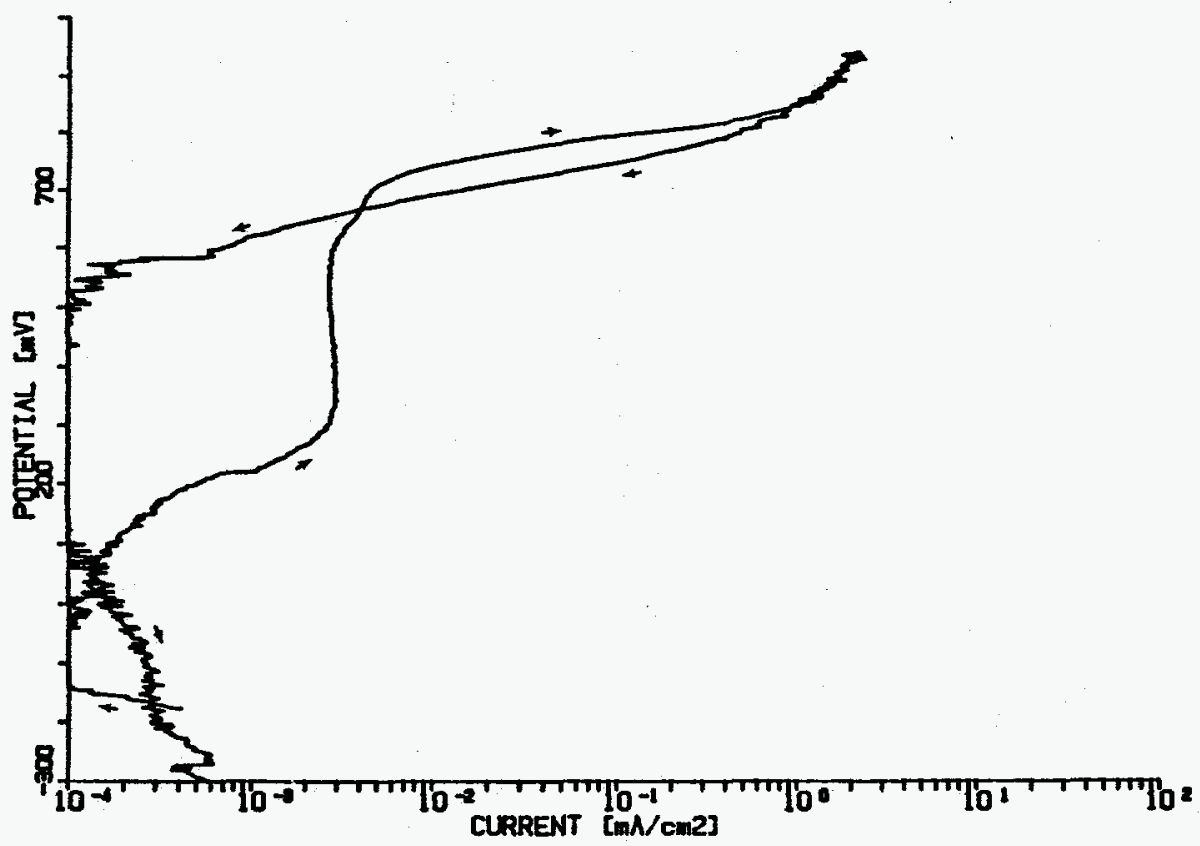

Figure C16. Potont lodynanic Polerization Curve For Alloy 304L In Solution \$o. 16 At $90^{\circ} \mathrm{C}$. 


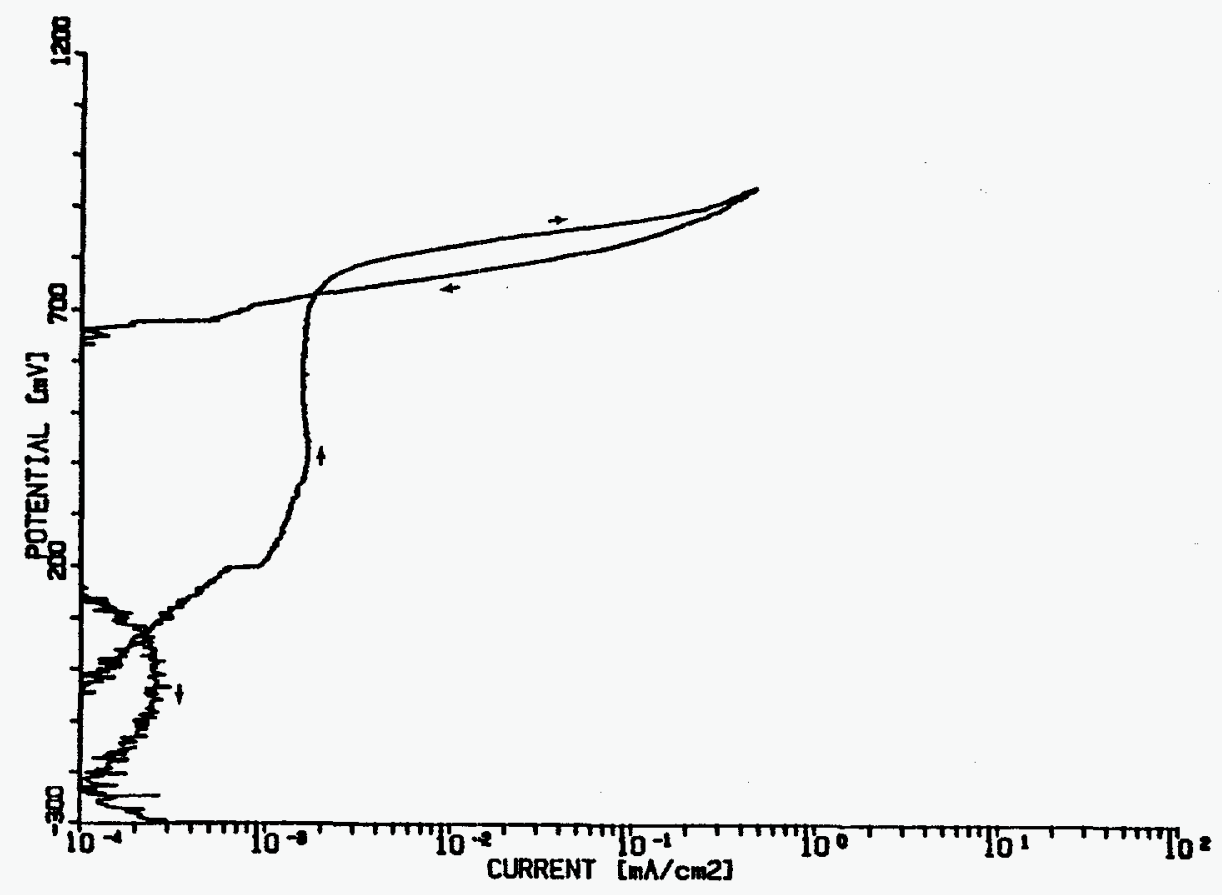

Figure C17. Potentiodynende Polarleation Curve For Alloy 304L In Solution No. 17 At $50^{\circ} \mathrm{C}$.

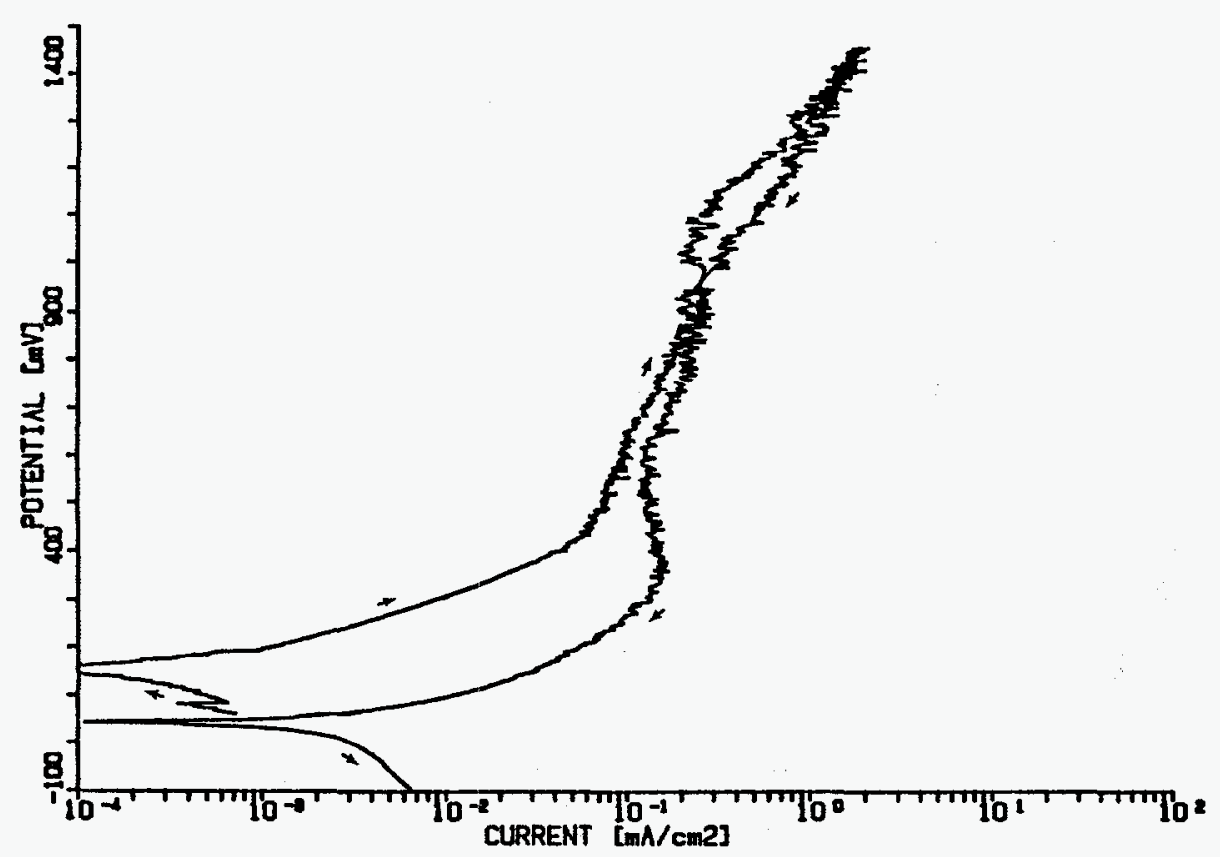

Figure C18. Potent lodynamle Polarization Curve For Alloy 304L In Solution No. 18 At $90^{\circ} \mathrm{C}$. 


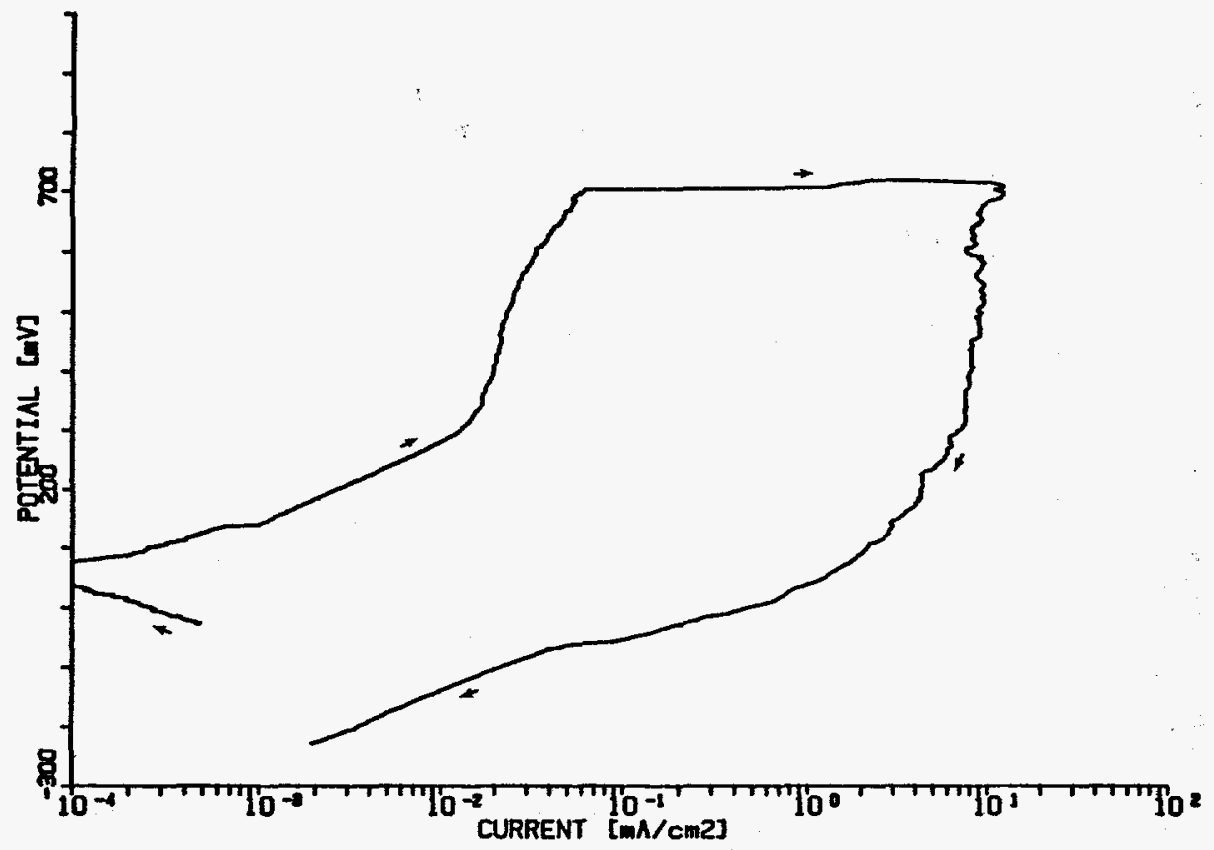

Figure C19. Potentiodynamie Polarization Curve For Alloy 304L In Solution Ho. 19 st $90^{\circ} \mathrm{C}$.

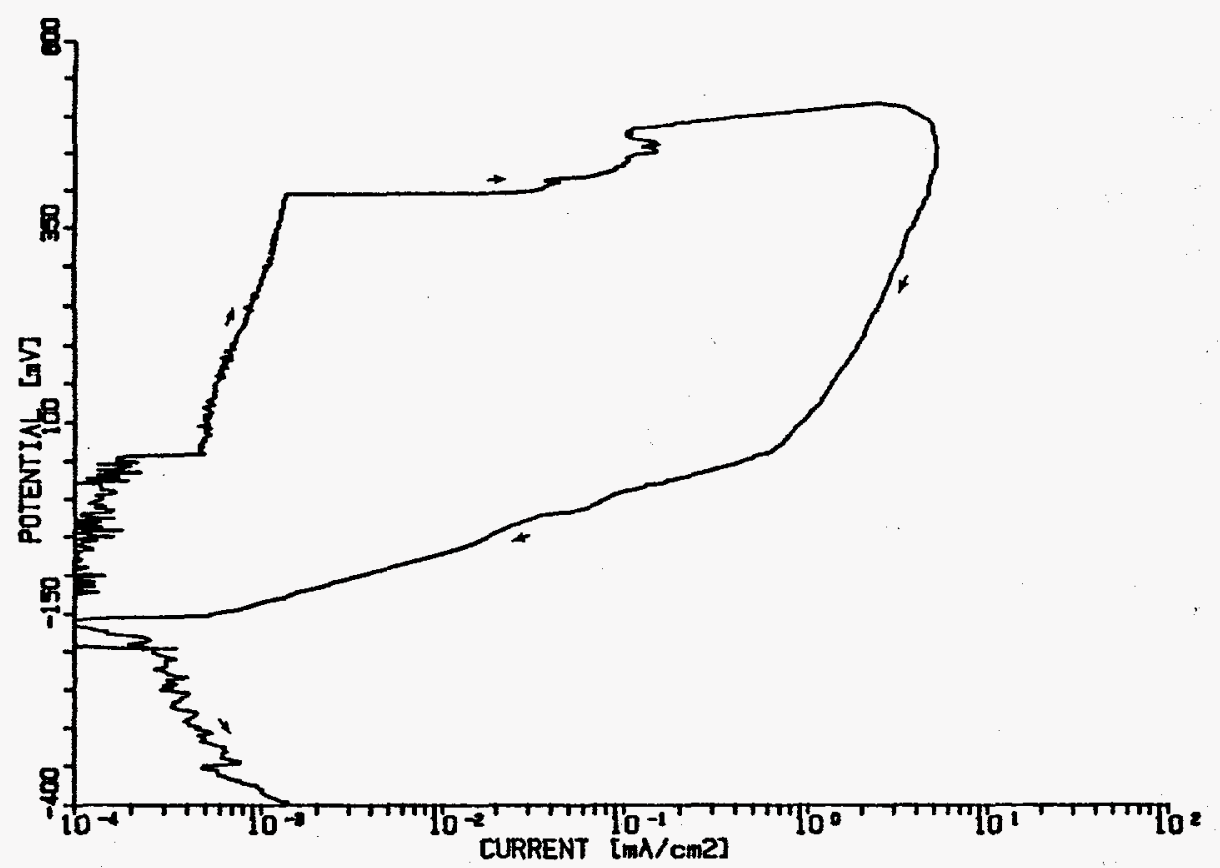

Figure C20. Potentiodynanle Polerization Curve For Alloy $304 \mathrm{~L}$ In Solution No. 20 At $50^{\circ} \mathrm{C}$. 


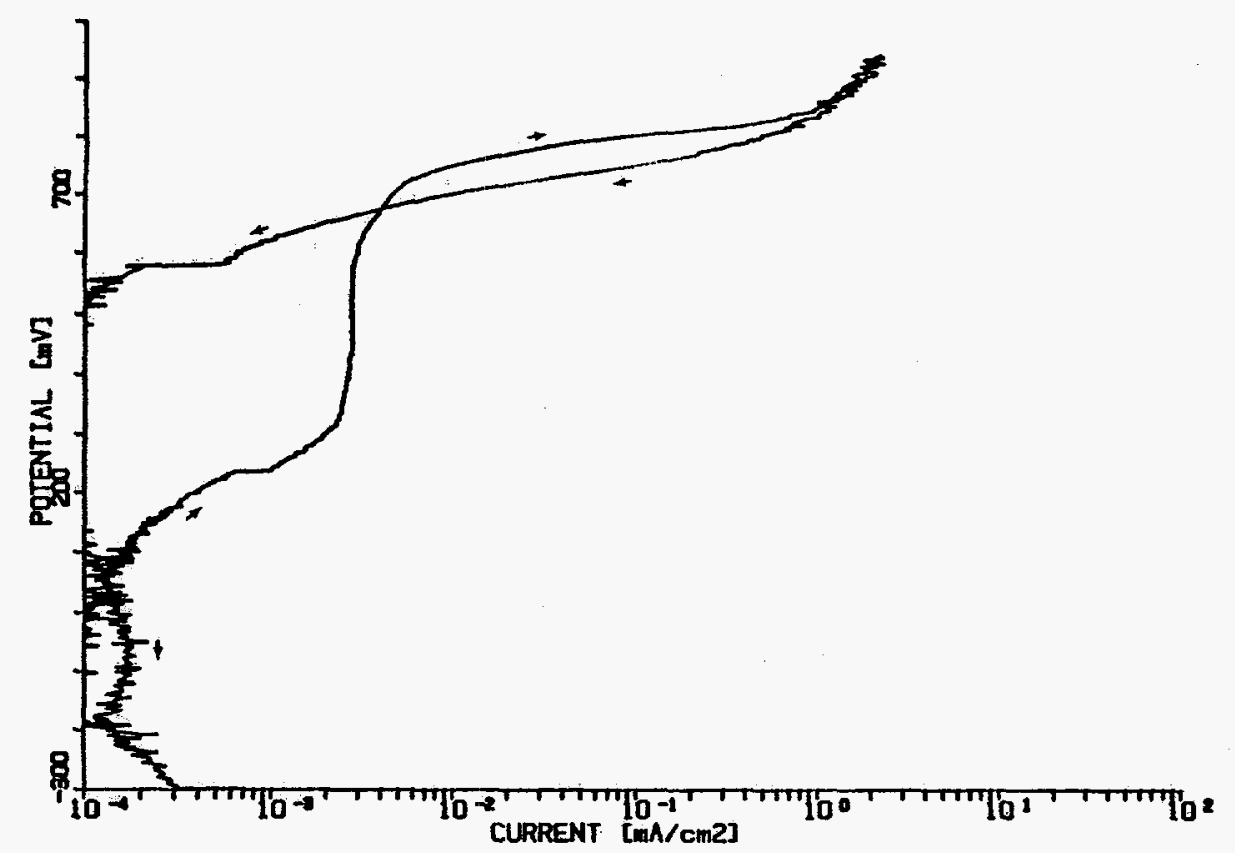

Igure C21. Fotentlodyaemle Rolarisetion Curve Tor Alloy 304L In Solution Ho. 21 at $90^{\circ} \mathrm{C}$.

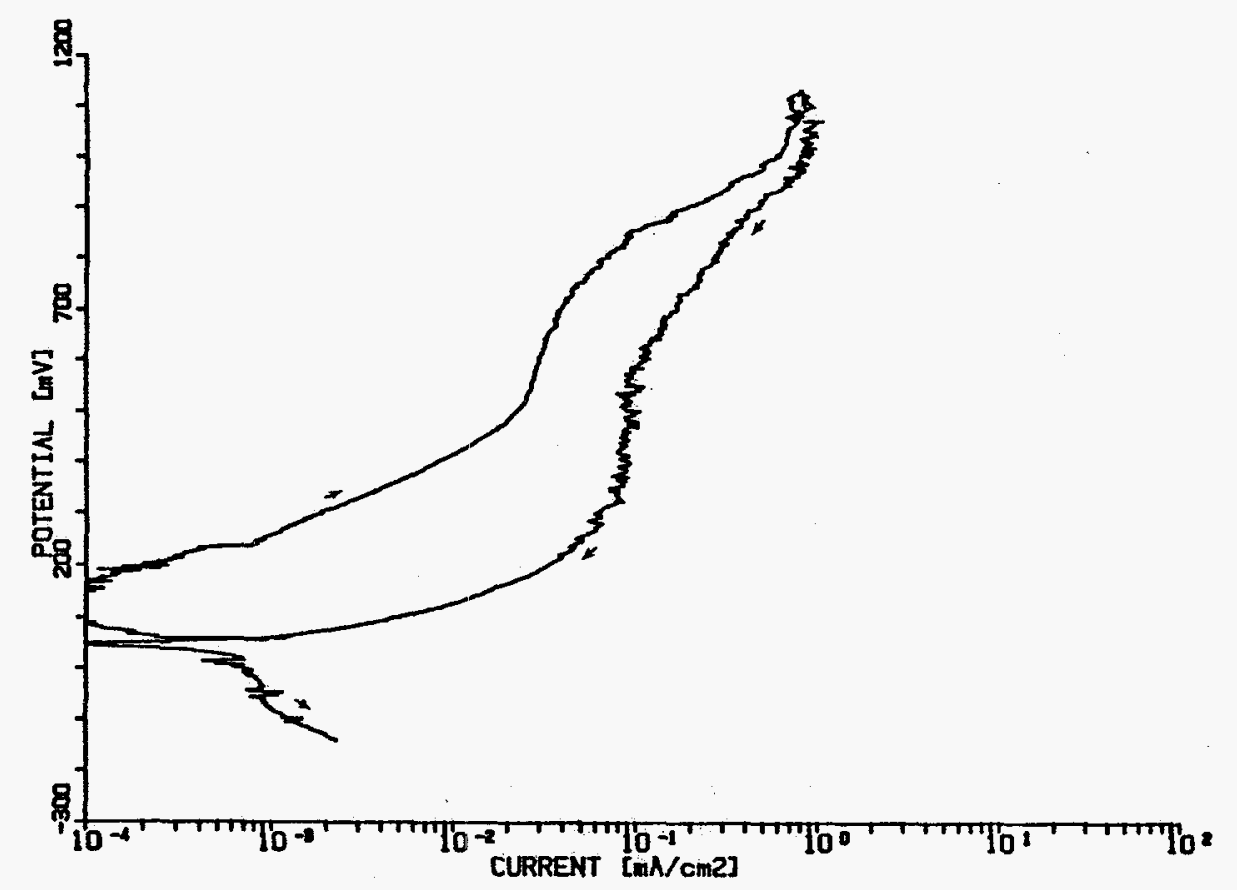

Figure C22. Fotentlodynamic Folerination Curve For A110y $304 \mathrm{~L}$ In Solution No. 22 At $50^{\circ} \mathrm{C}$. 


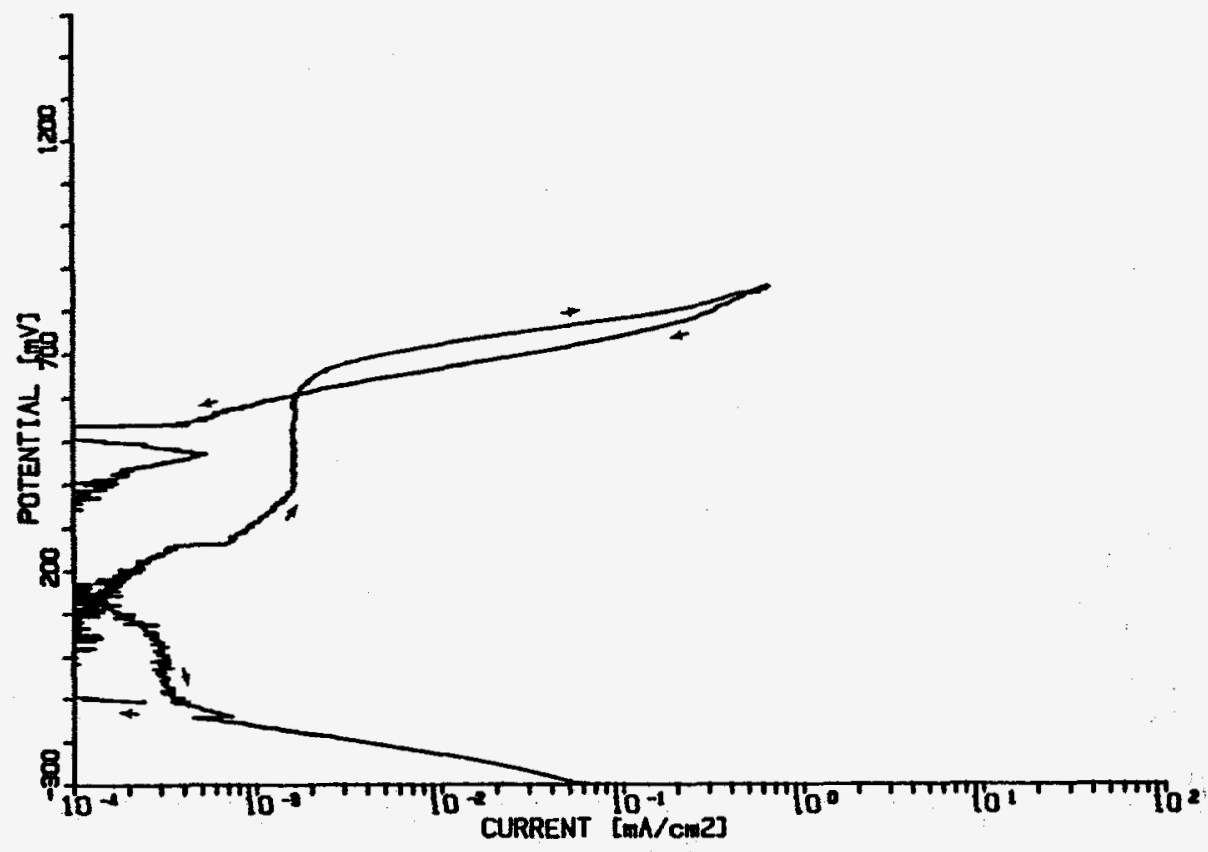

Figure C23. Rotentlodrnamic Folarizetion Curve For Alloy 304t in Solution No. 23 At $50^{\circ} \mathrm{C}$.

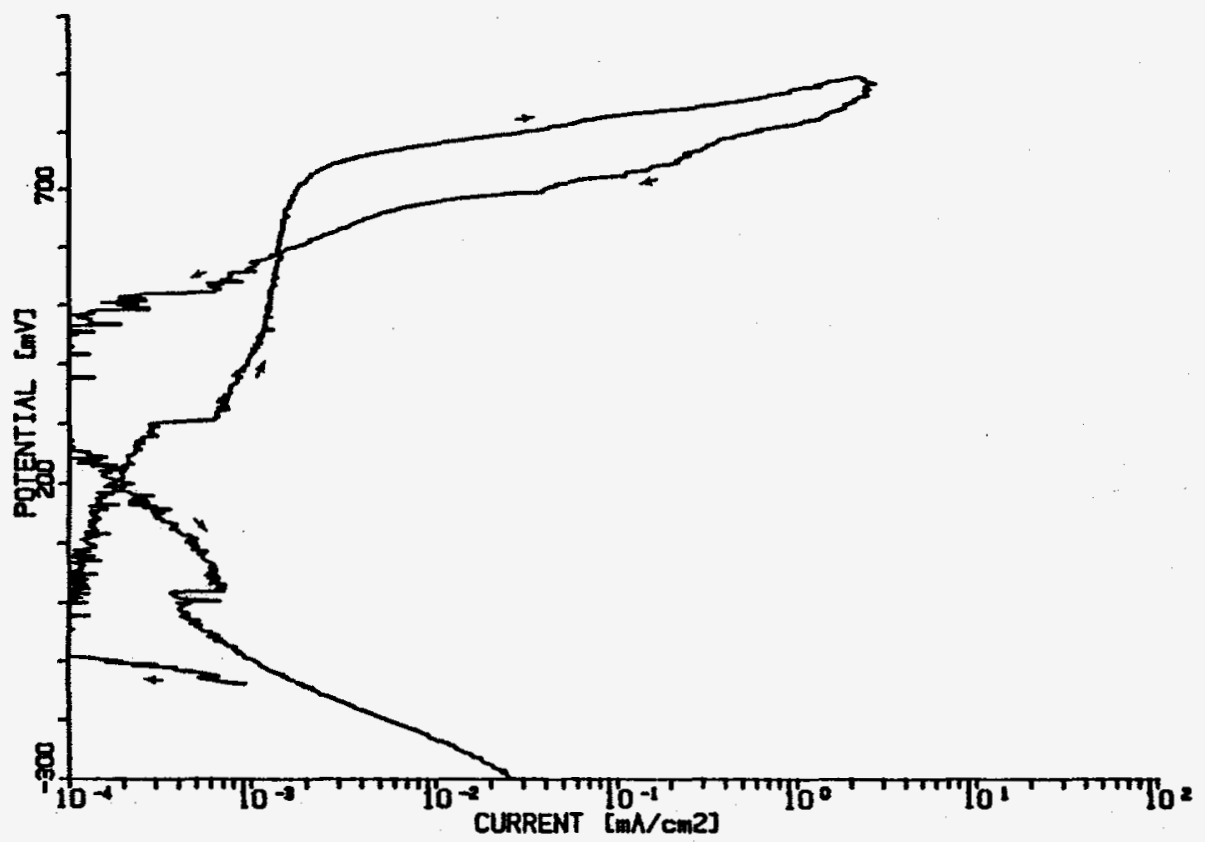

Figure C24. Rotentiodynamic Polarization Curve For Alloy 304L In Solution Ho. 24 st $90^{\circ} \mathrm{C}$. 


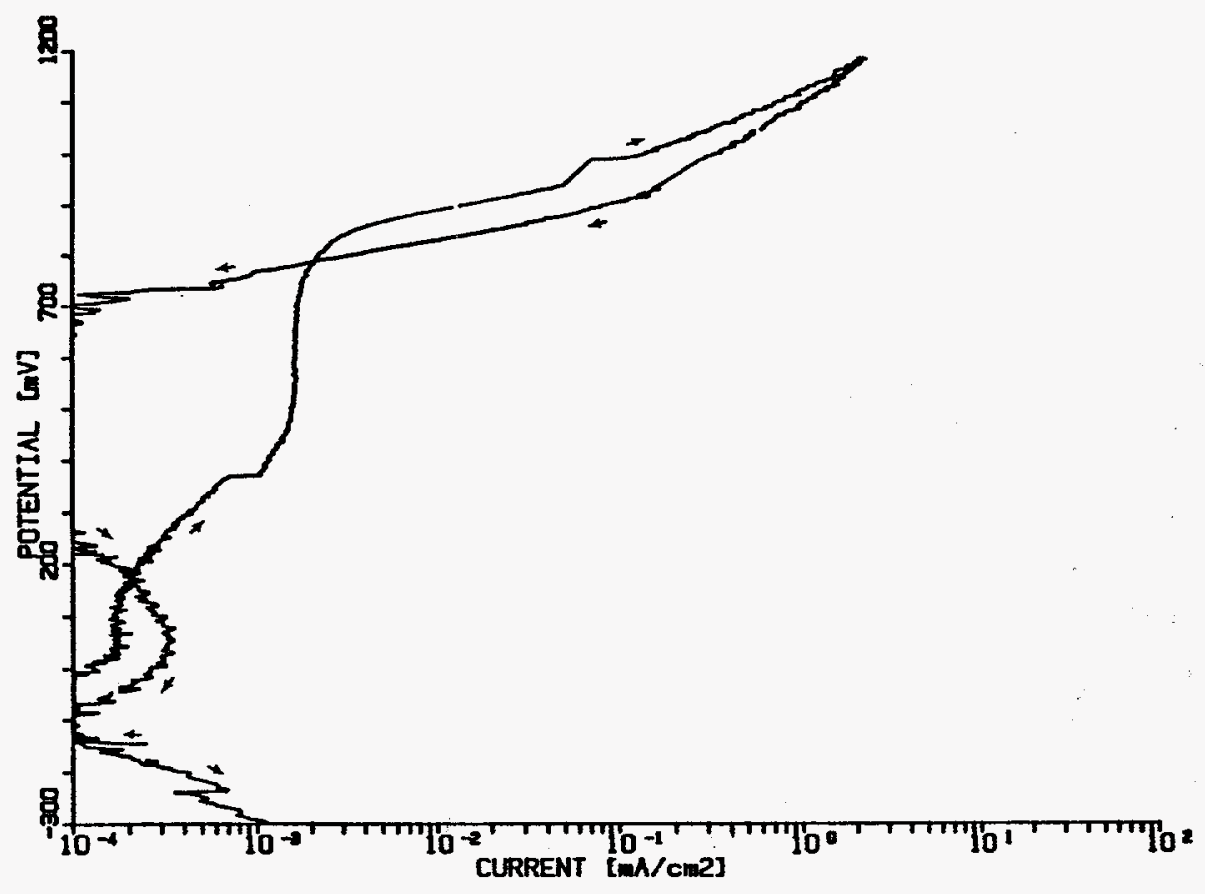

Figure C25. Potent lodynanic Polarization Curve For Alloy 304L In Solution Ho. 25 at $90^{\circ} \mathrm{C}$.

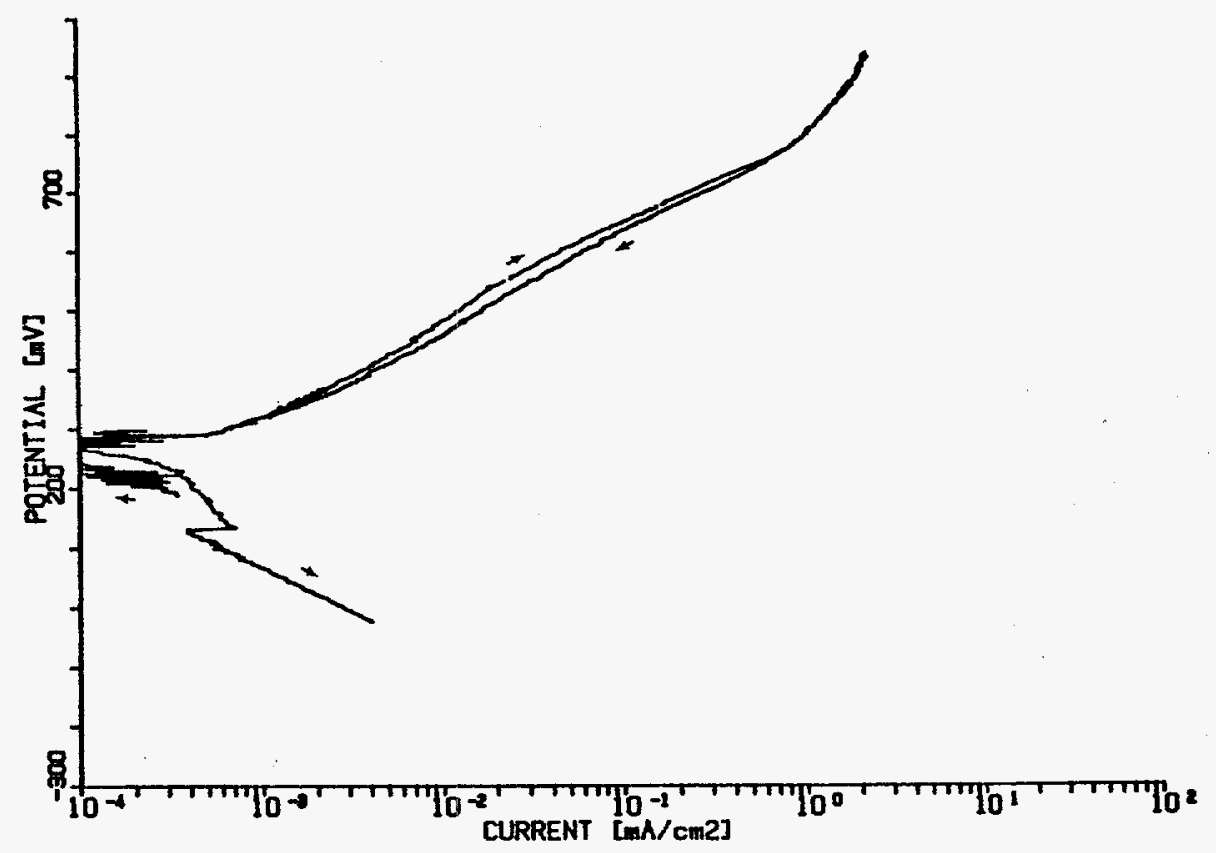

Figure C26. Potentlodyaanic Polarization Curve For Alloy $304 \mathrm{~L}$ In Solution No. 26 at $50^{\circ} \mathrm{C}$. 


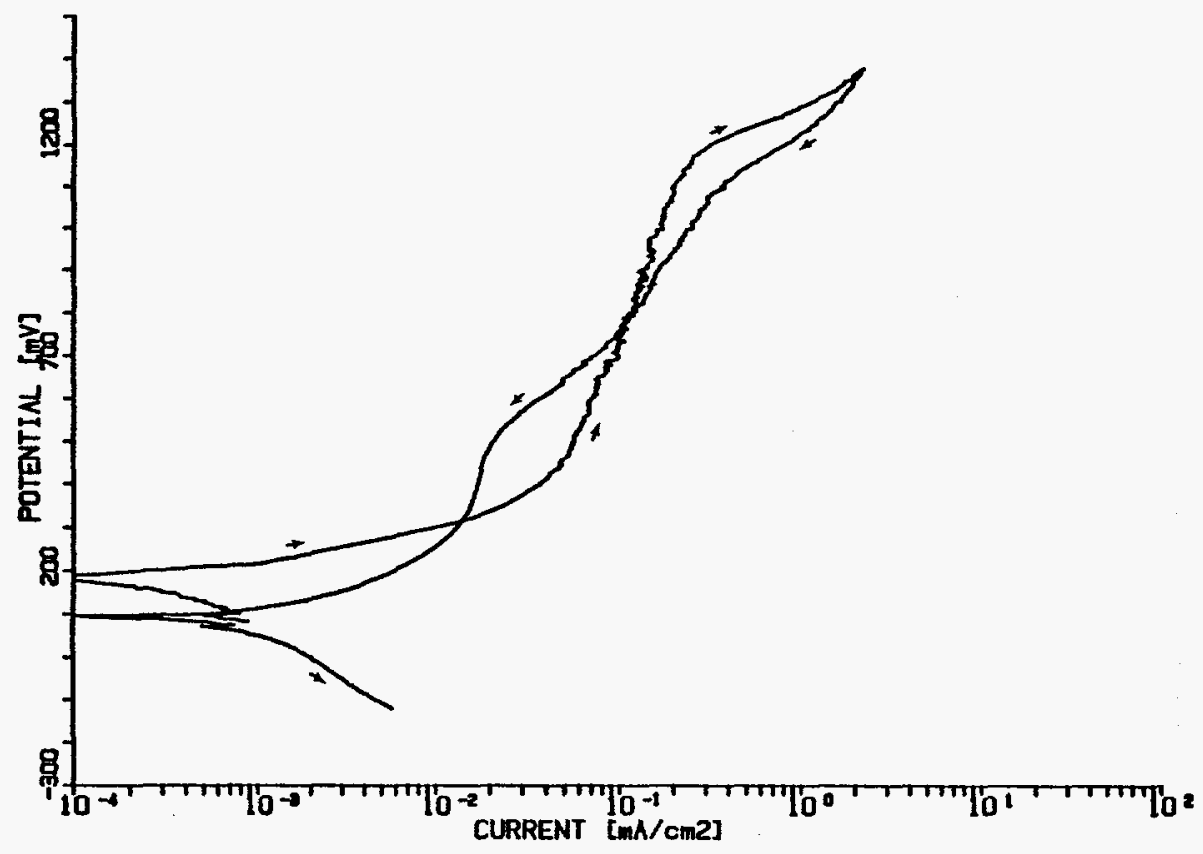

Figure C27. Potentfodynamie Polarization Curve For Alloy 304L In Solution Ho. 27 At $50^{\circ} \mathrm{C}$.

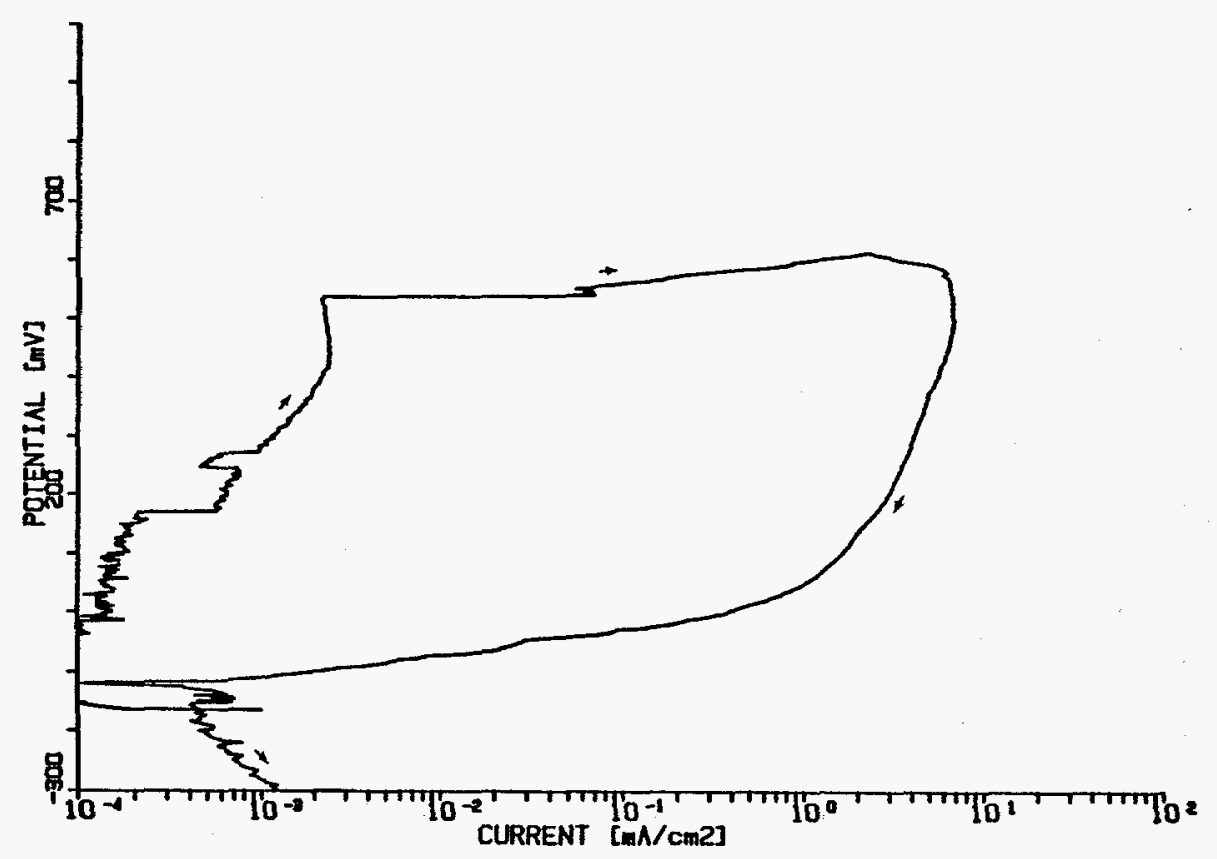

Flgure C28. Potentlodynamic Polarization Curve For Allog 304L In Solution No. 28 at $90^{\circ} \mathrm{C}$. 


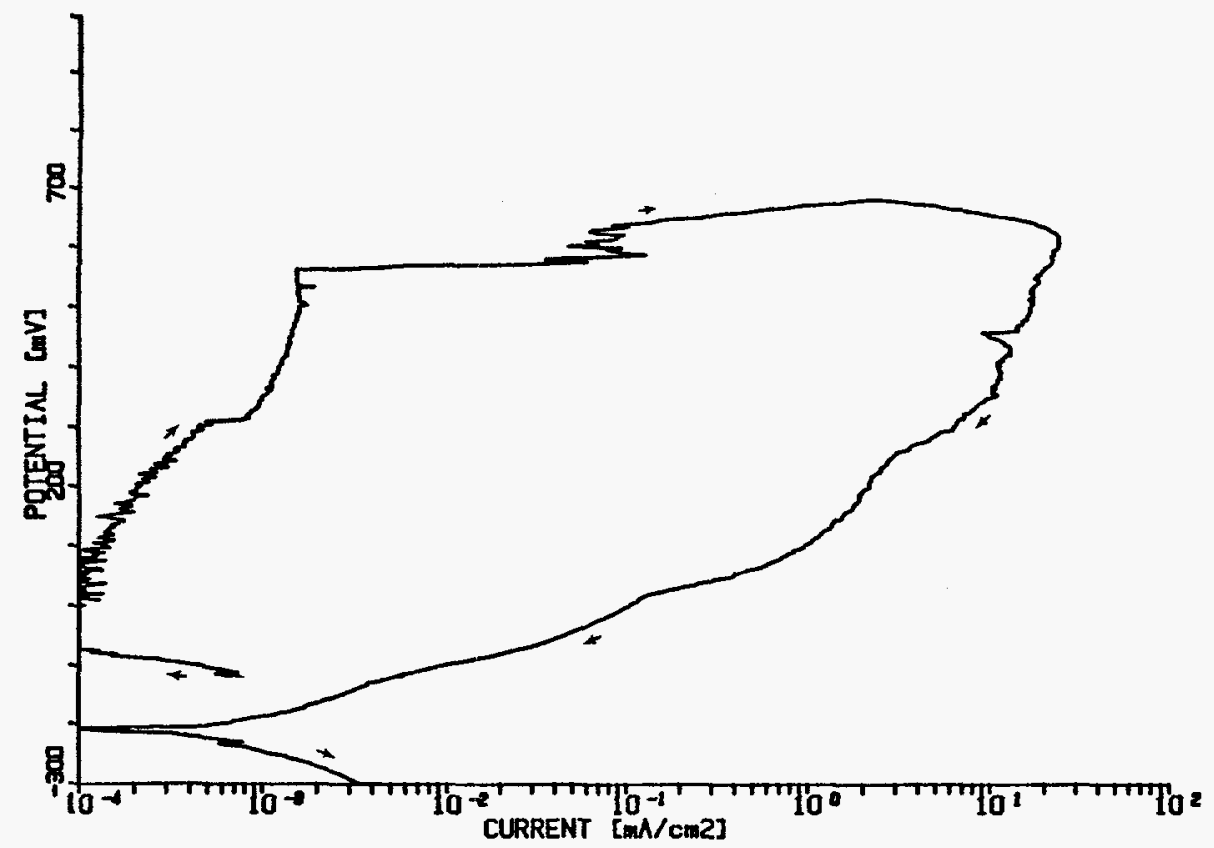

Flgure C29. Potentlodynamle Polarization Curve For Allog 304L In Solution No. 29 At $50^{\circ} \mathrm{C}$

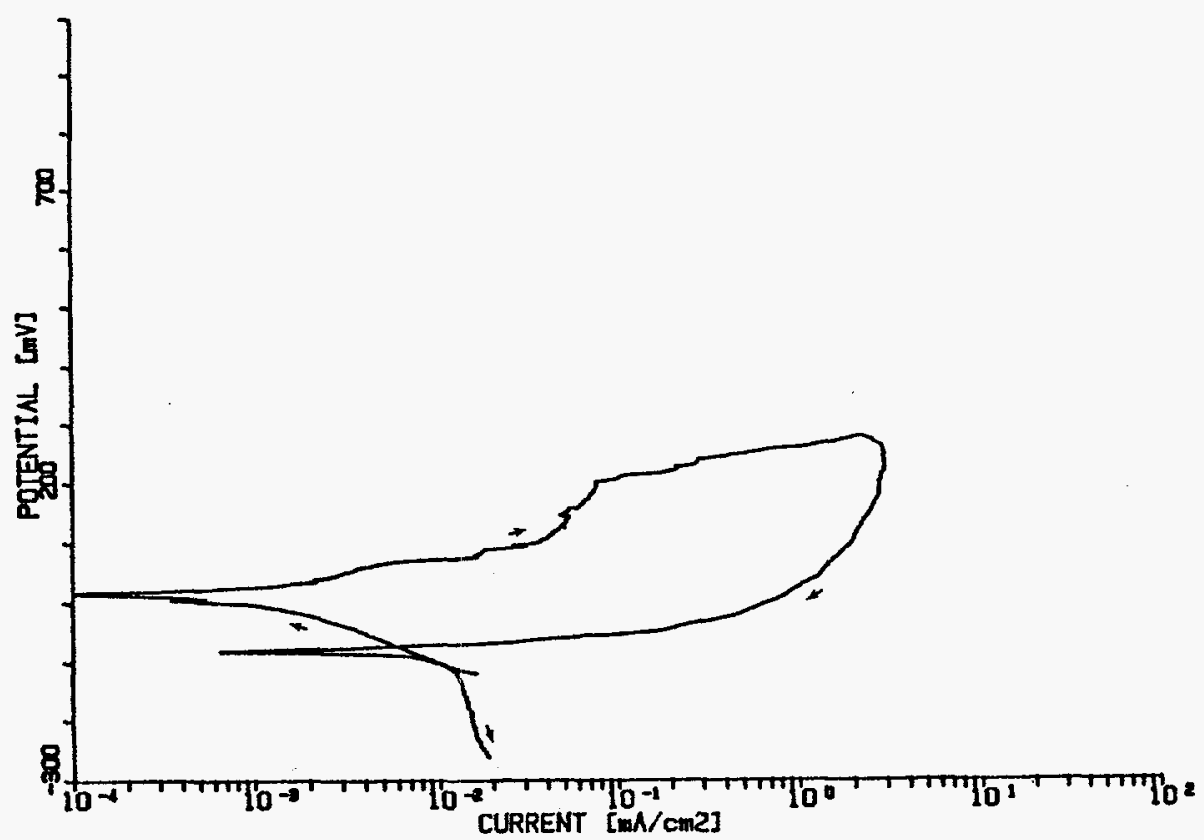

Fipure C30. Potentiodynalc Polarization Curve For Alloy $304 \mathrm{~L}$ In Solution No. 30 At $90^{\circ} \mathrm{C}$. 


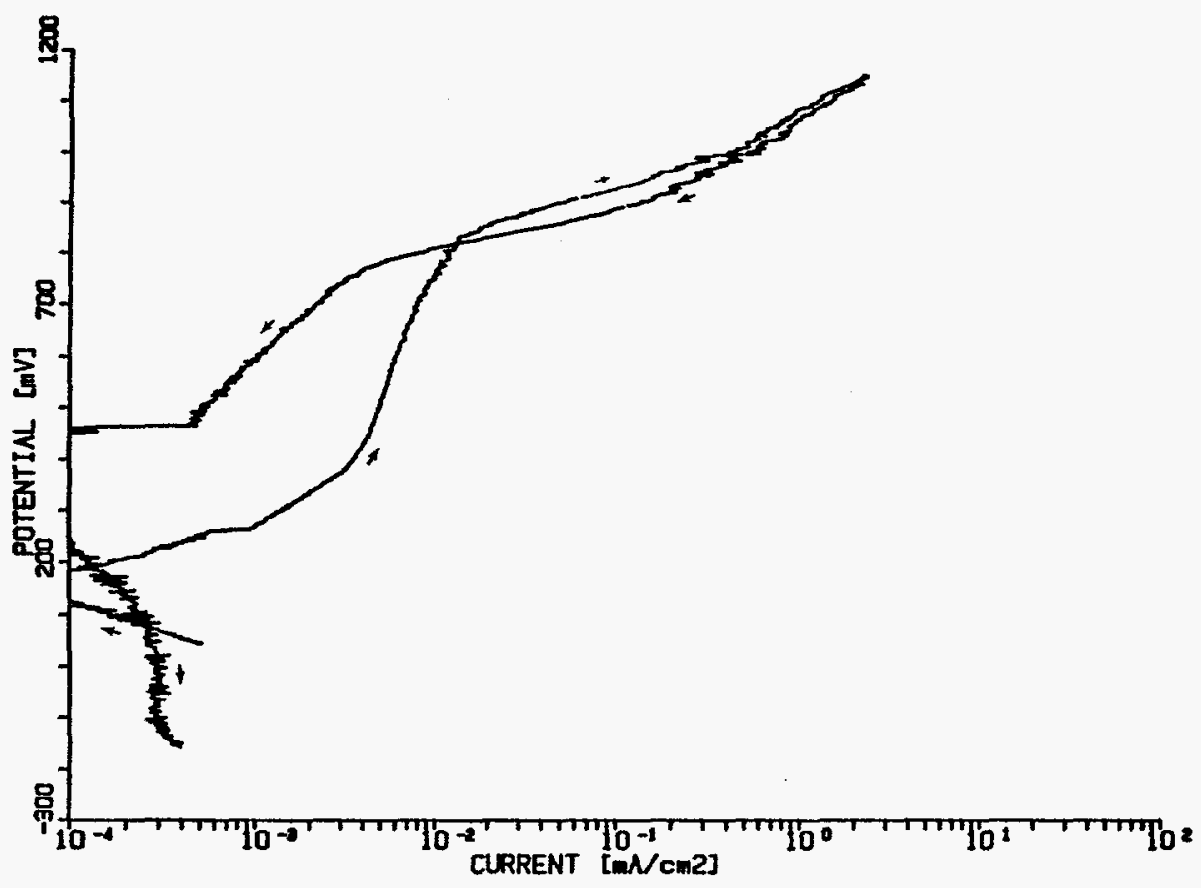

Pigure C31. Potentiodynamic Polarization Curve Por Alloy 304L In Solution Mo. 31 at $90^{\circ} \mathrm{C}$.

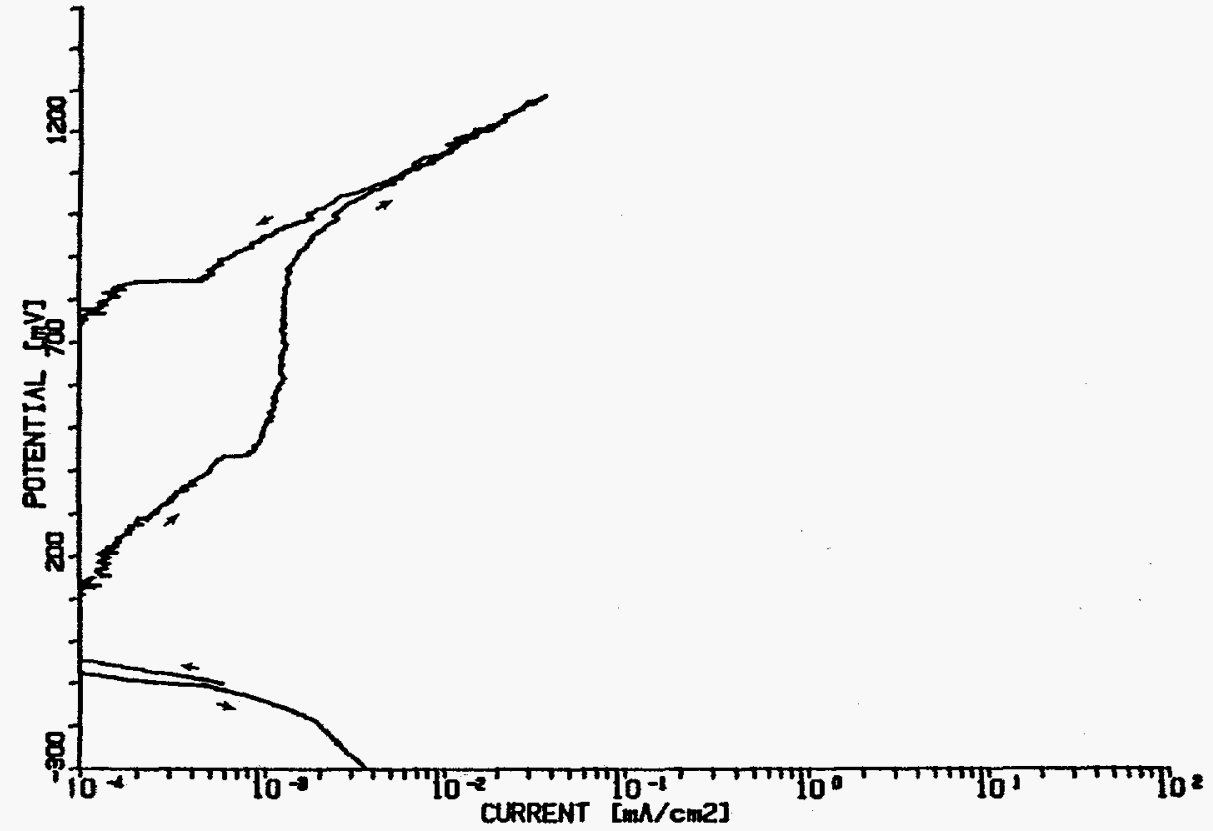

Igure C32. Potentlodjnanle Rolariration Curve For Alloy 304L In Solution Ho. 32 At $30^{\circ} \mathrm{C}$ 


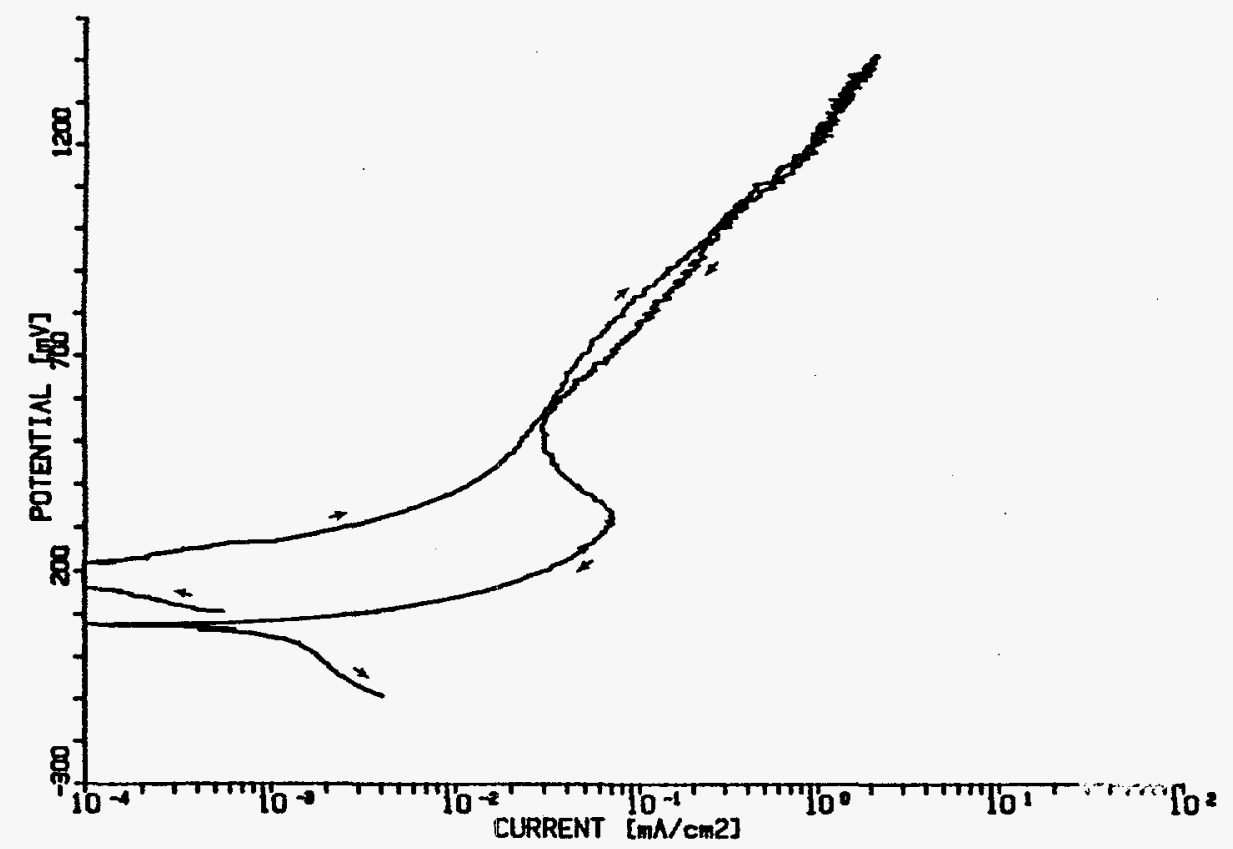

Figure C33. Potentlodynamic Rolarluation Curve For Alloy 304L In Solution No. 33 at $70^{\circ} \mathrm{C}$.

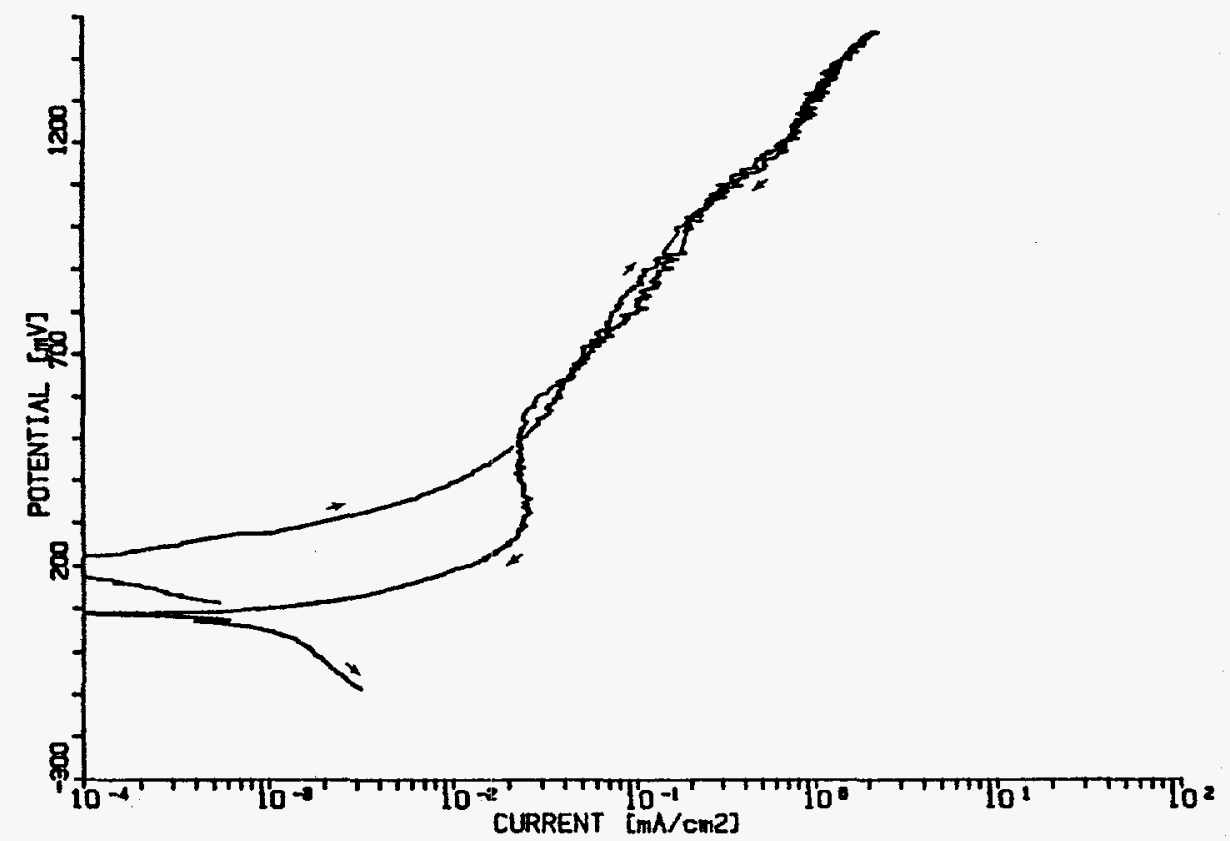

Figure C34. Potentlodynamic Eolerization Curve For Alloy 304L In Solution No. 34 at $70^{\circ} \mathrm{C}$. 


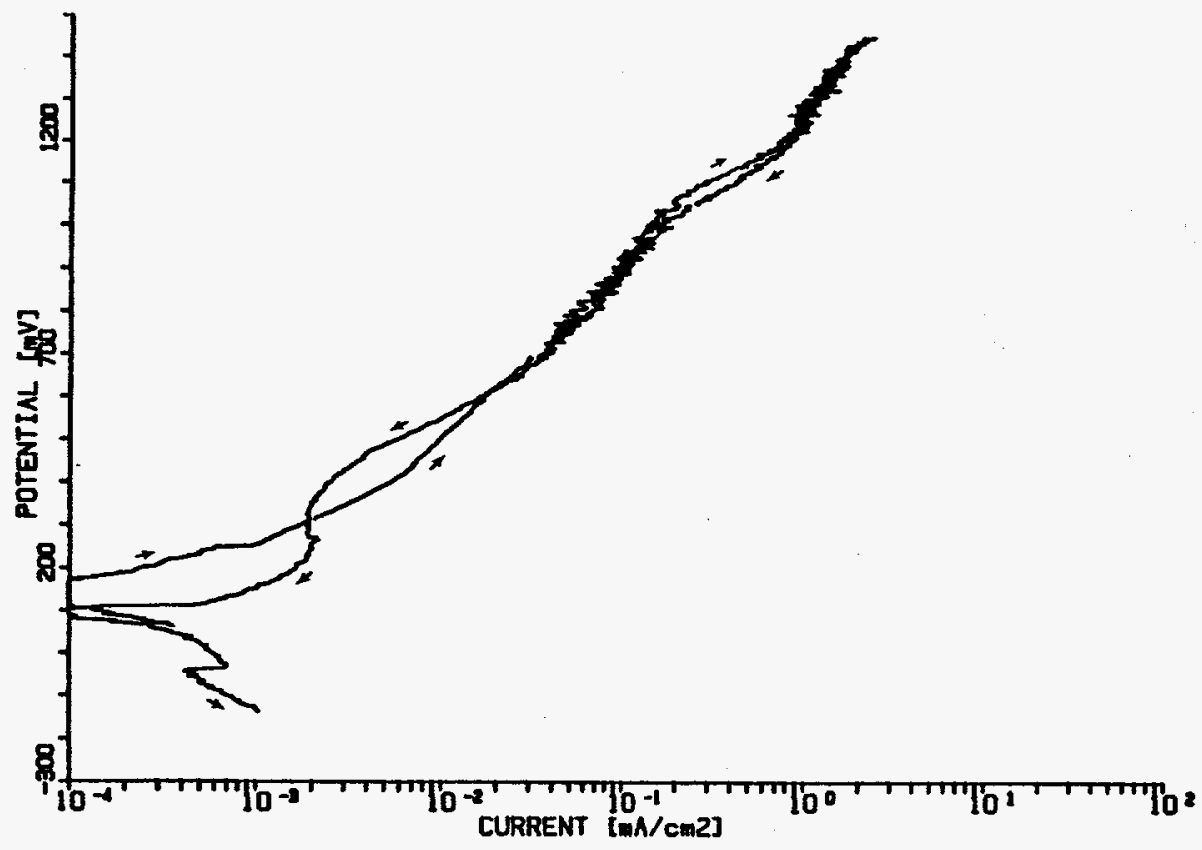

Figure C35. Fotent lodynamic Rolarization Curve For Mlloy 304L In Solution No. 35 At $70^{\circ} \mathrm{C}$.

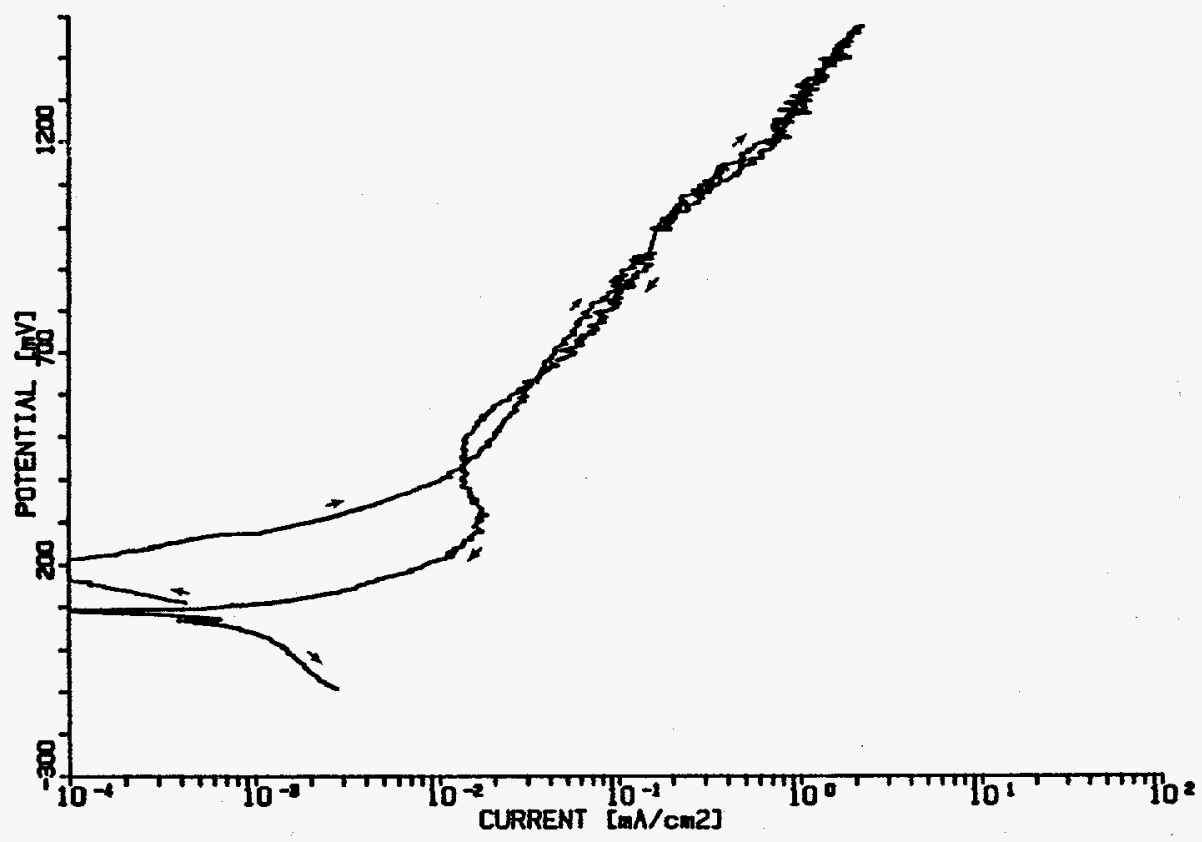

Figura C36. Potent lodynamic Rolerizetion Curve For Alloy $304 \mathrm{~L}$ In Solution Yo. 36 At $70^{\circ} \mathrm{C}$. 

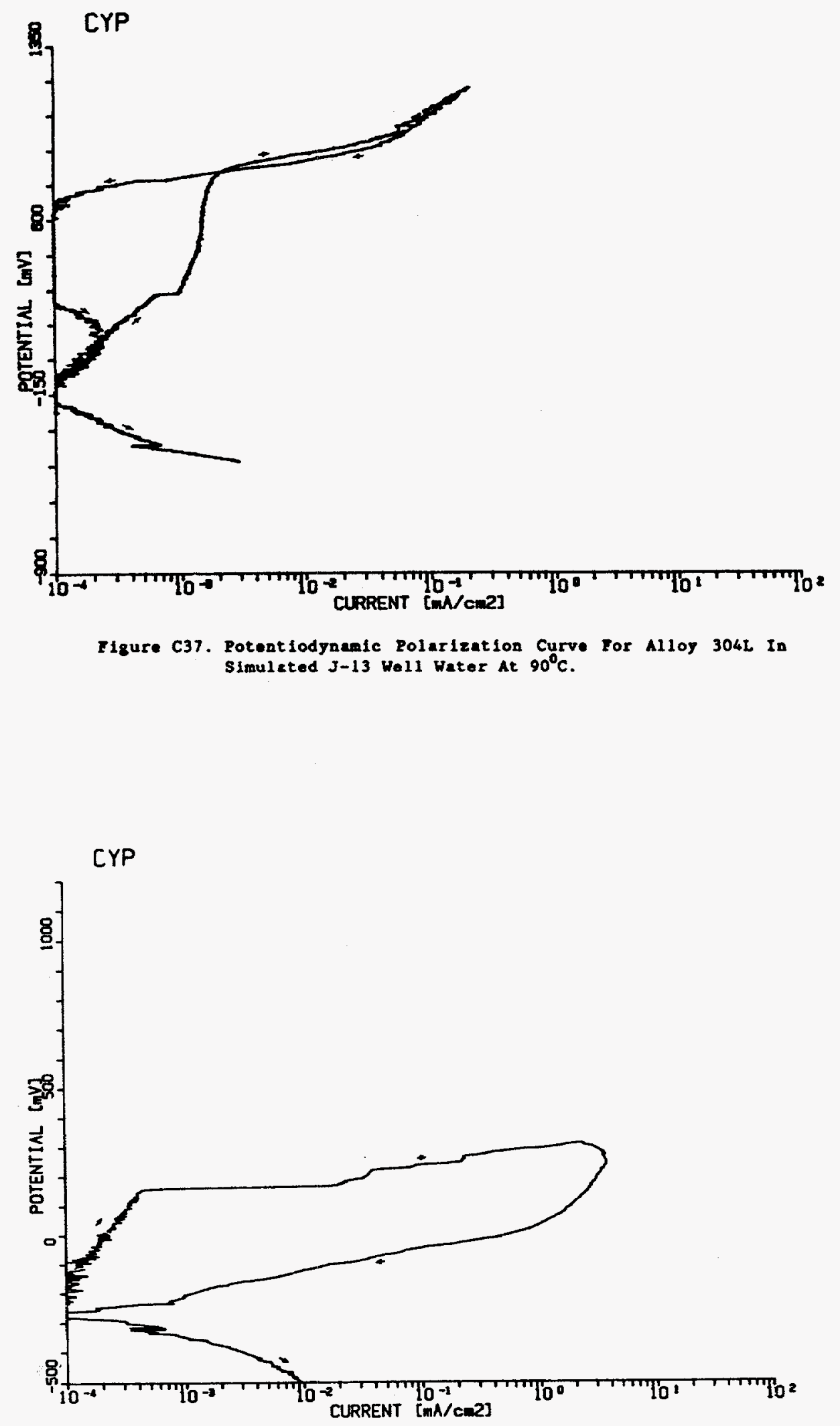

Figure C38. Potentlodynemic Polerizetion Curve For A11oy 304L In Simulated J-13 Well Weter Bith $1000 \mathrm{~m} / 1$ Chloride (Ae Mac1) At $90^{\circ} \mathrm{C}$. 

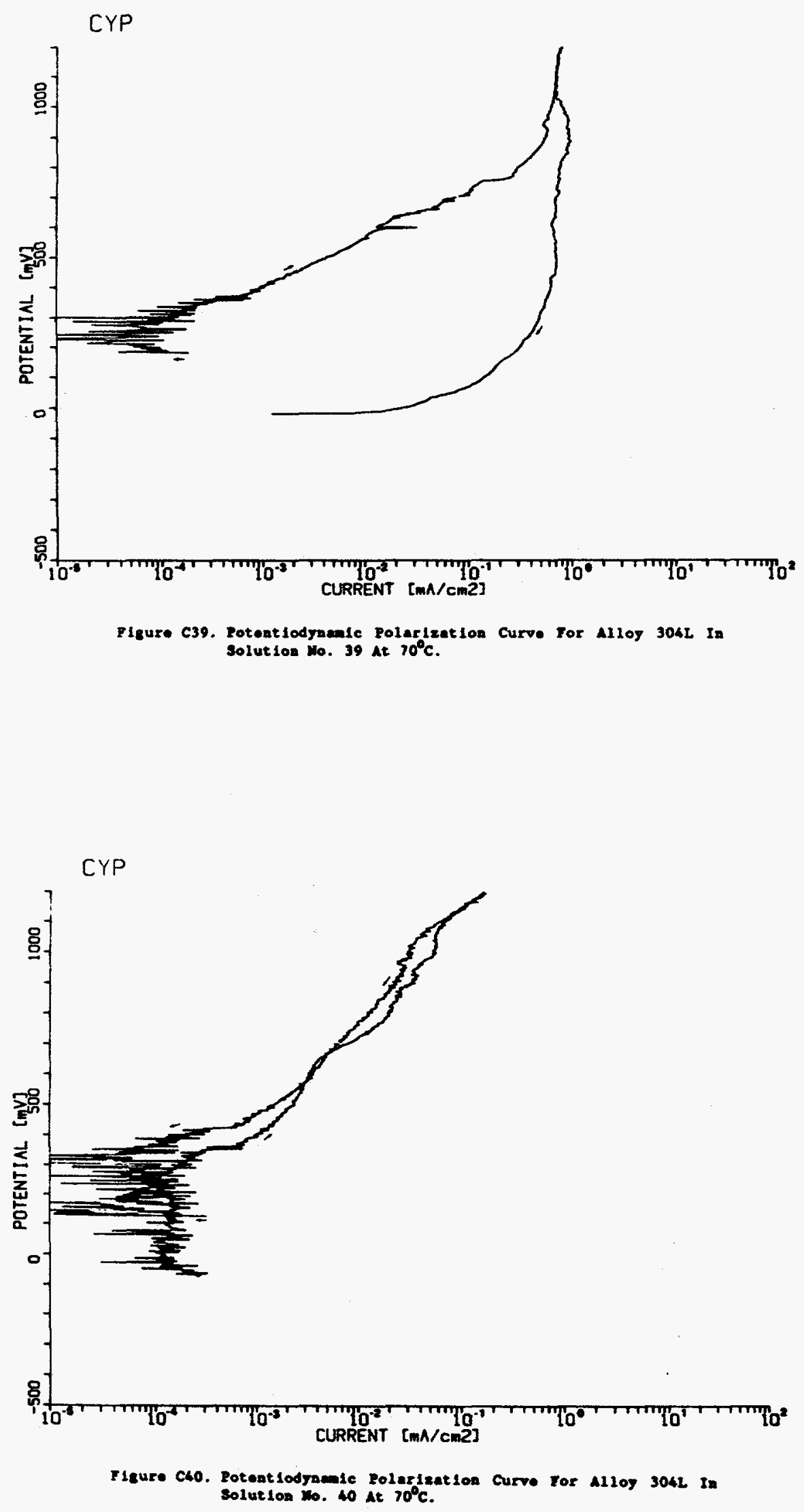

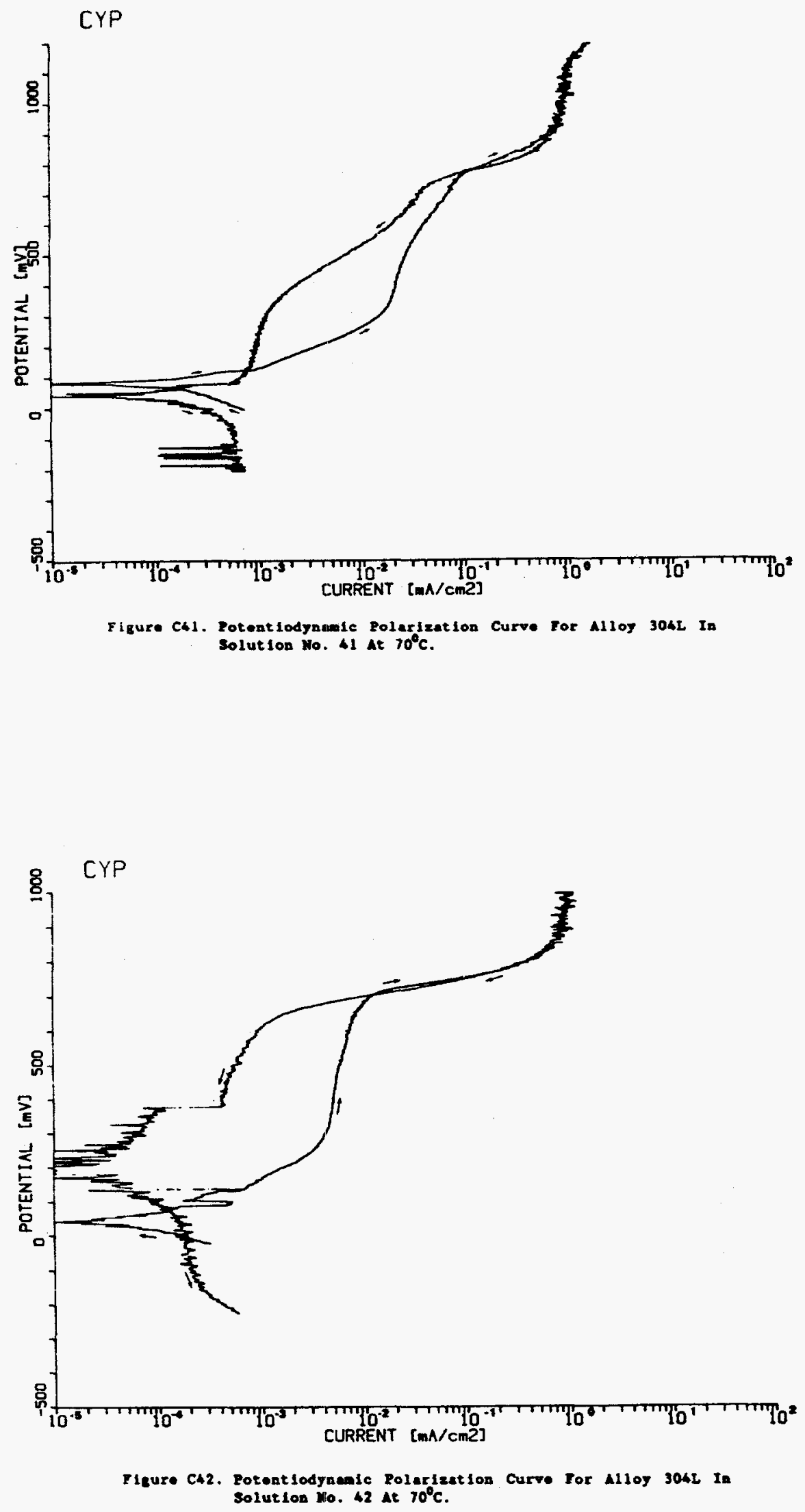
APPENDIX D

CYCLIC POTENTIODYNAMIC POLARIZATION CURVES

FOR ALLOY 825

IN TEST SOLUTIONS FROM THE

RESOLUTION IV MATRIX 


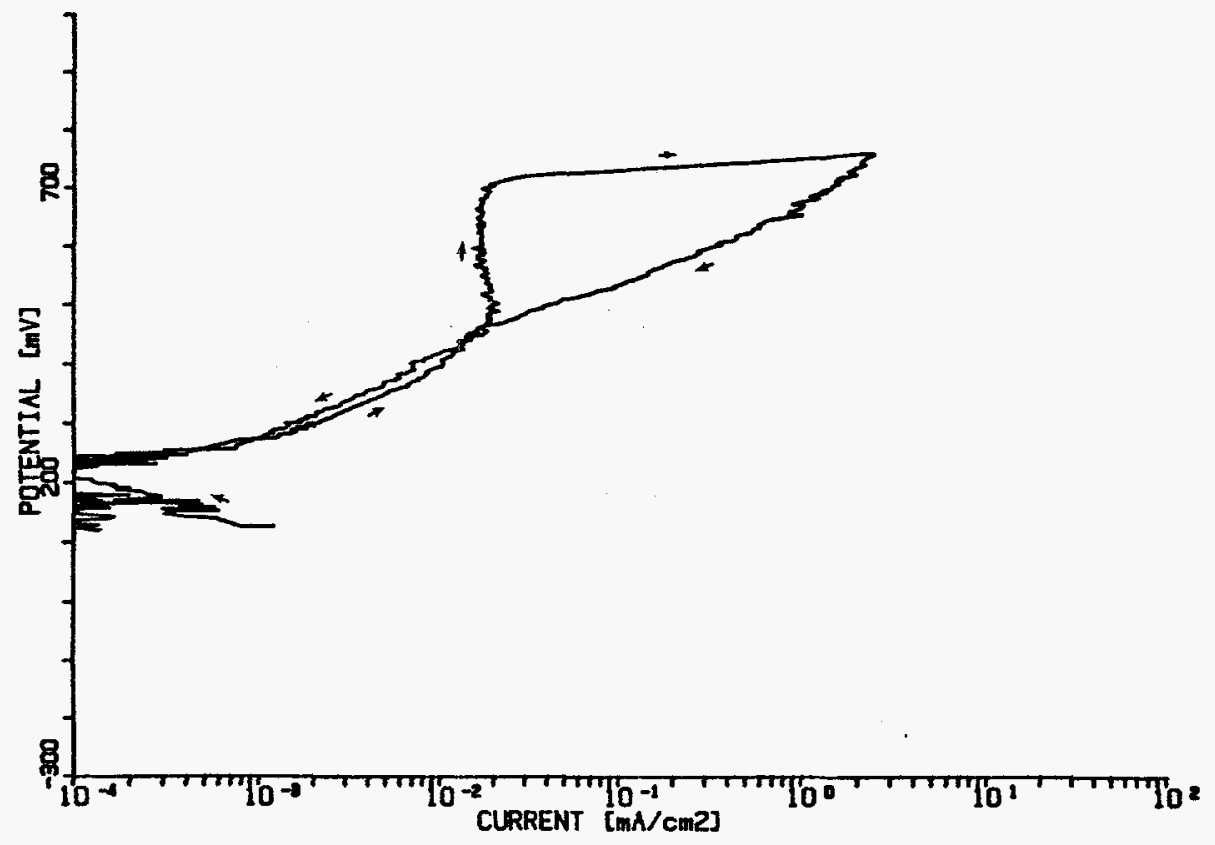

Figure Dl. Potent lodynamle Folarlzation Curve For Allog 825 In Solution No. 1 At $90^{\circ} \mathrm{C}$.

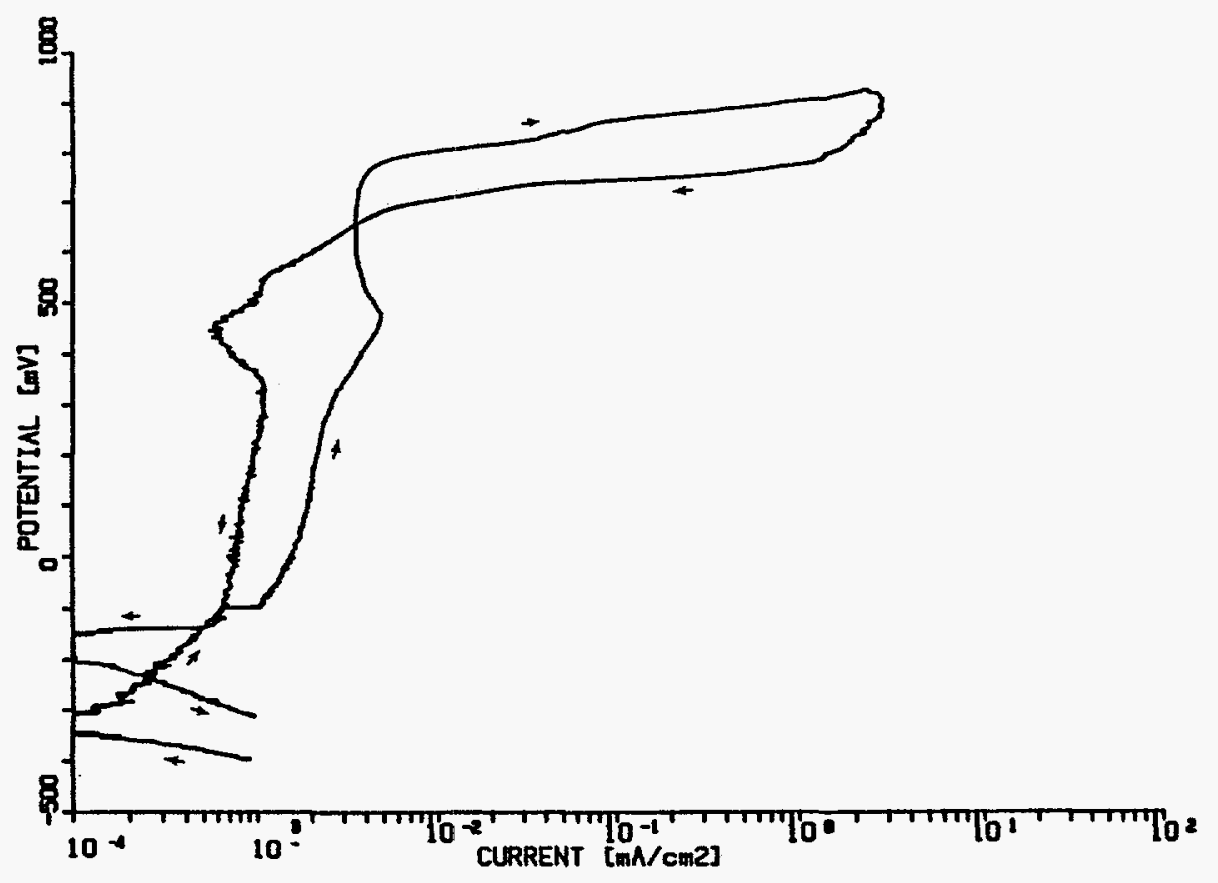

F1gure D2. Potentlodynamie Polerieation Curve For A110y 825 In Solution No. 2 at $30^{\circ} \mathrm{C}$. 


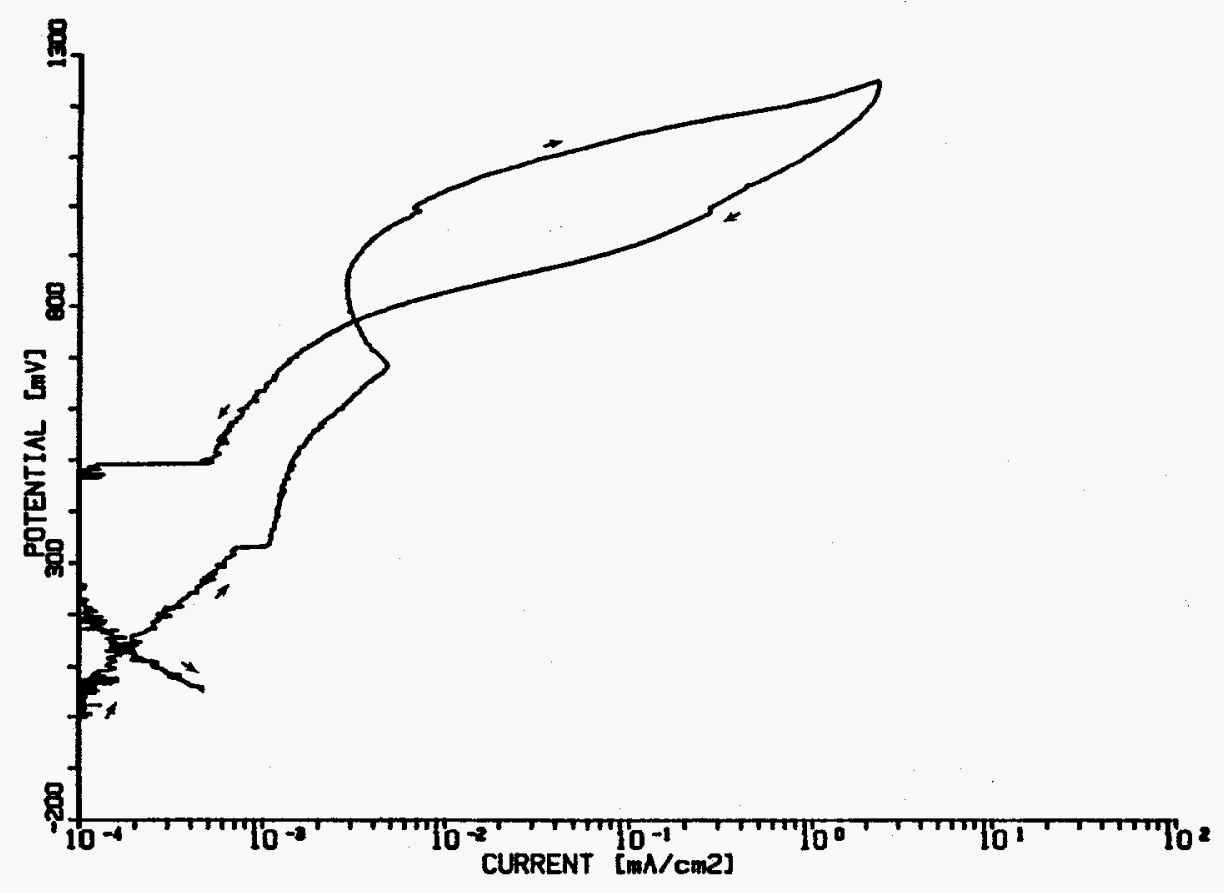

Figure D3. Potentiodyanic Polarization Curve For Allog 825 In Solution No. 3 at $50^{\circ} \mathrm{C}$.

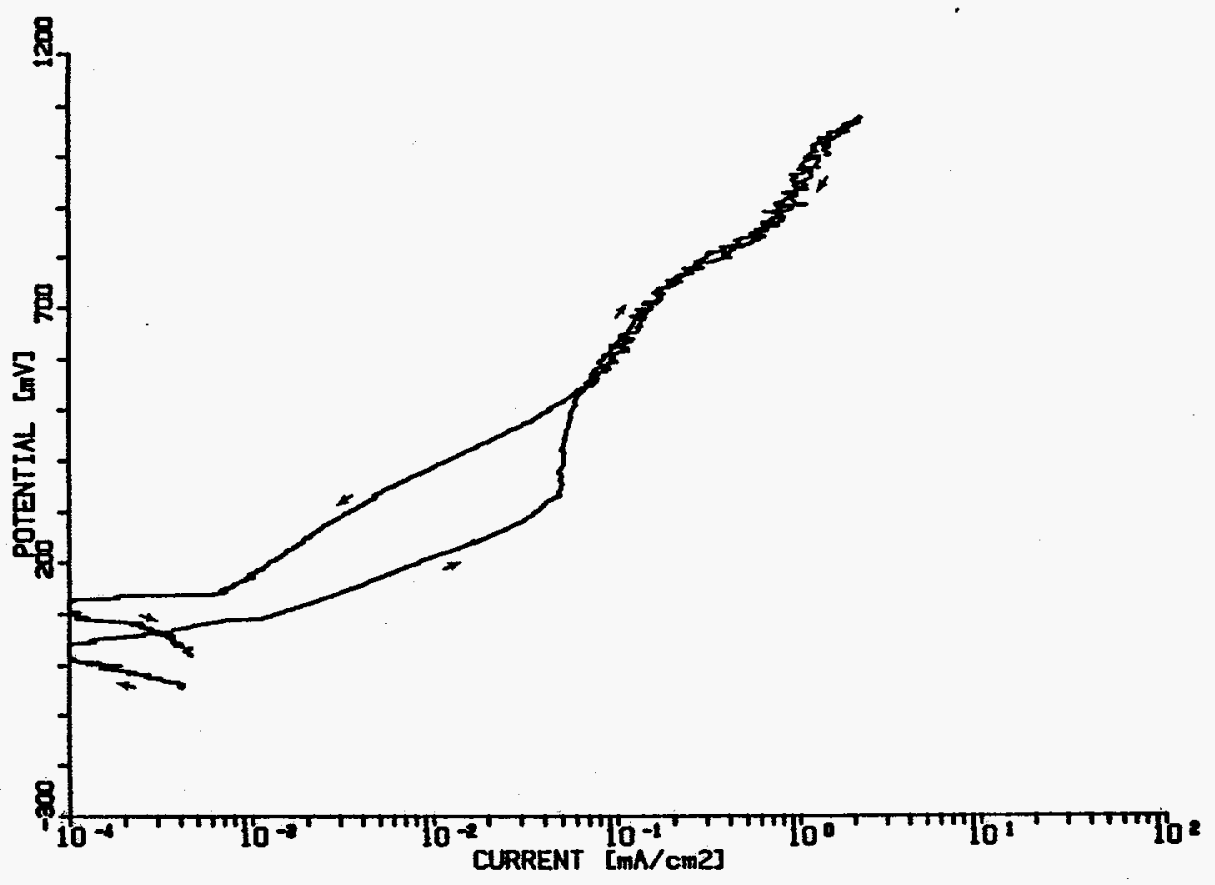

Figure D4. Potentlodynainic Polerization Curve For Alloy 825 In Solution No. At $90^{\circ} \mathrm{C}$. 


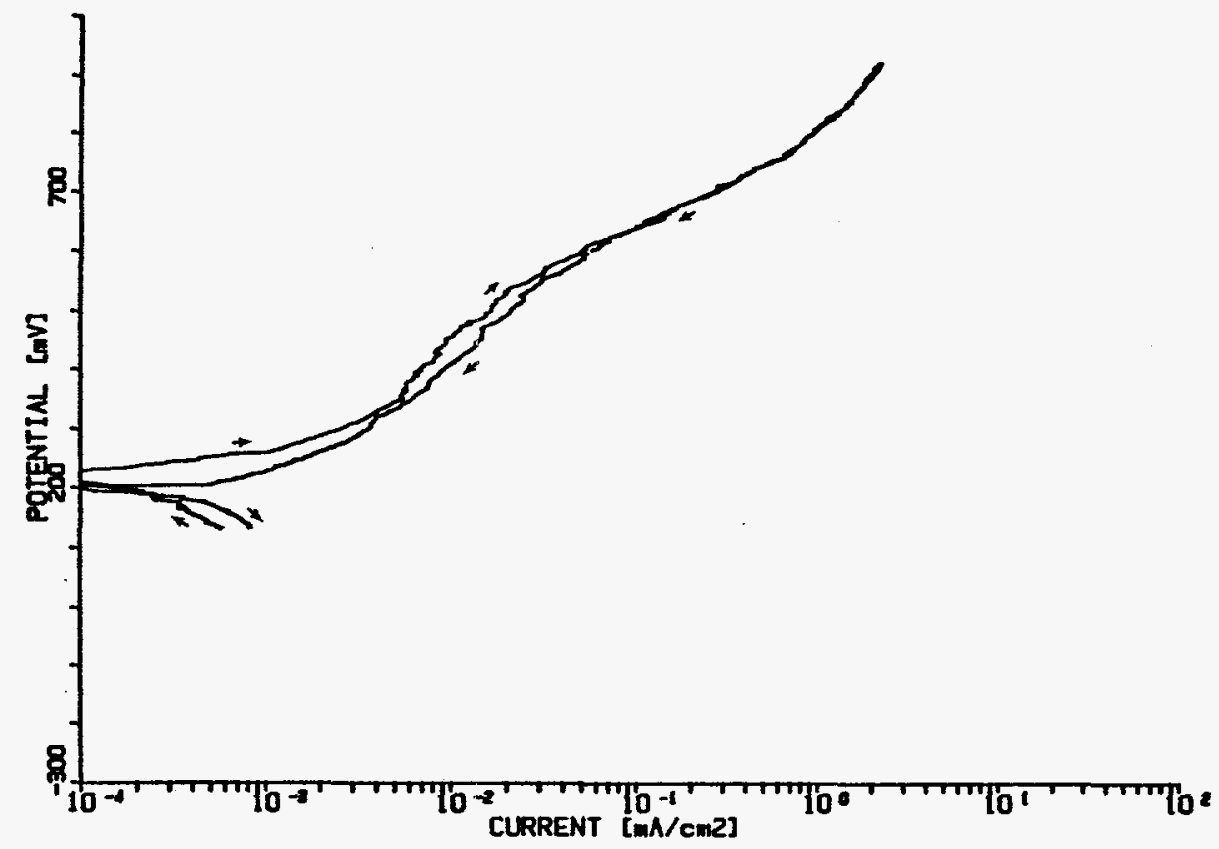

Figure D5. Potent lodynamic Polarleation Curve For Alloy 825 In Solution No. 5 at $50^{\circ} \mathrm{C}$.

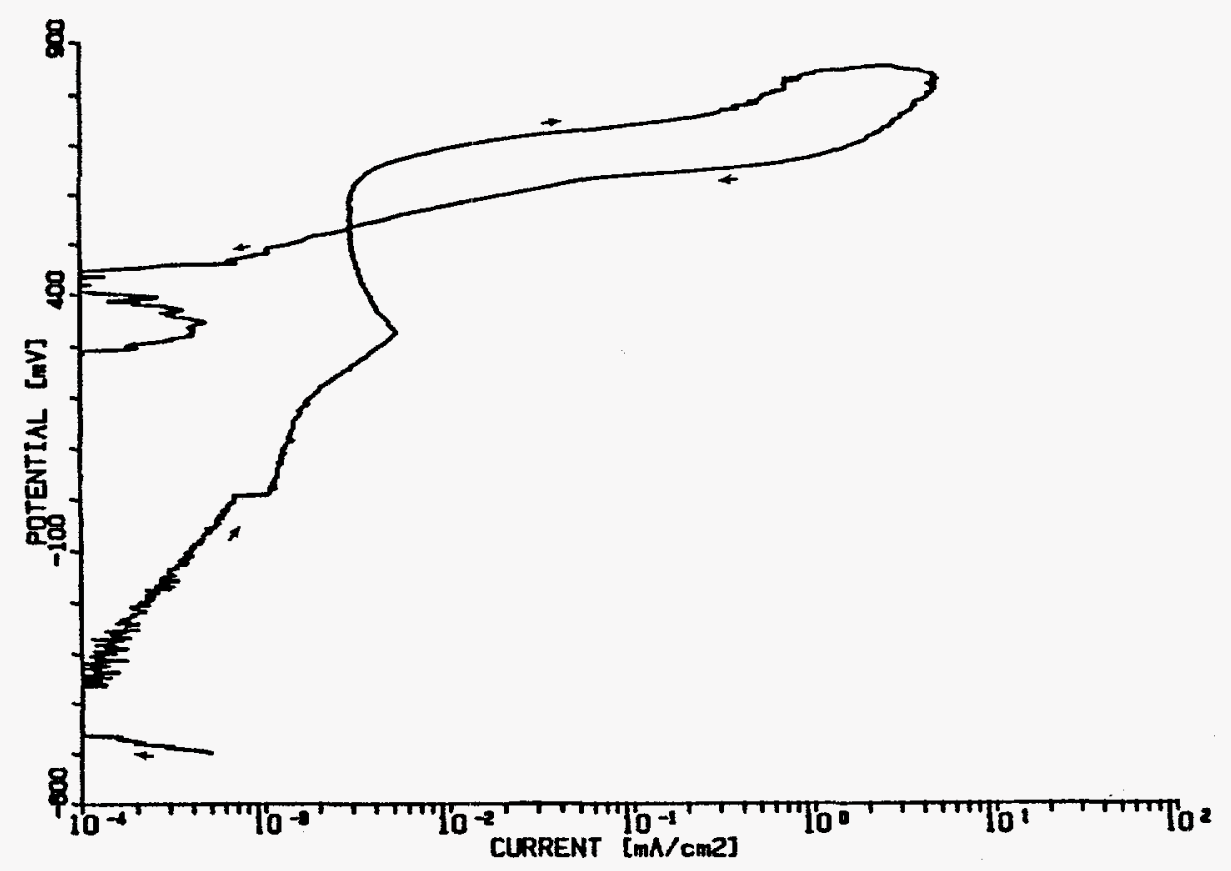

Figure D6. Potentlodynanie Polarization Curve For Alloy 825 In Solution No. 6 At $90^{\circ} \mathrm{C}$. 


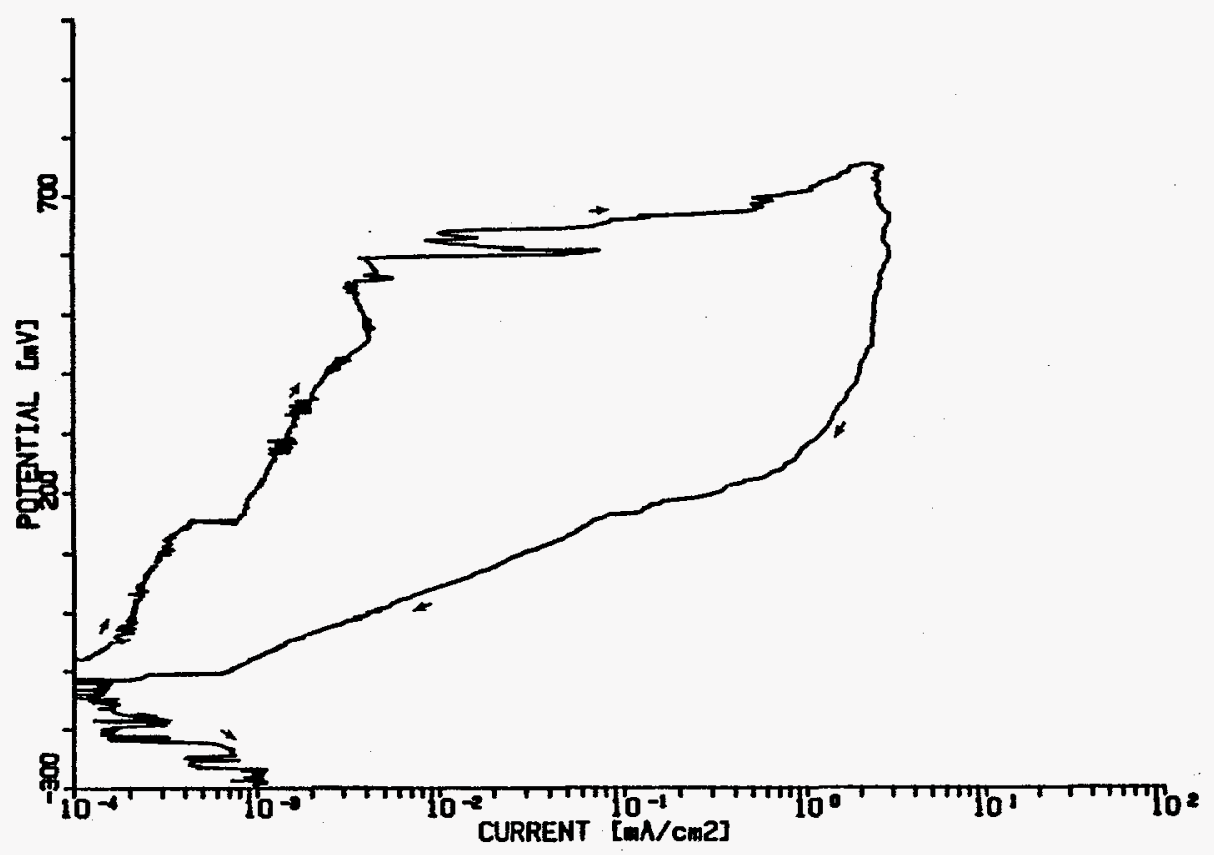

Figure D7. Potentlodynamic Polarization Curve For Alloj 825 In Solution No. 7 at $90^{\circ} \mathrm{C}$.

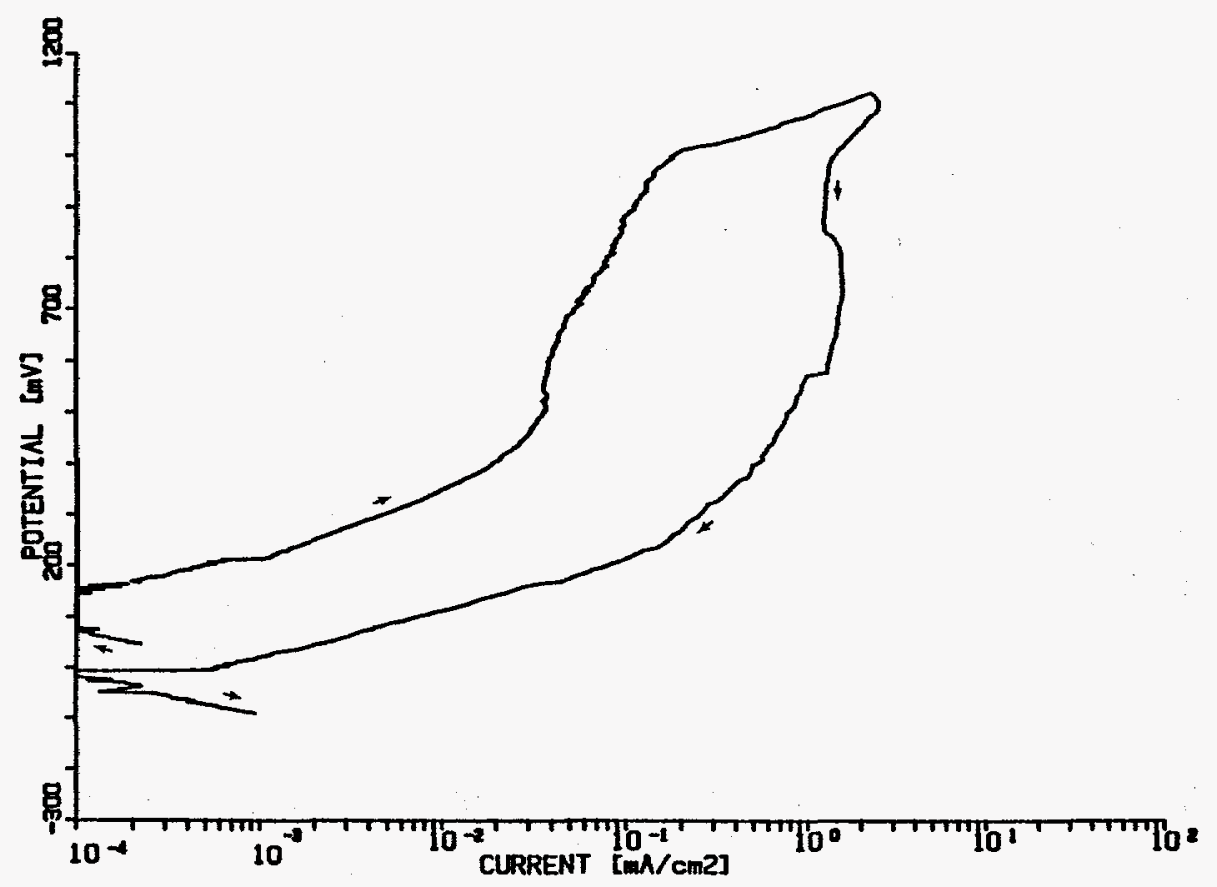

Figure D8. Potentiodynamic Polarization Curve For Alloy 825 In Solution No. 8 at $50^{\circ} \mathrm{C}$. 


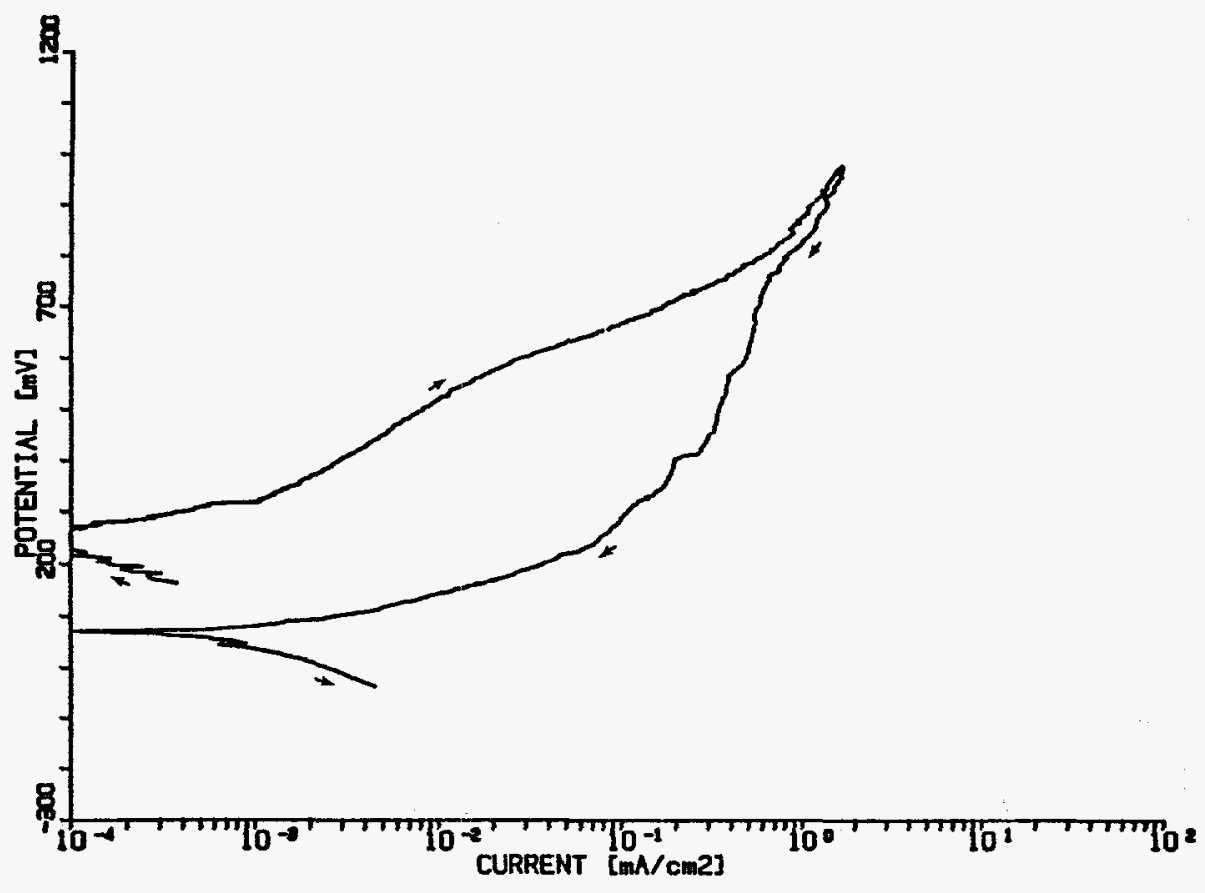

Igure D9. Rotentfodynamic Polarizetion Curve For Alloy 825 In Solution No. 9 at $50^{\circ} \mathrm{C}$.

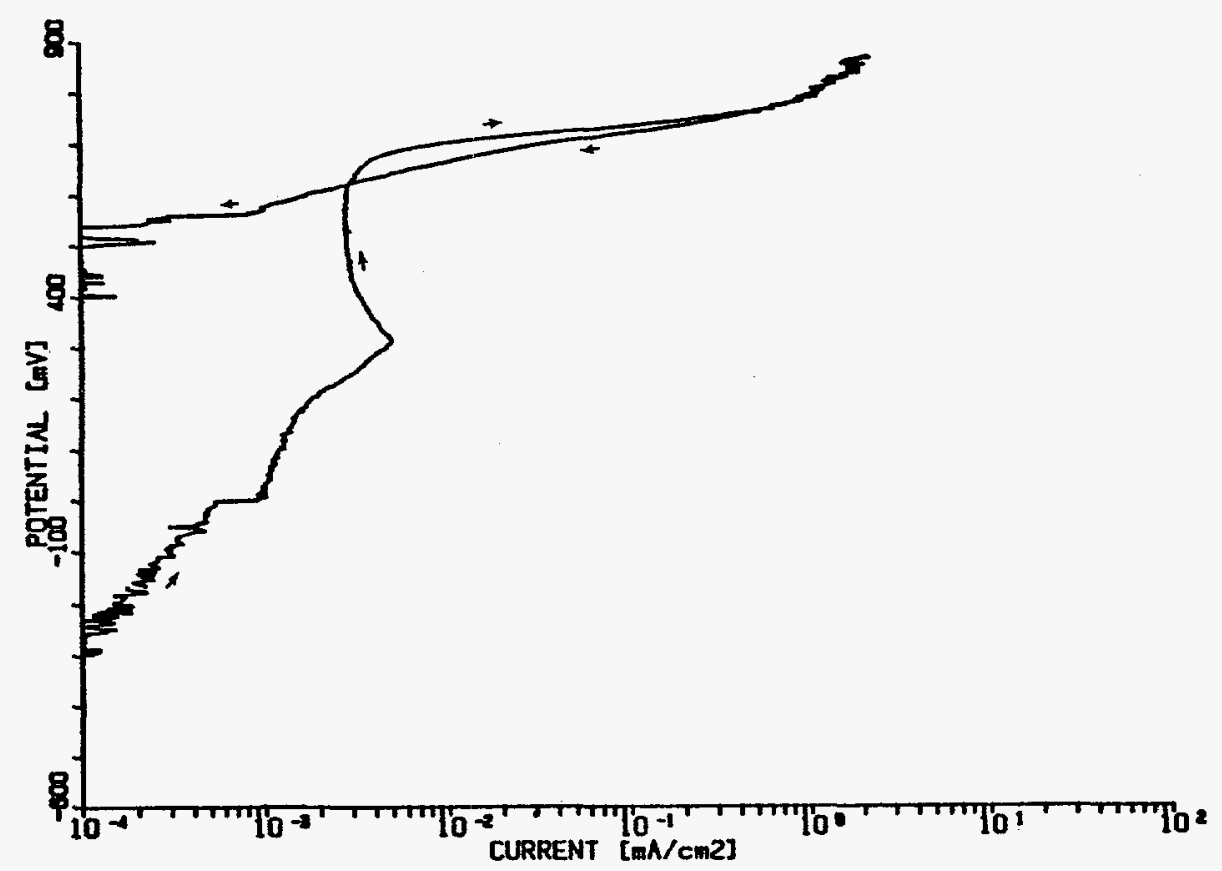

Figure D10. Potentlodynanfe Rolarlzation Curve For 11107 g25 In Solution No. 10 at $90^{\circ} \mathrm{C}$. 


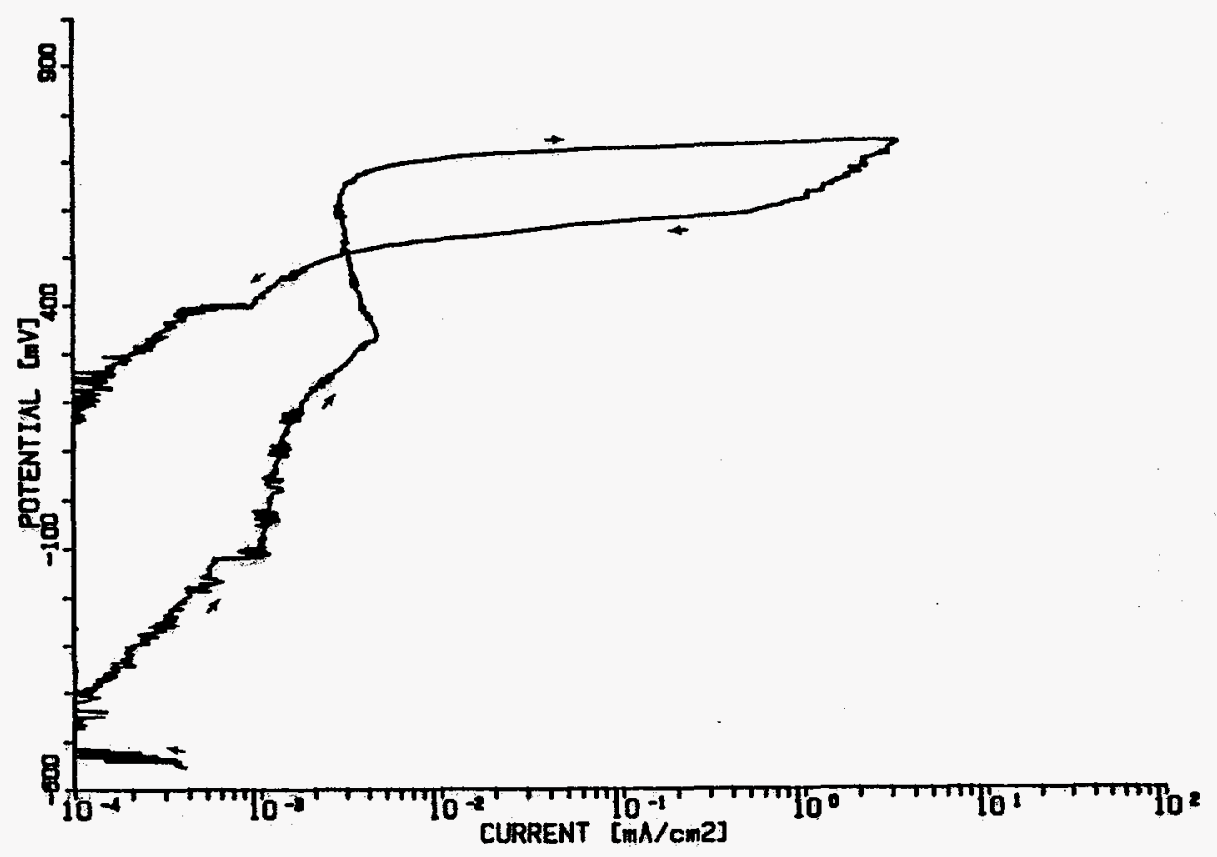

Figure D11. Potentiodynamic Polarization Curve For Alloy 825 In Solution Ho. 11 at $90: c$.

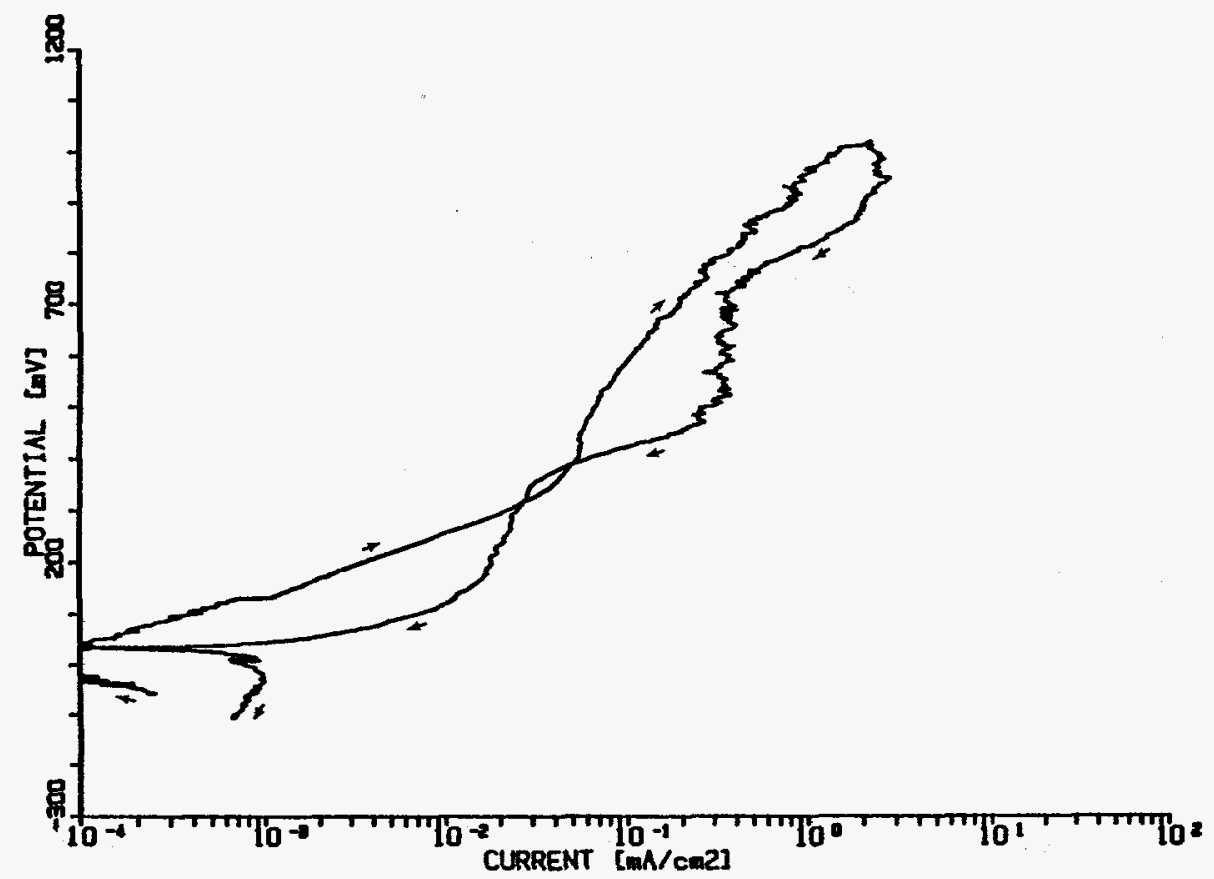

Figure D12. Potentlodynamic Polarization Curve For Alloy 825 In Solution 15o. 12 At $30^{\circ} \mathrm{C}$. 


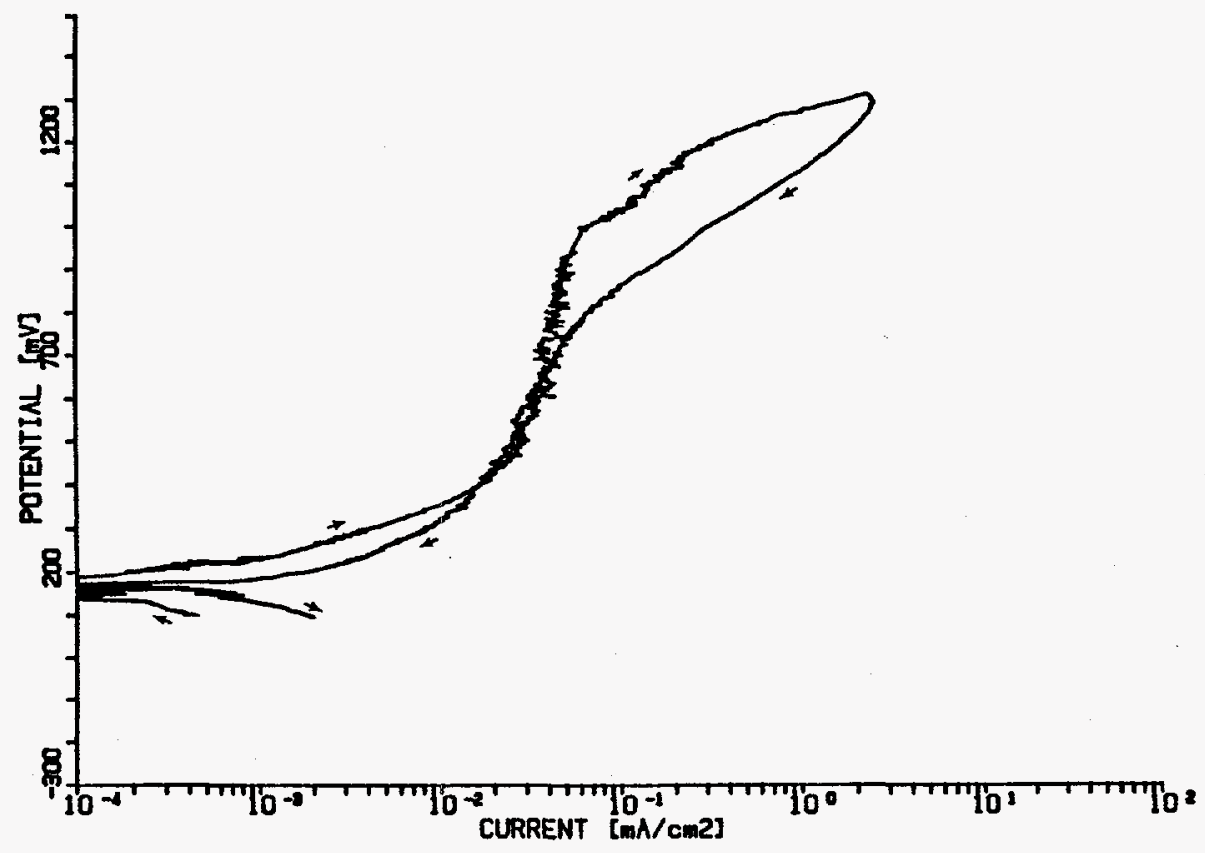

F1gure D13. Rotentiodynamic Polarization Curve For Alloy 825 In Solution No. 13 At $90^{\circ} \mathrm{C}$.

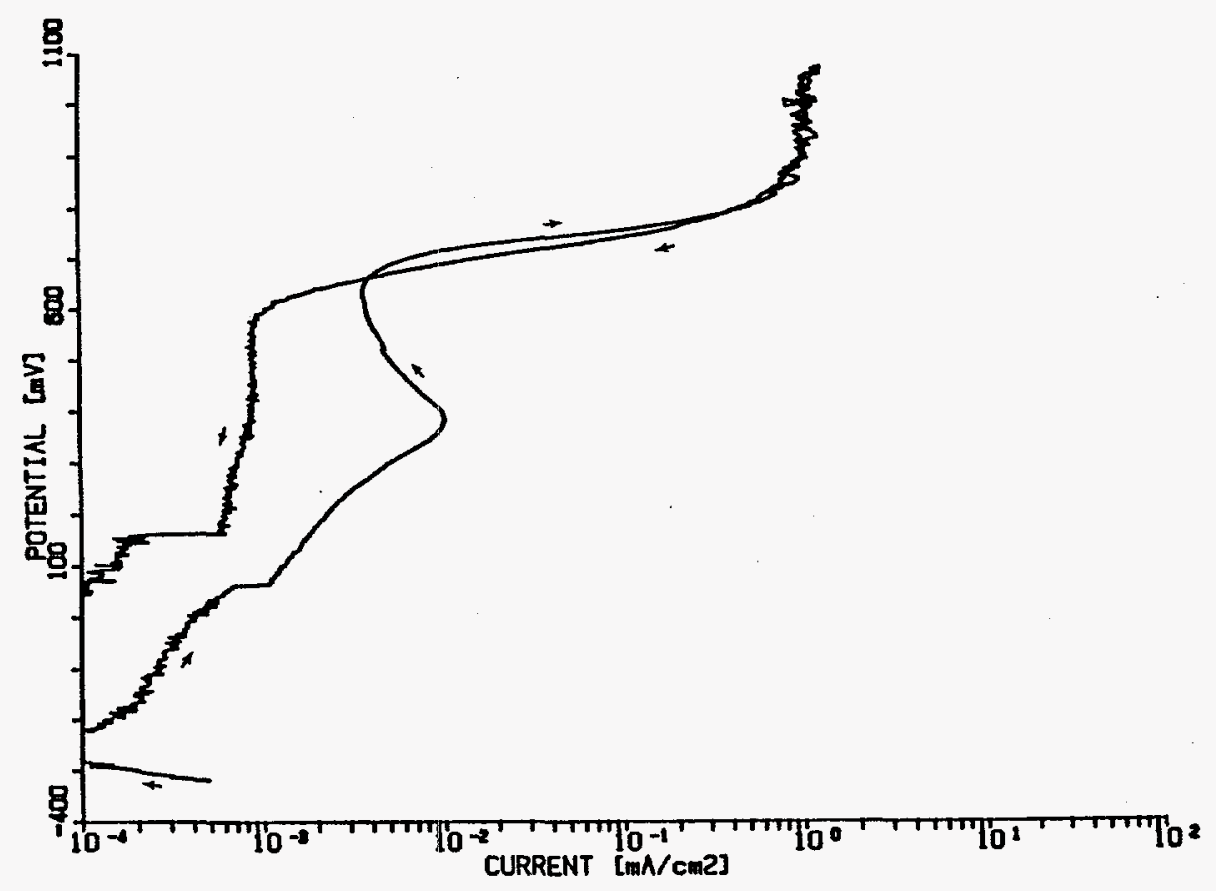

Figure D14. Potentlodynamic Polerization Curve For Alloy 825 In Solution No. 14 At $50^{\circ} \mathrm{C}$. 


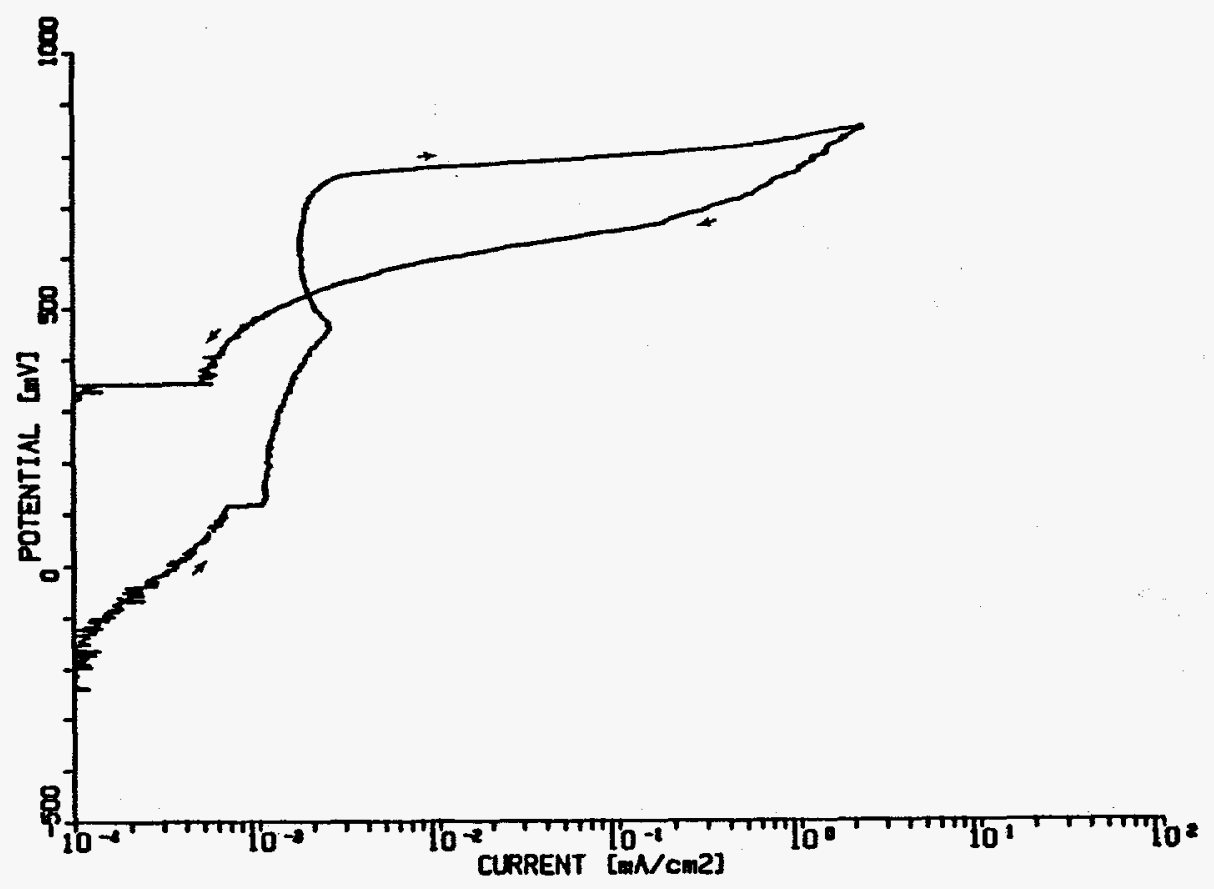

Figure D15. Potentiodynenic Eolerization Curve For Alloy 825 In Solution No. 15 At $50^{\circ} \mathrm{C}$.

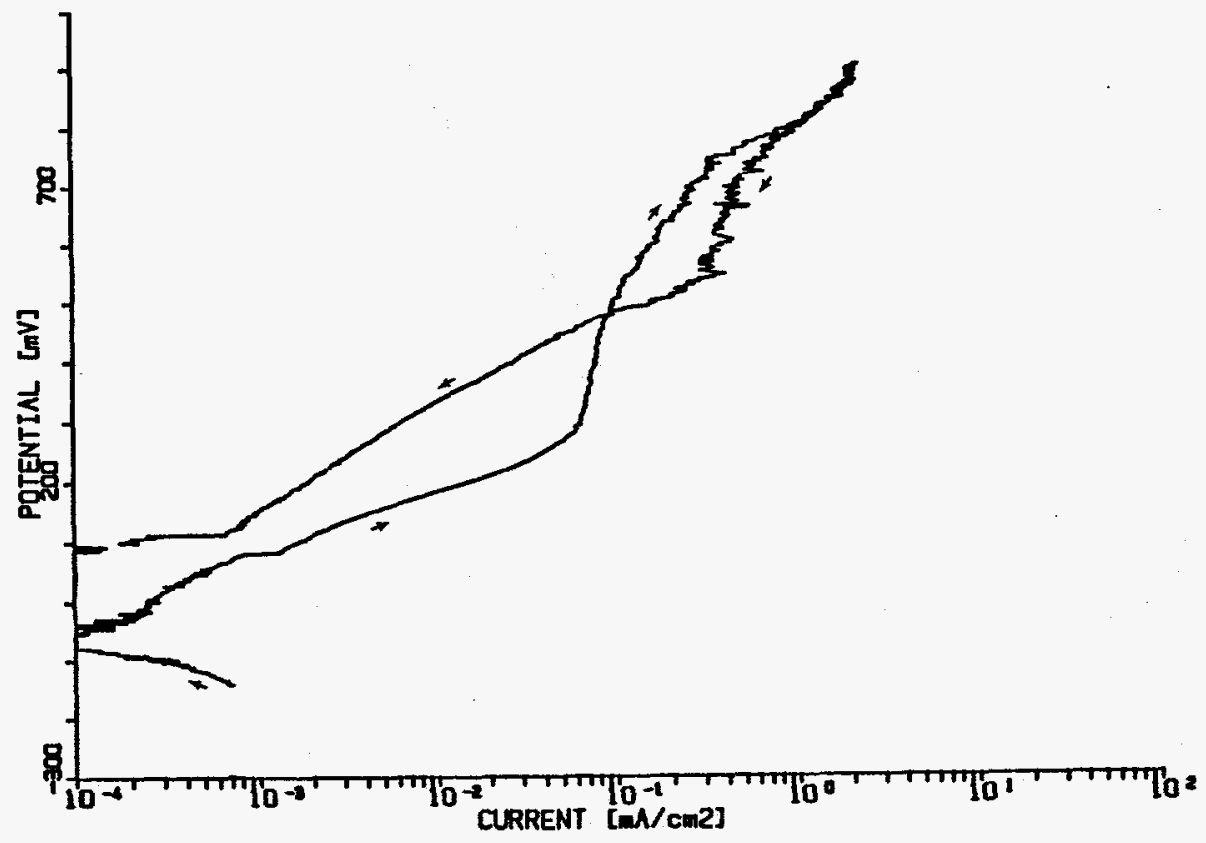

Flgure D16. Rotent lodynantc Polerigation Curve For Alloy a25 In Solution Ho. 16 at $90^{\circ} \mathrm{C}$. 


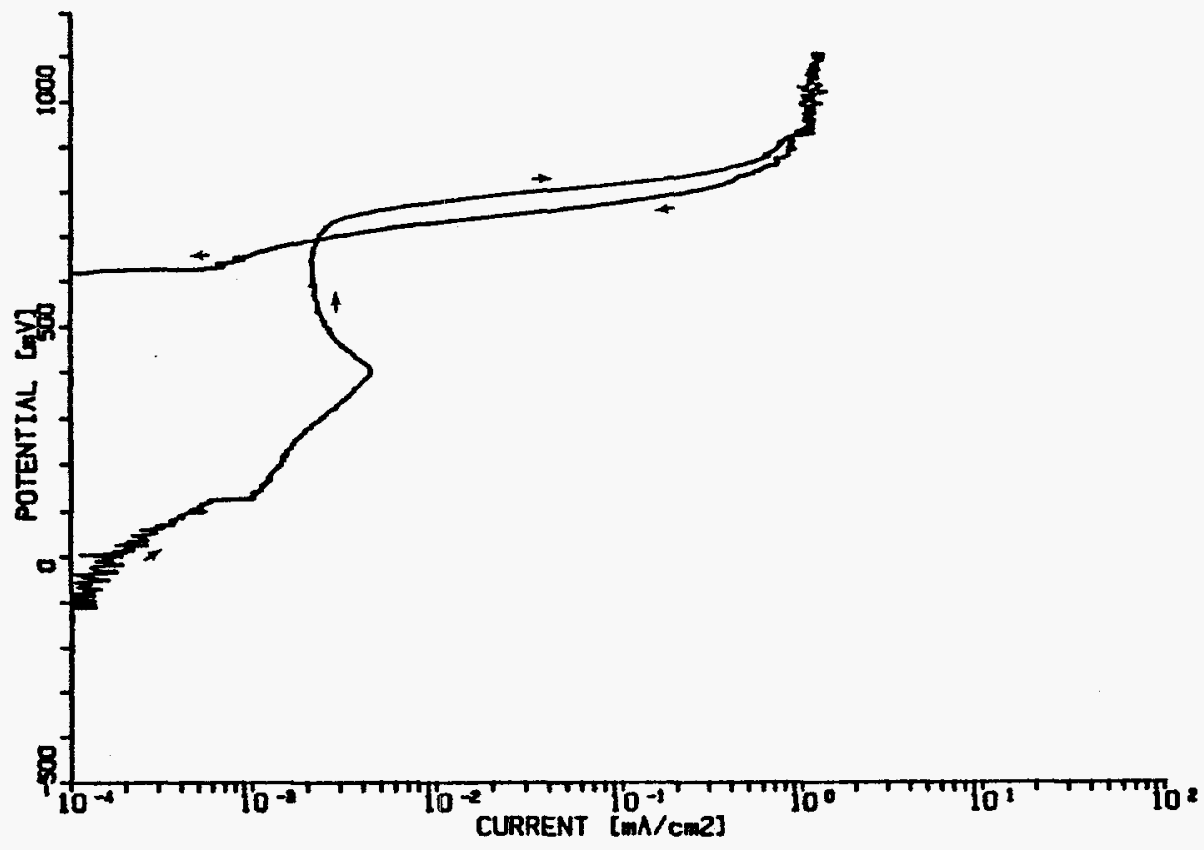

Figure D17. Potont lodynamic Polariantion Curve For Alloy 825 In Solution No. 17 At $50^{\circ} \mathrm{c}$.

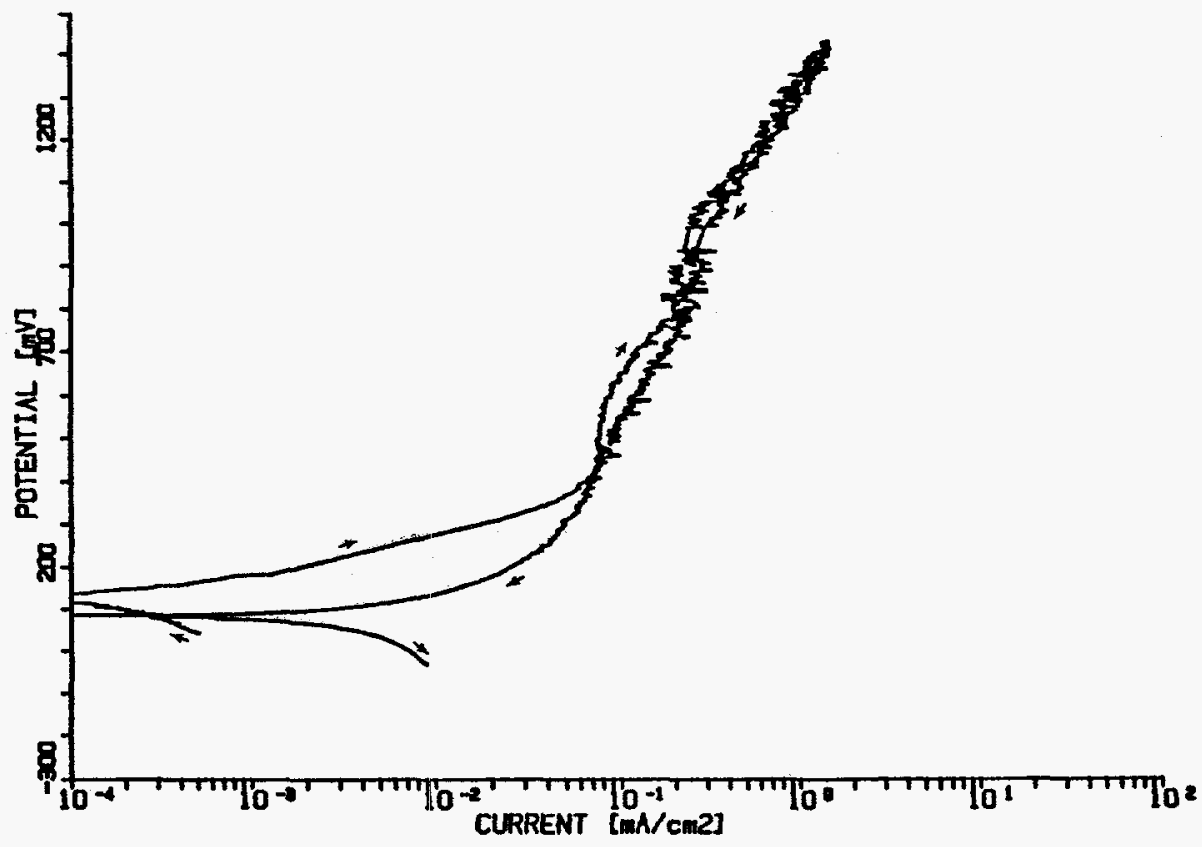

Figure D18. Fotent1odynesle Polarization Curve For Alloy 825 In Solution No. 18 At $90^{\circ} \mathrm{C}$. 


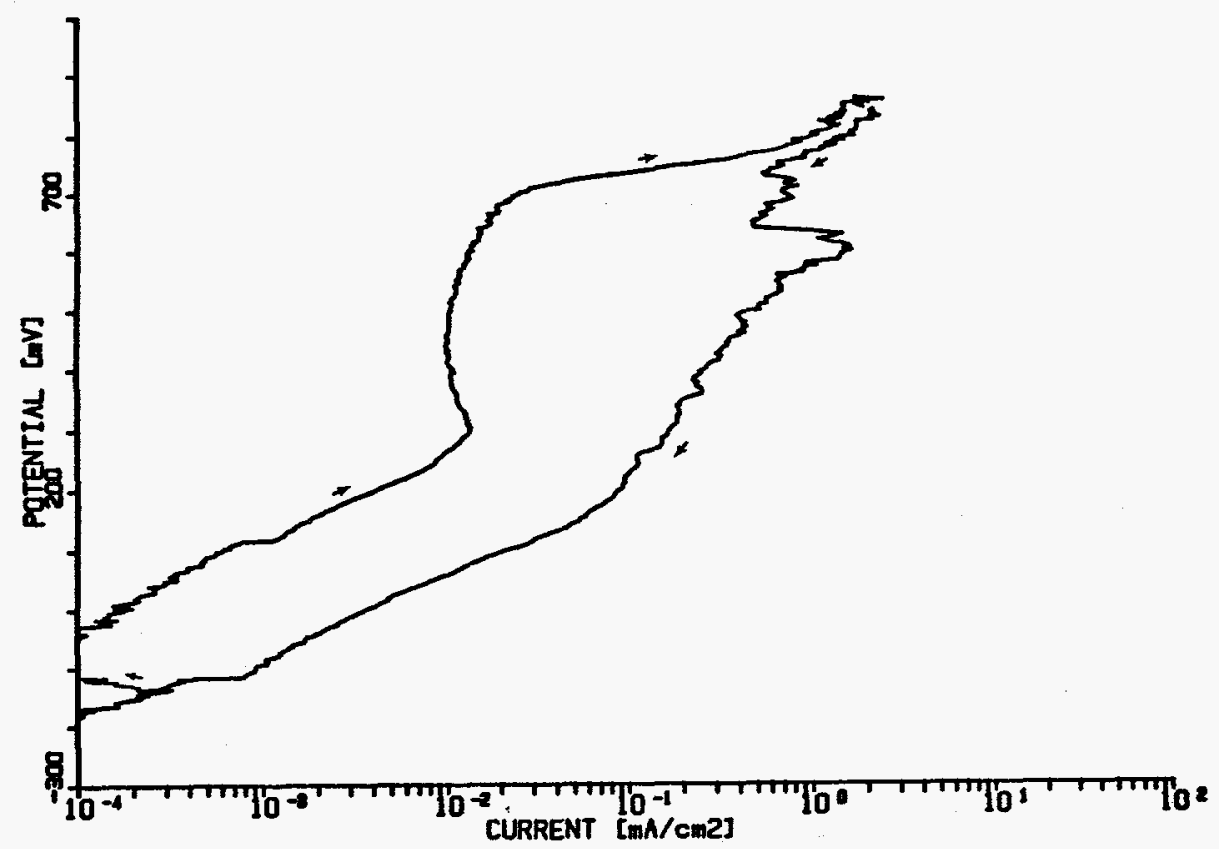

F1eure D19. Potentlodyneme Polerieation Curve For Alloy 225 In solution Ho. 19 at $90^{\circ} \mathrm{C}$

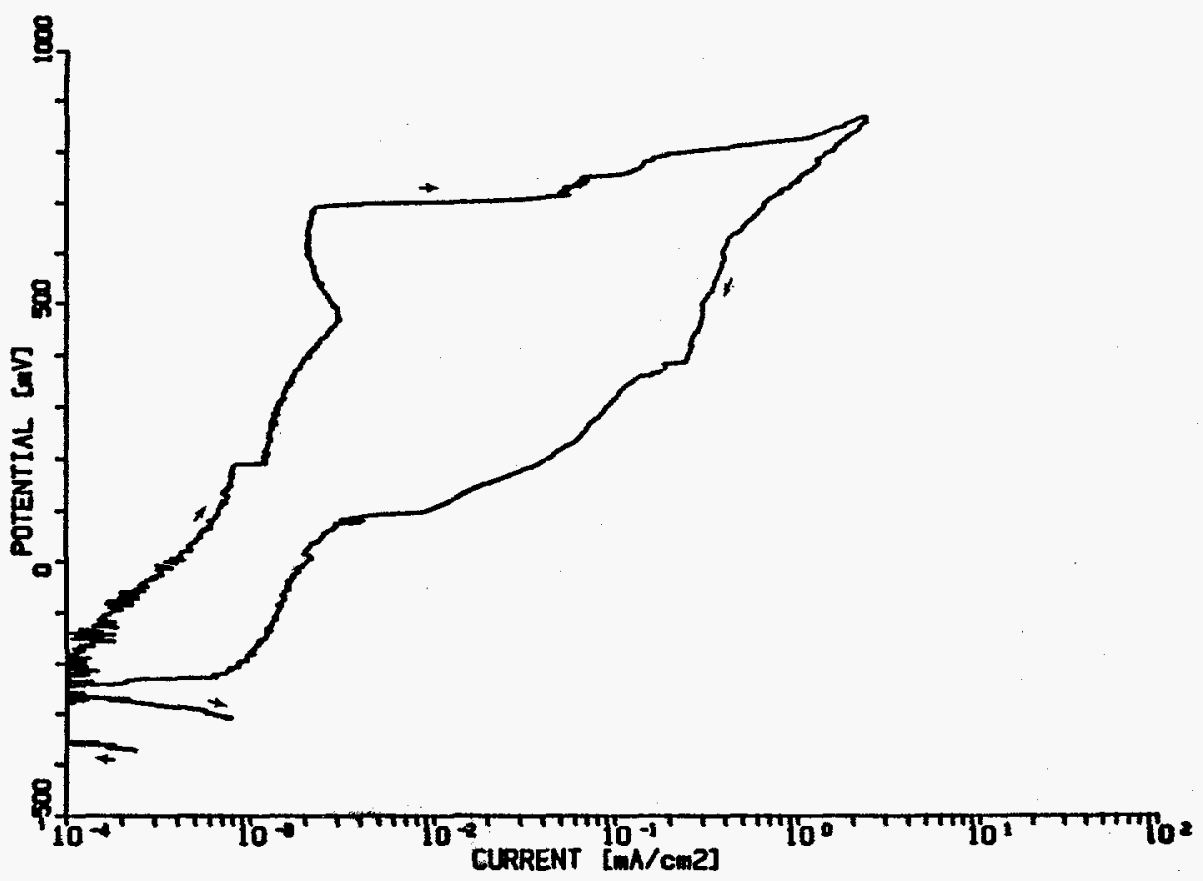

Figure D20. Rotent lodynale Rolerization Curve For Allog a25 In Solution No. 20 At $50^{\circ} \mathrm{C}$. 


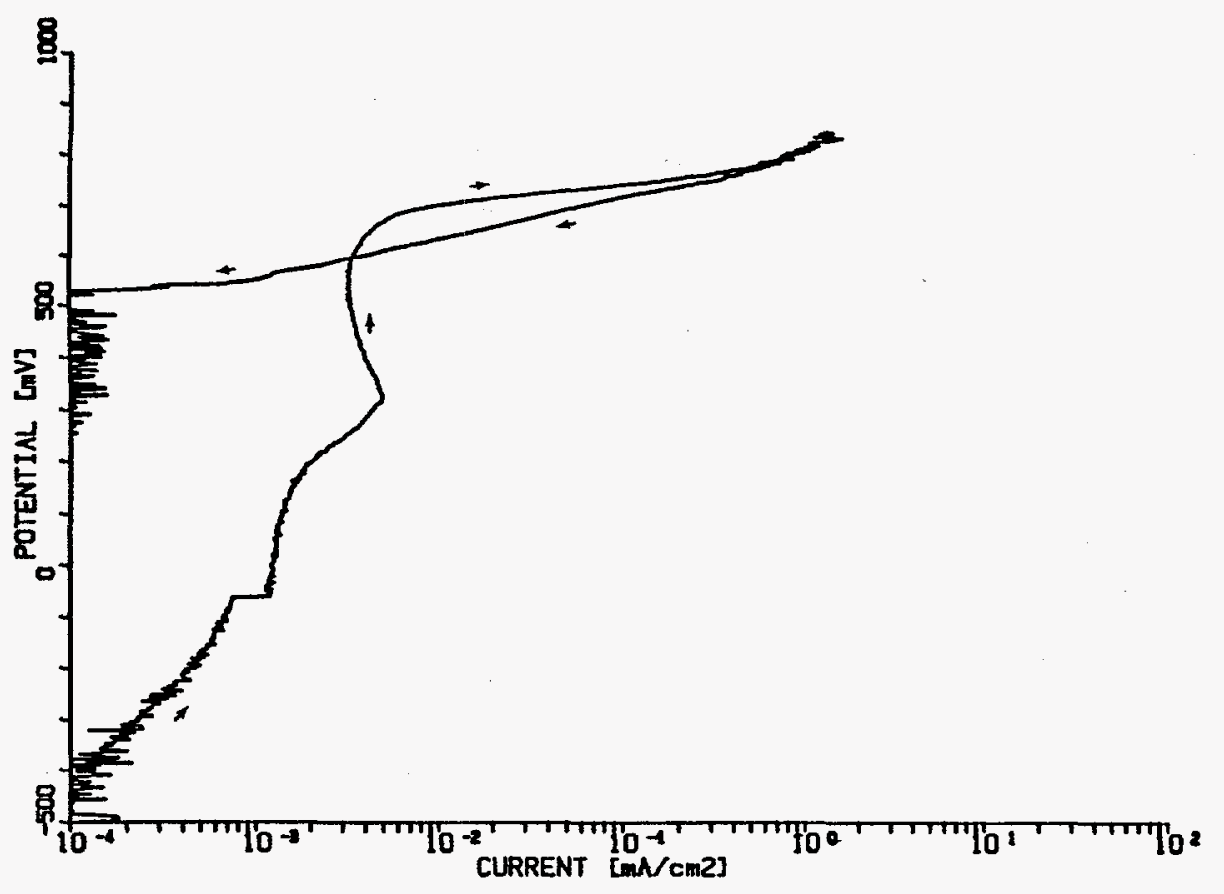

Figure D21. Potent lodynamie Polarization Curve For Allog 825 In Solution Ho. 21 At $90^{\circ} \mathrm{C}$.

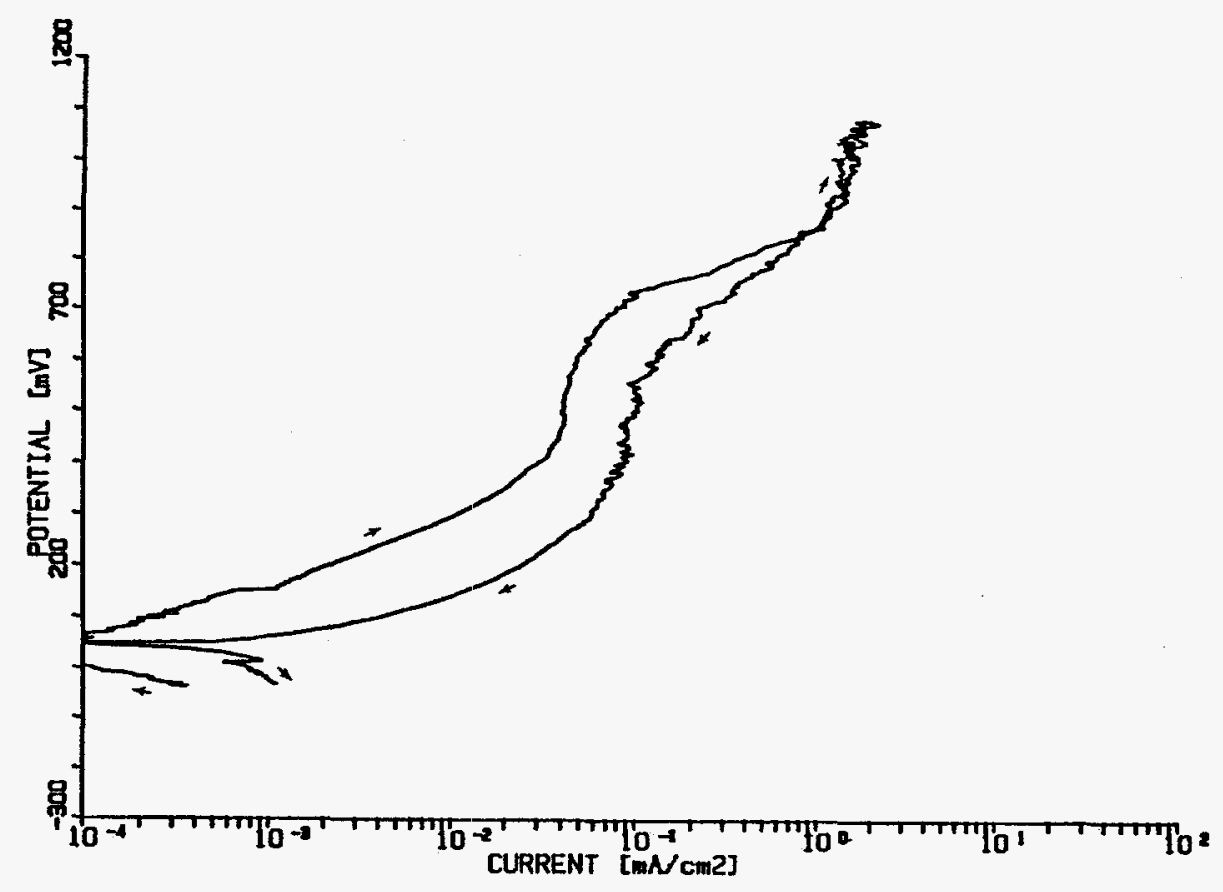

Figure D22. Potentiodynamic Polerization Curva For Alloy 825 In Solution No. 22 At $50^{\circ} \mathrm{C}$. 


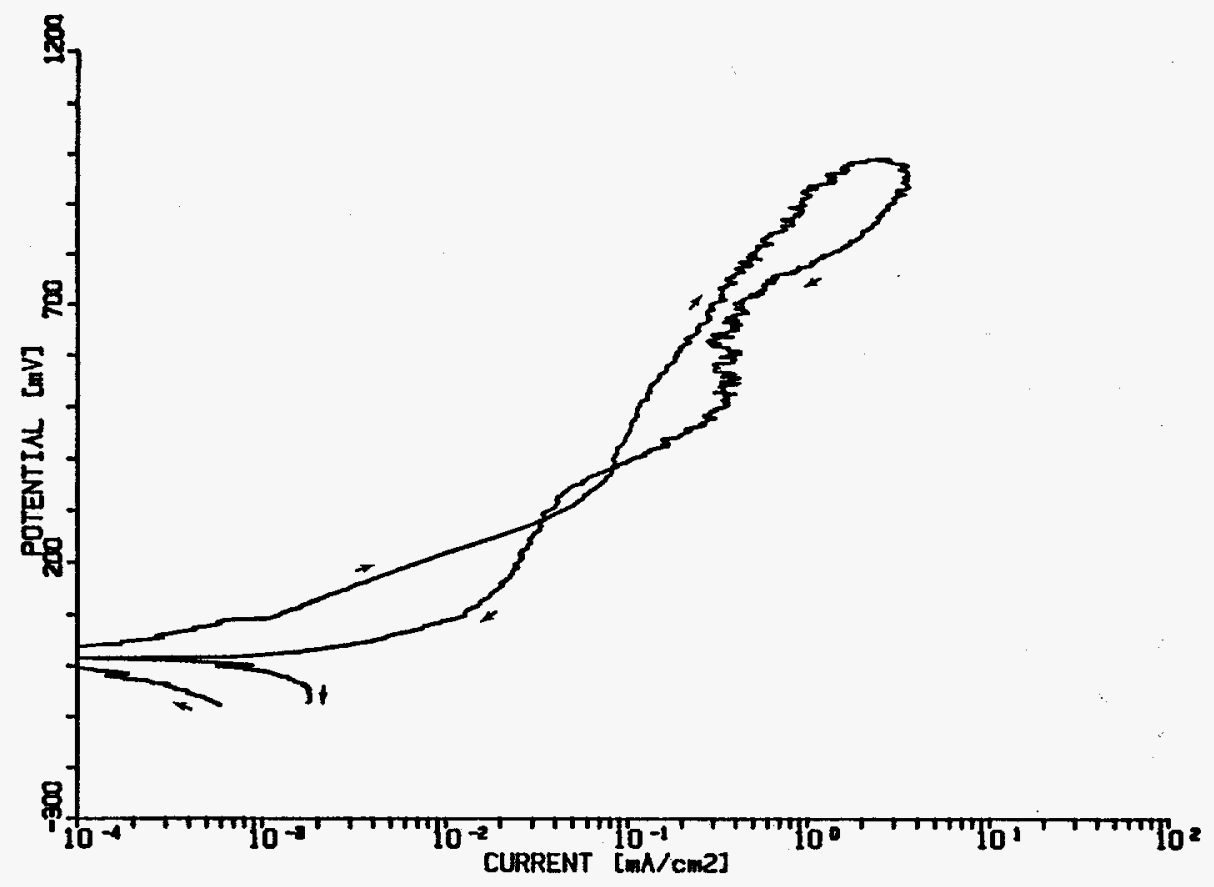

Figure D23. Potent lodynanic Rolarization Curve For Alloy 825 In Solution No. 23 At $50^{\circ} \mathrm{C}$.

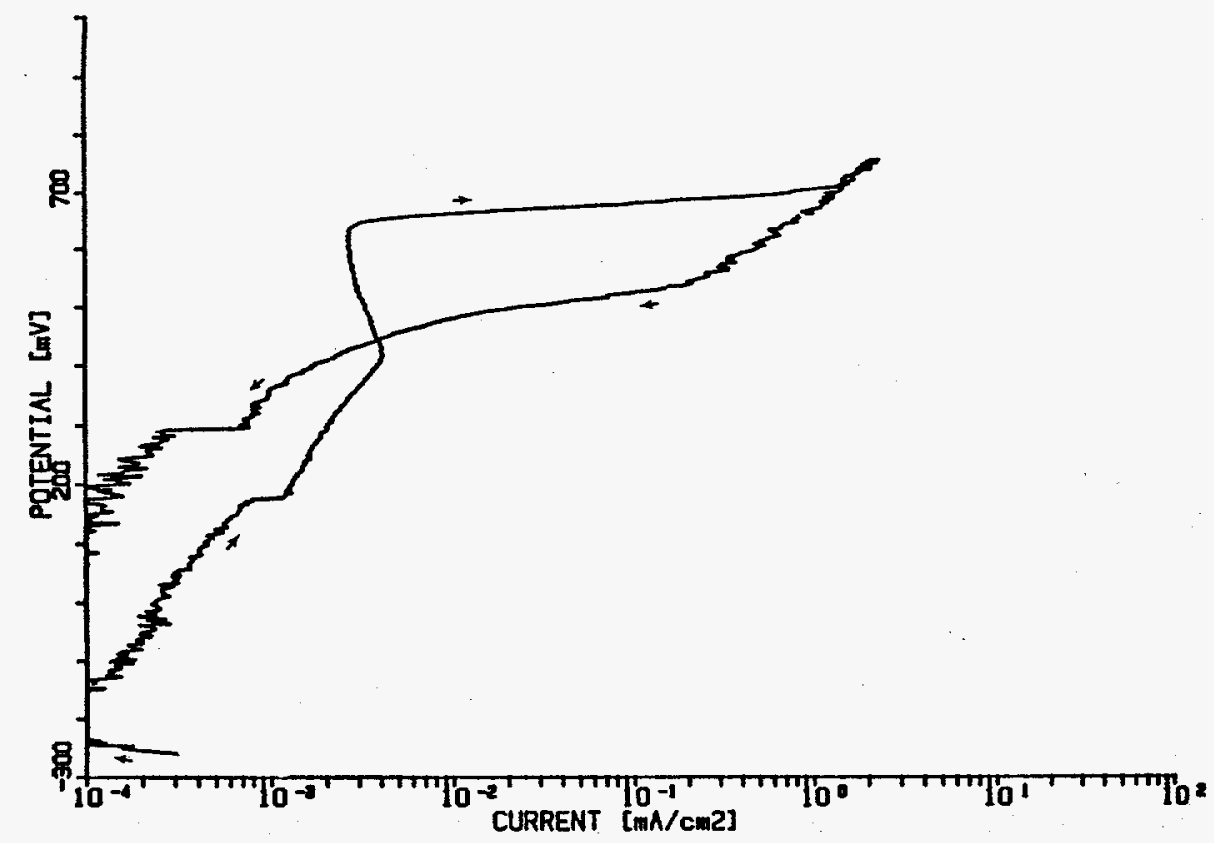

Figure D24. Potentiodynanic Polerization Curve For Alloy 825 In Solution No. 24 At $90^{\circ} \mathrm{C}$. 


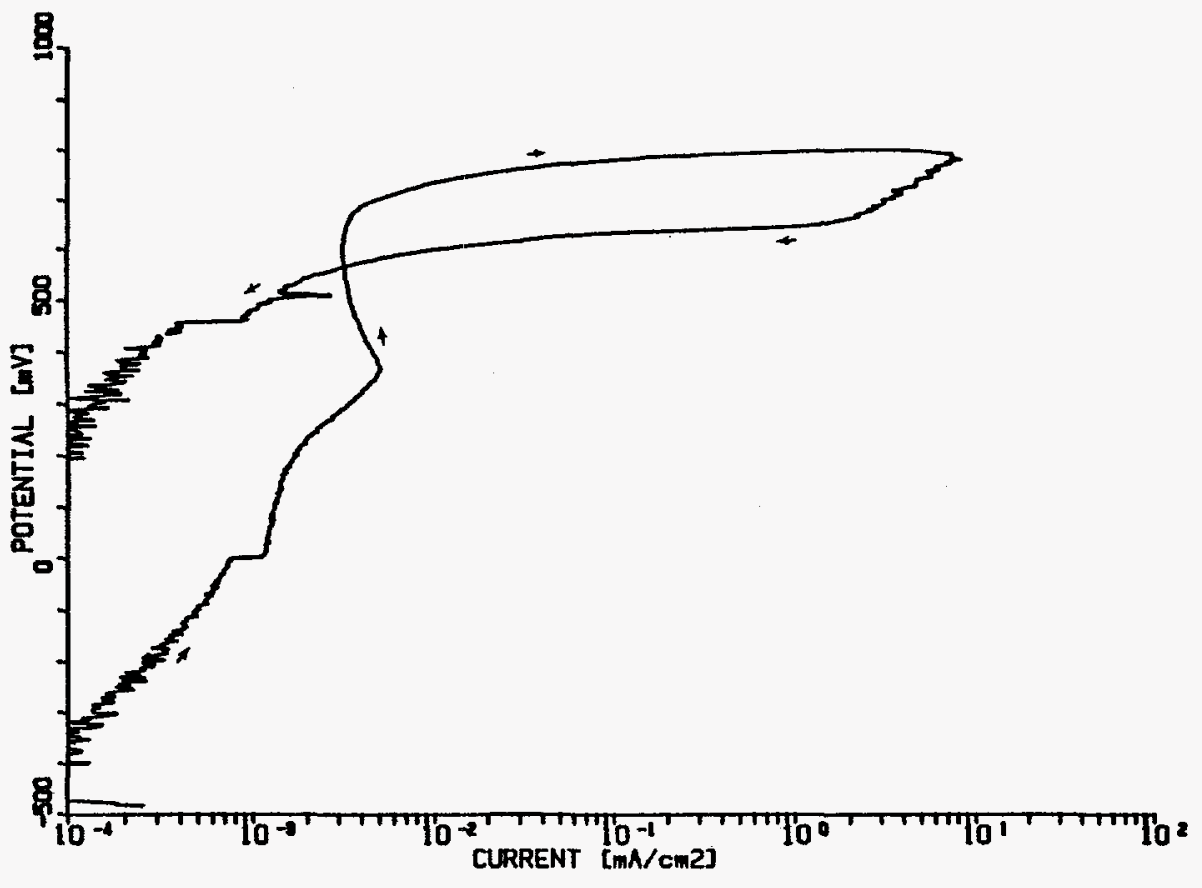

Figure D25. Potentlodyanic Polarization Curve For Alloy 825 In Solution No. 25 At $90^{\circ} \mathrm{C}$.

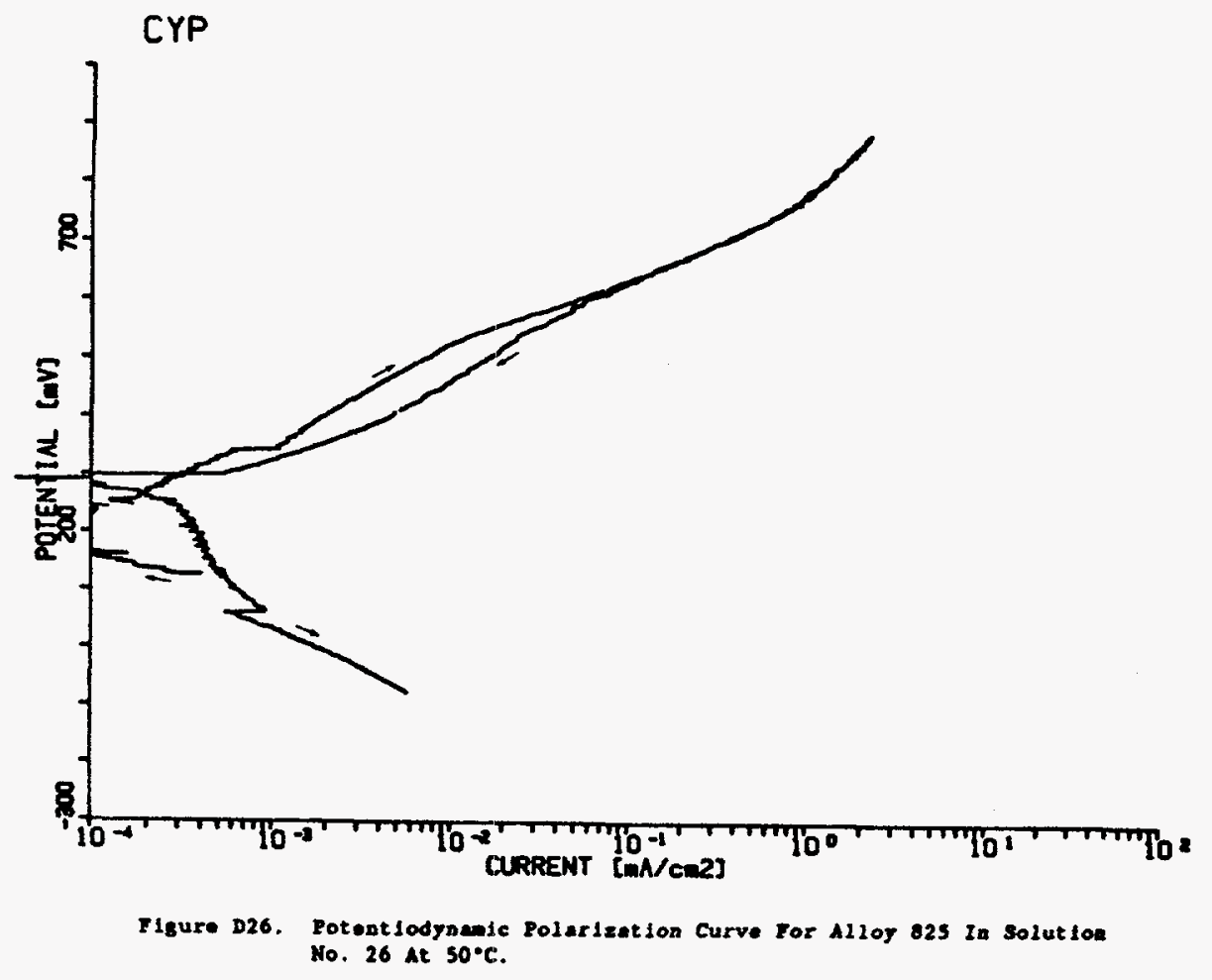




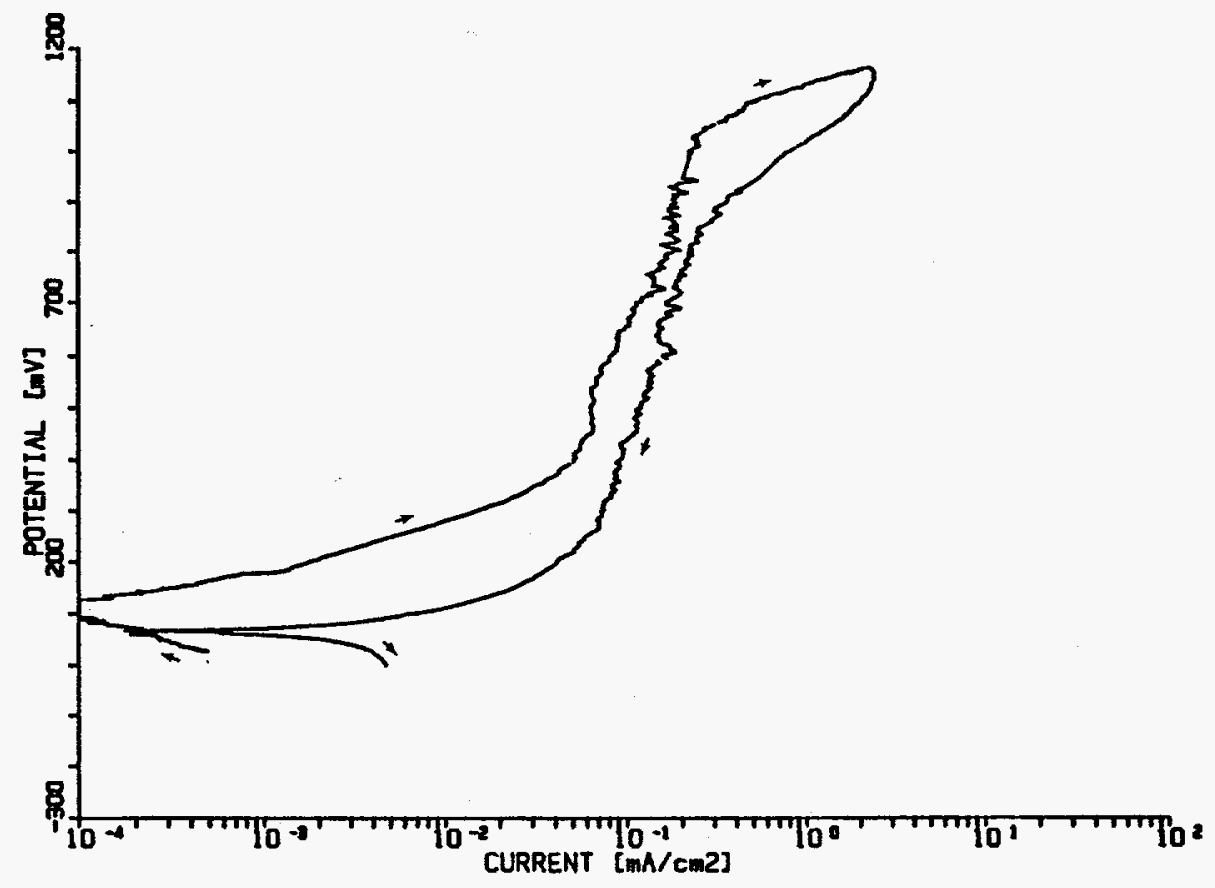

F18ure D27. Potentlodynanic Polarization Curve For Alloy 825 In Solution No. 27 At $50^{\circ} \mathrm{C}$.

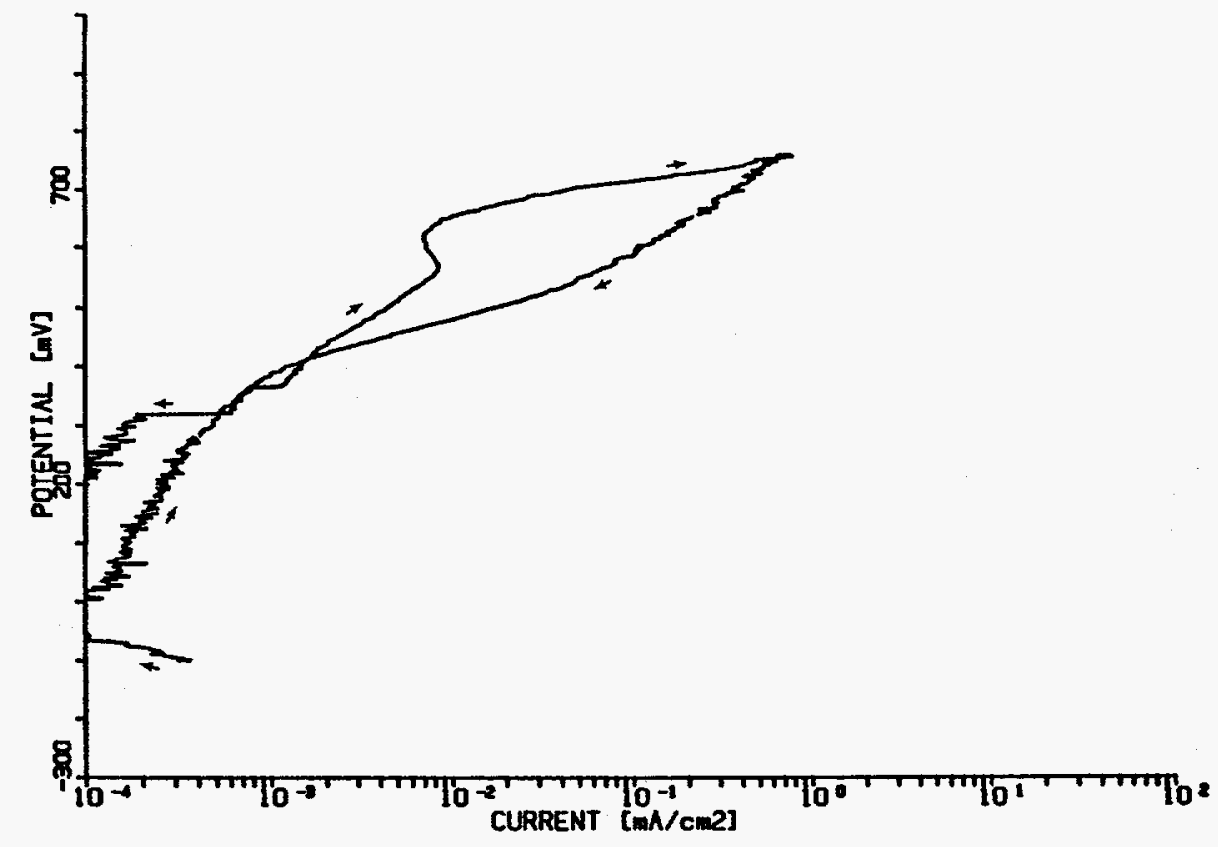

Figure D28. Fotentiodynamic Polarization Curve For Alloy 25 in Solution Ho. 28 At $90^{\circ} \mathrm{C}$. 


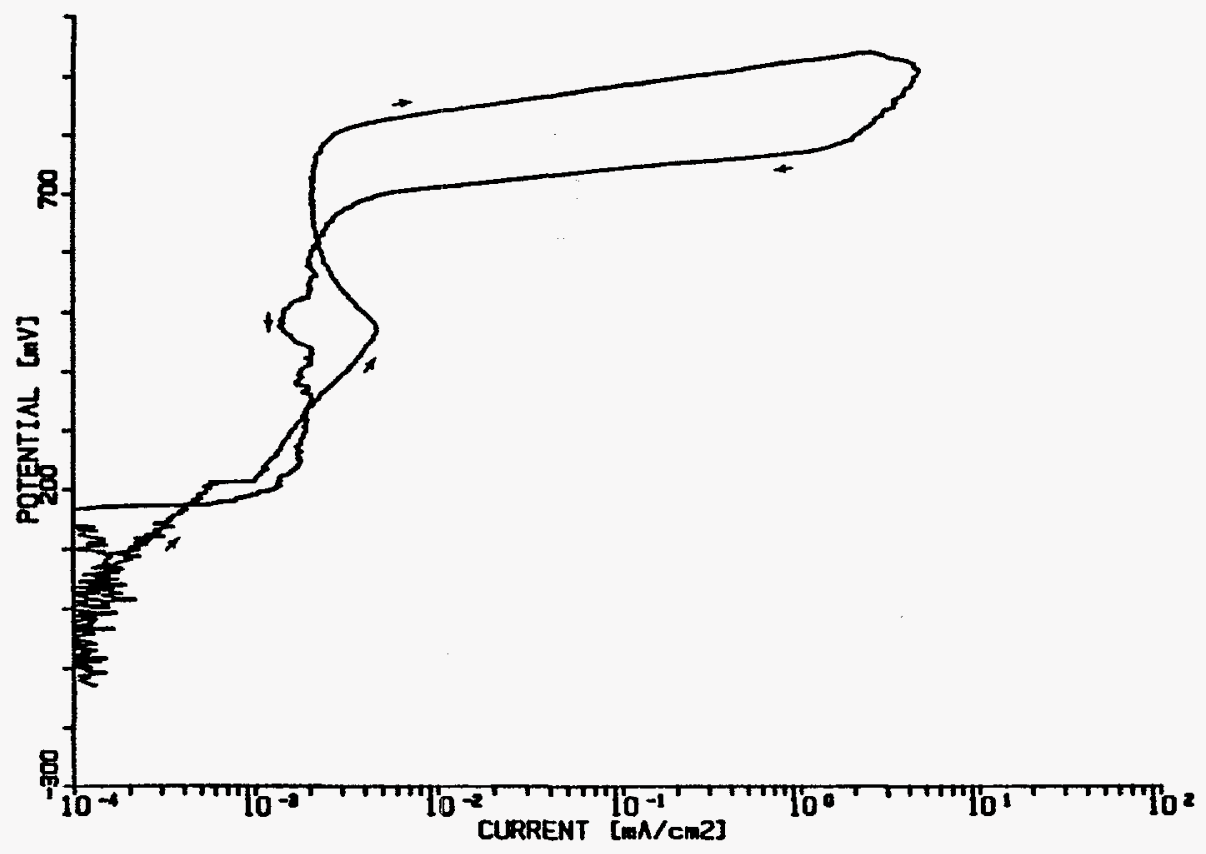

Figure D29. Potentiodynatic Polarization Curve For Alloy 825 in Solution No. 29 At $50^{\circ} \mathrm{C}$.

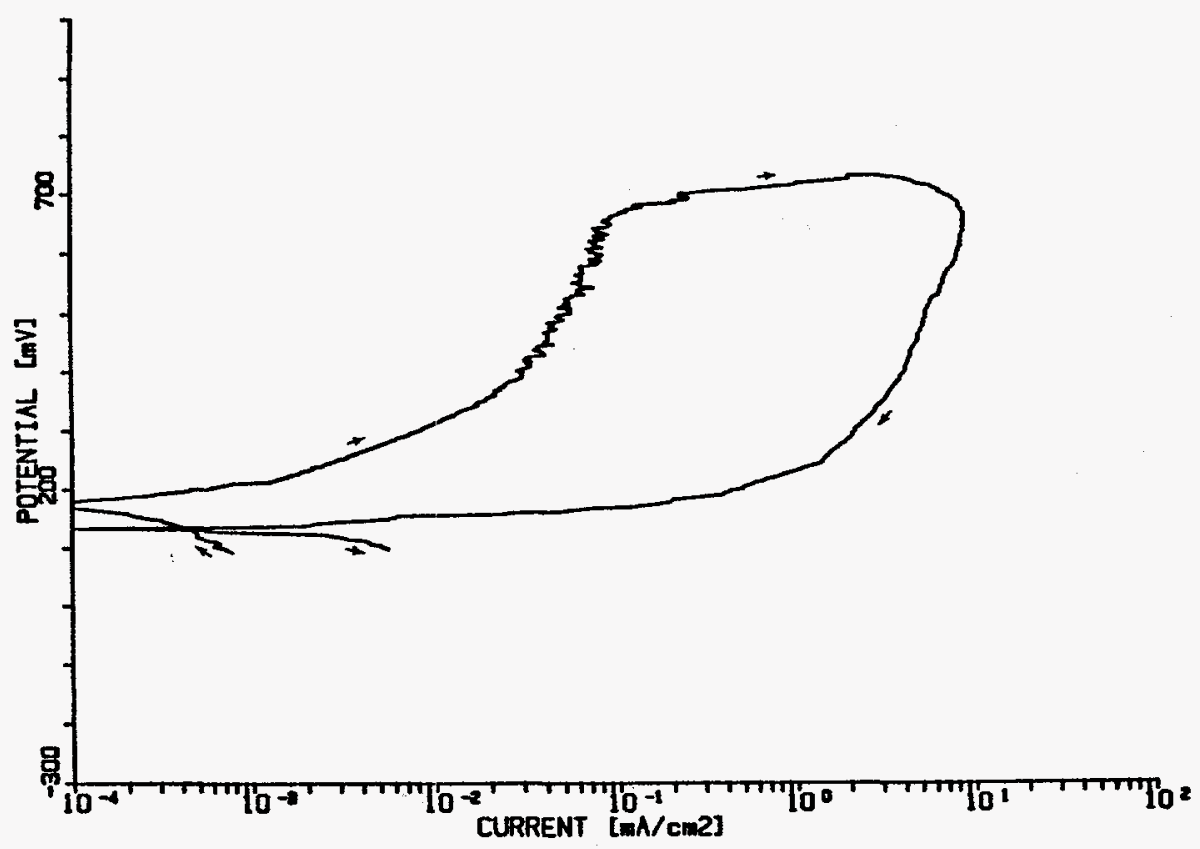

Figure D30. Rotentlodynamic Polerizetion Curve For M110y 825 In Solution No. 30 At $90^{\circ} \mathrm{C}$. 


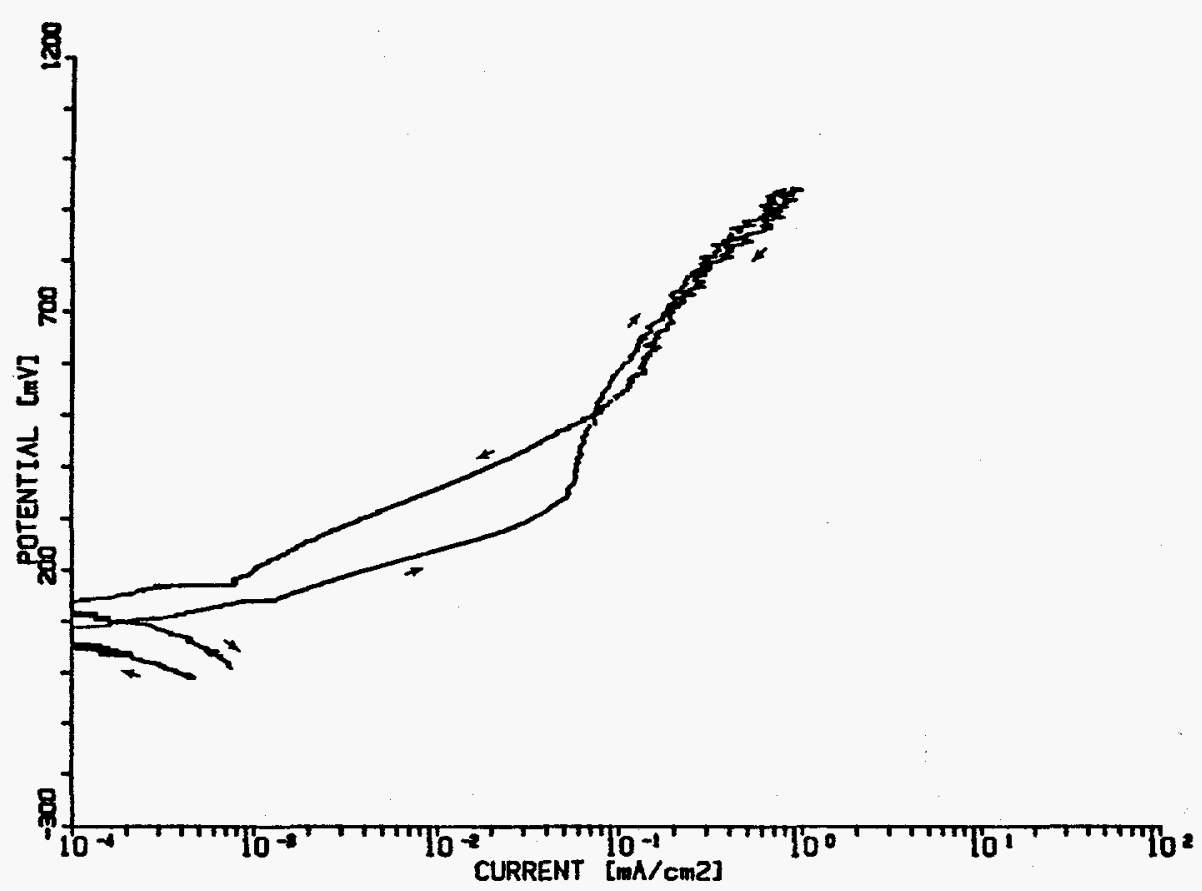

Figure D31. Potentlodyamic Polarization Curve For Alloy 25 in solution No. 31 At $90^{\circ} \mathrm{C}$.

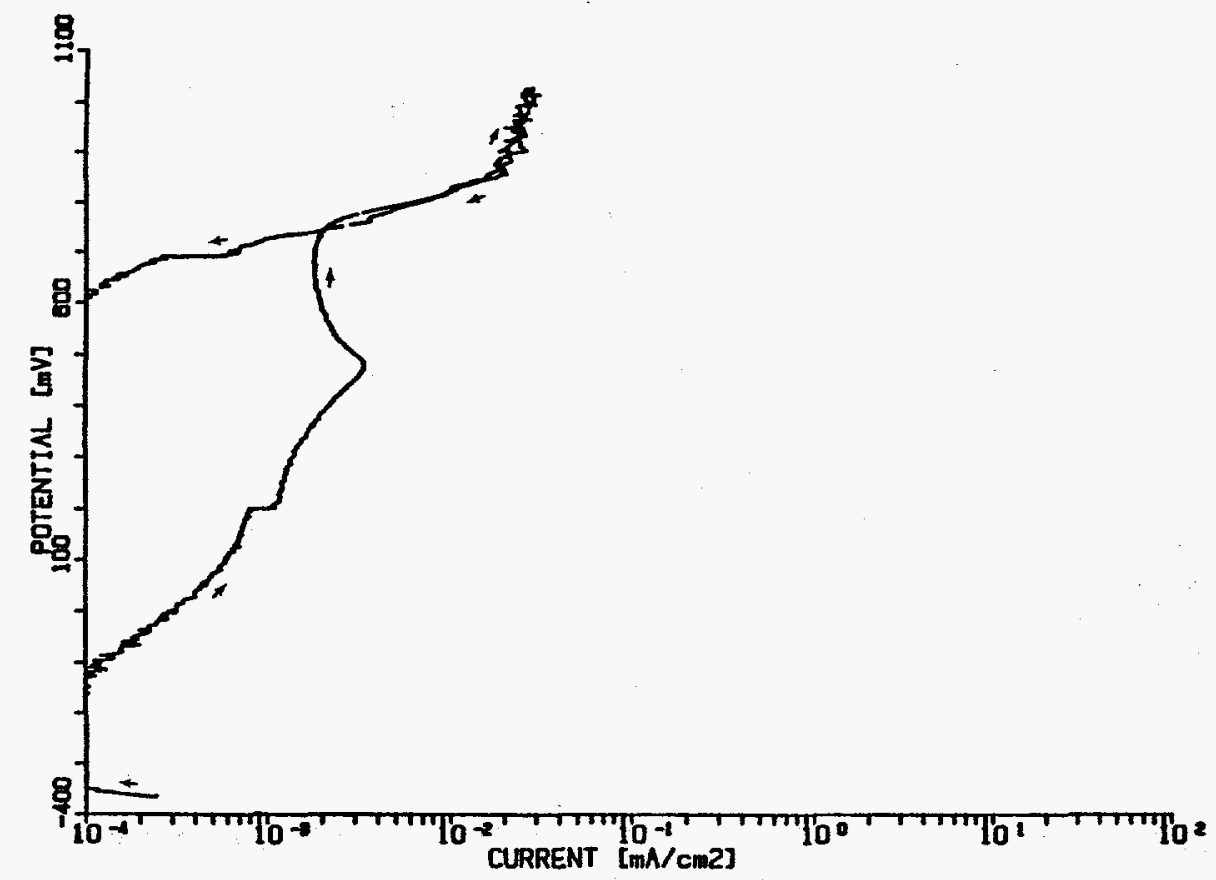

Figure D32. Potentlodynamic Polarization Curve For Alloy 85 In Solution No. 32 at $50^{\circ} \mathrm{C}$. 


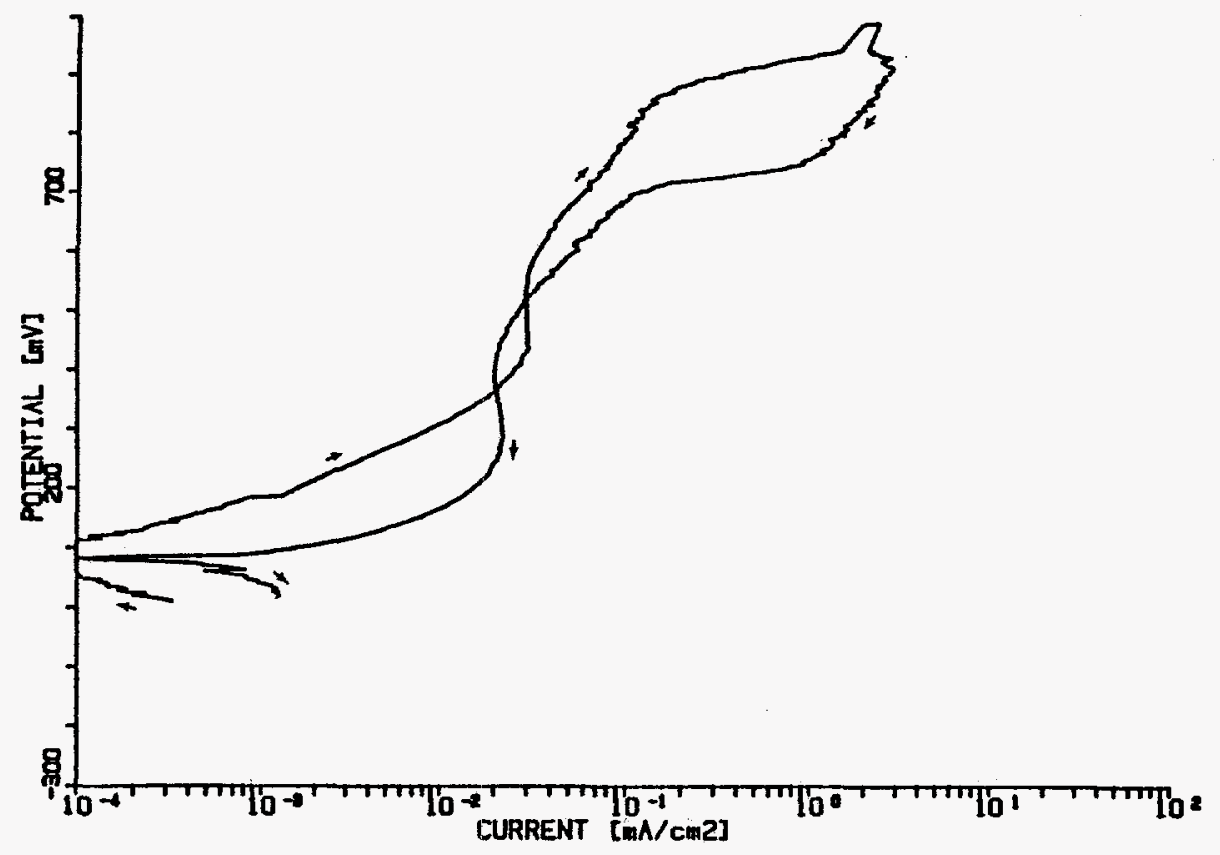

Figure D33, Rotent lodrnamic Folarization Curve For Alloy 825 In Solution Ho. 33 At $70^{\circ} \mathrm{C}$.

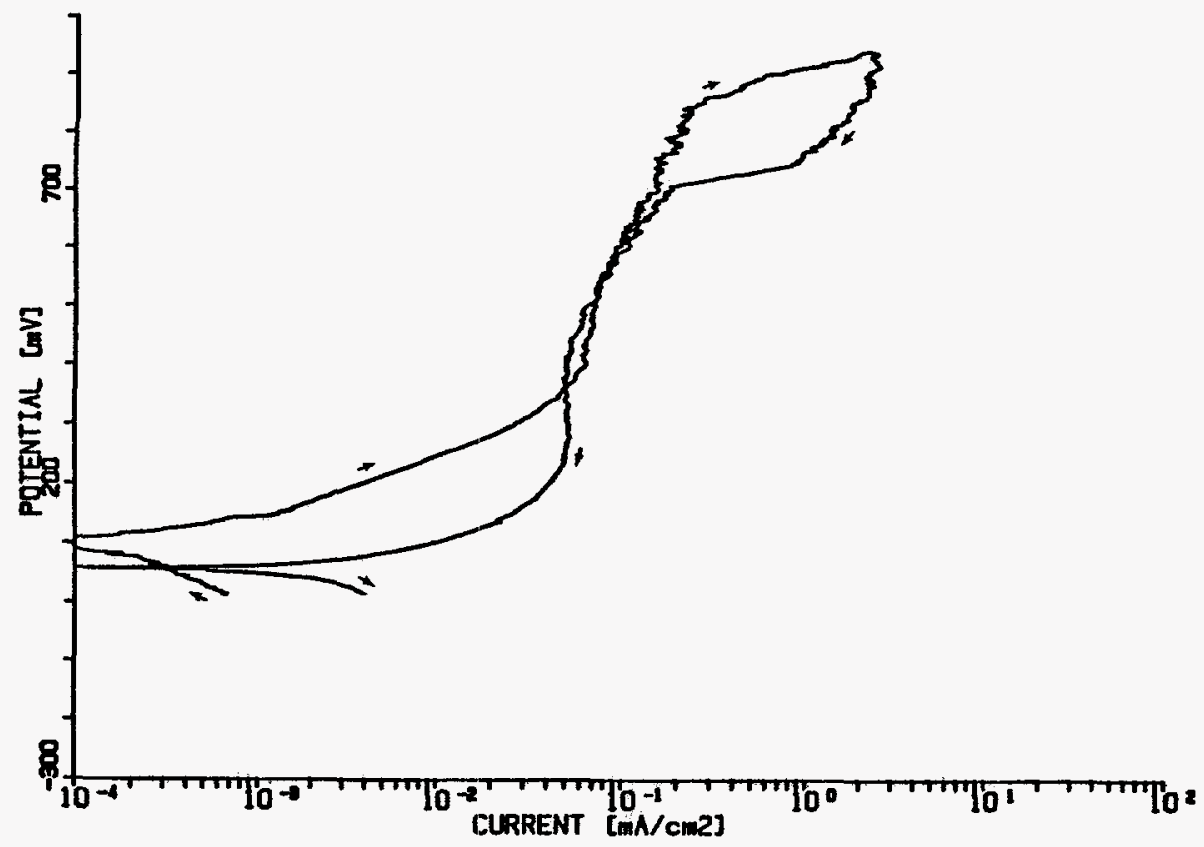

Figure D34. Potentlodynanic Folerizetion Curve For Allog 25 In Solution Ho. 34 At $70^{\circ} \mathrm{C}$. 


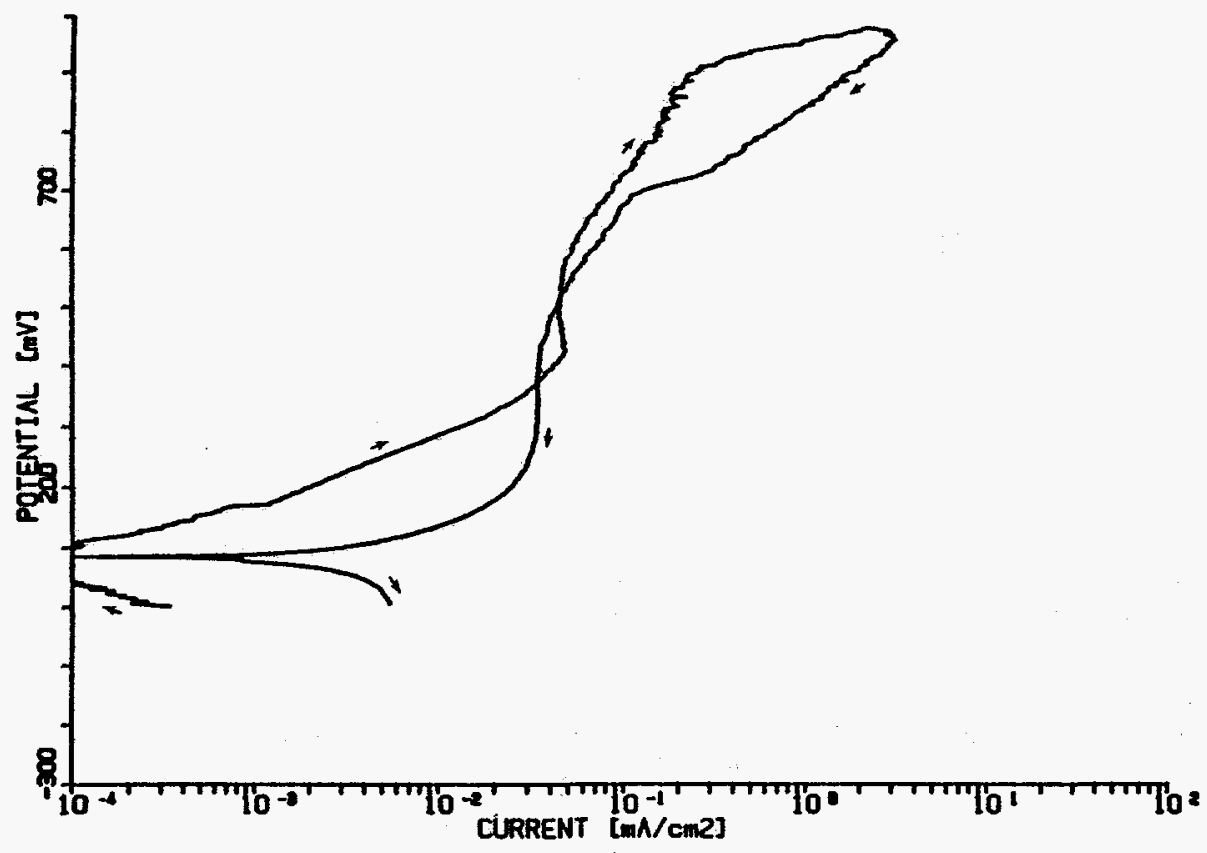

Figure D35, Potent lodynamic Polarization Curve For Alloy 825 In Solution No. 35 at $70^{\circ} \mathrm{C}$.

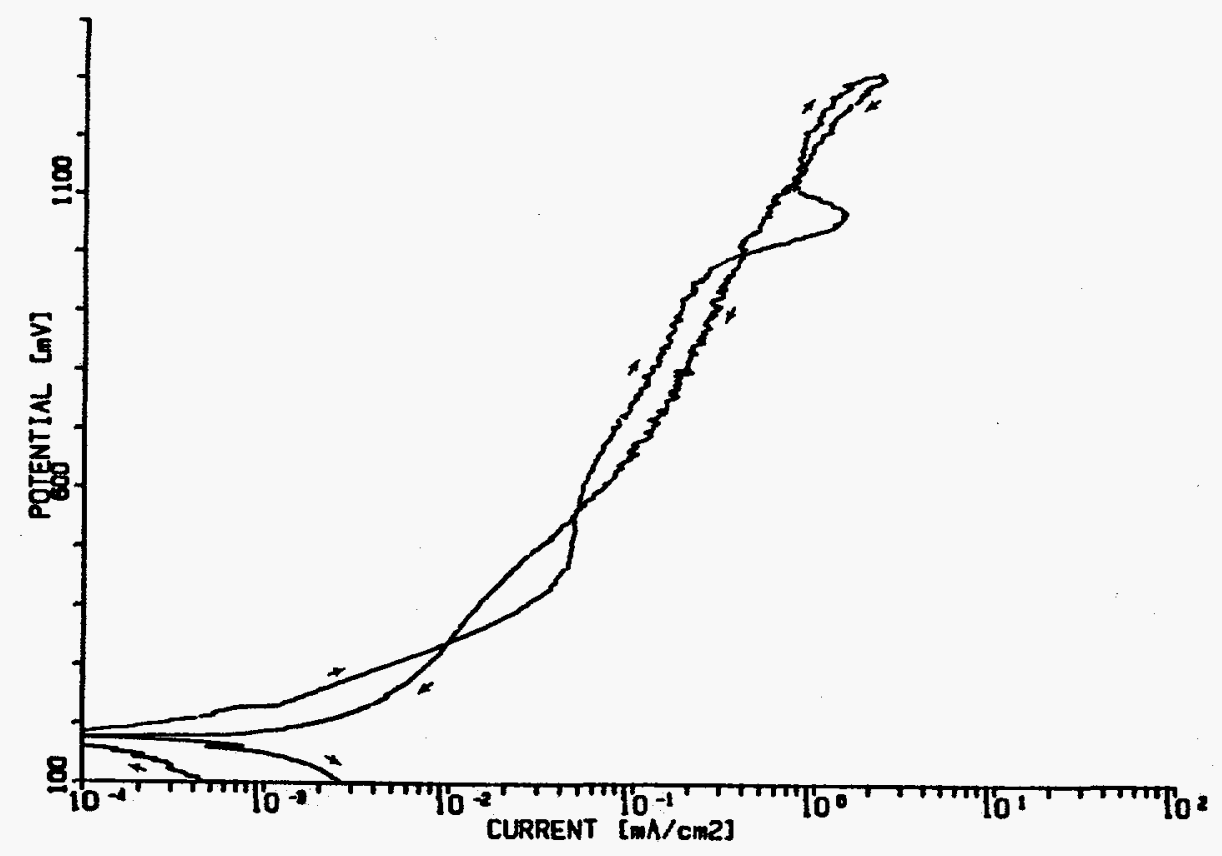

Figure D36. Potentlodynamic Polarization Curve For Alloy 825 in Solution No. 36 At $70^{\circ} \mathrm{C}$. 

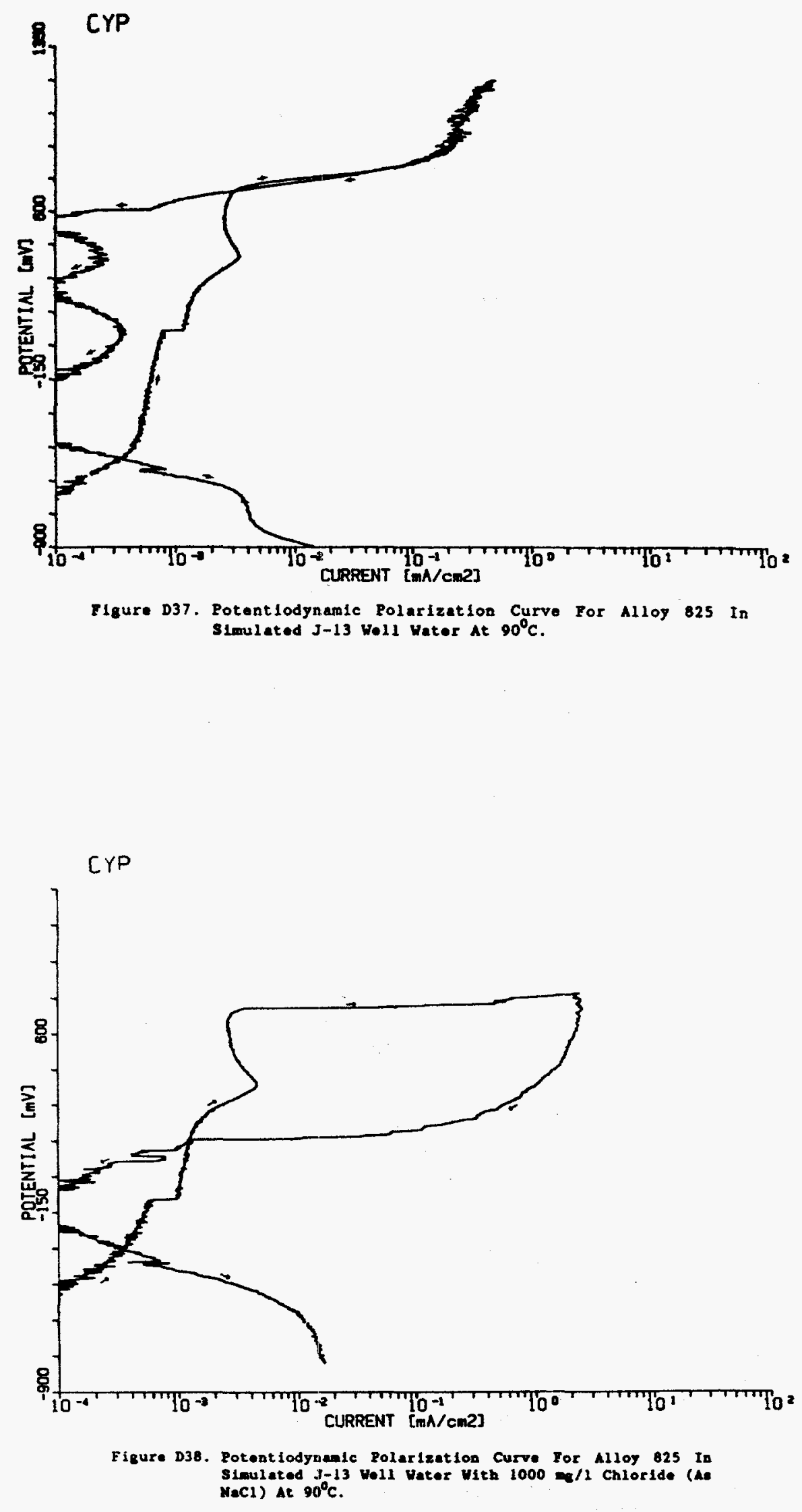


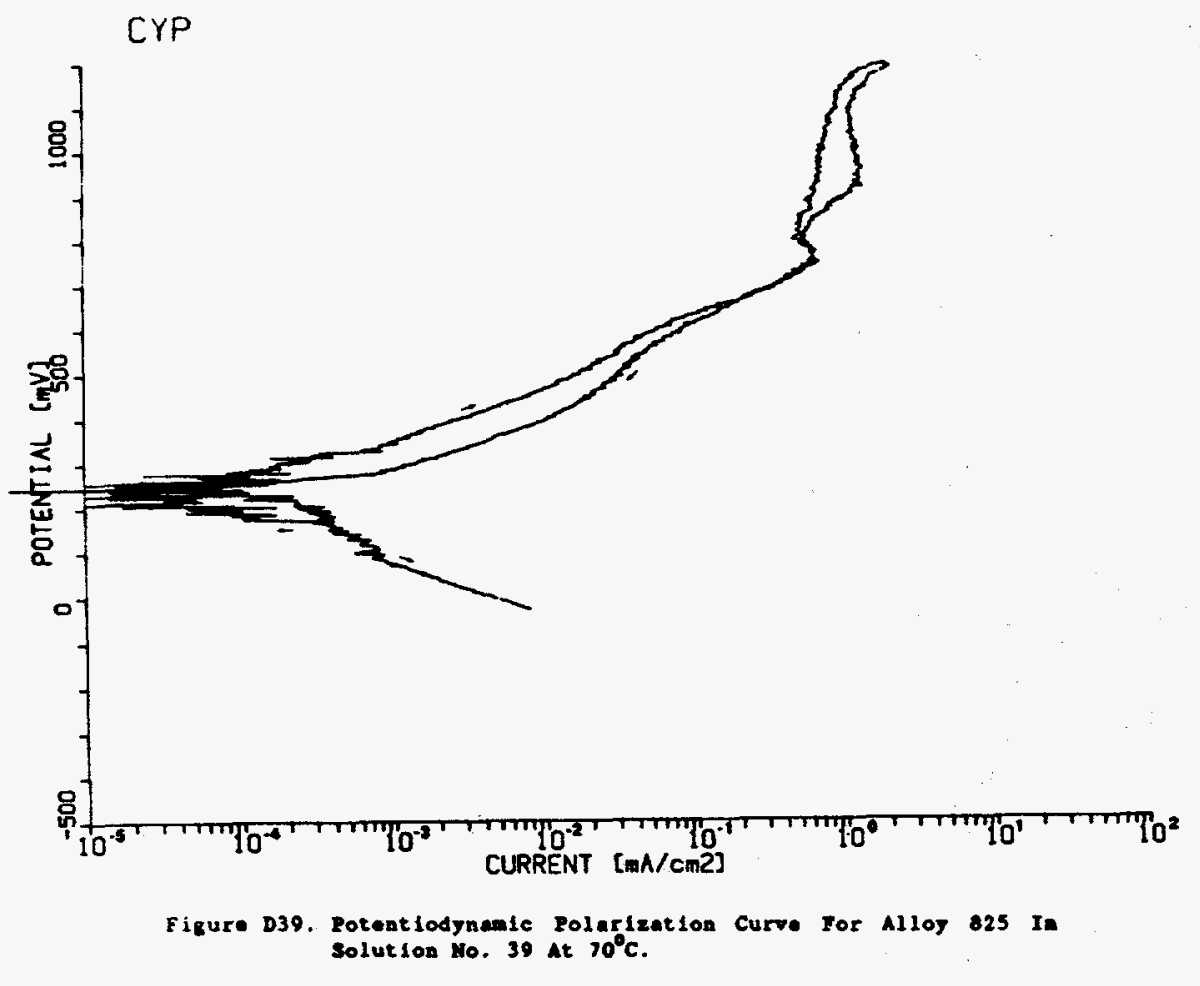

CYP

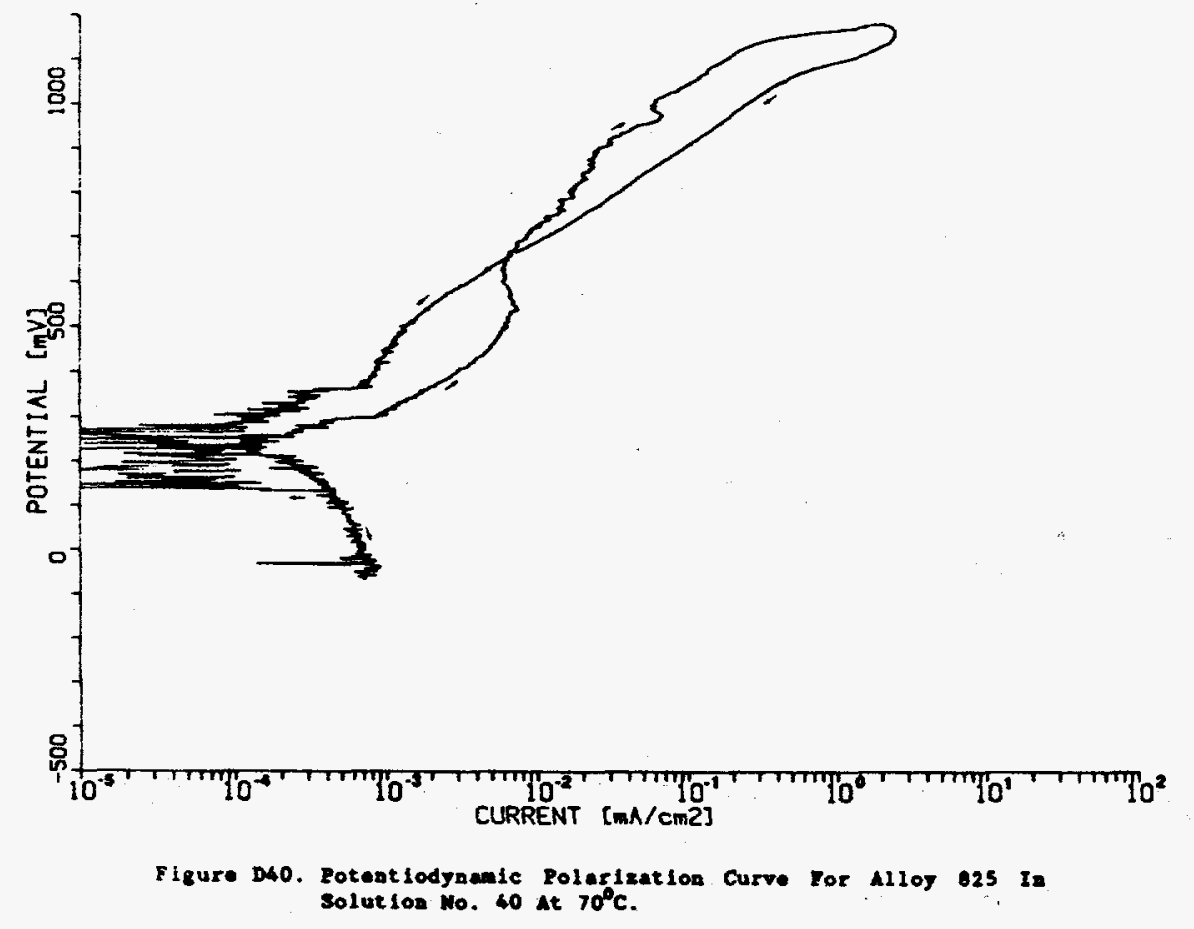



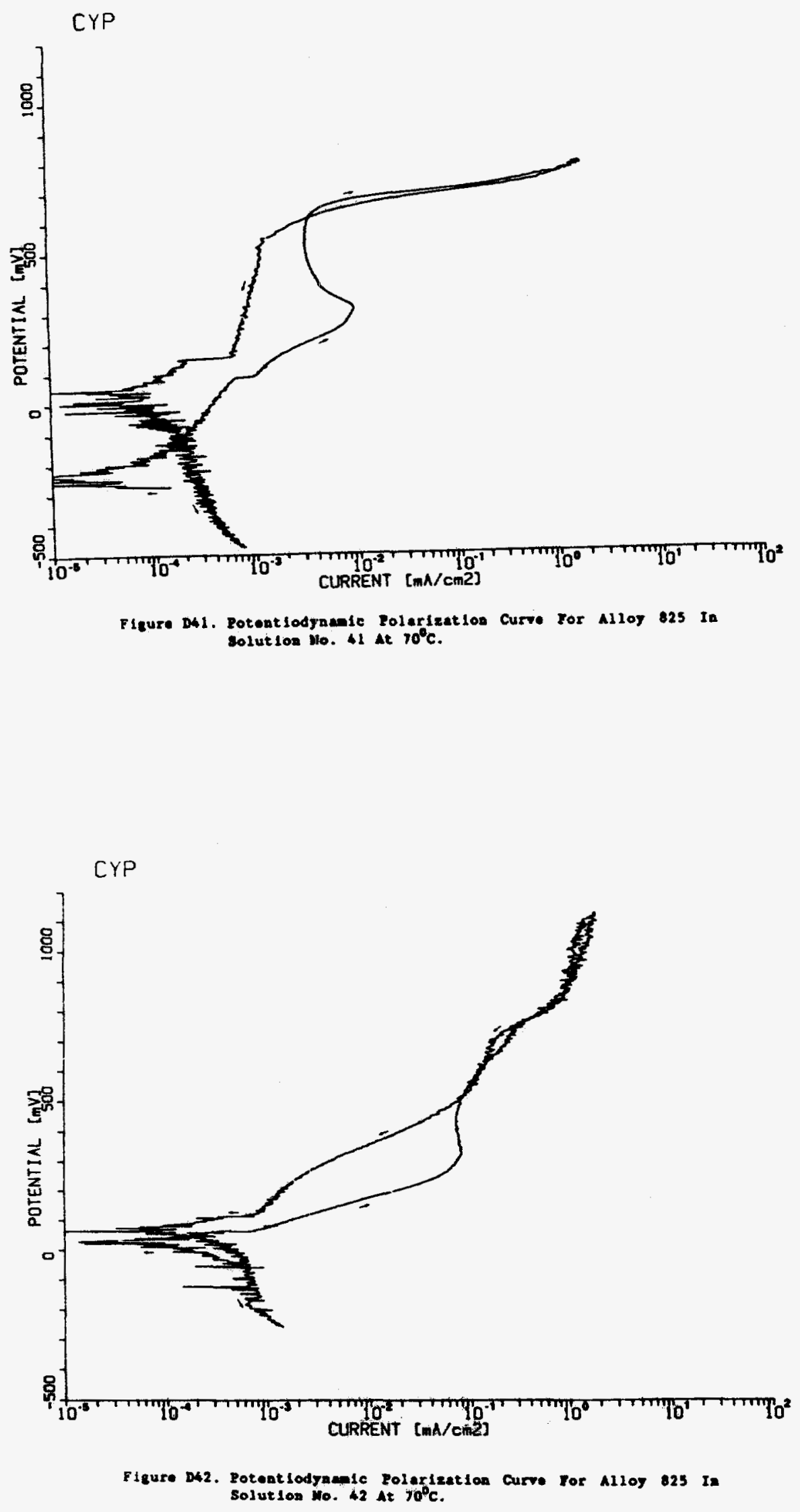
APPENDIX E

TEMPERATURE-EFFECT STUDIES

ON THE CANDIDATE CONTAINER ALLOYS

IN SELECTED SOLUTIONS FROM THE

RESOLUTION IV MATRIX 

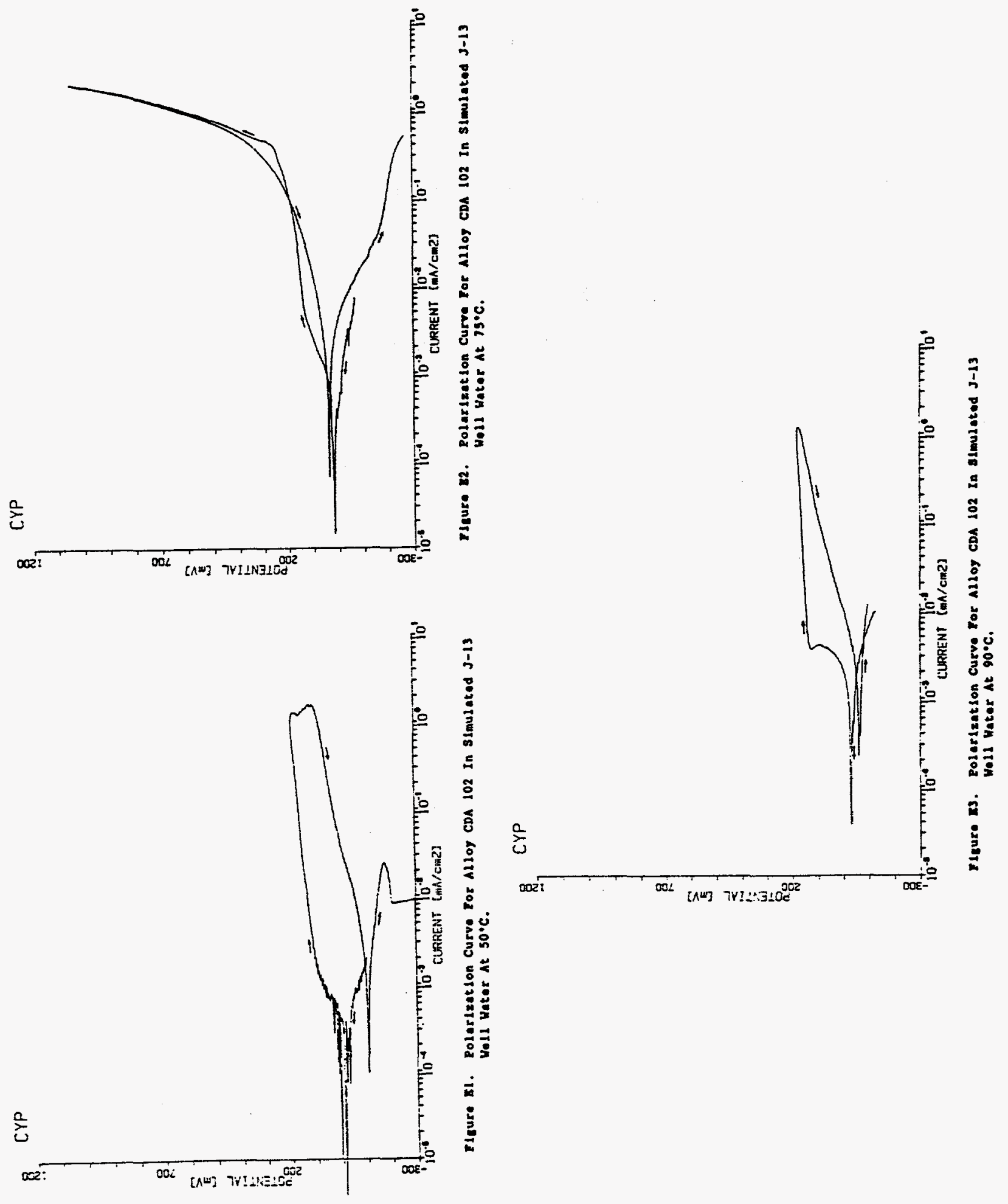


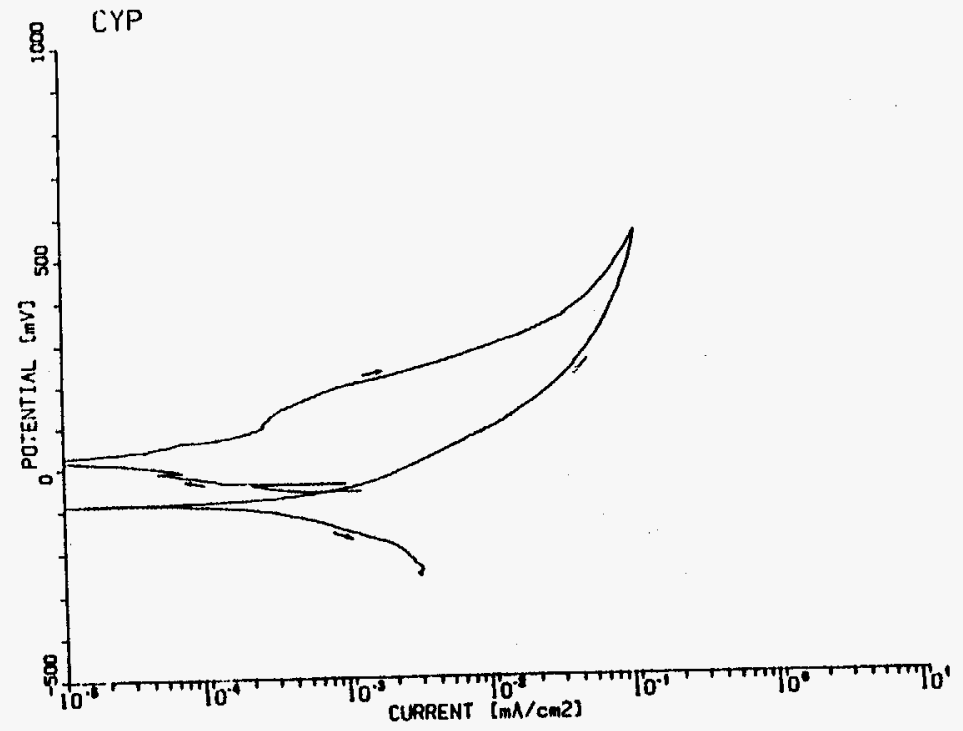

Ifaure 84. Polarization Curve For Alloy CDA 713 In simulated J-13 Wo11 wator At $30^{\circ} \mathrm{C}$.

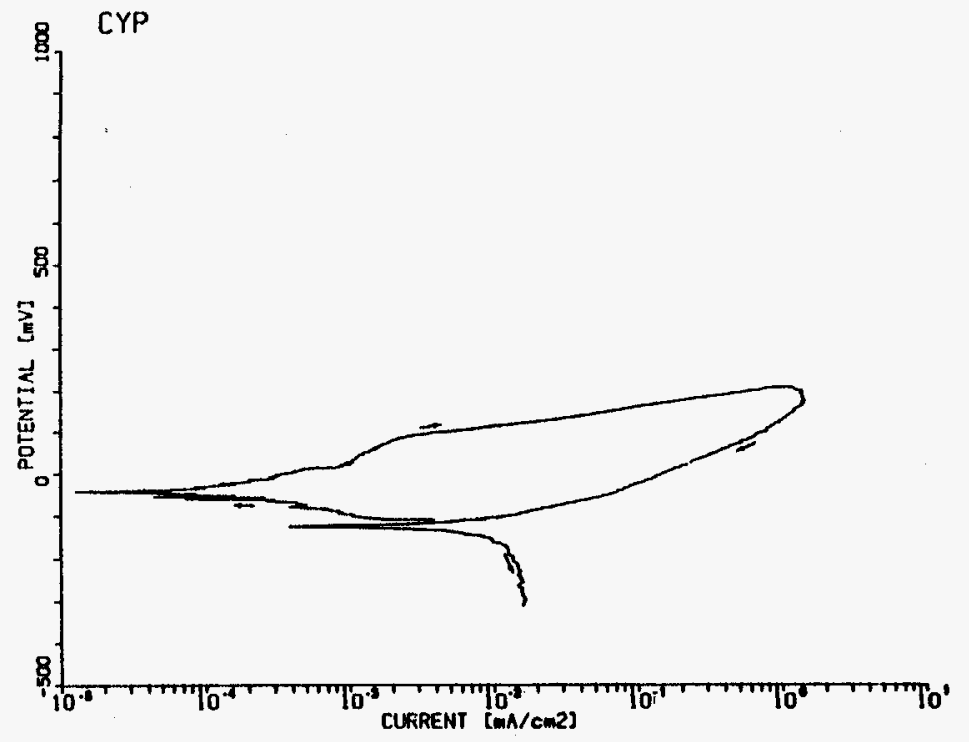

F1quxe 15. Polariantion Curvo Yor Alloy CDA 713 In simulated J-13 Yol1 yater At $73^{\circ} \mathrm{C}$.

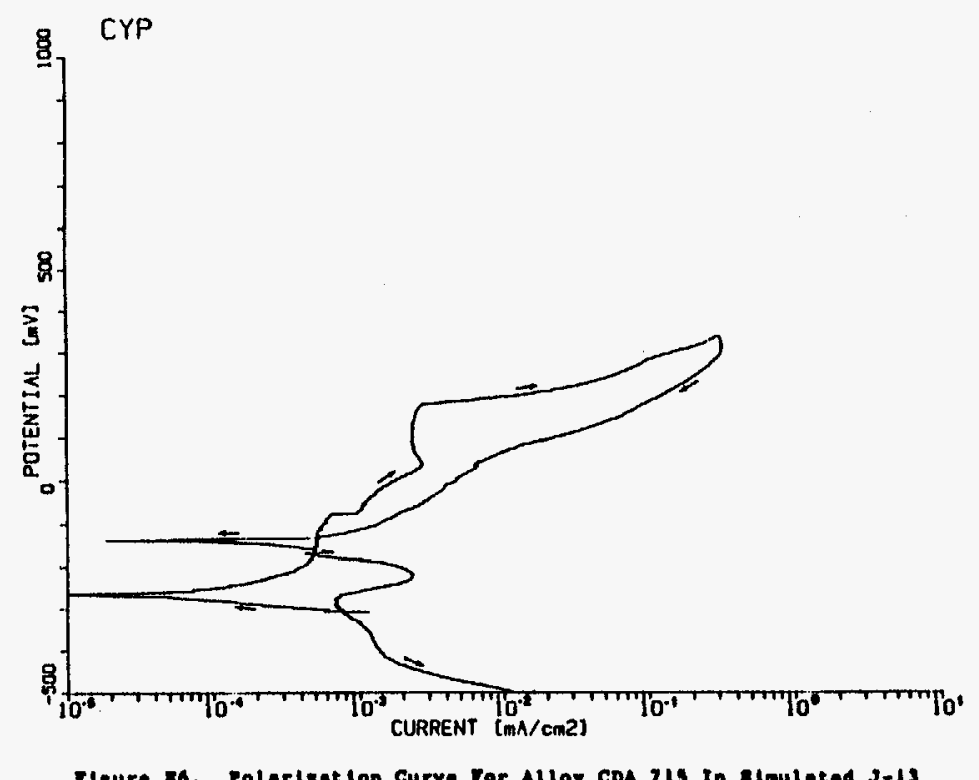

Fisure so. Polarikat lon Curve Yor Alloy CDA 115 in simulated J-1s Woll Water at $90^{\circ} \mathrm{C}$. 


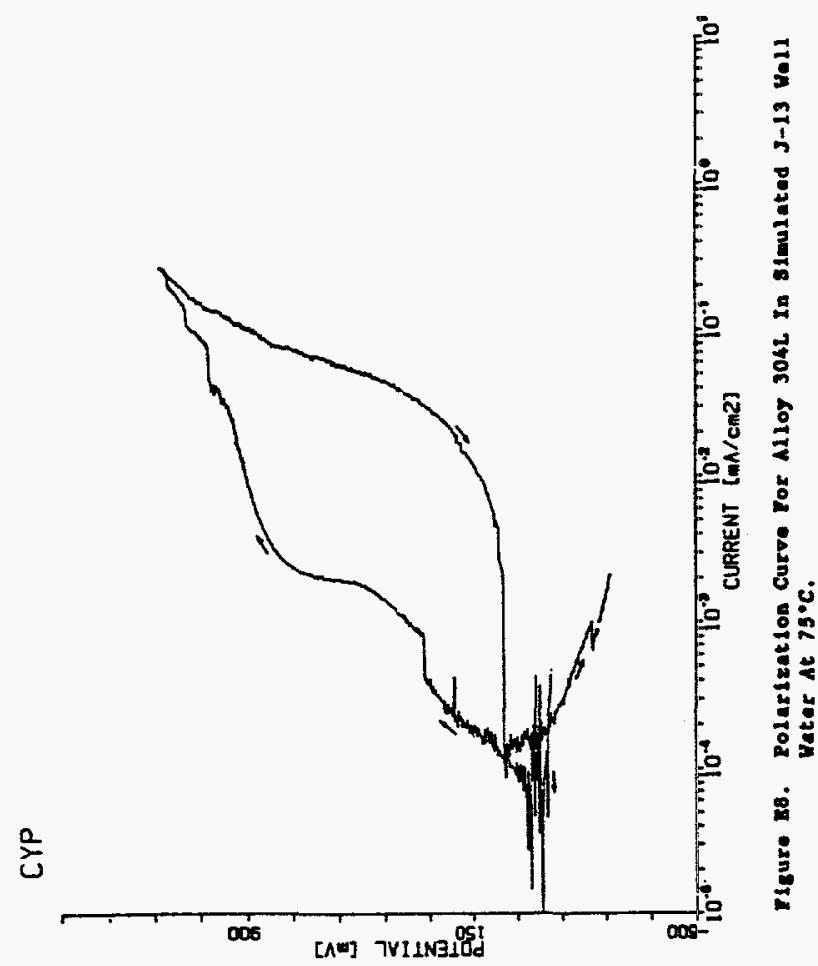




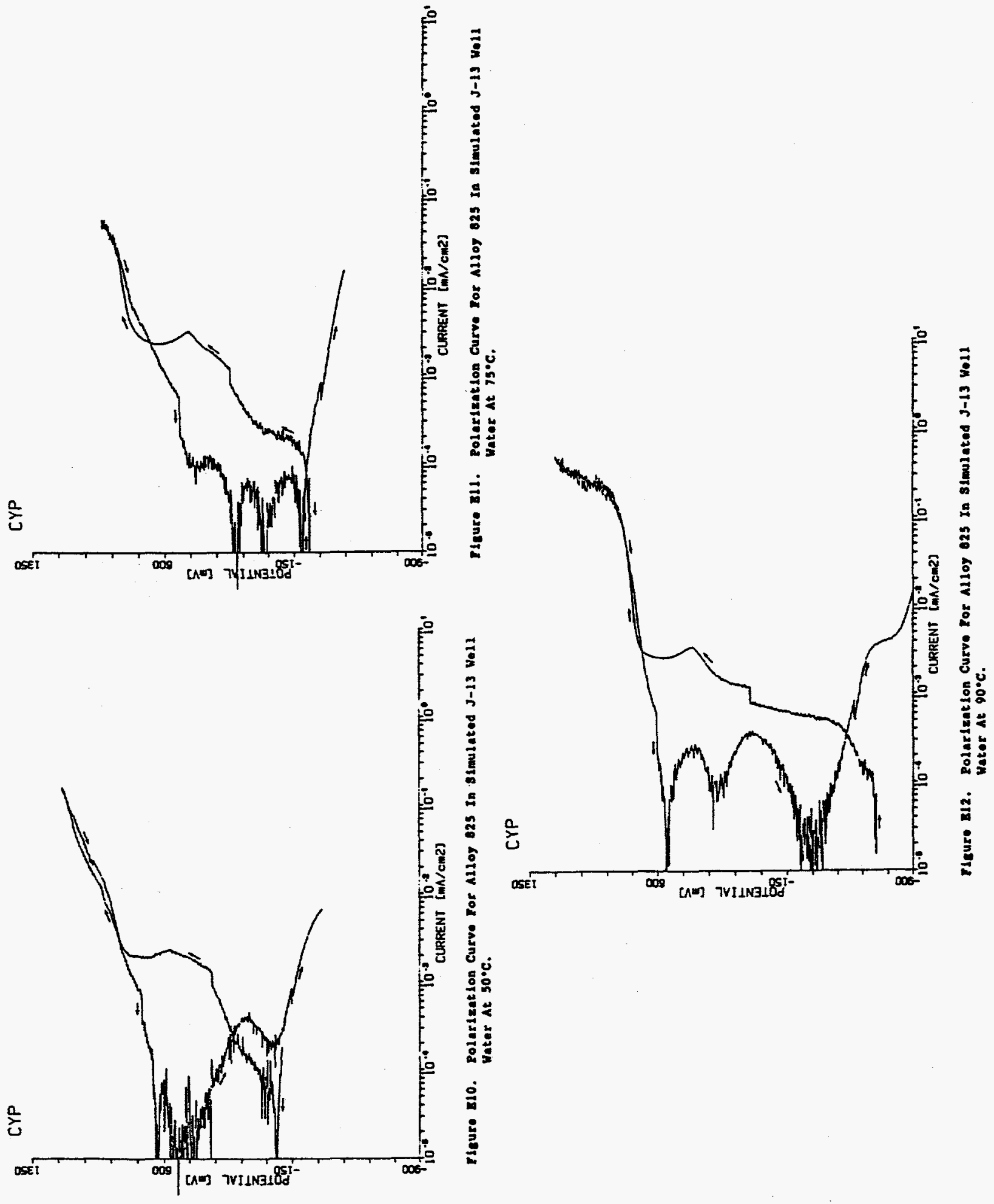



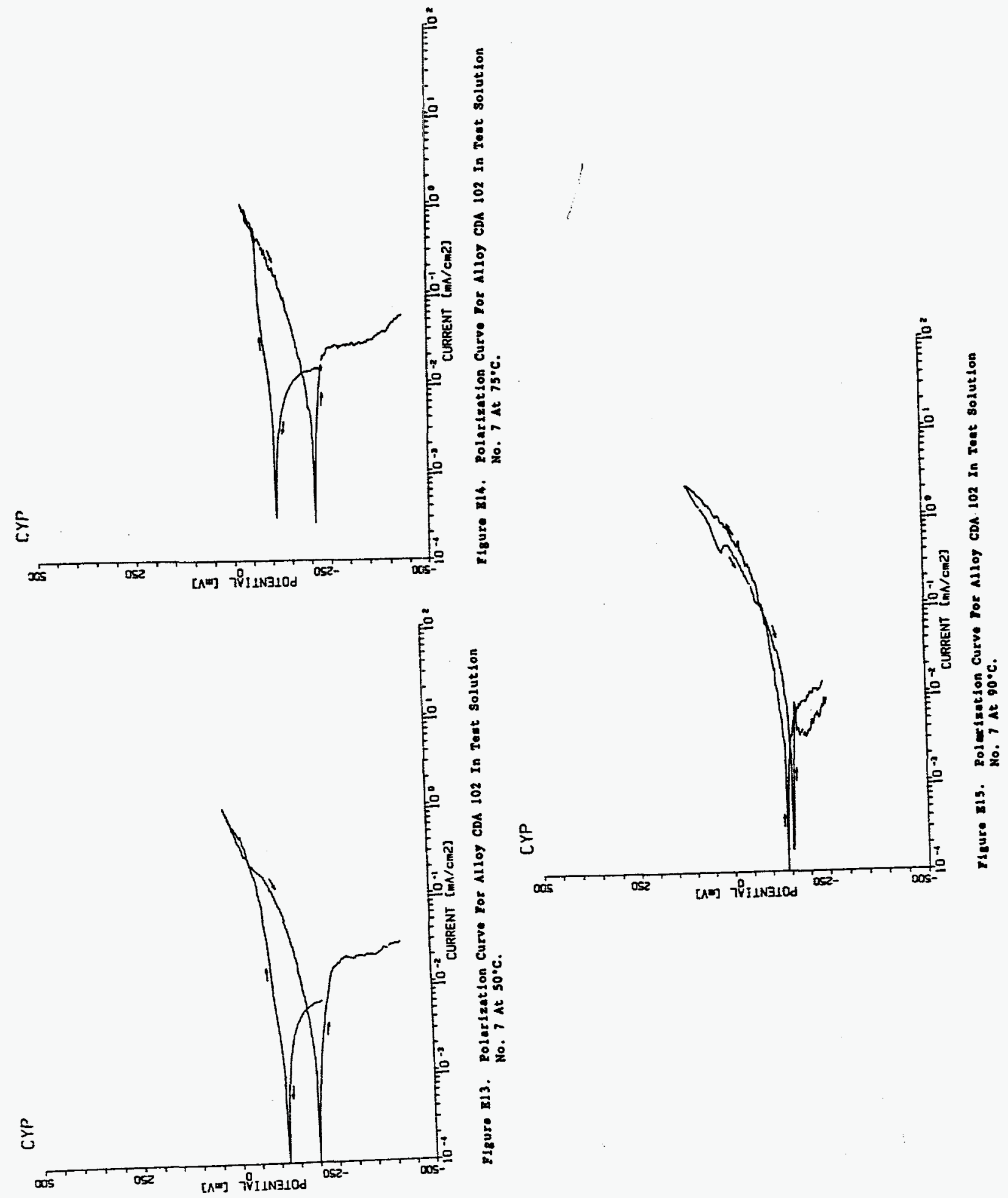

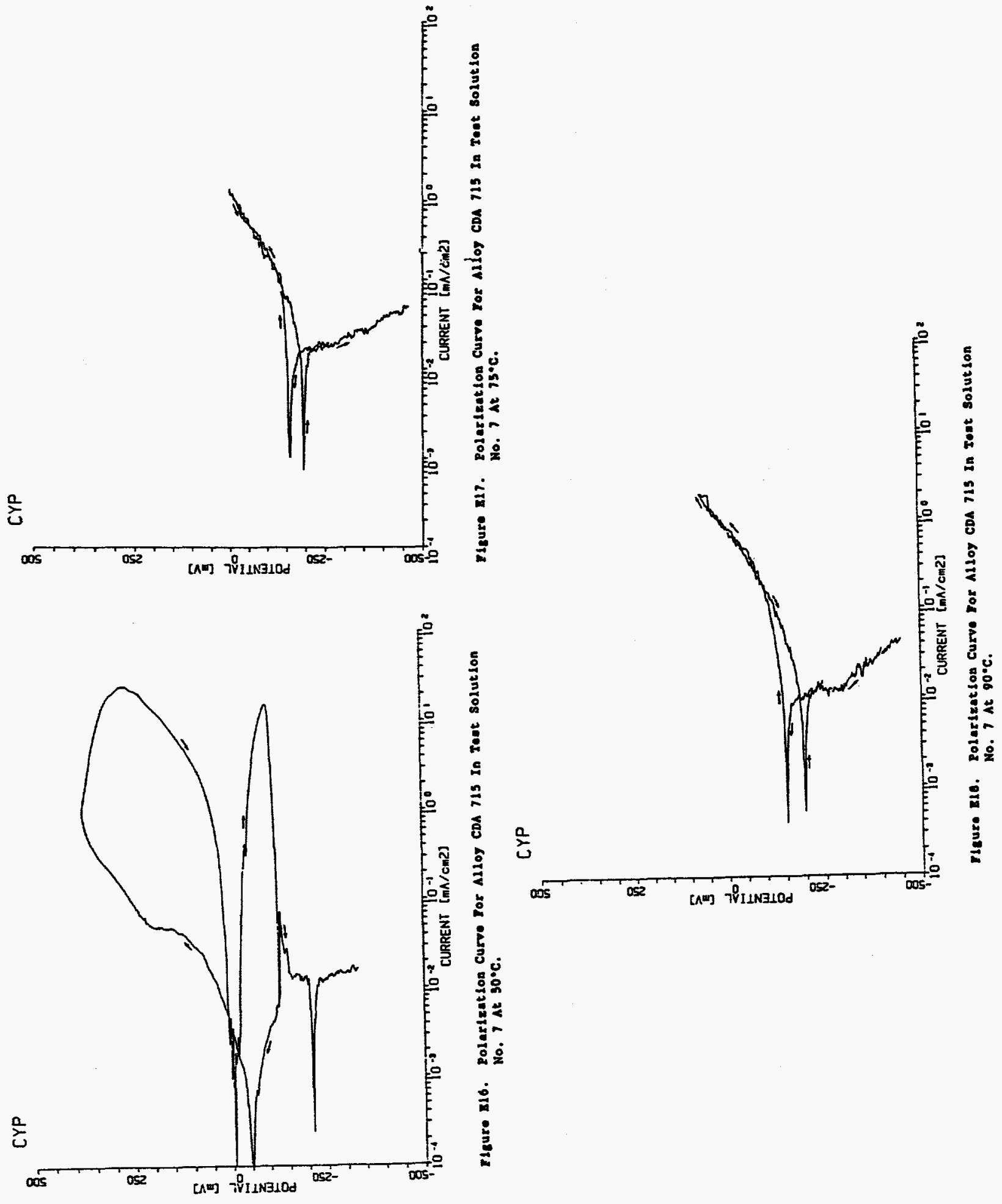


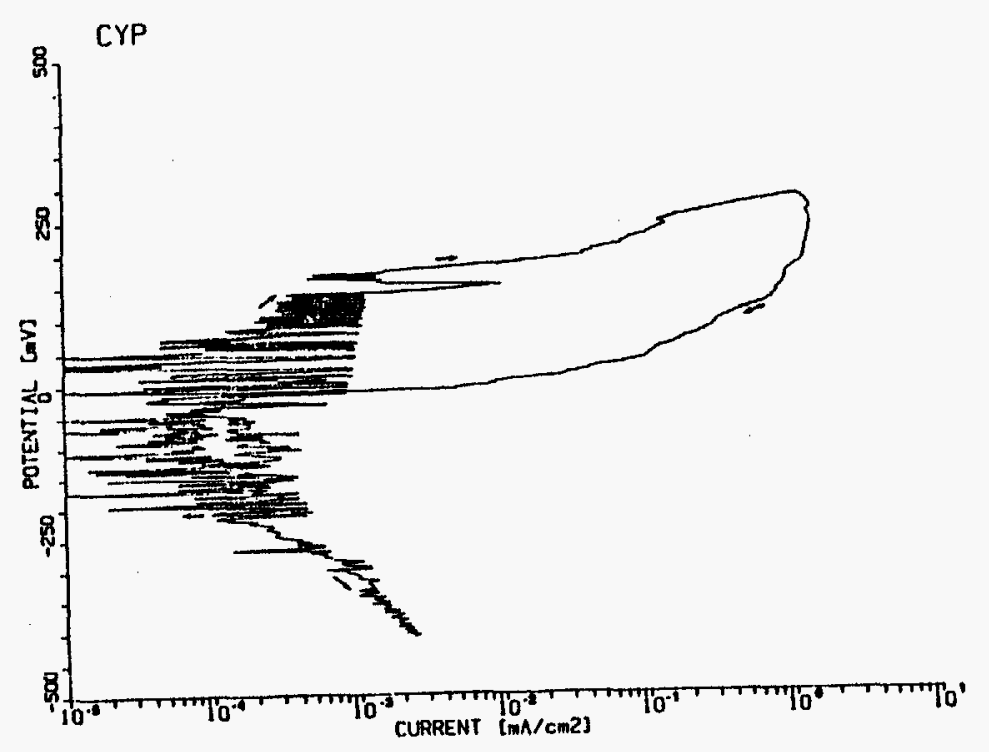

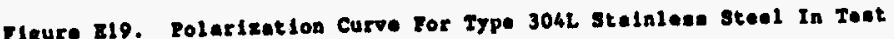
Polarization Curve ror
Solut 10 No. 1 At $30^{\circ} \mathrm{C}$.

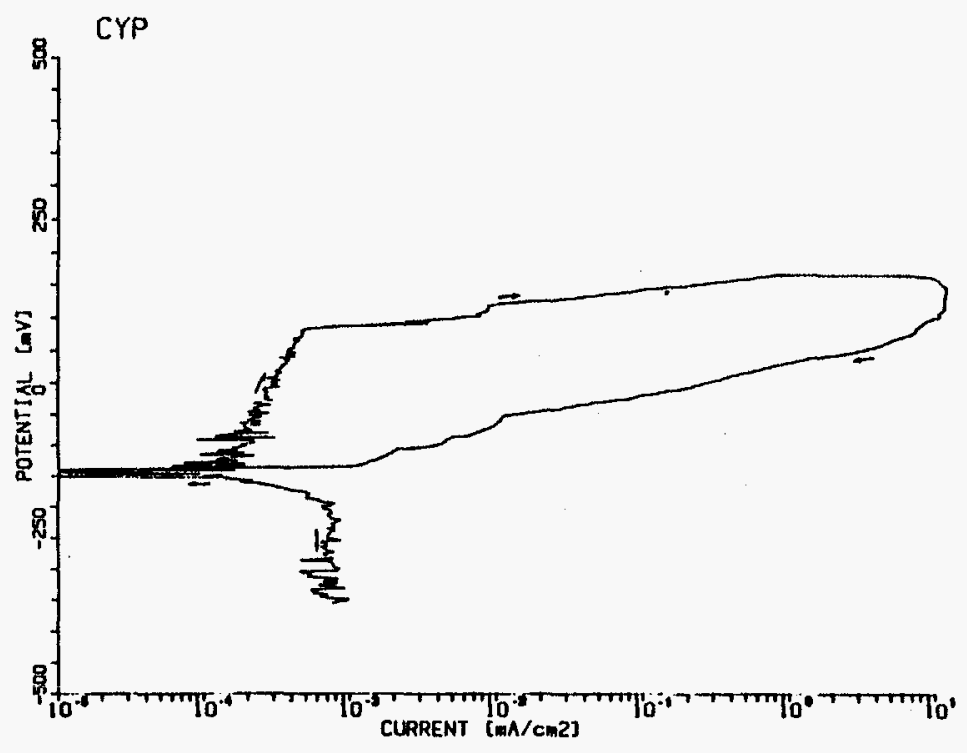

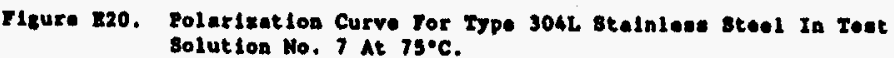

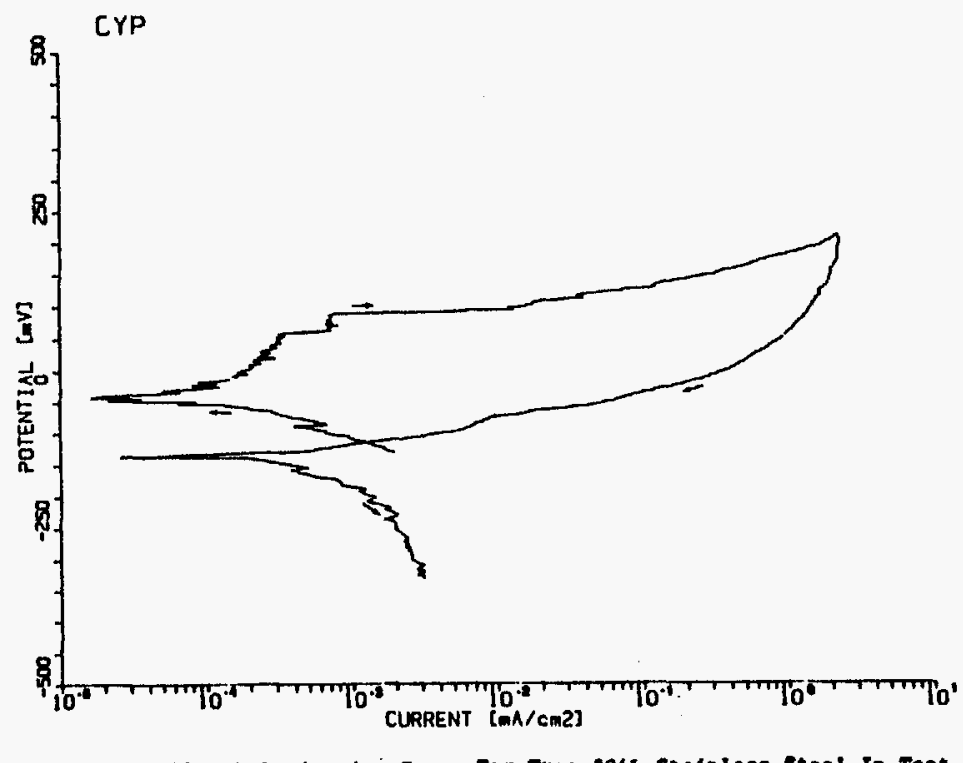

rigure x21. Folarkent lon Curve Tor Type g04L stednlees stoel In teat Solution Mo. 7 At $90^{\circ} \mathrm{C}$. 

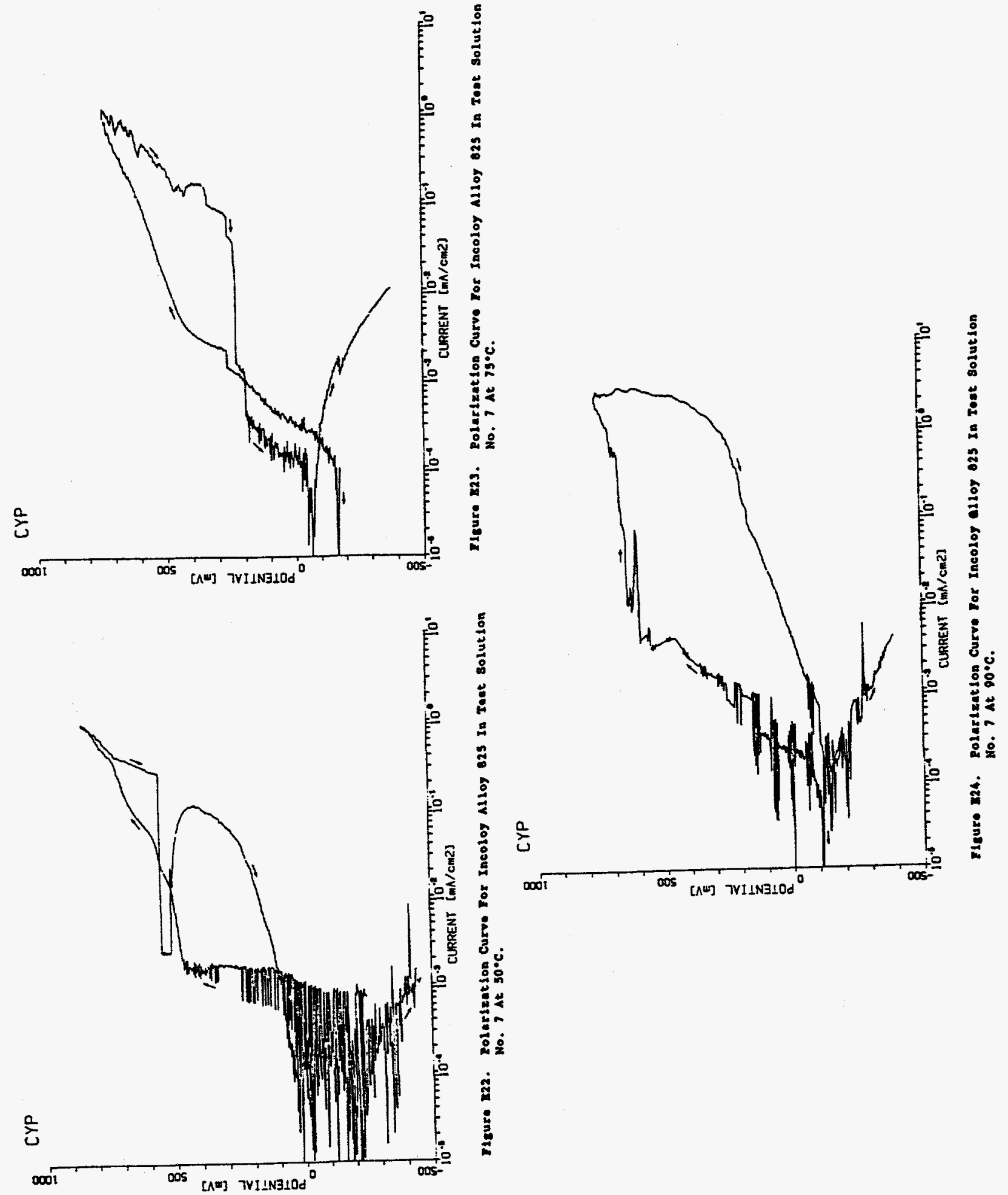

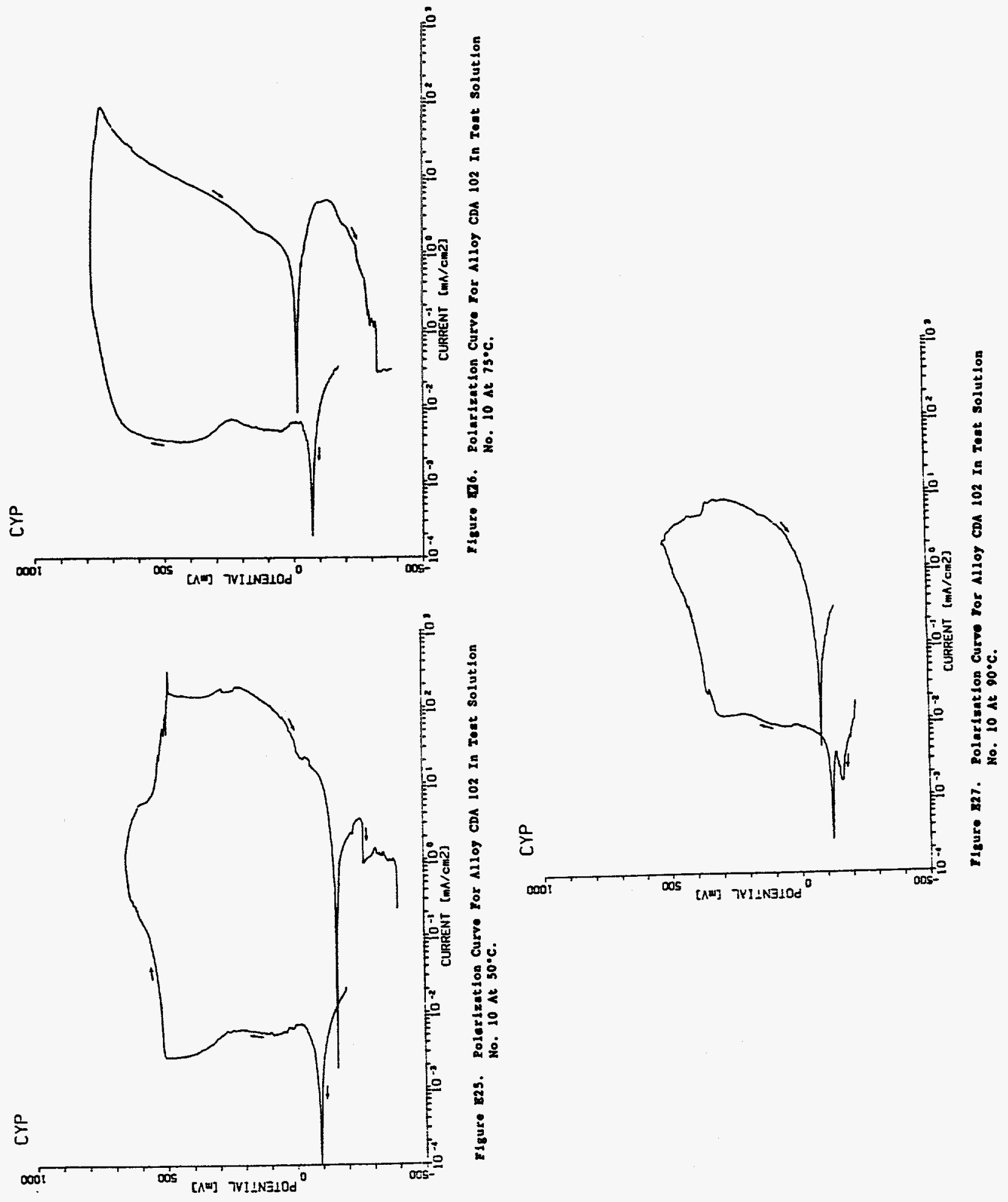

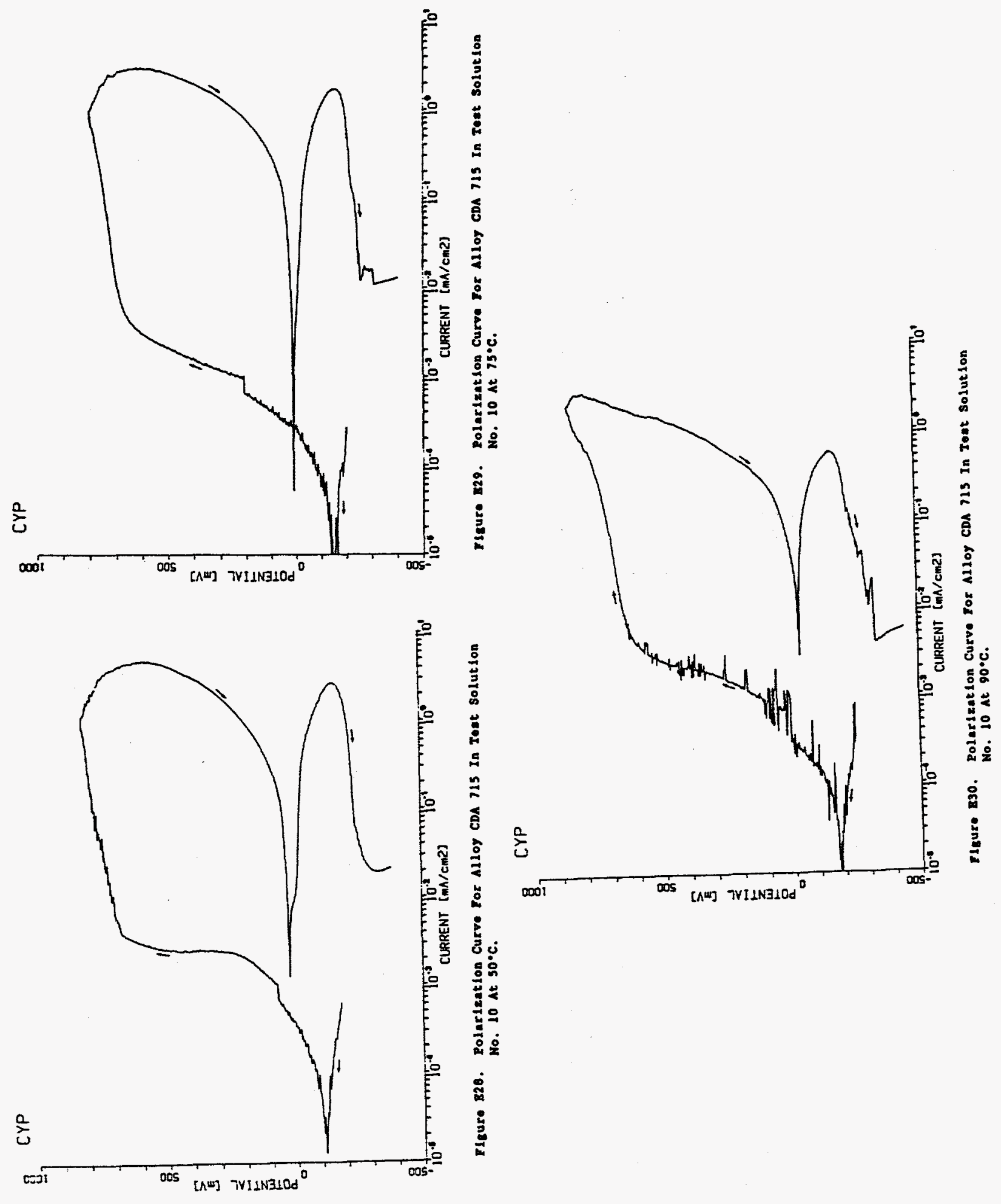

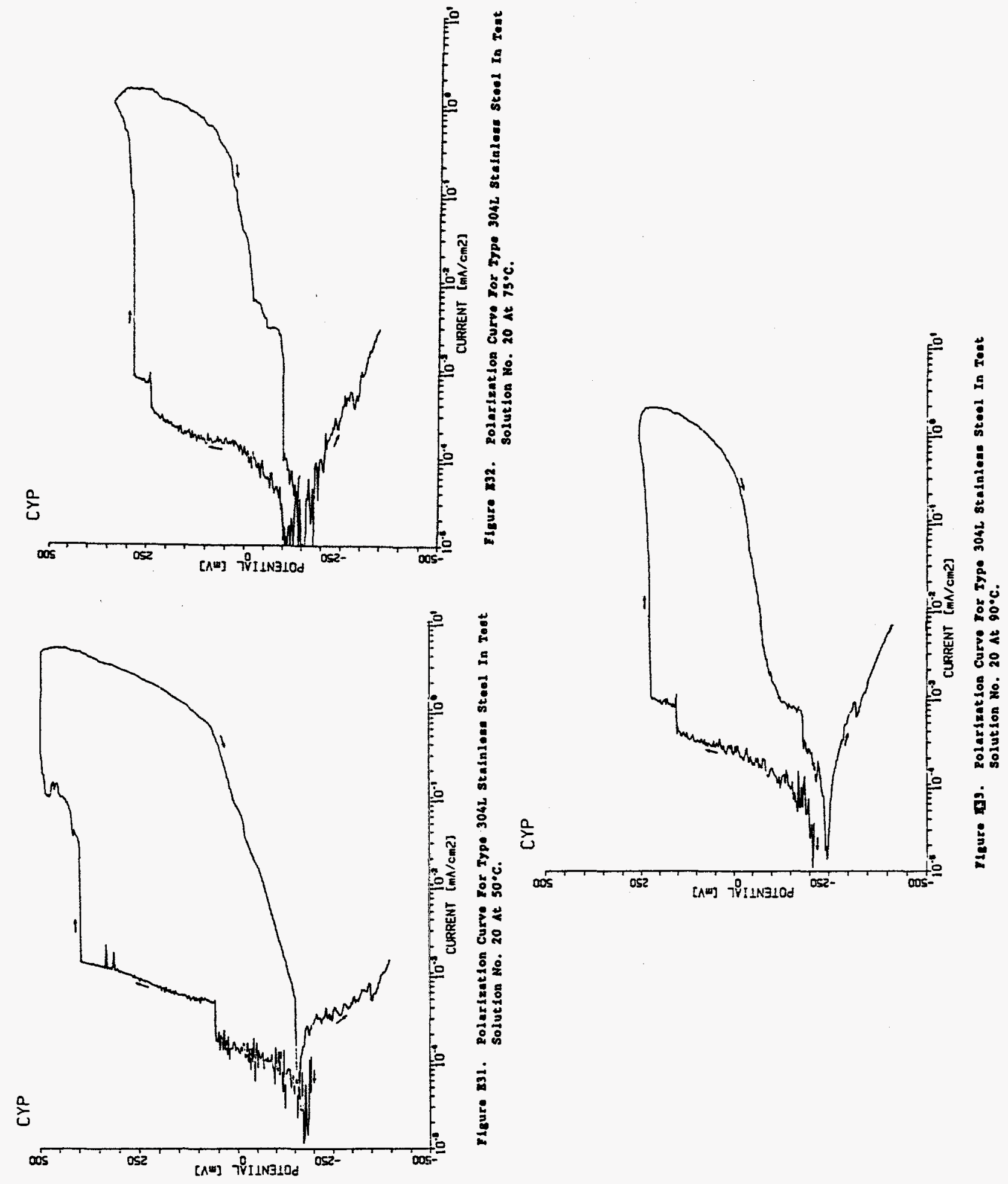

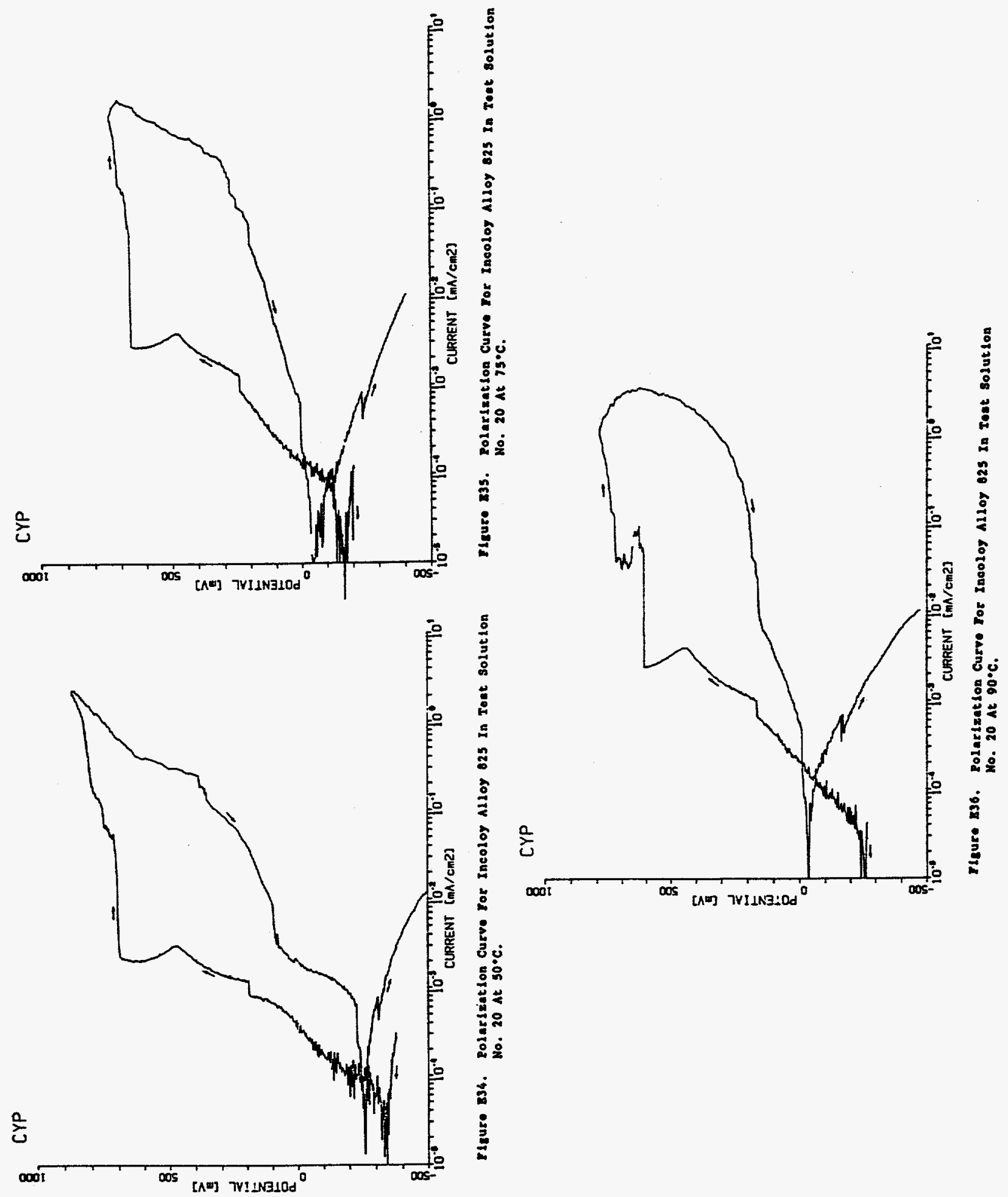
APPENDIX F

TEMPERATURE-EFFECT STUDIES

WITH HEAT-TRANSFER SPECIMENS

OF THE CANDIDATE CONTAINER ALLOYS

IN SELECTED SOLUTIONS FROM THE

RESOLUTION IV MATRIX 

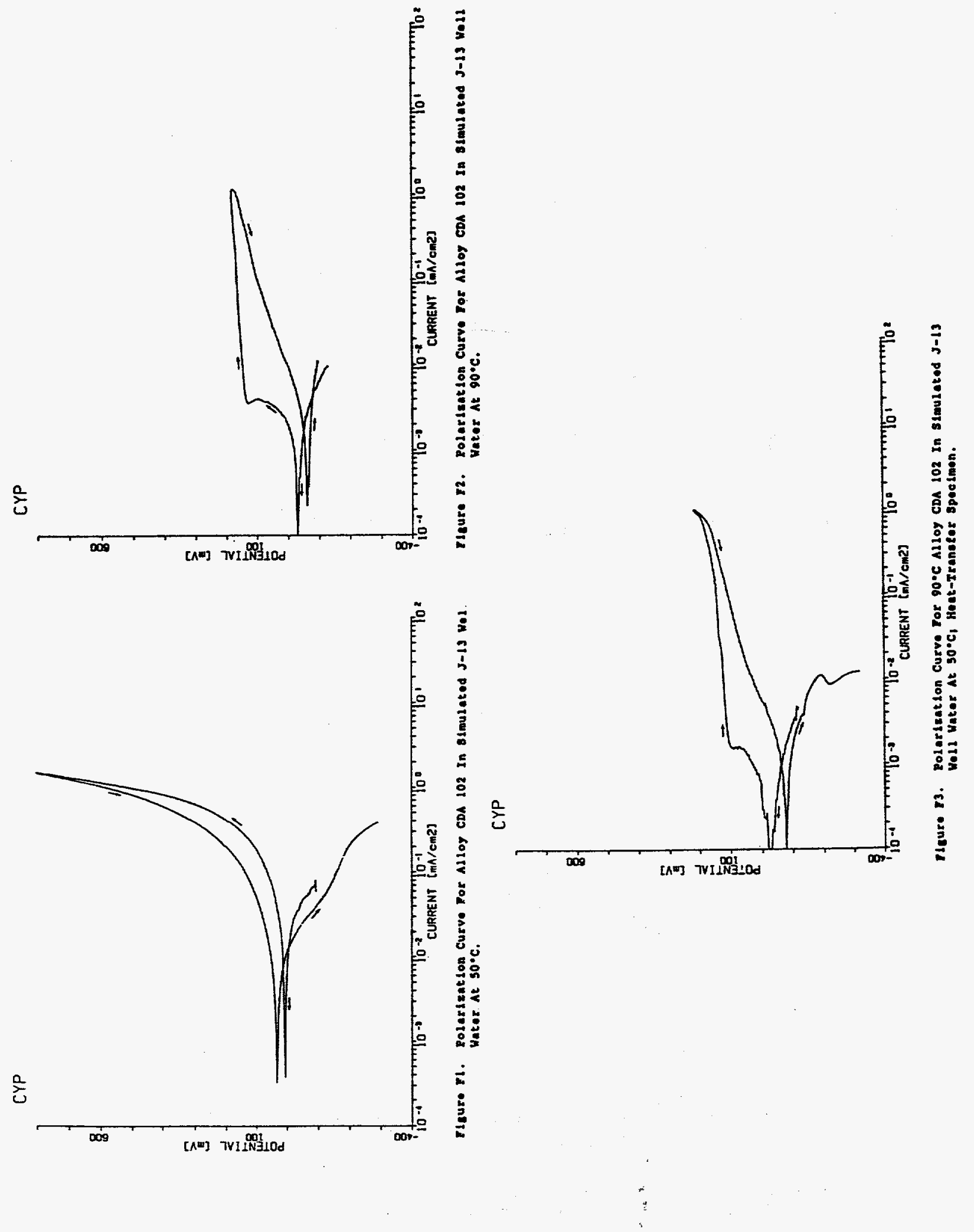


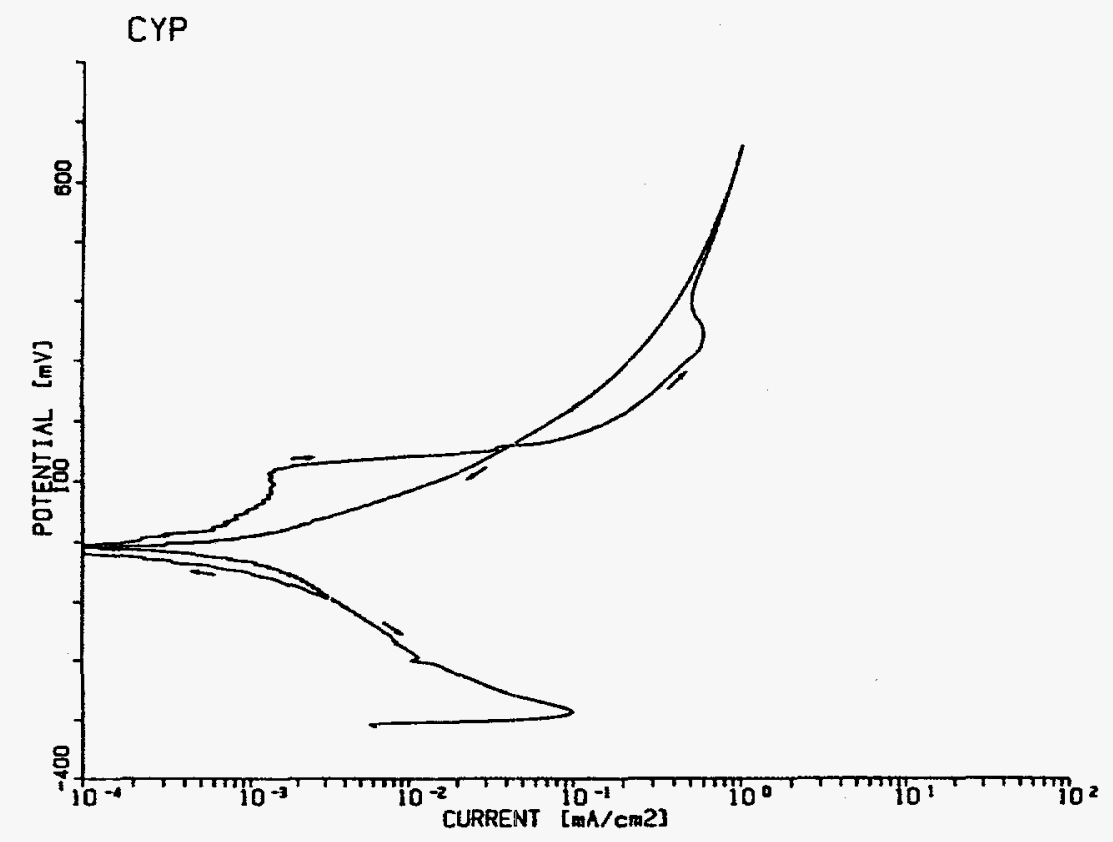

19ure F4. Folerization Curve for $90 \circ \mathrm{C}$ Alloy CDA 102 In Simulated J-13 uell Uater at $50^{\circ} \mathrm{C}$, Hoat-Iranner Speclmen (Repeat 1 ).

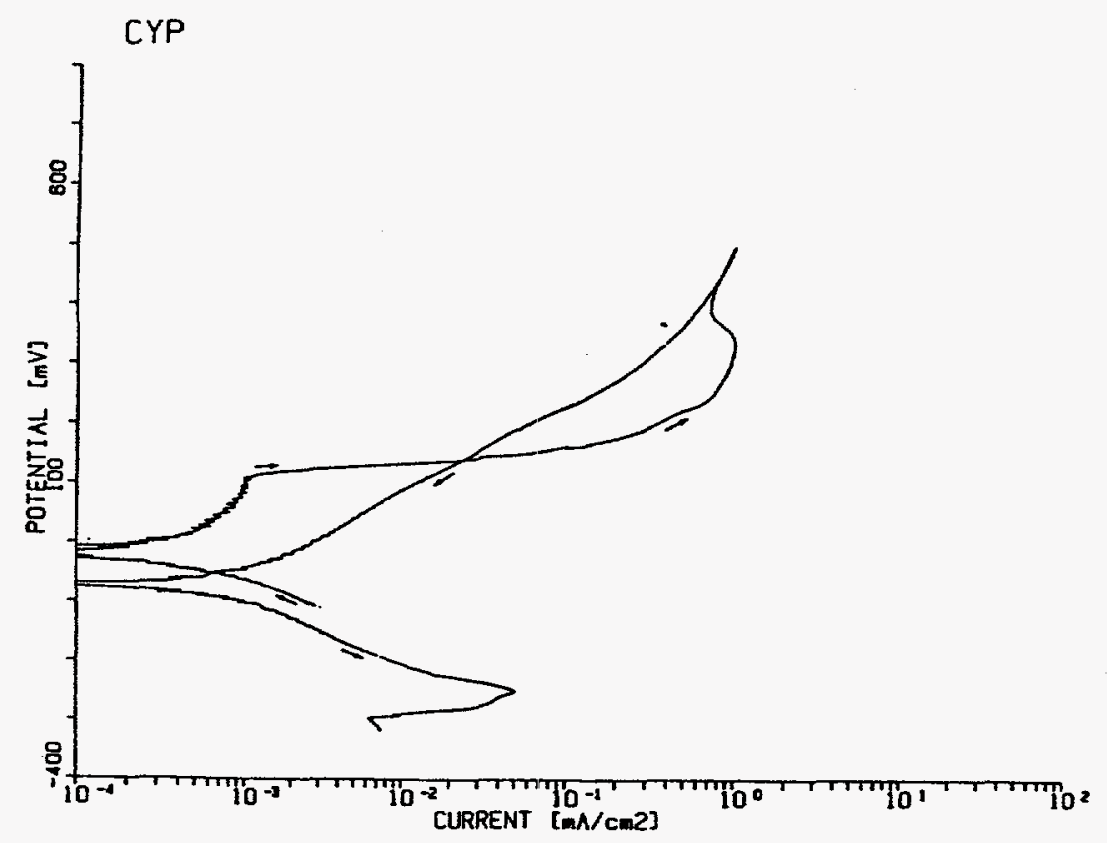

Figure 75. Folarization Curve For $90^{\circ} \mathrm{C}$ Alloy CDA 102 In Simulated J-13 vell Water At $30^{\circ} \mathrm{C}$; Hoit-Iranater Specimen (Repeat 2 ). 

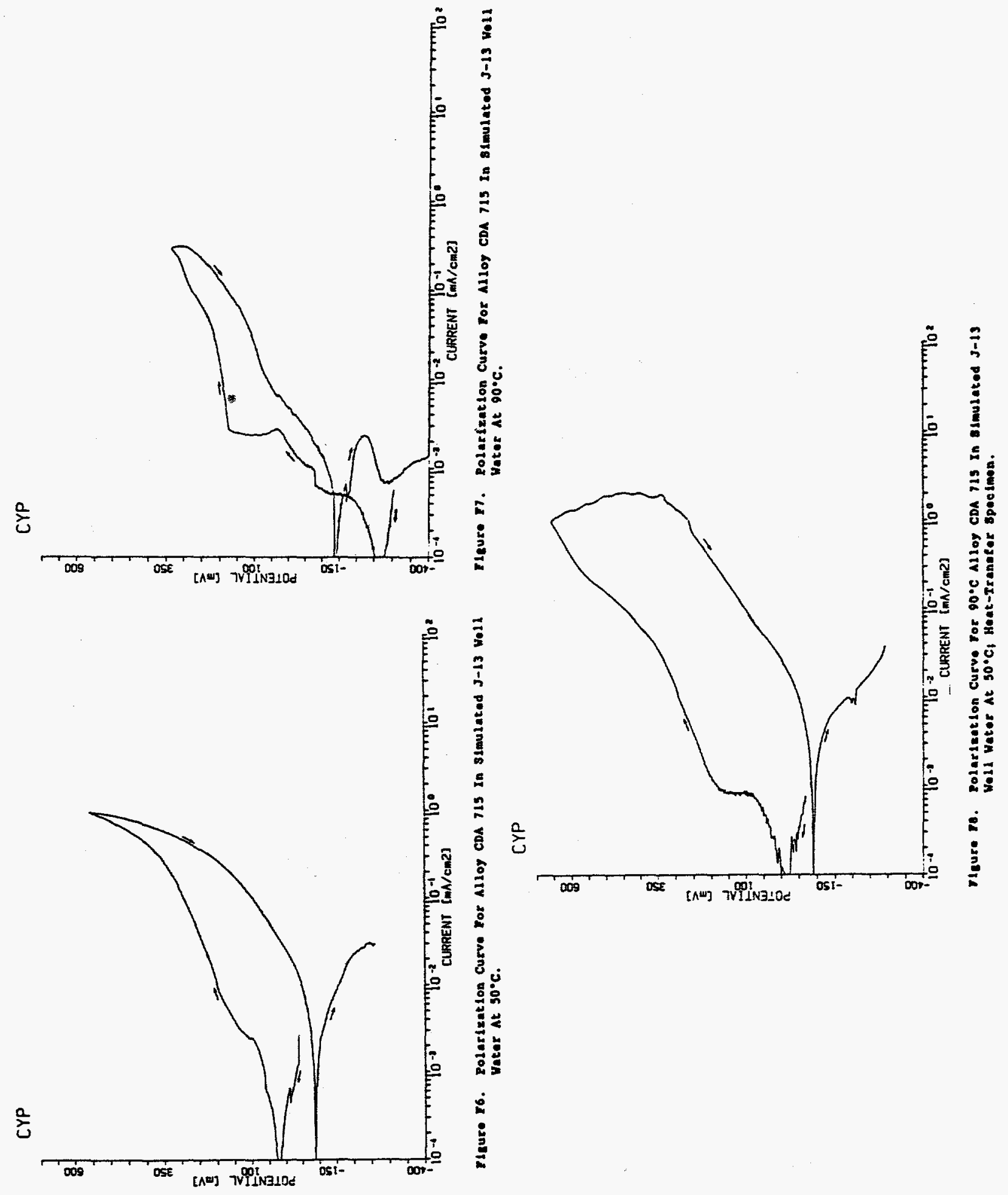


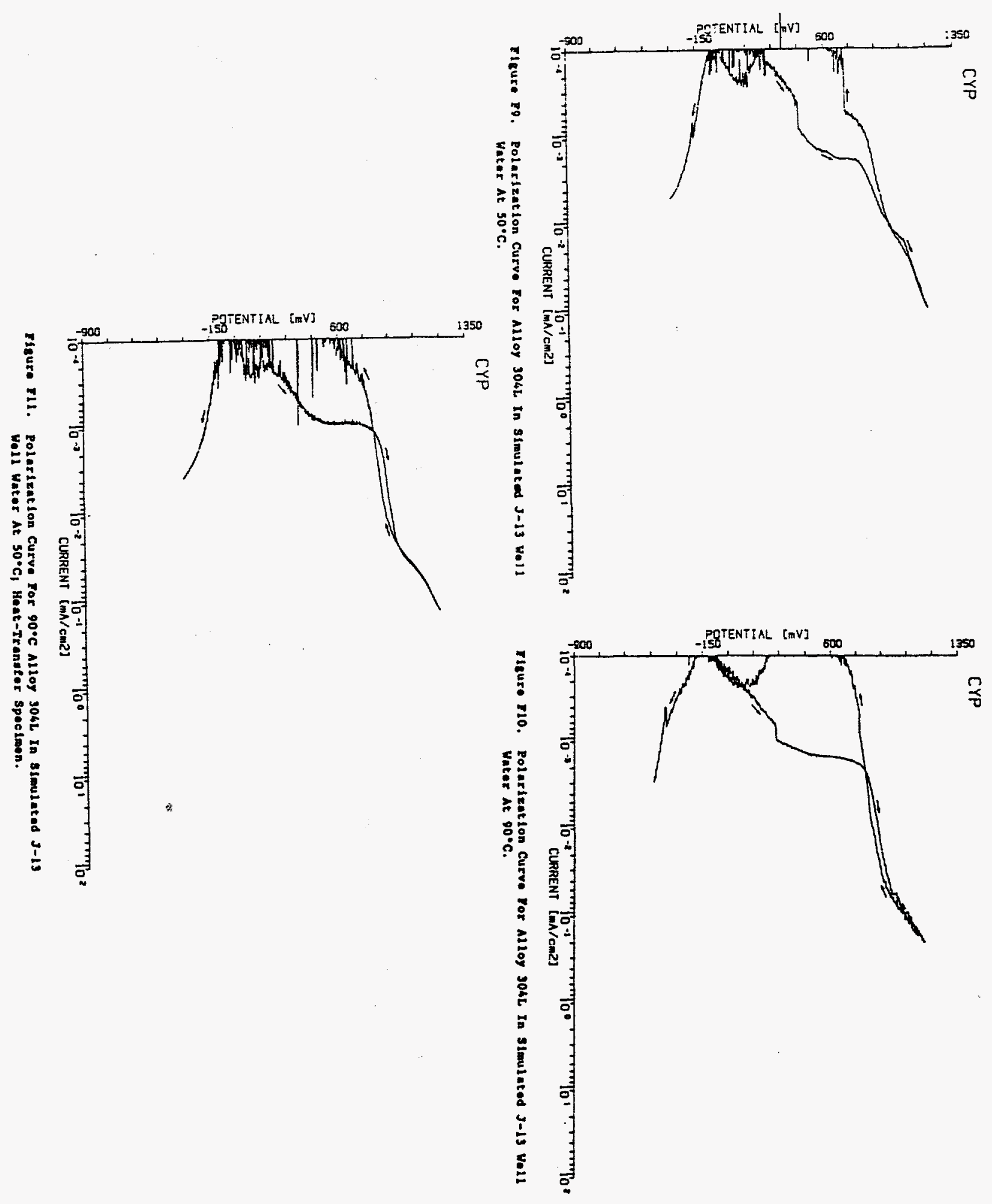



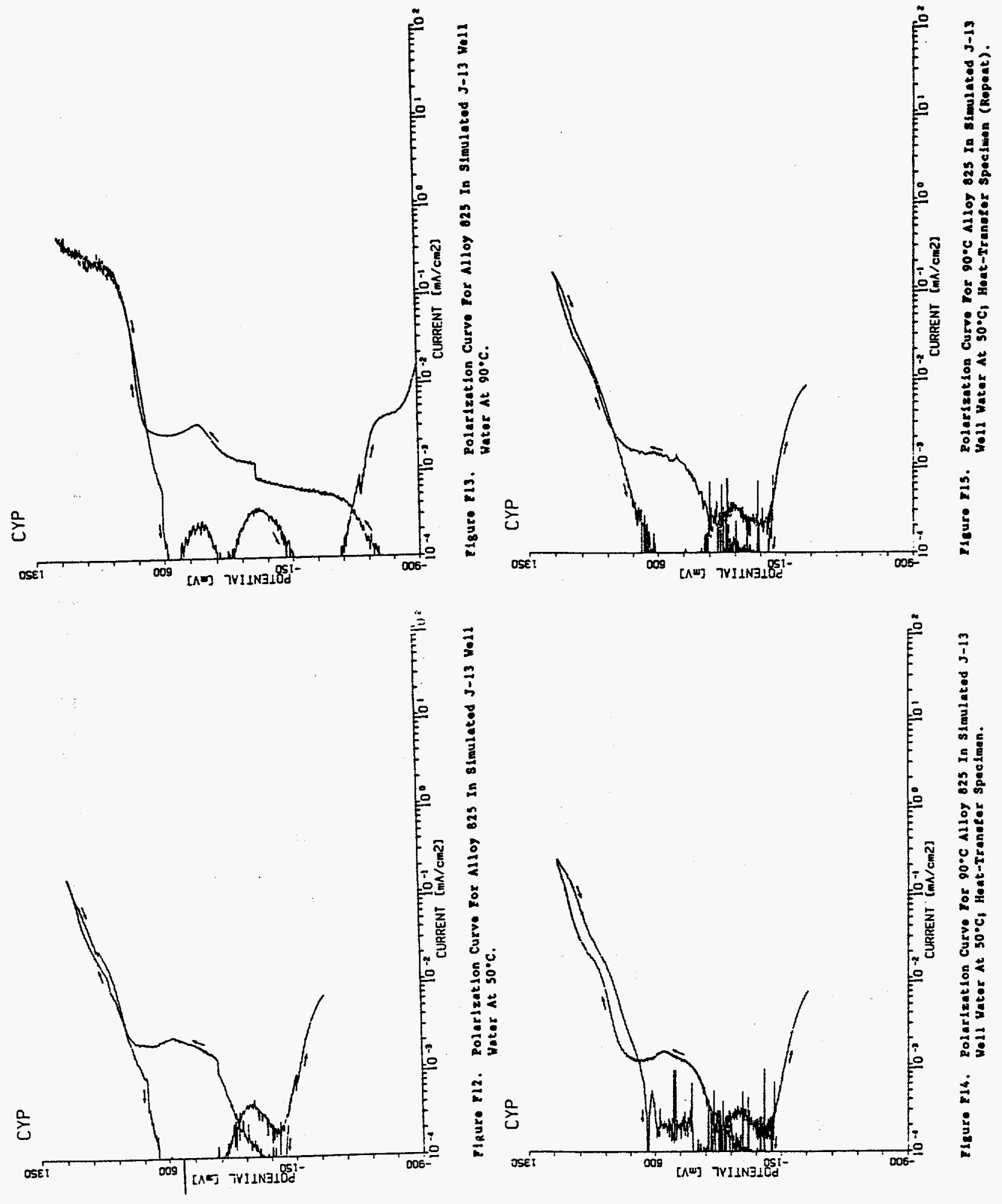

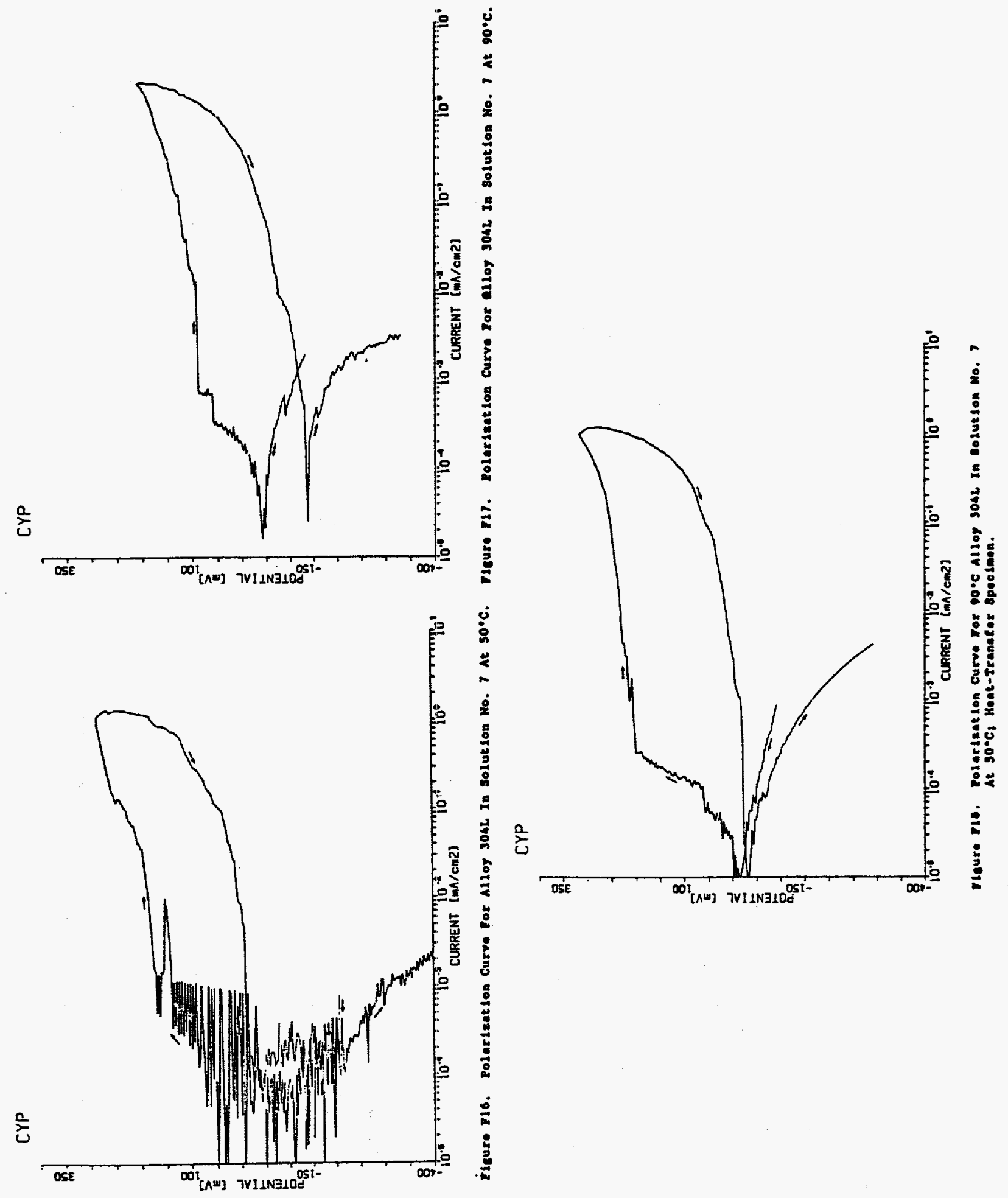

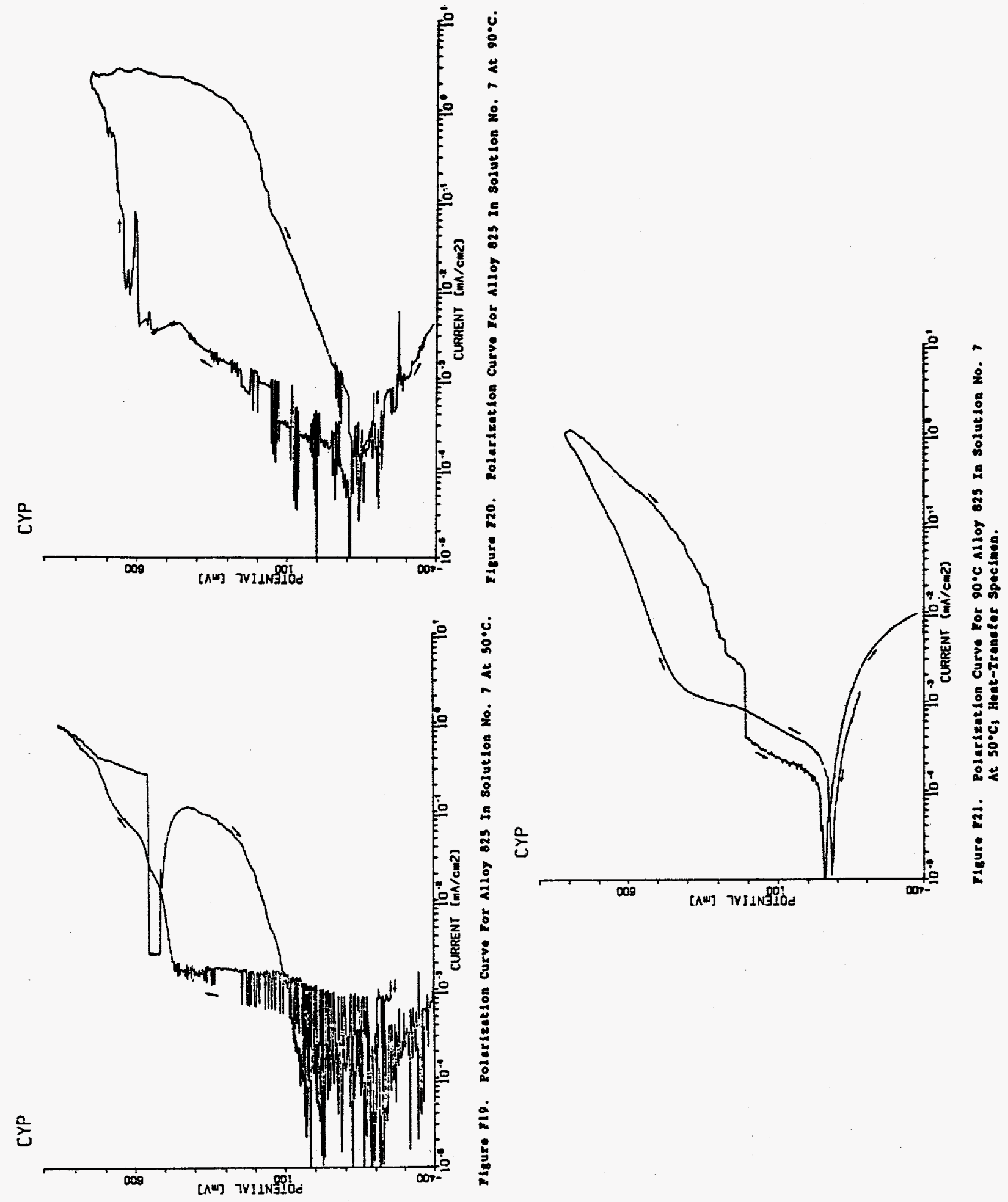


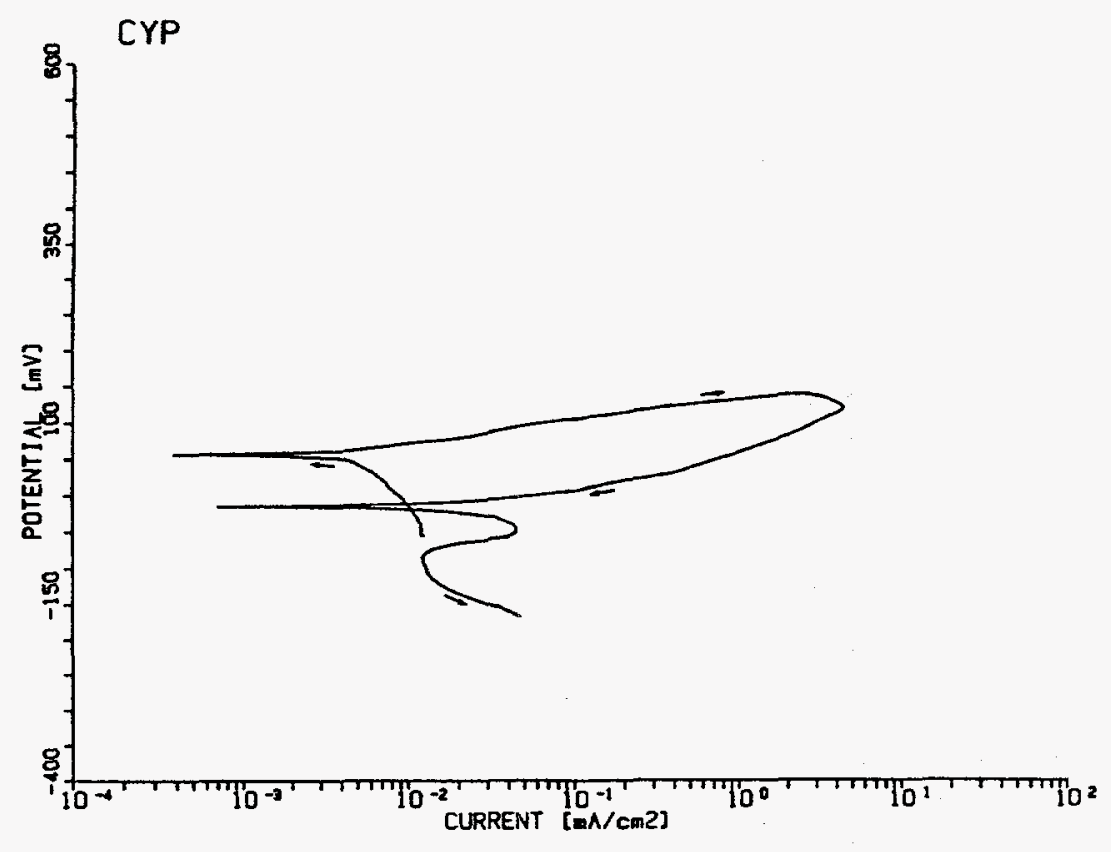

Figure 722. Bolerization Curve for 1110 CDA 102 In Solution Mo. 22 At $50^{\circ} \mathrm{C}$.

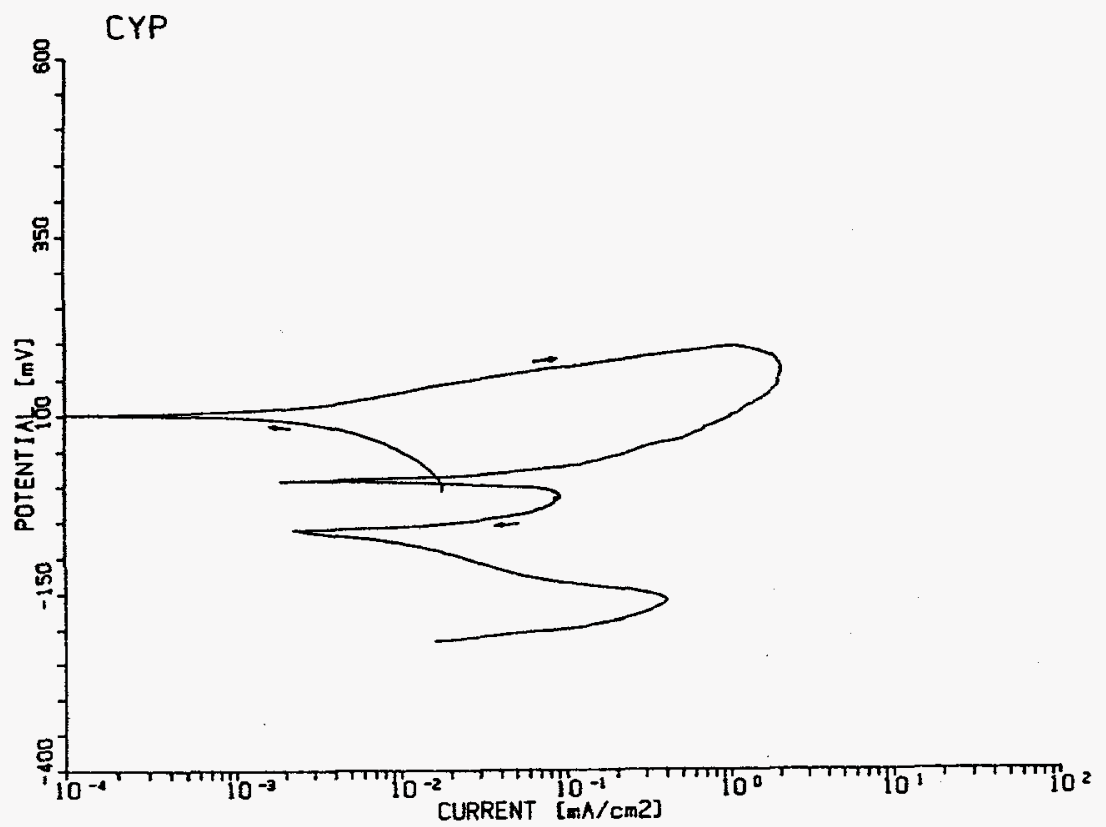

Figure, F23. Folerization Curve For $90^{\circ} \mathrm{C}$ 11loy CDA 102 In Solution No. 22 At $50^{\circ} \mathrm{C}$, Heat-Transter Specimen. 


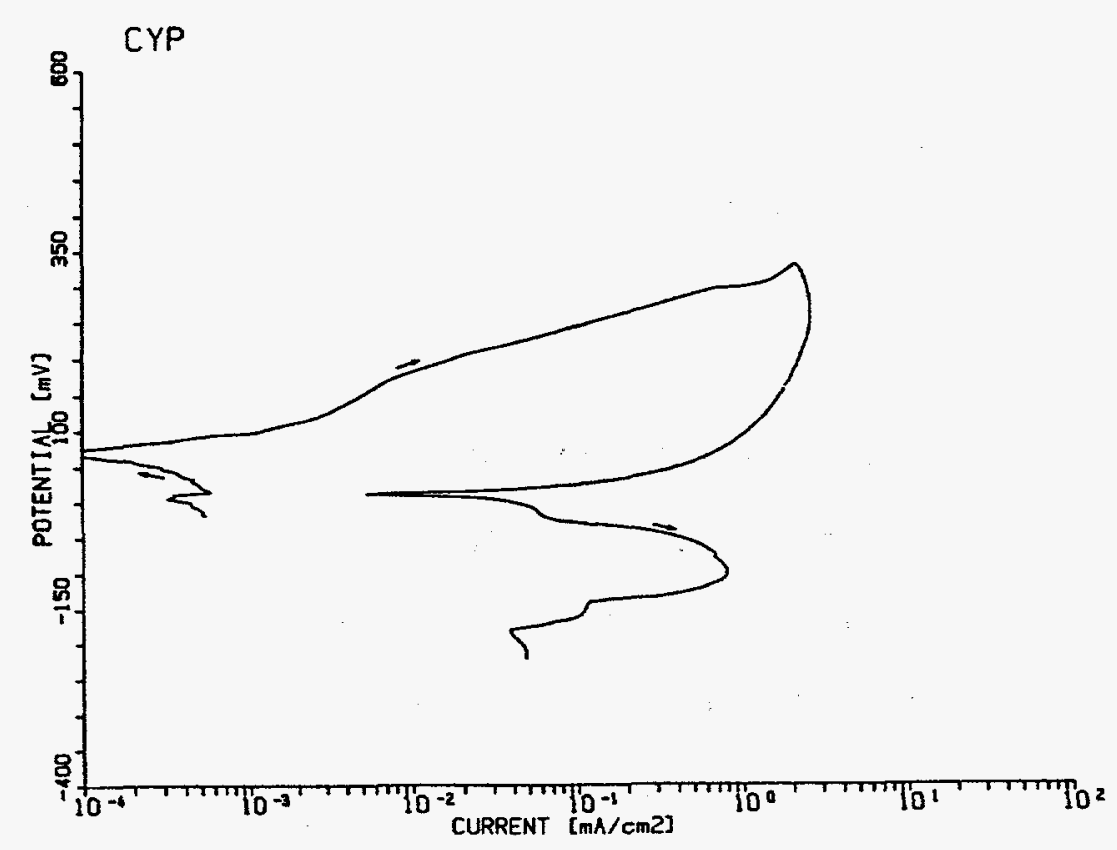

Figure F24. Polerietion Curve For Alloy CDA 715 In Solution No. 22 At 50.C.

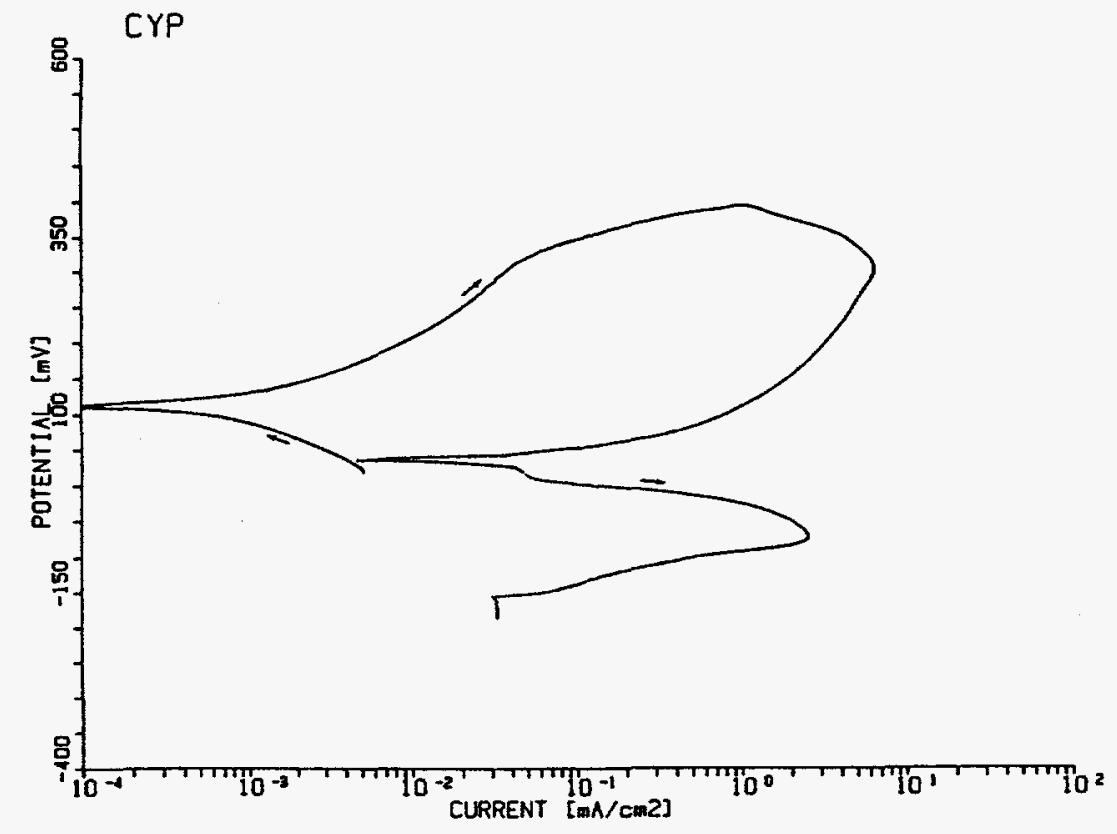

Figure F25. Polarization Curve For $90^{\circ} \mathrm{C}$ Alloy CDA 715 In Solution No. 22 at $50^{\circ} \mathrm{C}$; Heat-Transerer speciman. 
APPENDIX $G$

WELDING-EFFECT STUDIES

USING WELDED SPECIMENS

OF THE CANDIDATE CONTAINER ALLOYS

IN SELECTED SOLUTIONS FROM THE

RESOLUTION IV MATRIX 


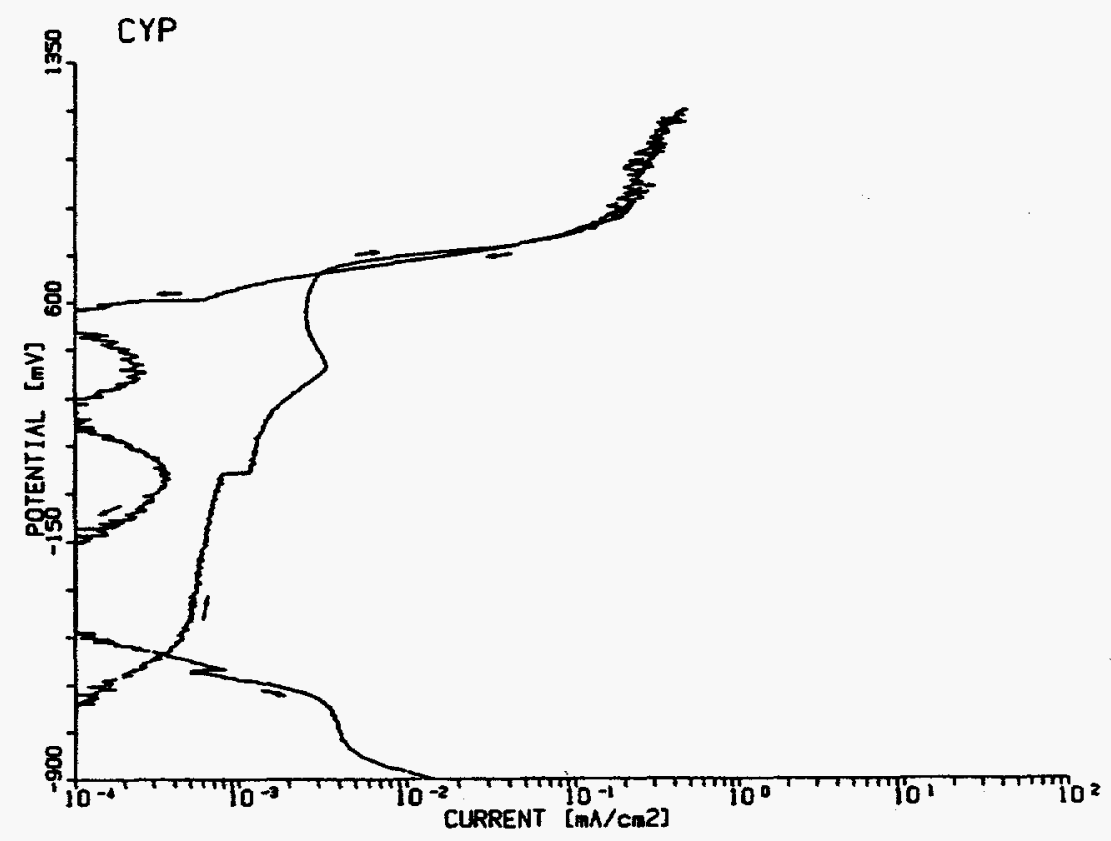

Figure G1. Polertzation Curve For dlloy 825 In Slevlated J-13 well vater at $90^{\circ} \mathrm{C}$.

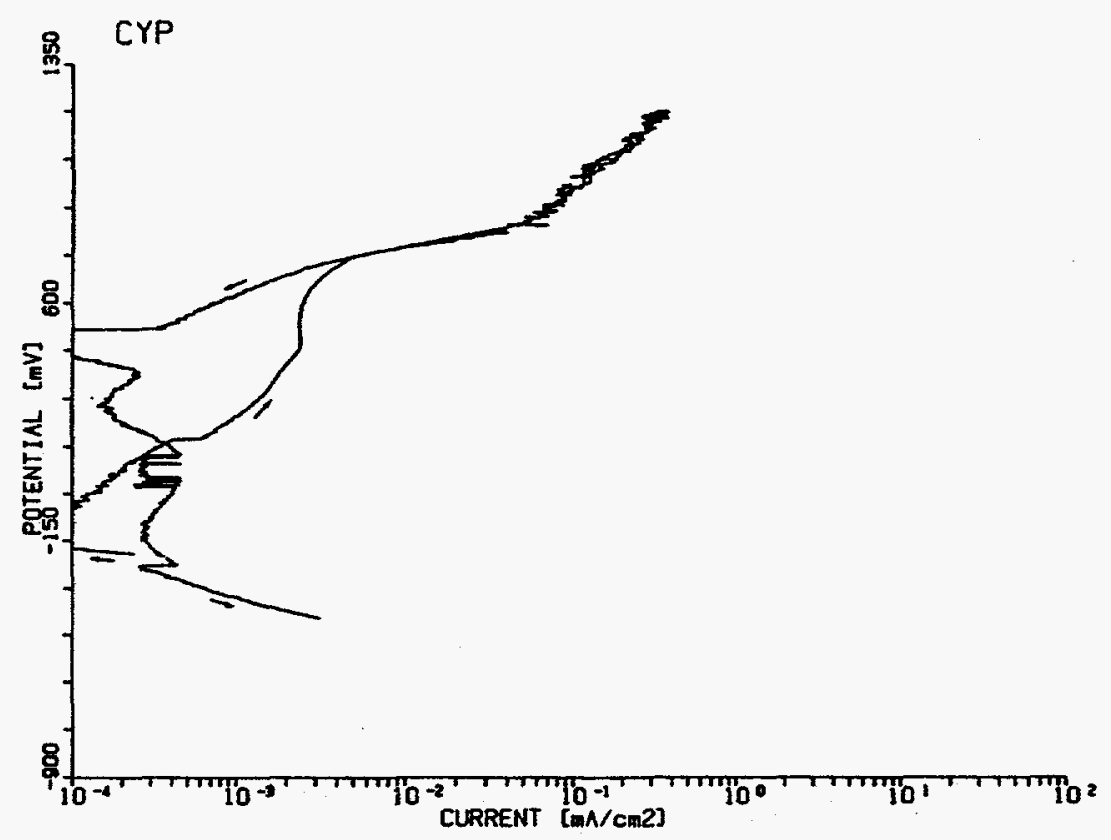

F1gure 62. Folarisetion Curve For illog o2s veld In Simlated J-13 vell Vater at $90^{\circ} \mathrm{C}$. 


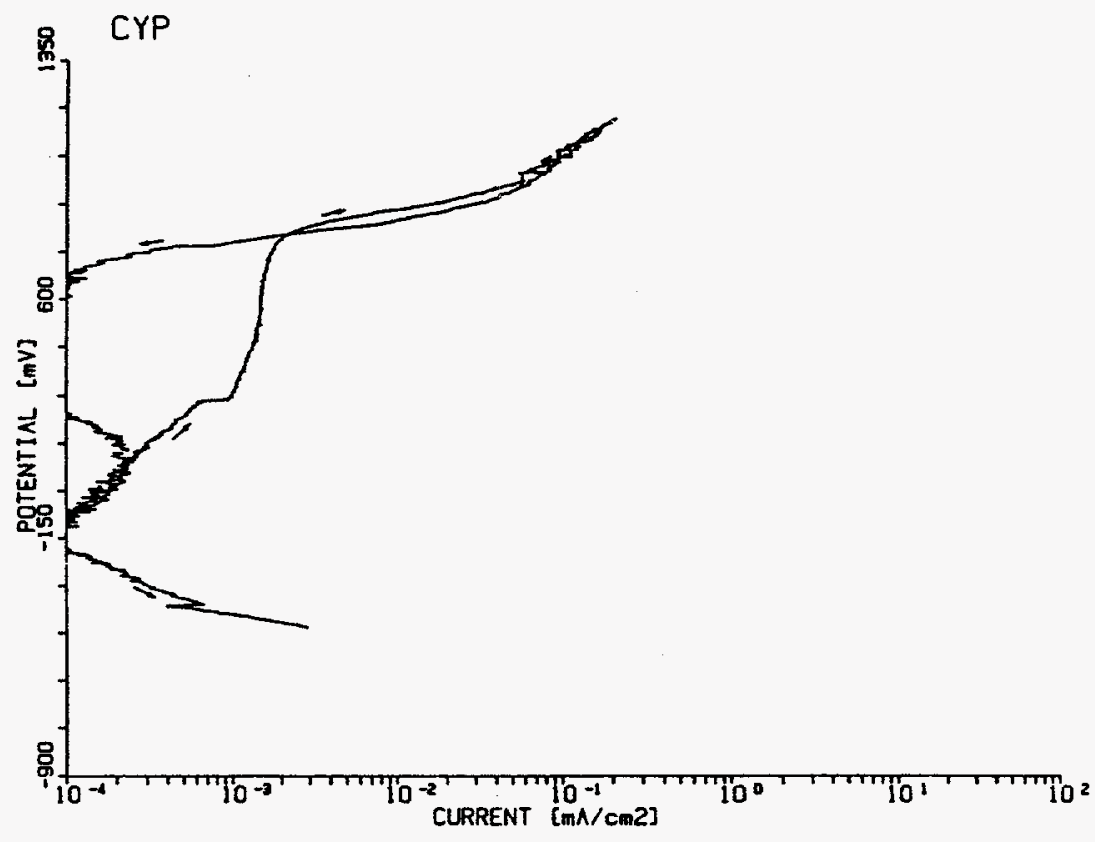

Figure 63. Polerieation Curve For Alloy 304L In SImulated J-13 Well Uater $\Delta t 90^{\circ} \mathrm{C}$.

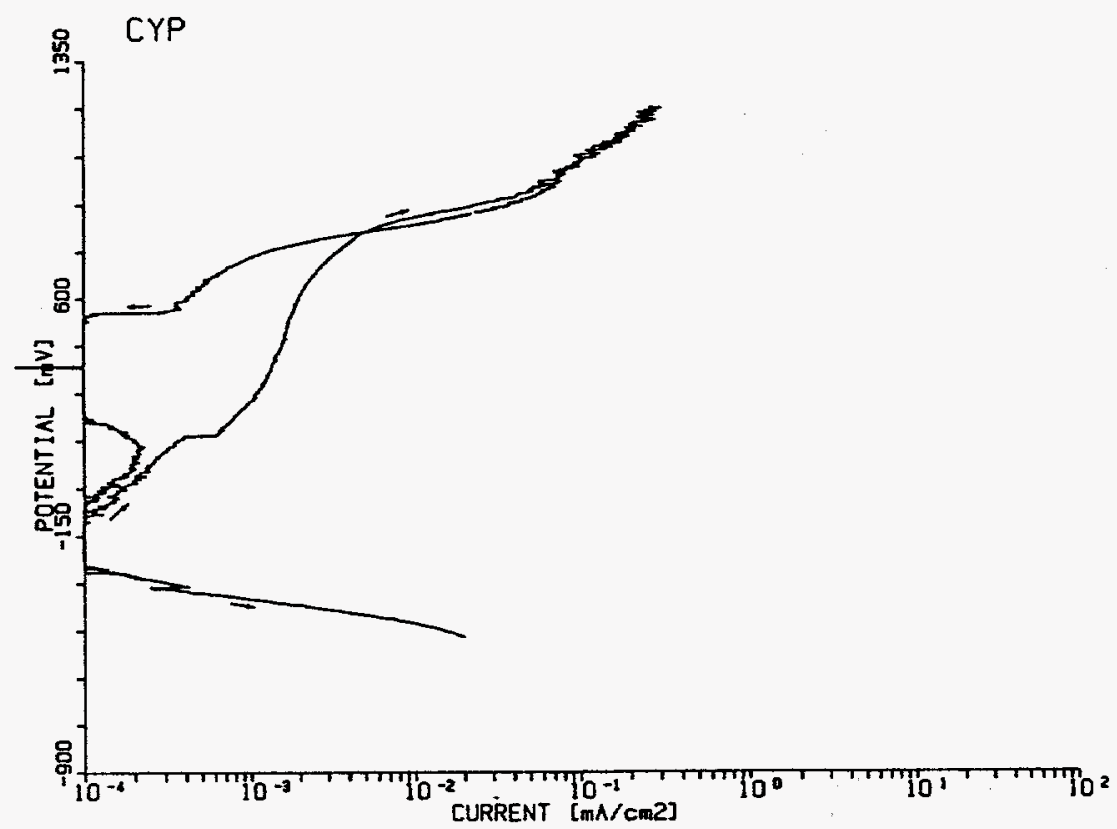

Figure G4. Polarization Curve For Alloy 304t Veld Is Simulated J-13 Well vater it $90^{\circ} \mathrm{C}$. 


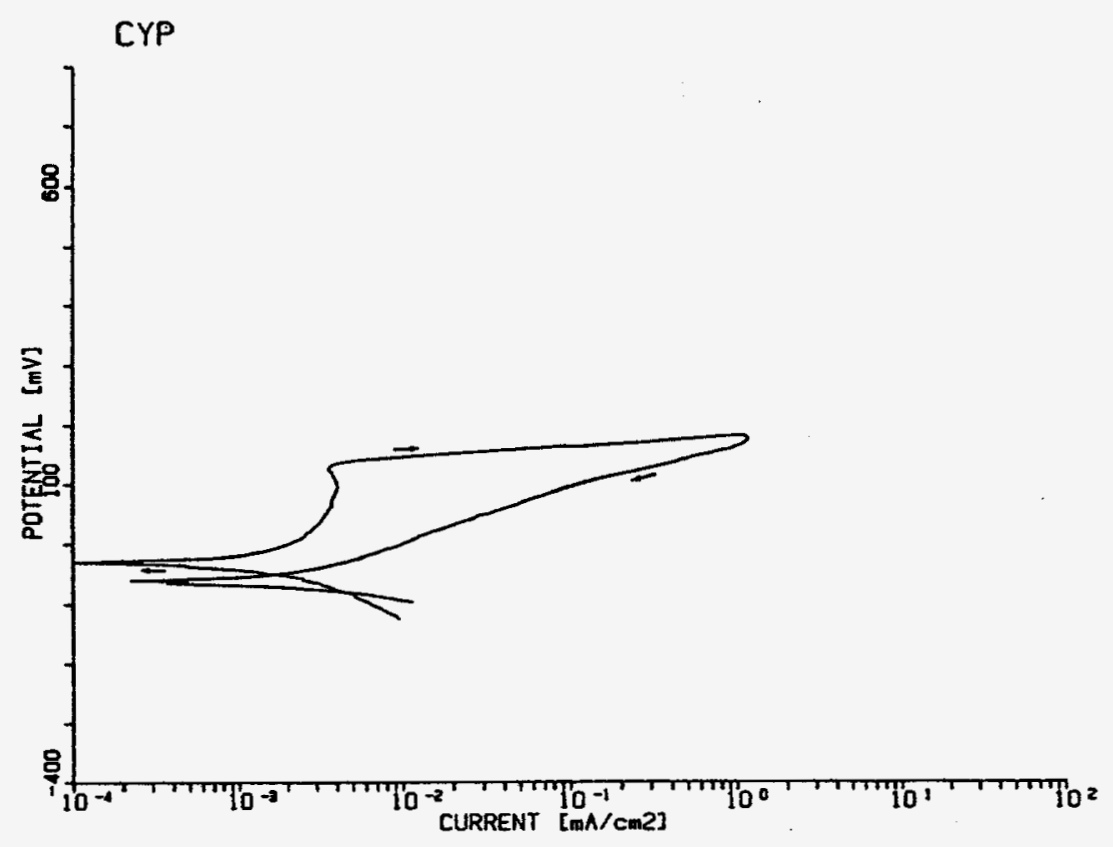

Figure G5. Polarization Curve For Alloy CDA 102 In Simulated J-13 Woll vater st $90^{\circ} \mathrm{C}$.

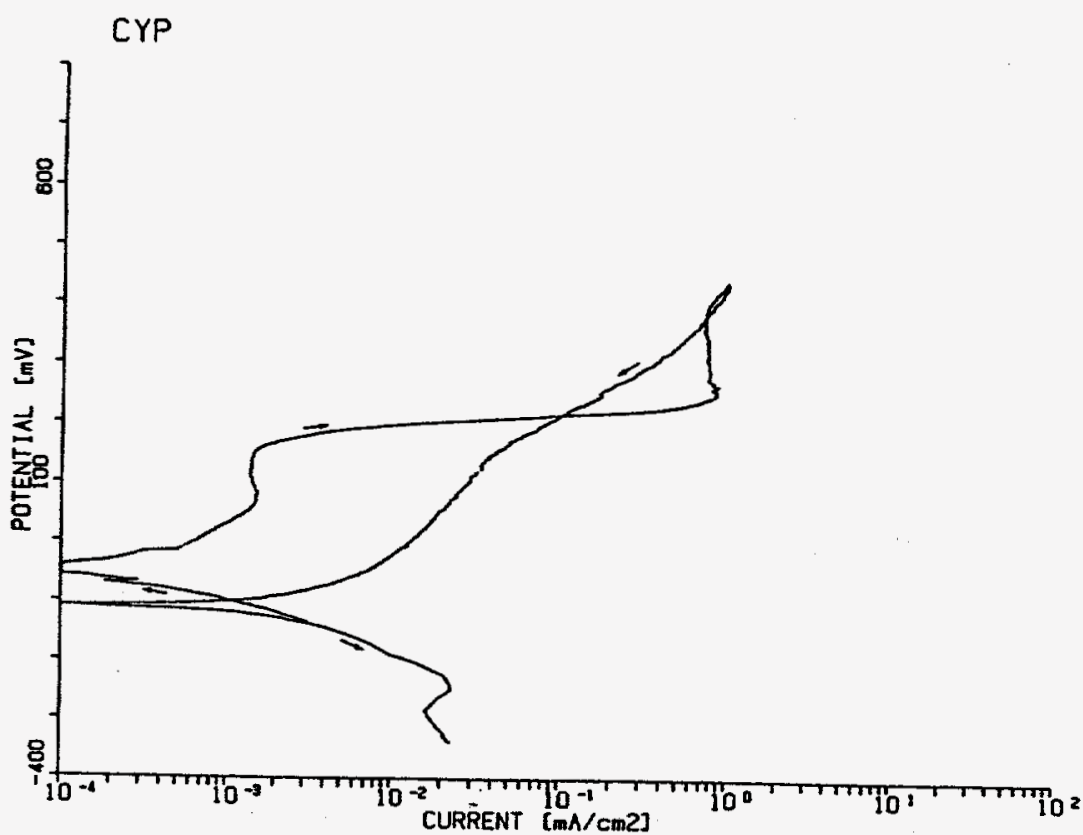

Figuro 66. Polarieation Curve For Alloy CDA 102 Veld In Simulated J-13 Vell Vater At $90^{\circ} \mathrm{C}$. 


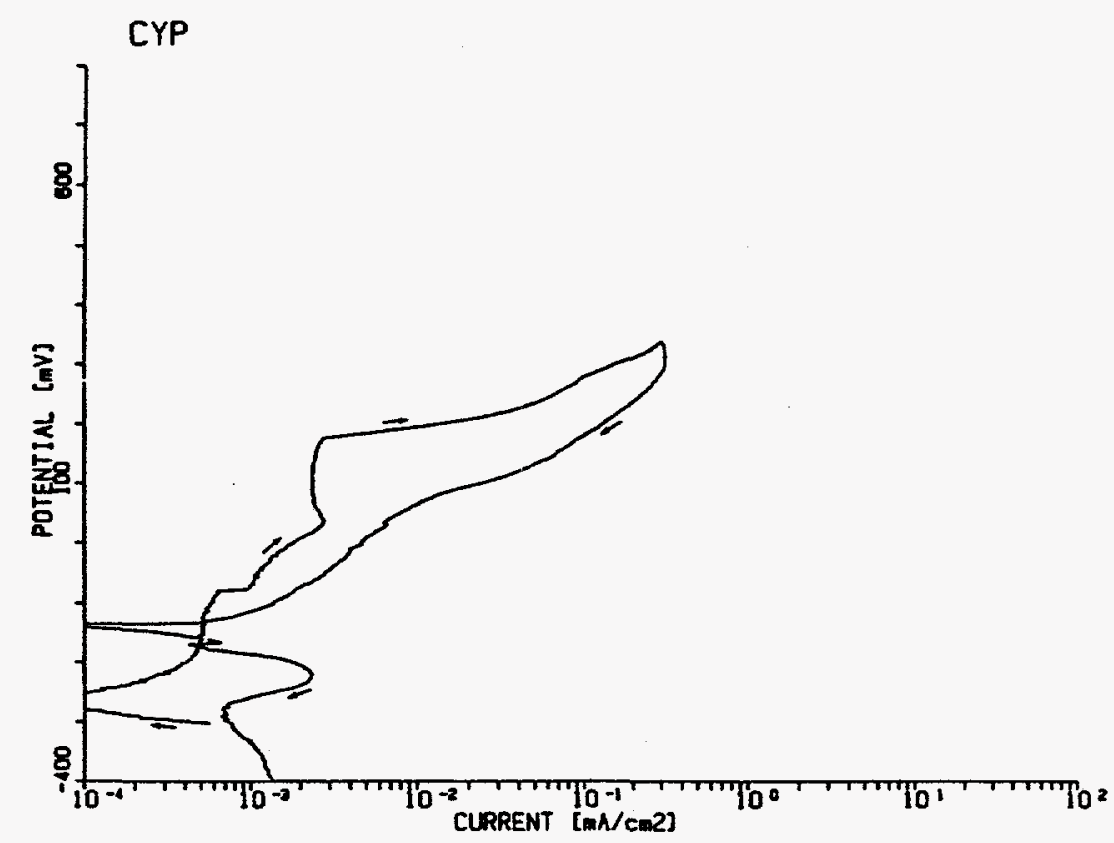

Plgure 61. Polerizetion Curve dor Alloy CDA 715 In simulated 3-13 woll vater it $90^{\circ} \mathrm{C}$.

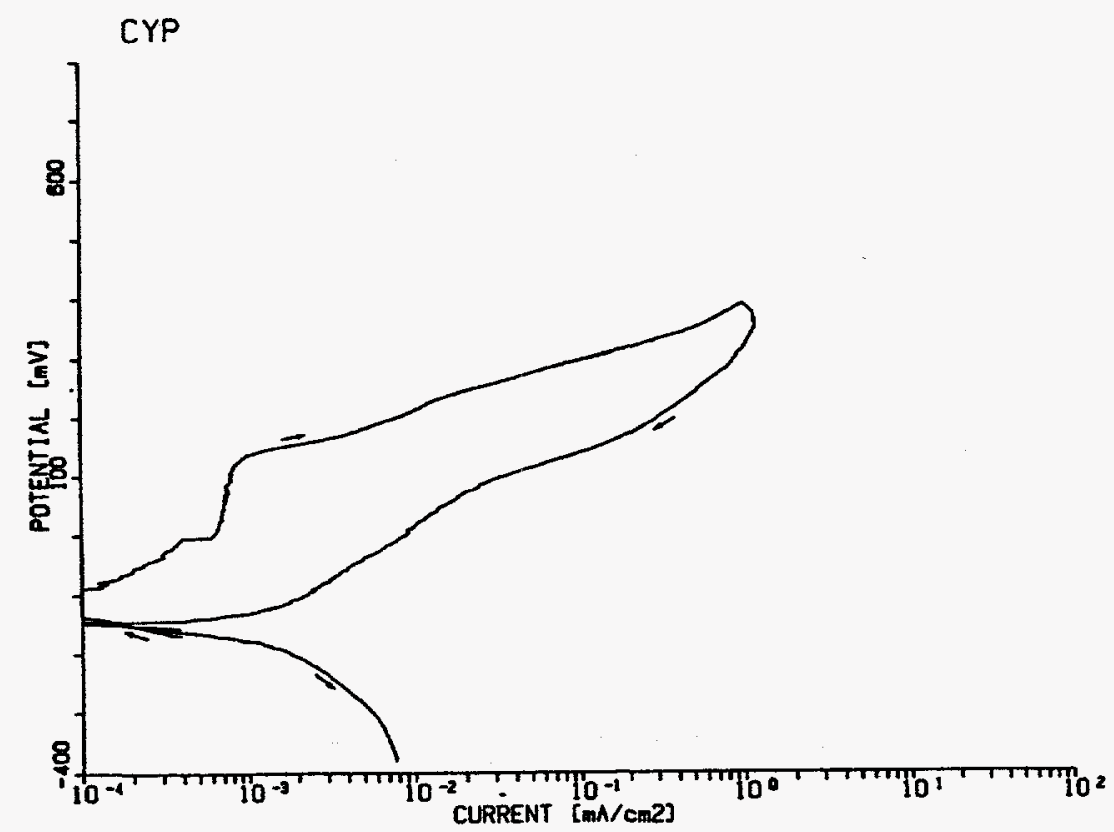

I1gure 68. Polerisation Curve Ior Alloy CDA 713 veld In simulated J-13 Well Vater At $90^{\circ} \mathrm{C}$. 


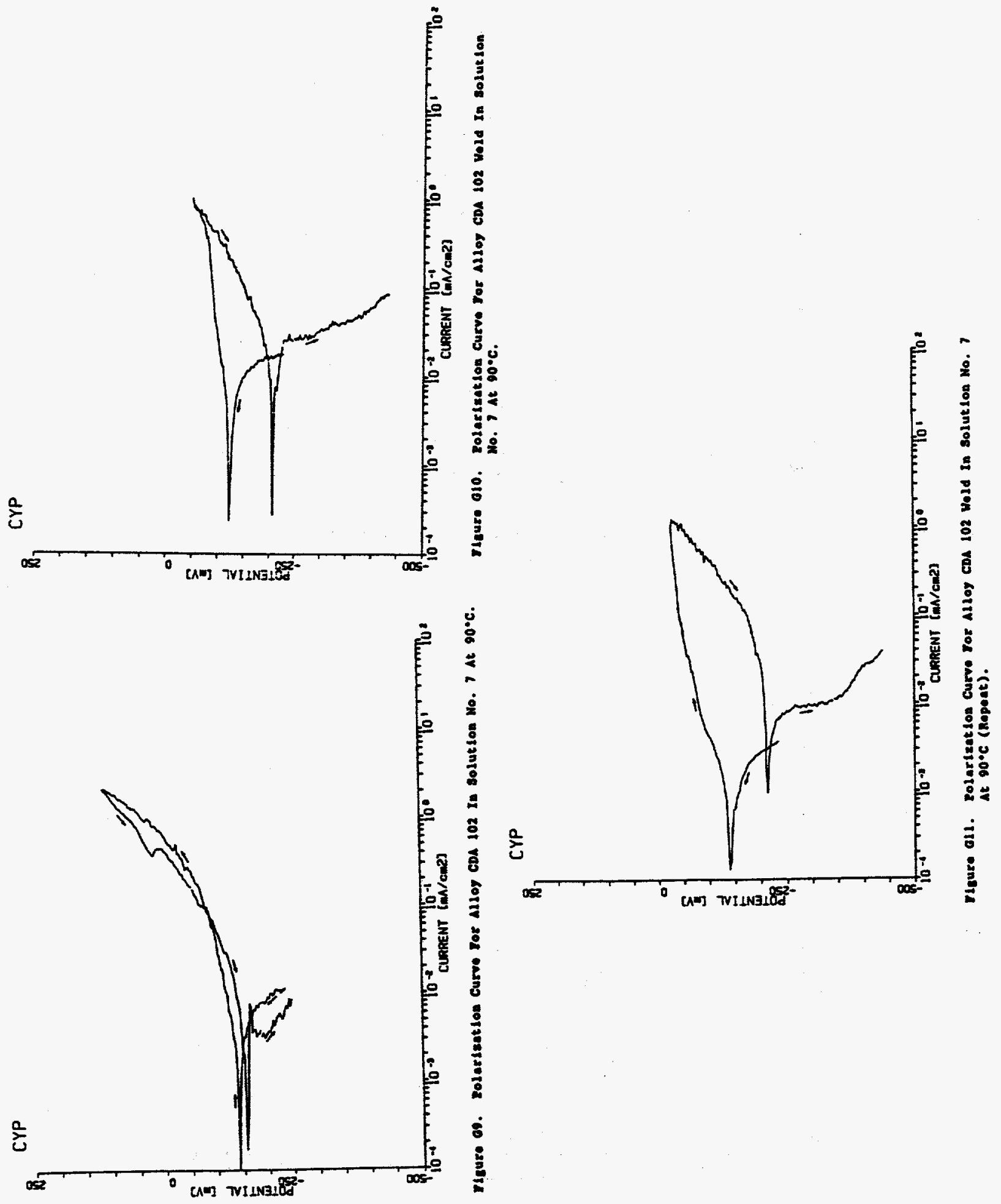




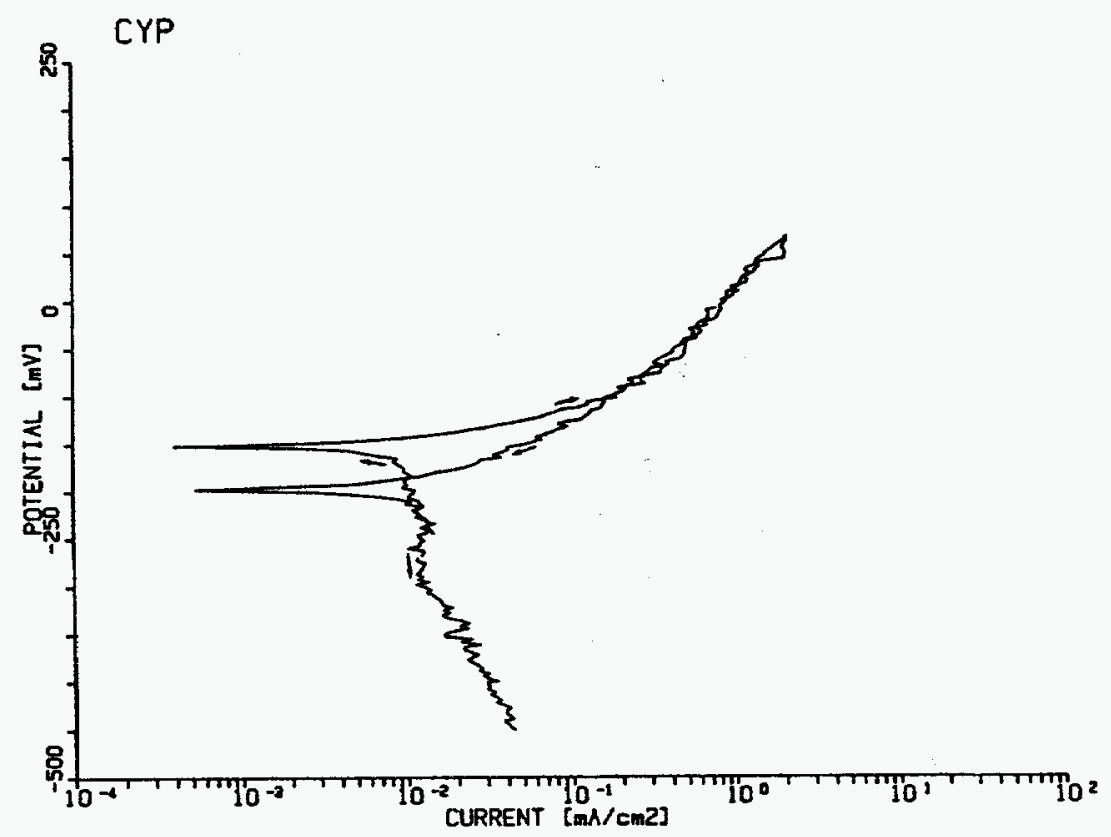

Figure G12. Polerization Curvo gor Alloy CDA 715 In Solution No. 7 At $90^{\circ} \mathrm{C}$.

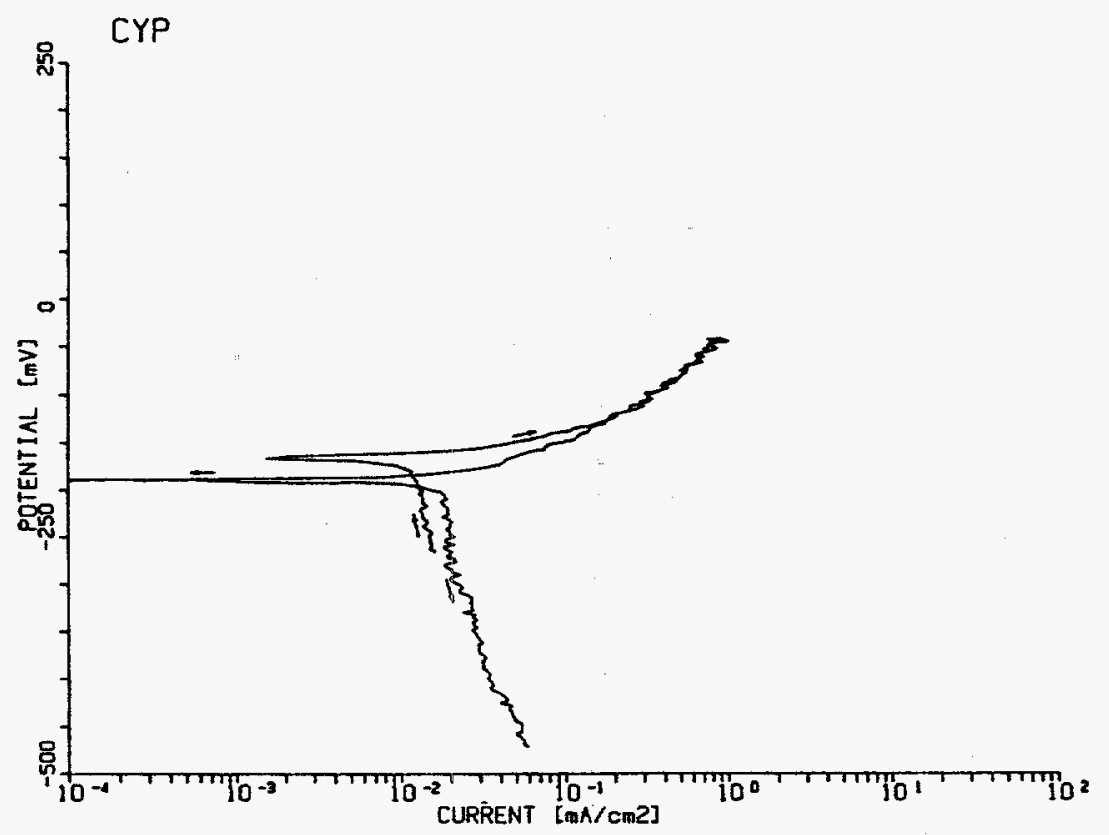

Figure G13, Polerization Curve For $4110 y$ CDS 715 veld In Solution No, 7 At $90^{\circ} \mathrm{C}$. 


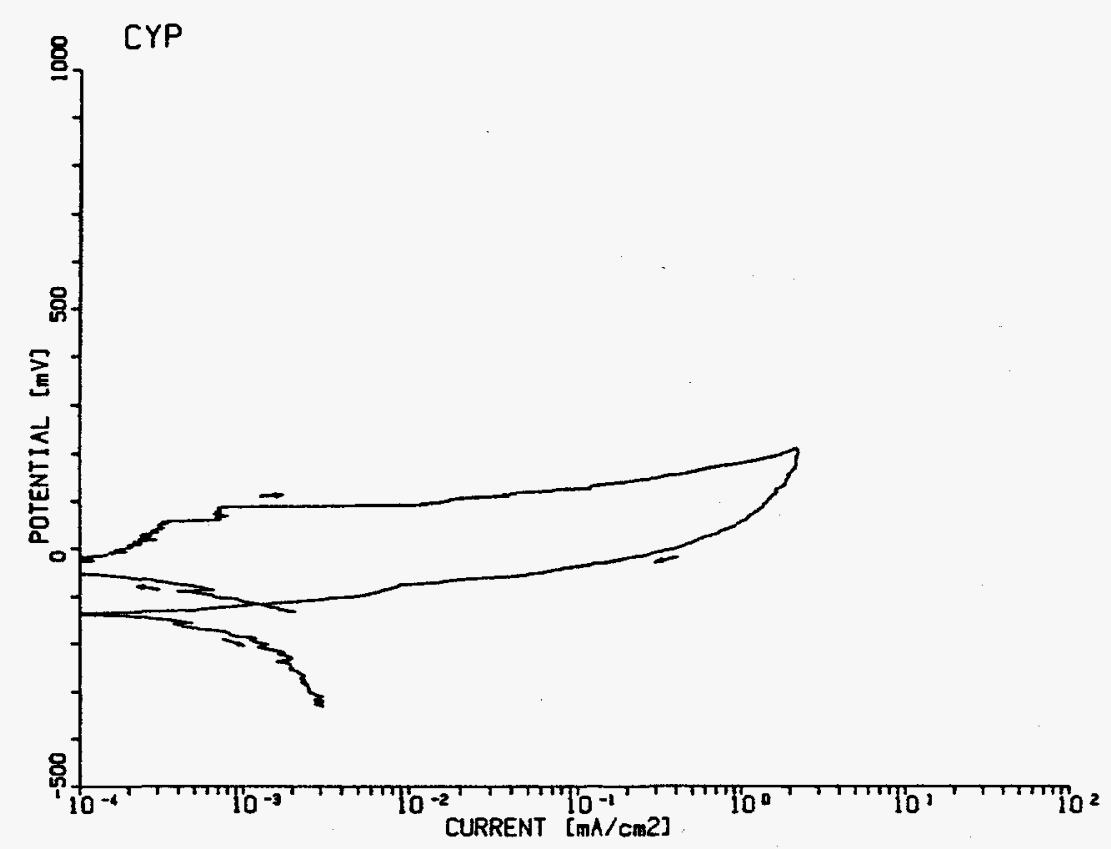

Figure 614. Polarization Curve For Alloy $304 \mathrm{~L}$ In Solution No. 7 at $90^{\circ} \mathrm{C}$.

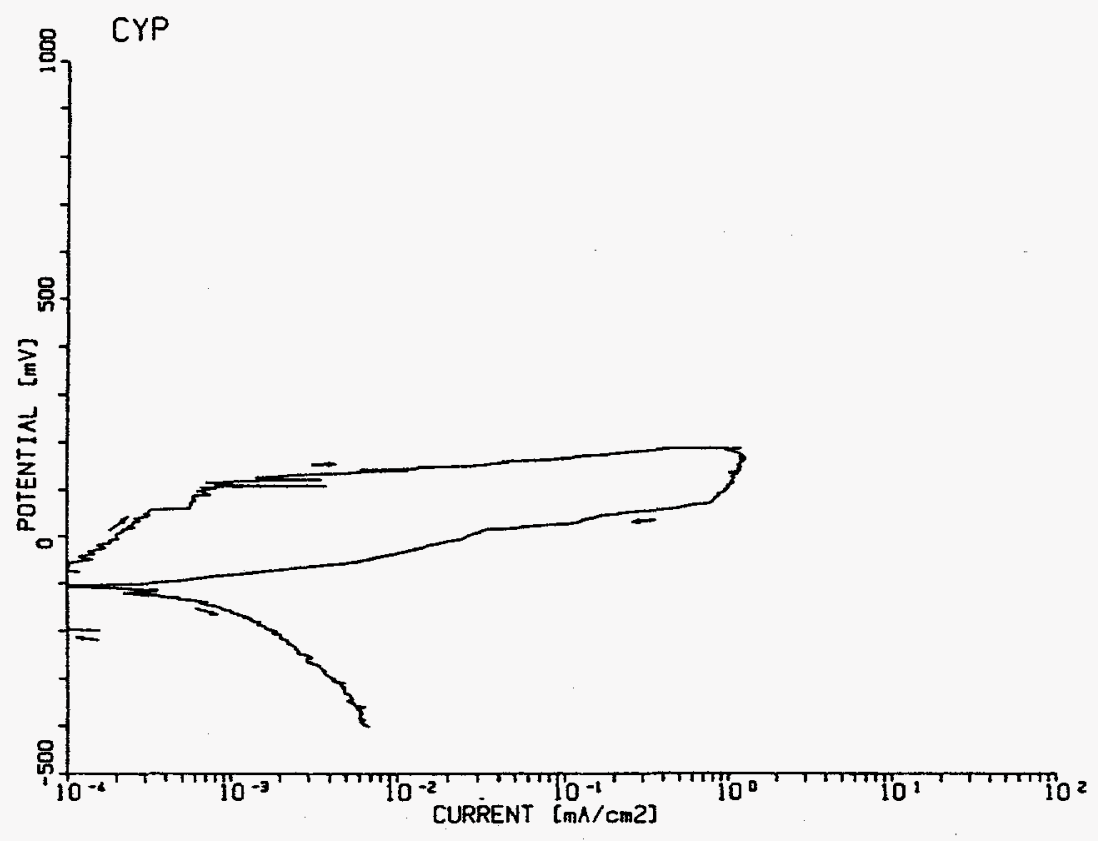

PIgure G15. Polerization Curve For Alloy $304 \mathrm{~L}$ veld In Solution Ho, At $90^{\circ} \mathrm{C}$. 


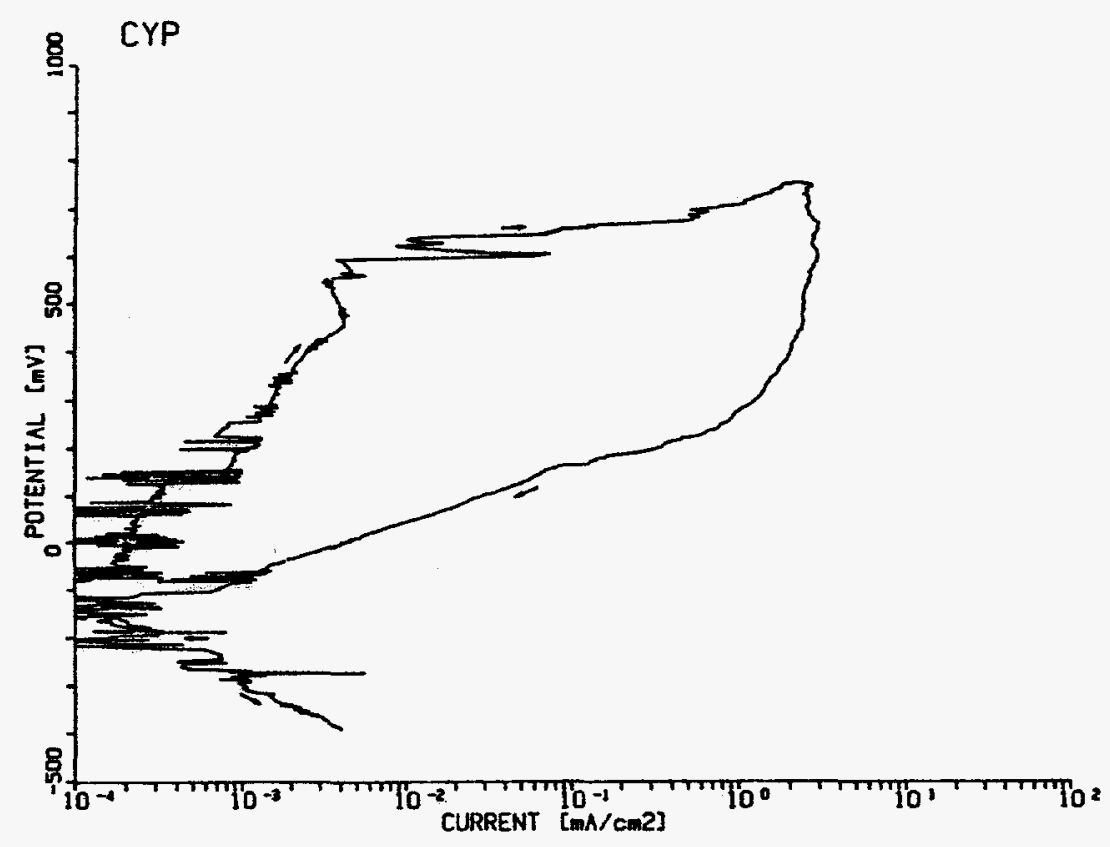

Figure 616. Eolerization Curve For alloy 825 In Solution Ho. I At $90^{\circ} \mathrm{C}$.

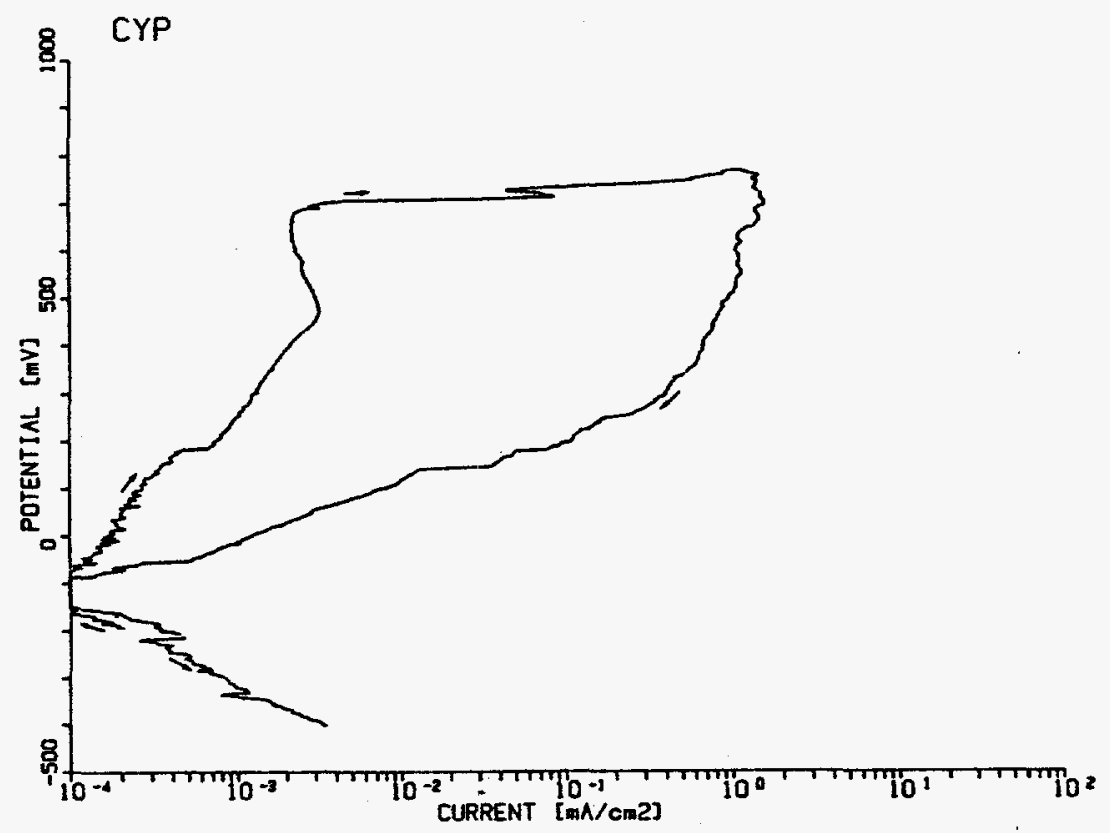

FIgure G17. Polerleatlos Curve For Alloy 825 weld In Solution No. I At $90 \cdot \mathrm{C}$. 


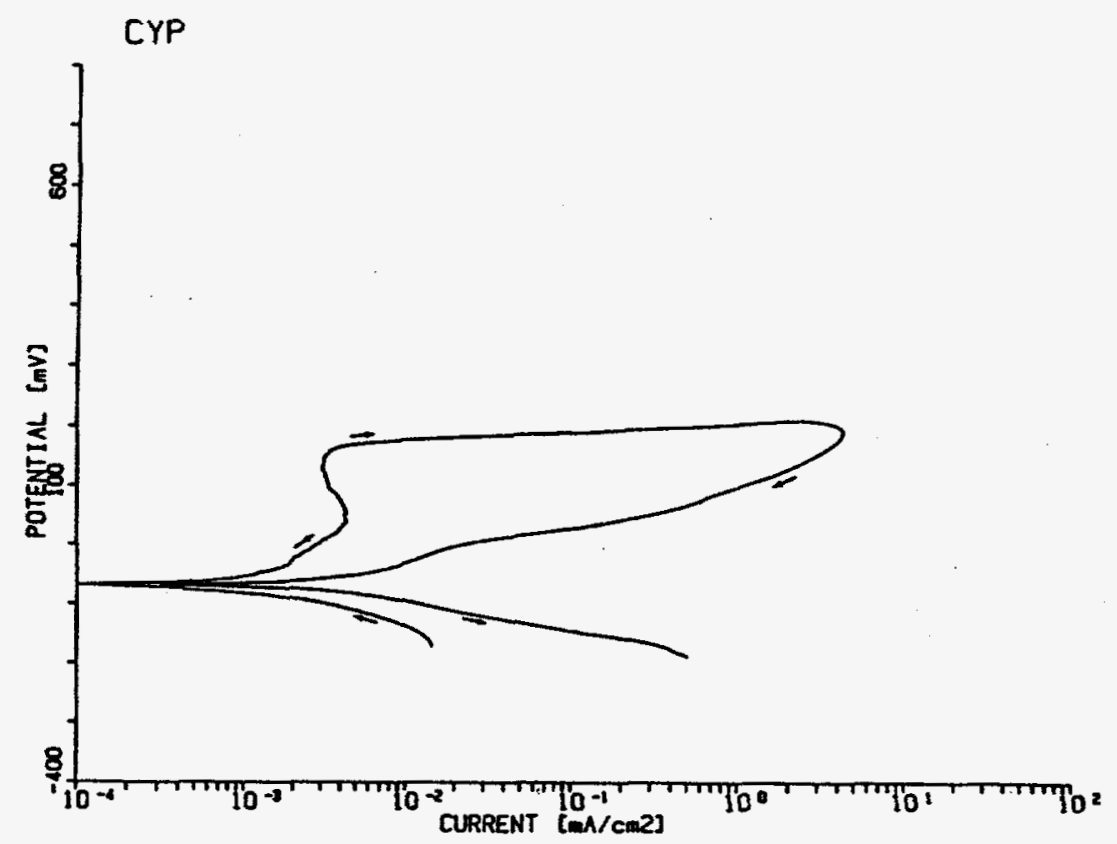

Figure G10. Zolerization Curve Ior Alloy $\operatorname{CDA} 102$ In solution No. 29 At $50^{\circ} \mathrm{C}$.

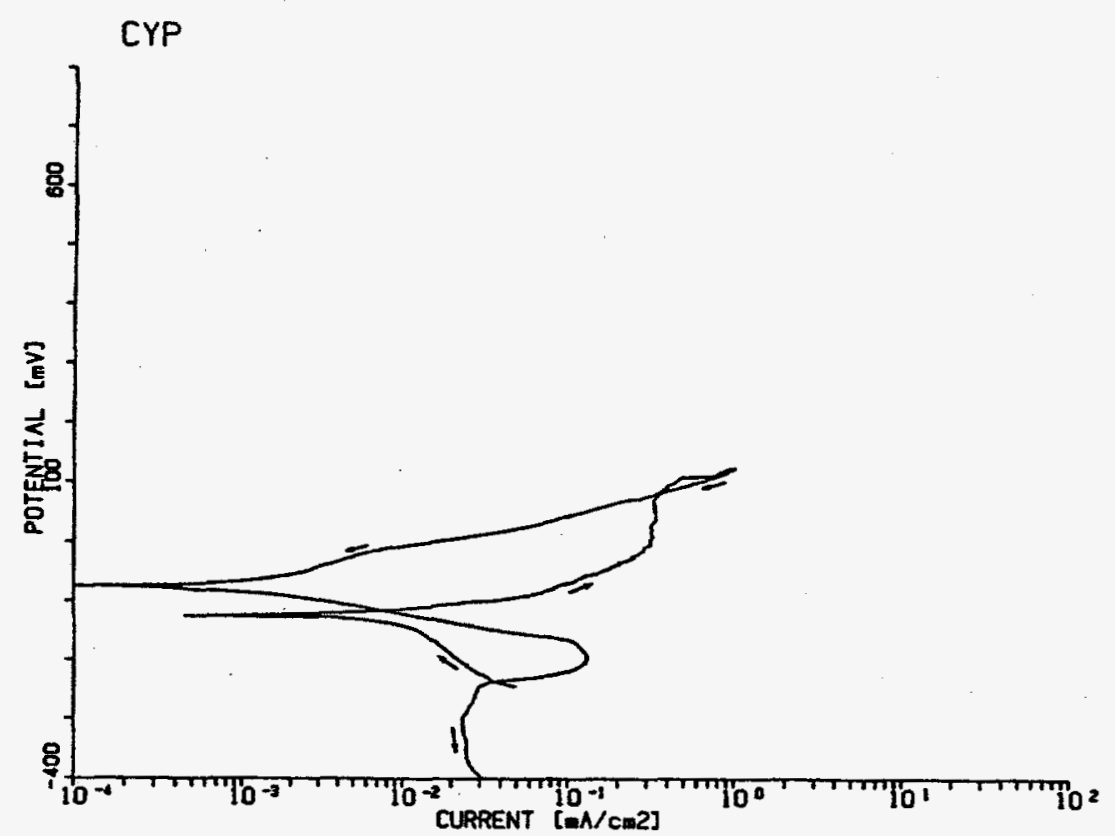

Figure G19. Poleriention curva For Alloy CDA 102 Wold In Solution to. 29 At $50^{\circ} \mathrm{C}$. 


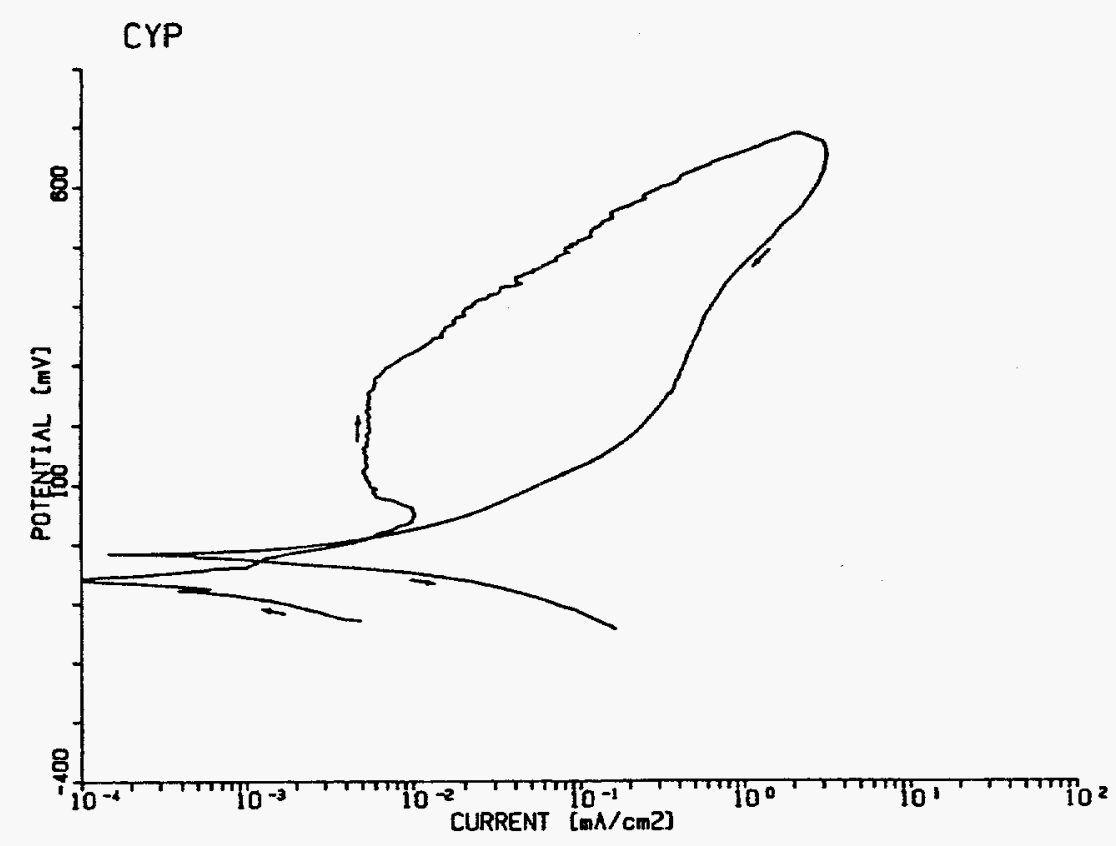

Tigure 620. Eolarleatlon Curve For Alloy CDA 115 In Solution No. 29 At $50^{\circ} \mathrm{C}$.

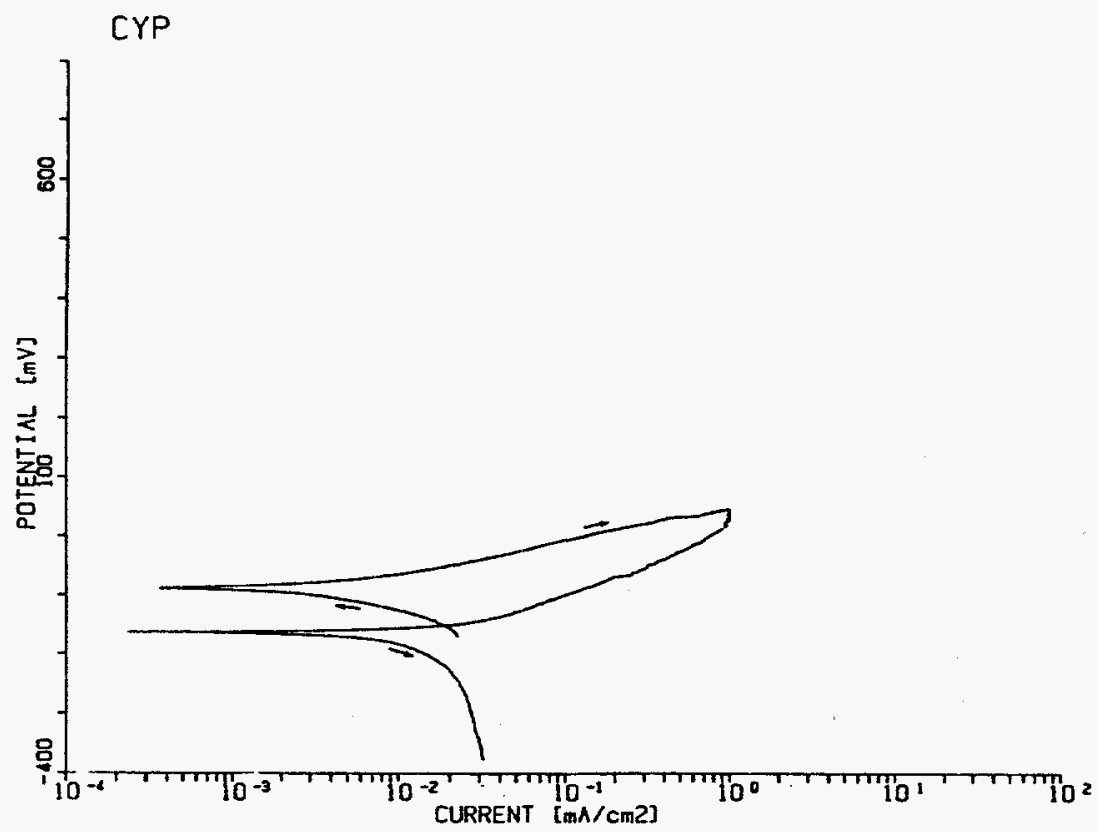

F1guro 621. Polarization Curve For Allos CDA 715 Veld In Solution No, 29 At $50^{\circ} \mathrm{C}$. 


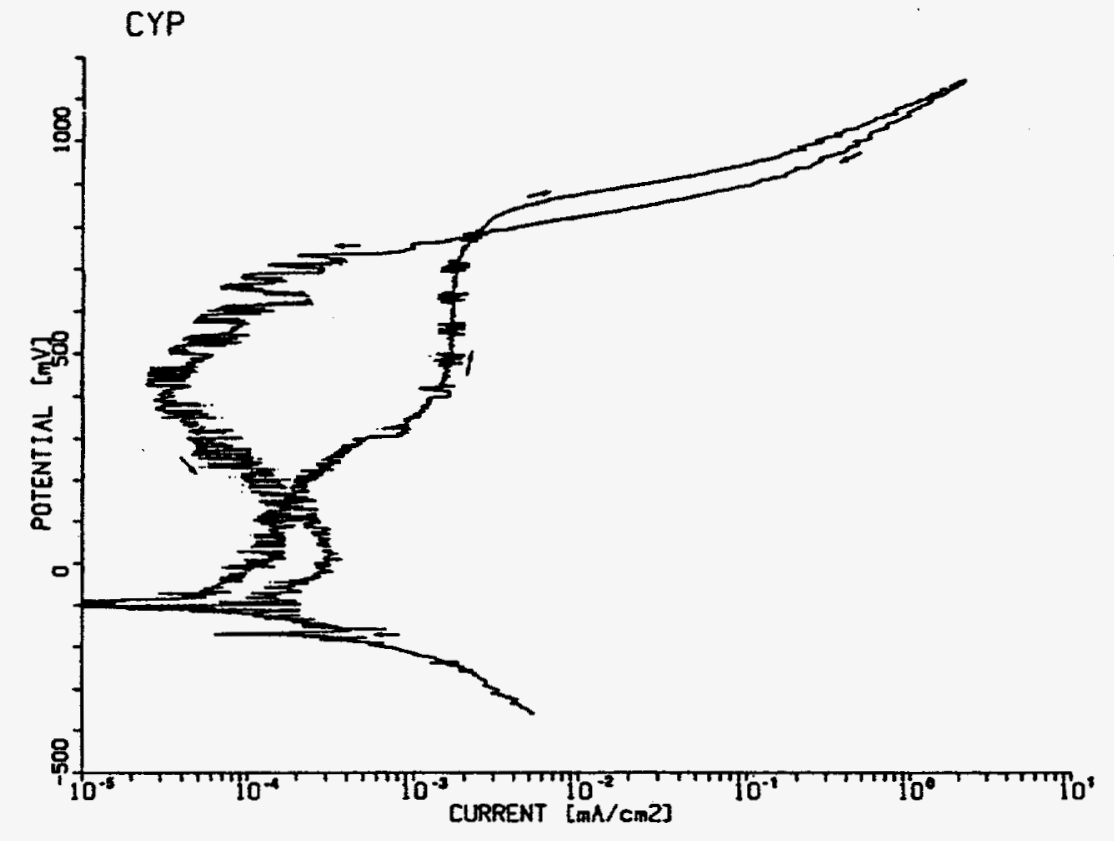

Figura 622. Rolerization Curve For A1LOy 304L In Solution No. 25 At $90^{\circ} \mathrm{C}$.

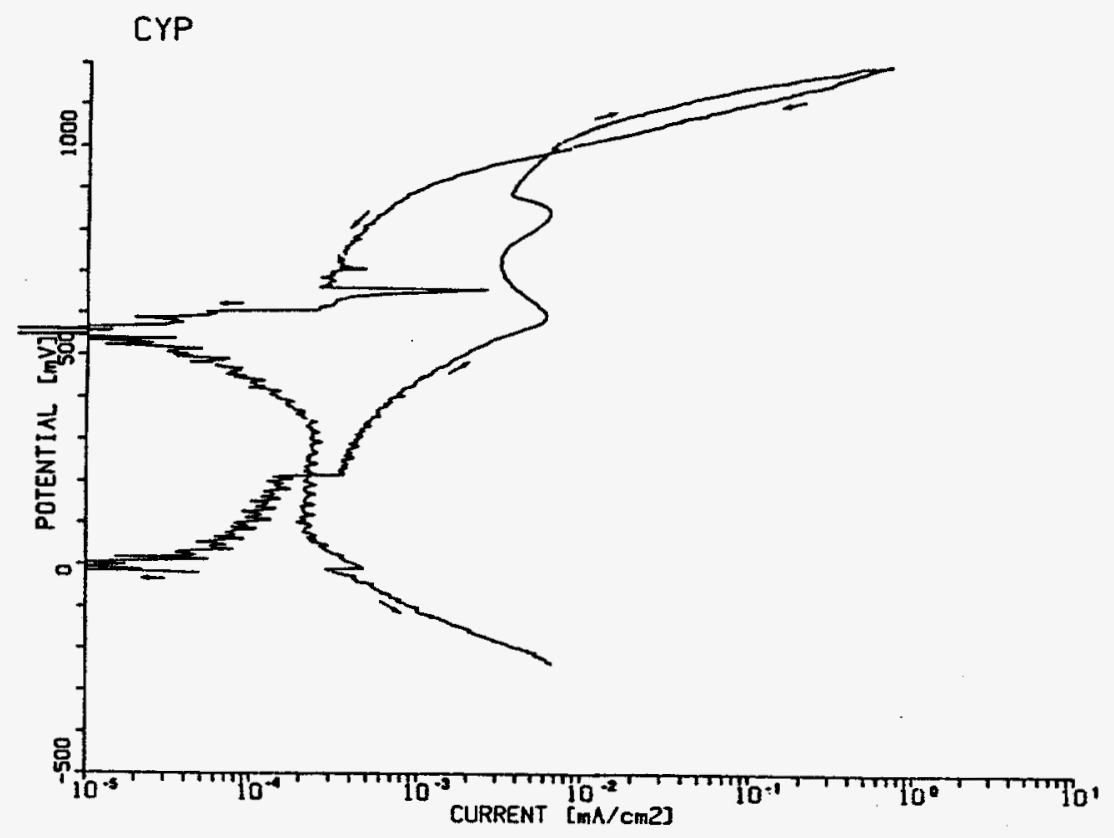

FIgure 623. Folariration Curve For $4110 \mathrm{~g} 304 \mathrm{~L}$ Veld In Solution No. 25 At $90^{\circ} \mathrm{C}$. 


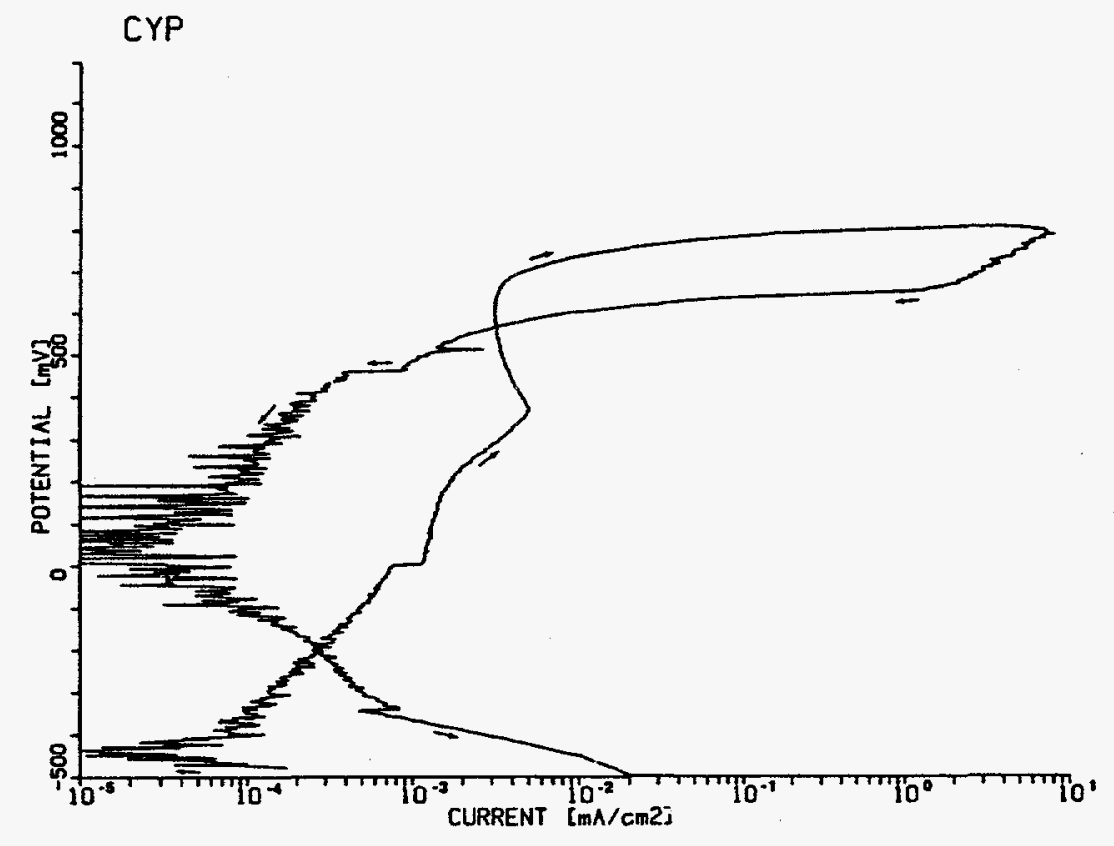

Figure G24. Rolerieation Curve For $1110 y 825$ In Solution Ho. 25 at $90^{\circ} \mathrm{C}$.

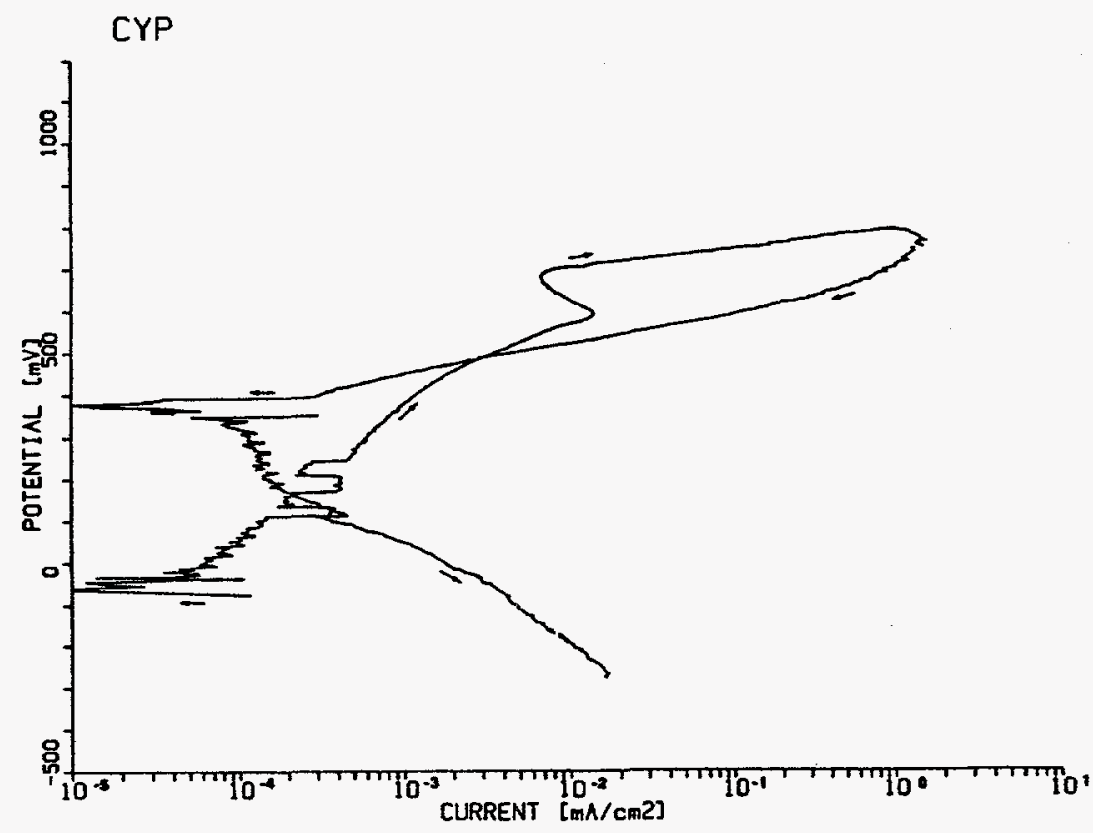

Figure 625. Polerization Curve For Alloy 625 Veld In Solution No. 25 At $20^{\circ} \mathrm{C}$. 
APEENDIX H

WELDING SPECIFICATIONS

FOR CONTAINER MATERIALS 
C10200 is known as an "oxygen free" or deoxidized copper alloy. It is nearly pure copper, with a copper content of 99.57 or greater. The absence of oxygen aids greatly in the weldability of this alloy, as it significantly decreases cracking tendencies. Gas Metal Arc Welding (GMAW) is an ideal welding process for joining this alloy, due to it's high deposition rate and cleanliness of deposit. GMAW allows this alloy to be joined with little difficulty, with the proper welding techniques and operators.

Due to the high thermal conductivity of copper, preheat is very important when welding this alloy. The material must be preheated to the temperature indicated on the welding procedure specification (WPS) in order to allow sufficient time for melting and solidification to occur. Actual welding must be done as quickly as possible, however, to avoid any oxides that may try to form. This is a fine balance which must be struck by the operator to obtain quality weldments. Adequate gas coverage is also important, and the welding procedure calls for a $50 \mathrm{cfh} g$ as flow of argon or 75 argon - 25 helium. The addition of helium to the shielding gas will result in a greater heat input, which, in the case of this highly conductive alloy, will again aid in melting and solidification. The parameters chosen for welding, as given in the attached (WPS), are standard industrial practice for welding this alloy, and with their application, good welds will be obtained. 
MATERIAL DESIGNATION: C10200 COPPER

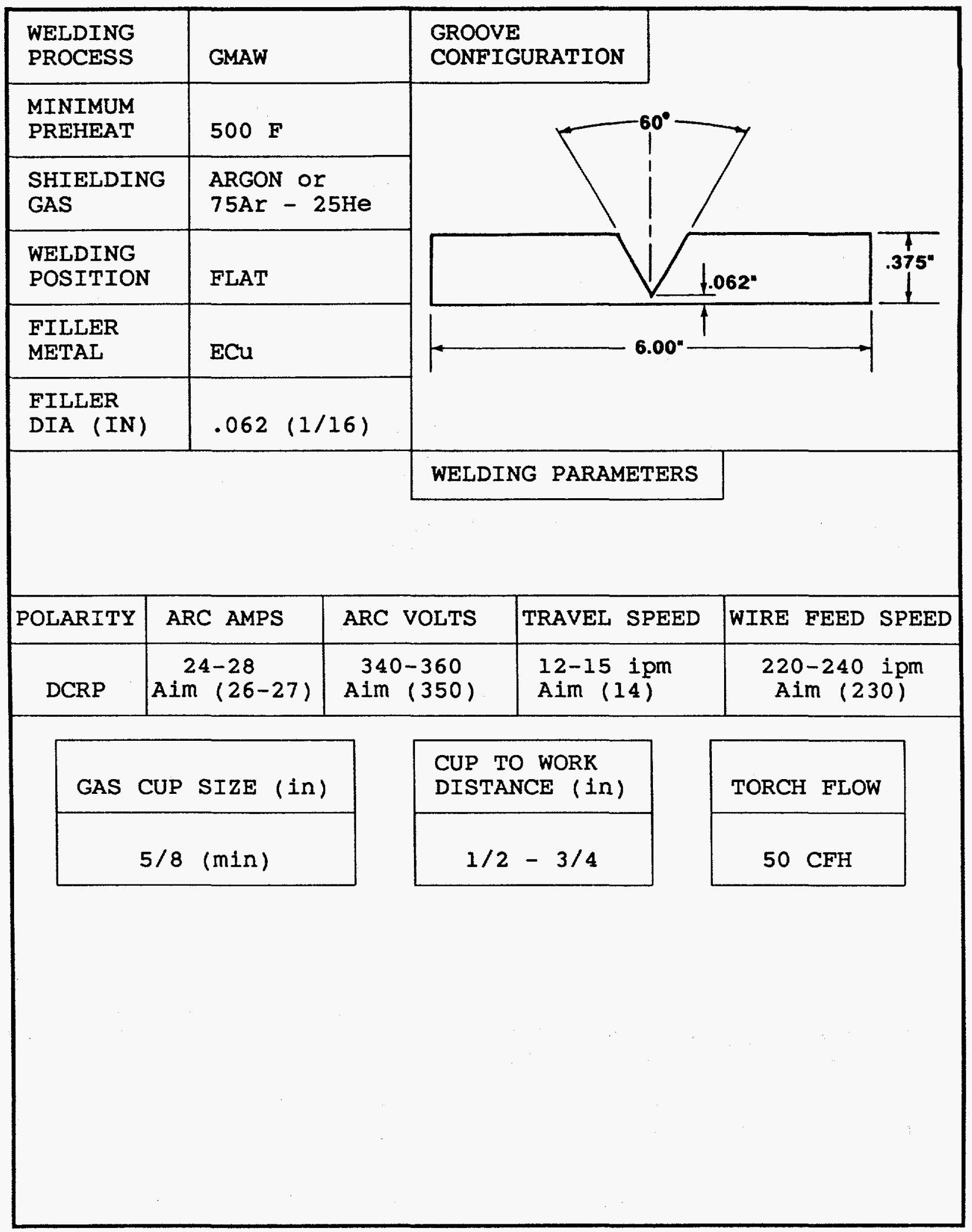


TECHNICAL JUSTIFICATION

WELDING OF C71500 COPPER-NICKEL

C71500 is a member of the copper-nickel alloy class. Gas Metal Arc Welding (GMAW) is commonly used to join this alloy. The parameters given on the attached Weld Procedure Specification (WPS) are used throughout industry to make high quality welds. In order to study the corrosion properties of this particular alloy (and yeldments), the most common parameters have been selected from various sources $(1,2,3)$ to produce welds that will simulate industrial fabrication.

C71500 contains approximately $70 \%$ copper and $30 \%$ nickel. As the WPS shows, this alloy does not require preheating, as many copper alloys normally do. The susceptibility of this alloy to forming nickel oxides is great, therefore, arc and puddle shielding must be complete, and the interpass temperature requirement must be closely observed. Prior to welding, the plates to be welded must be very clean and free of foreign material, dirt, greases, etc. To avoid overheating, welding must be done rapidly and a stringer bead deposition is preferred ${ }^{(1)}$. The higher travel speed and the use of stringer beads will reduce the heat input of the weld. The actual arc parameters (volts, amps, wire feed speed) have been chosen to facilitate a spray transfer mode of metal deposition, allowing for greater control of the arc, molten puddle, etc. Although these values are not absolute, they provide the operator with good guidelines for making these welds. If this WPS is followed, the resulting welds will be good models for the study of corrosion.

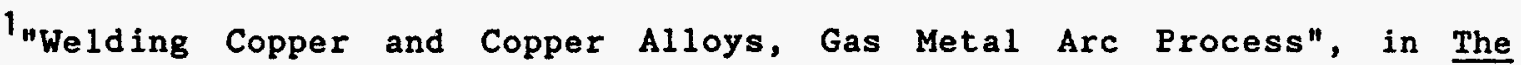
Procedure Handbook of Arc Welding, (Cleveland, Ohio: The Iincoln Electric Company, 1973), pp. 10.1-5-10.1-8.

2Howard B. Cary, "Copper and Copper Base Alloys", in Modern Welding Techniques, (Englewood Cliffs, New Jersey: Prentice-Hall, Inc., 1979), pp. 441446.

3"Welding Handbook", Vol. 4, "Metals and Their Weldability", American Welding Society, Miami, Florida, p. 283. 
MATERIAL DESIGNATION: C71500 COPPER/NICKEL

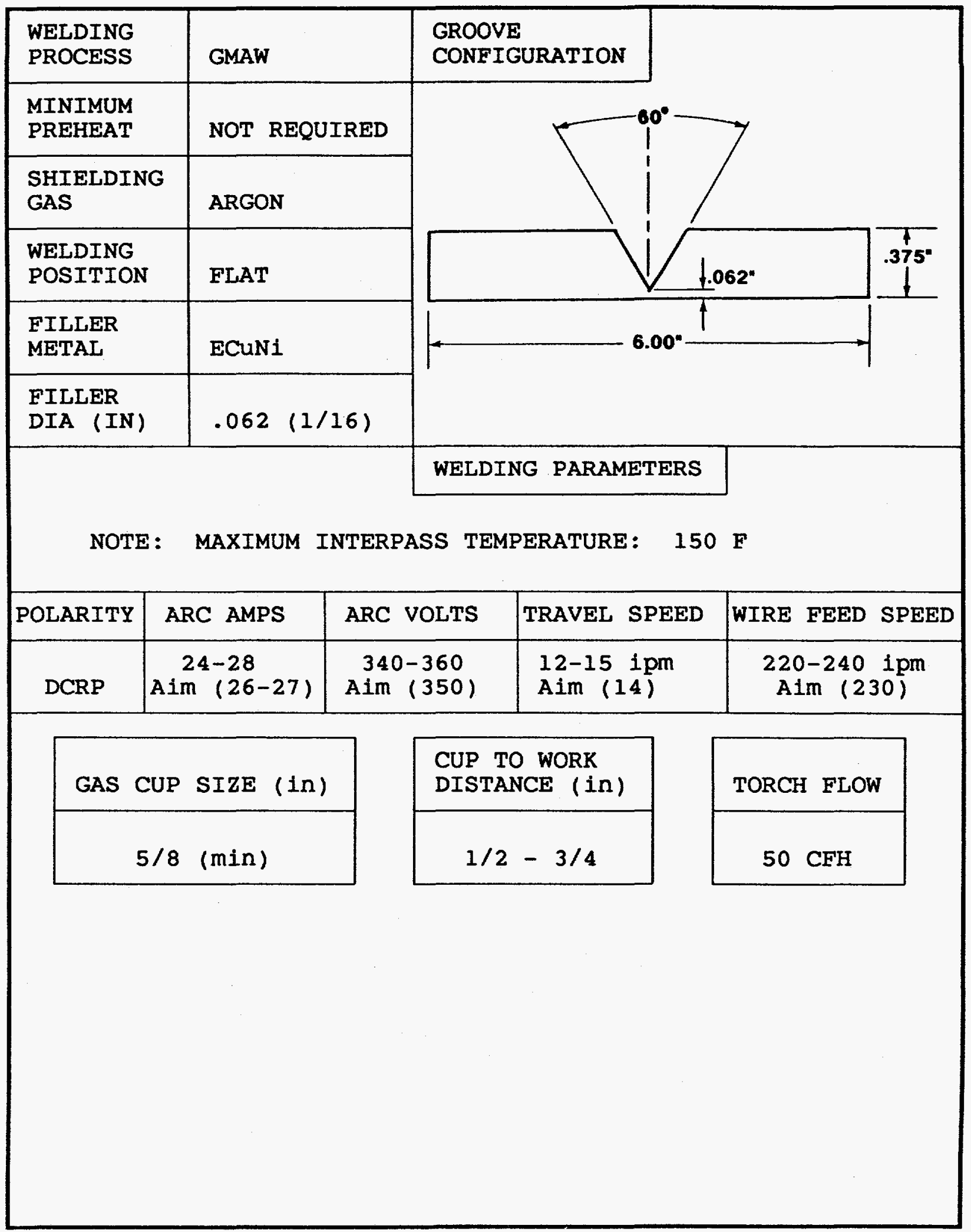


TECHNICAL JUSTIFICATION

WELDING OF 304L STAINLESS STEEL

304L is an austenitic stainless steel which can be readily joined using the Gas Metal Arc Welding (GMAW) process. 304L is perhaps the easiest of the austenitic stainless steels to weld due to it's decreased carbon content. The decrease in carbon means that chromium carbides are less apt to precipitate; therefore, this material is more resistant to intergranular attack in the heat-affected zone of the weld (compared to 304). The material is not completely immune to intergranular corrosion, however, and it is, therefore, best to limit the temperature of service to $800^{\circ} \mathrm{F}$ or below.

When welding this alloy, preheat is not required or desired, since no benefits are realized. The temperature of the plates prior to welding must be at least $60^{\circ} \mathrm{F}$. Since this alloy is slightly susceptible to sensitization, whenever practical, the welds of this material should be post-weld heat treated, in a temperature range above the sensitizing temperatures ( $165^{\circ} \mathrm{F}$ is a commonly used temperature). As stated above, GMAW is an excellent welding process to use for joining this material. Prior to welding, it is very important that the materials to be welded are free of foreign material, dirt, oils, greases, etc. Each bead should be cleaned with a stainless steel wire brush to avoid inclusions in the final weld. The inert gas shielding provides a very clean deposit, and has a fairly low heat input. The attached Weld Procedure Specification (WPS) provides the operator with the most commonly applied welding techniques. The spray mode of metal transfer is the best way to weld this stainless steel. The parameters chosen will have to be fine tuned to produce the most stable arc producing the least amount of splatter, but once these settings are found, this wPS will consistently yield good results.

The groove configuration shown will allow the operator to complete this weld in 2-3 passes. Although the sketch shows no backup plate being used, it would be wise to place a piece of copper or similar material beneath the root of the groove in the event that blow-through should occur. Another method of avoiding blow-through of the root pass would be to use the short-circuiting method of metal deposit. This would, however, require a power supply with controls of slope, voltage, and inductance. The shielding gas would also have to be changed from $98 \mathrm{ArO}_{2}$ to a mixture of $90 \%$ helium, $7.5 \%$ argon, and $2.5 \% \mathrm{CO}_{2}$. Since the use of $\mathrm{CO}_{2}$ will increase the possibility of carbide formation, this is not advised. As long as the operator is careful to weld the first pass with as low as current as possible, while still maintaining good sidewall fusion, this will not be a problem.

This alloy, along with all austenitic stainless steels, is susceptible to severe warpage and distortion. Tack welds should be placed twice as often as normal. Backstep, skip, and wandering techniques should be used, and welding should be done using the forehand technique, giving the operator better visibility of the fluid puddle. The gun should be moved back and forth in the direction of the joint and, at the same time, moved slightly from side to sidel. 
In general, this WES represents industry-wide applications of GMAw, of 304L stainless steel, and will produce good welds to use for corrosion testing.

${ }^{2}$ Howard B. Cary, "Welding Stainless Steels", in Modern Welding Techniques, (Englewood Cliffs, New Jersey: Prentice-Ha11, Inc., 1979), pp. 421-425. 
MATERIAL DESIGNATION: 304L STAINLESS STEEL

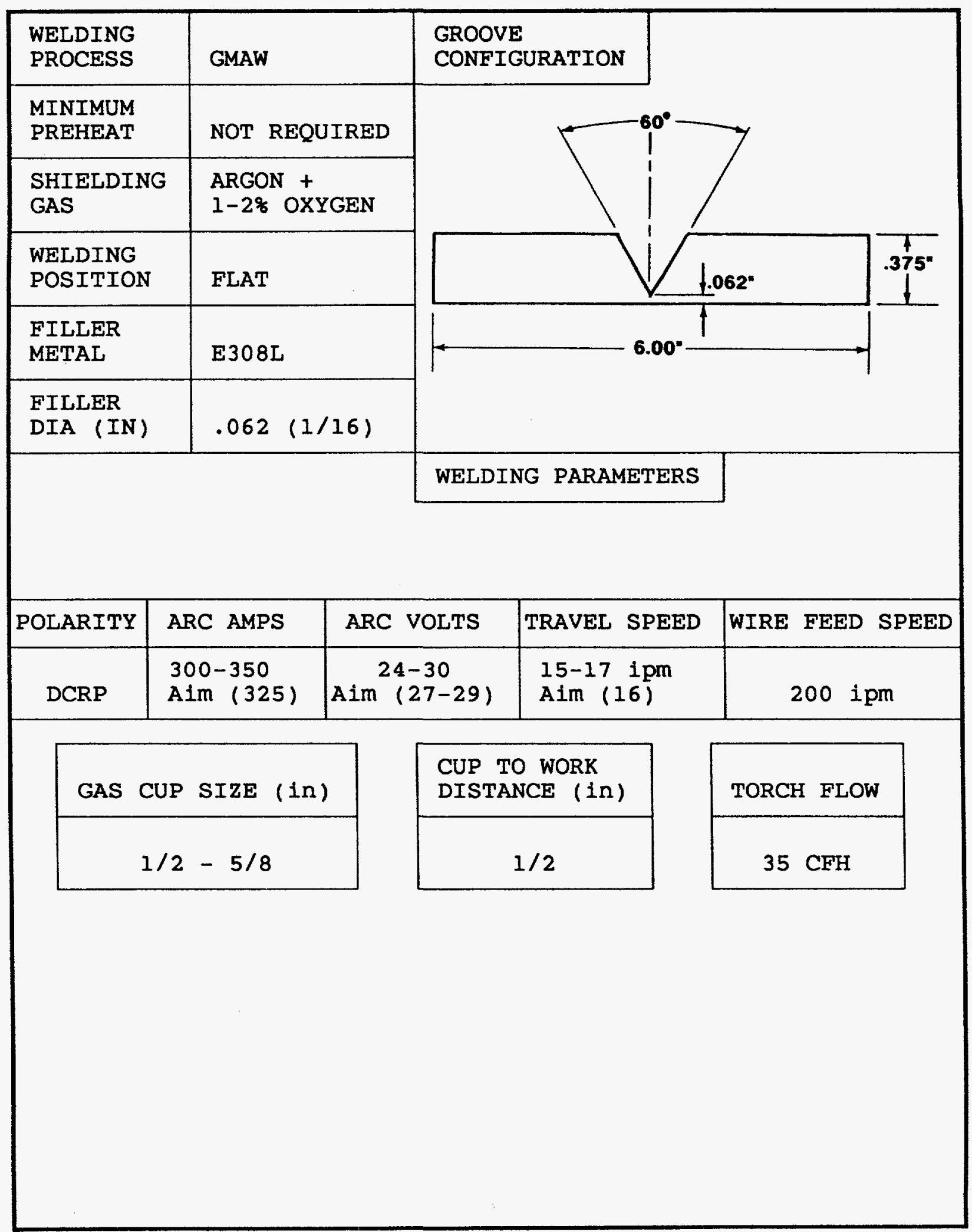


TECHNICAL JUSTIFICATION

WELDING OF INCOLOY 825

Incoloy 825 is a nickel-iron-chromium alloy specifically designed for use in corrosive environments. It's high nickel content makes it very resistant to stress-corrosion cracking, and this material can be welded without loss of this property. It is preferred to weld this alloy in the annealed condition, following by a heat treatment to relieve any sensitization which may have occurred as a result of welding. The attached Weld Procedure Specification (WPS) gives the parameters which are most widely used to produce weldments using the Gas Metal Arc Welding (GMAW) process. When welding this alloy, the operator must attempt to 1 imit the heat input to the weld (note interpass temperature on the WPS). Several small stringer beads should be used rather than trying to fill the joint as quickly as possible. A thin oxide layer may form during multiple-bead welding, and this layer must be removed for the weld to remain defect-free. If the oxide layer is not removed, the completed weld may have several oxide stringers along the joint, as the melting point of the oxide is much higher than that of the base metal (1). This oxide layer is tenacious and cannot be removed by simple wire brushing, as this will merely polish it. These oxide layers should be removed when they are heavy enough to become visible. Removal of the oxide layers is accomplished by abrasive blasting or grinding. Abrasive blasting is not very practical, so grinding is the simpler alternative. Also, the welding plate should not be restrained in any manner to limit the level of residual stresses resulting in the joint.

The attached parameters will allow the operator to weld using the spray mode of transfer. This is the preferred method of joining the nickel-base alloys when using the GMAW method. Prior to welding, however, the base metal and filler material must be cleaned so they are free of any foreign material. This is the single most important factor to consider when joining this class of alloys(2). Vapor degreasing solvents, alkaline cleaners may be used; however, their residues must also be removed (hot water). If the welding procedure and the comments here are followed closely, the resulting welds will provide good models for the corrosion behavior of Incoloy 825 welds. 


\section{WELDING OF INCOLOY 825}

\section{REFERENCES}

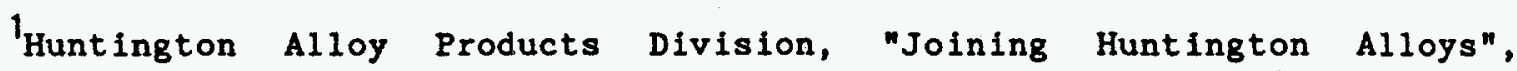
(Huntington, West Virginia: Inco Alloys International, Inc., 1972).

"Welding Handbook", Vol. 4, "Metals and Their Weldability", American Welding Society, Miami, Florida, pp. 232-236. 
MATERIAL DESIGNATION: INCOLOY 825

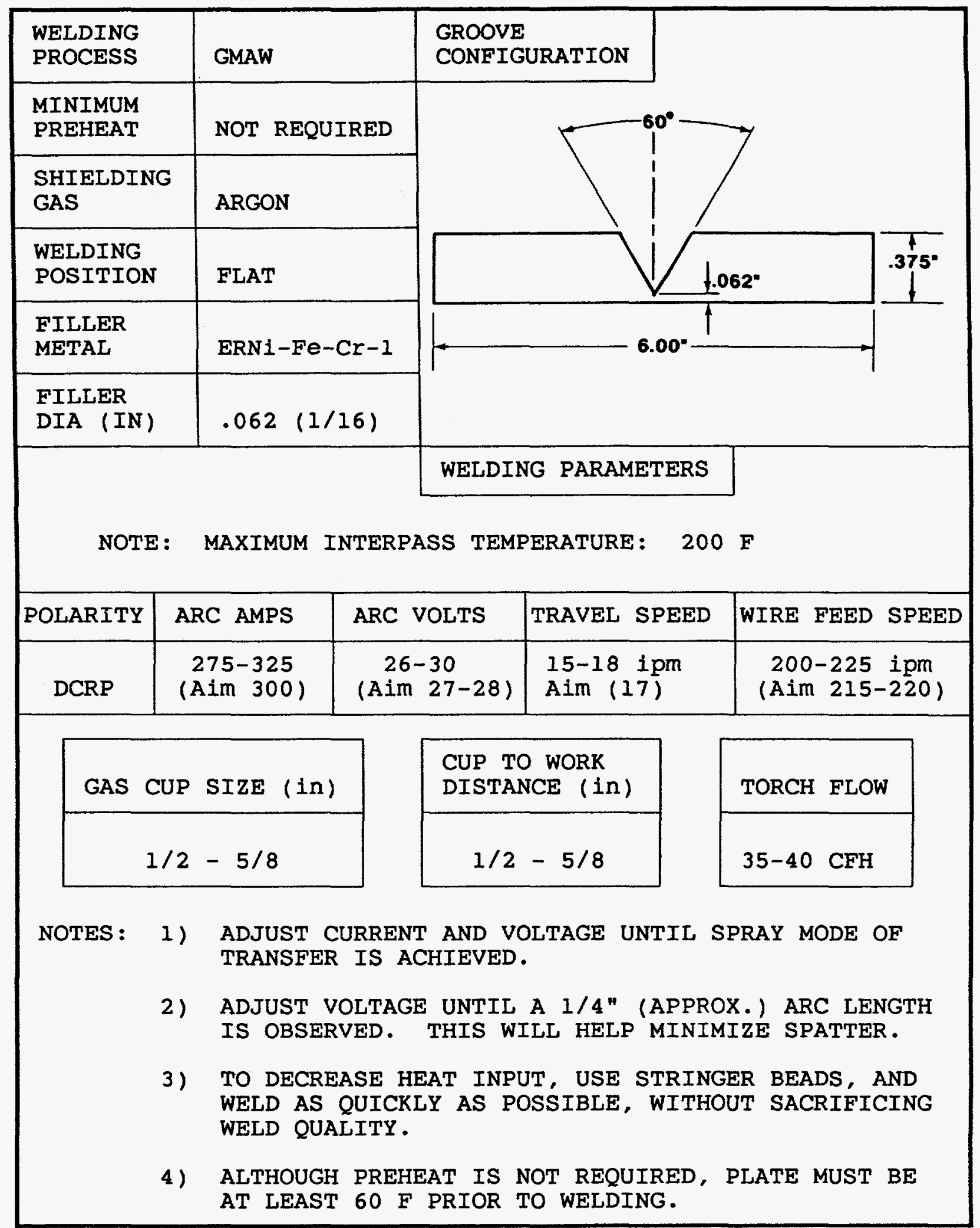


APPENDIX I

CANDIDATE ALLOY COMPOSITIONS

$-256-$ 
Table Il. Candidate Alloy Compositions of Specimens Used For The CyclicPotentiodynamic-Polarization Tests In The Experimental Matrix And Temperature Studies.

\begin{tabular}{|c|c|c|c|c|}
\hline ELEMENT & CDA 102 & CDA 715 & I825 & $304 \mathrm{~L}$ \\
\hline $\mathrm{Cu}$ & $99.99 \%$ & $67.17 \%$ & $1.90 \%$ & $0.190 \%$ \\
\hline $\mathrm{Ni}$ & - & $31.78 \%$ & $43.98 \%$ & $8.87 \%$ \\
\hline $\mathbf{F e}$ & - & $0.46 \%$ & $26.90 \%$ & Balance \\
\hline $\mathrm{Cr}$ & - & - & $22.70 \%$ & $18.22 \%$ \\
\hline Mo & - & - & $2.92 \%$ & $0.170 \%$ \\
\hline $\mathrm{Mn}$ & - & $0.56 \%$ & $0.37 \%$ & $1.21 \%$ \\
\hline C & - & $<0.01 \%$ & $0.02 \%$ & $0.021 \%$ \\
\hline$S$ & - & $<0.01 \%$ & $0.004 \%$ & $0.023 \%$ \\
\hline $\mathbf{Z n}$ & - & $0.01 \%$ & - & - \\
\hline $\mathbf{P}$ & - & $<0.01 \%$ & - & $0.026 \%$ \\
\hline $\mathrm{Pb}$ & - & $<0.01 \%$ & - & - \\
\hline Si & - & - & $0.08 \%$ & $0.520 \%$ \\
\hline A1 & - & - & $0.06 \%$ & - \\
\hline $\mathbf{T} \mathbf{i}$ & $=$ & - & $1.07 \%$ & - \\
\hline Co & - & - & - & - \\
\hline $\mathbf{N}$ & - & - & - & $0.066 \%$ \\
\hline
\end{tabular}


Table I2. Candidate Alloy Compositions of Specimens Used For The Heat-Transfer Studies.

\begin{tabular}{|c|c|c|c|c|}
\hline ELEMENT & CDA 102 & CDA 715 & I825 & $304 \mathrm{~L}$ \\
\hline $\mathrm{Cu}$ & $99.99 \%$ & $70.24 \%$ & $1.80 \%$ & $0.41 \%$ \\
\hline $\mathrm{Ni}$ & - & $29.20 \%$ & $39.84 \%$ & $9.21 \%$ \\
\hline Fe & - & $0.45 \%$ & $31.17 \%$ & Balance \\
\hline $\mathrm{Cr}$ & - & - & $22.11 \%$ & $18.51 \%$ \\
\hline Mo & - & - & $3.40 \%$ & $0.30 \%$ \\
\hline Mn & - & $0.02 \%$ & $0.37 \%$ & $1.45 \%$ \\
\hline C & - & - & $0.03 \%$ & $0.017 \%$ \\
\hline $\mathbf{s}$ & - & $<0.0004 \%$ & $0.001 \%$ & $0.004 \%$ \\
\hline Zn & - & $0.06 \%$ & - & - \\
\hline $\mathbf{P}$ & - & - & - & $0.026 \%$ \\
\hline $\mathbf{P b}$ & - & $<0.01 \%$ & - & - \\
\hline Si & - & - & $0.33 \%$ & $0.68 \%$ \\
\hline A1 & - & - & $0.07 \%$ & $=$ \\
\hline $\mathbf{T i}$ & - & - & $0.88 \%$ & - \\
\hline Co & - & - & $=$ & - \\
\hline $\mathbf{N}$ & - & - & $=$ & $0.034 \%$ \\
\hline
\end{tabular}


(See instructions on the reverse)

\section{Potentiodynamic Polarization Studies On Candidate Container Alloys For The Tuff Repository}

\begin{tabular}{|l|c|}
\hline 3. & \multicolumn{2}{c|}{ DATE REPORT PUBLISHED } \\
\hline MONTH & YEAR \\
JanuarY & 1992 \\
\hline $\begin{array}{c}\text { 4. FIN OR GRANT NUMBER } \\
\text { FIN D1692 }\end{array}$
\end{tabular}

N. G. Thompson, J. A. Beavers, and C. L. Durr
NUREG / CR-5708

6. TYPE OF REPORT

Technical

. REPORT NUMBER

(Adioned by NAC. Add Vol., Supo., Rev. and Addendum Numban, II eny.)

7. PERIOD COVERED (Inc/usive Dates/

$12 / 87-12 / 91$

8. PERFORMING ORGANIZATION - NAME AND ADDRESS (If NRC, provide Division, Office or Region, U.S. Nucleor Regulorory Commission, and mailing address; if contractor, provide nume and mailing oddress)

Cortest Columbus Technologies, Inc. 2704 Sawbury Boulevard Columbus, Ohio 43235

9. SPONSORING ORGANIZATION - NAME AND ADDRESS II NRC, tvpe "Same as sbove"; if controctor, provide NAC Division, Office or Region, U.S Nuclear Regulatory Commission. and moiling address)

Division of Regulatory Applications

Office of Nuclear Regulatory Research

U.S. Nuclear Regulatory Commission

Washington, DC 20555

10. SUPPLEMENTARY NOTES

11. ABSTRACT (200 words or less)

Cortest Columbus Technologies, Inc. (CC Technologies) is investigating the long-term performance of container materials used for high-level radioactive waste packages. This information is being developed for the Nuclear Regulatory Commission to aid in their assessment of the Department of Energy's application to construct a geologic repository for disposal of high-level radioactive waste. This report summarizes the results of cyclic-potentiodynamic-polarization (CPP) studies performed on candidate container materials for the Tuff Repository. The CPP technique was used to provide an understanding of how specific variables such as environmental composition, temperature, alloy composition, and welding affect both the general-and localized-corrosion behavior of two copper-base and two $\mathrm{Fe}-\mathrm{Cr}$-Ni alloys in simulated repository environments.

A statistically-designed test solution matrix was formulated, based on an extensive search of the literature, to evaluate the possible range of environmental species that may occur in the repository over the life of the canister. Forty-two CPP curves were performed with each alloy and the results indicated that several different types of corrosion were possible. The copper-base alloys exhibited unusual CPP behavior in that hysteresis was not always associated with pitting.

The effects of temperature on the corrosion behavior were evaluated in wo types of tests; isothermal tests at temperatures from $50^{\circ} \mathrm{C}$ to $90^{\circ} \mathrm{C}$ and heat-transfer tests where the solution was maintained at $50^{\circ} \mathrm{C}$ and the specimen was internally heated to $90^{\circ} \mathrm{C}$. In the isothermal test, CPP curves were obtained with each alloy in simulated environments at $50^{\circ} \mathrm{C}, 75^{\circ} \mathrm{C}$, and $90^{\circ} \mathrm{C}$. The results of these $\mathrm{CPP}$ experiments indicated that no systematic trends were evident for the environments tested.

In the heat-transfer test, CPP tests were performed with a specimen internally heated to $90^{\circ} \mathrm{C}$ while maintaining the test solution at $50^{\circ} \mathrm{C}$. The results of these experiments indicated that in simulated $\mathrm{J}-13$ well water, heat transfer appeared to have an effect on the corrosion behavior of each of the four alloys. Heat transfer did not appear to have a major effect in more aggressive simulated environments.

Lastly, the effects of welding on the corrosion behavior of the alloys in simulated environments were examined. Rod material was welded into a V-shaped grove in plate material. The weld was machined and evaluated by the CPP technique. These studies showed that weiding had relatively little effect on the CPP behavior of the $\mathrm{Fe}-\mathrm{Cr}$-Ni alloys in the environments that were selected. Welding was found to be detrimental to the performance of the copper-base alloys in both simulated groundwater and in a solution shown to promote pitting of the wrought copper-base alloys.

12. KEY WORDS/DESCR!PTORS (List words or phrases that will assist researchers in locating the report.)

Corrosion

Container Materials

General Corrosion

Localized Corrosion

Potentiodynamic Polarization

Heat Transfer
Copper-Base Alloys

Fe-Cr-Ni Alloys

Environmental Effects

High Level Nuclear Waste Disposal

Tuff Repository

Welding Effects

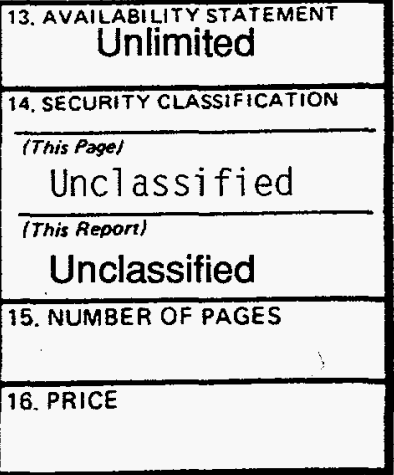

